\title{
¿USGS
}

science for a changing world

In cooperation with the U.S. Fish and Wildlife Service

Sand Resources, Regional Geology, and Coastal Processes of the Chandeleur Islands Coastal System: an Evaluation of the Breton National Wildlife Refuge

Scientific Investigations Report 2009-5252 



\section{Sand Resources, Regional Geology, and Coastal Processes of the Chandeleur Islands Coastal System: an Evaluation of the Breton National Wildlife Refuge}

Edited by Dawn Lavoie

In cooperation with the U.S. Fish and Wildlife Service

Scientific Investigations Report 2009-5252 y 


\title{
U.S. Department of the Interior \\ KEN SALAZAR, Secretary \\ U.S. Geological Survey \\ Marcia K. McNutt, Director
}

\section{U.S. Geological Survey, Reston, Virginia: 2009}

\author{
This and other USGS information products are available at http://store.usgs.gov/ \\ U.S. Geological Survey \\ Box 25286, Denver Federal Center \\ Denver, C0 80225 \\ To learn about the USGS and its information products visit http://www.usgs.gov/ \\ 1-888-ASK-USGS
}

Any use of trade, product, or firm names is for descriptive purposes only and does not imply endorsement by the U.S. Government.

Although this report is in the public domain, permission must be secured from the individual copyright owners to reproduce any copyrighted materials contained within this report.

Suggested citation:

Lavoie, D., ed., 2009, Sand resources, regional geology, and coastal processes of the Chandeleur Islands coastal system - an evaluation of the Breton National Wildlife Refuge: U.S. Geological Survey Scientific Investigations Report 2009-5252, $180 \mathrm{p}$ 


\title{
Table of Contents
}

\author{
Executive Summary
}

Chapter A. Hurricane Impact and Recovery Shoreline Change Analysis

and Historical Island Configuration: 1700s to $2005 \ldots$

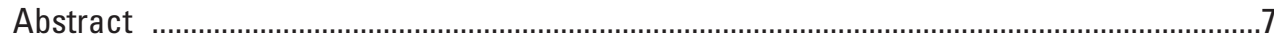

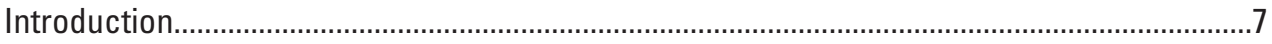

History of the Chandeleurs........................................................................................

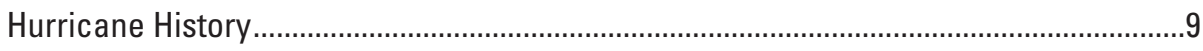

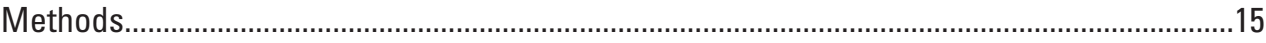

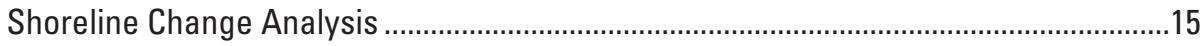

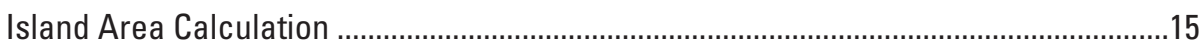

Uncertainty Analysis and Accuracy of Measurements .................................................17

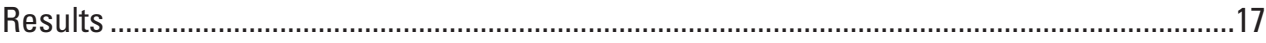

Northern Chandeleur Islands ................................................................................17

Storm Impact and Poststorm Recovery .............................................................17

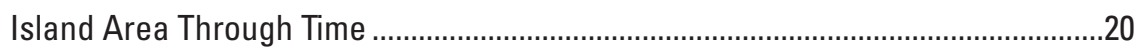

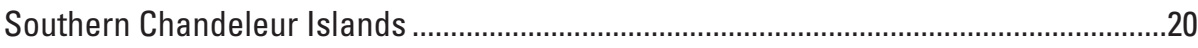

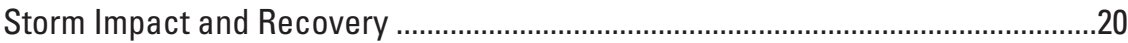

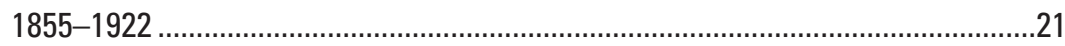

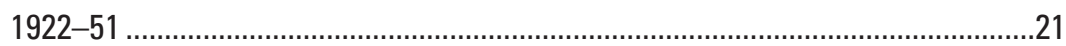

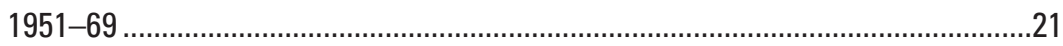

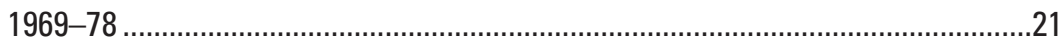

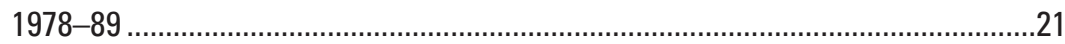

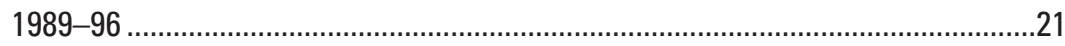

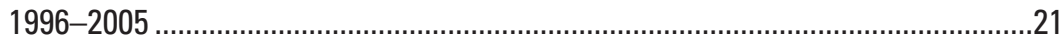

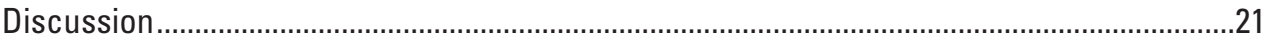

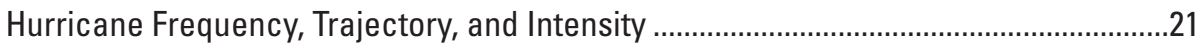

Historical Shoreline Evolution, Storm Impacts, and Future Scenarios............................22

Northern Chandeleur Islands ............................................................................22

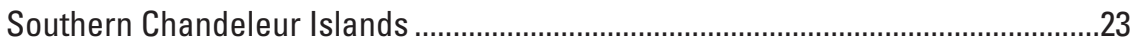

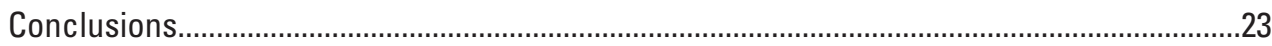

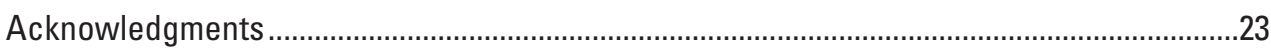

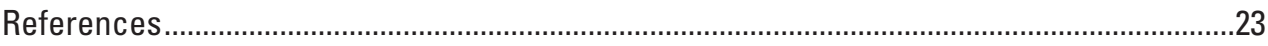

Appendix A-1. Shoreline Change Report (See Index Page To Access Data)

Appendix A-2. Shoreline Change Report-Geomorphology (See Index Page

To Access Data)

Appendix A-3. Shoreline Change Report-Hurricanes (See Index Page

To Access Data)

Chapter B. Extreme Coastal Changes on the Chandeleur Islands, Louisiana,

During and After Hurricane Katrina _..............................................................................27

Abstract. 
Introduction

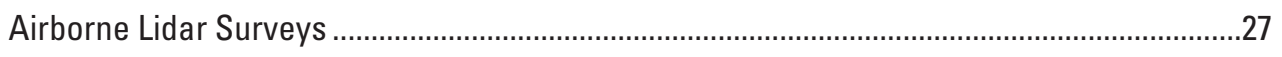

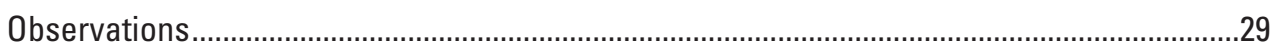

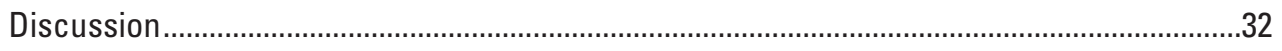

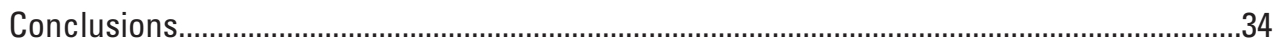

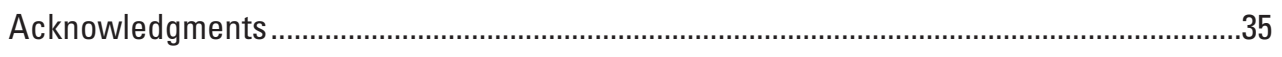

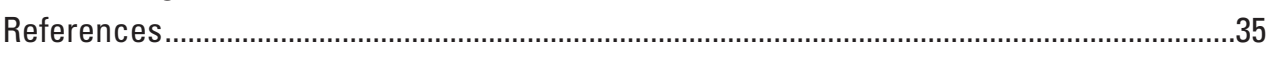

Appendix B-1. Chandeleur Islands Grids (See Index Page To Access Data)

\section{Chapter C. Past, Present, and Future Sea Level Rise and Effects on}

Coasts Under Changing Global Climate ...............................................................................37

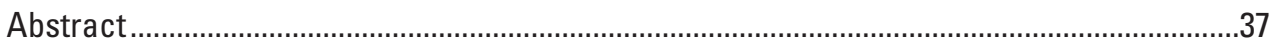

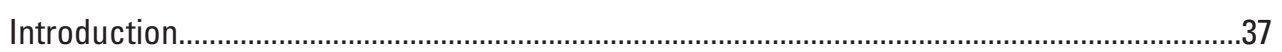

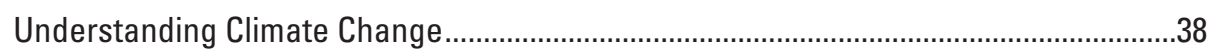

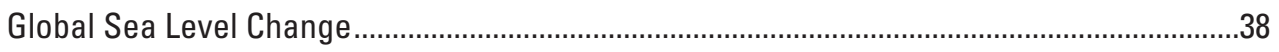

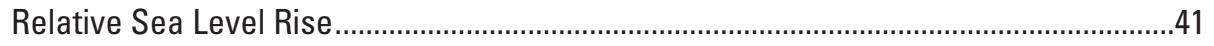

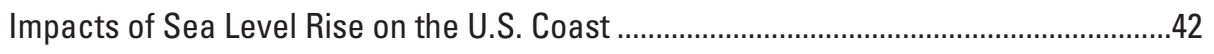

Climate Change and Storms.................................................................................... 43

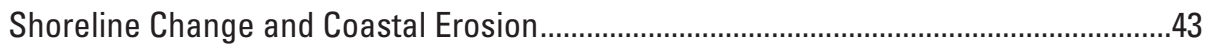

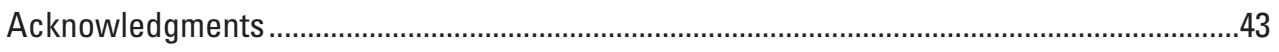

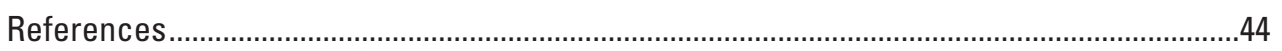

\section{Chapter D. Historical (1869-2007) Sea Floor Evolution and Sediment}

Dynamics Along the Chandeleur Islands .........................................................................47

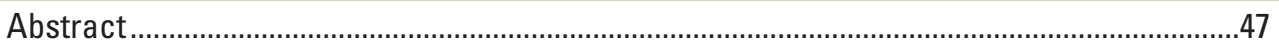

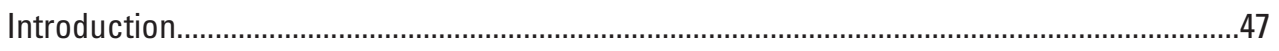

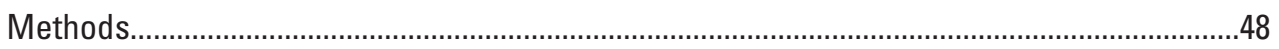

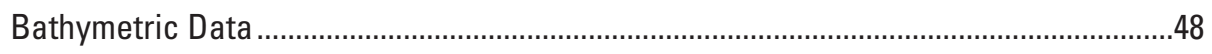

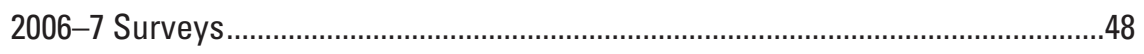

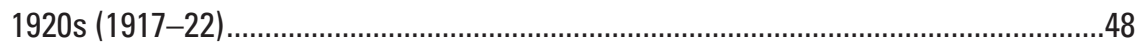

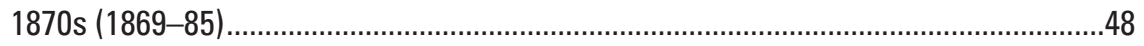

Adjustment of Historical Datasets for Relative Sea Level Rise .......................................50

Surface Gridding and Contouring ............................................................................5

Sea Floor Change and Volume Calculations ................................................................50

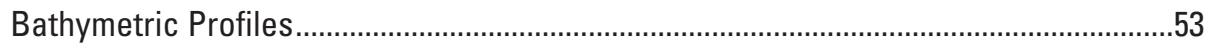

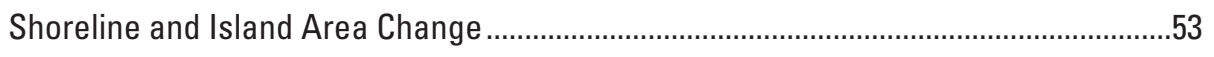

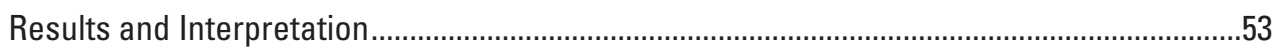

Sea Floor Morphology and Evolution .....................................................................53

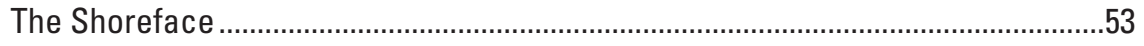

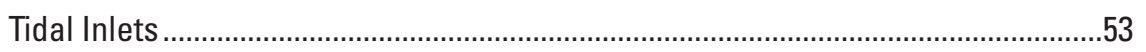

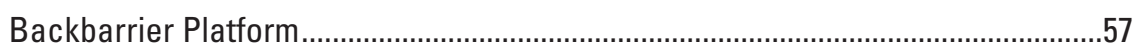

Spits

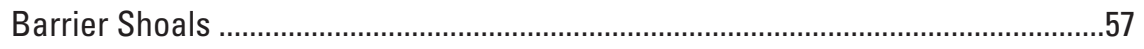

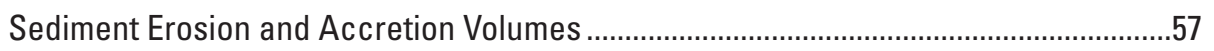

Northern Chandeleur Islands (Hewes Point South to Monkey Bayou) ....................58

Southern Chandeleur Islands (Monkey Bayou South to Breton Island) ..................62 


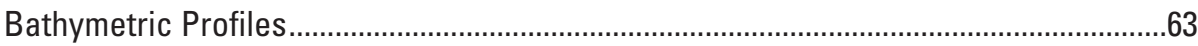

Sector 1: Hewes Point to Schooner Harbor ……………….................................63

Sector 2: Schooner Harbor to Redfish Point ..............................................................63

Sector 3: Redfish Point to Monkey Bayou ................................................................63

Sector 4: Monkey Bayou to the MRG0 ……………….........................................65

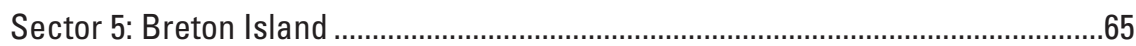

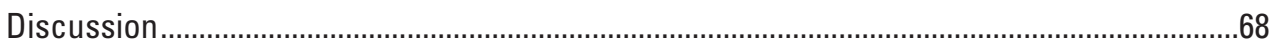

Sediment Transport ............................................................................................68

Shoreface Evolution and Transgressive Submergence ................................................69

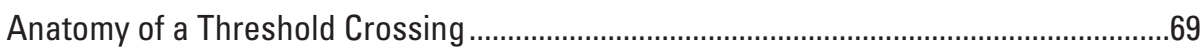

Conclusions and Implications for Island Management..........................................................

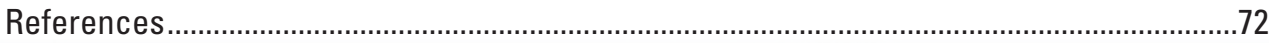

Chapter E. Geologic Mapping of Distribution and Volume of Potential

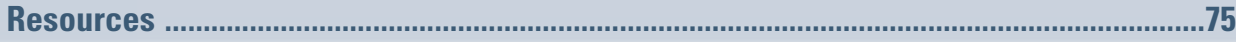

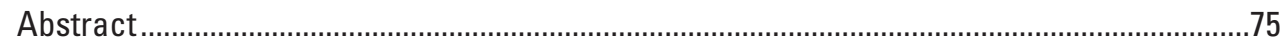

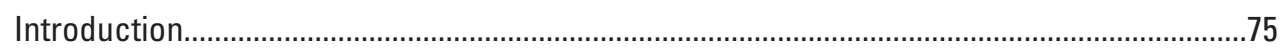

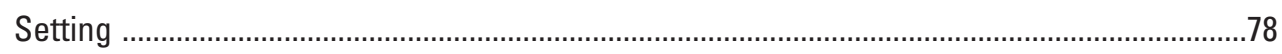

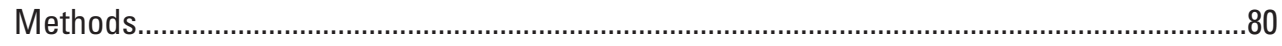

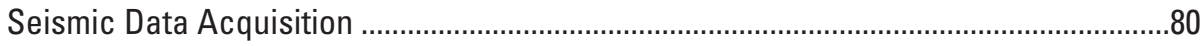

Seismic-Reflection Data Processing and Interpretation .................................................82

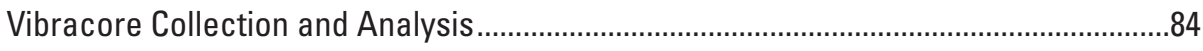

Fusion of Seismic-Reflection and Vibracore Data .......................................................84

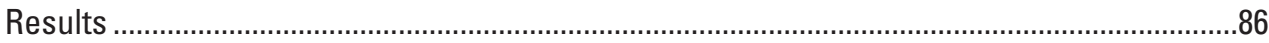

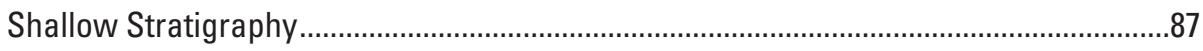

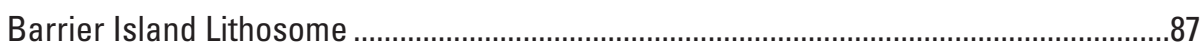

Potential Sand Resources off the Chandeleur Islands........................................................

Modern Sand Deposits ...........................................................................................

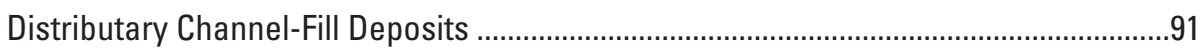

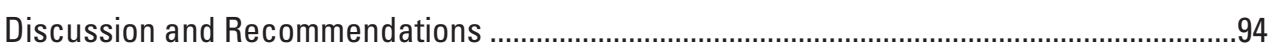

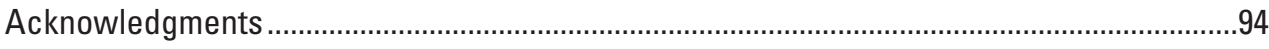

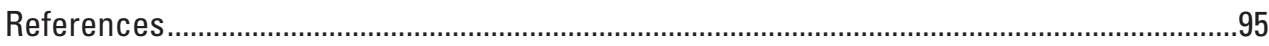

Appendix E-1. Geophysical Data from Offshore of the Chandeleur Islands

(See Index Page To Access Data)

Chapter F. Sediment Sampling Analysis To Define Quality of Sand

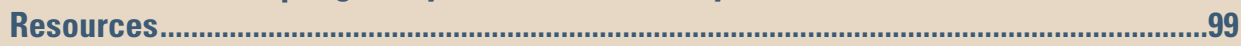

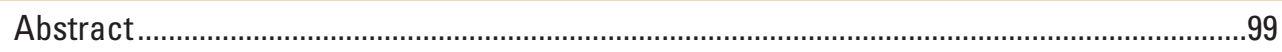

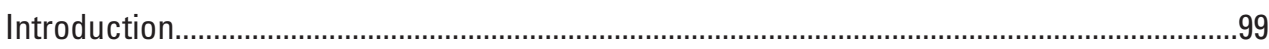

Methods

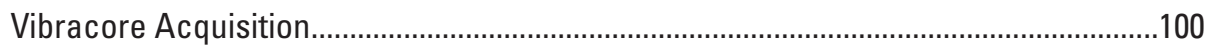

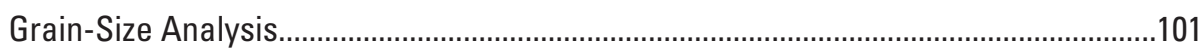

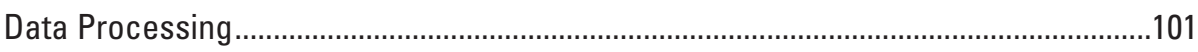

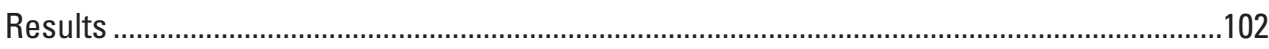

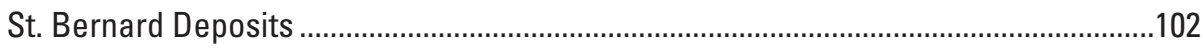

Fine-Grained Prodelta, Delta-Front, and Interdistributary Deposits ......................102 


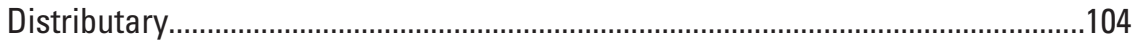

Transgressive Deposits........................................................................................111

Barrier Deposits ...........................................................................................111

Hewes Point Barrier and Northeast Sand Deposits ...............................................111

Tidal/Shallow Fluvial Channel Fill .........................................................................111

Backbarrier Deposits and Overwash Sand Sheets ...............................................112

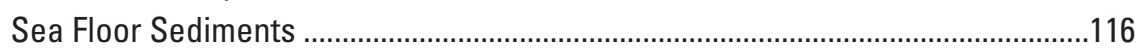

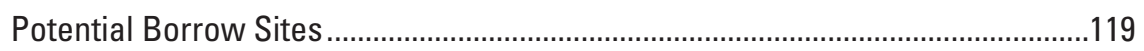

Hewes Point Sands ..................................................................................

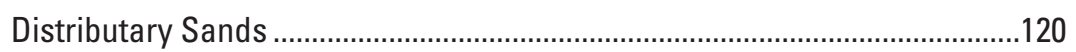

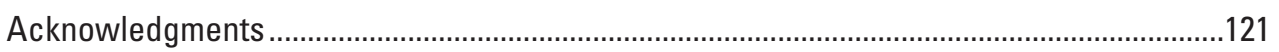

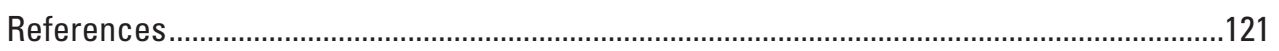

Appendix F-1. Core Descriptions (See Index Page To Access Data)

Appendix F-2. Geogrpahic Data (See Index Page To Access Data)

Appendix F-3. Grain Sizes (See Index Page To Access Data)

Chapter G. The St. Bernard Shoals: an Outer Continental Shelf Sedimentary

Deposit Suitable for Sandy Barrier Island Renourishment..............................................125

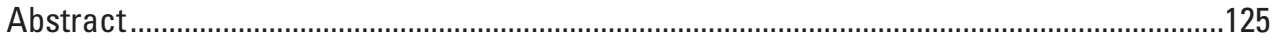

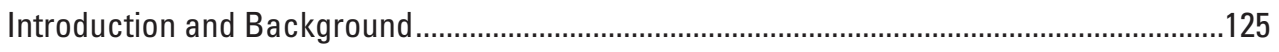

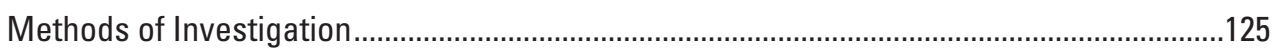

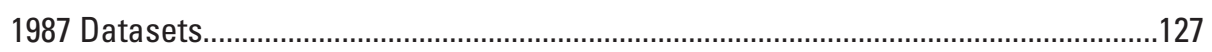

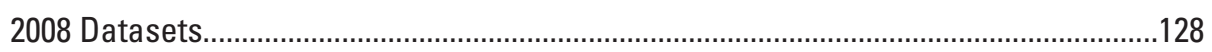

Morphology and Sedimentary Framework of the St. Bernard Shoals ..................................129

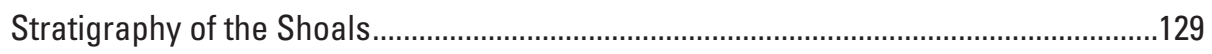

Textural Character and Volume of the Shoals ………......................................................133

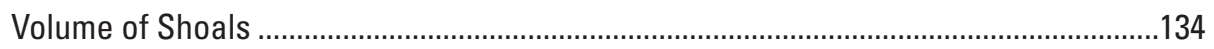

Current Process Affecting Modern Day Shoal Evolution....................................................134

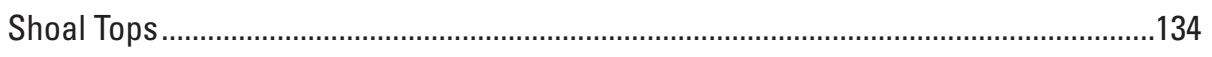

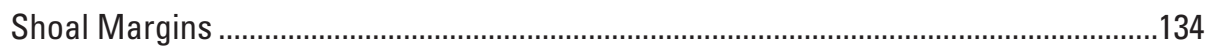

Suitability as Borrow Material for the Chandeleur Islands ................................................137

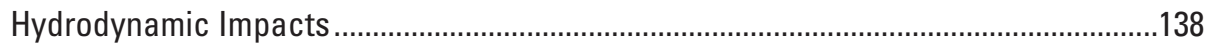

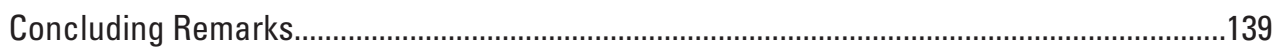

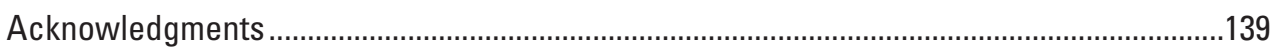

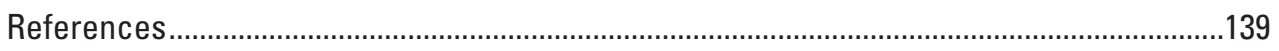

Appendix G-1. SBS-08 Seism (See Index Page To Access Data)

\section{Chapter H. Numerical Simulation of Waves and Sediment Transport}

Along a Transgressive Barrier Island ....................................................................................143

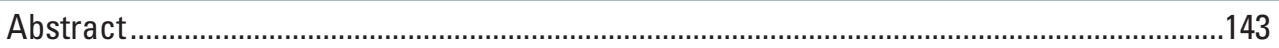

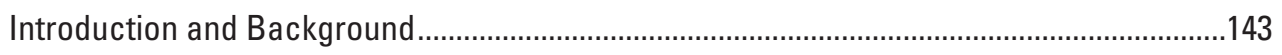

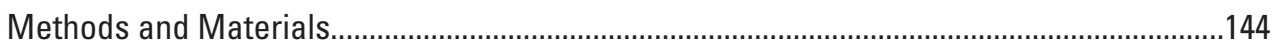

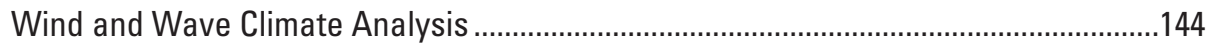

One-Dimensional Wave Modeling and Longshore Sediment Transport ........................145

Two-Dimensional Wave Modeling and Transport........................................................146

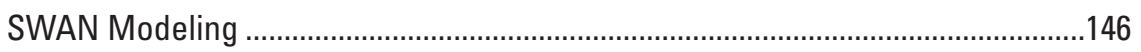


Tidal and Storm-Induced Circulation..............................................................................147

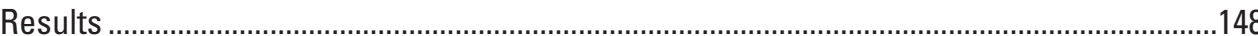

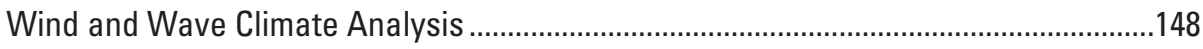

One-Dimensional Longshore Sediment Transport ......................................................148

Two-Dimensional Wave Modeling ...........................................................................150

SWAN Wave Modeling Setup and Results_Storm Weather Simulations...........150

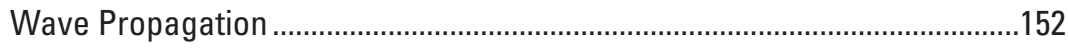

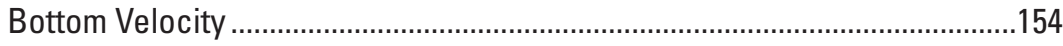

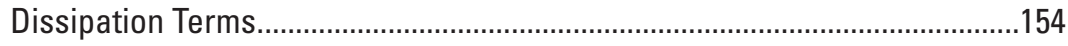

Implications for Sediment Transport .....................................................................154

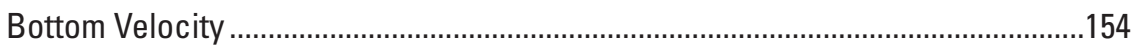

Winter Storms and Cold Fronts ...........................................................................158

Tide-Induced Currents .......................................................................................158

Storm-Induced Circulation and Transport.............................................................158

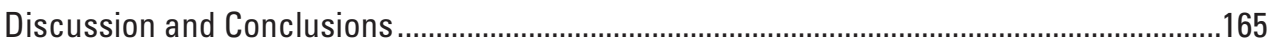

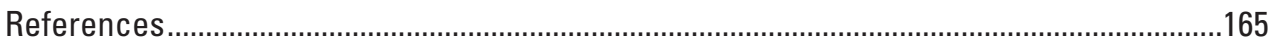

Appendix $\mathrm{H}-1$. Wind and Wave Climate Analysis, Wave Recasting, and

Simulation of Longshore Sediment Transport (See Index Page

To Access Data)

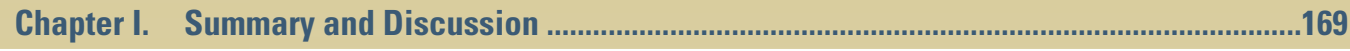

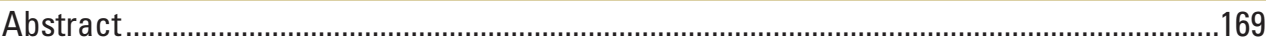

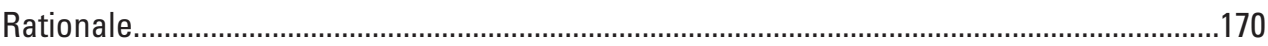

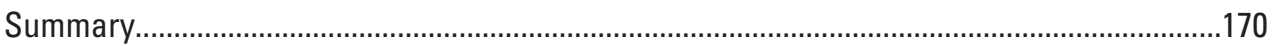

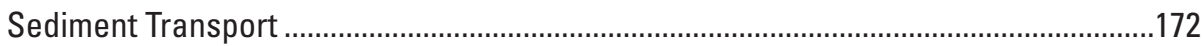

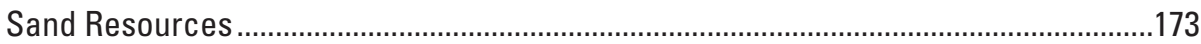

Conclusions and Implications for Island Management........................................................174 



\section{Executive Summary}

By Dawn Lavoie

Executive Summary of

Sand Resources, Regional Geology, and Coastal Processes of the

Chandeleur Islands Coastal System: an Evaluation of the Breton

National Wildlife Refuge

Edited by Dawn Lavoie

In cooperation with the U.S. Fish and Wildlife Service

Scientific Investigations Report 2009-5252 y 


\title{
U.S. Department of the Interior \\ KEN SALAZAR, Secretary \\ U.S. Geological Survey \\ Marcia K. McNutt, Director
}

\section{U.S. Geological Survey, Reston, Virginia: 2009}

\author{
This and other USGS information products are available at http://store.usgs.gov/ \\ U.S. Geological Survey \\ Box 25286, Denver Federal Center \\ Denver, C0 80225 \\ To learn about the USGS and its information products visit http://www.usgs.gov/ \\ 1-888-ASK-USGS
}

Any use of trade, product, or firm names is for descriptive purposes only and does not imply endorsement by the U.S. Government.

Although this report is in the public domain, permission must be secured from the individual copyright owners to reproduce any copyrighted materials contained within this report.

Suggested citation:

Lavoie, D., 2009, Executive summary, in Lavoie, D., ed., Sand resources, regional geology, and coastal processes of the Chandeleur Islands coastal system —an evaluation of the Breton National Wildlife Refuge: U.S. Geological Survey Scientific Investigations Report 2009-5252, p. 1-6. 


\title{
Executive Summary
}

\author{
By Dawn Lavoie ${ }^{1}$
}

\section{Abstract}

Breton National Wildlife Refuge, the Chandeleur Islands chain in Louisiana, provides habitat and nesting areas for wildlife and is an initial barrier protecting New Orleans from storms. The U.S. Geological Survey (USGS) in partnership with the University of New Orleans Pontchartrain Institute for Environmental Sciences undertook an intensive study that included (1) an analysis of island change based on historical maps and remotely sensed shoreline and topographic data; (2) a series of lidar surveys at 3- to 4-month intervals after Hurricane Katrina to determine barrier island recovery potential; (3) a discussion of sea level rise and effects on the islands; (4) an analysis of sea floor evolution and sediment dynamics in the refuge over the past 150 years; (5) an assessment of the local sediment transport and sediment resource availability based on the bathymetric and subbottom data; (6) a carefully selected core collection effort to groundtruth the geophysical data and more fully characterize the sediments composing the islands and surrounds; (7) an additional survey of the St. Bernard Shoals to assess their potential as a sand resource; and (8) a modeling study to numerically simulate the potential response of the islands to the low-intensity, intermediate, and extreme events likely to affect the refuge over the next 50 years.

Results indicate that the islands have become fragmented and greatly diminished in subaerial extent over time: the southern islands retreating landward as they reorganize into subaerial features, the northern islands remaining in place. Breton Island, because maintenance of the Mississippi RiverGulf Outlet (MRGO) outer bar channel requires dredging, is deprived of sand sufficient to sustain itself. Regional sediment transport trends indicate that large storms are extremely effective in transporting sand and controlling the shoreline development and barrier island geometry. Sand is transported north and south from a divergent zone near Monkey Bayou at the southern end of the Chandeleur Islands. Numerical simulation of waves and sediment transport supports the geophysical results and indicates that vast areas of the lower shoreface are affected and are undergoing erosion during storm events, that there is little or no fair weather mechanism to rework material into the littoral system, and that as a result, there is a net loss of sediment from the system. Lidar surveys revealed that the island chain immediately after Hurricane Katrina lost about 84 percent of its area and about 92 percent of its prestorm volume. Marsh platforms that supported the islands' sand prior to the storm were reduced in width by more than one-half. Repeated lidar surveys document that in places the shoreline has retreated about $100 \mathrm{~m}$ under the relatively low-energy waves since Hurricanes Katrina and Rita; however, this retreat is nonuniform.

Recent high-resolution geophysical surveys of the sea floor and subsurface within 5-6 km of the Chandeleur Islands during 2006 and 2007 show that, in addition to the sand that is rebuilding portions of the island chain, a large volume of sand is contained in Hewes Point, in an extensive subtidal spit platform that has formed at the northern end of the Chandeleur Islands. Hewes Point appears to be the depositional terminus of the alongshore transport system. In the southern Chandeleurs, sand is being deposited in a broad tabular deposit near Breton Island called the southern offshore sand sheet. These two depocenters account for approximately 70 percent of the estimated sediment volume located in potential borrow sites. An additional large potential source of sand for restoration lies in the St. Bernard Shoals, which are estimated to contain approximately $200 \times 10^{6} \mathrm{~m}^{3}$ of sand.

Successful restoration planning for the Breton National Wildlife Refuge should mimic the natural processes of early stages of barrier island evolution including lateral transport to the flanks of the island chain from a centralized sand source that will ultimately enhance the ability of the islands to naturally build backbarrier marsh, dunes, and a continuous sandy shoreline. Barrier island sediment nourishment should be executed with the understanding that gulf shoreline erosion is inevitable but that island area can be maintained and enhanced during retreat (thus significantly prolonging the life of the island chain) with strategic sand placement.

\section{Executive Summary}

Breton National Wildlife Refuge comprises a number of Louisiana barrier islands trending north-south from the northern Chandeleur Islands to Breton Island in the south. In addition to providing habitat and nesting areas for

${ }^{1}$ U.S. Geological Survey, Stennis Space Center, Miss. 
endangered species (for example, brown pelican [Pelecanus occidentalis], least tern [Sterna antillarum], piping plover [Charadrius melodus]) and other wildlife species (nesting and wading birds, waterfowl, rabbits, raccoons, and loggerhead sea turtles [Caretta caretta]), the refuge provides an initial barrier to storms for the southeastern Louisiana wetlands and is a fundamental component of the geomorphologic features that protect the metropolitan New Orleans area. The refuge has been impacted by hurricanes throughout history but never as severely as by Hurricanes Katrina and Rita in 2005. The severity of damage brings into question what the future configuration of the island chain will be, what protective function the islands will provide for the mainland wetlands and New Orleans, and whether the refuge can continue to provide the same level of functional habitat for endangered species and other wildlife as it did prior to the 2005 hurricanes.

The U.S. Geological Survey (USGS) in partnership with the University of New Orleans Pontchartrain Institute for Environmental Sciences undertook an intensive year-long study to provide the U.S. Fish and Wildlife Service (USFWS) with information needed to answer these questions and make management decisions relating to the future of the Breton National Wildlife Refuge. The effort built on a previous bathymetric data collection effort funded by the Louisiana Coastal Area Science and Technology Program (jointly funded by the Louisiana Department of Natural Resources and the U.S Army Corps of Engineers) that surveyed all of the sandy shorelines of Louisiana. The USFWS effort included (1) an analysis of island change based on historical maps and remotely sensed shoreline and topographic data; (2) a series of lidar surveys at 3- to 4-month intervals after Hurricane Katrina to document barrier island recovery; (3) a discussion of sea level rise and its effect on the islands; (4) an analysis of bathymetric data to document sea floor evolution and sediment dynamics in the refuge over the last 150 years; (5) an assessment of the local sediment transport and sediment resource availability based on bathymetric and subbottom data; (6) a carefully selected core collection effort to groundtruth the geophysical data and more fully characterize the sediments composing the islands and surrounds; (7) an additional survey of the St. Bernard Shoals to assess their potential as a sand resource; and (8) a modeling study to numerically simulate the potential response of the islands to the low-intensity, intermediate, and extreme events likely to affect the refuge over the next 50 years. Results from these efforts can be found in the eight chapters (chaps. A-H) that form the main body of this report. The main conclusions of the team can be found in the final synthesis chapter (chap. I). Metadata and information used to support the conclusions in each chapter can be found in the appendixes.

\section{Chapter A. Shoreline Change}

Of the more than 50 hurricanes that have impacted the Breton National Wildlife Refuge during the past century, 9 were severe. An analysis of shoreline change as a function of hurricane impacts clearly demonstrates that the erosional damage caused by the passage of Hurricane Katrina in 2005 was extremely large when compared with the shoreline erosion that resulted from all of the other hurricane passages during the 20th century. During the 20th century the Chandeleur Islands were characterized by shoreline erosion and island arc rotation due to varying rates of erosion along the shoreline. Between 1922 and 2004, the average rate of erosion was about $35 \mathrm{ft} / \mathrm{yr}$. The amount of erosion due to Hurricane Katrina was an unprecedented $661 \mathrm{ft}$ during the short time period of the hurricane's passage. Simply extrapolating the measured data in a linear fashion with appropriate error bars shows that the islands may persist until about 2064 if there are no future storms the magnitude of Hurricane Katrina. The islands may, however, become shoals or disappear entirely between 2013 and 2037 if one more Katrina-like storm affects the islands.

\section{Chapter B. Recovery Potential}

For nearly 2 years after Hurricane Katrina in 2005 removed 86 percent of the surface area of Louisiana's Chandeleur Islands, most of the island chain continued to erode rapidly. Feedback processes triggered by the hurricane enhanced this erosion even under relatively mild, poststorm conditions and pushed the island chain closer to complete submergence.

Lidar surveys revealed that the island chain immediately after Hurricane Katrina lost about 84 percent of its area and about 92 percent of its volume in comparison to the area and volume of the islands in 2002 (after Hurricane Lili). Peak elevations were reduced from more than $6 \mathrm{~m}$ to less than 3 $\mathrm{m}$, and the marsh platforms that supported the islands' sand prior to the storm were reduced in width by more than onehalf. During Katrina, all of the sand visible from the air was removed from the island, leaving only marshy outcrops. No dunes or beaches survived the storm. Sea, Lake and Overland Surges for Hurricanes (SLOSH) model calculations of storm surge compared to lidar elevations on the island show that the islands went entirely underwater during the later stages of the storm and were essentially a submerged shoal as opposed to a situation where waves simply lapped over the tops of the islands. USGS aerial photograph surveys 2 months after the storm showed conclusively that the island was still eroding rapidly after the storm, although some of the subsequent 
erosion may have been caused by Hurricane Rita, which made landfall in September 2005. Repeated lidar surveys document that in places the shoreline has retreated about $100 \mathrm{~m}$ under the relatively low-energy waves since Hurricanes Katrina and Rita; however, this retreat is not uniform. In other places (about 44 percent of the gulf shoreline) spits and welded swash bars have built the shoreline seaward.

The Chandeleur Islands are sand starved. Their original source of sand was a delta lobe deposited by the Mississippi River; however, about 1,800-2,000 years ago, the Mississippi River changed course, cutting off the sediment supply to the delta lobe. As the lobe eroded landward from lack of new sediment, it also compacted from its own weight, leaving the beach detached from the mainland and forming the remnant barrier islands of the Breton National Wildlife Refuge. With continued subsidence and sand starvation, the islands are forecast to become smaller and lower and eventually sink beneath the sea. The eventual demise of the Chandeleur Islands will depend on the frequency and/or intensity of future storms and the rate of sea level rise.

\section{Chapter C. Potential Effects of Sea Level Rise on the Chandeleur Islands}

Coastal regions are characterized by dynamic landforms and processes because they are the intersection between land, ocean, and atmosphere. The global climate is changing because of large population increases, the burning of fossil fuels, and land-use change over the past century. Warming of the global climate is unequivocal, but the effects of climate change are highly variable across regions and difficult to predict with high confidence when they are based on limited observations. Features such as barrier islands, bluffs, dunes, and wetlands constantly undergo change because of driving processes such as storms, sediment supply, and sea level change. Sea level rise will have profound effects by increasing flooding frequency and inundating low-lying coastal areas, but other processes such as erosion and accretion will have cumulative effects that are profound but not yet predictable. The consensus in the climate science community is that relative sea level rise (the combination of sea level rise and the land sinking) for the northern Gulf of Mexico coast is much greater than the average global sea level rise. Two direct effects of atmospheric warming on the Chandeleur Islands and other coasts are accelerated sea level rise and a likely increase in storm intensity. Recent scientific opinion holds that coastal landforms such as barrier islands, including the Chandeleur Islands, have tipping points from sea level rise and storms. Once this point is reached, rapid and irreversible change happens to the islands.
Coastal regions are often managed under the premises that sea level rise is not significant, that shorelines are static or can be fixed in place by engineering structures, that storms are regular and predictable, and that the physical processes driving coastal change are linear. The new reality of sea level rise and increased storminess due to climate change requires an understanding that coasts and barrier islands are dynamic and are best maintained by allowing natural processes to function.

\section{Chapter D. Sea Floor Evolution and Sediment Dynamics}

Shoreline and sea floor change analyses based on historical hydrographic data (dating from 1863), shoreline surveys (dating from 1855), and satellite imagery of the Chandeleur Islands reveal long-term trends of barrier shoreface retreat, barrier thinning, and recently, barrier disintegration. Volume calculations indicate that about $150 \times$ $10^{6} \mathrm{~m}^{3}$ of sediment has been deposited northward and seaward off Hewes Point, La., during the past 125 years. A similar volume of sediment has accreted at the extreme southern limits of the island chain (south of Breton Island); however, the volume deposited in the backbarrier (behind the islands) is only half that distributed to the flanks. The dominant transport direction is north and south from a midpoint (near Monkey Bayou [see location in fig. 4 in chap. D]) in the island chain. The depositional sinks at the flanks of the island arc accreted at rates of more than $1 \times 10^{6} \mathrm{~m}^{3} \mathrm{yr}^{-1}$ between 1870 and 2007 . The sediment sources for these accretionary zones at the flanks include (1) relict deltaic deposits eroded from the shoreface where about $790 \times 10^{6} \mathrm{~m}^{3}$ of erosion has occurred since 1870 and (2) nearshore and subaerial barrier sand. Long-term shoreline erosion and submergence of the islands are driven by pulses of rapid land loss triggered by storm events. The islands do not fully recover from storm impacts because sand is transported to the flanks of the arc, thus removing it from the littoral system; however, these sand reservoirs may provide a unique, quasi-renewable resource for nourishing the barrier system.

\section{Chapter E. Geologic Mapping of Potential Resources-Geophysics}

Recent high-resolution geophysical surveys of the sea floor and subsurface within 5-6 km of the Chandeleur Islands during 2006 and 2007 were used to map and describe shallow stratigraphy and potential sand resources within the Breton National Wildlife Refuge. These data, in concert with 
vibracore analyses, were utilized to map the distribution of the barrier island sand sheet and identify additional sand deposits that could serve as borrow areas if island renourishment is pursued.

Between 1880 and 2006, erosion dominated along the mid to southern extent of the island arc, whereas accretion has dominated along the backbarrier as washover deposits and to the north as spit growth. To date, sand accumulation onshore does not approach the pre-Hurricane Katrina sand volume of the barrier arc. Preliminary analyses of cores taken in 2007 and 2008 suggest that more sand was transported alongshore during the hurricane than moved across the island chain by washovers.

In addition to the sand that is rebuilding the island chain and closing tidal passes, a large volume of sand is contained in Hewes Point in an extensive subtidal spit platform that has formed at the northern end of the Chandeleur Islands. Hewes Point appears to be the depositional terminus of the alongshore transport system where sand is deposited in water that is deep enough for the sand to be removed from the littoral zone. In the southern Chandeleurs, sand is being transported southward from a littoral divergence zone near Monkey Bayou and is being deposited in a broad tabular deposit near Breton Island called the southern offshore sand sheet. Hewes Point (containing approximately $379 \mathrm{~m}^{3}$ of sediment) and the southern offshore sand sheet deposit account for approximately 70 percent of the estimated sediment volume located in the potential borrow sites.

An additional four potential sand resource sites within the Chandeleur Islands study area have been mapped. These four are distributary channel deposits associated with the formation of the delta upon which the islands stand. These deposits are significantly smaller in volume and generally have a lower and more variable sand content than the Hewes Point deposit. These sand deposits are in shallow enough water that sand from these deposits may potentially be redistributed by storms originating to the south.

\section{Chapter F. Geologic Mapping of Potential Resources-Cores}

The textural composition of the deposits identified by the seismic data was defined by vibracores collected throughout the northern half of the Breton National Wildlife Refuge. The textural composition of the four distributary channel deposits is a function of fluvial energy and proximity to the distributary mouth from which they were derived. The distributaries deposited sand-size sediments directly at the river mouth (mouth bar and delta front) and carried the fine-grained materials in suspension farther away from the distributaries, where they settled into extensive blankets of mud across the sea floor. The four distributary sites generally have a sand content of about 53 percent (about 47 percent mud), but the sand content is highly variable within individual cores. The sands in Hewes Point and the southern offshore sand sheet deposits are broad tabular deposits of sand. The sands in the Hewes Point deposit are relatively clean (approximately 90 percent sand), but the sand content of the southern offshore sand sheet is unknown because no cores are available from there.

\section{Chapter G. St. Bernard Shoals}

A final large potential source of sand for restoration may lie in the St. Bernard Shoals. The St. Bernard Shoals system comprises 61 discrete sand bodies ranging in aerial extent from $0.05 \mathrm{~km}^{2}$ to $44 \mathrm{~km}^{2}$. Individual shoals are separated into two different fields: the larger shoal field lies in the southern part of the system in 16-20 m of water, and the smaller one lies $5 \mathrm{~km}$ northwest of the larger field in $15 \mathrm{~m}$ of water. The shoal complex is estimated to contain approximately $200 \times$ $10^{6} \mathrm{~m}^{3}$. The southern, larger shoal field contains $192 \times 10^{6} \mathrm{~m}^{3}$ of sand ( 92 percent of the total volume). Sediment analyses indicate that sand found in the shoals is fine to very fine (2-2.5 phi), tan to gray in color, and well sorted. The shoals are all very similar in distribution of sediment types which resulted from deposition in fluvial channels and are similar to and probably derived from the same source as the sediments that form the Chandeleur Islands.

\section{Chapter H. Numerical Simulation of Waves and Sediment Transport}

A numerical simulation of waves and sediment transport was undertaken to quantify the response of the island chain to low-intensity, intermediate, and extreme events, as well as their recovery after such events. The modeling output indicates that the islands are undergoing high rates of sediment transport in the northward direction during high-intensity and intermediate storms, that vast areas of the lower shoreface are affected and are undergoing erosion during these events, that there is little or no fair weather mechanism to rework material into the littoral system, and that as a result there is a net loss of sediment from the system.

\section{Implications for Management Planning}

If the decision is made to restore any portions of the Breton National Wildlife Refuge, the restoration techniques should mimic the natural processes of early stages of barrier island evolution. These natural processes include lateral transport to the flanks of the island chain from a centralized sand source that will ultimately enhance the ability of the 
islands to naturally build backbarrier marsh, dunes, and a continuous sandy shoreline. Barrier island sediment nourishment should be executed with the understanding that gulf shoreline erosion is inevitable but that island area can be maintained and enhanced during retreat (thus significantly prolonging the life of the island chain) with strategic sand placement if the following criteria are met:

1. Nourishment sand recovered from deepwater sinks at the flanks of the island arc is reintroduced to the barrier sand budget at a centralized location that is chosen on the basis of longshore sediment transport predictions;

2. Distribution of naturally occurring hurricane-cut passes is maintained as storm surge/overwash pathways;

3. Sand is placed at a centralized location along the island arc where it will naturally disperse to the flanks;

4. Sand reserves are strategically placed in the backbarrier as shore-perpendicular platforms over which the island can migrate; and

5. A naturally well-established (decadal to century-scale) backbarrier vegetation is maintained for long-term sustainability.

Breton Island, because of its unique position and importance to habitat, might be treated somewhat differently. Breton Island has been sediment starved because of maintenance dredging of the Mississippi River-Gulf Outlet updrift of the island, resulting in rapid island degradation. The island is in need of immediate sand nourishment. A significant amount of sediment has accumulated downdrift (south) of Breton Island and can potentially be mined with minimal negative effect on the local hydrodynamics. 
Publishing support provided by Lafayette Publishing Service Center 


\section{Hurricane Impact and Recovery Shoreline Change Analysis and Historical Island Configuration: 1700s to 2005}

By Sarah Fearnley, Michael Miner, Mark Kulp, Carl Bohling, Luis Martinez, and Shea Penland

Chapter A of

Sand Resources, Regional Geology, and Coastal Processes of the Chandeleur Islands Coastal System: an Evaluation of the Breton National Wildlife Refuge

Edited by Dawn Lavoie

In cooperation with the U.S. Fish and Wildlife Service

Scientific Investigations Report 2009-5252 


\title{
U.S. Department of the Interior \\ KEN SALAZAR, Secretary \\ U.S. Geological Survey \\ Marcia K. McNutt, Director
}

\section{U.S. Geological Survey, Reston, Virginia: 2009}

\author{
This and other USGS information products are available at http://store.usgs.gov/ \\ U.S. Geological Survey \\ Box 25286, Denver Federal Center \\ Denver, C0 80225 \\ To learn about the USGS and its information products visit http://www.usgs.gov/ \\ 1-888-ASK-USGS
}

\begin{abstract}
Any use of trade, product, or firm names is for descriptive purposes only and does not imply endorsement by the U.S. Government.

Although this report is in the public domain, permission must be secured from the individual copyright owners to reproduce any copyrighted materials contained within this report.
\end{abstract}

Suggested citation:

Fearnley, S., Miner, M., Kulp, M., Bohling, C., Martinez, L., and Penland, S., 2009, Chapter A. Hurricane impact and recovery shoreline change analysis and historical island configuration-1700s to 2005, in Lavoie, D., ed., Sand resources, regional geology, and coastal processes of the Chandeleur Islands coastal system - an evaluation of the Breton National Wildlife Refuge: U.S. Geological Survey Scientific Investigations Report 2009-5252, p. 7-26. 


\title{
Chapter A. Hurricane Impact and Recovery Shoreline Change Analysis and Historical Island Configuration: 1700s to 2005
}

\author{
By Sarah Fearnley, ${ }^{1}$ Michael Miner, ${ }^{1}$ Mark Kulp, ${ }^{1}$ Carl Bohling, ${ }^{1}$ Luis Martinez, ${ }^{1}$ and Shea Penland ${ }^{1}$
}

\section{Abstract}

Changes of shoreline positions in the Chandeleur Islands in the Breton National Wildlife Refuge, La., have been occurring for thousands of years. In this chapter, results of analyzing the shoreline changes that have occurred since the early 1700 s are presented as part of a larger collaboration among the U.S. Fish and Wildlife Service, the U.S. Geological Survey, and the University of New Orleans Pontchartrain Institute for Environmental Sciences. The goal of this task was to analyze shoreline change data for southeast Louisiana from before and after several major storms and to investigate the relation between hurricane impact intensity and frequency and the amount of linear shoreline erosion to the islands.

Several maps from between 1744 and 1848 were examined to determine the historical position of the islands before the extensive influence of humans. The geomorphic response of the shoreline during the past century was investigated by using maps from five time periods including 1855, 1922, 1989, 2004, and 2005. Hurricane impact and recovery, geomorphic change, and age of discovery maps displaying all the data used in the analysis are available in appendix A-1. Detailed statistical datasets for both the geomorphic shoreline change analysis and the hurricane shoreline change analysis are available in appendixes A-2 and A-3.

Results from historical (1855-2005) shoreline change analysis conducted along the Chandeleur Islands demonstrate that tropical cyclone frequency dominates the long-term evolution of this barrier island chain. Island area changed at a rate of $-0.16 \mathrm{~km}^{2} / \mathrm{yr}$ for the relatively quiescent time period until 1996, when an increase in tropical cyclone frequency accelerated the reduction in island area to a rate of $-1.01 \mathrm{~km}^{2} /$ yr. Shoreline retreat rates were also affected by more frequent hurricanes, increasing from $-11.4 \mathrm{~m} / \mathrm{yr}$ between 1922 and 1996 to $-41.9 \mathrm{~m} / \mathrm{yr}$ between 1982 and 2005. The erosional impact caused by the passage of Hurricane Katrina in 2005 is unprecedented. Between 2004 and 2005, the shoreline of the

${ }^{1}$ University of New Orleans, Pontchartrain Institute for Environmental Sciences, New Orleans, La. northern Chandeleur Islands moved by $-201.5 \mathrm{~m} / \mathrm{yr}$, compared with an average rate of erosion of $-38.4 \mathrm{~m} / \mathrm{yr}$ between 1922 and 2004. A linear regression analysis of shoreline change predicts that the barrier island chain will become devoid of backbarrier marsh as early as 2013 if the storm frequency observed during the past decade persists. If storm frequency decreases to pre-1996 recurrence intervals, the backbarrier marsh is predicted to remain until 2037. The backbarrier marsh is an important controlling factor in stabilizing the barrier chain and maintaining subaerial exposure. Southern portions of the barrier island chain where backbarrier marsh is now absent behave as ephemeral islands that are destroyed after storm impacts and reemerge during extended periods of calm weather, a coastal behavior that will eventually be characteristic of the entire island chain.

\section{Introduction}

The Chandeleur Islands are an 80-km-long arcuateshaped barrier island chain located in southeast Louisiana on the north-central coast of the Gulf of Mexico (fig. 1). These islands are the longest barrier island chain in the gulf and are important because they (1) attenuate storm impacts for mainland Louisiana and Mississippi (Stone and Orford, 2004; Stone and others, 2005), (2) regulate estuarine salinity and circulation (Reyes and others, 2005) for an approximately $8,750-\mathrm{km}^{2}$ estuary that supports a $\$ 2.7$ billion fisheries industry, and (3) provide unique habitat for threatened and endangered species including nesting sea turtles (Caretta caretta, Chelonia mydas), brown pelicans (Pelecanus occidentalis), piping plovers (Charadrius melodus), and least terns (Sterna antillarum) (Poirrier and Handley, 2007). The islands are reworked remnants of the relict St. Bernard Delta Complex of the Mississippi River that was active 3,800-1,800 years before present (BP) (Frazier, 1967; Tornqvistand others, 1996). They are separated from the Louisiana mainland wetlands by the approximately 40-km-wide Breton and Chandeleur Sounds. As a result of this geographic position, the islands are susceptible to the effects of almost any major storm 


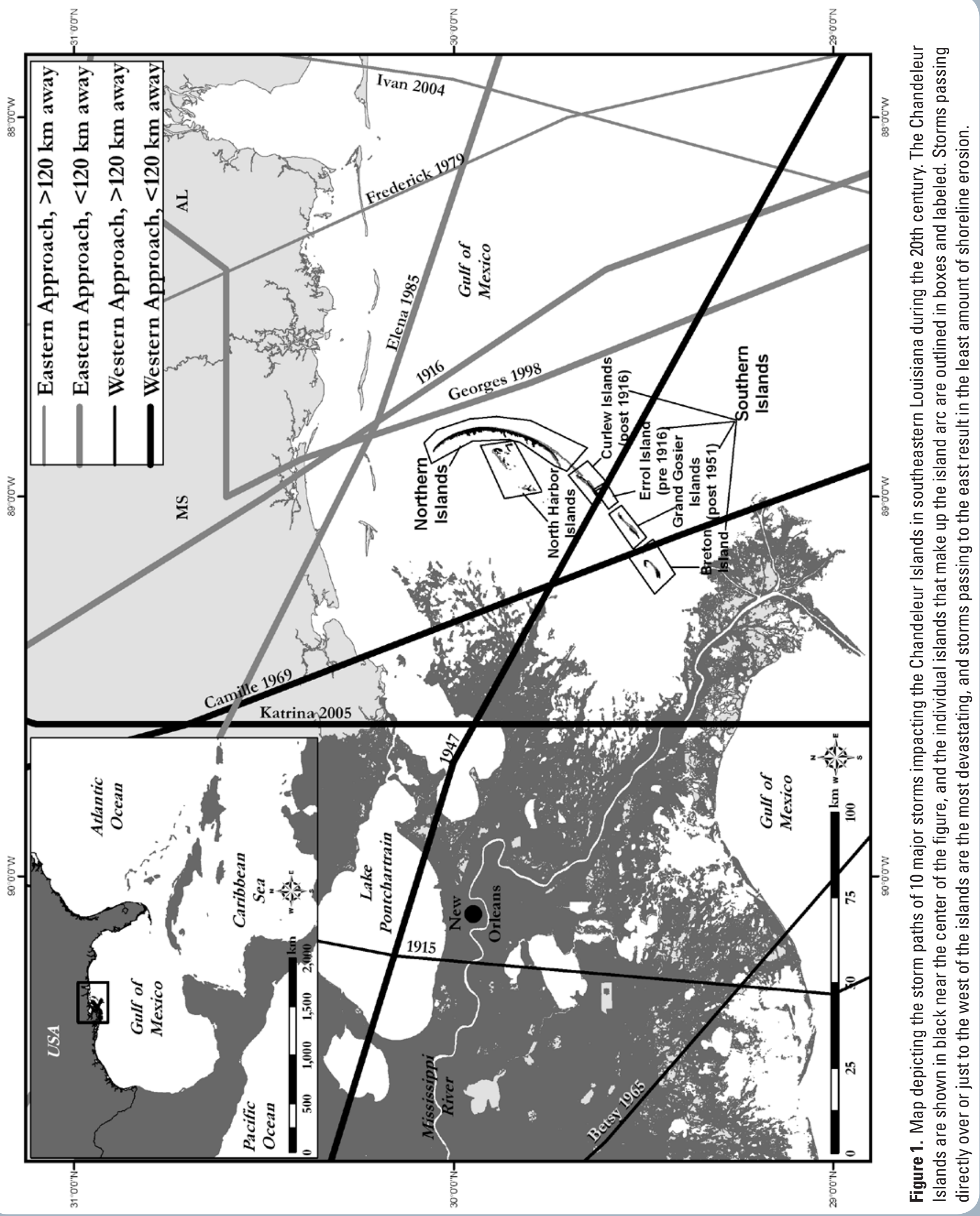


entering the northern Gulf of Mexico and have been impacted by about 42 hurricanes since the early 1900s.

It has been suggested that the long-term evolution of the Chandeleur Islands and their fate are governed by tropical cyclone impacts, which result in a long-term net land loss driven by insufficient poststorm recovery leading to the islands' conversion to an inner shelf shoal through transgressive submergence (Kahn and Roberts, 1982; Penland and others, 1983, 1988; Kahn, 1986; Suter and others, 1988). McBride and others (1992) suggested that the Chandeleur Islands would remain supratidal until the year 2360 on the basis of projected shoreline change and linear regression analysis of island area changes between 1855 and 1989. These predictions did not account, however, for the increase in northern Gulf of Mexico storm frequency and intensity that ensued in the decade following their analysis.

Recent increased storm frequency associated with the impacts of Hurricanes Georges, Ivan, and Katrina during the past approximately 10 years is unprecedented for the Chandeleur Islands during the historical record (1855-2005). These multiple, closely spaced (temporally) storm impacts culminated with those of Hurricane Katrina (Aug. 2005) completely inundating the islands, removing more than 90 percent of the sand, exposing backbarrier marsh along the gulf shoreline to wave attack (Miner and others, this volume), and reducing total island area by about 50 percent. These hurricane impacts have raised new questions regarding the longevity and sustainability of the Chandeleur Islands and their ability to recover from future storms. This study uses spatial analysis techniques to relate historical shoreline position and island area changes for several time periods (dating back to 1855) to hurricane impact frequency and storm intensity. The overall goal is to forecast the timeframe of island conversion to an inner shelf shoal.

\section{History of the Chandeleurs}

The Chandeleur Islands, located in both St. Bernard and Plaquemines Parishes in southeast Louisiana, are the largest barrier island arc in the northern Gulf of Mexico. The islands are remnants of the relict St. Bernard Delta Complex of the Mississippi River and trend north to south unlike the rest of the east-west trending barrier island chains in the northern Gulf of Mexico (Penland and others, 1988). As a result of the barrier chain's remote geographic position and lateral extent, it has been impacted by numerous storms throughout the past century.

Four historical maps of the Chandeleur Islands were used in this analysis to help develop a better understanding of the geomorphic configuration and position of the islands and Biloxi Marshes behind the islands for a time period extending back more than a century before the earliest U.S. Coast Survey maps of the islands were produced. Two maps produced by French geographer J.N. Bellin in 1744 (fig. 2) and 1764 (fig. 3) show similar representations of the location and extent of the islands (app. A-1). The 1778 map produced by British geographer G. Gauld (fig. 4) and the 1845 map produced by an unknown author (fig. 5) show the islands having a similar shape to those on the Bellin maps; however, the location and extent of the Biloxi Marshes to the west of the islands differ on all four maps. Thus, they should be viewed with caution because the various mapmakers' interpretations are not consistent, the dates of the actual surveys are not well documented, and navigation was primitive. Detailed prints of all four historical maps are in the Pontchartrain Institute for Environmental Sciences library at the University of New Orleans.

The barrier island and marshes depicted in the 1778 map by Gauld (fig. 4) are the best representation of the configuration prior to the influence of humans on delta processes. Shorelines that are more resilient to subsidence and erosion than marsh and barrier island shorelines are, such as the Mississippi and Alabama shorelines and the shorelines of Lakes Pontchartrain and Borne (Louisiana Geological Survey, 2008), appear in a similar configuration in Gauld's map to more recent maps, such as the much used 1932 topographic map of Louisiana by the U.S. Geological Survey. In the 1778 map by Gauld, the Chandeleur Islands are shown as two robust barriers separated by a large tidal inlet. The northern islands in 1778 included what became Errol Island until 1916 and Curlew Island until 1951, when Grand Gosier and Curlew became separate islands (figs. 1 and 4). The southern island in 1778 is Breton Island in a position seaward of the northern island. Also apparent is the extension of relict distributary channels along the shoreline of the Biloxi Marshes extending seaward towards the islands.

\section{Hurricane History}

The Chandeleur Islands have been impacted by 9 major storms during the 20th and 21st centuries; however, more than 40 hurricanes of varying strengths have impacted southeast Louisiana during the same time period (table 1; Williams and others, 1992; Yamazaki and Penland, 2001; Stewart, 2004; Knabb and others, 2005). Ten storms were selected for this investigation (see fig. 1). Storms were identified as significant on the basis of proximity to the Chandeleur Islands (passed within $150 \mathrm{~km}$ ) and intensity (winds more than $119 \mathrm{~km} / \mathrm{h}$ ). A 1947 hurricane, estimated to be Category 1 or 2 on the SaffirSimpson Hurricane Scale, was included in the analysis when other Category 1 and 2 storms were excluded because the 1947 hurricane passed directly over the southern Chandeleur Islands (fig. 1).

Hurricanes Frederic (1979), Elena (1985), Georges (1998), and the 1916 hurricane all passed within $120 \mathrm{~km}$ of the islands to the east (fig. 1). During the passage of these storms the eastern eye wall of the storm, where storm surge and windspeeds are the greatest, was seaward (east) of the islands. The 1915 hurricane, the 1947 hurricane, and Hurricanes Camille (1969) and Katrina (2005) passed landward (west) of 


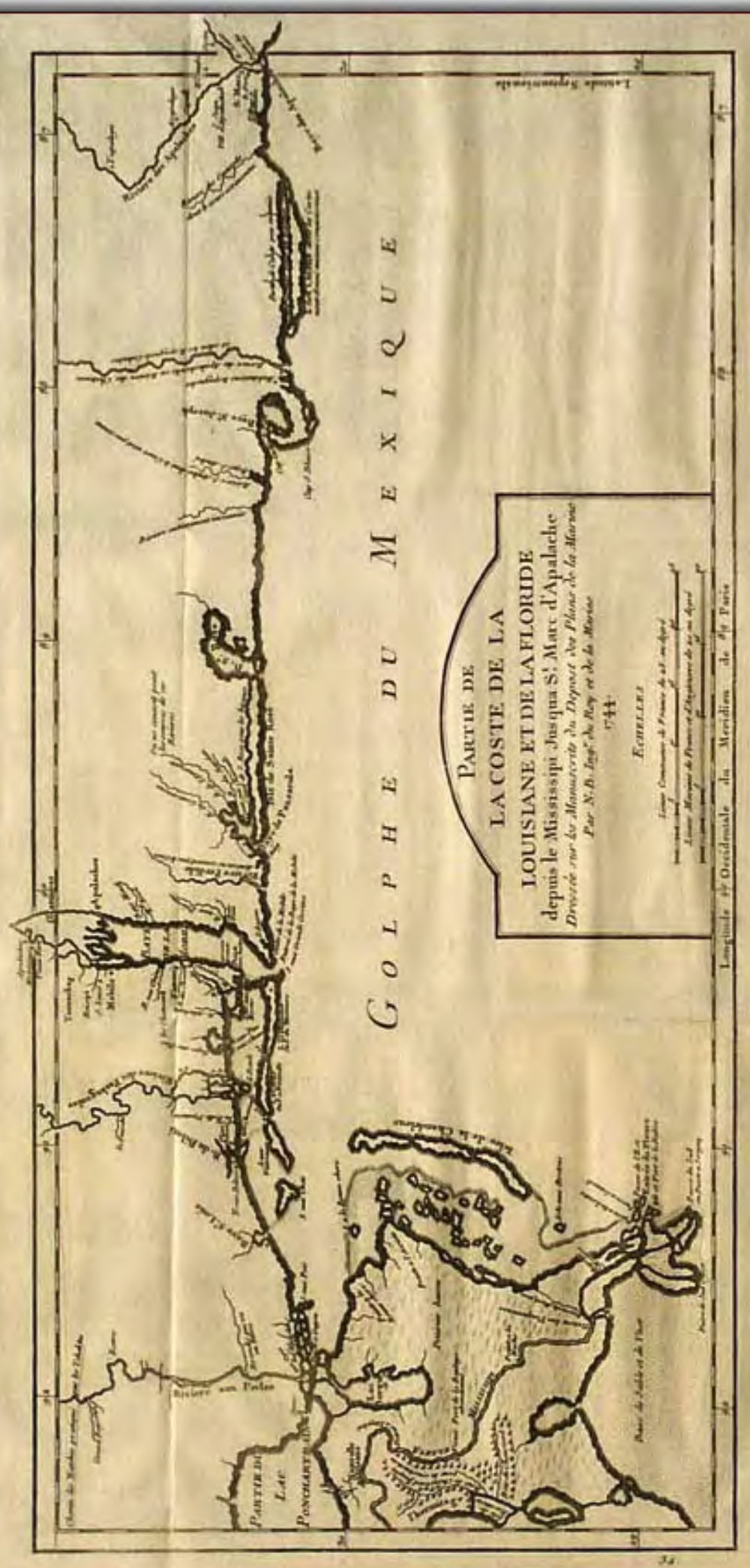

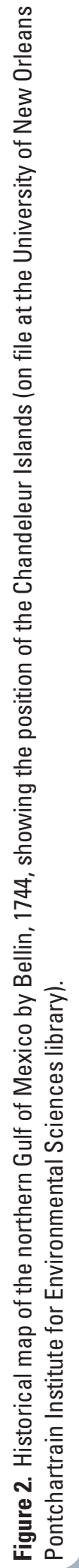



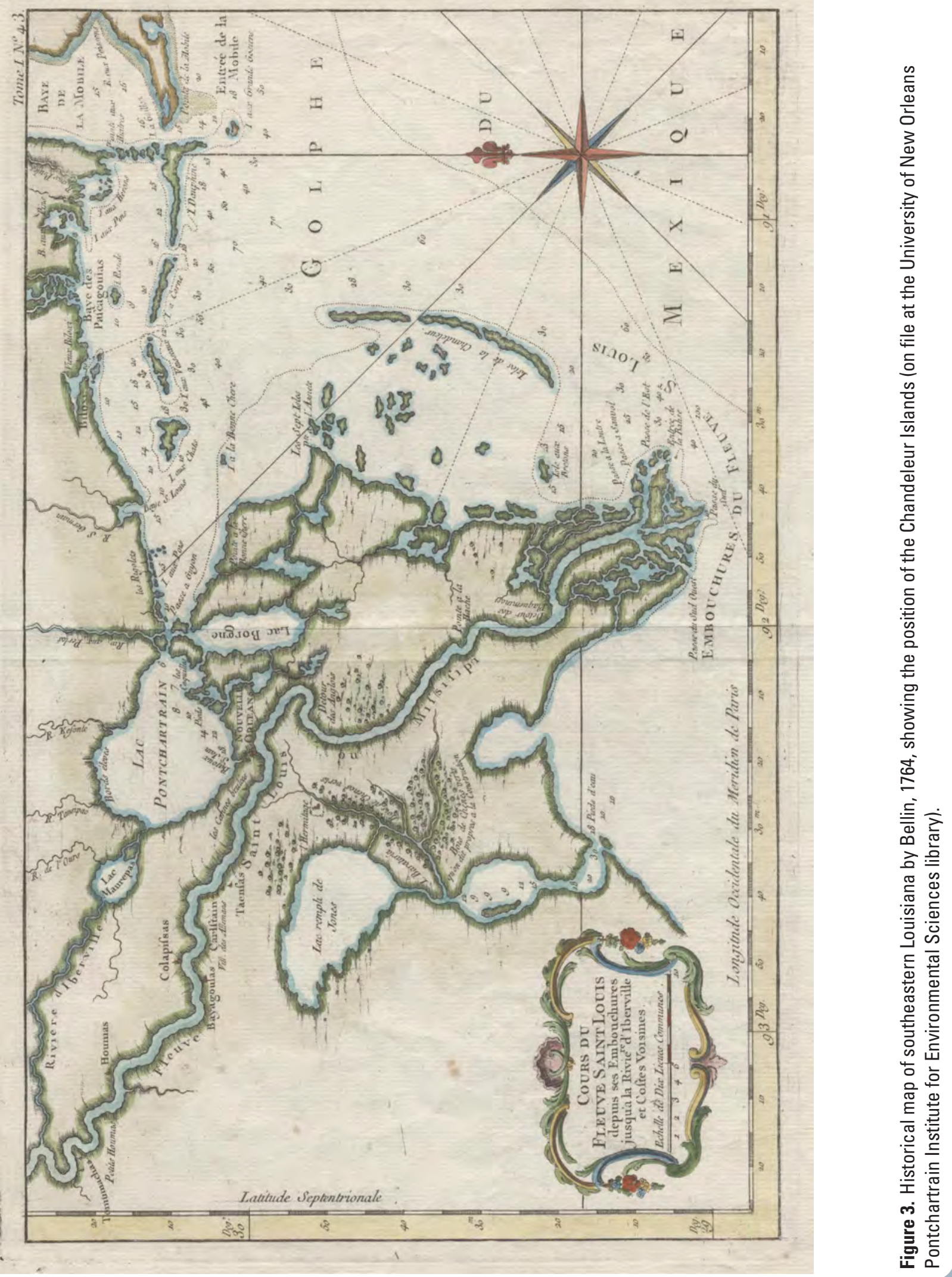


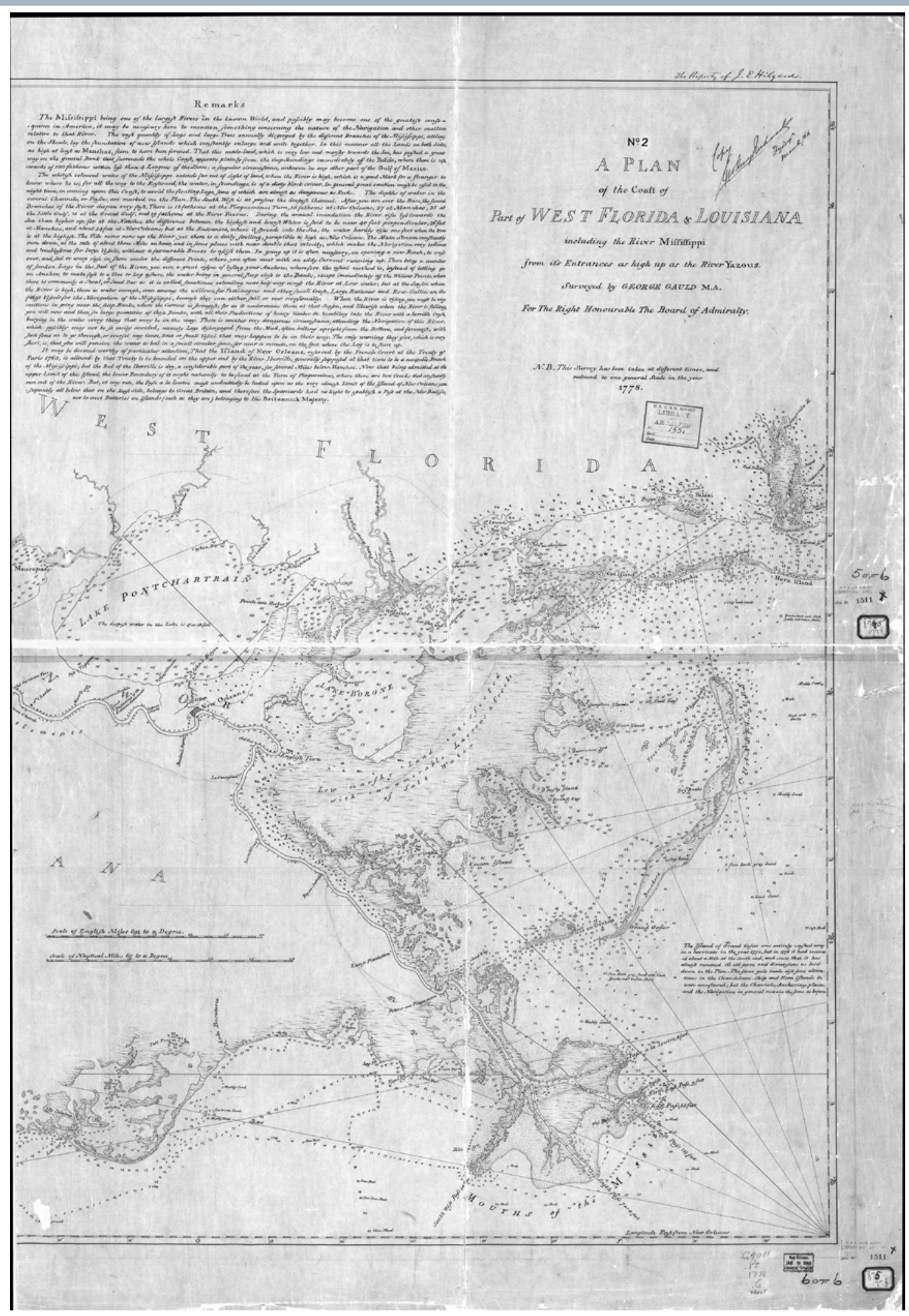

Figure 4. Portion of a larger historical map of the State of Louisiana by Gauld, 1778, showing the Chandeleur Islands and southeastern Louisiana (on file at the University of New Orleans Pontchartrain Institute for Environmental Sciences library). 


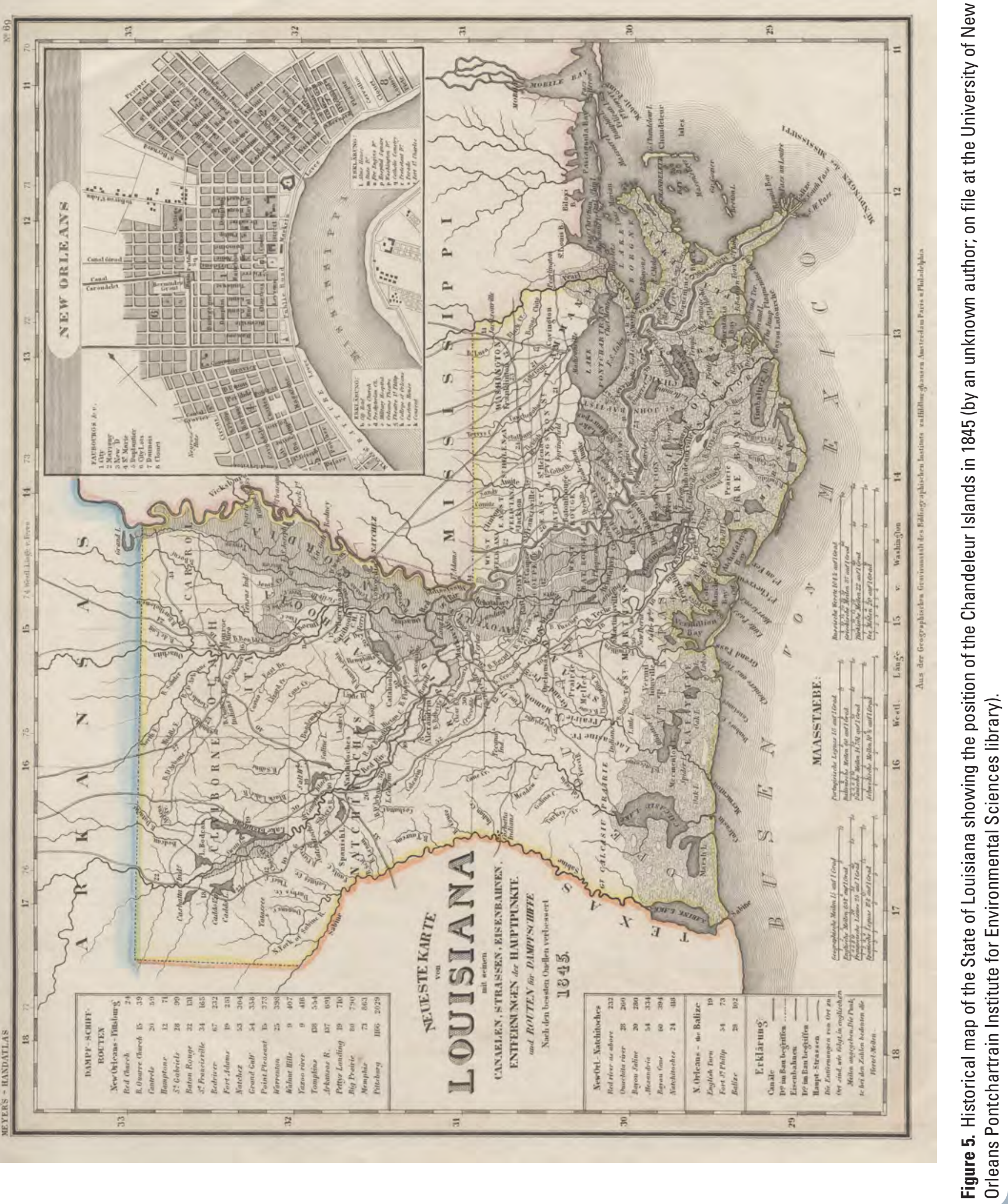


Table 1. A list and descriptions of the major hurricanes to impact the Chandeleur Islands, La., in the 20th century and the dates of the prestorm and poststorm imagery used for this analysis.

\begin{tabular}{cccc} 
Year & Date of \\
landfall & Name & Description & Prestorm \\
imagery date & Poststormagery date \\
\hline
\end{tabular}

4-m storm surge was reported in New Orleans, La. Storm surge at

1915 Sept. 29 No. $6 \quad$ Grand Isle, La., was estimated at 3 m; nearly the entire island was under water.*

1855

1922

1916 July 5 No. 2 Made landfall near Gulfport, Miss., with $>190 \mathrm{~km} / \mathrm{h}$ winds, crossing the Chandeleur Islands, La., as a strong Category 3 storm. ${ }^{\&}$

1855

1922

$>2.5 \mathrm{~m}$ of water flooded New Orleans from this hurricane that

1947 Sept. 19 No. 4 tracked directly over the city, generating a surge that easily overtopped the region's protective levees. ${ }^{*}$

Passed into Louisiana on September 9 with winds $>250 \mathrm{~km} / \mathrm{h}$ after passing over southern Florida. Grand Isle was inundated with a nearly $3 \mathrm{~m}$ surge height. The entire island was covered, and the rest of the inundated area in Louisiana exceeded $12,000 \mathrm{~km}^{2} . *$

One of the most violent storms ever to hit the U.S. mainland.

1969 Aug. $17 \quad$ Camille

Crossed the southern Chandeleurs as a Category 5 storm. A 6-m

1969

1969 storm surge was recorded near New Orleans."

1979 Sept. $12 \quad$ Frederic

Made landfall in southern Alabama, crossing within $16 \mathrm{~km}$ east of the Chandeleur Islands. ${ }^{*}$

1978

Made final U.S. landfall near Biloxi, Miss., with maximum sustained surface winds of $167 \mathrm{~km} / \mathrm{h}$ and a minimum central

1998 Sept. $28 \quad$ Georges
pressure of 96,400,000 MPa. Maximum storm surge in Louisiana was $>2.5 \mathrm{~m}$ at Point a la Hache. The storm severely eroded the Chandeleur Islands. ${ }^{* *}$

Made landfall just west of Gulf Shores, Ala., with winds of $>190$

2004 Sept. $16 \quad$ Ivan
$\mathrm{km} / \mathrm{h}$ and an eye wall diameter of $60-80 \mathrm{~km}$. The storm passed approximately $160 \mathrm{~km}$ to the east of the Chandeleur Islands. ${ }^{+}$

Made landfall on the southern tip of Florida as a Category 1 storm before restrengthening in the Gulf of Mexico and passing into southern Louisiana as a Category 3 storm. Katrina made landfall by crossing the Mississippi River at Buras, La., and then

2005 Aug. $29 \quad$ Katrina
continued north making a third landfall along the LouisianaMississippi border; however, hurricane-force winds extended for $320 \mathrm{~km}$ from the center of the massive $225-\mathrm{km}$-wide eye. The surge, which peaked along the Mississippi Gulf Coast at over 8 $\mathrm{m}$, also flooded $80 \%$ of the city of New Orleans when several levees were breached.+

\footnotetext{
${ }^{*}$ From Williams and others (1992).

${ }^{* * *}$ From Yamazaki and Penland (2001).

${ }^{+}$From Stewart (2004).

${ }^{++}$From Knabb and others (2005).

${ }^{\&}$ From National Hurricane Center (2008).
} 
or directly over the islands (fig. 1). During storms that passed to the west, the islands were directly impacted by the eastern eye wall, and more erosion of the shoreline likely took place than during the passage of storms to the east of the islands.

\section{Methods}

\section{Shoreline Change Analysis}

Linear shoreline change measurements were made from early ground survey data and remotely sensed imagery. The vector shoreline data originated from a variety of sources including georeferenced U.S. Coast and Geodetic Survey (USCGS) topographic surveys (T-sheets) and USCGS hydrographic smooth sheets (H-sheets), black and white and color infrared aerial photography, and satellite imagery. The geometry of the 1855 shoreline is a compilation of an 1869 $\mathrm{T}$-sheet for the southern islands and an $1855 \mathrm{~T}$-sheet for the northern islands. Sources used to determine shoreline position in each of the analysis years are presented in table 2.

ESRI ArcGIS software, version 9.2 (Environmental Systems Research Institute, Inc., Redlands, Calif.), was used to complete all shoreline measurements by using the following steps: (1) obtain shoreline, (2) establish baseline and transects, and (3) calculate shoreline change for each time period relative to the offshore baseline (fig. 6). A more comprehensive documentation of methods, uncertainty analysis, and measurement accuracy can be found in McBride and others (1992), Morton and others (2004), and Martinez and others (2009).

\section{Island Area Calculation}

Island area was determined for the Chandeleur Islands for all years in which polygon shoreline data were available. The polygons represent the entire island boundary from the gulf shoreline to the backbarrier rather than a single line depicting the mean high water mark along the gulf shoreline of the islands.

Island area was plotted against time, and a trend line was fitted to the data, yielding a slope value. Where the trend line intersects with the $\mathrm{x}$-axis (time), the y value (area) will be zero, yielding a date of estimated island conversion to an inner shelf shoal. Trend lines were determined for the entire dataset and also for two intervals within the dataset, one representing a period of lower storm frequency and the other representing a second period of higher storm frequency.

Table 2. Sources of imagery used in the determination of shoreline position of the Chandeleur Islands, La., for each of the analysis years.

[T-sheet refers to topographic sheets; B\&W refers to black and white; CIR refers to color infrared]

Year Original imagery type Imagery source

1855 T-sheet

1922

T-sheet

1951

10-13-1965

B\&W aerial photography

04-1969

10-1969

1978

1982

1996

1998

2002

2004

2005
B\&W aerial photography

$\mathrm{B} \& \mathrm{~W}$ aerial photography

B\&W aerial photography

B\&W aerial photography

CIR aerial photography

CIR aerial photography

CIR aerial photography

QUICKBIRD satellite imagery

QUICKBIRD satellite imagery

QUICKBIRD satellite imagery
U.S. Coast and Geodetic Survey

U.S. Coast and Geodetic Survey

University of New Orleans Pontchartrain Institute for Environmental Sciences

National Oceanic and Atmospheric Administration

Louisiana State University School of the Coast and Environment

Louisiana State University School of the Coast and Environment

Louisiana State University School of the Coast and Environment

National Oceanic and Atmospheric Administration

University of New Orleans Pontchartrain Institute for Environmental Sciences

University of New Orleans Pontchartrain Institute for Environmental Sciences

University of New Orleans Pontchartrain Institute for Environmental Sciences

University of New Orleans Pontchartrain Institute for Environmental Sciences

University of New Orleans Pontchartrain Institute for Environmental Sciences 

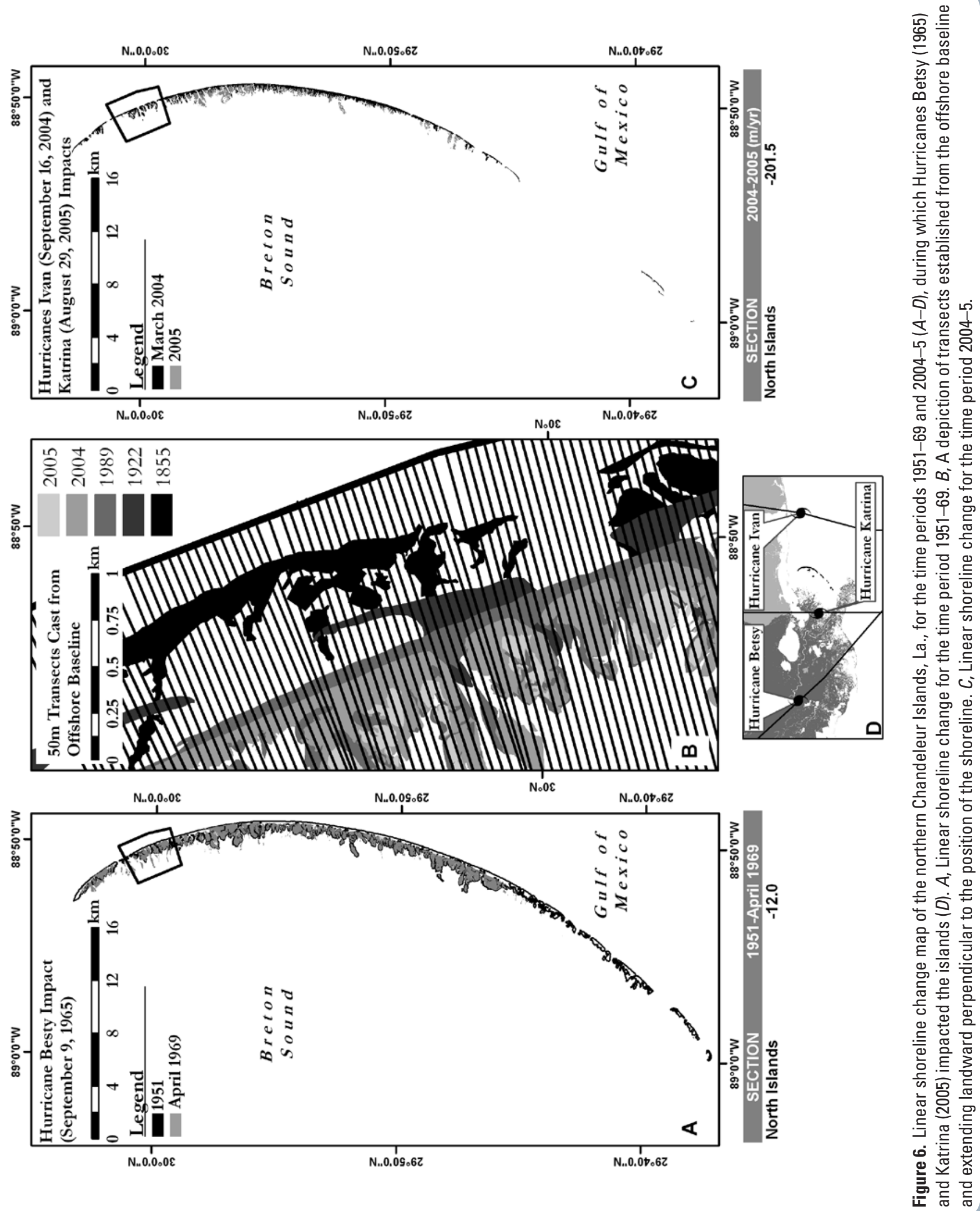


\section{Uncertainty Analysis and Accuracy of Measurements}

Morton and others (2004) attributed error to three categories in this type of shoreline change analysis: (1) measurement errors that affect the accuracy of each shoreline position, (2) sampling errors that do not account for the along-strike variability of shoreline position, and (3) statistical errors associated with compiling and comparing shoreline positions. The largest errors exist because of scales and inaccuracies in the original surveys. T-sheets typically contain the largest measurement and sampling errors on the order of $\pm 10 \mathrm{~m}$; however, the influence of this error is reduced by long time periods between analysis years (McBride and others, 1992). Measurement and sampling errors for more shorelines produced from more recent satellite imagery decreased to $\pm 1 \mathrm{~m}$. These measurements take into account both Global Positioning System (GPS) positioning errors and errors resulting from the resolution of the imagery (Martinez and others, 2009). Error associated with statistical averaging of transect measurements was accounted for by using the standard deviation of the data.

\section{Results}

\section{Northern Chandeleur Islands}

\section{Storm Impact and Poststorm Recovery}

Shoreline change data documenting shoreline response to storm impacts of varying intensities and orientations were compiled for nine storms that affected the Chandeleur Islands between the years 1855 and 2005. Shoreline retreat distance from the baseline versus time is linear for the longest period used in this study (1855-2005). There are two periods during which the distance between the shoreline and the offshore baseline increased: (1) 1965-69 during the recovery period between Hurricanes Betsy and Camille and (2) between 2002 and 2004 just prior to the impact of Hurricane Ivan in 2004 (fig. 7).

The average rate of linear shoreline loss indicates that the distance from the shoreline to the offshore baseline will be equal to the distance from the bayside backbarrier marshes in 2005 to the baseline in 2035 (fig. 7). At this time, 2035, the shoreline will erode to the bayside position of the islands, and the marsh area is predicted to be zero. Transgressive sand bodies will remain for some time after, behaving much like the southern Chandeleur Islands (fig. 8; Miner and others, this volume). Conversion of the northern Chandeleur Islands to an inner shelf shoal, on the basis of the long-term averages in shoreline retreat rates (fig. 7) and average decreasing area of their extent (footprint) (fig. 9), is predicted to occur during the mid to late 2030 s.

The rate of average annual shoreline change per year between storm impacts and in the interstorm periods (recovery phase) demonstrates a relatively constant rate $(-2.0 \mathrm{~m} / \mathrm{yr})$ of shoreline retreat during calm periods that accelerates abruptly after storm impacts (fig. 10). Interestingly, the islands maintained a steady rate of erosion of about $12 \mathrm{~m} / \mathrm{yr}$ between 1922 and 2004. There were brief periods of accretion in the period before Hurricane Camille and in the period after Hurricane Georges but before Hurricanes Ivan and Katrina. Because recovery periods do not reverse the trend of erosion for long periods of time, however, the storm impacts serve to accelerate the long-term retreat rate and have a lasting effect on barrier evolution.

Besides gulf shoreline erosion, the long-term evolution of the northern Chandeleur Islands is characterized by island arc rotation, a reflection of variability in rates of erosion along the shoreline that is possibly a response to altered wave climate associated with progradation of the modern Balize Delta Complex of the Mississippi River (Georgiou and Schindler, this volume; fig. 2). Material eroded from the gulf shoreline and nearshore is transported laterally to the north and south (Miner and others, this volume). Shoreface and gulf shoreline erosion is not balanced by increased land area in the backbarrier or a landward migration of the backbarrier shoreline (Miner and others, this volume); therefore, the islands have undergone thinning, causing a net decrease in area of $44.5 \mathrm{~km}^{2}$ in 1855 to $4.7 \mathrm{~km}^{2}$ in 2005 .

The impacts of Hurricanes Ivan and Katrina along the northern Chandeleur Islands were extreme erosional events, and the average amount of linear shoreline erosion for the two storms combined $(-201.5 \mathrm{~m} / \mathrm{yr})$ was unprecedented throughout the rest of the analysis time period (1855-2004). This period includes the effects of Hurricane Camille, which was a Category 5 storm when it passed directly over the southern Chandeleur Islands but only resulted in an average rate of linear erosion of $-58.5 \mathrm{~m} / \mathrm{yr}$ (fig. 9). When the collective impact of Hurricanes Ivan and Katrina is included in the long-term shoreline change analysis (1855-2005), the rate of erosion is in excess of $-27 \mathrm{~m} / \mathrm{yr}$, more than twice the average rate of linear shoreline erosion $(-12 \mathrm{~m} / \mathrm{yr})$ that was calculated for the time period prior to Hurricane Katrina (1855-2005).

The extraordinary shoreline erosion rates resulting from the impact of Hurricane Katrina were a consequence of both the intensity of the storm (windspeed, wave heights, current velocity, and storm surge elevation) and the storm track west of the islands. The analysis of hurricane impacts and shoreline data indicates that a major hurricane (Category 3 or stronger) crossing just west of the islands causes the most shoreline erosion (fig. 11). 


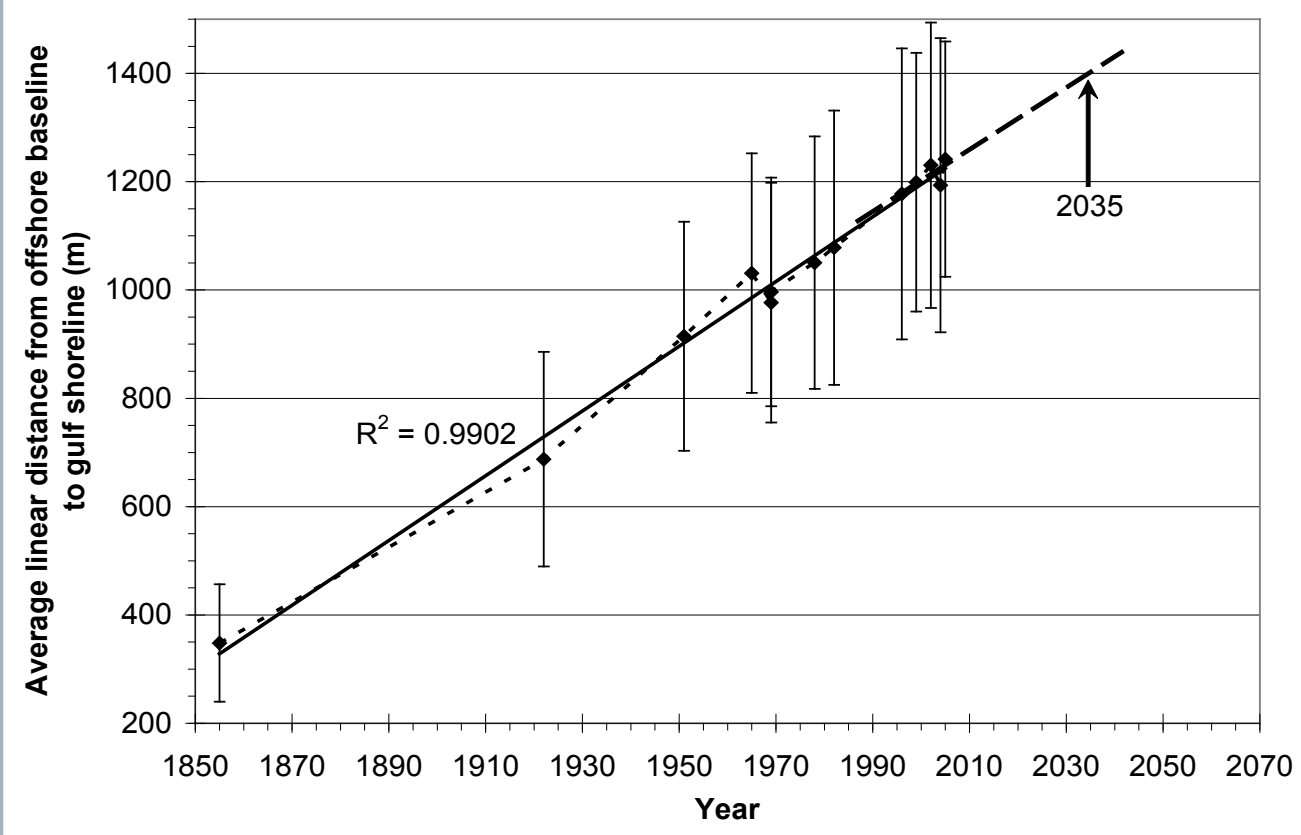

Figure 7. Average linear distance of the shoreline of the northern Chandeleur Islands, La., from the offshore baseline for 13 time periods between 1855 and 2005. The year 2035 is the date at which the rate of linear shoreline loss predicts that the distance from the shoreline to the offshore baseline will be equal to the distance from the 2005 bayside backbarrier marsh shoreline to the offshore baseline. At this time, 2035, the shoreline will erode to the bayside position of the islands, and the area of marsh is expected to be zero. The estimated date of disappearance for the northern Chandeleurs from the shoreline change data (2035) corresponds well with the estimated date of disappearance computed from the area change measurements (2037).

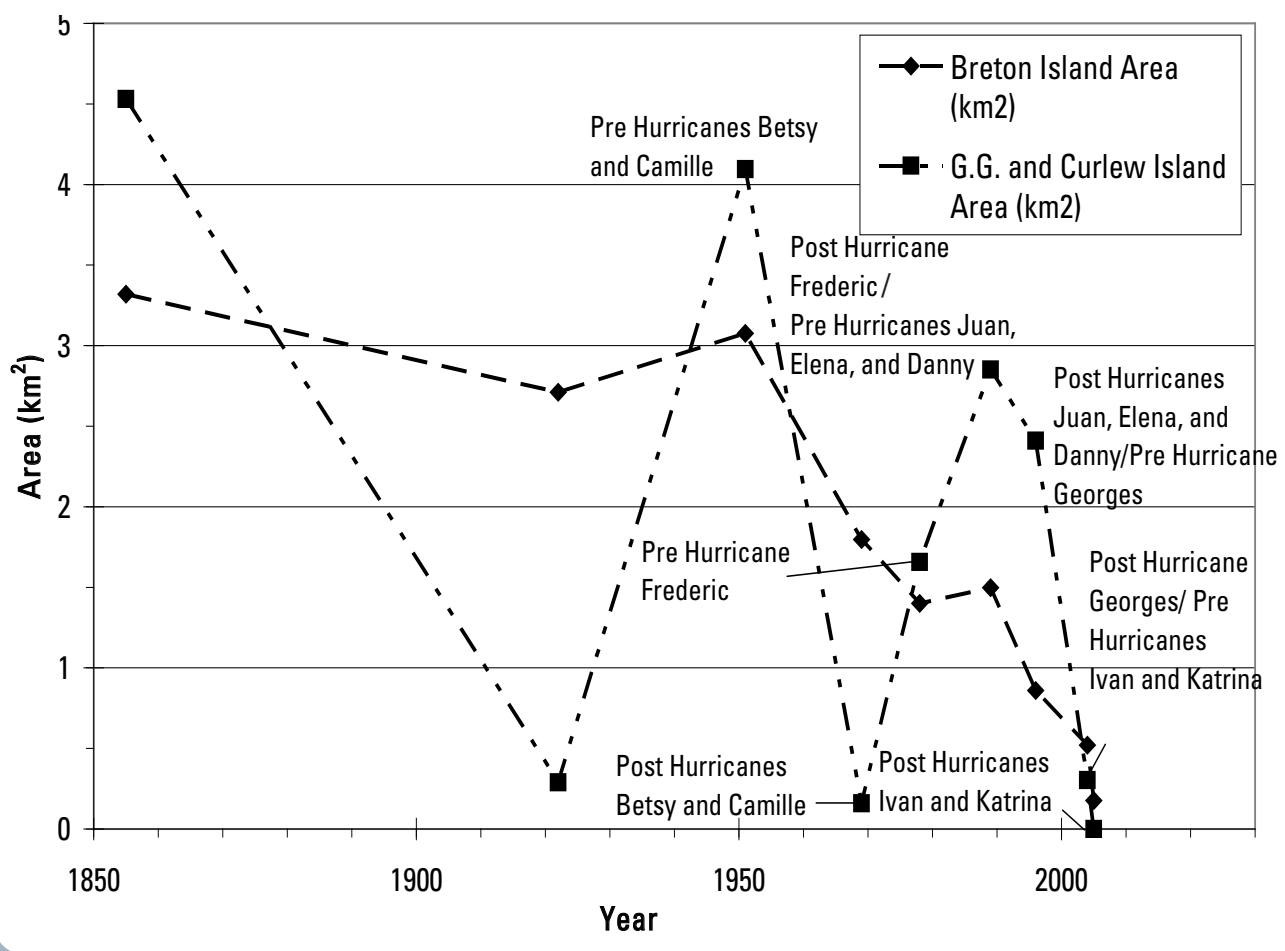

Figure 8. Average island area of the southern Chandeleur Islands, La. (Breton, Grand Gosier [G.G.], and Curlew), based on the measured average annual amount of land change between 1869 and 2005. 


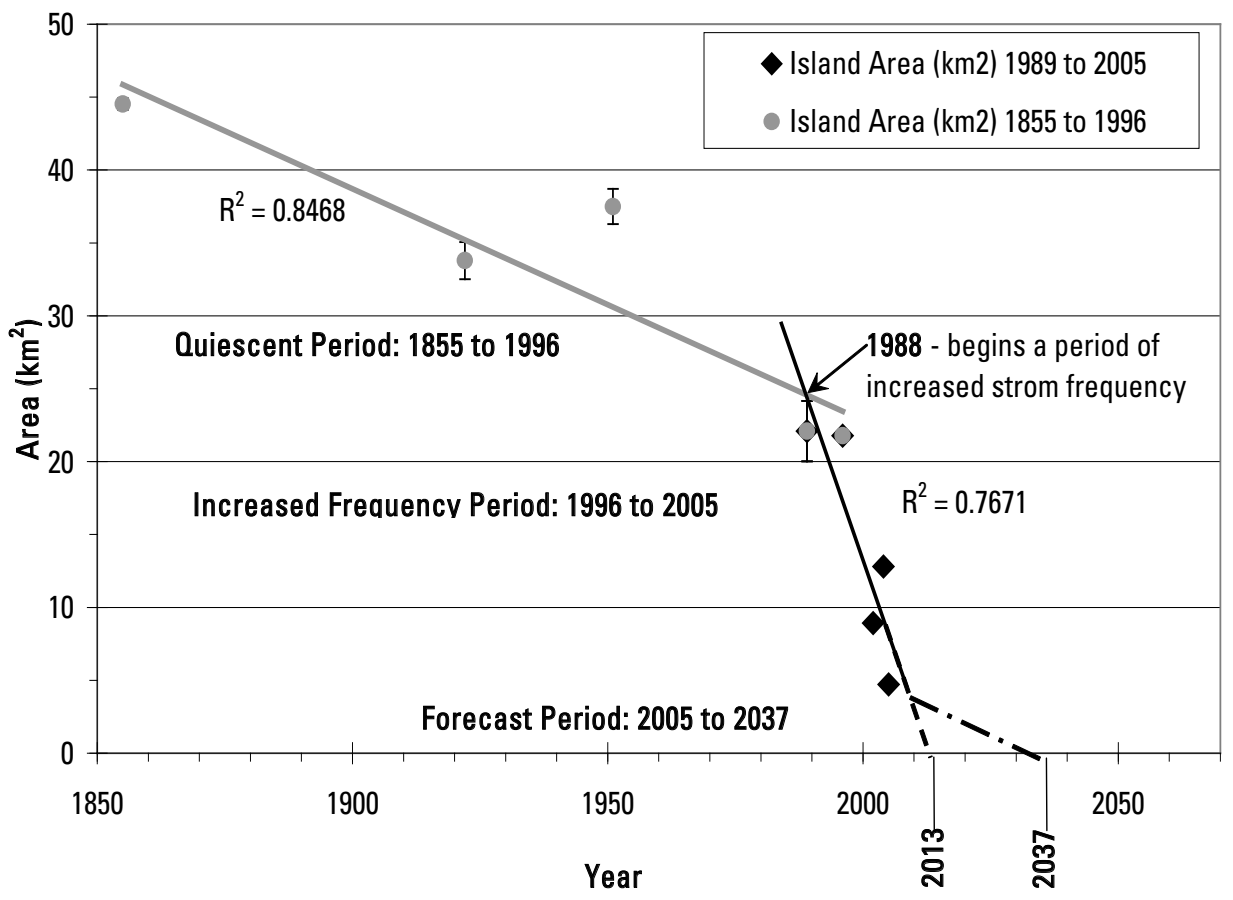

Figure 9. Area of the northern Chandeleur Islands, La., and trend lines for the two time periods 1855-1996 (gray line) and 1989-2005 (black line), which depicts two different trajectories for island survival on the basis of the frequency of storm activity. The dash-dot-dash line depicts the trajectory of the islands in their current state under lower frequency storm conditions such as existed during the earlier half of the 20th century and indicates a disappearance date of 2037.

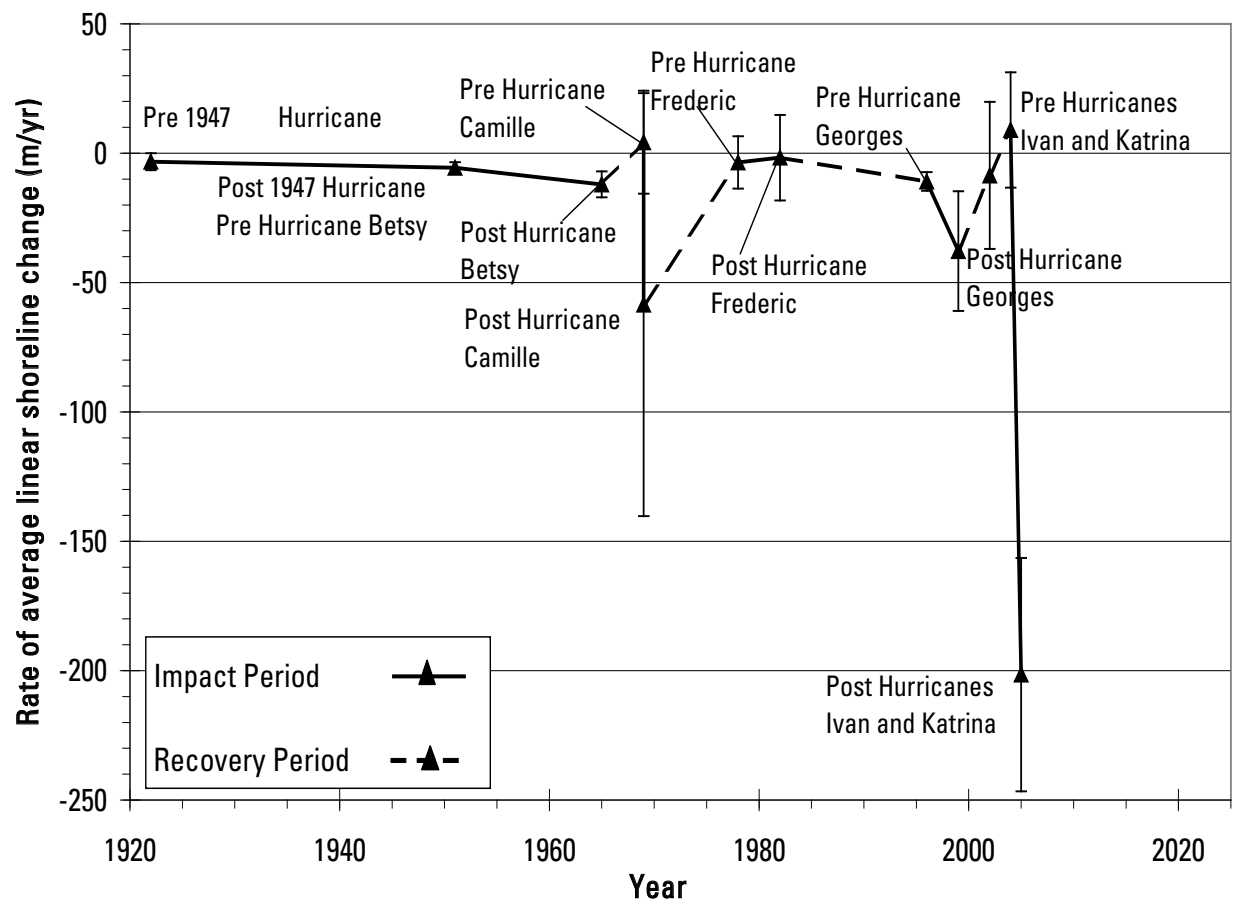

Figure 10. Average linear shoreline change of the northern Chandeleur Islands, La., beginning in 1922 and through the impact period of Hurricane Katrina in 2005. The solid portions of the line indicate periods of storm impact and reflect periods of increased shoreline erosion (average of more than $-35.0 \mathrm{~m} / \mathrm{yr}$ ). The dashed portions of the line indicate periods of recovery between storm impacts. The recovery periods do not always signify an accretionary shoreline but often represent a period of less severe shoreline erosion rates than during previous impact periods and average $-4.7 \mathrm{~m} / \mathrm{yr}$. 


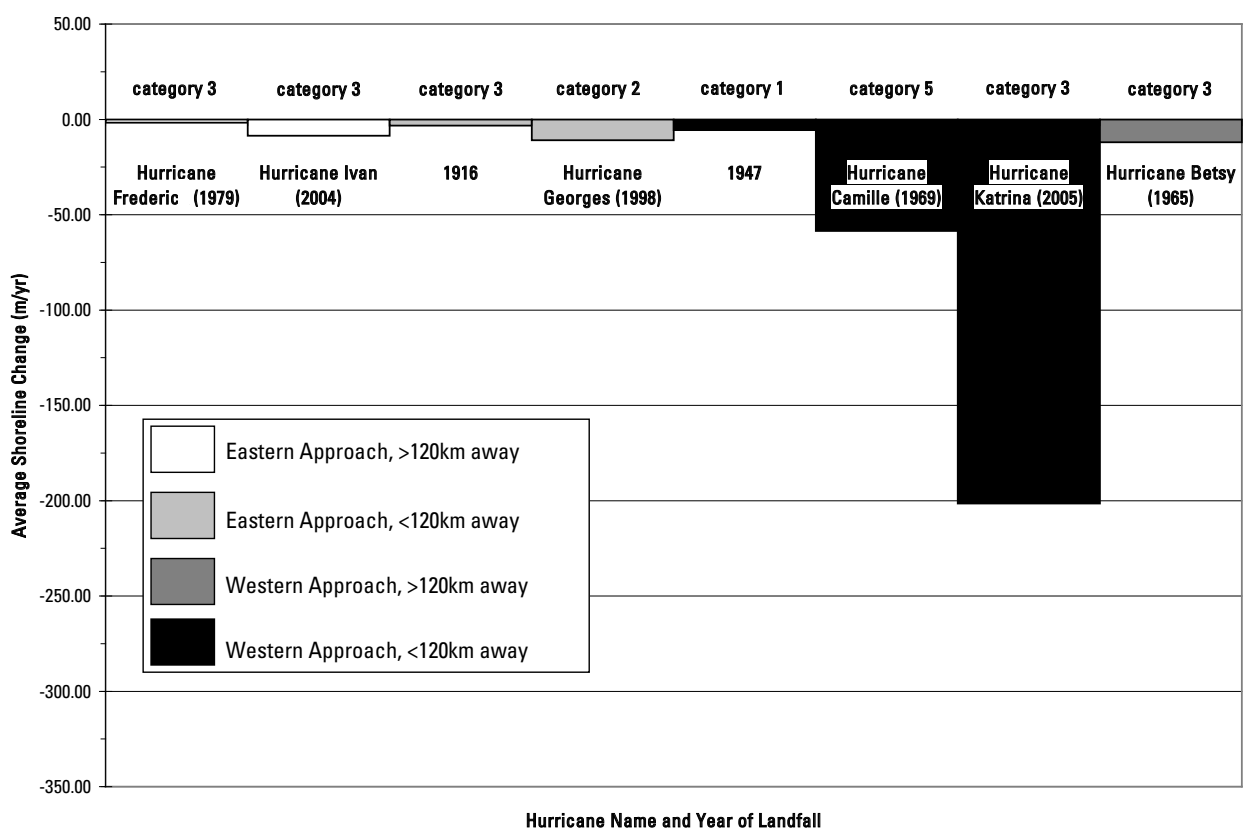

Figure 11. Average shoreline change of the northern Chandeleur Islands, La., of storms of varying intensities and storm tracks. Storms represented by black bars approached the islands from within $120 \mathrm{~km}$ to the west and caused the most severe shoreline erosion. Storms represented by dark gray bars passed the islands from more than $120 \mathrm{~km}$ to the west and were slightly less devastating than those that passed within $120 \mathrm{~km}$ to the west (in black). Storm tracks from the east within $120 \mathrm{~km}$ were even less devastating to the islands (represented by light gray bars), and the least amount of shoreline erosion occurred when storms passed more than $120 \mathrm{~km}$ to the east of the islands (represented by white bars).

\section{Island Area Through Time}

For time periods for which polygon shoreline data are available, island area change was calculated and related to storm impact frequency (fig. 9). Results from a linear regression analysis of the data demonstrate a land loss rate of $-0.16 \mathrm{~km}^{2} / \mathrm{yr}$ between 1922 and 1996 and a land loss rate of $-1.01 \mathrm{~km}^{2} / \mathrm{yr}$ between 1996 and 2005. There is an inflection point at 1996 that indicates a shift from a relatively quiescent period with a storm recurrence interval of five storms within a period of 141 years to a period of high-frequency storms between 1996 and 2005 with a storm recurrence interval of five storms within a period of 9 years. By projecting trends calculated from the linear regression analysis of island area change through time, the expected date of the conversion of the northern Chandeleur Islands to an inner shelf shoal falls between 2013 and 2037 (fig. 9). The earlier date is based on a projected storm frequency consistent with that of the past decade, whereas the later date represents a projected low storm recurrence interval similar to that for the period from 1922 to 1996.

\section{Southern Chandeleur Islands}

\section{Storm Impact and Recovery}

The southern Chandeleur Islands (fig. 2), which include Breton Island, Grand Gosier Islands, Curlew Island, and Errol Island (historical), encompass a different storm impact response and mode of recovery than do the northern Chandeleur Islands (fig. 8). Like the northern barrier arc, the southern Chandeleur Islands are characterized by shoreface retreat; however, major storm impacts result in almost complete island destruction and conversion to inner shelf shoals. During extended periods of calm weather following storm impacts, new islands emerge along this sector. Because the islands are completely destroyed during storms, it is difficult to relate storm impacts to shoreline position. Moreover, island area change through time has not been linear because relatively long periods of calm weather produce more robust islands. During long-term periods (more than 100 years), however, the rate of shoreline retreat was approximately $-15 \mathrm{~m} / \mathrm{yr}$ for the time period from 1869 to 
1996. Between 1869 and 2005 island area decreased from 48.3 $\mathrm{km}^{2}$ to $1.7 \mathrm{~km}^{2}$. The following sections provide the results of the shoreline change analysis in reference to storm impact frequency and are presented on the basis of the time periods for which shoreline data exist.

\section{$1855-1922$}

The southern Chandeleurs were impacted by three major hurricanes (1889, 1915, and 1916) between 1855 and 1922. Shoreline data from 1869 show a robust Errol Island (later named Curlew Island) with a sandy shoreline backed by mangrove swamp. As a result of the three major hurricanes, the 1922 shoreline configuration comprised a discontinuous series of intertidal shoals. Combined island area for the southern Chandeleurs decreased from $7.8 \mathrm{~km}^{2}$ to $3.0 \mathrm{~km}^{2}$ during this time period.

\section{$1922-51$}

By 1951, a new set of islands (Grand Gosier and Curlew) had emerged along this southern stretch of shoreline. Between 1922 and 1951, the 1947 hurricane (Category 2) made landfall along the southern Chandeleur Islands, the only major storm during this time period to impact the islands. The 1947 hurricane did not result in total island destruction and submergence, similar to the multiple hurricane impacts during the 1855-1922 time period. Island area for the southern Chandeleurs increased more than twofold from $3.0 \mathrm{~km}^{2}$ in 1922 to $7.2 \mathrm{~km}^{2}$ in 1951 .

\section{1-69}

The time period covering 1951-69 included two major hurricanes, Betsy (1965) and Camille (1969). Shoreline data from 1969 (post-Camille) show that once again the robust barrier islands were segmented into an intertidal shoal dotted with small sandy islets. Island area decreased more than threefold during this time period from $7.2 \mathrm{~km}^{2}$ to $2.0 \mathrm{~km}^{2}$.

\section{9-78}

During the time period between 1969 and 1978, no major storms impacted the study area. The islands responded to this calm period by expanding laterally, broadening, and gaining elevation (Otvos, 1981). Island area increased from $2.0 \mathrm{~km}^{2}$ in 1969 to $3.1 \mathrm{~km}^{2}$ in 1978 .

\section{$1978-89$}

The time period between 1978 and 1989 was characterized by smaller storms that did not have major impacts on the southern Chandeleurs. Hurricane Frederic in 1979 had the greatest impact, which is well documented by Kahn and Roberts (1982) and Nummedal and others (1980).
By 1989, however, the islands resembled the form of the 1978 configuration. Island area increased from $3.1 \mathrm{~km}^{2}$ to $4.3 \mathrm{~km}^{2}$.

1989-96

The timespan from 1989 to 1996 was another relatively calm period. Hurricane Opal in 1995 made landfall along the Florida Panhandle and was the only major storm that impacted the Chandeleur Islands during this period. The 1996 shoreline shows that Curlew Island maintained much of its area and remained fixed. The downdrift spits on Grand Gosier Islands were destroyed, decreasing island area along this sector from $4.3 \mathrm{~km}^{2}$ in 1989 to $3.3 \mathrm{~km}^{2}$ in 1996 . Breton Island was breached into three segments, and area was reduced from 1.5 $\mathrm{km}^{2}$ in 1989 to $0.9 \mathrm{~km}^{2}$ in 1996 and has remained segmented since.

\section{6-2005}

Between 1996 and 2005 Hurricanes Georges (1998), Isidore (2002), Ivan (2004), and Katrina (2005) had major impacts on the southern Chandeleur Islands. In 1996 the total area for the southern Chandeleur Islands was $3.3 \mathrm{~km}^{2}$. Shoreline data from 1999 (post-Georges) show that once again the southern islands were reduced to a series of small islets. By 2004 Curlew Island was supratidal as a thin linear barrier, but that same year Ivan transformed the shoreline into sparse sandy islets. The following year, Hurricane Katrina destroyed Curlew and Grand Gosier Islands, leaving only 1.8 $\mathrm{km}^{2}$ of Breton Island supratidal along the southern Chandeleur Islands.

\section{Discussion}

\section{Hurricane Frequency, Trajectory, and Intensity}

Hurricane impact to the Chandeleur Islands is dependent upon storm intensity, path, and duration, and because of this, the geomorphic response to each storm and subsequent recovery are highly variable. The long-term (1855-2005) evolution of the northern islands documented in this study, however, has been characterized by a continual decrease in island area from $44.5 \mathrm{~km}^{2}$ to $4.7 \mathrm{~km}^{2}$, a reduction that was driven by storm impacts. Almost instantaneously, major hurricanes substantially increase the rates of shoreline retreat and reduction in island area. Any increase in storm frequency and intensity rapidly accelerates the land loss, and with each storm impact the islands become less capable of a recovery to prestorm conditions as sediment is removed from the active sediment transport system (Miner and others, this volume; Georgiou and others, this volume). 
The highly variable geomorphic response of the Chandeleur Islands to storm impacts was documented by Penland and others (1989) when they classified island response for three separate storms, Hurricanes Danny, Elena, and Juan, in 1985. Each of these storms had a different track, distance from the Chandeleurs, and intensity. Hurricane Danny crossed the central Gulf of Mexico and made landfall on the "Chenier Plain" (Kulp and others, 2005) portion of the Louisiana coast as a Category 1 hurricane with estimated surge levels at the Chandeleur Islands of about $1 \mathrm{~m}$ (Penland and others, 1989). Hurricane Elena passed to the north of the Chandeleur Islands making landfall near Biloxi, Miss., as a strong Category 3 storm with estimated surge elevations of more than $2 \mathrm{~m}$ at the Chandeleur Islands (Penland and others, 1989). Hurricane Juan was downgraded to a tropical storm as it headed east across the Mississippi River Delta and passed to the east of the Chandeleurs making landfall along the Alabama coast with estimated surge levels of more than $2 \mathrm{~m}$ at the Chandeleur Islands (Penland and others, 1989).

Hurricane Danny resulted in minor beach erosion, dune scarping, and landward-directed overwash fans. Hurricane Elena resulted in beach erosion, seaward-directed overwash fans, dune scarping, overwash scour, and island breaching. Hurricane Juan produced major beach erosion, landwarddirected overwash fans, island breaching, overwash scour, and severe dune destruction (Penland and others, 1989). It is interesting to note that, even though Juan was a weak tropical storm when it passed the Chandeleurs, the storm response was characterized by severe dune erosion, possibly attributable to the short recovery time between Juan and the two previous storms. The results from Penland and others (1989) emphasized the control that storm track, intensity, and frequency have on barrier geomorphic response and provide a means to understand and predict geomorphic response on the basis of the storm characteristics.

In this investigation the storm track was identified as a key factor in estimating shoreline erosion rates from a given storm (fig. 11). Hurricanes Camille and Katrina caused the most severe rates of shoreline erosion on the northern islands, -58.5 and $-201.5 \mathrm{~m} / \mathrm{yr}$, respectively (fig. 11). The high rates of erosion are attributed to the storms' trajectories and proximity to the Chandeleur Islands. These storm paths (Camille and Katrina) placed the eastern eye wall (where winds are strongest and surge elevations are highest) directly over the northern islands, causing extensive shoreline erosion. Because the storm path was landward of the islands, after the eye wall continued to track north, hurricane-force winds were directed in an offshore direction. This pattern, coupled with the ebbing surge, resulted in a net offshore transfer of sand. Other Category 3 storms of similar size to Katrina (such as Hurricane Betsy, which passed more than $120 \mathrm{~km}$ to the west of the islands) did not result in shoreline erosion rates of magnitudes similar to those caused by Hurricanes Camille and Katrina.

\section{Historical Shoreline Evolution, Storm Impacts, and Future Scenarios}

\section{Northern Chandeleur Islands}

In the midst of increasing rates of relative sea level rise and overall reduced sediment supply, as well as continual storm impacts, the northern Chandeleur Islands have been in a constant state of shoreline retreat and decreasing island area during the past century. A temporary reversal of shoreline erosion trends did take place between 1965 (post-Betsy) and 1969 (pre-Camille), and the shoreline prograded seaward (fig. 10). A second period of accretion occurred between the analysis years 2002 and 2004 during a recovery period following the impact of Hurricane Georges in 1998 and prior to the impacts of Hurricane Ivan in late 2004. During other recovery time periods between major storm events, the average rate of linear shoreline erosion slows considerably when compared to storm impact periods.

The amount of shoreline erosion of the northern Chandeleur Islands during the combined impact of Hurricanes Ivan and Katrina (-201.5 m/yr) is unprecedented for earlier time periods, which average $-38.4 \mathrm{~m} / \mathrm{yr}$ between 1922 and 2004 (fig. 10). As a result of the lack of similarity to other storms of record, it is unknown whether another erosional event of similar magnitude will take place again. On the basis of the entire available dataset for island area measurements (fig. 9), the northern islands will persist until 2037.

The northern Chandeleur Islands may reach a threshold of erosion that results in the transition to ephemeral sand bodies as early as 2013 if the level of storm frequency seen in recent decades persists (fig. 9). If storm frequency decreases to levels similar to the 1955-98 period, however, the islands may remain subaerial until 2037. At present sediment availability (Miner and others, this volume; Twichell and others, this volume; Flocks and others, this volume), the northern Chandeleur Islands will transition to ephemeral barrier island/ shoal sand bodies between 2013 and 2037 (fig. 9).

The range of projected dates of island conversion to inner shelf shoal is within the next 30 years, stressing the vulnerability of the Chandeleur Islands to future storm impacts. These predictions are as much as an order of magnitude more rapid (30 versus 300 years) than those made just over decade ago by using the same methods (McBride and others, 1992). The differences between predictions made a decade ago and those resulting from our analysis are the increased storm frequency during the past decade and, specifically, the catastrophic erosional event associated with Hurricane Katrina in 2005 that greatly accelerated the rate of island area reduction and shoreline retreat. 


\section{Southern Chandeleur Islands}

The southern Chandeleur Islands are ephemeral barrier islands undergoing early stages of transgressive submergence and conversion to an inner shelf shoal (Miner and others, this volume). Storm intensity and frequency are the major controls on island/shoal evolution. The islands are destroyed and converted to submerged shoals during periods of high storm frequency and historically have emerged and naturally rebuilt as relatively robust barrier shorelines during extended periods of calm weather. The time between 1969 (post-Camille) and 1998 (pre-Hurricane Georges) was a period of relative quiescence, during which Curlew and Grand Gosier Islands were able to recover from complete destruction and increase in area from $0.03 \mathrm{~km}^{2}$ to $5.9 \mathrm{~km}^{2}$. During this time, backbarrier marsh and mangrove swamp accreted in the shelter of the sandy shoreline, and extensive submerged grass bed meadows blanketed the sea floor landward of the islands (based on aerial photography used during this study). This period of relative quiescence was followed by the stormiest period on record for the northern Gulf of Mexico, during which four major hurricanes resulted in the destruction and submergence once again of these islands.

The submergence of the southern islands after storms and subsequent reemergence at a location landward of their prestorm positions result in the landward translation of the entire barrier island. This landward barrier retreat in response to relative sea level rise is not driven by storm-induced overwash processes; instead, fair weather hydrodynamics and attendant sediment transport processes reorganize the islands into subaerial features. This trend is in contrast to the northern islands, where minimal landward translation of the subaerial barrier occurs (Miner and others, this volume). The disparity between the responses of the northern islands and the southern islands to storms, storm recovery periods, and sea level rise is attributable to the absence of a well-established backbarrier marsh along the southern chain (with the exception of small portions of Breton Island) (Miner and others, this volume). As the northern islands erode and are stripped of sand during storms, this backbarrier marsh becomes exposed, and because it is composed of a thick organic root mat within a cohesive fine-grained sediment matrix, it resists rapid erosion and prohibits island submergence.

\section{Conclusions}

The erosional impact of Hurricane Katrina on the northern Chandeleur Islands is unprecedented within the rest of the dataset used in this study. The impact of Hurricane Katrina highlights the vulnerability of the northern Chandeleur Islands to major storm events. Island area measurements available between 1855 and 2005 indicate that the northern
Chandeleur Islands can be expected to be completely converted to ephemeral barrier island/shoals between 2013 and 2037. In an environment of frequent storm impacts, such as has been occurring during the past two decades, the projected date of transition to ephemeral sand bodies is 2013. In their present state, if storm frequency subsides to conditions such as existed during the early part of the 20th century, the projected date of island transition is 2037. The trajectory of the storm track with respect to the position of the islands stands out as a key determinant of shoreline response to a storm impact. Storms that pass within $120 \mathrm{~km}$ to the west of the islands result in the highest rates of shoreline erosion, and storms that pass more than $120 \mathrm{~km}$ to the east result in a relatively small amount of shoreline erosion.

As a result of the high storm recurrence interval during the past decade, the southern Chandeleur Islands of Curlew and Grand Gosier have been reduced to submerged shoals. These ephemeral islands have undergone submergence in the past as a result of storm impacts and subsequently emerged during periods of calmer weather. The ephemeral nature of these islands is attributed to the absence of a stabilizing backbarrier marsh (Miner and others, this volume). As the northern islands erode and island area is reduced to include only the sandy shoreline deposits, with no backbarrier marsh, they will begin to behave similarly to the southern ephemeral islands.

\section{Acknowledgments}

The authors gratefully acknowledge Dawn Lavoie and Dick Poore for editorial assistance and the U.S. Geological Survey for help in acquiring archived imagery. Suggestions by Duncan FitzGerald and Abby Sallenger greatly improved this manuscript. Research staff at the University of New Orleans Pontchartrain Institute for Environmental Sciences assisted in the shoreline change analysis.

\section{References}

Frazier, D., 1967, Recent deltaic deposits of the Mississippi River; their development and chronology: TransactionsGulf Coast Association of Geological Societies, v. 17, p. 287-315.

Kahn, J., 1986, Geomorphic recovery of the Chandeleur Islands, Louisiana, after a major hurricane: Journal of Coastal Research, v. 2, no. 3, p. 337-344.

Kahn, J., and Roberts, H., 1982, Variations in storm response along a microtidal transgressive barrier-island arc: Sedimentary Geology, v. 33, p. 129-146. 
Knabb, R., Rhome, J., and Brown, D., 2005, Tropical cyclone report-Hurricane Katrina 23-30 August, 2005: Miami, Fla., National Hurricane Center.

Kulp, M.A., Penland, S., Williams, S.J., Jenkins, C., Flocks, J., and Kindinger, J., 2005, Geologic framework, evolution, and sediment resources for restoration of the Louisiana coastal zone: Journal of Coastal Research, no. 44, p. 56-71.

Louisiana Geological Survey, 2008, Generalized geology of Louisiana: Baton Rouge, Louisiana Geological Survey, Louisiana State University, 1 p.

Martinez, L., Penland, S., Fearnley, S., O'Brien, S., Bethel, M., and Guarisco, P., 2009, Louisiana Barrier Island Comprehensive Monitoring Program (BICM), task 3shoreline change analysis-1800's to 2005: New Orleans, La., University of New Orleans, Pontchartrain Institute for Environmental Sciences, Technical Report no. 001-2008.

McBride, R., Penland, S., Hiland, M., Williams, S., Westphal, K., Jaffe, B., and Sallenger, A., Jr., 1992, Analysis of barrier shoreline change in Louisiana from 1853 to 1989, in Williams, S., Penland, S., and Sallenger, A., eds., Louisiana barrier island erosion study, atlas of shoreline changes in Louisiana from 1853 to 1989: Reston, Va., U.S. Geological Survey and Louisiana State University, Miscellaneous Investigations Series I-2150-A, p. 36-97.

Morton, R., Miller, T., and Moore, L., 2004, National assessment of shoreline change-part 1, historical shoreline changes and associated coastal land loss along the U.S. Gulf of Mexico: U.S. Department of the Interior, U.S. Geological Survey Open-File Report 2004-1043, 42 p.

National Hurricane Center, 2008, NHC archive of hurricane seasons: National Oceanic and Atmospheric Administration National Hurricane Center, accessed December 18, 2008, at http://www.nhc.noaa.gov/pastall.shtml.

Nummedal, D., Penland, S., Gerdes, R., Schramm, W., Kahn, J., and Roberts, H., 1980, Geologic response to hurricane impact on low profile Gulf Coast barriers: TransactionsGulf Coast Association of Geological Societies, v. 30, p. 183-194.

Otvos, E.G., 1981, Barrier island formation through nearshore aggradation - stratigraphic and field evidence: Marine Geology, v. 43, p. 195-243.

Penland, S., Boyd, R., and Suter, J., 1988, Transgressive depositional systems of the Mississippi Delta Plain - a model for barrier shoreline and shelf sand development: Journal of Sedimentary Petrology, v. 58, no. 6, p. 932-949.

Penland, S., Suter, J., and Moslow, T., 1983, Generation of inner shelf bodies by erosional shoreface retreat and sea level rise processes: Eos, Transactions, American Geophysical Union, v. 64, no. 52, p. 1065-1066.
Penland, S., Suter, J., Sallenger, A., Jr., Williams, S., McBride, R., Westphal, K., Reimer, P., Jaffe, B., and Ritchie, W., 1989, Morphodynamic signature on the 1985 hurricane impacts on the northern Gulf of Mexico: Proceedings of the Symposium on Coastal and Ocean Management, v. 6, p. 4220-4234.

Poirrier, M.A., and Handley, L.R., 2007, Chandeleur Islands, in Handley, L., Altsman, D., and DeMay, R., Seagrass status and trends in the northern Gulf of Mexico-1940-2002: U.S. Geological Survey Scientific Investigations Report 2006-5287, p. 62-71.

Reyes, E., Georgiou, I., Reed, D., and McCorquodale, A., 2005, Using models to evaluate the effects of barrier islands on estuarine hydrodynamics and habitats - a numerical experiment: Journal of Coastal Research, Special Issue 44, p. $176-185$.

Stewart, S., 2004, Tropical cyclone report-Hurricane Ivan 2-24 September, 2004: Miami, Fla., National Hurricane Center.

Stone, G., and Orford, J., 2004, Storms and their significance in coastal morpho-sedimentary dynamics: Marine Geology, v. 210 , nos. 1-4, p. 1-362.

Stone, G.W., Zhang, X., and Sheremet, A., 2005, The role of barrier islands, muddy shelf, and reefs in mitigating the wave field along coastal Louisiana: Journal of Coastal Research, Special Issue 44, p. 40-55.

Suter, J., Penland, S., Williams, S., and Kindinger, J., 1988, Stratigraphic evolution of Chandeleur Islands, Louisiana: Transactions - Gulf Coast Association of Geological Societies, v. 72, no. 9, p. 1124-1125.

Tornqvist, T., Kidder, T., Autin, W., van der Borg, K., de Jong, A., Klerks, C., Snijders, E., Storms, J., van Dam, R., and Wiemann, M., 1996, A revised chronology for Mississippi River subdeltas: Science, v. 273, no. 5282, p. 1693-1696.

Williams, S., Penland, S., and Sallenger, A., Jr., 1992, Appendix A: Louisiana's hurricane history, in Williams, S., Penland, S., and Sallenger, A., eds., Louisiana barrier island erosion study, atlas of shoreline changes in Louisiana from 1853 to 1989: Reston, Va., U.S. Geological Survey and Louisiana State University, Miscellaneous Investigations Series I-2150-A, p. 98-99.

Yamazaki, G., and Penland, S., 2001, Recent hurricanes producing significant basin damage, in Penland, S., Beall, A., and Waters, J., eds., Environmental atlas of the Lake Pontchartrain basin: New Orleans, La., Lake Pontchartrain Basin Foundation, p. 36-37. 
Appendix A-1. Shoreline Change Final Report (See Index Page To Access Data)

Appendix A-2. Shoreline Change Final Report-Geomorphology (See Index Page To Access Data)

Appendix A-3. Shoreline Change Final Report-Hurricanes (See Index Page To Access Data) 
Publishing support provided by Lafayette Publishing Service Center 


\section{Extreme Coastal Changes on the Chandeleur Islands, Louisiana, During and After Hurricane Katrina}

By Asbury H. Sallenger, Jr., Charles W. Wright, Peter Howd, Kara Doran, and Kristy Guy

Chapter B of

Sand Resources, Regional Geology, and Coastal Processes of the Chandeleur Islands Coastal System: an Evaluation of the Breton National Wildlife Refuge

Edited by Dawn Lavoie

In cooperation with the U.S. Fish and Wildlife Service

Scientific Investigations Report 2009-5252 


\title{
U.S. Department of the Interior \\ KEN SALAZAR, Secretary \\ U.S. Geological Survey \\ Marcia K. McNutt, Director
}

\section{U.S. Geological Survey, Reston, Virginia: 2009}

\author{
This and other USGS information products are available at http://store.usgs.gov/ \\ U.S. Geological Survey \\ Box 25286, Denver Federal Center \\ Denver, C0 80225 \\ To learn about the USGS and its information products visit http://www.usgs.gov/ \\ 1-888-ASK-USGS
}

\begin{abstract}
Any use of trade, product, or firm names is for descriptive purposes only and does not imply endorsement by the U.S. Government.

Although this report is in the public domain, permission must be secured from the individual copyright owners to reproduce any copyrighted materials contained within this report.
\end{abstract}

Suggested citation:

Sallenger, A.H., Jr., Wright, C.W., Howd, P., Doran, K., and Guy, K., 2009, Chapter B. Extreme coastal changes on the Chandeleur Islands, Louisiana, during and after Hurricane Katrina, in Lavoie, D., ed., Sand resources, regional geology, and coastal processes of the Chandeleur Islands coastal system —an evaluation of the Breton National Wildlife Refuge: U.S. Geological Survey Scientific Investigations Report 2009-5252, p. 27-36. 


\title{
Chapter B. Extreme Coastal Changes on the Chandeleur Islands During and After Hurricane Katrina
}

\author{
By Asbury H. Sallenger, Jr., ${ }^{1}$ Charles W. Wright,, Peter Howd, ${ }^{1}$ Kara Doran, ${ }^{1}$ and Kristy Guy'
}

\section{Abstract}

For nearly 2 years after Hurricane Katrina in 2005 removed 86 percent of the surface area of Louisiana's Chandeleur Islands, most of the island chain continued to erode rapidly. Feedback processes triggered by the hurricane enhanced this erosion even under relatively mild, poststorm conditions and pushed the system towards failure. During the storm, the Chandeleurs were completely submerged by storm surge as if they had become shoals. When such submergence occurs locally, it can lead to differences in sea level across an island, forcing currents to erode a narrow breach, or inlet, connecting sea and bay. In this chapter, we show that during total island submergence the Gulf of Mexico-front shores were eroded landward an average of $268 \mathrm{~m}$, likely the largest storminduced shoreline retreat ever reported. Peak elevations on the islands decreased from more than $6 \mathrm{~m}$ to less than $3 \mathrm{~m}$, and all of the sand visible from the air was stripped from the islands, exposing remnant marsh platforms to continued degradation by relatively small waves following Katrina. Twenty-two months later, some sand had returned to the islands, although elevations had not rebuilt appreciably, leaving the Chandeleurs vulnerable to inundation by weak storms. These islands are conditioned for extreme erosion and ultimate disappearance because of small sand supply and rapid sea level rise induced on the Mississippi River Delta by subsidence.

\section{Introduction}

Barrier islands undergo overwash when the elevation of wave runup periodically exceeds the elevation of the foredune or, in the absence of a dune, the elevation of the beach berm (see for example Sallenger, 2000). The portion of runup that overtops this crest of the active beach system is driven by gravity down the landward slope of the berm or dune as overwash. In general, under these conditions, gradients in landward flow erode sand seaward of the crest and deposit sand landward of the crest, forcing a landward migration of the beach system. Should the cross-shore width of this system

${ }^{1}$ U.S. Geological Survey, St. Petersburg, Fla. approach the width of the barrier island, and assuming no system losses or gains of sand, the island migrates landward while maintaining its form and size.

This simple overwash model of barrier island response to storms did not apply to the Chandeleur Islands during Hurricane Katrina in 2005. Rather, the 36-km-long island chain on the eastern flank of Louisiana (fig. 1) was not periodically overwashed by waves but, during the latter stages of the storm, was completely and continuously inundated by storm surge, the increase in sea level due primarily to onshore wind stress, reduced barometric pressure, and wave setup. During the storm, the Chandeleurs were no longer barrier islands; rather, they became shoals that underwent landward retreat and area losses of scales not previously observed.

In this chapter we show how the Chandeleur Islands changed when subjected to this inundation regime. Further, we show how feedback processes from these changes forced continued erosion of the islands during the relatively low waves following the storm, erosion that persisted for nearly 2 years after Katrina's landfall, and pushed the islands toward failure.

\section{Airborne Lidar Surveys}

The topography of the Chandeleur Islands was surveyed before and several days after the landfall of Hurricane Katrina and then resurveyed four additional times over the following 22 months by using airborne lidar. The surveys were intercompared to detect changes to the islands during the storm and during the recovery period of nearly 2 years.

These lidar surveys were part of a cooperative research program on the coastal impacts of extreme storms in the United States involving the U.S. Geological Survey, the National Aeronautics and Space Administration (NASA), the U.S. Army Corps of Engineers, and in Louisiana, the Louisiana Department of Natural Resources (see for example Sallenger and others, 2002, 2006; Stockdon and others, 2007). Three systems were used to acquire the different surveys: NASA's Airborne Topographic Mapper (ATM; see Brock and others, 2002), NASA's Experimental Advanced Airborne Research Lidar (EAARL; see Wright and Brock, 2002), and the U.S. Navy and U.S. Army Corps of Engineers' Compact 


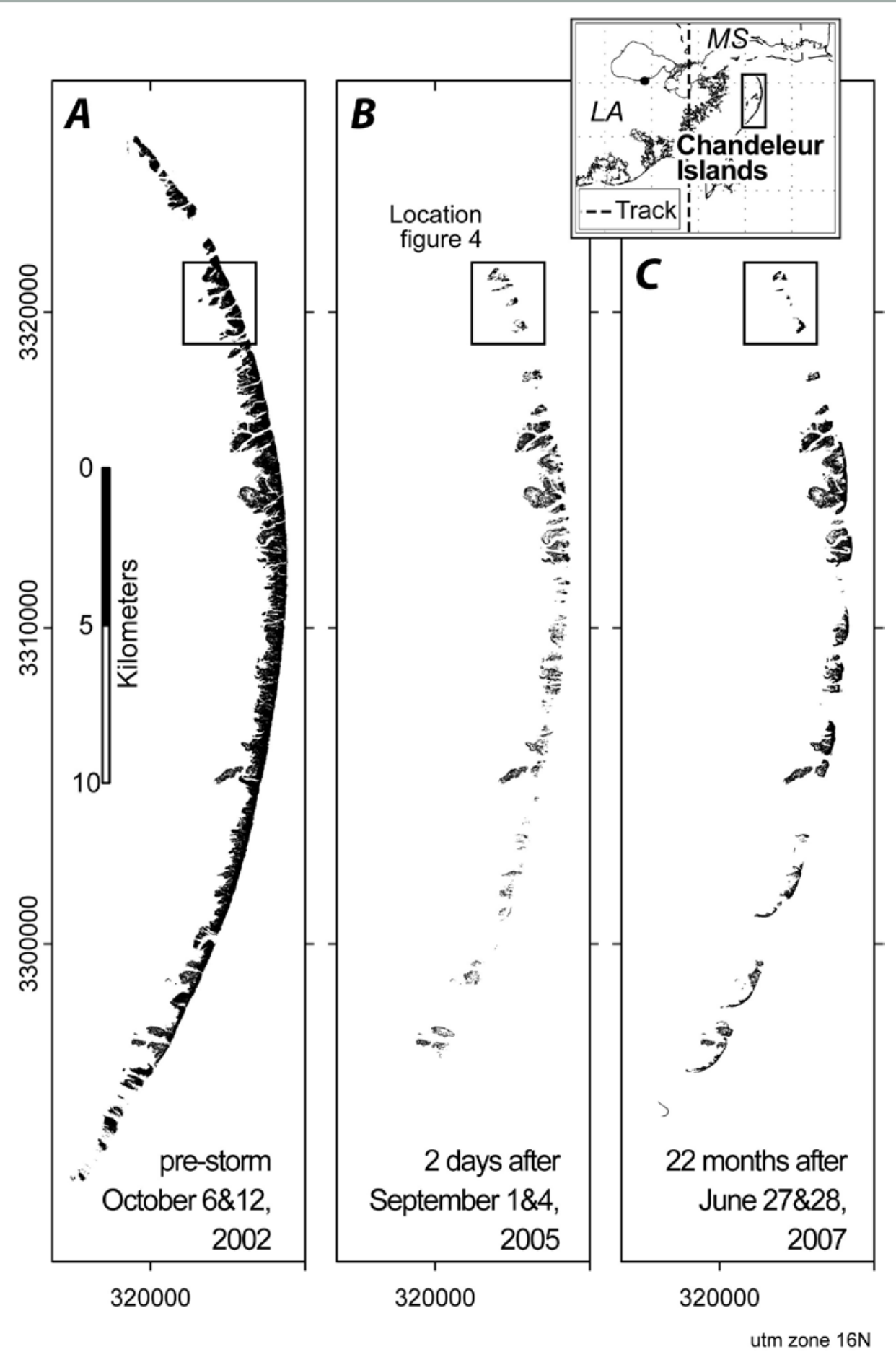

Figure 1. Maps of the Chandeleur Islands on the eastern flank of Louisiana from before and after Hurricane Katrina in August 2005. The maps are based on airborne lidar data; elevations above mean high water (MHW) are shaded black, and elevations below MHW are white. $A$, Lidar survey from before Hurricane Katrina acquired by using the National Aeronautics and Space Administration's (NASA) Airborne Topographic Mapper on October 6 and 12, 2002; referred to in the text as the "prestorm" survey. B, Survey within several days of the landfall of Katrina taken by using NASA's Experimental Advanced Airborne Research Lidar (EAARL) from September 1 and 4, 2005; referred to in the text as the survey 2 days after. C, Survey nearly 2 years after landfall taken by using NASA's EAARL on June 27 and 28, 2007; referred to in the text as the survey 22 months after. 
Hydrographic Airborne Rapid Total Survey (CHARTS; see Heslin and others, 2003).

Multiple surveys of a 70-km-long reach of beach in North Carolina taken within a single day showed the vertical accuracy of ATM over unvegetated sand to be about 15 $\mathrm{cm}$ root mean square (RMS) (Sallenger and others, 2003). The other two systems provide topography data of similar vertical accuracy (for EAARL, see Wright and Brock, 2002; for CHARTS, see http://shoals.sam.usace.army.mil/Charts. aspx/). With their capability to survey a swath several hundred meters wide with estimates of elevation every $1-2 \mathrm{~m}^{2}$ and over hundreds of kilometers of coast in several hours, lidar systems have revolutionized the quantification of coastal change.

EAARL has the only topographic lidar of the three that records the full waveform of reflected light from the ground. (CHARTS records the full waveform for its bathymetric sensor but, at this time, not for its separate topographic sensor. EAARL uses the same laser for both topography and bathymetry.) Hence, EAARL is the only system that can effectively discriminate vegetation, such as the marsh grasses found on the sound side of the Chandeleurs, to produce bare earth topography of the islands. EAARL was tested for its accuracy in determining bare earth elevations on the Chandeleurs by comparing bare earth elevations of a vegetated area with a ground survey of the same area completed at about the same time (Doran and others, 2008). The mean error (or bias) was $8 \mathrm{~cm}$, and the random error was $14 \mathrm{~cm}$, similar to the vertical accuracies determined for ATM over unvegetated sand by Sallenger and others (2003).

\section{Observations}

On August 29, 2005, Hurricane Katrina came ashore on the Mississippi River Delta in central Louisiana at Category 3 intensity on the Saffir-Simpson Hurricane Scale with sustained winds of $204 \mathrm{~km} / \mathrm{h}(110 \mathrm{kn}$; Knabb and others, 2005). During the peak of the storm, a deepwater buoy in the Gulf of Mexico southeast of the Chandeleur Islands reported a significant wave height of $16.9 \mathrm{~m}$ and peak period of $14.3 \mathrm{~s}$ (National Oceanic and Atmospheric Administration [NOAA] buoy 42040). As the hurricane moved inland, its track passed parallel to, and about $70 \mathrm{~km}$ west of, the Chandeleurs (fig. 1), sweeping at least a portion of the storm's powerful right-front quadrant across the islands. (Hurricane-force winds extended to the right, or east, from the track about 195 $\mathrm{km}$.) With the storm's track parallel to the island trend and its counterclockwise swirl, wind direction over the islands changed progressively as the storm moved north: approaching the islands, the winds were onshore (east to west); abreast of the islands, the winds were alongshore (south to north); and leaving the islands, the winds blew offshore (west to east).

Prior to Hurricane Katrina's landfall, a survey recorded the Chandeleurs as a chain of barrier islands $35.9 \mathrm{~km}$ long
(Oct. 2002; fig. 1A). This prestorm survey was acquired several days after a low-intensity hurricane (Category 1 Hurricane Lili) made landfall about $250 \mathrm{~km}$ to the west of the Chandeleurs. As shown in figure $1 \mathrm{~A}$, the islands appeared relatively continuous, although the lidar data detected 21 islets separated by narrow breaches. The islets averaged $1.6 \mathrm{~km}$ in length; the longest was $20.8 \mathrm{~km}$. The mean high water contour determined from gridded lidar data defines the limits of the subaerial islands, whose surface area was $13.9 \mathrm{~km}^{2}$.

By 2 days after landfall, the surface area of the islands had decreased to $2.5 \mathrm{~km}^{2}$, a reduction of 82 percent (fig. $1 B$ ). The islands had been breached in many locations; the lidar data now detected 45 islets. Lengths of islets now averaged only $0.31 \mathrm{~km}$; the maximum length was $3.1 \mathrm{~km}$. These changes are cumulative between the prestorm survey and the survey taken 2 days after the storm, although we assume that the bulk of the observed changes can be attributed to Katrina, which was by far the most intense storm to impact the islands during the period between surveys.

Historically, the Gulf of Mexico-front shores of the Chandeleur Islands have undergone net erosion, retreating landward an average of $6.5 \mathrm{~m} / \mathrm{yr}$ based on comparisons of surveys from 1855 and 1989 (McBride and others, 1992). During the same period, the islands' bayside shores accreted, building landward an average of $2.9 \mathrm{~m} / \mathrm{yr}$ from repeated storm overwashes. During Katrina, however, massive erosion occurred on the gulf front with no concomitant deposition of sand on the sound side. In fact, aerial reconnaissance 2 days after landfall could detect no visible sand on the islands. What remained were fragments of marsh that before the storm served as platforms on which sand beaches and dunes of the islands had lain. The average gulf-front erosion for the Chandeleurs was $269 \mathrm{~m}$ (fig. 2A). Maximum measured shoreline retreat was $1.37 \mathrm{~km}$. Assuming that during the 3 -year interval between the prestorm survey and the landfall of Katrina the islands eroded at their historical rate, the average gulf-front erosion during the storm would have been roughly $250 \mathrm{~m}$, which we believe to be the largest barrier island erosion ever reported for a storm.

Further, with massive erosion on the gulf side and no sand deposition on the sound side, the islands significantly narrowed (fig. $2 B$ ). The prestorm survey indicated that the widths of the islands were on average $415 \mathrm{~m}$. Two days after Katrina, the average width was only $167 \mathrm{~m}$, a decrease of 60 percent.

Prior to the storm, peak elevations (which were determined within adjacent bins that spanned the width of the islands and were $5 \mathrm{~m}$ wide along the length of the islands) were 4-6 $\mathrm{m}$ along the northern half of the islands (fig. $3 A$ ), indicating the presence of dunes. The islands' southern half had lower elevations, indicating the absence of prominent dunes; there the highest ground elevations would have been at the crests of beach berms. These elevations were first-return lidar data from NASA's ATM and, hence, may be biased high by the laser reflecting off island vegetation, such as the 


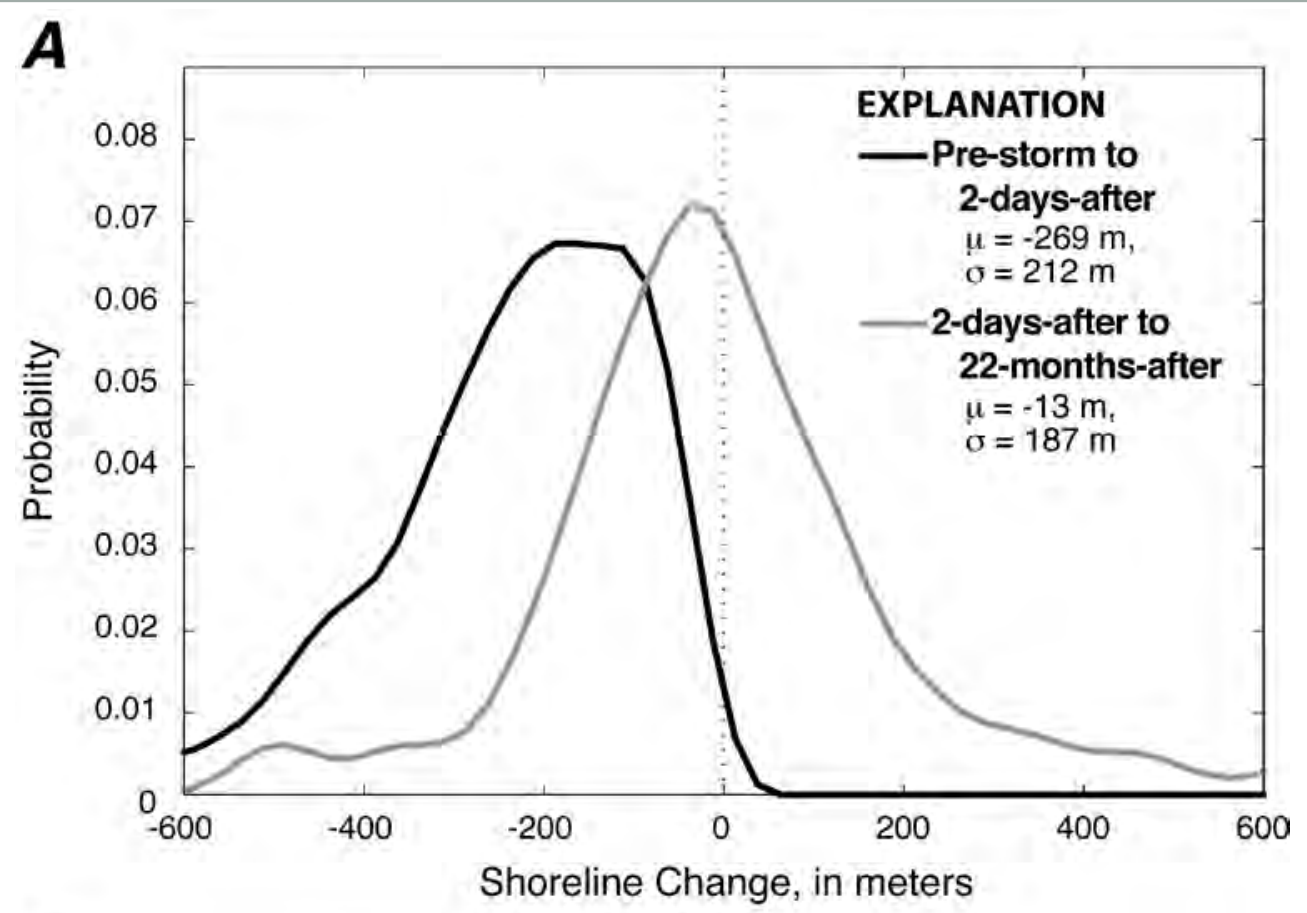

B

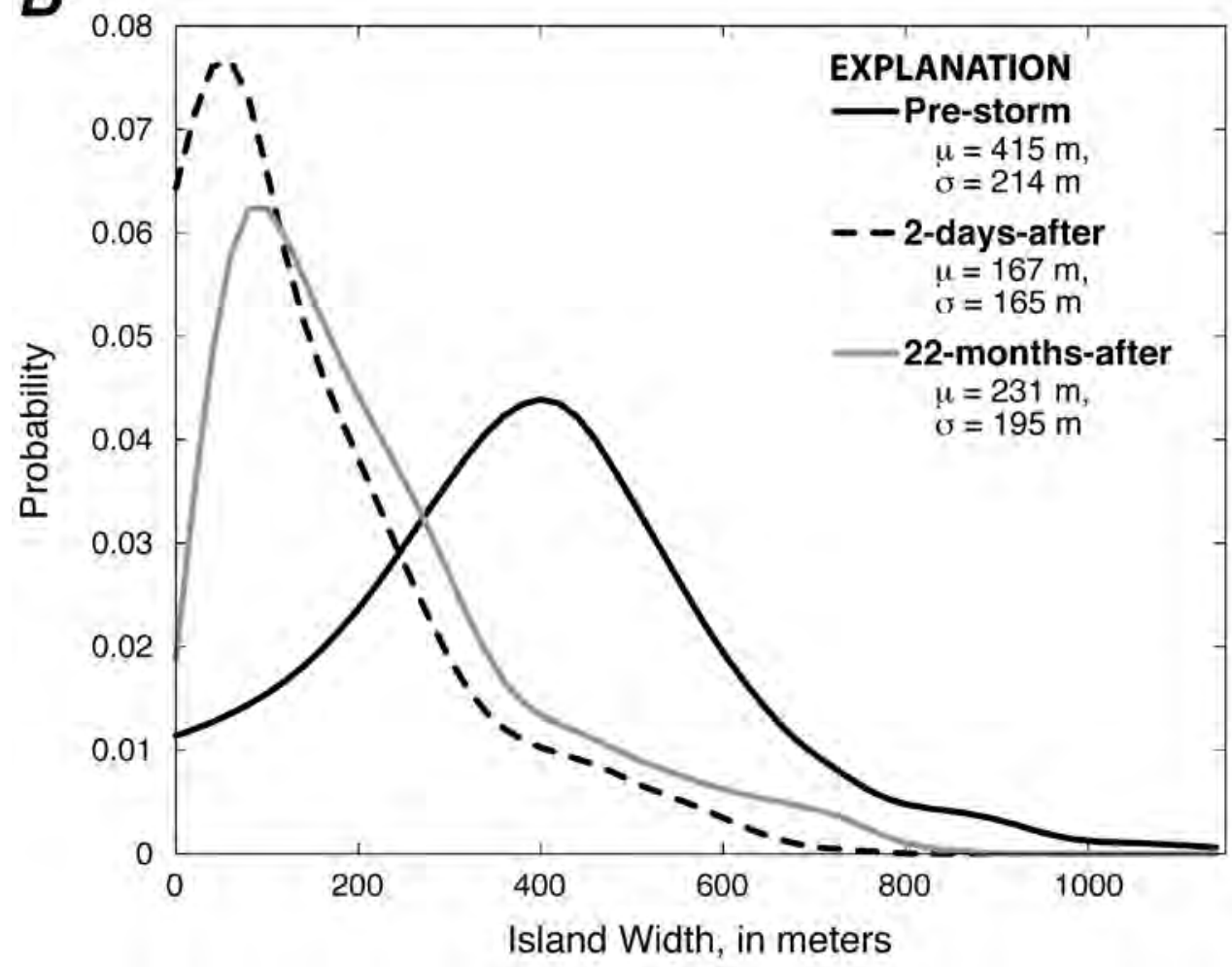

Figure 2. Changes in the shoreline and width of the Chandeleur Islands, La., before Hurricane Katrina in August 2005 ("prestorm"), 2 days after the storm, and 22 months after the storm. $A$, Distribution of shoreline changes determined every $50 \mathrm{~m}$ along the $35-\mathrm{km}$ length of the Chandeleur Islands between lidar surveys taken prestorm and 2 days after and between surveys taken 2 days after and 22 months after Katrina. B, Distribution of island widths determined every $50 \mathrm{~m}$ along the Chandeleurs for surveys taken prestorm, 2 days after, and 22 months after Katrina. 

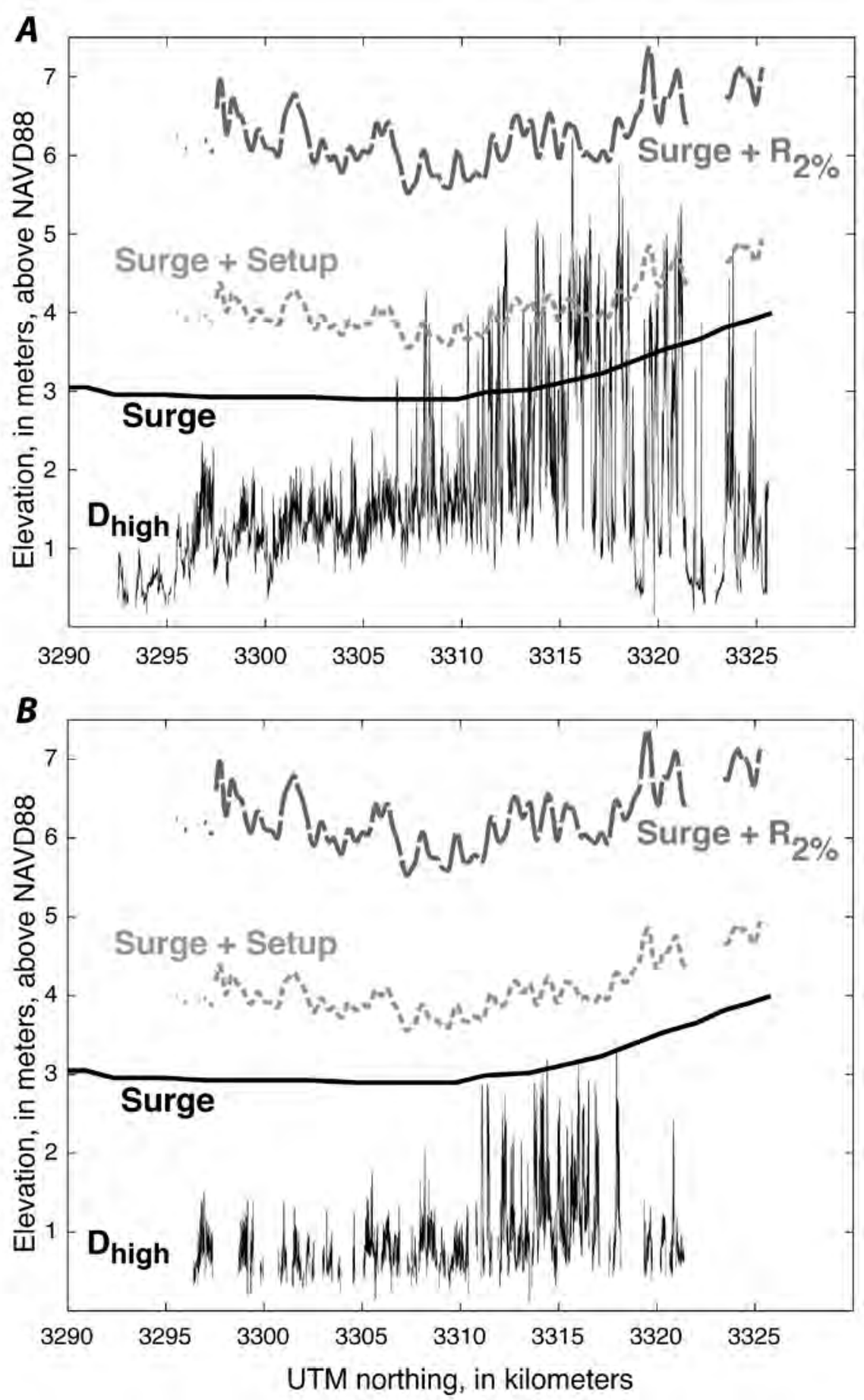

Figure 3. Peak elevations $\left(D_{\text {high }}\right)$ determined every $20 \mathrm{~m}$ along the length of the Chandeleur Islands, La., by using lidar data processed for first return. Only first return is available for the prestorm survey, so even though bare earth data are available for 2 days after Hurricane Katrina in 2005, we show first return here to be comparable with prestorm data. Also shown are storm surge elevations along the shore as determined by the National Oceanic and Atmospheric Administration (NOAA) using the SLOSH model, surge plus calculated wave setup, and surge plus extreme (2\%) wave runup. $A$, Prestorm (merged 2001 and 2002) $D_{\text {high }}$ determined from lidar data acquired with the National Aeronautics and Space Administration's (NASA) Airborne Topographic Mapper. B, $\mathrm{D}_{\text {high }}$ from 2 days after the storm determined from lidar data acquired with NASA's Experimental Advanced Airborne Research Lidar. 
roughly 1-m-high beach and marsh grasses, rather than the sand surface.

Peak surge during the storm was determined by NOAA's National Hurricane Center by using the SLOSH model (Jarvinen and Lawrence, 1985); the plotted values (fig. 3) were extracted from grid cells immediately offshore of the gulf front of the Chandeleurs. This surge was added to wave setup to provide an estimate of still water level during the storm and to $\mathrm{R}_{2 \%}$ to provide an estimate of the total vertical reach of the highest 2 percent of wave runup. Setup and $R_{2 \%}$ runup were found from parameterizations by Stockdon and others (2006) and by using wave data modeled at a shallow-water NOAA buoy location in $13.4 \mathrm{~m}$ of water off the northern tip of the Chandeleurs (lat 30.09 N., long 88.77 W.). The buoy stopped operating before the peak of the storm; the peak conditions were provided by modeled data and presented in Interagency Performance Evaluation Task Force (2007).

Storm surge along the Mississippi coast approached $10 \mathrm{~m}$. (According to Knabb and others, 2005, the highest measured water mark was near Bay St. Louis, Miss., at 8.5 m.) The peak surges along the Chandeleurs were smaller, ranging from about $3 \mathrm{~m}$ in the south to nearly $4 \mathrm{~m}$ in the north. Setup associated with wave breaking on the gulf front of the Chandeleurs added approximately an additional $1 \mathrm{~m}$ of still water level. This level was sufficient to submerge the southern half of the island chain; in the northern half, peak island elevations emerged through the combined surge and setup (fig. $3 A)$.

The total elevation of wave runup on the beach, however, was sufficient to overtop prestorm peak elevations along the entire length of the islands (fig. $3 A$ ). Hence, during the early stages of the storm, the entire area of the islands was periodically overwashed by waves, driving sand on beaches and dunes from the gulf side of the islands towards the sound side.

During the storm, the topography of the islands was, of course, not static; because of inundation and overwash, peak elevations during the course of the storm were reduced (compare fig. $3 A$ with $3 B$ ). With these lower peak elevations along the islands, the still water level during the peak of the storm was sufficient to completely submerge the islands in what Sallenger (2000) called the inundation regime. During such a regime, the Chandeleur Islands became shoals, and differences in sea level between gulf and sound drove mean currents across the island shoal. These mean currents likely contributed to the net transport of beach and dune sand from the islands and exposed the underlying marsh platforms.

Following storms, beaches usually recover naturally, at least to some extent, with sand migrating onshore in swash bars, for instance, and welding onto the beach in the weeks and months after the event (for example, Owens and Frobel, 1977). Over a 22-month period after Katrina's landfall, however, repeated lidar surveys showed that the islands did not uniformly recover. In fact, between 2 days and 22 months after landfall, 56 percent of the gulfside shore continued to retreat landward (fig. $2 A$ ). Within an example reach of shore, the islands progressively retreated landward between successive lidar surveys (fig. $4 A$ ); the total retreat at one location approached $500 \mathrm{~m}$.

The composition of the poststorm gulf shore likely contributed to the continued rapid retreat. With the sand stripped from the islands, the muddy marsh fragments that remained were exposed to the surf of the Gulf of Mexico and were vulnerable to erosion even by the relatively low postKatrina waves. These marsh fragments contained some sand, however. As the marsh shore eroded landward, this sand was released and made available to form incipient beaches, while the fine sediments in the eroded marsh continue to disperse. Over time, these beaches will likely buffer the marshy shore from continued rapid erosion.

The 44 percent of the gulf shore that did not continue to erode over the 22 months after the storm showed the development of spits and welded swash bars that advanced the shore seaward. Within an example reach of this shore, a beach developed seaward of the shoreline position from 2 days after the storm, prograding the shoreline as much as $100 \mathrm{~m}$ seaward. This accretion along the 44 percent of the gulf shore was sufficient to widen the islands from an average of $167 \mathrm{~m}$ ( 2 days after) to $231 \mathrm{~m}$ (22 months after; fig. $2 B$ ). The mean shoreline change for the islands over the same period, though, was $13 \mathrm{~m}$ of erosion (fig. $2 A$ ).

Bare earth elevations (vegetation removed) are available for the surveys taken 2 days after and 22 months after the storm; these can be used to assess the recovery of peak elevations on the islands. Immediately after the storm, elevations averaged about $1 \mathrm{~m}$ (fig. $5 A$ ); 22 months later they had increased by only $0.3 \mathrm{~m}$ (figs. $5 B$ and $5 C$ ). Also shown on these plots are the worst case (maximum of the maximum) storm surge elevations for Category 1 through Category 3 hurricanes, as well as the surge simulated by NOAA using SLOSH for Katrina conditions. Immediately after the hurricane, the islands were vulnerable to complete submergence (inundation regime) by a Category 1 hurricane. Nearly 2 years later, the elevations of the islands had recovered vertically only enough that a portion of the northern half of the islands would be emergent through a Category 1 surge. The implication is that the islands in 2008 remained highly vulnerable to inundation and to having all of their sand swept from the marsh platforms again, which would expose the muddy fragments to further degradation.

\section{Discussion}

The Chandeleur Islands are sand starved. Their original source of sand was the Mississippi River, which deposited a delta lobe from which the islands originally formed (Penland and others, 1985). When the Mississippi River switched to a new course about 1,800 to 2,000 years before present, the source of sand building the lobe was cutoff, and the lobe 


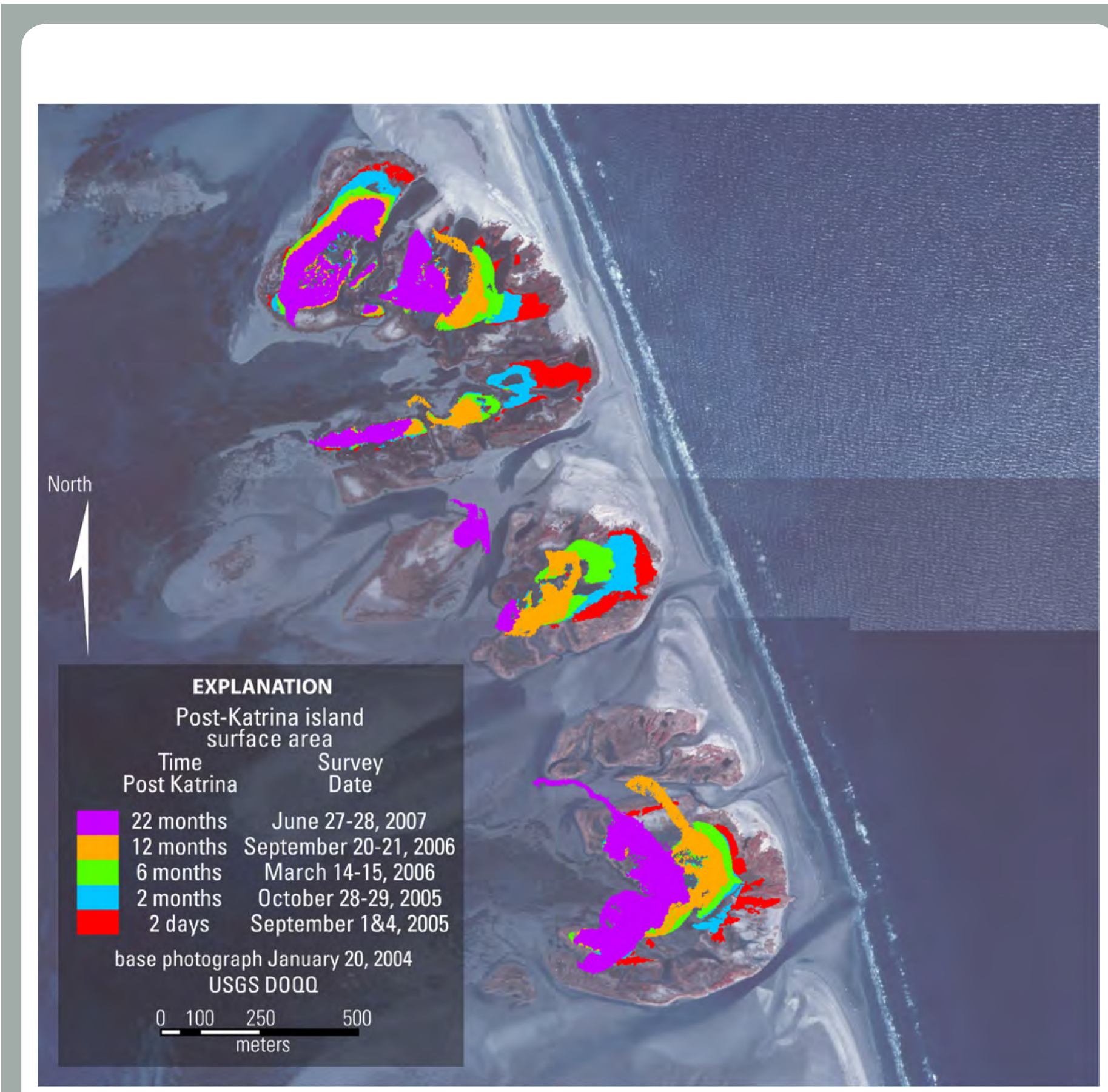

Figure 4. Changes to a 2.5-km-long reach of the Chandeleur Islands, La. (see fig. 1), showing persistent erosion during and for 22 months after Hurricane Katrina's landfall. The base map is a rectified, vertical photograph from before the storm, January $20,2004$. Subsequent lidar maps are stacked on top of the photograph; more recent surveys are overlaid on previous surveys. If no change occurred, only the last (22 months after) survey (indicated in purple) would be visible, as the other surveys would be underneath it. Since red is exposed along the gulf side of the islands, erosion is indicated between 2 days after (red) and 2 months after (blue). Note that each color of the five successive surveys can be seen along the gulfside shore and that together the lidar surveys indicate persistent landward erosion of the gulfside shore. 


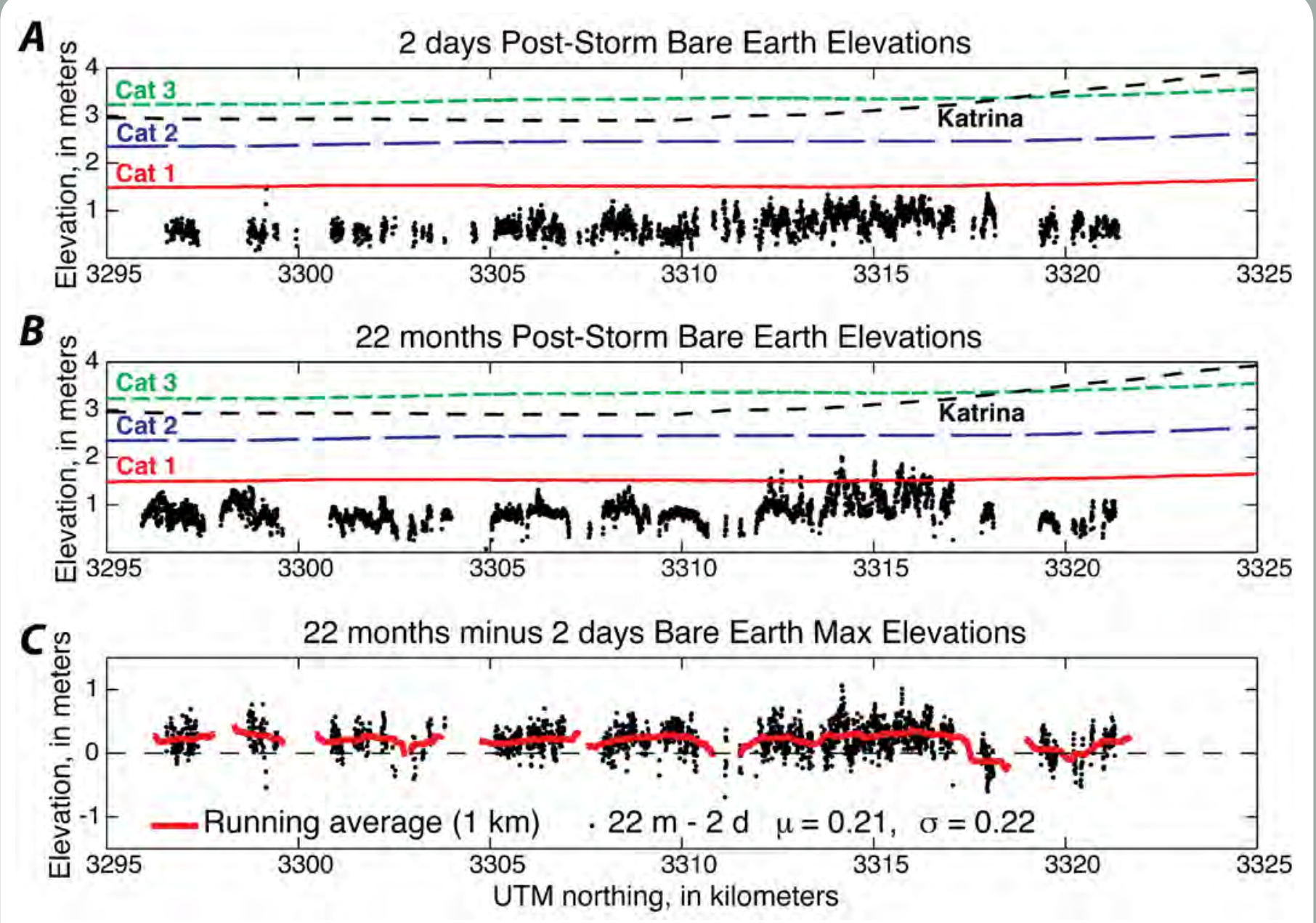

Figure 5. Bare earth peak elevations ( $\left.D_{\text {high }}\right)$, maximum of the maximum storm surge elevations for different categories ("cat") of hurricanes, and storm surge for Hurricane Katrina computed by using the SLOSH model. $A, 2$ days after. $B, 22$ months after. $C$, Change in $D_{\text {high }}$ between 2 days after and 22 months after.

began to erode landward because of the lack of new sediments and the subsidence from the weight of the already deposited sediments. Waves reworked the lobe, concentrating sand into a headland beach and transporting additional sand to either side of the headland into spits. With the subsidence, the beach detached from the mainland, thereby forming the Chandeleur Islands. Ultimately, with continued subsidence and sand starvation, the islands are forecast to become smaller and lower and eventually sink beneath the sea (see four-step model in Penland and others, 1985).

The lidar observations of the response to, and recovery from, Hurricane Katrina reveal failure modes that may ultimately contribute to the demise of the Chandeleur Islands. The hurricane stripped sand from the islands' marsh platforms along the entire island chain, leaving the muddy platforms exposed to waves. For over 50 percent of the shore, the marsh platforms continued to erode rapidly. Their ultimate disappearance will increase the potential for island failure because additional sand, from the local sand budget, will be required to rebuild islands vertically from the sea floor. If the available sand is insufficient, the islands will become subaqueous.

\section{Conclusions}

Hurricane Katrina caused massive changes to Louisiana's Chandeleur Islands. An extreme storm that impacts a barrier island that is already stressed from low sand supply and rapid sea level rise may trigger failure by both degrading the island during the event and exposing the island to continued extreme erosion following the event. 


\section{Acknowledgments}

We thank Karen Morgan (U.S. Geological Survey [USGS]), Kristy Guy (USGS), Dennis Krohn (USGS), Virgil Rabine (National Aeronautics and Space Administration [NASA]), Billy Reynolds (USGS), Charlene Sullivan (formerly of the USGS), and Richard Mitchell (EG\&G) for data processing and field support related to the 2005 lidar dataset and William Krabill (NASA), Robert Swift (EG\&G), and the air and ground crews of NASA's ATM during acquisition of the 2002 lidar dataset.

\section{References}

Brock, J.C., Wright, C.W., Sallenger, A.H., Krabill, W.B., and Swift, R.N., 2002, Basis and methods of NASA Airborne Topographic Mapper lidar surveys for coastal studies: Journal of Coastal Research, v. 18, no. 1, p. 1-13.

Doran, K., Sallenger, A., Reynolds, B.J., and Wright, C.W., in press, Accuracy of EAARL lidar ground elevations using a bare-earth algorithm in marsh and beach grasses on the Chandeleur Islands, Louisiana: U.S. Geological Survey Open-File Report.

Heslin, J., Lillycrop, W.J., and Pope, R., 2003, CHARTS - an evolution in airborne lidar hydrography: Proceedings, U.S. Hydro, 2003 Conference, Biloxi, Miss., Paper 5.2. (Also available at http://www.thsoa.org/hy03/5_2.pdf.)

Interagency Performance Evaluation Task Force, 2007, Volume IV - the storm, in Performance evaluation of the New Orleans and southeast Louisiana hurricane protection system: U.S. Army Corps of Engineers, accessed December 1, 2009, at https://ipet.wes.army.mil/.

Jarvinen, B.R., and Lawrence, M.B., 1985, An evaluation of the SLOSH storm surge model: Bulletin of the American Meteorological Society, v. 66, no. 11, p. 1408-1411.

Knabb, R., Rhome, J.R., and Brown, D.P., 2005, Tropical cyclone report, Hurricane Katrina, 23-30 August 2005, accessed December 1, 2009, at http://www.nhc.noaa.gov/ pdf/TCR-AL122005_Katrina.pdf.

McBride, R.A., Penland, S., Hiland, M.W., Williams, S.J., Westphal, K.A., Jaffe, B.E., and Sallenger, A.H., 1992, Analysis of barrier shoreline change in Louisiana from 1853 to 1989, in Williams, S.J., Penland, S., and Sallenger, A.H., eds., Louisiana barrier island erosion study —atlas of barrier shoreline changes in Louisiana from 1853-1989: U.S. Geological Survey Miscellaneous Investigations Series I-2150-A, p. 36-97.
Owens, E., and Frobel, D.H., 1977, Ridge and runnel systems in the Magdelan Islands, Quebec: Journal of Sedimentary Petrology, v. 47, no. 1, p. 191-198.

Penland, S., Suter, J., and Boyd, R., 1985, Barrier island arcs along abandoned Mississippi River deltas: Marine Geology, v. 63 , p. $197-233$.

Rahmstorf, S., 2007, A semi-empirical approach to projecting future sea-level rise: Science, v. 315, p. 368-370.

Sallenger, A., Krabill, W., Brock, J., Swift, R., Manizade, S., and Stockdon, H., 2002, Sea-cliff erosion as a function of beach changes and extreme wave runup during the 1997-98 El Nino: Marine Geology, v. 187, p. 279-297.

Sallenger, A., Stockdon, H., Fauver, L., Hansen, M., Thompson, D., Wright, C.W., and Lillycrop, J., 2006, Hurricane 2004 - an overview of the characteristics and coastal change: Estuaries and Coasts, v. 29, no. 6A, p. 880-888.

Sallenger, A.H., 2000, Storm impact scale for barrier islands: Journal of Coastal Research, v. 16, no. 3, p. 890-895.

Sallenger, A.H., Krabill, W., Swift, R., Brock, J., List, J., Hansen, M., Holman, R.A., Manizade, S., Sontag, J., Meredith, A., Morgan, K., Yunkel, J.K., Frederick, E., and Stockdon, H., 2003, Evaluation of airborne scanning lidar for coastal change application: Journal of Coastal Research, v. 19 , no. 1 , p. $125-133$.

Stockdon, H., Holman, R.A., Howd, P., and Sallenger, A., 2006, Empirical parameterization of setup, swash, and runup: Coastal Engineering, v. 53, issue 7, p. 573-588.

Stockdon, H.F., Sallenger, A.H., Holman, R.A., and Howd, P.A., 2007, A simple model for the large-scale, spatiallyvariable coastal response to hurricanes: Marine Geology, v. 238, p. 1-20.

Wright, C.W., and Brock, J., 2002, EAARL-a lidar for mapping shallow coral reefs and other coastal environments, in Seventh International Conference on Remote Sensing for Marine and Coastal Environments, Miami, Fla., 20-22 May 2002, Proceedings: Ann Arbor, Mich., Veridian International Conferences, CD-ROM. 


\section{Appendix B-1. Chandeleur Islands Grids (See Index Page To Access Data)}




\title{
Past, Present, and Future Sea Level Rise and Effects on Coasts Under Changing Global Climate
}

\author{
By S. Jeffress Williams
}

Chapter C of

Sand Resources, Regional Geology, and Coastal Processes of the Chandeleur Islands Coastal System: an Evaluation of the Breton National Wildlife Refuge

Edited by Dawn Lavoie

In cooperation with the U.S. Fish and Wildlife Service

Scientific Investigations Report 2009-5252 


\title{
U.S. Department of the Interior \\ KEN SALAZAR, Secretary \\ U.S. Geological Survey \\ Marcia K. McNutt, Director
}

\section{U.S. Geological Survey, Reston, Virginia: 2009}

\author{
This and other USGS information products are available at http://store.usgs.gov/ \\ U.S. Geological Survey \\ Box 25286, Denver Federal Center \\ Denver, C0 80225 \\ To learn about the USGS and its information products visit http://www.usgs.gov/ \\ 1-888-ASK-USGS
}

\begin{abstract}
Any use of trade, product, or firm names is for descriptive purposes only and does not imply endorsement by the U.S. Government.

Although this report is in the public domain, permission must be secured from the individual copyright owners to reproduce any copyrighted materials contained within this report.
\end{abstract}

Suggested citation:

Williams, S.J., 2009, Chapter C. Past, present, and future sea level rise and effects on coasts under changing global climate, in Lavoie, D., ed., Sand resources, regional geology, and coastal processes of the Chandeleur Islands coastal system - an evaluation of the Breton National Wildlife Refuge: U.S. Geological Survey Scientific Investigations Report 2009-5252, p. 37-46. 


\title{
Chapter C. Past, Present, and Future Sea Level Rise and Effects on Coasts Under Changing Global Climate
}

\author{
By S. Jeffress Williams ${ }^{1}$
}

\section{Abstract}

Coastal regions, at the interface between the land, oceans, and atmosphere, are highly dynamic because of storms, sea level change, and other processes that act together in complex ways. The geologic record shows that sea level has risen and fallen in cycles of more than $120 \mathrm{~m}$ as the climate has shifted because of natural processes from glacial cold periods to interglacial warm periods. Humans are altering the global climate through greenhouse gas emissions to the atmosphere, and observations show that climate is warming on a global average, as well as becoming more variable, and that sea level rise is accelerating. Earth's climate system this century and beyond is likely to be quite different from how it was in the 20th century. Coastal regions are especially vulnerable to climate change effects and sea level rise, and increased storminess will affect the entire Gulf of Mexico region including the Chandeleur Islands, La. Projections of sea level rise for the 21 st century vary, ranging from one-half meter to more than a meter. Rising sea level can inundate low-lying areas and increase flooding, coastal erosion, wetland loss, and saltwater intrusion into estuaries and freshwater aquifers. The coastal zone is dynamic because of erosion and accretion, and the response of coastal areas to sea level rise is more complex than simple inundation. Much of the United States, and especially the northern Gulf of Mexico region, consists of coastal environments and landforms such as barrier islands and wetlands that will respond to sea level rise by changing shape, size, or position. The combined effects of sea level rise and other climate change factors such as storms may cause rapid and irreversible coastal change when geomorphic thresholds are exceeded. Such changes are likely to dramatically affect coastal landforms, coastal habitats, and species for the Chandeleur Islands, as well as other regions around the Nation.

\section{Introduction}

The Mississippi River Delta Plain and coastal features of the northern Gulf of Mexico region, including the Chandeleur

${ }^{1}$ U.S. Geological Survey, Woods Hole, Mass.
Islands, La., are products of complex and highly variable physical processes and interactions (for example, sediment budgets, storms, sea level change, land subsidence) among the land, the ocean, the atmosphere, and human activities over the past century and longer. Global climate, a primary driver of many processes, has considerable natural variability. Climate conditions affecting the Chandeleur Islands region specifically - in the way of temperature, storm intensity and frequency (for example, wave character and surge flooding), and rates of relative sea level rise - are highly likely to be quite different for the rest of this century and beyond compared to the climate condition effects on the islands over the 20th century. Scientific evidence and observations over the past several decades are unequivocal in demonstrating that the warming of Earth's atmosphere and oceans are very likely the result of carbon emissions from fossil fuel burning and land-use changes. Worldwide observations and data also show that changing rates of global sea level rise are consistent with increasing greenhouse gas concentrations and global warming (IPCC, 2001, 2007; Hansen and others, 2007; Broecker and Kunzig, 2008). Global climate change is underway and already having significant effects on Earth's ecosystems and human populations (Nicholls and others, 2007).

Effects from climate change are not uniform but vary considerably from region to region and over a range of time periods (Nicholls and others, 2007). These variations are caused by regional and local differences in atmospheric, terrestrial, and oceanographic processes. The processes driving climate change are complex, and so-called feedback interactions among the various processes can either enhance or diminish sea level rise impacts, making quantitative prediction of long-term effects difficult. Accelerated global sea level rise, a major outcome of climate warming, will have increasingly far-reaching impacts on all coastal regions of the United States and around the world (Nicholls and others, 2007). Impacts will be particularly dramatic on the very low relief northcentral delta plain of the Gulf Coast, including the Chandeleur Islands, where land subsidence adds significantly to the rate of global sea level rise.

Sea-level rise impacts are already evident for many coastal regions (southern Louisiana, Chesapeake Bay, North Carolina) and are likely to increase significantly during this century and beyond. Future sea level rise will cause further changes to coastal landforms (for example, barrier islands, 
beaches, dunes, marshes), as well as to estuaries, waterways, and human populations and development (Nicholls and others, 2007; FitzGerald and others, 2008; Rosenzweig and others, 2008). Low-lying coastal plain regions - particularly those that are densely populated, including the north-central Gulf of Mexico - are especially vulnerable to sea level rise and its associated impacts (for example, Day and others, 2007; McGranahan and others, 2007).

As stated above, the effects of sea level rise are evident in many ways. Arguably, the most visible effect is seen in changing coastal landscapes, which are altered through inundation and coastal erosion as beaches and sand dunes change shape and move landward (Nordstrom, 2000). In addition, the alteration or loss of coastal habitats such as wetlands, bays, and estuaries has negative impacts on many animal and plant species that depend on these coastal ecosystems.

The analyses of long-term sea level measurements show that sea level rose globally on average $19 \mathrm{~cm}$ during the 20th century (Jevrejeva and others, 2008). In addition, satellite data show that global sea level rise has accelerated over the past 15 years but at highly variable rates on regional scales. Analyses indicate that future sea level rise will likely exceed 20th century observations by the end of the 21 st century (Meehl and others, 2007; Rahmstorf, 2007; Jevrejeva and others, 2008).

\section{Understanding Climate Change}

The scientific study of climate change and associated global sea level rise are complicated because of differences in observations, data quality, cumulative effects, and many other factors. Both direct and indirect methods are useful for studying past climate change (Peltier, 2001). Instrument records and historical documents are the most accurate but are limited to the past 100-150 years in the United States. Geological information from analyses of continuous cores sampled from ice sheets and glaciers, sea and lake sediments, and sea corals provides useful proxies that have allowed researchers to decipher past climate conditions and a record of climate changes stretching back several million years (Miller and others, 2005; Jansen and others, 2007). The most precise methods are annually age-dated paleorecords from ice cores that provide accurate high-resolution data on the climate (for example, global temperature, atmospheric composition) dating back more than 400,000 years. Other paleorecords can extend back even further but provide lower resolution records.

The Intergovernmental Panel on Climate Change (IPCC) in its Fourth Assessment Report provided a comprehensive scientific review and assessment of global climate change trends, expected changes over this century, and the impacts and challenges that both humans and the rest of the natural world are likely to be confronted with (IPCC, 2007). Some key findings from this report are summarized in the IPCC text box. A U.S. Climate Change Science Program (CCSP) report (CENR, 2008) provided a general assessment of current scientific understanding of climate change impacts to the United States, and the recently published CCSP Science and Assessment Product (SAP) 4.1 specifically addressed sea level rise effects on the United States (CCSP, 2009). This chapter is based on chapter 1 of the CCSP SAP 4.1 report.

\section{Global Sea Level Change}

The elevation of global sea level is determined in large part by the dynamic balance between the mass of ice on land and the mass of water in ocean basins. This balance is largely determined by Earth's atmospheric temperature. During the last 800,000 years, global sea level has repeatedly risen and fallen about $120 \mathrm{~m}$ in response to the alternating accumulation and decline of large continental ice sheets as the climate warmed and cooled in naturally occurring 80,000 - to 120,000 year astronomical cycles (Imbrie and Imbrie, 1986; Lambeck and others, 2002). A record of large global sea level change over the past 400,000 years during the last four cycles consists of glacial maximums with low sea levels and interglacial warm periods with high sea levels (fig. 1). The last interglacial period, about 125,000 years ago, lasted about 10,000 to 12,000 years, and global sea level was 4-6 m higher than present (Imbrie and Imbrie, 1986). Following the peak of the Last Glacial Maximum (LGM) about 18,000 to 20,000 years ago, Earth entered the present interglacial warm period. Global sea level rose very rapidly at rates as high as $50 \mathrm{~mm} / \mathrm{yr}$ and a mean rate of about $10 \mathrm{~mm} / \mathrm{yr}$ between about 15,000 and 6,000 years ago. The rate of sea level slowed to about $0.5 \mathrm{~mm} / \mathrm{yr}$ over the past 6,000 years. During the past 3,000 to 2,000 years the rate appears to have slowed further to approximately 0.1 to $0.2 \mathrm{~mm} / \mathrm{yr}$ (IPCC, 2001).

There is growing scientific evidence that during the transition from the LGM to the present interglacial warm period about 12,000 years ago (see fig. 1) Earth underwent abrupt changes when the climate system crossed some thresholds or tipping points (points or levels in the evolution of Earth's climate) that triggered abrupt changes in temperature, precipitation, ice cover, and sea level over decades or less. The causes are not well understood (National Academy of Sciences, 2002; Alley and others, 2003), but one plausible cause is thought to be disruption of major ocean currents by catastrophic influxes of freshwater from glacial lakes, which disrupted ocean circulation and heat transport processes. It is unknown how anthropogenic climate change may alter the natural glacial-interglacial cycle or the forcings that drive abrupt change in Earth's climate system.

At the peak of the LGM, global sea level was approximately $120 \mathrm{~m}$ lower than it is today (fig. 2), so coastlines were far seaward of their present locations near the margins of the continental shelf. As the global climate warmed and ice sheets melted, sea level rose rapidly but at highly 


\section{Selected Findings of the Intergovernmental Panel on Climate Change} (IPCC) on Climate and Global Sea Level Rise

\section{Recent Global Climate Change}

As discussed in IPCC (2007), warming of Earth's climate system is unequivocal, as is now evident from observations of increases in global average air and ocean temperatures, widespread melting of snow and ice, and rising global average sea level.

Human-induced increase in atmospheric carbon dioxide is the most important factor affecting the warming of Earth's climate since the mid-19th century. The atmospheric concentration of carbon dioxide in 2005 exceeds by far the natural range over the last 650,000 years.

Most of the observed increase in global average temperatures since the mid-20th century is very likely due to the observed increase in human-caused greenhouse gas concentrations. Discernible human influences now extend to other aspects of climate, including ocean warming, continental average temperatures, temperature extremes, and wind patterns.

\section{Recent Global Sea Level Rise}

Observations since 1961 show that the average temperature of the global ocean has increased to depths of at least 3,000 $\mathrm{m}$ and that the ocean has been absorbing more than 80 percent of the heat added to the climate system. Such warming causes seawater to expand, contributing to global sea level rise.
Mountain glaciers and snow cover have declined on average in both hemispheres. Widespread decreases in glaciers and ice caps have contributed to global sea level rise.

New data show that losses from the ice sheets of Greenland and Antarctica have very likely contributed to global sea level rise between 1993 and 2003.

Global average sea level rose at an average rate of 1.8 (a range of 1.3-2.3) $\mathrm{mm} / \mathrm{yr}$ between 1961 and 2003. The rate was faster between 1993 and 2003: about 3.1 (2.4-3.8) $\mathrm{mm} / \mathrm{yr}$. Whether the faster rate for 1993-2003 reflects decadal variability or an increase in the longer term trend is unclear.

Global average sea level in the last interglacial period (about 125,000 years ago) was likely 4-6 $\mathrm{m}$ higher than during the 20th century, mainly because of the retreat of polar ice. Ice core data indicate that average polar temperatures at that time were $3{ }^{\circ} \mathrm{C}$ $5^{\circ} \mathrm{C}$ higher than present because of differences in Earth's orbit. The Greenland ice sheet and other arctic ice fields likely contributed no more than $4 \mathrm{~m}$ of the observed global sea level rise. There may also have been contributions from Antarctica ice sheet melting.

\section{Projections for the Future}

Continued greenhouse gas emissions at or above current rates would cause further warming and induce many changes in the global climate system during the $21 \mathrm{st}$ century that would very likely be larger than those observed during the 20th century.

On the basis of a range of possible greenhouse gas emission scenarios for the next century, the IPCC estimates that the global increase in temperature will likely be between $1.1^{\circ} \mathrm{C}$ and $6.4^{\circ} \mathrm{C}$. Estimates of sea level rise for the same scenarios are $0.18-0.59 \mathrm{~m}$, excluding the contribution from accelerated ice discharges from the Greenland and Antarctica ice sheets.

Extrapolating the recent acceleration of ice discharges from the polar ice sheets would imply an additional contribution up to $0.20 \mathrm{~m}$. If melting of these ice caps increases, larger values of sea level rise cannot be excluded.

In addition to global sea level rise, the storms that lead to coastal storm surges could become more intense. The IPCC indicates that on the basis of a range of computer models it is likely that tropical storms such as hurricanes will become more intense, with larger peak windspeeds and more heavy precipitation associated with ongoing increases of tropical sea surface temperatures, while the tracks of "winter" or nontropical storms are projected to shift toward the poles and increase in intensity in the North Atlantic. 


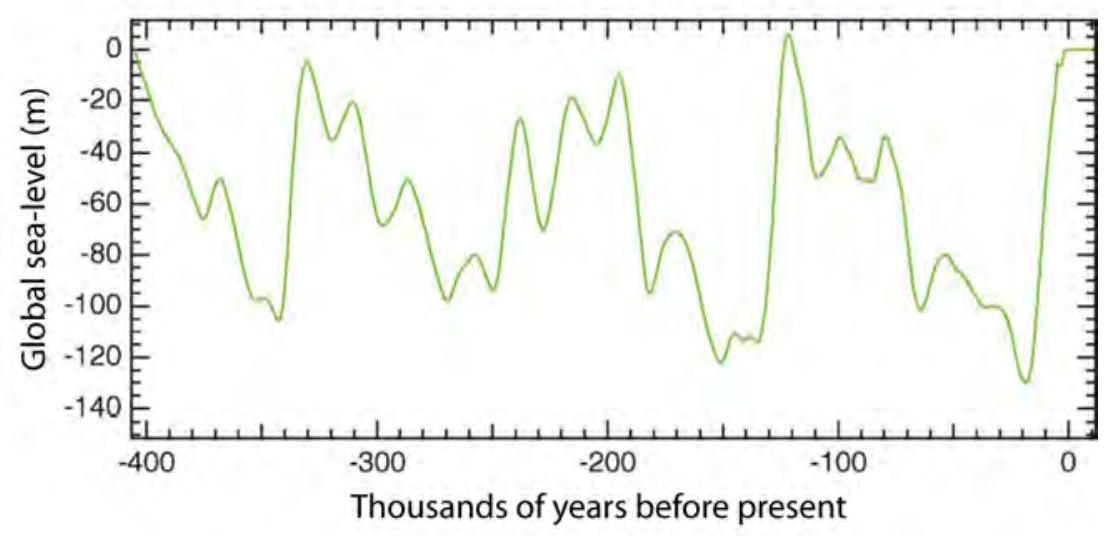

Figure 1. Plot of large variations in global sea level elevation over the past 400,000 years resulting from four glacial and interglacial global climate cycles. Evidence suggests that sea level was about 4-6 $\mathrm{m}$ higher than present during the last interglacial warm period 125,000 years ago and $120 \mathrm{~m}$ lower during the Last Glacial Maximum, about 21,000 years ago (see reviews in Muhs and others, 2004, and Overpeck and others, 2006). Reprinted from Quaternary Science Reviews, 21/1-3, Huybrechts (2002), Sealevel changes at the LGM from ice-dynamic reconstructions of the Greenland and Antarctic ice sheets during the glacial cycles, 203-231, Copyright [2002], with permission from Elsevier.

variable rates, eroding and submerging the continental shelves, drowning ancestral river valleys, and creating major estuaries such as Long Island Sound, Delaware Bay, Chesapeake Bay, Tampa Bay, Lake Pontchartrain, Galveston Bay, and San Francisco Bay. With one model of sea level rise (as described above) based on sea level data compiled from salt marsh deposits, global sea level rise slowed considerably 6,000 years ago and was within a couple of meters of its current elevation about 3,000 years ago (fig. 2).

Global sea level was relatively stable, with rates of rise averaging $0-0.2 \mathrm{~mm} / \mathrm{yr}$ until increasing in the late 19th and early 20th centuries (Lambeck and others, 2004; Bindoff and others, 2007; Gehrels and others, 2008). Some studies indicated that acceleration in sea level rise may have begun earlier, in the late 18th century (Jevrejeva and others, 2008). Analyses of tide gage data indicate that the 20th century rate of sea level rise averaged $1.7 \mathrm{~mm} / \mathrm{yr}$ on a global scale (fig. 3) (Bindoff and others, 2007) but that the rate fluctuated over decadal periods throughout the century (Church and White, 2006; Jevrejeva and others, 2006, 2008). Between 1993 and 2003, both satellite altimeter and tide gage data indicate that the global average rate of sea level rise increased to $3.1 \mathrm{~mm} / \mathrm{yr}$ (Bindoff and others, 2007); however, with such a short record, it is not yet possible to determine with certainty whether this is a natural decadal variation or an accelerated rise that is due to climate warming or some combination of the two (Bindoff and others, 2007).

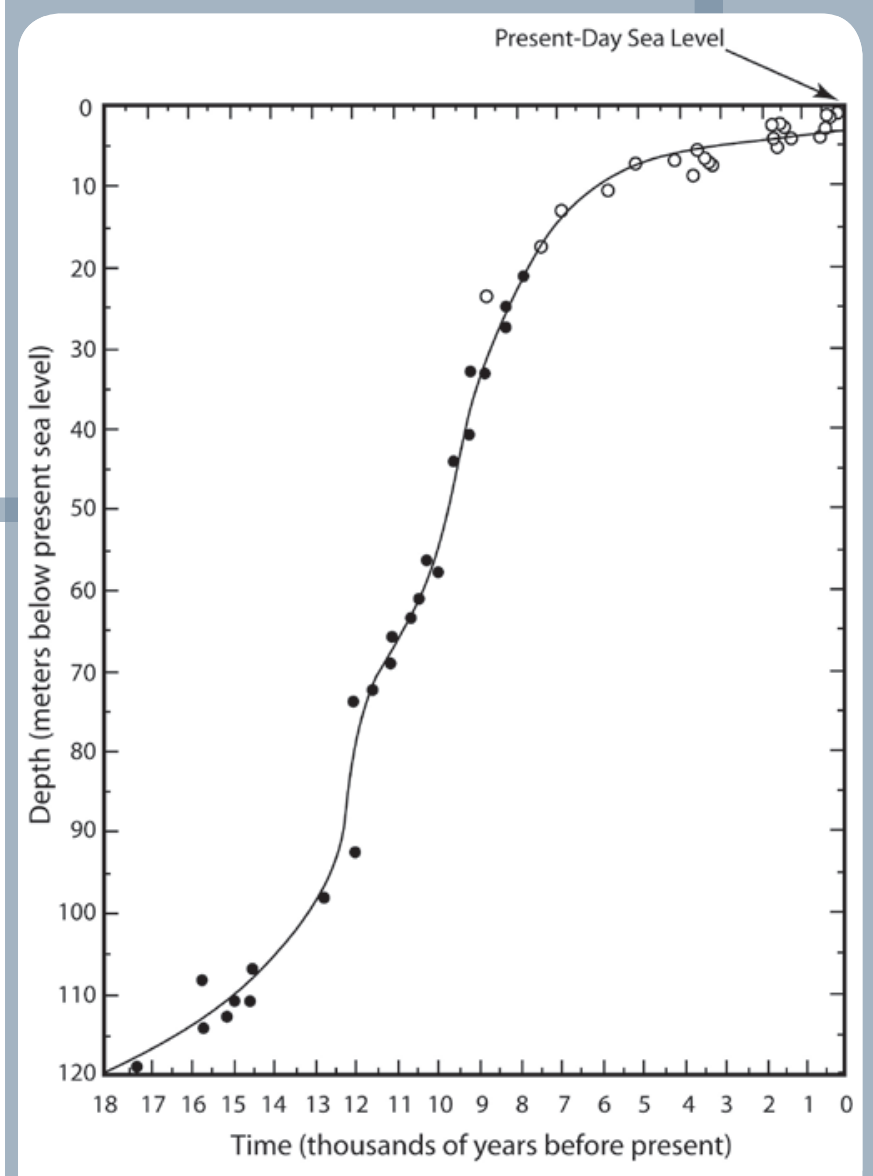

Figure 2. Generalized plot of the rise in global sea level at variable rates over the last 18,000 years as Earth moved from a glacial period to the present interglacial warm period. This curve is reconstructed from geologic samples, shown as data points. Rise was rapid but highly variable for much of the time and slowed about 3,000 years ago. Recent acceleration is not shown at this scale. Reprinted by permission and adapted from Macmillan Publishers Ltd: Nature (Fairbanks, 1989), A 17,000-year glacio-eustatic sea level record-influence of glacial melting rates on the Younger Dryas event and deep-sea circulation, copyright (1989). 


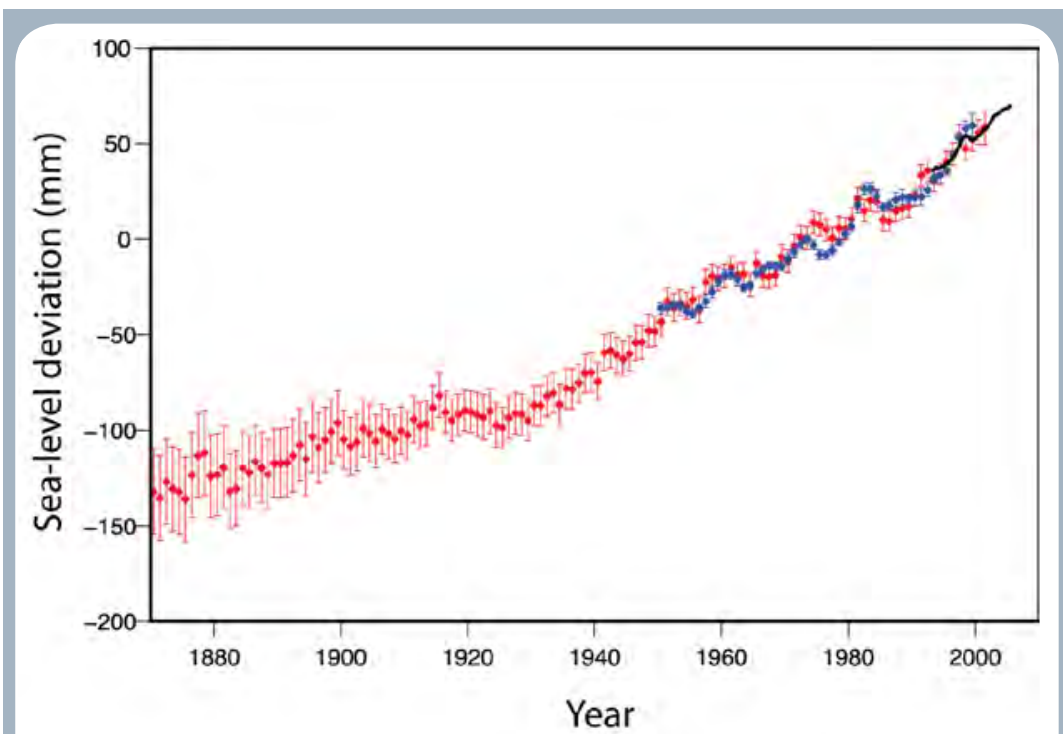

Figure 3. Annual averages of global mean sea level in millimeters from IPCC (2007). The red curve shows sea level fields since 1870 (updated from Church and White, 2006), the blue curve displays tide gage data from Holgate and Woodworth (2004), and the black curve is based on satellite observations from Leuliette and others (2004). The red and blue curves are deviations from their averages for 1961-90, and the black curve is the deviation from the average of the red curve for the period 1993-2001. Vertical error bars show 90 percent confidence intervals for the data points. From Climate Change 2007: The Physical Science Basis. Working Group I Contribution to the Fourth Assessment Report of the Intergovernmental Panel on Climate Change. Figure 5.13. Cambridge University Press.

\section{Relative Sea Level Rise}

Geologic data from age-dating organic sediments in sediment cores and coral reefs are methods used for determining sea level elevations over the past 40,000 years, but the records from long-term (the past 50-100 years) tide gage stations have been the primary direct measurements of relative sea level trends over the past century (Douglas, 2001).

Large variations for relative sea level rise (and fall) around the United States range from a fall of $16.7 \mathrm{~mm} / \mathrm{yr}$ at Skagway in southeast Alaska that was caused by tectonic processes and land rebound upward as a result of glacier melting to a rise of $9.9 \mathrm{~mm} / \mathrm{yr}$ at Grand Isle, La., west of the Mississippi River Delta, that was caused by land subsidence from natural compaction and oil and gas and water extraction. Most of the U.S. northern Gulf of Mexico coast undergoes higher rates of sea level rise $(2-10 \mathrm{~mm} / \mathrm{yr})$ than the current global average $(1.7 \mathrm{~mm} / \mathrm{yr})$ (Zervas, 2001). Unfortunately, there are no long-term tide gages along the Chandeleur Islands chain. The closest long-term tide gages to the Chandeleur Islands are at Grand Isle with a 60-year record of $9.9 \mathrm{~mm} / \mathrm{yr}$ and at Dauphin Island, Ala., with a 39-year record of $2.9 \mathrm{~mm} /$ yr (Zervas, 2001). The Chandeleur Islands are approximately

\section{Relative Sea Level}

Global sea level rise results mainly from the worldwide increase in the volume of the world's oceans that occurs as a result of thermal expansion of warming ocean water and the addition of water to the ocean from melting ice sheets and glaciers (ice masses on land). Relative sea level rise is measured directly by coastal tide gages, which record both the movement of the land to which they are attached and the changes in global sea level. Global sea level rise can be estimated from tide gage data by subtracting the land elevation change component. Thus, tide gages are important observation instruments for measuring sea level change trends; however, because variations in climate and ocean circulation can cause fluctuations over 10-year time periods, the most reliable sea level data are from tide gages having records of 50 years or longer and for which the rates have been adjusted by using a global isostatic adjustment model (Douglas, 2001).

At regional and local scales along the coast, vertical movements of the land surface can also contribute significantly to sea level change, and the combination of global sea level and land level change is referred to as "relative sea level" (Douglas, 2001).Thus, the term "relative sea level rise" refers to the change in sea level relative to the elevation of the land, which includes both global sea level rise and vertical movements of the land.

Vertical changes of the land surface result from many factors including tectonic processes and subsidence (sinking of the land) that is due to compaction of sediments and extraction of subsurface fluids such as oil, gas, and water. A principal contributor to this change along the northern Gulf Coast is sediment loading, which also contributes to regional subsidence of the land surface. Subsidence contributes to high rates of relative sea level rise $(9.9 \mathrm{~mm} / \mathrm{yr})$ in the Mississippi River Delta, where thick sediments have accumulated and are compacting. Likewise, fluid withdrawal from coastal aquifers causes the sediments to compact locally as the water is extracted. In Louisiana and Texas, oil, gas, and groundwater extractions have contributed markedly to subsidence and relative sea level rise (Gornitz and Lebedeff, 1987; Emery and Aubrey, 1991; Galloway and others, 1999; Morton and others, 2004). In locations where the land surface is subsiding, rates of relative sea level rise exceed the average rate of global rise. 
midway between the gages, yielding an extrapolated rate of $6.4 \mathrm{~mm} / \mathrm{yr}$; however, because the subsurface geology of the islands and adjacent sea floor are thought to be more stable than those west of the delta, this rate is likely an upper limit.

The IPCC (2007) estimated on the basis of modeling studies that global sea level is likely to rise $18-59 \mathrm{~cm}$ over the next century (fig. 4); however, an important caveat in the IPCC predictions is that possible increased meltwater contributions from Greenland and the Antarctica have been excluded because of limited capability at the time the report was being prepared to understand and model ice flow processes (IPCC, 2007; Meehl and others, 2007). The IPCC projections (fig. 4) represent a likely range of sea level rise that inherently allows for the possibility that the actual rise may be higher or lower. Recent satellite data suggest that sea level rise rates (about $3.1 \mathrm{~mm} / \mathrm{yr}$ ) may already be approaching the higher end of the IPCC estimates (Rahmstorf and others, 2007; Jevrejeva and others, 2008), and scientific consensus is growing that the IPCC estimates are conservative and should be considered low estimates because meltwater contributions from Greenland and Antarctica - which are increasingly recognized as important - were excluded. Rahmstorf (2007), as well as other climate scientists, has suggested that a global sea level rise of about $1 \mathrm{~m}$ or more is plausible within this century; therefore, prudence suggests that this value be considered for planning and management of the coast, including the Chandeleur Islands region. As climate data and scientific understanding improves, this prediction may likely change.

This discussion focuses on the effects of sea level rise on U.S. coasts, including the Chandeleur Islands, over this century, but climate warming and its effects are likely to continue and accelerate in effects well into the future because of the amount of greenhouse gases already in the atmosphere (IPCC, 2007). Currently, potential ice melting from land-based ice masses (primarily Greenland and west Antarctica) has some scientific uncertainty and therefore may not be adequately incorporated into sea level rise model projections. Recent observations of changes in ice cover and glacial melting on Greenland, west Antarctica, and smaller glaciers and ice caps around the world indicate that ice loss could be more rapid than the trends evaluated for the IPCC (2007) report (Chen and others, 2006; Fettweis and others, 2007; Meier and others, 2007; Shepherd and Wingham, 2007). The science needed to assign probability to these high scenarios is not yet established, but this topic is worthy of continued study because of the grave implications for coastal and low-lying areas in the United States and around the world.

\section{Impacts of Sea Level Rise on the U.S. Coast}

Coastal communities and habitats will be increasingly stressed by climate change impacts that are due to sea level rise and storms (Field and others, 2007). To varying degrees over decades, rising sea level will affect entire coastal systems from the ocean shoreline well landward across the coastal plain. The physical and ecological changes that are likely to occur in the near future will impact people, coastal development, and natural ecosystem resources. Impacts from sea level rise include land loss through submergence and erosion of lands in coastal areas, migration of coastal landforms and habitats, increased frequency and extent of storm-related flooding, wetland losses, and increased salinity in estuaries and coastal freshwater aquifers. Each of these effects can have impacts on both natural ecosystems and human development. Often the impacts act together, and the effects can be cumulative over time.

Other impacts of climate change, such as increasingly severe droughts and storm intensity-combined with continued rapid coastal development - could increase the extent of sea level rise impacts (Nicholls and others, 2007). To deal with these impacts, several things should be considered: new practices in managing coasts, the combined

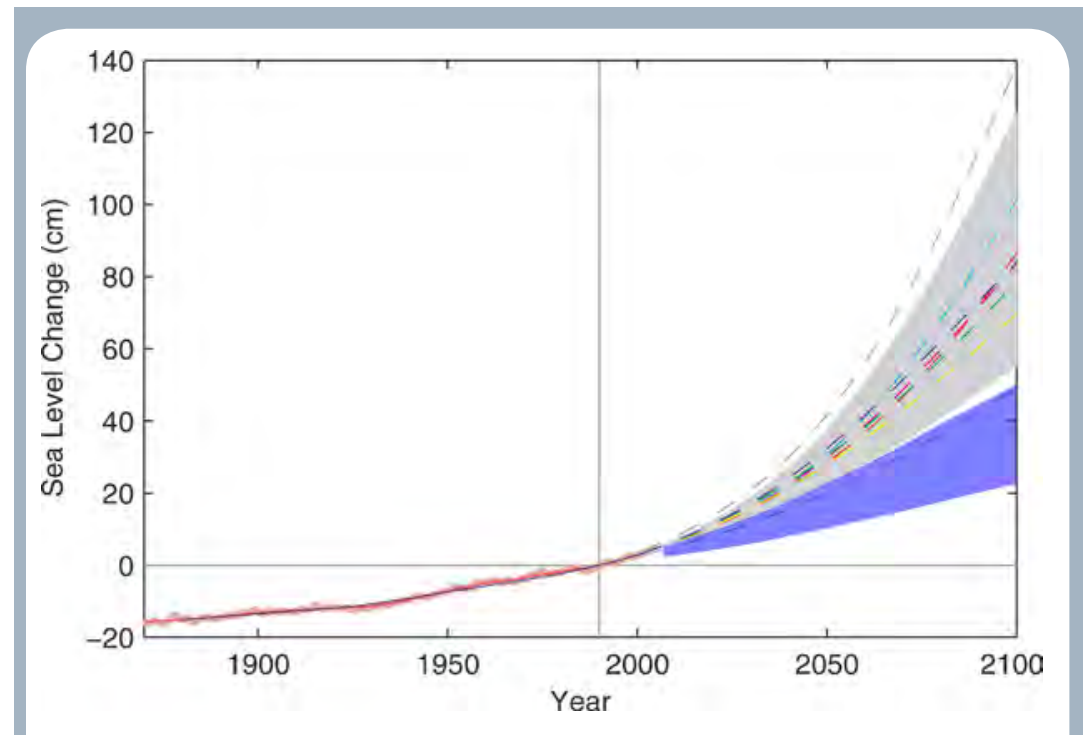

Figure 4. Plot in centimeters rise over time of past sea level observations and several future sea level projections to the year 2100 based on various computer models. The blue shaded area is the projection by Bindoff and others (2007) and the basis for the IPCC (2007) estimates. The higher gray and dashed line projections are from Rahmstorf (2007) considering the factors used in the IPCC estimates and also potentially increased melting of ice sheets in Greenland and Antarctica. From: Rahmstorf, S., 2007: A semiempirical approach to projecting future sea-level rise. Science, 315(5810), 368-370. Reprinted with permission from AAAS. 
impacts of mitigating changes to the physical system (for example, coastal erosion or migration, wetland losses), and the combination of impacts to the environment as well as to humans (for example, property losses, more frequent flood damage).

Global sea level rise, in combination with the factors above, is already having significant effects on many U.S. coastal areas. Flooding of low-lying regions by storm surges and spring tides is becoming more frequent. In many areas around the United States (for example New Jersey, North Carolina, Chesapeake Bay, Louisiana), wetland losses are occurring, fringe forests are dying and being converted to marsh, farmland and lawns are being converted to marsh (for example, see Riggs and Ames, 2003), and some roads and urban areas (Charleston, Chesapeake Bay) in low-elevation areas are more frequently flooded during spring high tides (Douglas, 2001). Rising sea level is causing saltwater intrusion into estuaries and threatening freshwater resources.

\section{Climate Change and Storms}

Although storms occur episodically, they can have long-term impacts to the physical environment and human populations. Coupled with rise in sea level, the effects of storms could be more extensive in the future because of changes in storm character, such as intensity, frequency, and storm tracking. In addition to higher sea level, coastal storm surge from hurricanes could become higher, and more intense rainfall could raise the potential for flooding from land runoff. Recent studies (for example, Emanuel and others, 2004; Emanuel, 2005, 2008; Elsner and others, 2008; Komar and Allan, 2008) concluded that there is evidence that hurricane intensity has increased during the past 30 years over the Atlantic Ocean; however, it is unknown whether this trend will continue into the future. There is currently no scientific consensus on changes in the frequency of major storms. Emanuel (2008) suggested that increased wind shear (which weakens hurricanes) resulting from global warming may reduce the global frequency of hurricanes. The topic of storm effects resulting from climate warming is being studied but is very much unsettled at the present time.

Extratropical storms can also produce significant storm surges. Over the last 50 years, the pattern of these storms shows a northward shift in track (Karl and others, 2008), which has reduced storm frequencies and intensities in the middle latitudes and increased storm frequencies and intensities at high latitudes (Gutowski and others, 2008). Karl and others (2008) concluded that future intense nontropical storms will become more frequent and will have stronger winds and greater wave heights. Projections for changes in extratropical storm activity for the Gulf of Mexico are not available. Thus, while increased storm intensity is a serious risk in concert with sea level rise, storm predictions are not so well established that planners can yet rely on them.

\section{Shoreline Change and Coastal Erosion}

The diverse landforms that make up the more than $150,000 \mathrm{~km}$ of U.S. tidal coastline reflect a dynamic interaction between (1) natural factors and physical processes that act on the coast (for example, storms, waves, currents, sand sources and sinks, relative sea level), (2) human activity (for example, dredging, dams, coastal engineering), and (3) the geological character of the coast and nearshore. Variations of these physical processes in both location and time, as well as the local geology along the coast, result in the majority of U.S. coastlines undergoing overall long-term net erosion at highly varying rates.

The complex interactions between these factors make it difficult to relate sea level rise and shoreline change and to reach agreement among coastal scientists on approaches to predict how shorelines will change in response to sea level rise. The difficulty in linking sea level rise to coastal change stems from the fact that shoreline change is not driven solely by sea level rise. Instead, coasts are in dynamic flux, responding to many driving forces, such as storm activity, dominant winds, the coastal geological character, changes in tidal flow, and volume of sediment (that is, sediment budget) in the coastal system. For example, FitzGerald and others (2008) reported the dramatic effects that changes in tidal wetland area can have on entire coastal systems by altering tidal flow, which in turn affects the size and shape of tidal inlets, ebb and flood tide deltas, and barrier islands. Consequently, while there is strong scientific consensus that climate change is accelerating sea level rise and affecting coastal regions, there are still considerable uncertainties in predicting in any detail how the coast will respond to future sea level rise in concert with the other driving processes.

Some scientific evidence suggests that barrier islands, wetlands, and other landforms within coastal systems might have tipping points or thresholds, such that when limits are exceeded the landforms become unstable and undergo large irreversible changes (National Academy of Sciences, 2002; Riggs and Ames, 2003; Nicholls and others, 2007). These changes are thought to occur rapidly and are thus far unpredictable. It is possible that this process is happening to barrier islands and wetlands along the Louisiana coast, including the Chandeleur Islands, which have been subject to high rates of sea level rise, frequent major storms over the past decade, land subsidence, high rates of erosion, and limited sediment supply as detailed in the other chapters of this report and in Sallenger and others (2007).

\section{Acknowledgments}

Reviews by Thomas Cronin, David Twichell, and Matthew Arsenault (all U.S. Geological Survey) were helpful and are appreciated. Thanks are extended to colleagues for 
their collaboration and contributions to chapter 1 of CCSP (2009) Science and Assessment Product 4.1 on which part of this paper is based.

\section{References}

Alley, R.B., Marotzke, J., Nordhaus, W.D., Overpeck, J.T., Peteet, D.M., Pielke, R.A., Jr., Pierrehumbert, R.T., Rhines, P.B., Stocker, T.F., Talley, L.D., and Wallace, J.M., 2003, Abrupt climate change: Science, v. 299, no. 5615, p. 2005-2010.

Bindoff, N.L., Willebrand, J., Artale, V., Cazenave, A., Gregory, J., Gulev, S., Hanawa, K., C. Le Quéré, Levitus, S., Nojiri, Y., Shum, C.K., Talley, L.D., and Unnikrishnan, A., 2007, Observations - oceanic climate change and sea level, in Solomon, S., Qin, D., Manning, M., Chen, Z., Marquis, M., Avery, K.B., Tignor, M., and Miller, H.L., eds., Climate change 2007-the physical science basis. Contribution of Working Group I to the Fourth Assessment Report of the Intergovernmental Panel on Climate Change: Cambridge, U.K., and New York, Cambridge University Press, p. 385-432.

Broecker, W.S., and Kunzig, R., 2008, Fixing climate-what past climate changes reveal about the current threat—and how to counter it: New York, Hill and Wang, 253 p.

CCSP (Climate Change Science Program), 2009, Coastal sensitivity to sea-level rise - a focus on the mid-Atlantic region. A report by the U.S. Climate Change Science Program and the Subcommittee on Global Change Research (James G. Titus [Coordinating Lead Author], K. Eric Anderson, Donald R. Cahoon, Stephen K. Gill, E. Robert Thieler, S. Jeffress Williams [Lead Authors]): Washington, D.C., U.S. Environmental Protection Agency, 320 p.

CENR (Committee on Environment and Natural Resources), 2008, Scientific assessment of the effects of global change on the United States: Washington, D.C., National Science and Technology Council, Committee on Environment and Natural Resources, $261 \mathrm{p}$.

Chen, J.L., Wilson, C.R., and Tapley, B.D., 2006, Satellite gravity measurements confirm accelerated melting of Greenland ice sheet: Science, v. 313, no. 5795, p. 19581960.

Church, J.A., and White, N.J., 2006, A 20th century acceleration in global sea-level rise: Geophysical Research Letters, v. 33, L01602, doi:10.1029/2005GL024826.
Day, J.W., Jr., Biesch, D.F., Clairain, E.J., Kemp, G.P., Laska, S.B., Mitsch, W.J., Orth, K., Mashriqui, H., Reed, D.J., Shabman, L., Simenstad, C.A., Streever, B.J., Twilley, R.R., Watson, C.C., Wells, J.T., and Whigham, D.F., 2007, Restoration of the Mississippi Delta-lessons from Hurricanes Katrina and Rita: Science, v. 315, no. 5819, p. 1679-1684.

Douglas, B.C., 2001, Sea level change in the era of the recording tide gauges, in Douglas, B.C., Kearney, M.S., and Leatherman, S.P., eds., Sea level rise - history and consequences: San Diego, Academic Press, International Geophysics Series, v. 75, p. 37-64.

Elsner, J.B., Kossin, J.P., and Jagger, T.H., 2008, The increasing intensity of the strongest tropical cyclones: Nature, v. 455 , no. 7209 , p. 92-95.

Emanuel, K.A., 2005, Increasing destructiveness of tropical cyclones over the past 30 years: Nature, v. 436, no. 7051, p. 686-688.

Emanuel, K., 2008, The hurricane-climate connection: Bulletin of the American Meteorological Society, v. 89, no. 5, p. ES10-ES20.

Emanuel, K., DesAutels, C., Holloway, C., and Korty, R., 2004, Environmental control of tropical cyclone intensity: Journal of the Atmospheric Sciences, v. 61, no. 7, p. 843-858.

Emery, K.O., and Aubrey, D.G., 1991, Sea levels, land levels, and tide gauges: New York, Springer-Verlag, 237 p.

Fairbanks, R.G., 1989, A 17,000-year glacio-eustatic sea level record - influence of glacial melting rates on the Younger Dryas event and deep-sea circulation: Nature, v. 342, no. 6250, p. 637-642.

Fettweis, X., van Ypersele, J.-P., Gallee, H., Lefebre, F., and Lefebvre, W., 2007, The 1979-2005 Greenland ice sheet melt extent from passive microwave data using and improved version of the melt retrieval XPGR algorithm: Geophysical Research Letters, v. 34, L05502, doi:10.1029/2006GL028787.

Field, C.B., Mortsch, L.D., Brklacich, M., Forbes, D.L., Kovacs, P., Patz, J.A., Running, S.W., and Scott, M.J., 2007, North America, in Parry, M.L., Canziani, O.F., Palutikof, J.P., van der Linden, P.J., and Hanson, C.E., eds., Climate change 2007-impacts, adaptation and vulnerability. Contribution of Working Group II to the Fourth Assessment Report of the Intergovernmental Panel on Climate Change: Cambridge, U.K., and New York, Cambridge University Press, p. 617-652. 
FitzGerald, D.M., Fenster, M.S., Argow, B.A., and Buynevich, I.V., 2008, Coastal impacts due to sea-level rise: Annual Review of Earth and Planetary Sciences, v. 36, p. 601-647.

FitzGerald, D.M., Fenster, M.S., Argow, B.A., and Buynevich, I.V., 2008, Coastal impacts due to sea-level rise: Annual Review of Earth and Planetary Sciences, v. 36, p. 601-647.

Galloway, D., Jones, D.R., and Ingebritsen, S.E., 1999, Land subsidence in the United States: Reston, Va., U.S. Geological Survey Circular 1182, 177 p.

Gehrels, W.R., Hayward, B.W., Newnham, R.M., and Southall, K.E., 2008, A 20th century acceleration in sea-level rise in New Zealand: Geophysical Research Letters, v. 35, L02717, doi:10.1029/2007GL032632.

Gornitz, V., and Lebedeff, S., 1987, Global sea-level changes during the past century, in Nummedal, D., Pilkey, O.H., and Howard, J.D., eds., Sea-level fluctuation and coastal evolution: Tulsa, Okla., Society of Economic Paleontologists and Mineralogists, Special Publication 41, p. 3-16.

Gutowski, W.J., Hegerl, G.C., Holland, G.J., Knutson, T.R., Mearns, L.O., Stouffer, R.J., Webster, P.J., Wehner, M.F., and Zwiers, F.W., 2008, Causes of observed changes in extremes and projections of future changes, in Karl, T.R., Meehl, G.A., Miller, C.D., Hassol, S.J., Waple, A.M., and Murray, W.L., eds., Weather and climate extremes in a changing climate - regions of focus - North America, Hawaii, Caribbean, and U.S. Pacific Islands. Synthesis and Assessment Product 3.3: Washington D.C., U.S. Climate Change Science Program, p. 81-116.

Hansen, J., Sato, M., Kharecha, P., Russell, G., Lea, D.W., and Siddall, M., 2007, Climate change and trace gases: Philosophical Transactions of the Royal Society A, v. 365, no. 1856, p. 1925-1954.

Huybrechts, P., 2002, Sea-level changes at the LGM from ice-dynamic reconstructions of the Greenland and Antarctic ice sheets during the glacial cycles, Quaternary Science Reviews, v. 21, nos. 1-3, p. 203-231.

Holgate, S.J., and Woodworth, P.L., 2004, Evidence for enhanced coastal sea level rise during the 1990s: Geophysical Research Letters, v. 31, L07305, doi:10.1029/2004GL019626.

Imbrie, J., and Imbrie, K.P., 1986, Ice ages - solving the mystery: Cambridge, Mass., Harvard University Press, 224 p.
IPCC (Intergovernmental Panel on Climate Change), 2001, Climate change 2001 - the scientific basis. Contribution of Working Group I to the Third Assessment Report of the Intergovernmental Panel on Climate Change (Houghton, J.T., Ding, Y., Griggs, D.J., Noguer, M., van der Linden, P.J., Dai, X., Maskell, K., and Johnson, C.A., eds.): Cambridge, U.K., and New York, Cambridge University Press, $881 \mathrm{p}$.

IPCC (Intergovernmental Panel on Climate Change), 2007, Climate change 2007-the physical science basis. Contribution of Working Group I to the Fourth Assessment Report of the Intergovernmental Panel on Climate Change (Solomon, S., Qin, D., Manning, M., Chen, Z., Marquis, M., Averyt, K.B., Tignor, M., and Miller, H.L., eds.): Cambridge, U.K., and New York, Cambridge University Press, 996 p.

Jansen, E., Overpeck, J., Briffa, K.R., Duplessy, J.-C., Joos, F., Masson-Delmotte, V., Olago, D., Otto-Bliesner, B., Peltier, W.R., Rahmstorf, S., Ramesh, R., Raynaud, D., Rind, D., Solomina, O., Villalba, R., and Zhang, D., 2007, Palaeoclimate, in Solomon, S., Qin, D., Manning, M., Chen, Z., Marquis, M., Averyt, K.B., Tignor, M., and H.L. Miller, H.L., eds., Climate change 2007-the physical science basis. Contribution of Working Group I to the Fourth Assessment Report of the Intergovernmental Panel on Climate Change: Cambridge, U.K., and New York, Cambridge University Press, p. 433-497.

Jevrejeva, S., Grinsted, A., Moore, J.C., and Holgate, S., 2006, Nonlinear trends and multiyear cycles in sea level records: Journal of Geophysical Research, v. 111, C09012, doi:10.1029/2005JC003229.

Jevrejeva, S., Moore, J.C., Grinsted, A., and Woodworth, P.L., 2008, Recent global sea level acceleration started over 200 years ago?: Geophysical Research Letters, v. 35, L08715, doi:10.1029/2008GL033611.

Karl, T.R., Meehl, G.A., Peterson, T.C., Kunkel, K.E., Gutowski, W.J., Jr., and Easterling, D.R., 2008, Executive summary, in Karl, T.R., Meehl, G.A., Miller, C.D., Hassol, S.J., Waple, A.M., and Murray, W.L., eds., Weather and climate extremes in a changing climate-regions of focus - North America, Hawaii, Caribbean, and U.S. Pacific Islands. Synthesis and Assessment Product 3.3: Washington, D.C., U.S. Climate Change Science Program, p. 1-9.

Komar, P.D., and Allan, J.C., 2008, Increasing hurricanegenerated wave heights along the U.S. east coast and their climate controls: Journal of Coastal Research, v. 24, no. 2, p. 479-488.

Lambeck, K., Esat, T.M., and Potter, E.-K., 2002, Links between climate and sea levels for the past three million years: Nature, v. 419, no. 6903, p. 199-206. 
Lambeck, K., Anzidei, M., Antonioli, F., Benini, A., and Esposito, A., 2004, Sea level in Roman time in the central Mediterranean and implications for recent change: Earth and Planetary Science Letters, v. 224, nos. 3-4, p. 563-575.

Leuliette, E.W., Nerem, R.S., and Mitchum, G.T., 2004, Calibration of TOPEX/Poseidon and Jason altimeter data to construct a continuous record of mean sea level change: Marine Geodesy, v. 27, nos. 1-2, p. 79-94.

McGranahan, G., Balk, D., and Anderson, B., 2007, The rising tide - assessing the risks of climate change and human settlements in low elevation coastal zones: Environment \& Urbanization, v. 19, no. 1, p. 17-37.

Meehl, G.A., Stocker, T.F., Collins, W.D., Friedlingstein, P., Gaye, A.T., Gregory, J.M., Kitoh, A., Knutti, R., Murphy, J.M., Noda, A., Raper, S.C.B., Watterson, I.G., Weaver, A.J., and Zhao, Z.-C., 2007, Global climate projections, in Solomon, S., Qin, D., Manning, M., Chen, Z., Marquis, M., Averyt, K.B., Tignor, M., and Miller, H.L., eds., Climate change 2007-the physical science basis. Contribution of Working Group I to the Fourth Assessment Report of the Intergovernmental Panel on Climate Change: Cambridge, U.K., and New York, Cambridge University Press, p. 747-845.

Meier, M.F., Dyurgerov, M.B., Ursula, K.R., O’Neel, S., Pfeffer, W.T., Anderson, R.S., Anderson, S.P., and Glazovsky, A.F., 2007, Glaciers dominate eustatic sealevel rise in the 21st century: Science, v. 317, no. 5841, p. 1064-1067.

Miller, K.G., Kominz, M.A., Browning, J.V., Wright, J.D., Mountain, G.S., Katz, M.E., Sugarman, P.J., Cramer, B.S., Christie-Blick, N., and Pekar, S.F., 2005, The Phanerozoic record of global sea-level change: Science, v. 310, no. 5752, p. $1293-1298$.

Morton, R.A., Miller, T.L., and Moore, L.J., 2004, National assessment of shoreline change - part 1, historical shoreline changes and associated coastal land loss along the U.S. Gulf of Mexico: Reston, Va., U.S. Geological Survey Open-File Report 2004-1043, 44 p.

Muhs, D.R., Wehmiller, J.F., Simmons, K.R., and York, L.L., 2004, Quaternary sea level history of the U.S., in Gillespie, A.R., Porter, S.C., and Atwater, B.F., eds., The Quaternary Period of the United States: Amsterdam, Elsevier, p. 147-183.

National Academy of Sciences, 2002, Abrupt climate change - inevitable surprises: Washington, D.C., National Academy Press, $230 \mathrm{p}$.
Nicholls, R.J., Wong, P.P., Burkett, V.R., Codignotto, J.O., Hay, J.E., McLean, R.F., Ragoonaden, S., and Woodroffe, C.D., 2007, Coastal systems and low-lying areas, in Parry, M.L., Canziani, O.F., Palutikof, J.P., van der Linden, P.J., and Hanson, C.E., eds., Climate change 2007impacts, adaptation and vulnerability. Contribution of Working Group II to the Fourth Assessment Report of the Intergovernmental Panel on Climate Change: Cambridge, U.K., and New York, Cambridge University Press, p. 315-356.

Nordstrom, K.F., 2000, Beaches and dunes of developed coasts: New York, Cambridge University Press, 338 p.

Overpeck, J.T., Otto-Bliesner, B.L., Miller, G.H., Muhs, D.R., Alley, R.B., and Keihl, J.T., 2006, Paleo-climatic evidence for the future ice-sheet instability and rapid sea level rise: Science, v. 311 , no. 5768 , p. $1747-1750$.

Peltier, W.R., 2001, Global glacial isostatic adjustment and modern instrumental records of relative sea level history, in Douglas, B.C., Kearney, M.S., and Leatherman, S.P., eds., Sea level rise - history and consequences: San Diego, Academic Press, International Geophysics Series, v. 75, p. 65-95.

Rahmstorf, S., 2007, A semi-empirical approach to projecting future sea-level rise: Science, v. 315, no. 5810, p. 368-370.

Rahmstorf, S., Cazenave, A., Church, J.A., Hansen, J.E., Keeling, R.F., Parker, D.E., and Somerville, R.C.J., 2007, Recent climate observations compared to projections: Science, v. 316, no. 5825, p. 709.

Riggs, S.R., and Ames, D.V., 2003, Drowning of North Carolina - sea-level rise and estuarine dynamics: Raleigh, North Carolina Sea Grant College Program, Publication no. UNC-SG-03-04, 152 p.

Rosenzweig, C., Karoly, D., Vicarelli, M., Neofotis, P., Wu, Q., Casassa, G., Menzel, A., Root, T.L., Estrella, N., Seguin, B., Tryjanowski, P., Liu, C., Rawlins, S., and Imeson, A., 2008, Attributing physical and biological impacts to anthropogenic climate change: Nature, v. 453, no. 7193, p. 353-358.

Sallenger, A.S., Wright, C.W., and Lillycrop, J., 2007, Coastalchange impacts during Hurricane Katrina-an overview, in Kraus, N.C., and Rosati, J.D., eds., Coastal sediments '07: Reston, Va., America Society of Civil Engineers, p. 888-896.

Shepherd, A., and Wingham, D., 2007, Recent sea-level contributions of the Antarctic and Greenland ice sheets: Science, v. 315, no. 5818, p. 1529-1532.

Zervas, C., 2001, Sea level variations of the United States 1854-1999: Silver Spring, Md., National Oceanic and Atmospheric Administration (NOAA) National Ocean Service, NOAA technical report NOS CO-OPS 36. 


\section{Historical (1869-2007) Sea Floor Evolution and Sediment Dynamics Along the Chandeleur Islands}

By Michael D. Miner, Mark Kulp, H. Dallon Weathers, and James Flocks

Chapter D of

Sand Resources, Regional Geology, and Coastal Processes of the Chandeleur Islands Coastal System: an Evaluation of the Breton National Wildlife Refuge

Edited by Dawn Lavoie

In cooperation with the U.S. Fish and Wildlife Service

Scientific Investigations Report 2009-5252 


\title{
U.S. Department of the Interior \\ KEN SALAZAR, Secretary \\ U.S. Geological Survey \\ Marcia K. McNutt, Director
}

\section{U.S. Geological Survey, Reston, Virginia: 2009}

\author{
This and other USGS information products are available at http://store.usgs.gov/ \\ U.S. Geological Survey \\ Box 25286, Denver Federal Center \\ Denver, C0 80225 \\ To learn about the USGS and its information products visit http://www.usgs.gov/ \\ 1-888-ASK-USGS
}

\begin{abstract}
Any use of trade, product, or firm names is for descriptive purposes only and does not imply endorsement by the U.S. Government.

Although this report is in the public domain, permission must be secured from the individual copyright owners to reproduce any copyrighted materials contained within this report.
\end{abstract}

Suggested citation:

Miner, M.D., Kulp, M., Weathers, H.D., and Flocks, J., 2009, Chapter D. Historical (1869-2007) sea floor evolution and sediment dynamics along the Chandeleur Islands, in Lavoie, D., ed., Sand resources, regional geology, and coastal processes of the Chandeleur Islands coastal system —an evaluation of the Breton National Wildlife Refuge: U.S. Geological Survey Scientific Investigations Report 2009-5252, p. 47-74. 


\title{
Chapter D. Historical (1869-2007) Sea Floor Evolution and Sediment Dynamics Along the Chandeleur Islands
}

\author{
By Michael D. Miner, ${ }^{1}$ Mark Kulp, ${ }^{1}$ H. Dallon Weathers, ${ }^{1}$ and James Flocks ${ }^{2}$
}

\section{Abstract}

Shoreline and sea floor change analyses based on historical hydrographic data (dating back to 1869), shoreline surveys (dating back to 1855), and satellite imagery for the Chandeleur Islands, La., reveal long-term trends of barrier shoreface retreat, barrier thinning, and recently, barrier disintegration. Volume calculations indicate that about $150 \times 10^{6} \mathrm{~m}^{3}$ of sediment has been deposited downdrift (northward) and seaward of the northern terminal spit during the past 125 years. A similar volume of sediment has accreted at the extreme southern limits of the island chain (south of Breton Island). The volume deposited in the backbarrier, however, is only half of that distributed to the flanks, suggesting that the dominant transport mode is alongshore as opposed to cross-shore. The depositional sinks at the flanks of the island arc accreted at rates of more than $1 \times 10^{6} \mathrm{~m}^{3} \mathrm{yr}^{-1}$ between 1870 and 2007; however, calculations of potential longshore sediment transport rates based on 20 years of offshore wave data are two orders of magnitude less than the accretion rates. The sediment sources for these accretionary zones at the flanks include (1) relict deltaic deposits eroded from the shoreface where about $790 \times 106 \mathrm{~m}^{3}$ of erosion has occurred since 1870 and (2) nearshore and subaerial barrier sand. Long-term shoreline erosion and transgressive submergence are primarily event driven and associated with major storms. Rapid land loss accompanies these high-energy events. The islands do not fully recover from storm impacts because sand is transported to the flanks of the arc, removing it from the littoral system. These downdrift sand reservoirs provide a unique, quasi-renewable potential resource for nourishing the updrift barrier system.

\section{Introduction}

The processes that govern coastal evolution occur over varied temporal and spatial scales; therefore, significant processes may go undetected in the absence of a regionalscale investigation covering a long time period (Sallenger and others, 1992). In this study of the Chandeleur Islands, La., we used historical bathymetric and shoreline data from the U.S. Coast and Geodetic Survey (USCGS) from the 1870s and 1920 s as a basis for comparing bathymetry and shoreline data collected in 2006 and 2007 by the University of New Orleans (UNO) and the U.S. Geological Survey (USGS). The two datasets were used to construct sea floor change digital elevation models (DEMs) for the region, which allowed us to determine zones of erosion and accretion, sediment volumes, and ultimately, long-term sediment transport trends and a sediment budget for the system. This is the first comprehensive coastal evolutionary model for the Chandeleur Islands, and the results demonstrate that processes that occur offshore along the lower shoreface govern sediment supply to the shoreline and, ultimately, long-term coastal evolution. Similar conclusions were reached by List and others (1991, 1994), Sallenger and others (1992), and Jaffe and others (1997) as a result of their study of the south-central Louisiana barrier islands. Hydrodynamic modeling of the Chandeleurs (Jaffe and others, 1997; Georgiou and Schindler, this volume) demonstrates that sediment transport processes along the lower shoreface are active primarily during large storms. Consequently, shoreface retreat and the ensuing large volumes of sediment that eroded from this region, as well as the volume of sediment deposited at the ends of the barrier arc, cannot be accounted for by typical sediment transport equations used for the littoral zone. Prior to the findings presented here, our understanding of the evolution of the Chandeleur Islands suffered from the lack of regionalscale, long-term analyses.

A significant component of this effort included data collected under the Barrier Island Comprehensive Monitoring (BICM) program, a cooperative agreement between UNO and the USGS funded by the Louisiana Coastal Area Science and

\footnotetext{
${ }^{1}$ University of New Orleans, Pontchartrain Institute for Environmental Sciences, New Orleans, La.

${ }^{2}$ U.S. Geological Survey, St. Petersburg, Fla.
} 
Technology Program (LCA S\&T). This chapter was designed to augment BICM findings and provide a framework and basis for planning and designing barrier management projects, for developing operation and maintenance activities, and for assessing the range of impacts from past and future tropical storms along the Chandeleur Islands.

\section{Methods}

\section{Bathymetric Data}

The bathymetric data employed for the sea floor change analysis were collected and assimilated as a part of the BICM program. What follows is a general methods summary, which is meant to provide a basic understanding of the data collection, processing, and analyses that led to the results and interpretations presented in this report. For a detailed account of the methods and uncertainty calculations see Miner and others (2009) and Baldwin and others (2009).

\section{6-7 Surveys}

During the summers of 2006 and 2007, UNO and the USGS conducted bathymetric surveys of the northern (2006) and southern (2007) Chandeleur Islands as a part of the BICM program (fig. 1). Bathymetric surveys were conducted by using single-beam echo sounders for shallow water and nearshore zones and by using an interferometric swath bathymetric system for the offshore zone. Bathymetric coverage extended from the shoreline to $7 \mathrm{~km}$ offshore on the Gulf of Mexico (eastern) side and from the backbarrier shoreline to $5 \mathrm{~km}$ into Chandeleur Sound to the west. For the single-beam bathymetry, shore-perpendicular survey transects were spaced at 750 $\mathrm{m}$ with shore-parallel tie lines spaced at $1,000 \mathrm{~m}$.

Single-beam bathymetry was acquired and processed by using the USGS-developed System for Accurate Nearshore Depth Surveying (SANDS; see DeWitt and others, 2007, and Miner and others, 2009, for details). SANDS employs postprocessed kinematic Global Positioning System (PPK GPS) to incorporate static GPS base station data, survey-vessel GPS navigation, and depth soundings to derive an $\mathrm{x}, \mathrm{y}, \mathrm{z}$ position for each sounding referenced vertically to the North American Vertical Datum of 1988 (NAVD 88) and horizontally to North American Datum of 1983 (NAD 83).

Swath bathymetry was collected by using interferometric sonar, and NAD 83 ship position was recorded by using differential GPS navigation. Tidal corrections were applied by using a discrete tidal zoning model provided by the National Oceanic and Atmospheric Administration (NOAA) National Ocean Service's Hydrographic Planning Team (see Miner and others, 2009, and Baldwin and others, 2009, for details). A correction was applied to shift the data from mean low water tidal datum to NAVD 88 so that the swath bathymetry could be integrated into a single dataset with the single-beam data.

Uncertainty analysis performed on the final processed bathymetric dataset for the entire study area provided an estimate of $\pm 0.11 \mathrm{~m}$ vertical uncertainty for each $\mathrm{x}$, y location where empirical data exist (see Miner and others, 2009, for details).

\section{0s (1917-22)}

The 1920s data were acquired digitally from the Hydrographic Surveys Division of NOAA's Office of Coast Survey (table 1; fig. 2). The hydrographic survey smooth sheets (H-sheets) that were used to produce the bathymetric maps are listed in table 1 . The smooth sheets associated with these surveys were digitized between 2001 and 2004 by a NOAA contractor. The data were downloaded as an $\mathrm{x}, \mathrm{y}, \mathrm{z}$ file referenced to NAD 83 by using soundings expressed in meters relative to mean low water (MLW) at the time of the survey.

Horizontal positioning was achieved by using a system of triangulations based on a series of towers (up to $100 \mathrm{ft}$ high) and base stations located along the Chandeleur Islands. Beyond the limit of sight from the shoreline, buoys using cuts and fixes from the shore signal were placed at the outer limit of the planned survey lines. Soundings were acquired by using sextant three-point fixes for horizontal positioning when in sight of the positioning signals and by using dead reckoning (estimation of position based on ship speed and heading) when the signals were out of sight. A lead weight handline was used to a depth of 15 fathoms. From the 15 -fathom to the 25 -fathom depth, a trolley rig consisting of a leadline with copper core was used. In depths greater than 25 fathoms, a mechanical sounding machine was used. A tidal staff at the Chandeleur Islands light, along with automatic tide gages at Bay St. Louis and Biloxi, Miss., and Ft. Morgan, Ala., was used to correct soundings to a common datum of MLW (summarized from USCGS, 1917, 1920, 1922; Hawley, 1931).

\section{0s (1869-85)}

For the 1870s bathymetric data (fig. 3), USCGS H-sheets were acquired through the Hydrographic Surveys Division of NOAA's Office of Coast Survey as high-resolution scanned image files (tagged image file format [TIFF] and Joint Photographic Experts Group [JPEG]). The H-sheets that were used for this analysis are listed in table 1. The H-sheets, originally referenced to a geographical (latitude/longitude) coordinate system based on the Clarke 1866 ellipsoid model, were converted to NAD 83 (see Miner and others, 2009, for details). The depth soundings are reported relative to MLW at the time of the survey and are therefore referenced to an arbitrary vertical datum (more details are given in Sea Floor Change and Volume Calculations section below). Soundings were measured by using the lead weight handline method described above. Horizontal positioning for the soundings was 


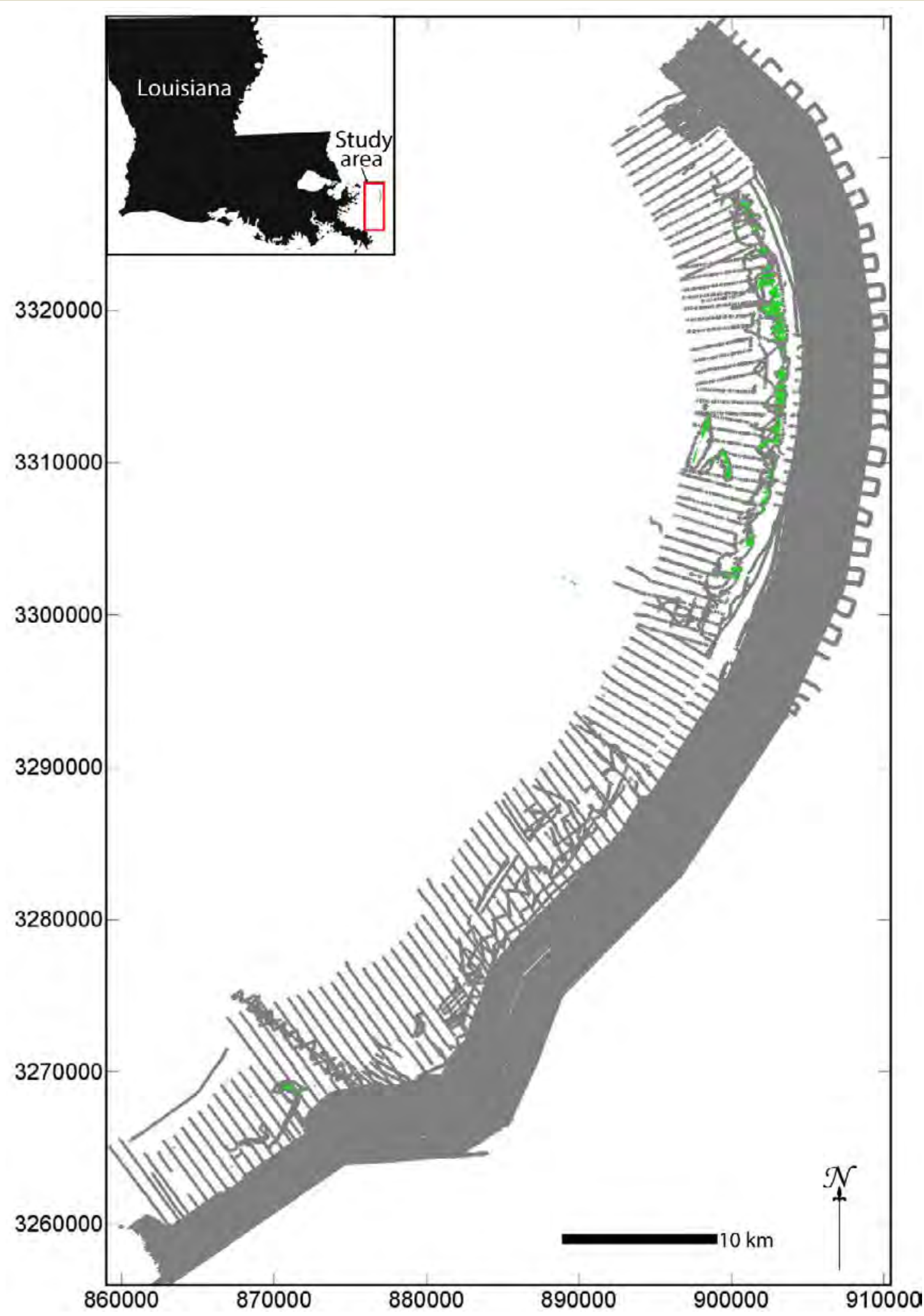

Figure 1. Data coverage for the 2006-7 bathymetric surveys of the Chandeleur Islands, La., conducted by the University of New Orleans and the U.S. Geological Survey. Note the nearly 100-percent swath coverage on the Gulf of Mexico side of the islands. Green polygons indicate 2005 shoreline configuration. Coordinates are in Universal Transverse Mercator Zone $15 \mathrm{~N}$ meters. 
Table 1. Historical U.S. Coast and Geodetic Survey hydrographic survey smooth sheets (H-sheets) used in this analysis of the Chandeleur Islands, La.

\begin{tabular}{lcl} 
H-sheet & Date & \multicolumn{1}{c}{ Location } \\
\hline H00999 & \multicolumn{1}{c}{ 1870s } \\
H01000 & 1869 & Breton Island offshore \\
H01171 & 1869 & Breton Sound \\
H01654 & 1873 & Chandeleur Sound \\
\hline & 1885 & Chandeleur Islands offshore \\
\hline H04000 & & 1920s \\
H04171 & 1917 & Hewes Point \\
H04212 & 1920 & Northern Chandeleur Islands \\
\hline
\end{tabular}

accomplished by means of recording sextant angles from the ship to known landmarks, recording theodolite angles to the survey vessel from the shoreline positions, and dead reckoning (List and others, 1994).

\section{Adjustment of Historical Datasets for Relative Sea Level Rise}

To compare surfaces from two different time periods for calculating sediment erosion and accretion trends, all surfaces must be referenced to a common vertical datum. This requirement presented a problem in the study area because much of the historical data were referenced to an arbitrary datum, MLW at the time of the survey. Because relative sea level rise (RSLR) rates are so high in the study area, the MLW elevation is constantly increasing. Therefore, if RSLR is not taken into account and corrected for, there will be a bias towards erosion in the comparison analysis and sediment volumetric change calculations. This problem was encountered by List and others (1994) when attempting to perform sea floor change analysis in Louisiana. The reader is referred to Jaffe and others (1991), List and others (1994), and Miner and others (2009) for extensive discussion on methods employed to account for RSLR in Louisiana.

For the sea floor change portion of this study, historical data were shifted to reference an elevation relative to NAVD 88 for comparison to the 2006-7 bathymetry. There were two steps to this process. The first involved shifting each bathymetric dataset to a common datum that takes into account the RSLR that occurred between each time period. Both historical datasets were shifted to MLW for the modern tidal epoch by applying a $0.5 \mathrm{~cm} / \mathrm{yr}$ RSLR correction. Because there are no local sea level rise data that exist for the Chandeleur Islands for the period of study, a value had to be estimated on the basis of tide gage records in the region and depth versus age calculations from radiocarbon-dated peats from the Mississippi River Delta Plain (see Miner and others, 2009). Studies of subsidence-induced sea level rise in Louisiana have shown that there is a direct correlation between RSLR rates and thickness of the Holocene substrates (Kolb and Van Lopik, 1958; Penland and Ramsey, 1990; Kulp, 2000; Meckel and others, 2006; Törnqvist and others, 2006, 2008). On the basis of these findings, sea level rise rates for the Chandeleurs and associated range of uncertainty were estimated by relating RSLR values from tide gages $(0.92 \mathrm{~cm} / \mathrm{yr}$ at Grand Isle, La.; $0.56 \mathrm{~cm} / \mathrm{yr}$ at Delacroix, La.; and 0.29 $\mathrm{cm} / \mathrm{yr}$ at Dauphin Island, Ala.) to thickness of Holocene substrate at each location (Miner and others, 2009). On the basis of this relation between relative thickness of Holocene deposits and regional tide gage data, an RSLR value of $0.5 \mathrm{~cm} / \mathrm{yr}$ for the Chandeleur Islands was applied to shift the historical datasets for comparison to the recent bathymetric surface.

\section{Surface Gridding and Contouring}

The final x,y,z bathymetric data were used to construct surface "grids" for the study area. Gridding is the process of taking irregularly spaced $x, y, z$ data and producing a grid file that contains a regularly spaced array of $\mathrm{z}$ data at locations called grid nodes (Golden Software, Inc., 2002). Because the $\mathrm{x}, \mathrm{y}, \mathrm{z}$ bathymetric data consist entirely of elevations below the intertidal zone and in order to prevent interpolation across islands (between offshore and backbarrier) during gridding, shoreline representing $0.5-\mathrm{m}$ elevation was included in the bathymetric dataset to constrain the grid algorithm. The shoreline was digitized from a mosaic of USGS digital ortho quarter quadrangles (DOQQs) and/or NOAA Office of Coast Survey topographic surveys (T-Sheets) that were acquired at a time period comparable to each bathymetric dataset (see Martinez and others, 2009).

Final grids for both historical and newly acquired bathymetric data were created in Surfer 8 (Golden Software, Golden, Colo.) and interpolated by kriging with a $100-\mathrm{m}$ grid node spacing (Miner and others, 2009). The grids created by the kriging method became the basis for contouring bathymetry and subsequent grid comparisons for sediment volumetric change calculations.

\section{Sea Floor Change and Volume Calculations}

Grid math calculations were carried out between two survey datasets to determine the difference between the historical and more recent $\mathrm{Z}$ values at each grid node (for example, $\mathrm{Z}_{2007}$ $-\mathrm{Z}_{1920 \mathrm{~s}}=$ net bathymetric change). Calculations resulted in the creation of a new grid that showed areas of accretion and erosion through positive and negative values, respectively. A new DEM was contoured from these differential $\mathrm{z}$ values to show changes (erosion, deposition, or dynamic equilibrium) that occurred during the time period separating the two surveys. 


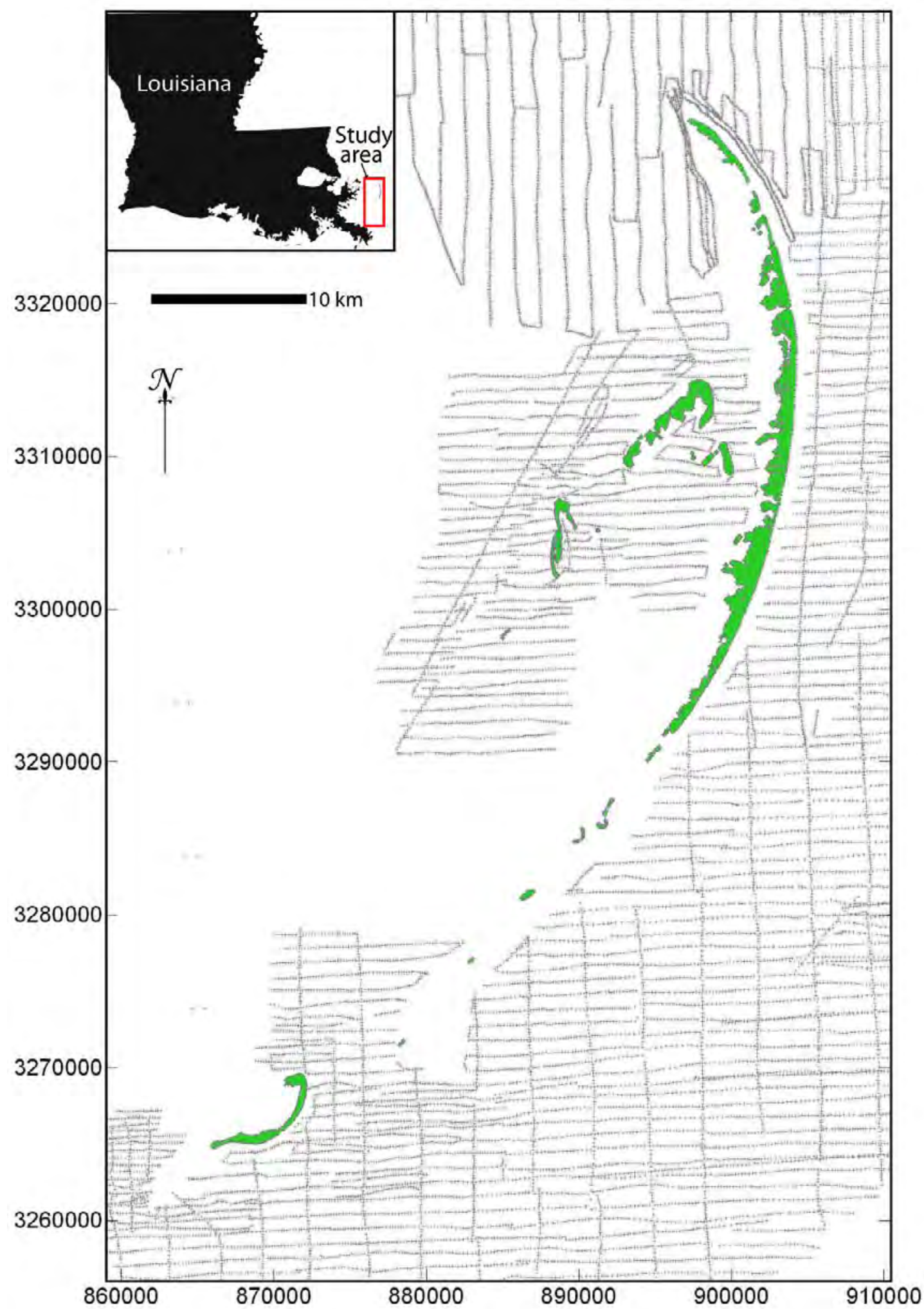

Figure 2. Data coverage for the 1920s U.S. Coast and Geodetic Survey hydrographic surveys of the Chandeleur Islands, La. (see table 1 for a list of hydrographic survey smooth sheets used in this study). Green polygons indicate 1922 shoreline configuration. Coordinates are in Universal Transverse Mercator Zone $15 \mathrm{~N}$ meters. 


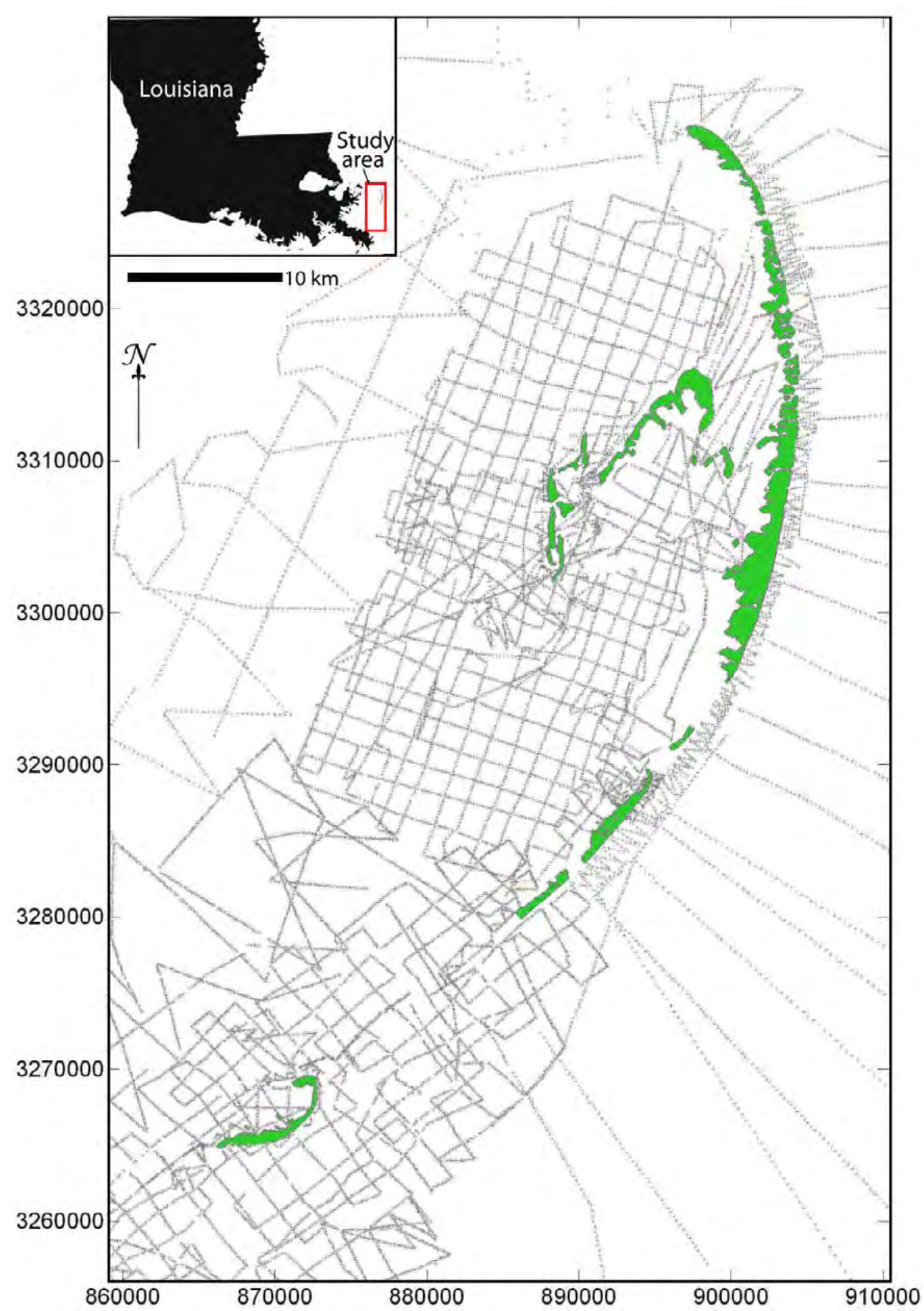

Figure 3. Data coverage for the 1870s U.S. Coast and Geodetic Survey hydrographic surveys of the Chandeleur Islands, La. Green polygons indicate 1855/1869 shoreline configuration. Coordinates are in Universal Transverse Mercator Zone $15 \mathrm{~N}$ meters. 
Sea floor change DEMs were produced for the 1870 s to 1920 s, 1920s to 2006-7, and 1870s to 2006-7. Volume calculations of the bathymetric change grids were computed in Surfer 8 to determine positive volume (accretion) and negative volume (erosion). The bathymetric change grids were then broken up into polygons that delineated geomorphically distinct regions of either erosion or accretion. These sea floor change maps and sediment volume calculations form the basis for interpreting long-term sediment transport trends for the study area.

\section{Bathymetric Profiles}

While the bathymetric change grid was used to produce a DEM that shows the sea floor change in plan view and quantify volumetric change, it is also optimal to graphically represent changes in profile view to better understand shoreface evolution and estimate cross-shore sediment transport processes. Profiles were selected along transects where 1870s empirical bathymetric data exist because this historical dataset had the coarsest resolution. Profile data were extracted from the interpolated grid data so that each point on the profile represented the $\mathrm{x}, \mathrm{y}, \mathrm{z}$ position of a grid node. Calculations of cross-sectional area difference between profiles along the same transect representing two different time periods were used to estimate the magnitude of localized erosion and/or accretion. When compared along the extent of the island arc, the profiles provide a means for understanding along-strike variations in shoreface progradation or retreat.

\section{Shoreline and Island Area Change}

An analysis of shoreline and island area change through time was conducted by Fearnley and others (this volume), Martinez and others (2009), and McBride and others (1992). The results are employed here to relate shoreface retreat magnitude and rates to shoreline change, as well as to relate sea floor sediment volumetric changes to changes in barrier island area.

\section{Results and Interpretation}

\section{Sea Floor Morphology and Evolution}

Bathymetric data for all three time periods show similar sea floor morphology and document an evolution that is driven by processes associated with the degradation of a relict delta lobe. The geomorphic features documented in the bathymetric data include the shoreface, tidal inlets, backbarrier platform, backbarrier tidal channels, recurved spits, and sandy barrier shoals. The details of these features and their general role in sea floor evolution are presented below. Geographic names are presented on figures 4-6. A more quantitative analysis follows in the Sediment Erosion and Accretion Volumes section.

\section{The Shoreface}

The shoreface includes the area seaward of the breaker zone extending offshore to the inner shelf at a depth of approximately $7.5 \mathrm{~m}$ (determined from bathymetric data for this study) for most of the Chandeleurs. This is the most dynamic geomorphic region along the Chandeleur Islands. The shoreface slopes relatively steeply seaward until it reaches a break in slope that marks the transition to the more gently sloping inner shelf. The shoreface profile is shaped by storm and fair weather wave activity and associated sediment transport. Along the Chandeleur Islands the shoreface is the geomorphic region that underwent the largest magnitude of erosion during the time of study; however, the relatively sediment-rich northern section of the islands offshore of Hewes Point is a zone where the shoreface has prograded seaward.

\section{Tidal Inlets}

A tidal inlet is an opening along a barrier shoreline that connects a gulf with bays, lagoons, marsh, and tidal creeks (Davis and FitzGerald, 2004). Tidal currents maintain the inlet channel by shore-perpendicular flushing of sediment that is transported alongshore by waves (Brown, 1928; Escoffier, 1940). There are four large tidal inlets responsible for the majority of tidal exchange between the Gulf of Mexico and the Chandeleur and Breton Sounds and numerous (more than 60) ephemeral hurricane-cut inlets along the northern island arc.

The two dominant tidal inlets in the system are the channels that flank the terminal spits of the Chandeleurs barrier arc and include an inlet which is north of Hewes Point and an inlet that is south of Breton Island. These two channels are not traditional tidal inlets because they are not bound by a barrier island on both sides of the channel; however, the bathymetry shows a distinct channel form at each of these locations, and current measurements and numerical modeling show that these two flanking channels are responsible for the majority of tidal flow into and out of Chandeleur and Breton Sounds (Hart and Murray, 1978). The inlet north of Hewes Point extends from the backbarrier and wraps around Hewes Point where maximum channel depths are greater than $15 \mathrm{~m}$. Lateral spit accretion towards the north at Hewes Point has forced a northerly migration of this inlet. 


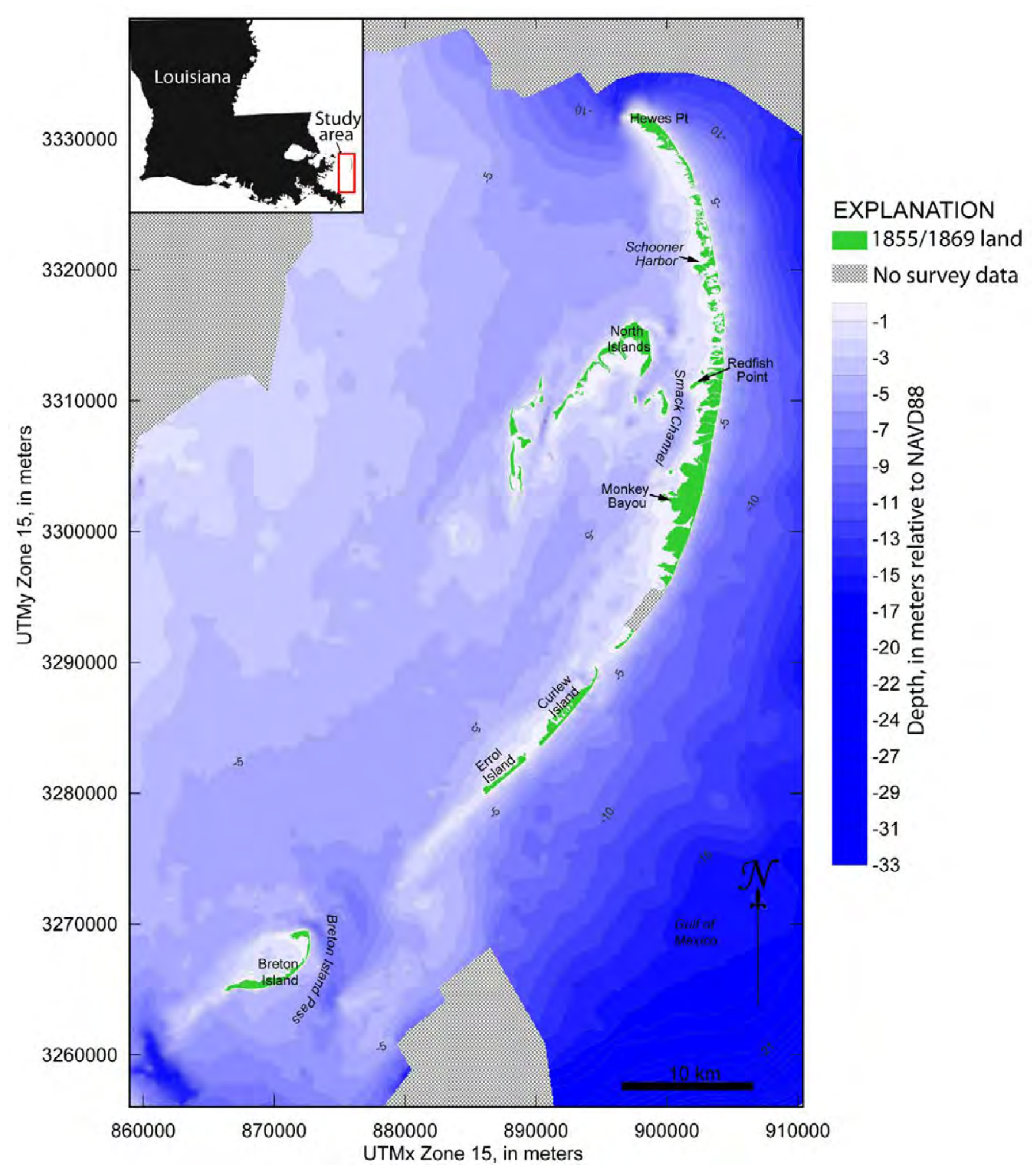

Figure 4. Shoreline configuration and bathymetry for the 1870 s for the Chandeleur Islands, La. UTM, Universal Transverse Mercator; NAVD 88, North American Vertical Datum of 1988. 


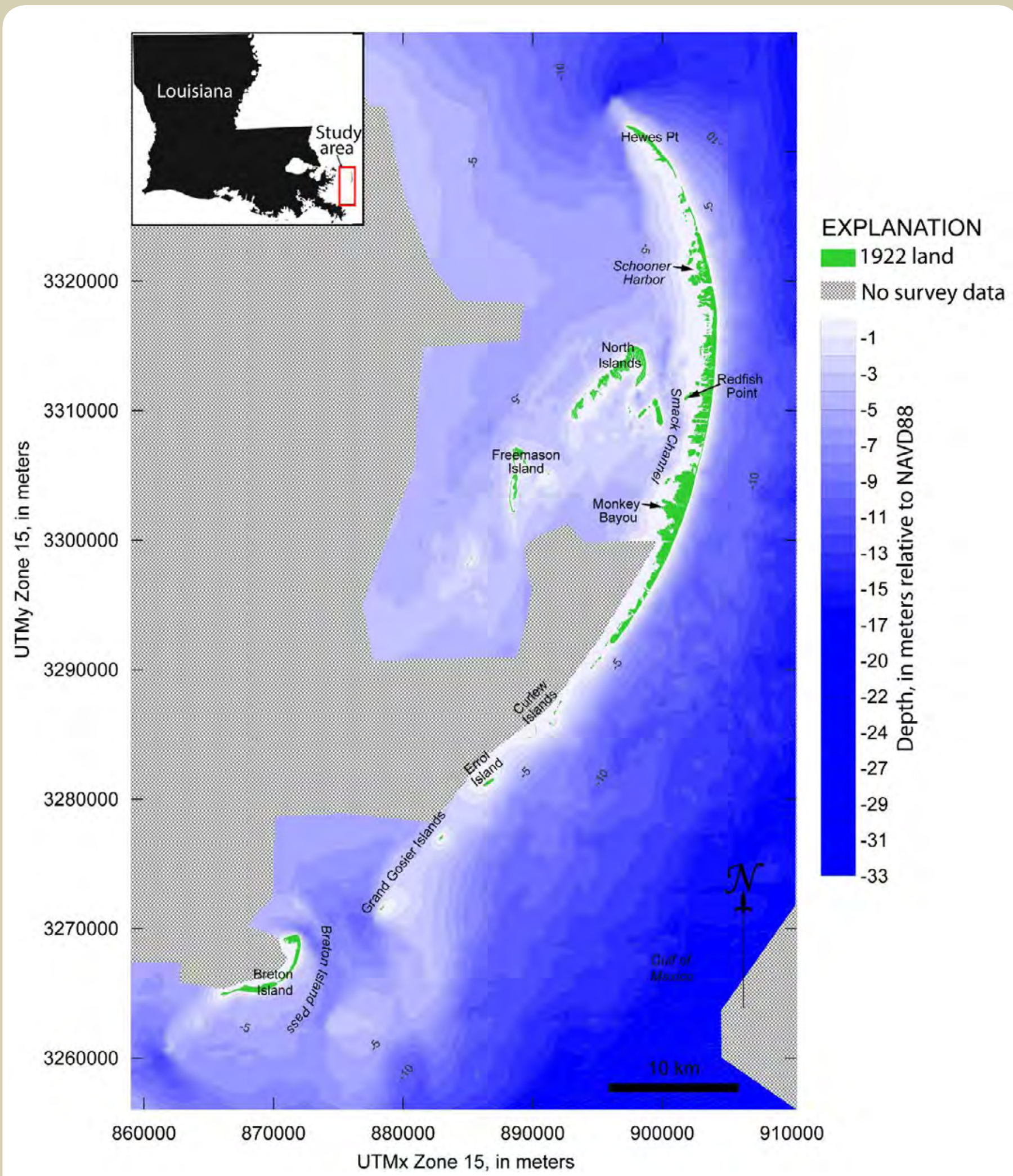

Figure 5. Shoreline configuration and bathymetry for the 1920s for the Chandeleur Islands, La. UTM, Universal Transverse Mercator; NAVD 88, North American Vertical Datum of 1988. 


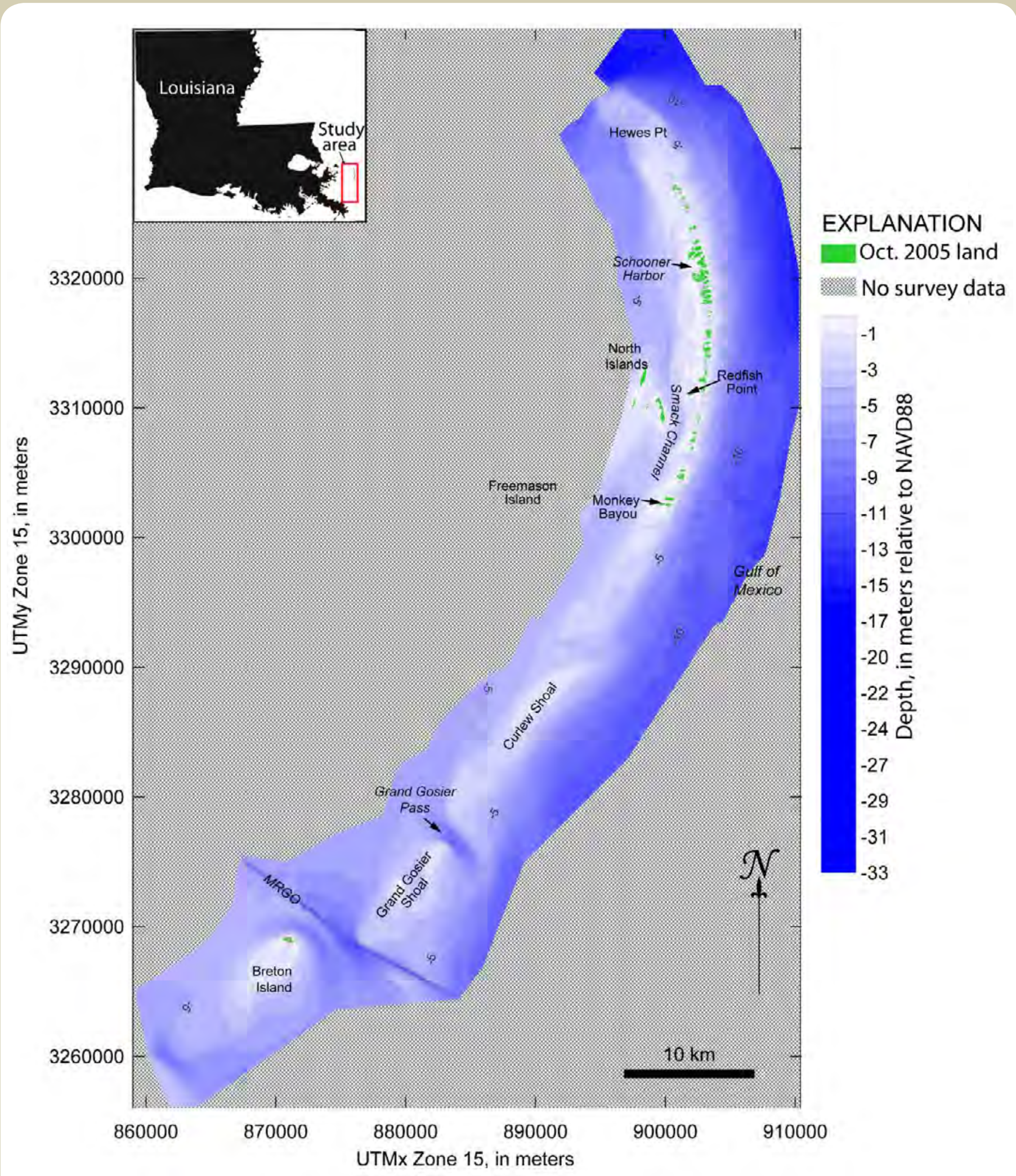

Figure 6. The 2005 shoreline configuration and bathymetry for 2006/2007 for the Chandeleur Islands, La. UTM, Universal Transverse Mercator; NAVD 88, North American Vertical Datum of 1988; MRGO, Mississippi River-Gulf Outlet. 
The inlet marking the southern extent of the Chandeleur Islands located south of Breton Island has migrated south and undergone considerable infilling. This may be the result of construction of the Mississippi River-Gulf Outlet (MRGO) and deepening of Grand Gosier Pass by tidal scour, both of which captured tidal prism (the volume of water that passes through the inlet during half of each tidal cycle) from this southernmost inlet. Observations during surveying and subsequent aerial reconnaissance flights confirm strong tidal currents flowing through this broad channel.

The MRGO intersects the Chandeleur Islands just north of Breton Island and was cut through the existing tidal inlet of Breton Island Pass. Although the natural inlet configuration was downdrift offset (the inlet channel was oriented to the south in an alongshore direction), the MRGO trends perpendicular to the shoreline. The MRGO construction did not result in the abandonment of the natural channel in favor of the engineered one, and both channels remained open. The MRGO required frequent maintenance dredging to remove sand before being decommissioned in 2008. Strong tidal currents flow through the MRGO, which is a conduit for tidal exchange for much of the Lake Pontchartrain Basin. The increased tidal prism and strong ebb tidal currents result in seaward transport of sand to distal ebb shoals that would have otherwise bypassed the inlet and nourished downdrift Breton Island.

Grand Gosier Pass is a natural tidal inlet located between Curlew Island Shoal and Grand Gosier Islands Shoal. This inlet was not present in the 1870 s bathymetry but, by 2007 , had scoured to a depth of more than $9 \mathrm{~m}$. An ebb tidal delta has developed there as indicated by a seaward excursion of the 3-m contour offshore of Curlew Shoal since the 1870s.

Historically, numerous ephemeral hurricane-cut inlets along the barrier chain were active for several years after a storm impact and then filled in to form a continuous barrier shoreline along the northern arc during extended periods of calm weather (Kahn, 1986). Since Hurricane Katrina (2005), more than 60 hurricane-cut tidal inlets have remained open. Based on the 2006 bathymetric surveys, widths range from 80 to $3,100 \mathrm{~m}$, and maximum depths reach $3.5 \mathrm{~m}$.

\section{Backbarrier Platform}

The northern island arc (north of Monkey Bayou [see figs. 4-6]) is backed by a broad (maximum width of about $2.5 \mathrm{~km}$ ), sandy platform that averages less than $1 \mathrm{~m}$ in depth and is blanketed by submerged aquatic vegetation. Stormgenerated flood tidal deltas have formed landward of deeper hurricane-cut inlets. The backbarrier platform is intersected by channels that were scoured during storms.

\section{Spits}

A spit is a ridge of sand attached to the land at one end and terminating in open water at the other (Evans, 1942).
Spits are built by lateral accretion that is due to wave-induced sediment transport. Spits accrete laterally over the subaqueous spit platform, which progrades ahead of the subaerial spit. Seasonal variations in wave approach and the refraction of waves bending around the spit end often form a hook-shaped recurve spit that extends into the backbarrier. Lateral accretion of a terminal spit (at the end of a barrier island) usually results in development of a thick sand body because the leading edge of the prograding spit fills a relatively deep inlet channel (fig. 7; Hoyt and Henry, 1967).

Hewes Point is a prominent spit system in the northern end of the Chandeleur Islands. Smaller recurved spits flank hurricane-cut tidal inlets; however, these smaller scale features are not within the scope of this regional-scale report on sea floor evolution. The Hewes Point spit is prograding because of northerly longshore transport into the marginal deltaic basin that flanks the St. Bernard Delta Complex.

The scale of this terminal spit accretionary process is important because it demonstrates how an abandoned deltaic headland is reworked by marine processes to form Stage 1 flanking barriers and eventually a Stage 2 barrier island arc (fig. 8; Penland and others, 1988). Lateral spit accretion remains an important process throughout Stage 2, as shown by the lateral accretion of Hewes Point in a northerly direction (Penland and others, 1988), a concept that is emphasized throughout this report.

\section{Barrier Shoals}

The barrier shoals that occur along the Chandeleur Islands are present in the southern portion south of Monkey Bayou and include Curlew Island Shoal and Grand Gosier Islands Shoal. These shoals are actually ephemeral barrier islands that are destroyed during storms and reemerge during extended fair weather periods (Otvos, 1981; Penland and Boyd, 1985; Fearnley and others, this volume); however, recent increased storm frequency and a decrease in sediment supply has inhibited island emergence since Hurricane Katrina (Fearnley and others, this volume). The same factors inhibiting reemergence have also forced other, more stable portions of the Chandeleur Islands into ephemeral island/shoal mode. We predict that this evolutionary behavior will eventually be characteristic of the entire island arc as it is converted to an inner shelf shoal through transgressive submergence (fig. 8).

\section{Sediment Erosion and Accretion Volumes}

The sea floor change DEMs and volumetric change calculations for the 1870 s to $2006-7$ provide a means of tracking sediment dynamics during the 136-year time period covered by this study. Fifteen zones were delineated on the basis of geomorphology and erosion/accretion trends (fig. 9; table 2).

Because the northern Chandeleur Islands are evolving somewhat differently than the islands in the south are, we have 


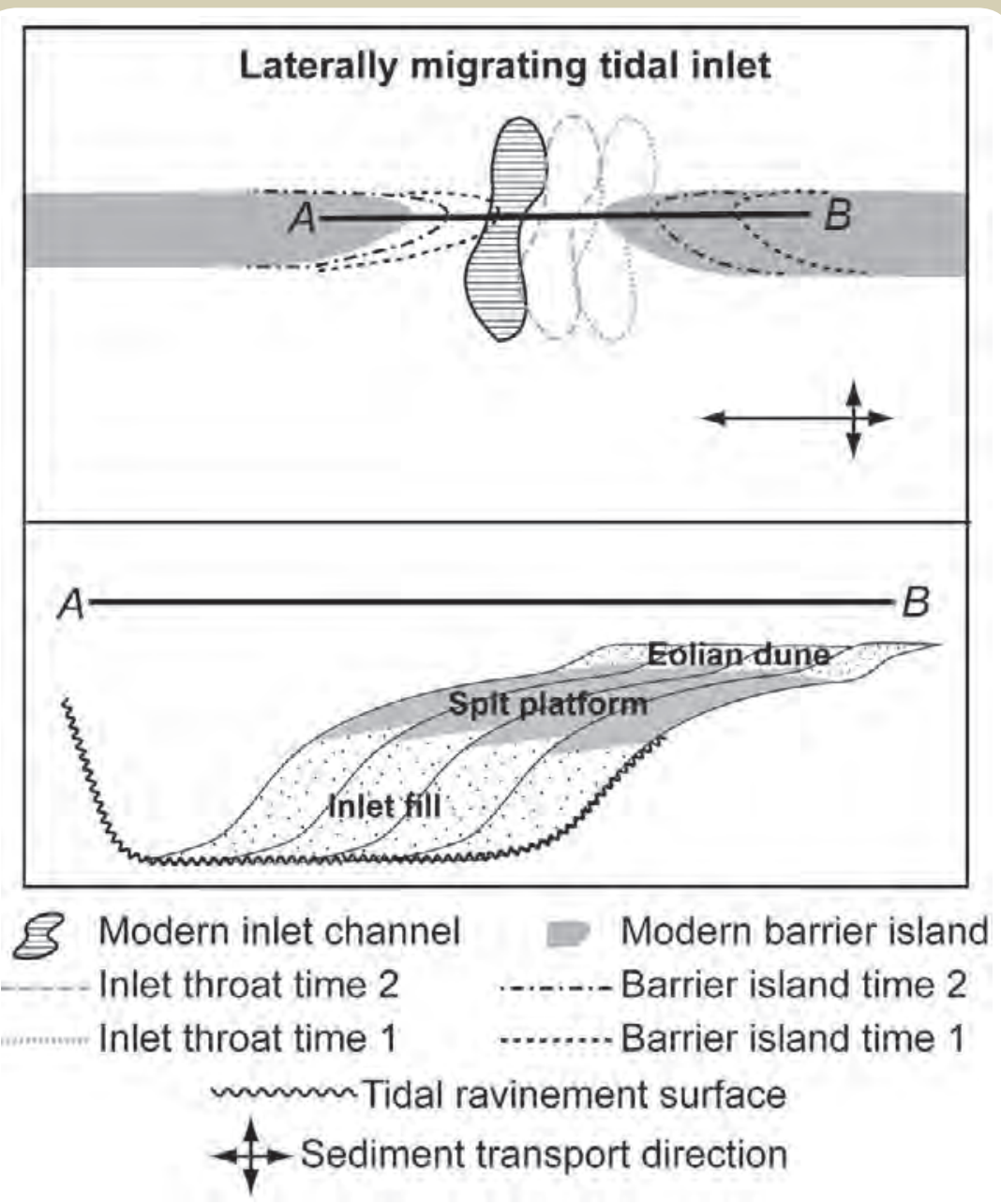

Figure 7. Conceptual model for inlet fill development from lateral spit accretion (modified from Hoyt and Henry, 1967). maximum vertical erosion was $8.06 \mathrm{~m}$. In a regime of landward shoreface retreat, a net landward transfer of sediment is necessary to maintain a supratidal exposure of barrier islands in a regime of sea level rise. The backbarrier of the northern arc (Zone 3 ) underwent a net accretion of $84.11 \times$ $10^{6} \mathrm{~m}^{3}$, approximately 29 percent of the total volume eroded from the shoreface. The maximum vertical accretion measured was $5.88 \mathrm{~m}$ in the backbarrier. The terminal spit in the northernmost portion of the study area (Zone 1 ) is a zone of accretion where $128.77 \times 10^{6} \mathrm{~m}^{3}$ of sediment has been deposited since 1870 (45 percent of the total volume eroded from the shoreface). The maximum vertical accretion measured in this zone was $10.82 \mathrm{~m}$. This deposit has developed through lateral spit accretion to the north; however, the shoreface is also prograding in a seaward direction (eastward) along this sedimentabundant northern section of the island arc.

To account for the large deficit in the calculated volumes, which is probably attributable to the removal of finegrained sediment from the coastal system, the percent sand content of the eroded or deposited volume must be determined. To estimate the sand component for each zone, grain-size data from the top $1 \mathrm{~m}$ of sediment cores (see Flocks and others, this volume) were analyzed. The percent sand value for each core (vertically averaged from surface to 1-m depth) was then averaged with all cores contained within each divided the island arc into two separate sections (northern and southern) for the purpose of discussing the results of volumetric change analysis. This division is not meant to imply that one section does not have influence on the other or that sediment is retained within a closed system for each section.

\section{Northern Chandeleur Islands (Hewes Point South to Monkey Bayou)}

The majority of sea floor change documented in the northern Chandeleur Islands occurred in three geomorphic regions: (1) the shoreface (Zone 2), (2) backbarrier (Zone 3), and (3) downdrift of terminal spit at Hewes Point (Zone 1) (zones are delineated in fig. 9). The shoreface along the northern island arc (Zone 2 ) is dominated by erosion and underwent a net loss of $285.29 \times 10^{6} \mathrm{~m}^{3}$ of sediment between 1870 and 2006, forcing a landward retreat of the shoreface. The zone to estimate a percent sand for that zone. Once the percent sand value was calculated for each zone, a "sand only" volume could be calculated by multiplying the percent sand times the total volume eroded or accreted (table 3 ). The net volume deficit prior to the sand correction for the northern Chandeleur Islands was $-72.41 \times 10^{6} \mathrm{~m}^{3}$, and after applying the correction there was a net difference of $1.47 \times 10^{6} \mathrm{~m}^{3}$ (more sand deposited than eroded). This excess of sand deposited can be partially explained by the erosion of the subaerial barrier island that was not included in the sea floor volumetric change analysis. Between 1855 and 2005 an area approximately 19 $\times 10^{6} \mathrm{~m}^{2}$ of exposed island was converted to open water in Zones 1, 2, and 3 (Martinez and others, 2009; Fearnley and others, this volume). The result of this sediment budget for the northern Chandeleurs is not meant to imply that Zones 1-3 are a closed system with regard to sand dynamics. Based on the map in figure 9, it is clear that our study area does not capture the entire depositional area in Zone 1, nor does it capture the 


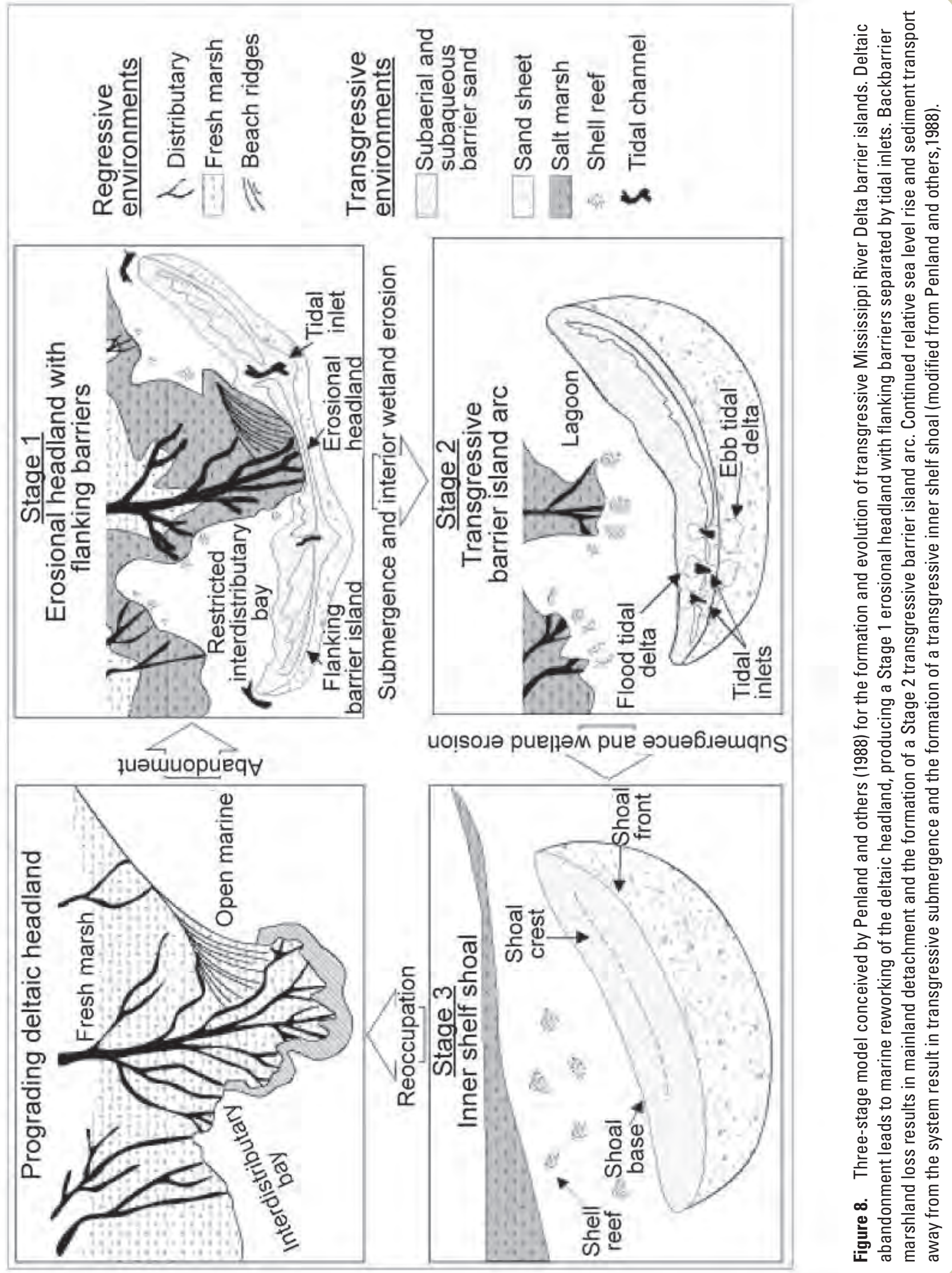




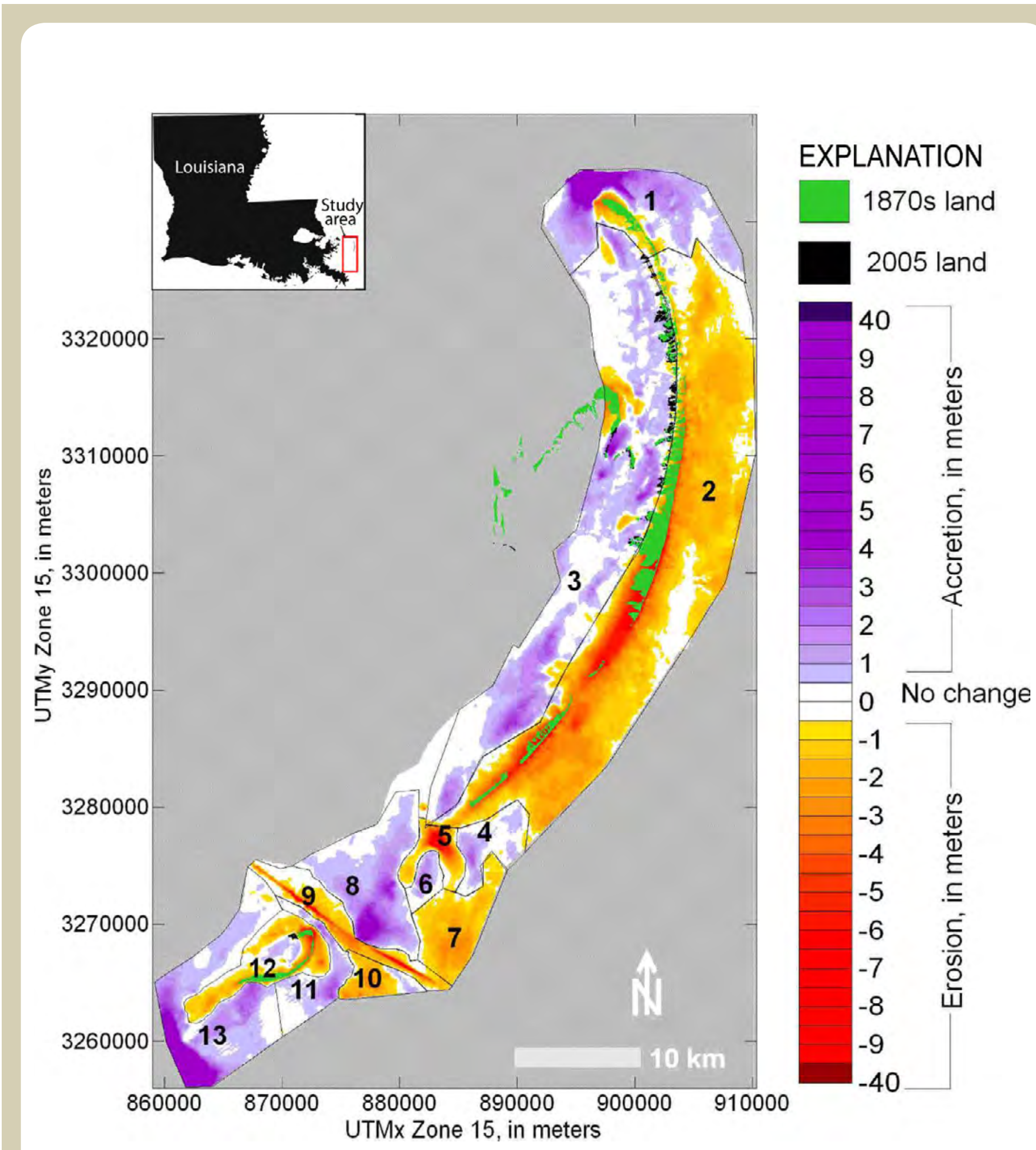

Figure 9. Sea floor change results for the Chandeleur Islands, La. (1870-2007). Numbered polygons delineate erosional or accretionary zones for which volumetric change data are presented in table 2. UTM, Universal Transverse Mercator. 


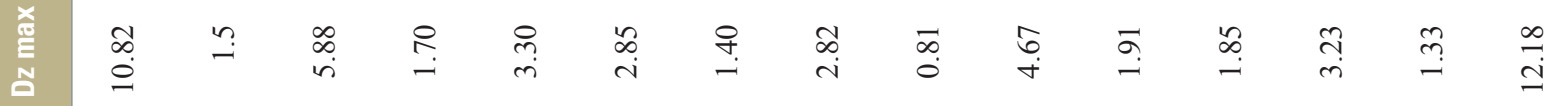

言

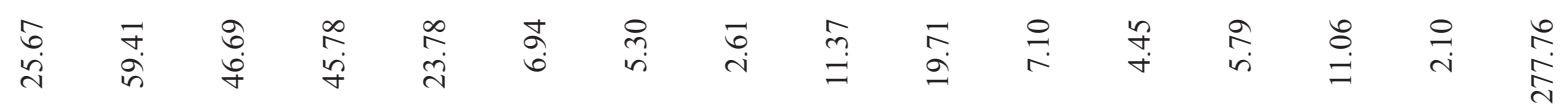

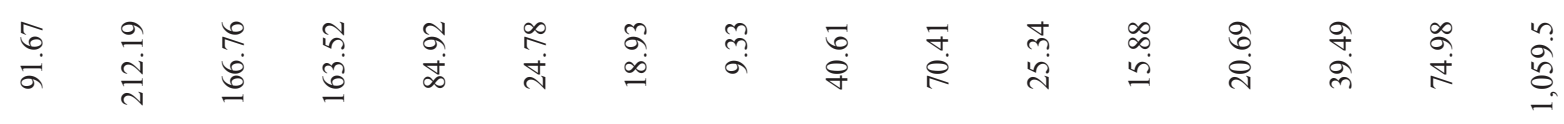

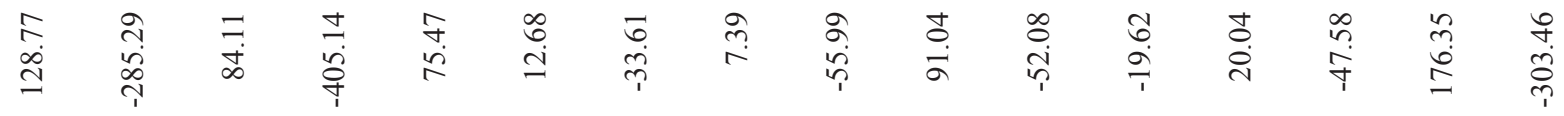

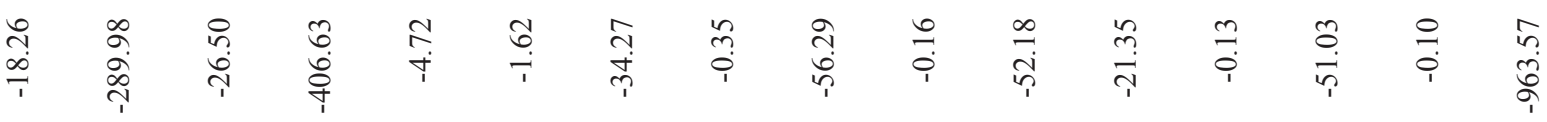

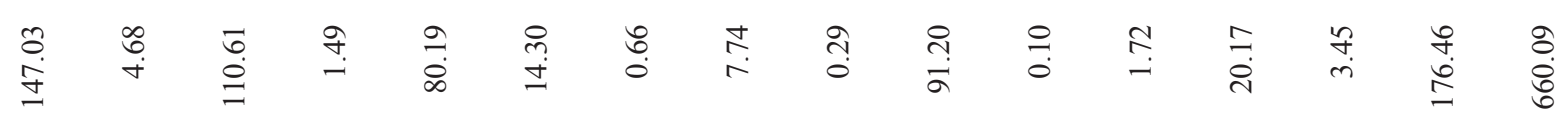

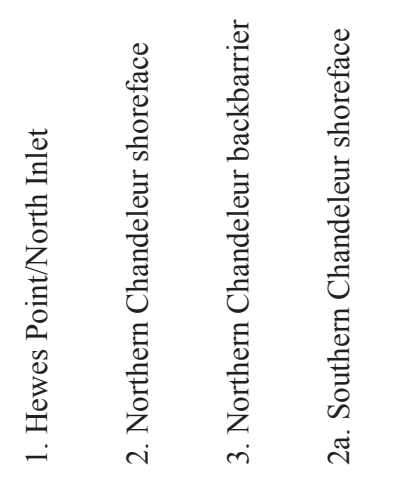

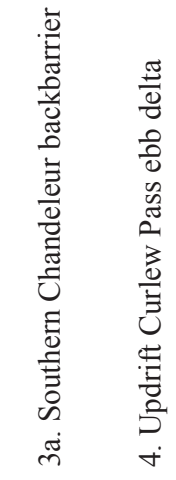

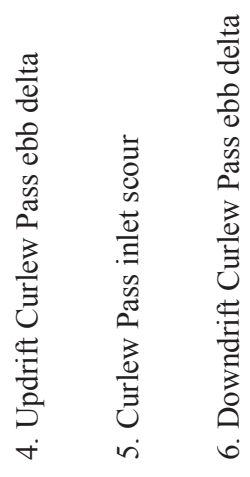

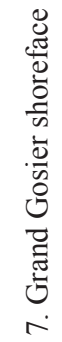

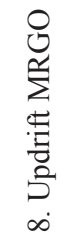

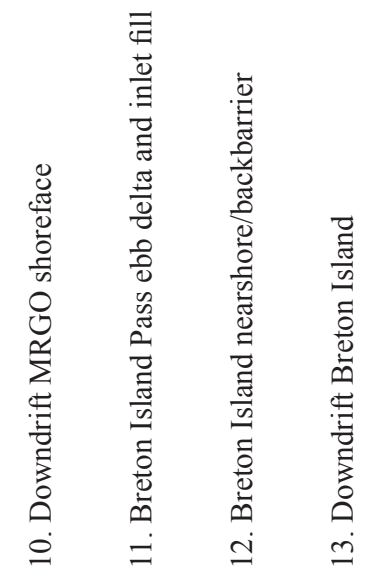

要 
entire erosional area in Zone 2. The absence of sediment core data for the southern Chandeleurs does not allow for a percent sand correction factor to be applied for balancing the sediment budget as was done for the northern Chandeleurs.

\section{Southern Chandeleur Islands (Monkey Bayou South to Breton Island)}

The southern Chandeleurs are geomorphically more complex because of the presence of three major tidal inlets along this sector of coast, one of which, the MRGO, was maintained as a navigation channel until 2005. Another complicating factor is the ephemeral nature of the barriers along this stretch. Today there are no subaerially exposed barriers between Monkey Bayou and the northern tip of Breton Island. Instead, this $45-\mathrm{km}$ stretch of former coastline is characterized by a series of subaqueous shoals separated by tidal inlets.

The southern Chandeleur shoreface (Zone 2a [zones are delineated in fig. 9]) that extends from Monkey Bayou south to Grand Gosier Pass underwent the greatest magnitude of erosion in the entire study area. Shoreface erosion resulted in the removal of $405.14 \times 10^{6} \mathrm{~m}^{3}$ of sediment between 1870 and 2007, and maximum vertical erosion was $8.89 \mathrm{~m}$. This stretch of coast has also undergone the highest rates (up to 17 $\mathrm{m} / \mathrm{yr}$ between 1869 and 2004) of shoreline retreat along the entire Chandeleur Island shoreline. Deposition in the backbarrier (Zone 3a) was only $75.47 \times 10^{6} \mathrm{~m}^{3}$ for this area. Much of the backbarrier deposition can be attributed to the landward migration of Curlew Island Shoal and Errol Shoal sand bodies.

Grand Gosier Pass, a tidal inlet that separates Curlew Island Shoal from Grand Gosier Islands Shoal, is not present in the pre-2007 survey datasets; however, it is noted on nautical charts dating back to the 1950s. The 2007 bathymetric data show that the inlet had scoured to a depth of more than $9 \mathrm{~m}$, removing $33.61 \times 10^{6} \mathrm{~m}^{3}$ of sediment from the inlet channel (Zone 5) since the 1870 s. The development and seaward progradation of an ebb tidal delta associated with inlet formation (Zones 4 and 6) increased in volume by $20 \times 10^{6} \mathrm{~m}^{3}$ during the time period covered by the study. The sequestering of sand updrift (north) of the inlet reversed the trend of shoreface retreat along this stretch of coast and accounted for $12.68 \times$ $10^{6} \mathrm{~m}^{3}$ (Zone 4 ) of sediment deposition, and a downdrift lobe accounted for $7.39 \times 10^{6} \mathrm{~m}^{3}$ of deposition.

Downdrift (south) of Grand Gosier Pass and north of the MRGO are Grand Gosier Shoals/Islands. These are part of the linear ephemeral barrier shoal/island trend that has migrated to the south since the 1870 s by spit accretion. These islands also migrate landward (about $15 \mathrm{~m} / \mathrm{yr}$ ) by a process that involves total island destruction during storms and reemergence at a location landward of the prestorm island position during extended periods of calm weather (Penland and Boyd, 1985; Fearnley and others, this volume). This trend of lateral migration to the south has resulted in the deposition of a large volume of sediment $\left(81.04 \times 10^{6} \mathrm{~m}^{3}\right)$ updrift of the MRGO (Zone 8).

The MRGO channel area (Zone 9) has undergone $52.08 \times$ $10^{6} \mathrm{~m}^{3}$ of erosion since 1870 , most of which can be attributed to the mechanical removal of sediment during the construction of the navigation channel. Maintenance dredging of this channel after hurricanes complicated sediment dynamics in this area because sediment removed from the channel was deposited in an offshore disposal area downdrift of the channel. Most of this disposal area is beyond the seaward limit of the study area. It should be noted that sand disposal in these offshore locations removed it from the littoral system, depleting the southern Chandeleur Islands of sediment.

Offshore of the MRGO is a zone of shoreface erosion (Zones 7 and 10). Much of this erosion can be attributed to collapse and landward retreat of the Breton Island Pass ebb tidal delta (Zone 11) resulting from natural tidal inlet landward migration in response to RSLR, as well as decreased sediment supply that is due to maintenance dredging. A total of $75.61 \times 10^{6} \mathrm{~m}^{3}$ of sediment has eroded from this zone, with maximum vertical erosion of $3.43 \mathrm{~m}$. Between 1870 and 2007 Breton Island Pass migrated to the west, forcing the retreat of northern Breton Island. Deposition in the form of inlet fill and ebb tidal delta growth (Zone 11) resulted in $20.03 \times 10^{6} \mathrm{~m}^{3}$

Table 3. Sediment budget for the northern Chandeleur Islands, La., with percent sand corrections applied.

$[\mathrm{m}, \mathrm{meters}]$

\begin{tabular}{|c|c|c|c|}
\hline Zone & Net volume $\left(\times 10^{6} \mathrm{~m}^{3}\right)$ & Percent sand & Corrected net volume $\left(\times 10^{6} \mathrm{~m}^{3}\right)$ \\
\hline
\end{tabular}

1. Hewes Point/North Inlet

2. Northern Chandeleur shoreface

3. Northern Chandeleur backbarrier
128.77

$-285.29$

84.11
80

58

76
103.02

$-165.47$ 
of added sediment offshore of Breton Island. Tidal scour and storm wave reworking of the Breton Island barrier complex resulted in $51.03 \times 10^{6} \mathrm{~m}^{3}$ of net erosion in the vicinity of Breton Island (Zone 12). Moreover, only $3.45 \times 10^{6} \mathrm{~m}^{3}$ of sediment has been deposited in the backbarrier. Much of this decrease in island area and subaerial sand volume at Breton Island is possibly due to sediment starvation associated with updrift MRGO channel maintenance dredging. Zone 13, which encompasses downdrift of Breton Island and the southernmost limits of the bathymetric data, underwent the greatest magnitude $\left(176.35 \times 10^{6} \mathrm{~m}^{3}\right)$ of accretion of all geomorphic zones within the Chandeleur Islands study area. This southern subaqueous terminal spit is characterized by inlet fill development, lateral spit accretion to the south, and shoreface progradation and can be thought of as the southern counterpart to Hewes Point in the north (Zone 1). It should be noted that the limits of the study area do not capture the full extent of the Zone 13 downdrift and offshore depositional sand body.

\section{Bathymetric Profiles}

The bathymetric profiles were grouped into five sectors along the length of the barrier island arc on the basis of the shoreface evolution interpreted from the profiles. The sectors include, from north to south, (1) Hewes Point to Schooner Harbor (Profiles Hewes1, 1, and 2), (2) Schooner Harbor to Redfish Point (Profiles 7 and 9), (3) Redfish Point to Monkey Bayou (Profile 11), (4) Monkey Bayou to the MRGO (Profiles 14 and 17), and (5) Breton Island (Profile 21) (profile locations are presented in fig. 10). Typical profiles for each sector were selected for presentation here.

\section{Sector 1: Hewes Point to Schooner Harbor}

Sector 1 bathymetric profiles exhibit spit platform development and spit accretion north of Hewes Point and shoreface progradation in a gulfward (easterly) direction. The Hewes Point spit platform accreted 1,439 m laterally to the north (fig. 11) between 1870 and 2006 and broadened by approximately $800 \mathrm{~m}$ between 1920 and 2006 (fig. 12). South of Hewes Point, Profile 2 demonstrates that $626 \mathrm{~m}$ of shoreface progradation occurred during the period of study (fig. 13). The average rate of shoreface progradation for Sector 1 is $2.5 \mathrm{~m} / \mathrm{yr}$. Collectively these profiles illustrate the large volume of sediment deposited $\left(128.77 \times 10^{6} \mathrm{~m}^{3}\right)$ in Zone 1 (see fig. 9) and the geometry of this deposit. It is important to note that all of this accretion took place below mean low water.

\section{Sector 2: Schooner Harbor to Redfish Point}

Sector 2 profiles an area characterized by shoreface retreat and a decreasing steepness of the shoreface profile. The average rate of shoreface retreat for this sector was $5.6 \mathrm{~m} / \mathrm{yr}$ with magnitudes ranging from 461 to $902 \mathrm{~m}$ for the time period between 1870 and 2006. Many of the profiles in Sector 2 show shoreface erosion in a landward direction and erosion of the backbarrier shoreline in a seaward direction, resulting in an overall thinning of the island (fig. 14). Some of the profiles show barrier landward migration between the 1870 s and 1920 s with little to no backbarrier deposition between the 1920s and 2006 (fig. 15). The latter situation is typical along the central portion of the island arc and into Sector 3 .

\section{Sector 3: Redfish Point to Monkey Bayou}

The mean shoreface retreat rate along Sector 3 was 8.8 $\mathrm{m} / \mathrm{yr}$, and the average magnitude of net change was 1,196 $\mathrm{m}$ between 1870 and 2007 (fig. 16). Shoreface retreat rates increased in a southerly direction. Average shoreface slope decreased from 0.0044 to 0.0031 for the same time period.

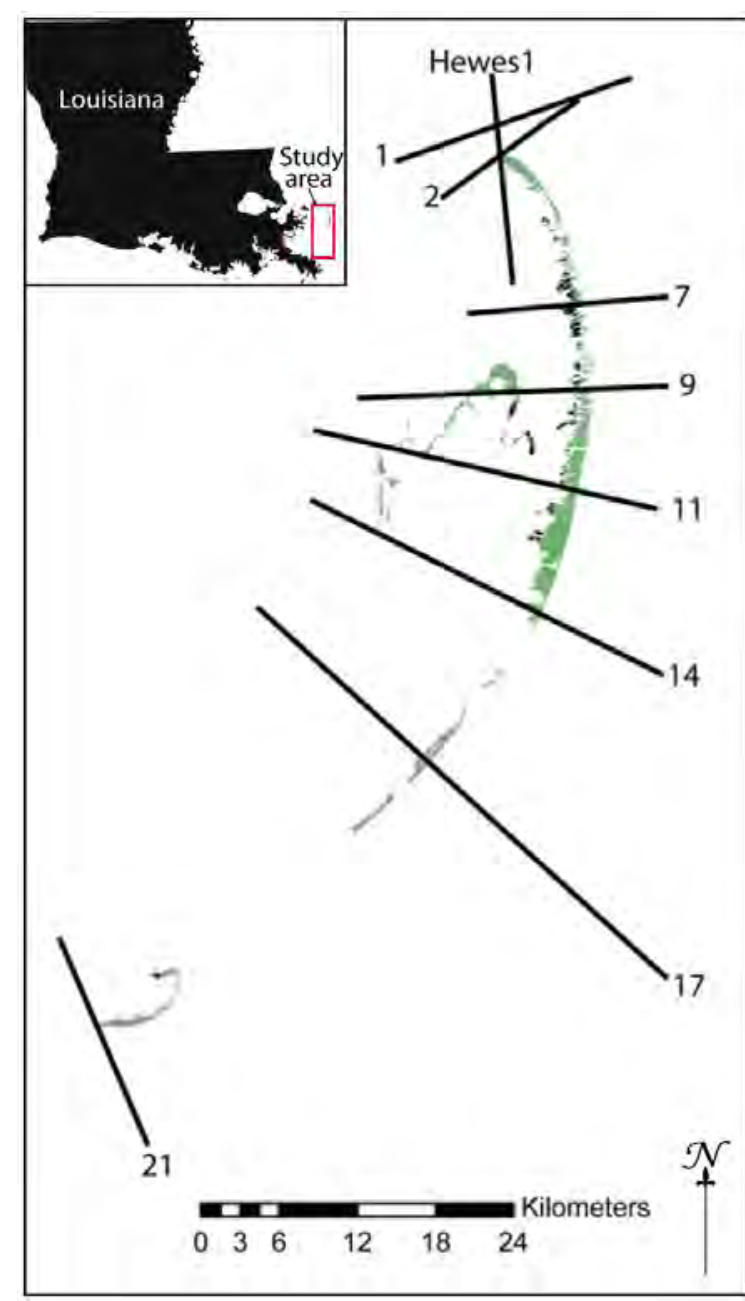

Figure 10. Representative bathymetric profile transect locations for the Chandeleur Islands, La. Shoreline configurations are for 1855/69 (green) and 2005 (black). 


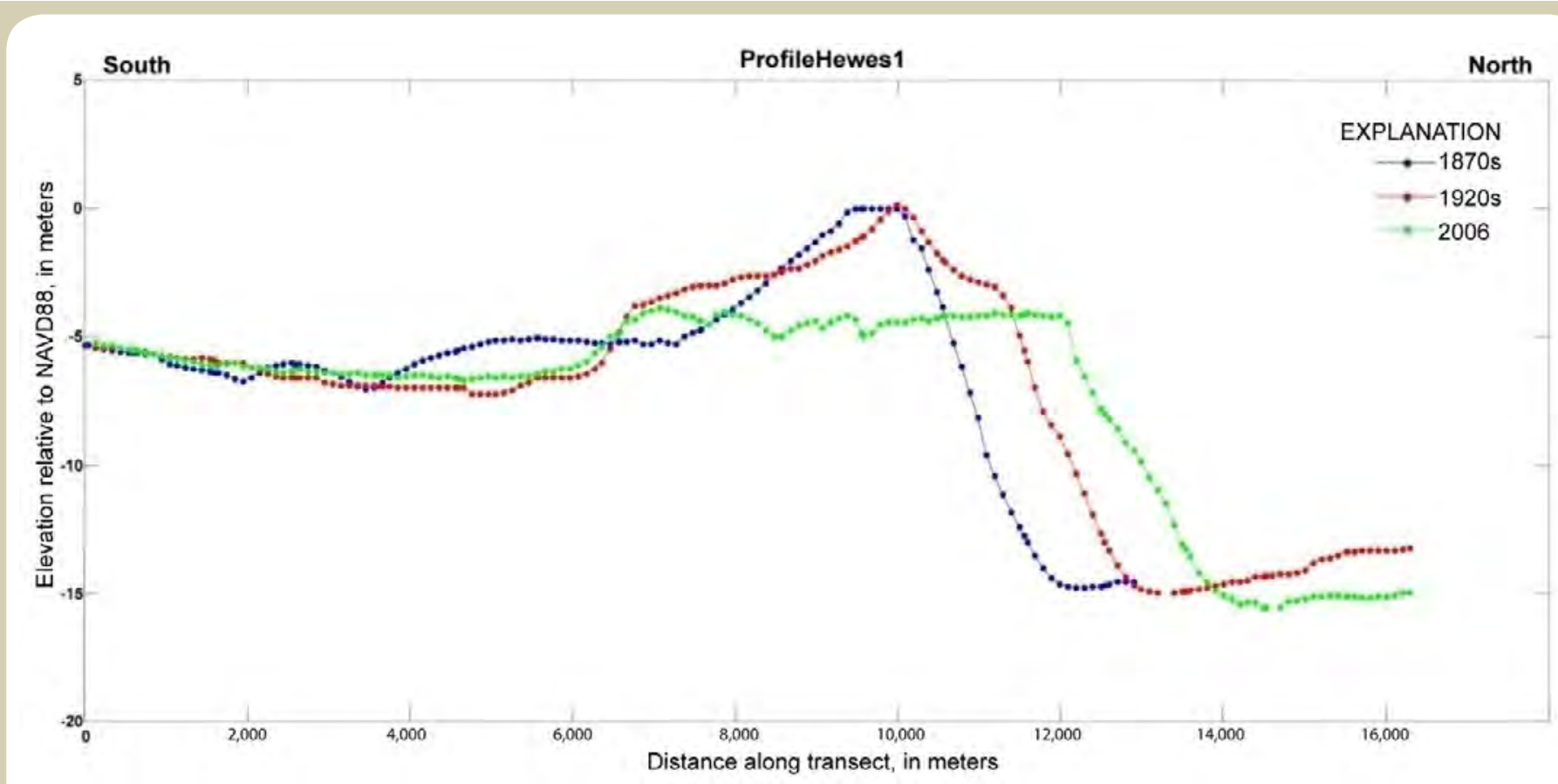

Figure 11. Profile Hewes1 trending north-south across Hewes Point, La. Note the nearly 1,500 m of northerly spit accretion between the 1870s and 2006. NAVD 88, North American Vertical Datum of 1988.

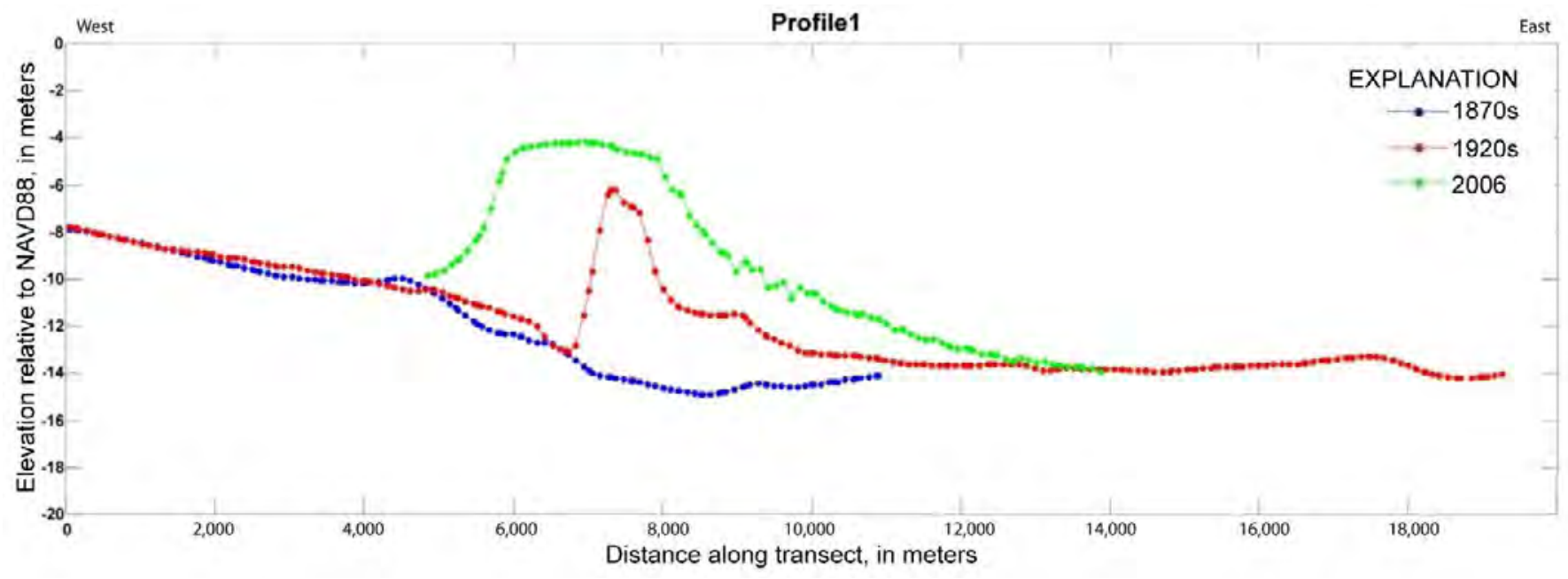

Figure 12. Profle 1 trending from Chandeleur Sound, La. (west), to the Gulf of Mexico (east). Note the vertical shoal aggradation by spit platform development north of Hewes Point, La. NAVD 88, North American Vertical Datum of 1988. 


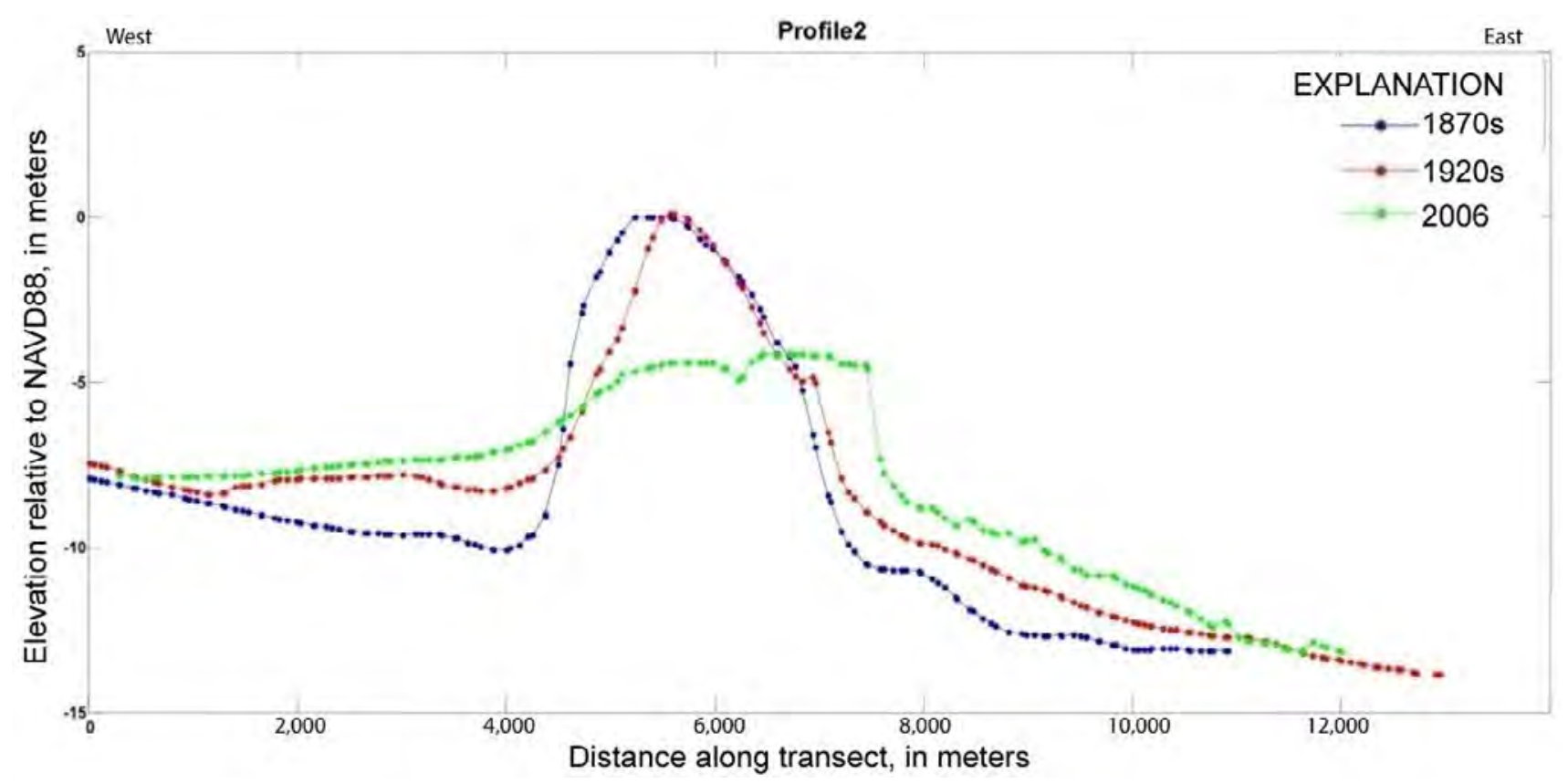

Figure 13. Profile 2 trending from Chandeleur Sound, La. (west), to the Gulf of Mexico (east). While the island became submerged along this northern section after Hurricane Katrina, $626 \mathrm{~m}$ of shoreface progradation occurred between 1870 and 2006. NAVD 88, North American Vertical Datum of 1988.

Shoreface retreat profiles show similar trends to the shoreline change trends for this sector (Fearnley and others, this volume): the 1870s and 1920s profiles show landward migration of the barrier (deposition in the backbarrier), but between the 1920s and 2007 there is little to no backbarrier deposition (landward island migration). Most of these profiles intersect shore-parallel backbarrier tidal channels that trend between the Chandeleur Islands and the North and New Harbor Islands in Chandeleur Sound. As the New Harbor Islands degrade, the channels are less constricted and show shoaling in later years. The new hurricane-cut tidal inlets (due to Hurricanes Ivan and Katrina) along the barrier shoreline provide additional pathways for tidal exchange between the sound and the gulf, causing an overall reduction in current velocity in some of the backbarrier tidal channels. The ensuing decrease in tidal current velocity in backbarrier channels allowed overwash sand deposition in some of the deeper channel sections.

\section{Sector 4: Monkey Bayou to the MRG0}

Sector 4 is also characterized by shoreface retreat, barrier conversion to shoals (there were no subaerially exposed barriers along this $45-\mathrm{km}$ stretch of coast today), and a decrease in shoreface slope. The average shoreface profile slope decreased from 0.0032 in 1870 to 0.0021 in 2007. The average shoreface retreat was $1,864 \mathrm{~m}$, and the average rate was $14 \mathrm{~m} / \mathrm{yr}$. The northern part of Sector 4 showed the greatest difference between the historical and present slopes, highest rates of shoreface retreat along the entire Chandeleur Islands shoreface, and little to no backbarrier deposition (fig. 17). The southern portion of Sector 4, containing the stretch of coast that includes Curlew Island Shoal and Grand Gosier Islands Shoal, exhibited the most consistent shoreface slope angles during the study period and was also characterized by barrier/ shoal landward migration (fig. 18).

\section{Sector 5: Breton Island}

Shoreface behavior at Breton Island is complex because of the construction and maintenance dredging of the MRGO, migration of Breton Island Pass toward the island, and enlargement of the ebb tidal delta (figs. 1-3, 9). Shore-normal profiles are difficult to interpret because of these complexities. Retreat of the Breton Island shoreface to the south-southwest is driven by the southerly migration of Breton Island Pass at a rate of approximately $9 \mathrm{~m} / \mathrm{yr}$. South of Breton Island is a zone of accretion similar to Hewes Point; the shoreface seaward of Breton Island has prograded more than $2 \mathrm{~km}$ in a seaward direction since 1870 (fig. 19). 


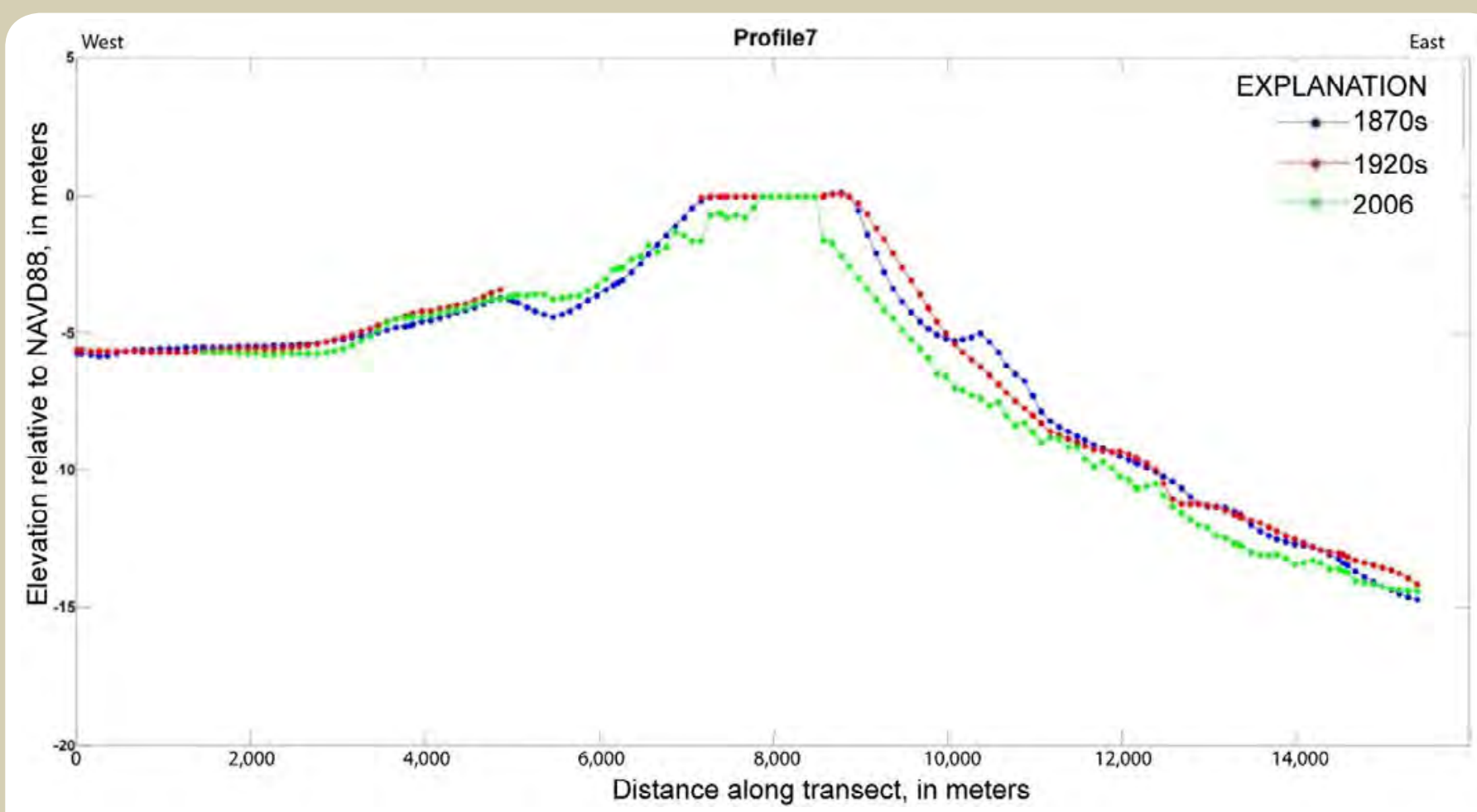

Figure 14. Profile 7 from Sector 2 near Schooner Harbor, La., showing shoreface retreat accompanied by backbarrier shoreline erosion resulting in in-place island thinning. NAVD 88, North American Vertical Datum of 1988.

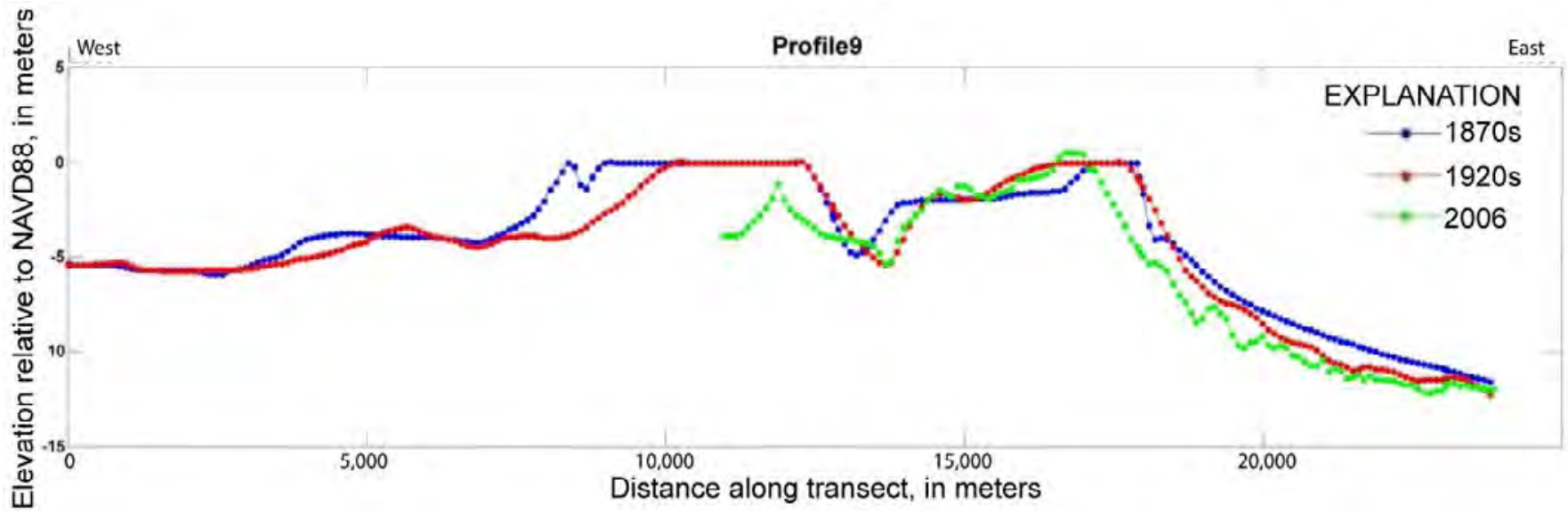

Figure 15. Profile 9 from Sector 2 north of Redfish Point, La., showing shoreface-retreat-accompanied deposition in the backbarrier for the 1870-1920 time period; backbarrier deposition did not occur during the 1920-2007 period. NAVD 88, North American Vertical Datum of 1988. 


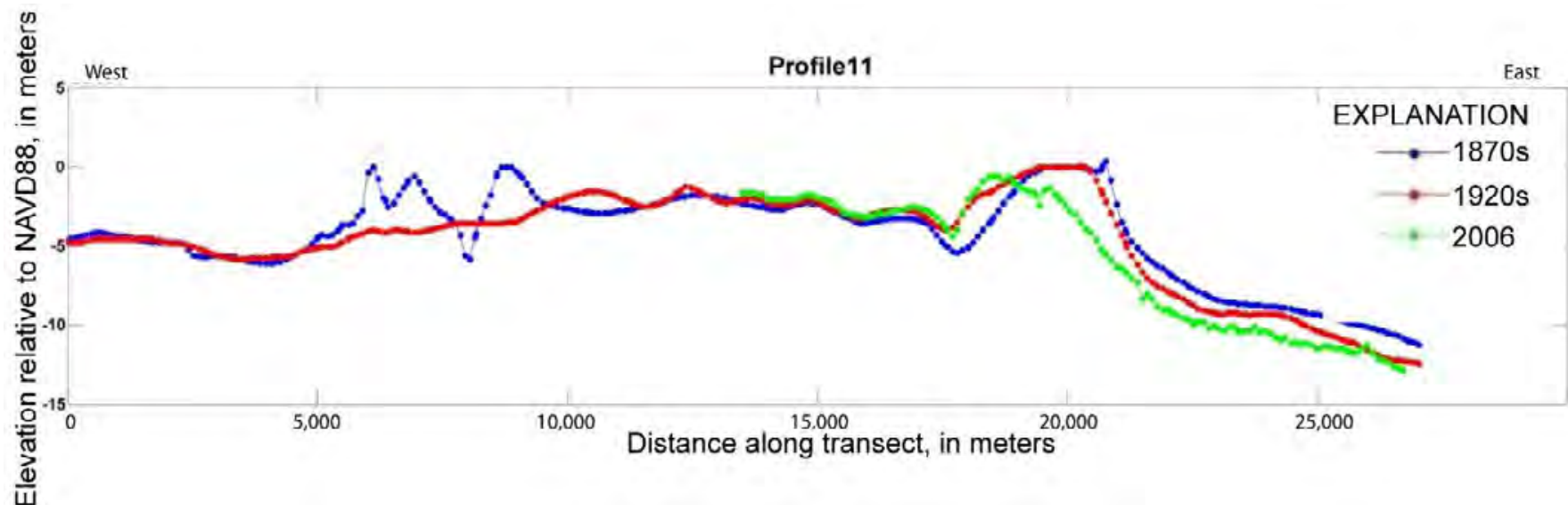

Figure 16. Profile 11 from Sector 3 between Monkey Bayou and Redfish Point, La., showing shoreface retreat accompanied by backbarrier deposition resulting in landward barrier migration. Note the decrease in slope between the 1870s and 1920s profiles and the 2007 profile. NAVD 88, North American Vertical Datum of 1988.

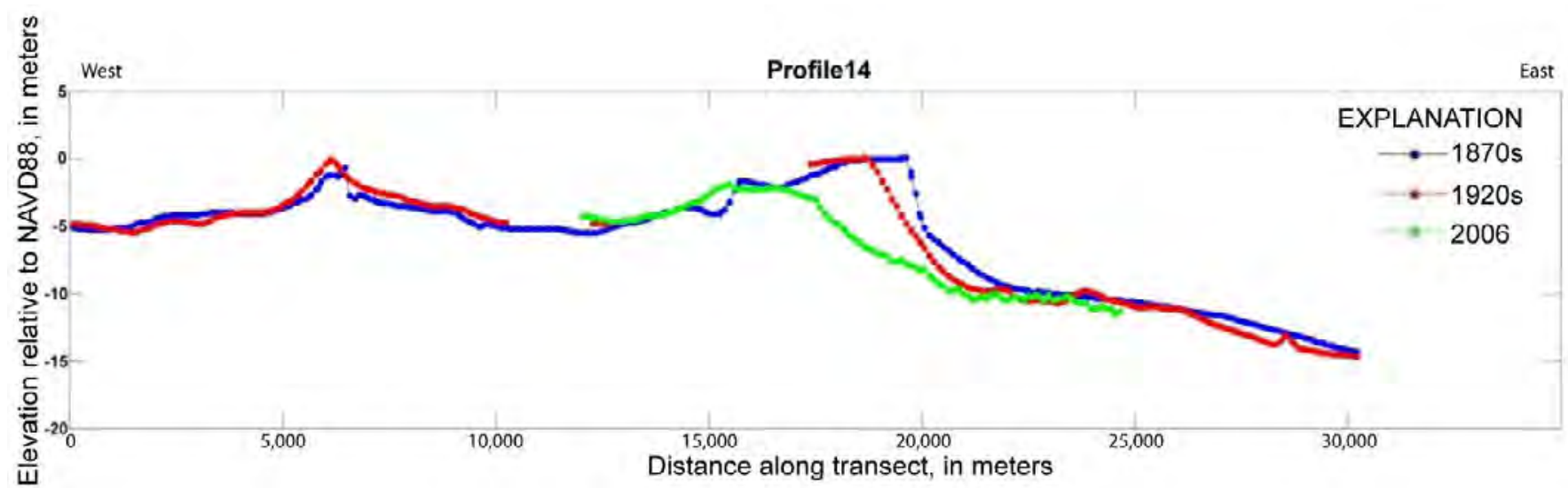

Figure 17. Profile 14 from Sector 4 south of Monkey Bayou, La. Profiles from the northern portion of Sector 4 are characterized by decreasing shoreface slope as islands migrate landward, converting to shoals with minimal backbarrier deposition. NAVD 88, North American Vertical Datum of 1988. 


\section{Discussion}

\section{Sediment Transport}

Barrier island evolution along the Mississippi River Delta Plain involves the reworking of an abandoned deltaic headland by waves, storms, and tidal currents to form a sandy shoreline (fig. 8). Shoreline development and barrier geometry are controlled by orientation of the abandoned deltaic headland relative to the dominant wave approach. Wave-induced lateral transport is the most significant factor in the development of a barrier coastline along the Mississippi River Delta Plain (Penland and Boyd, 1985) and produces sand-rich flanking barrier islands. Because the transgressive shoreline is naturally isolated from the sediment load of the Mississippi River, there is a finite supply of sand for natural island maintenance. In earlier stages of barrier development a significant sand source is derived from erosion of deltaic deposits down to the shoreface. Once the deltaic sediment source has been completely reworked, or has subsided below effective wave base (about $7 \mathrm{~m}$ for the Chandeleur Islands; Penland and Boyd, 1985), the barrier and lagoonal deposits are continually recycled at the shoreface during retreat, which for a period of time allows the barrier system to maintain its exposure during RSLR.

Prior to this study, it had been suggested that the net loss of sediment from the Chandeleur Islands system was driven by an imbalance between onshore sediment transport volumes during fair weather conditions and offshore sediment transport volumes during storm conditions (Penland and others, 1988). This net export of sediment in an offshore direction produces a thin transgressive sand sheet offshore of the islands that is too deep for onshore transport by constructive fair weather waves. Based on this model, transgressive submergence eventually occurs because development of this sand sheet constantly removes sediment from the barrier system until a threshold is reached, beyond which the islands cannot maintain exposure (Penland and others, 1988). Here we present findings that show that sand is indeed being lost from the nearshore system to deepwater sinks, but the process is more complicated than previously suggested in the cross-shore sediment budget model. Our updated model includes a large volume of sediment transported to the flanks of the island arc, a condition that is similar to the early stages of barrier island development.

As demonstrated by the sea floor change DEM, the dominant sediment transport trends are shoreface erosion and deposition in deepwater sinks at the flanks of the island arc. Backbarrier deposition is minimal relative to the volumes eroded from the shoreface, indicating that, for the most part, sand is not being transferred in a landward direction for future recycling by means of shoreface retreat. Instead, lateral spit accretion, sourced by island and shoreface erosion, has led to sand being sequestered in downdrift, deepwater sinks and removed from the littoral system.

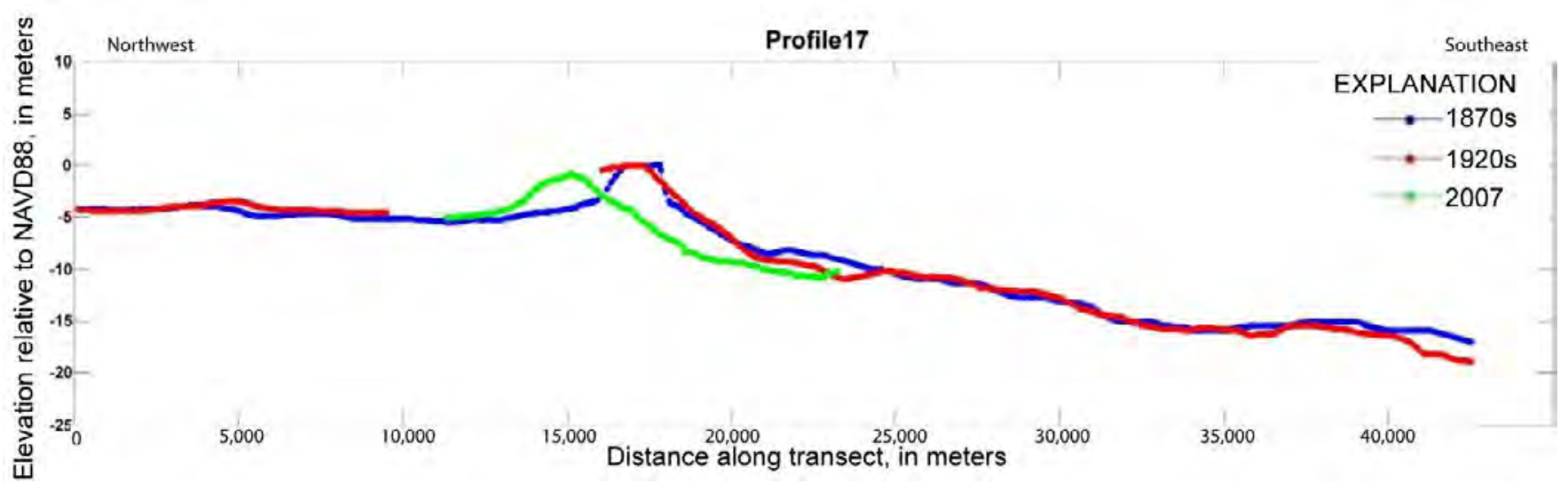

Figure 18. Profile 17 from Sector 4 at Curlew Island/Shoal, La. Profiles from the southern portion of Sector 4 are characterized by low-gradient shoreface slope and landward-migrating islands/shoals. NAVD 88, North American Vertical Datum of 1988. 


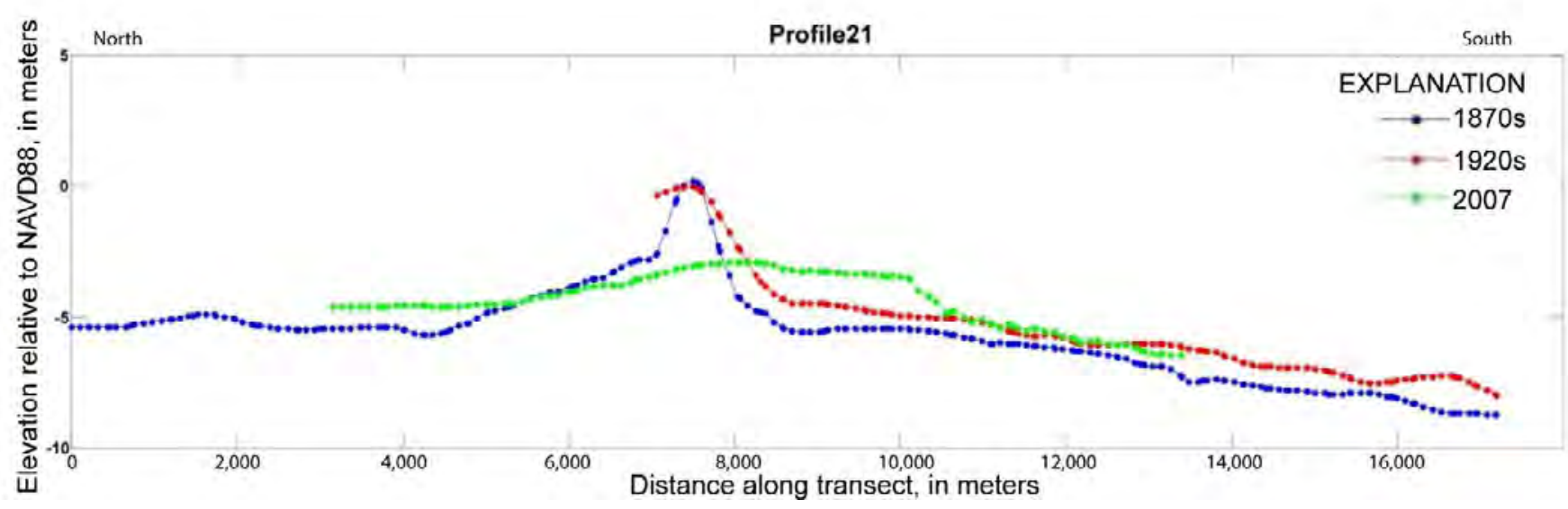

Figure 19. Profile 21 from Sector 4 south of Breton Island, La., showing more than $2 \mathrm{~km}$ of seaward shoreface progradation south of Breton Island, La., that is accompanied by island submergence. NAVD 88, North American Vertical Datum of 1988.

\section{Shoreface Evolution and Transgressive Submergence}

One of the most apparent trends demonstrated in the profile data is the relation among shoreface retreat rates, shoreline erosion rates, and decreasing shoreface slope through time (fig. 20). There is also a correlation between the shoreface slope angle and barrier evolution during the period of study. The southern Chandeleurs have a relatively gentle shoreface slope and are characterized by barrier landward retreat, barrier shoals, and ephemeral barrier islands with no well-established backbarrier marsh. The northern Chandeleurs have a relatively steep shoreface and are characterized by barriers that are undergoing shoreline erosion that is not accompanied by landward barrier island migration. These islands are backed by a well-established (based on historical maps, more than 150 years) backbarrier marsh. Within the period of study, some sections of coast (for example, central Chandeleurs just south of Monkey Bayou; fig. 17) have converted from the steeply sloping/shoreline erosion category to the gently sloping/ ephemeral barrier type.

Along sections of the island chain where a thick backbarrier marsh is present, the shoreline is somewhat anchored by the cohesive sediment and root mat that make up the marsh deposits. These marsh deposits serve as nucleation sites upon which sand can accumulate during storm recovery periods. This more resistant substrate inhibits the total destruction of islands during storms. It serves to slow the rate of shoreline erosion because it forms a barrier beyond which sand transported by waves cannot pass and therefore accumulates as bars weld to the shoreline. In contrast, where no backbarrier marsh is present or where it is destroyed during storms, sand in the nearshore zone can be transported landward by waves, and there is no nucleation site for sand accumulation and the formation of accreting spits.

The parts of the islands that are backed by marsh do not migrate as rapidly, and the shoreface matures and becomes steeper. Parts of the islands that are not backed by marsh are destroyed during storms and reemerge during calm weather in a position landward of their prestorm location.

Results of this study capture a transition from relatively sediment-rich barriers (1870s to 1922) that built new land in the backbarrier by overwash, flood tidal delta, and recurved spit formation to sediment-starved barriers that no longer built new backbarrier land and began to thin in place (1922-2005). Once the thinning reaches the point where no backbarrier marsh exists, the barriers cross the transgressive submergence threshold, becoming mobile sand bodies that migrate landward through a cycle encompassed by storm destruction followed by emergence landward of their former positions during calm weather (fig. 21).

\section{Anatomy of a Threshold Crossing}

The Chandeleur Islands are undergoing transgressive submergence by means of a multistage process that involves the following:

- Decreased barrier sand supply restricting new backbarrier marsh development;

- Continued gulf and backbarrier shoreline erosion resulting in barrier thinning and segmentation. 


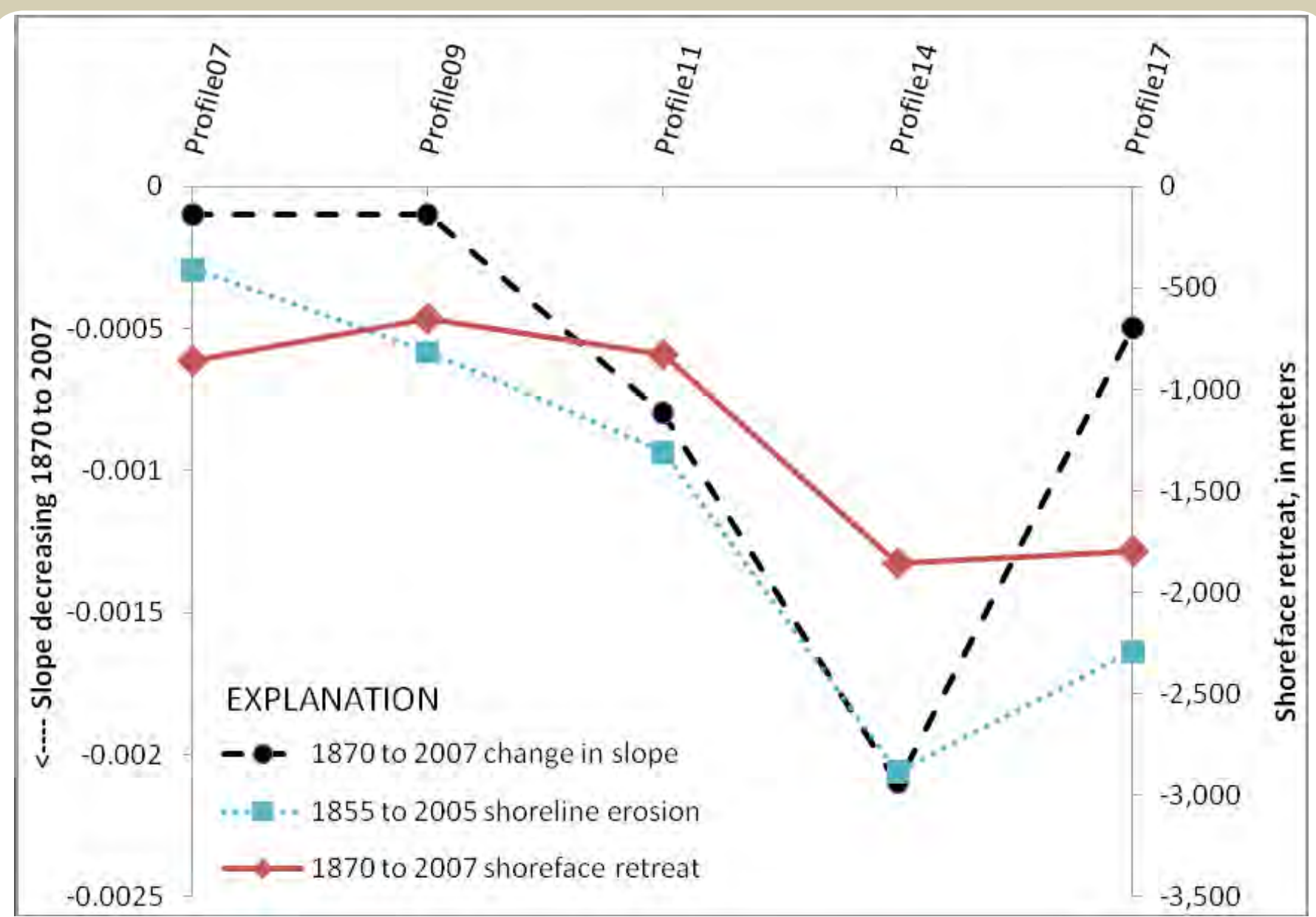

Figure 20. Relation among magnitude of decreased shoreface slope between 1870 and 2007, shoreface retreat rates, and shoreline erosion rates. Note the correlation among decrease in slope magnitude, shoreface retreat, and shoreline erosion. Profile locations are shown in figure 10 .

In this multistage process, landward migration is limited because the Chandeleur Islands are stabilized by backbarrier marsh deposits that inhibit landward transfer of sediment by waves. Overwash and eolian processes are not effective at facilitating landward migration of barrier sediment because of the paucity of sand in the subaerial barrier. Fragmented marsh islets that are the remnants of landward protrusions from the backbarrier shoreline (for example, Redfish Point, Schooner Harbor, Monkey Bayou) anchor the longshore sediment transport system. Spits accrete laterally to connect individual islets forming a continuous shoreline.

The gulf shoreline ultimately reaches the backbarrier shoreline, and islands are no longer stabilized by backbarrier marsh, resulting in a sandy ephemeral barrier and the onset of transgressive submergence. The ephemeral barriers are destroyed during storms when the sand is dispersed both offshore and into the backbarrier. During calm weather, landward migration slows, allowing sand that is stored in the gently sloping shoreface to move onshore, forming an equilibrium shoreface profile. This process facilitates the transfer of sand in a landward direction in volumes that are sufficient to maintain island exposure in response to RSLR. The loss of backbarrier marsh forces a shift in the sediment transport regime from the previously dominant longshore direction to one dominated by cross-shore processes. The system becomes more efficient at recycling sediment during landward retreat; however, increased storm frequency inhibits island reemergence and subaerial expansion, processes that occur during extensive calm weather periods. In a regime of frequent storms, the sand that is transported offshore during a storm does not have sufficient time to move onshore and reorganize into a linear shoal 


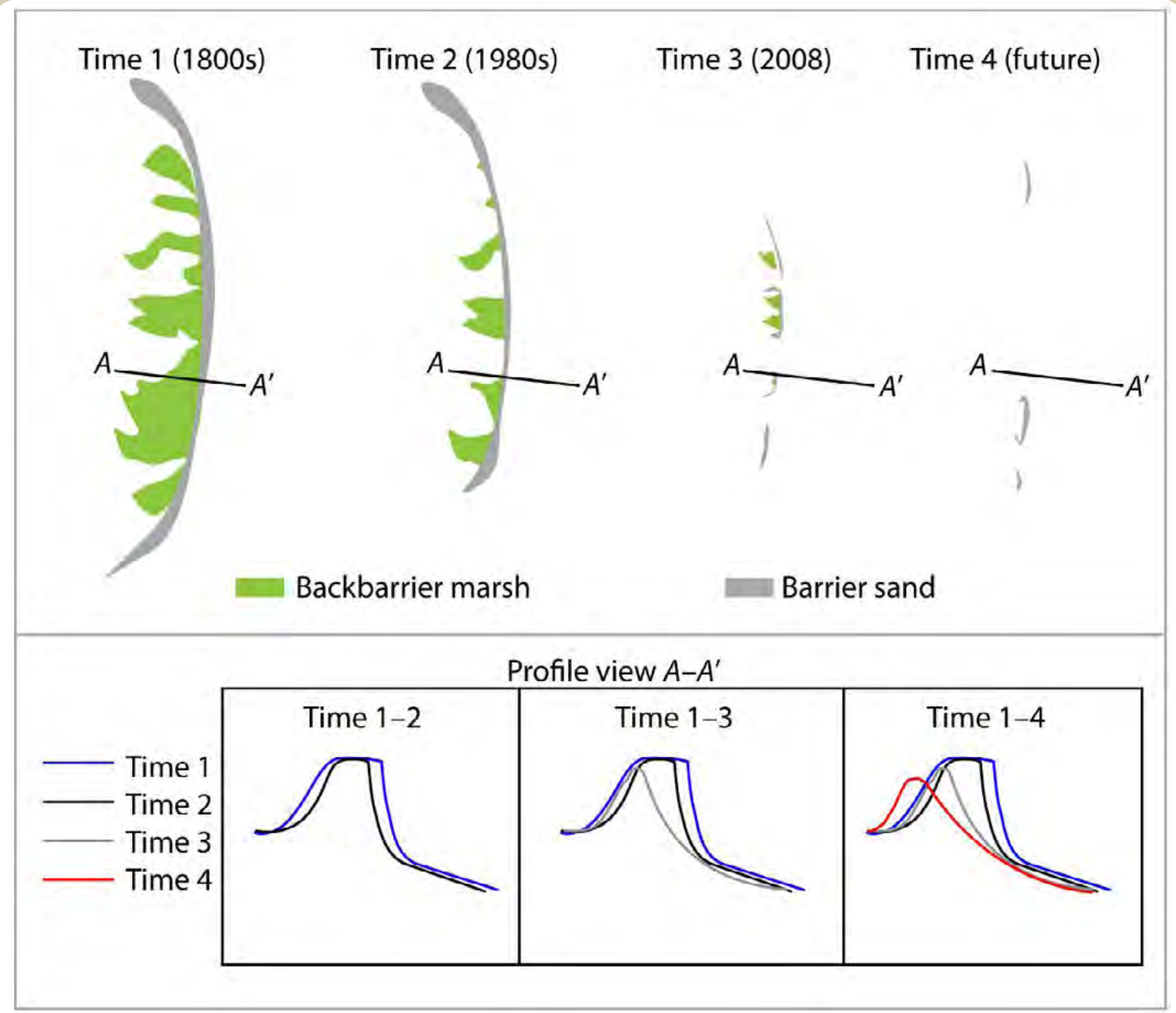

Figure 21. Conceptual model for barrier island transgressive submergence.

before being impacted by a subsequent storm resulting in a net loss of sand offshore and development of an offshore sand sheet in the retreat path of the landward-migrating ephemeral barrier islands/shoals.

\section{Conclusions and IImplications for Island Management}

1. Long-term reduction in island area is driven by pulses of rapid land loss triggered by storm events. The islands do not fully recover from storm impacts because sand is transported to the flanks of the arc and is thus removed from the littoral system. The remnant marsh islands are the "backbone" that stabilizes the barrier chain. Once this marsh has eroded, the entire chain will begin to behave 
similar to the southern ephemeral barriers (Curlew and Grand Gosier Islands/Shoals).

2. Because of long-term volume reduction in the littoral sand budget, a trend that was greatly accelerated by Hurricane Katrina, the islands are incapable of maintaining exposure by means of landward transfer of sand during storm events (overwash processes). It has been observed that during the poststorm recovery period, however, the landward transfer of sand occurs by (a) landward migration of offshore bars that weld to marsh islets, (b) recurved spit formation at hurricane-cut inlets, and (c) eolian processes (dunes, wind tidal flats, and winddeposited sand on the backbarrier marsh surface). Because of the large volume of sand removed from the littoral system during Hurricane Katrina, the islands have become sediment starved, and the recovery processes described above appear to have exhausted most of the available sand supply, limiting further recovery.

3. The long-term diminished sediment supply, location of sediment sinks, and storm recovery processes documented in this study provide an understanding of what drives early stages of barrier island arc transgressive submergence and the natural sediment dispersal processes at work that prolong submergence. On the basis of this documentation of where the sand is going, how long it takes to get there, and how the islands naturally respond to a rapid introduction of new sediment, we can more confidently formulate barrier management strategies; however, future storm frequency is a major unknown.

4. A modification of the transgressive barrier island evolution model proposed by Penland and others (1988) is an outcome of this study. The finding that lateral transport dominates over cross-shore transport is important because instead of sand being removed and deposited offshore as thin sand sheets we now know that sand is being concentrated as thick spit platform sediment bodies at the flanks of the island arc. These downdrift sand reservoirs may provide a unique, quasi-renewable resource for nourishing the updrift barrier system (that is, the central arc). Barrier island sediment nourishment should be executed with the understanding that gulf shoreline erosion is inevitable, distribution of hurricane-cut passes should be maintained as storm surge/overwash pathways, and well-established (decadal to century scale) sandy backbarrier platform construction and vegetation are crucial to long-term sustainability.

\section{References}

Baldwin, W.E., Pendleton, E.A., and Twichell, D.C., 2009, Geophysical data from offshore of the Chandeleur Islands, eastern Mississippi Delta: U.S. Geological Survey OpenFile Report 2008-1195 [DVD-ROM].

Brown, E.I., 1928, Inlets on sandy coasts: Proceedings of the American Society of Civil Engineers, v. 54, no. 4, p. 505-553.

Davis, R.A., Jr., and FitzGerald, D.M., 2004, Beaches and coasts: Blackwell, Oxford, U.K., 419 p.

DeWitt, N.T., Flocks, J.G., Hansen, M., Kulp, M., and Reynolds, B.J., 2007, Bathymetric survey of the nearshore from Belle Pass to Caminada Pass, Louisiana: Methods and Data Report, U.S. Geological Survey Data Series 312 [CDROM].

Escoffier, F.F., 1940, The stability of tidal inlets: Shore and Beach, v. 8, no. 4, p. 114-115.

Evans, O.F., 1942, The origin of spits, bars, and related structures: Journal of Geology, v. 50, p. 846-863.

Golden Software, Inc., 2002, Surfer 8 contouring and 3D surface mapping for scientists and engineers user's guide: Golden, Colo., Golden Software, Inc., 640 p.

Hart, W.E., and Murray, S.P., 1978, Energy balance and wind effects in a shallow sound: Journal of Geophysical Research, v. 83, p. 4097-4106.

Hawley, J.H., 1931, Hydrographic manual: Washington, D.C., Department of Commerce, U.S. Coast and Geodetic Survey, Special Publication no. 143, $170 \mathrm{p}$.

Hoyt, J.H., and Henry, V.J., Jr., 1967, Influence of island migration on barrier-island sedimentation: Geological Society of America Bulletin, v. 78, p. 77-86.

Jaffe, B.E., List, J.H., Sallenger, A., Jr., and Holland, T., 1991, Louisiana Barrier Island Erosion Study - correction for the effect of relative sea level change on historical bathymetric survey comparisons, Isles Derniere area, Louisiana: Reston, Va., U.S. Geological Survey, Open-File Report 91-276, 33 p.

Jaffe, B.E., List, J.H., and Sallenger, A.H., Jr., 1997, Massive sediment bypassing on the lower shoreface of a wide tidal inlet-Cat Island Pass, Louisiana: Marine Geology, v. 136, p. 131-149.

Kahn, J.H., 1986, Geomorphic recovery of the Chandeleur Islands, Louisiana after a major hurricane: Journal of Coastal Research, v. 2, no. 3, p. 337-344. 
Kolb, C.R., and Van Lopik, J.R., 1958, Geology of the Mississippi River deltaic plain, southeastern Louisiana: Vicksburg, Miss., U.S. Army Corps of Engineers Waterways Experiment Station, Technical Report no. 3-483, 120 p.

Kulp, M.A., 2000, Holocene stratigraphy, history, and subsidence of the Mississippi River Delta region, northcentral Gulf of Mexico: Lexington, University of Kentucky, Ph.D. thesis, 283 p.

Kulp, M.A., FitzGerald, D.M., and Penland, S., 2005, Sandrich lithosomes of the Holocene Mississippi River Delta Plain, in Liviu, G., and Bhattacharya, J.P., eds., River deltas; concepts, models, and examples: Society for Sedimentary Geology (SEPM), Special Publication, v. 83, p. 279-293.

List, J.H., Jaffe, B.E., and Sallenger, A.H., 1991, Large-scale coastal evolution of Louisiana's barrier islands: American Society of Civil Engineers, Proceedings Coastal Sediments 1991, p. 1532-1546.

List, J.H., Jaffe, B.E., Sallenger, A.H., Jr., Williams, S.J., McBride, R.A., and Penland, S., 1994, Louisiana Barrier Island Erosion Study - atlas of seafloor changes from 1878 to 1989: Reston, Va., U.S. Geological Survey and Louisiana State University, Miscellaneous Investigations Series I-2150-A, $81 \mathrm{p}$.

Martinez, L., Penland, S., Fearnley, S., O’Brien, S., Bethel, M., and Guarisco, P., 2009, Louisiana Barrier Island Comprehensive Monitoring Program (BICM), task 3 shoreline change analysis - 1800's to 2005: Pontchartrain Institute for Environmental Sciences, Technical Report no. 001-2008, University of New Orleans, New Orleans, La.

McBride, R.A., Penland, S., Hiland, M.W., Williams, S.J., Westphal, K.A., Jaffe, B.E., and Sallenger, A.H., Jr., 1992, Analysis of barrier shoreline change in Louisiana from 1853 to 1989, in Williams, S.J., Penland, S., and Sallenger, A.H., eds., Louisiana Barrier Island Erosion Study - atlas of shoreline changes in Louisiana from 1853 to 1989: Reston, Va., U.S. Geological Survey and Louisiana State University, Miscellaneous Investigations Series I-2150-A, p. 36-97.

Meckel, T.A., ten Brink, U., and Williams, S.J., 2006, Current subsidence rates due to compaction of Holocene sediments in southern Louisiana: Geophysical Research Letters, v. 33, L11403.
Miner, M.D., Kulp, M., Flocks, J., Twichell, D., Penland, S., Martinez, L., Motti, J., Weathers, D., DeWitt, N., Reynolds, B.J., Baldwin, W., Danforth, B., Worley, C., Bergeron, E., Ferina, N., McCarty, P., Brown, M., and Torres, J., 2009, Louisiana Barrier Island Comprehensive Monitoring program, v. 3 - south-central Louisiana and northern Chandeleur Islands, bathymetry and historical seafloor change 1873-2006, part 1-methods and error analysis for bathymetry: New Orleans, La., University of New Orleans Pontchartrain Institute for Environmental Sciences Technical Report, submitted to Louisiana Department of Natural Resources, 44 p.

Otvos, E.G., 1981, Barrier island formation through nearshore aggradation - stratigraphic and field evidence: Marine Geology, v. 43, p. 195-243.

Penland, S., and Boyd, R., 1985, Transgressive depositional environments of the Mississippi River Delta Plain — a guide to the barrier islands, shoals, and beaches in Louisiana, Louisiana State Geological Survey Guidebook Series, no. 3: Baton Rouge, Louisiana Geological Survey.

Penland, S., Boyd, R., and Suter, J.R., 1988, Transgressive depositional systems of the Mississippi Delta Plain - model for barrier shoreline and shelf sand development: Journal of Sedimentary Petrology, v. 58, p. 932-949.

Penland, S., and Ramsey, K.E., 1990, Relative sea level rise in Louisiana and the Gulf of Mexico-1908-1988: Journal of Coastal Research, v. 6, no. 2, p. 323-342.

Sallenger, A.H., Jr., List, J.H., Jaffe, B.E., Penland, S., and Williams, S.J., 1992, Regional coastal erosion research and beach preservation, in New directions in beach management: Proceedings of the Fifth Annual National Conference on Beach Preservation Technology, St. Petersburg Hilton \& Towers, St. Petersburg, Fla., February 12-14, 1992, p. 115-134.

Törnqvist, T.E., Bick, S.J., van der Borg, K., and de Jong, A.F.M., 2006, How stable is the Mississippi Delta?: Geology, v. 34, no. 8, p. 697-700.

Törnqvist, T.E., Wallace, D.J., Storms, J.E.A., Wallinga, J., van Dam, R.L., Blaauw, M., Derksen, M.S., Klerks, C.J.W., Meijneken, C., and Snijders, E.M.A., 2008, Mississippi Delta subsidence primarily caused by compaction of Holocene strata: Nature Geoscience, v. 1, p. 173-176.

U.S. Coast and Geodetic Survey, 1917, Descriptive report for hydrographic survey sheet no. 4000, Gulf of Mexico, Mississippi Sound: Washington, D.C., Department of Commerce, U.S. Coast and Geodetic Survey, 7 p. 
U.S. Coast and Geodetic Survey, 1920, Descriptive report for hydrographic survey sheet no. 4171, Gulf of Mexico, Mobile Bay entrance to Chandeleur Islands offshore:

Washington, D.C., Department of Commerce, U.S. Coast and Geodetic Survey, 13 p.

U.S. Coast and Geodetic Survey, 1922, Descriptive report for hydrographic survey sheet no. 4219, Chandeleur Sound, North, Freemason, and Old Harbor Islands: Washington, D.C., Department of Commerce, U.S. Coast and Geodetic Survey, $9 \mathrm{p}$. 


\section{Geologic Mapping of Distribution and Volume of Potential Resources}

By David Twichell, Elizabeth Pendleton, Wayne Baldwin, and James Flocks

Chapter E of

Sand Resources, Regional Geology, and Coastal Processes of the Chandeleur Islands Coastal System: an Evaluation of the Breton National Wildlife Refuge

Edited by Dawn Lavoie

In cooperation with the U.S. Fish and Wildlife Service

Scientific Investigations Report 2009-5252 


\title{
U.S. Department of the Interior \\ KEN SALAZAR, Secretary \\ U.S. Geological Survey \\ Marcia K. McNutt, Director
}

\section{U.S. Geological Survey, Reston, Virginia: 2009}

\author{
This and other USGS information products are available at http://store.usgs.gov/ \\ U.S. Geological Survey \\ Box 25286, Denver Federal Center \\ Denver, C0 80225 \\ To learn about the USGS and its information products visit http://www.usgs.gov/ \\ 1-888-ASK-USGS
}

\begin{abstract}
Any use of trade, product, or firm names is for descriptive purposes only and does not imply endorsement by the U.S. Government.

Although this report is in the public domain, permission must be secured from the individual copyright owners to reproduce any copyrighted materials contained within this report.
\end{abstract}

Suggested citation:

Twichell, D., Pendleton, E., Baldwin, W., and Flocks, J., 2009, Chapter E. Geologic mapping of distribution and volume of potential resources, in Lavoie, D., ed., Sand resources, regional geology, and coastal processes of the Chandeleur Islands coastal system - an evaluation of the Breton National Wildlife Refuge: U.S. Geological Survey Scientific Investigations Report 2009-5252, p. 75-98. 


\title{
Chapter E. Geologic Mapping of Distribution and Volume of Potential Resources
}

\author{
By David Twichell, ${ }^{1}$ Elizabeth Pendleton, ${ }^{1}$ Wayne Baldwin, ${ }^{1}$ and James Flocks ${ }^{2}$
}

\section{Abstract}

A dense grid of high-resolution seismic data and vibracores have been used to define the shallow stratigraphy of the Breton National Wildlife Refuge and the inner shelf immediately surrounding the refuge. These data allowed mapping of the distribution and volume of sediment contained in the barrier island lithosome and identification of potential sand resource sites. The islands within the refuge are built upon the St. Bernard Delta Complex of the larger Mississippi River Delta Plain. These deltaic deposits are primarily fine grained with the exception of distributary channels that can be filled with sand and muddy sand. The barrier islands, which extend from Breton Island to the northern tip of the Chandeleur Islands, are the exposed parts of the barrier island lithosome that rests on top of the deltaic deposits. This lithosome is primarily sand; has a volume of approximately $1,600 \times 10^{6} \mathrm{~m}^{3}$; and is unevenly distributed along its length. The lithosome is a broad sheet-like deposit at its southern end, is narrowest and thinnest in the vicinity of the Chandeleur Islands, and extends north of these islands into deeper water as the Hewes Point spit. The Hewes Point part of the lithosome exceeds $9 \mathrm{~m}$ in thickness and contains approximately 25 percent of its total volume. Hewes Point is the product of northward alongshore transport and as such represents sediment removed from the littoral zone of the barrier island system. Six areas have been identified as potential sand resource sites. Because of its location at the end of the littoral transport pathway, Hewes Point may be the most promising of the sites. Four distributary channel systems that are exposed on the innermost shelf may also be sand resource targets, but their irregular shapes and high mud content suggest that they are not ideal targets. A smaller deposit at the southern end of the study area that appears to be the sink for southerly directed alongshore transport is the sixth potential site. The lack of cores from this site, however, means that its sediment composition is unknown.

\section{Introduction}

The Chandeleur Islands are a discontinuous barrier island chain along the eastern side of the Mississippi River Delta that trends northward from Breton Island for approximately $85 \mathrm{~km}$ (fig. 1). The Breton National Wildlife Refuge is located on the islands, which provide habitat for the brown pelican (Pelecanus occidentalis), least tern (Sterna antillarum), piping plover (Charadrius melodus), and other migratory shore birds, as well as sea turtles and a wide variety of fishes. During Hurricane Katrina in 2005 this island chain lost 84 percent of its areal extent (Sallenger and others, 2006). In the 2 years following the hurricane, the islands showed only limited and slow recovery, which raises the question: Will the islands recover or will they continue to diminish in size and eventually become submerged shoals?

In response to the extreme coastal change and land loss caused by Hurricane Katrina within the Breton National Wildlife Refuge, the U.S. Fish and Wildlife Service has sought aid in developing a clearer understanding of the evolution of these islands, the extent of sand associated with the island chain, and the presence of other potential sand resources around the islands, which are needed to continue effective management of the refuge and its wildlife. To achieve these goals, the U.S. Geological Survey (USGS) conducted a highresolution geophysical survey of the sea floor and subsurface within 5-6 km of the islands and collected 124 vibracores (fig. 2 ). The geological data have been used to map and describe the shallow stratigraphy and potential sand resources within close proximity to the refuge. This chapter summarizes findings derived from the high-resolution seismic-reflection data collected around the islands. In addition to characterizing the geologic framework, these data, in concert with vibracore analyses, are utilized to map the distribution of the barrier island sand sheet (called the barrier island lithosome) and identify additional deposits that could serve as sand resource areas if island renourishment is pursued. Deposits shoreward

${ }^{1}$ U.S. Geological Survey, Woods Hole, Mass.

${ }^{2}$ U.S. Geological Survey, St. Petersburg, Fla. 


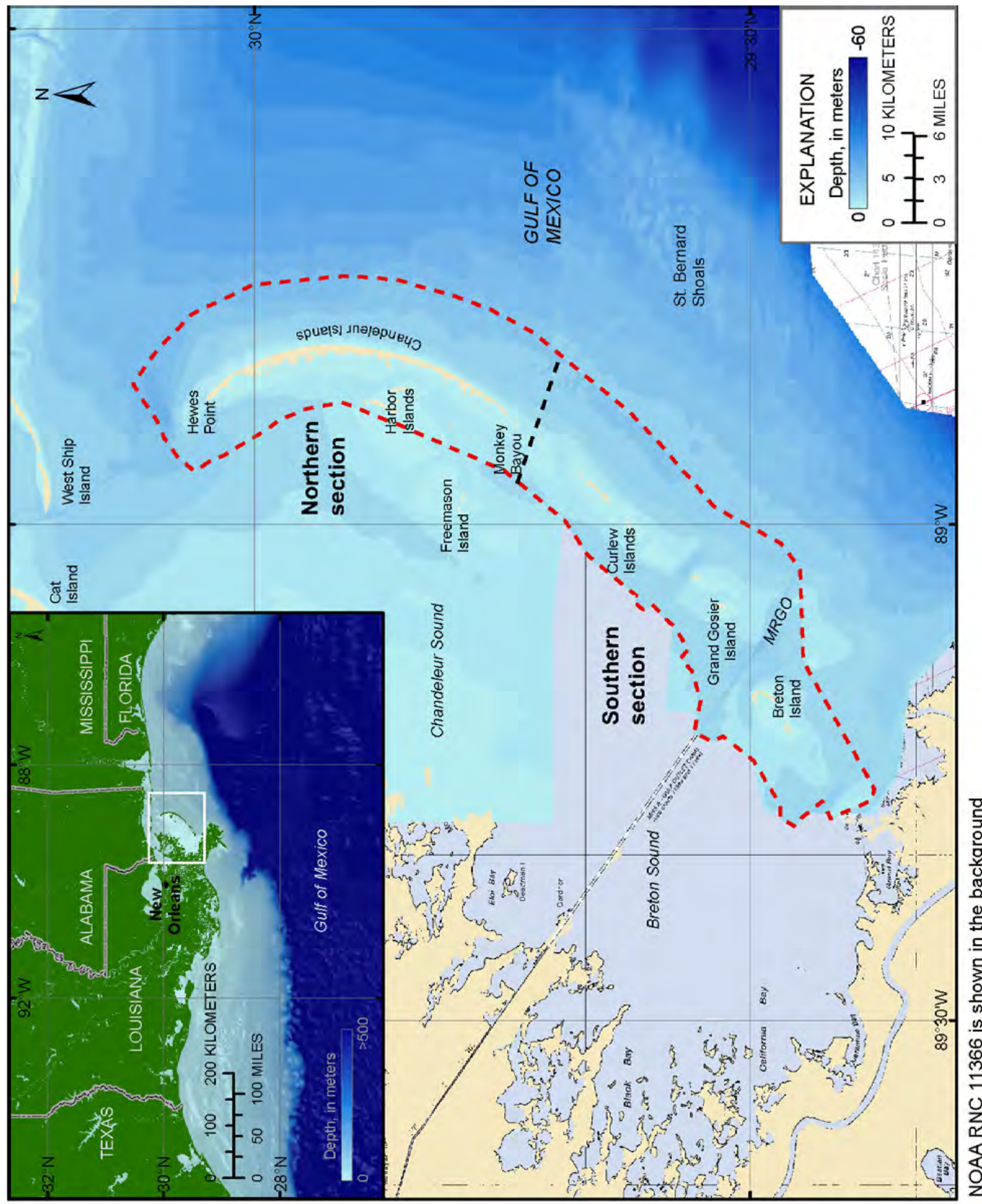

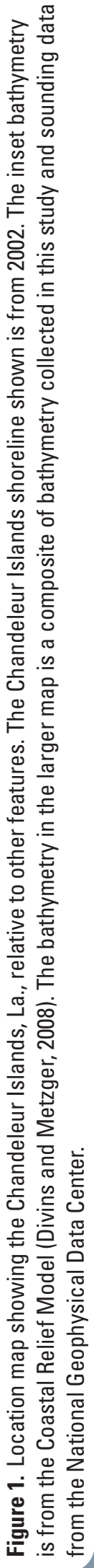




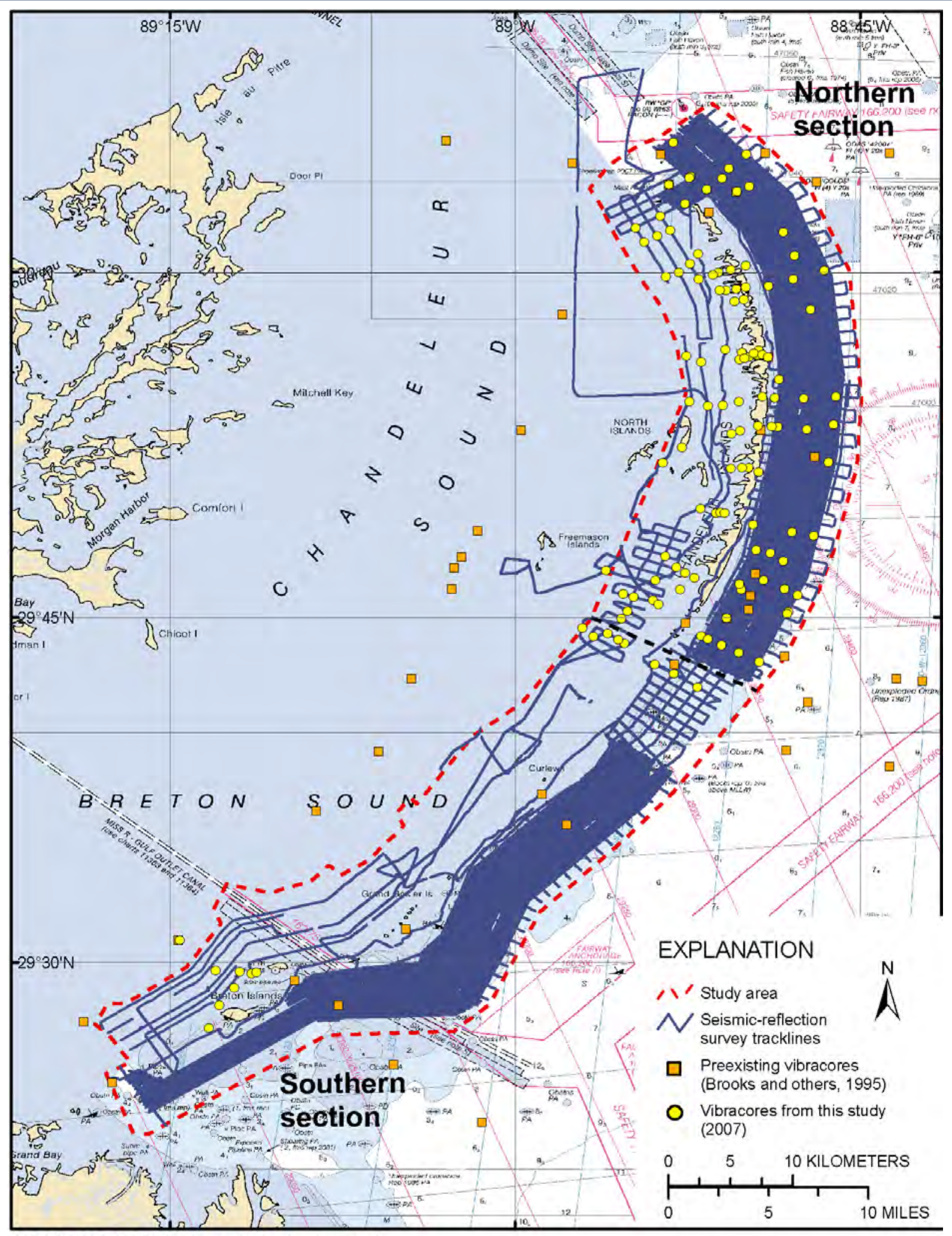

NOAARNC 11366 is shown in the background

Figure 2. Locations of high-resolution CHIRP seismic-reflection tracklines and vibracore coverage in the vicintiy of the Chandeleur Islands, La. 
of the islands were not evaluated for their resource potential because of the shallow water depths in this region and because this area is the platform on which the islands eventually would stand if they migrate shoreward. This chapter outlines the location and estimated sediment volume for six potential sand resource areas; chapter $F$ provides textural analyses of sediment within the different resource areas on the basis of vibracore data.

\section{Setting}

Several coastal and geologic studies conducted on and around the Chandeleur Islands have led to an improved understanding of their evolution (Penland and Boyd, 1981; Penland and others, 1985; Suter and others, 1988) and the processes that continue to shape them (Georgiou and others, 2005; Ellis and Stone, 2006), but no sand resource assessments have been conducted in this area to date. Previous studies show that the location of the Chandeleur Islands is controlled by the late Holocene development of the Mississippi River
Delta (Penland and others, 1988), which started forming on the shelf about 7,000 years before present (BP). Frazier (1967) and McFarlan (1961) noted that the sites of active deltaic deposition shifted over time, and they described a framework of several smaller delta complexes that form the larger composite feature (fig. 3). One of the intermediate deltas, the St. Bernard Delta Complex, forms the foundation beneath the Chandeleur Islands. This delta complex was active from about 4,000 to 2,000 years BP when it advanced eastward across the inner shelf south of the present day State of Mississippi (Frazier, 1967; fig. 4A, 4B). Once the St. Bernard Delta Complex was abandoned, the Chandeleur Islands started to form about 2,000 years BP in response to erosion of deltaic headlands and spit elongation driven by alongshore transport (Penland and others, 1985; Brooks and others, 1995; fig. 4C). With continued subsidence of the underlying deltaic deposits the islands became separated from the subaerial part of the delta and consequently from their original sand source (fig. $4 D$ ). Historically, the islands have decreased in subaerial extent largely by narrowing, but they have not moved landward appreciably (Penland and Boyd, 1981; Williams and

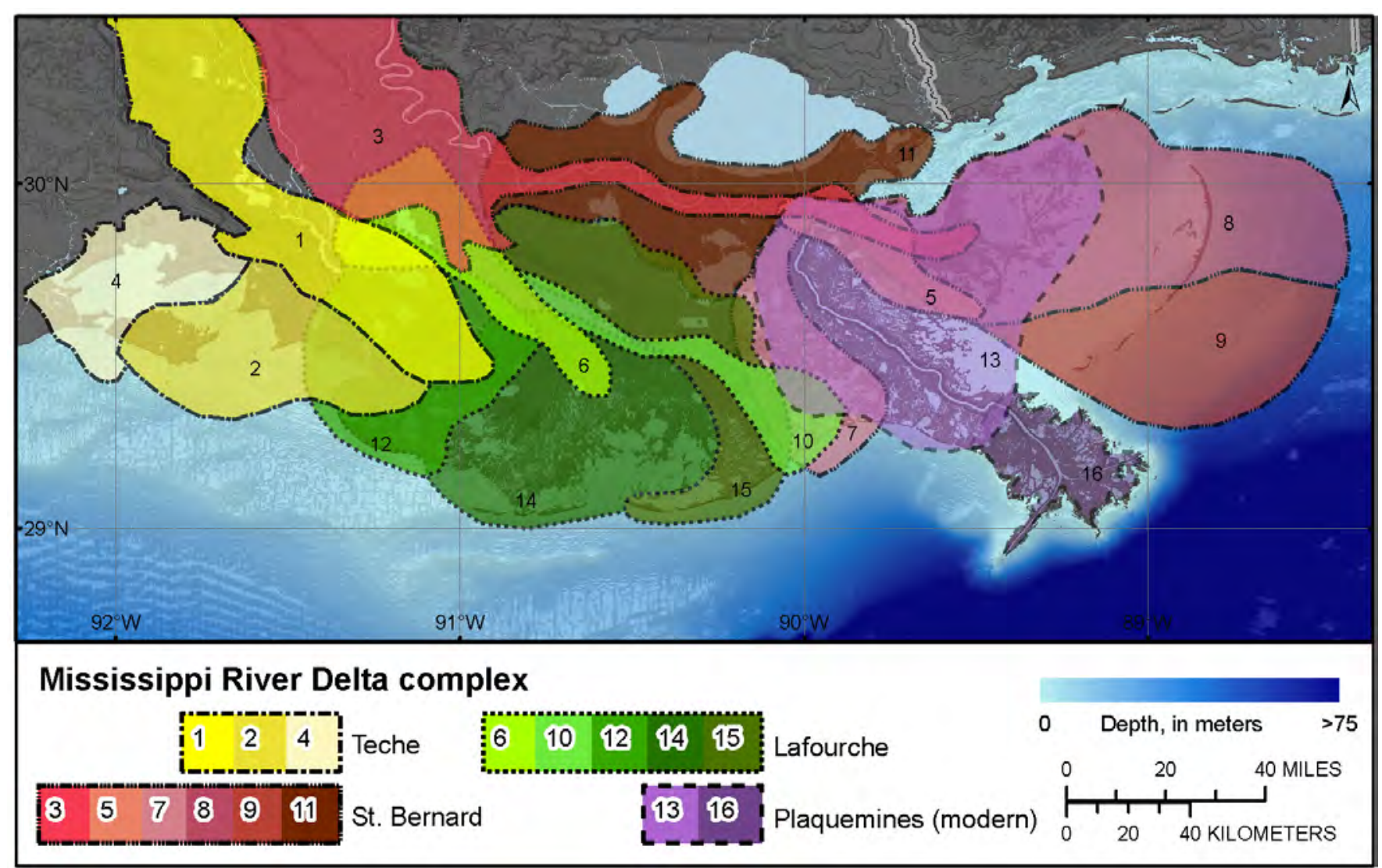

Figure 3. Mississippi River Delta Complex (adapted from Frazier, 1967, and Penland and others, 2002). The numbers and colors indicate the relative timing (1-16) of their development. The St. Bernard Delta Complex was active between 4,600 and 1,800 years before present (BP). 


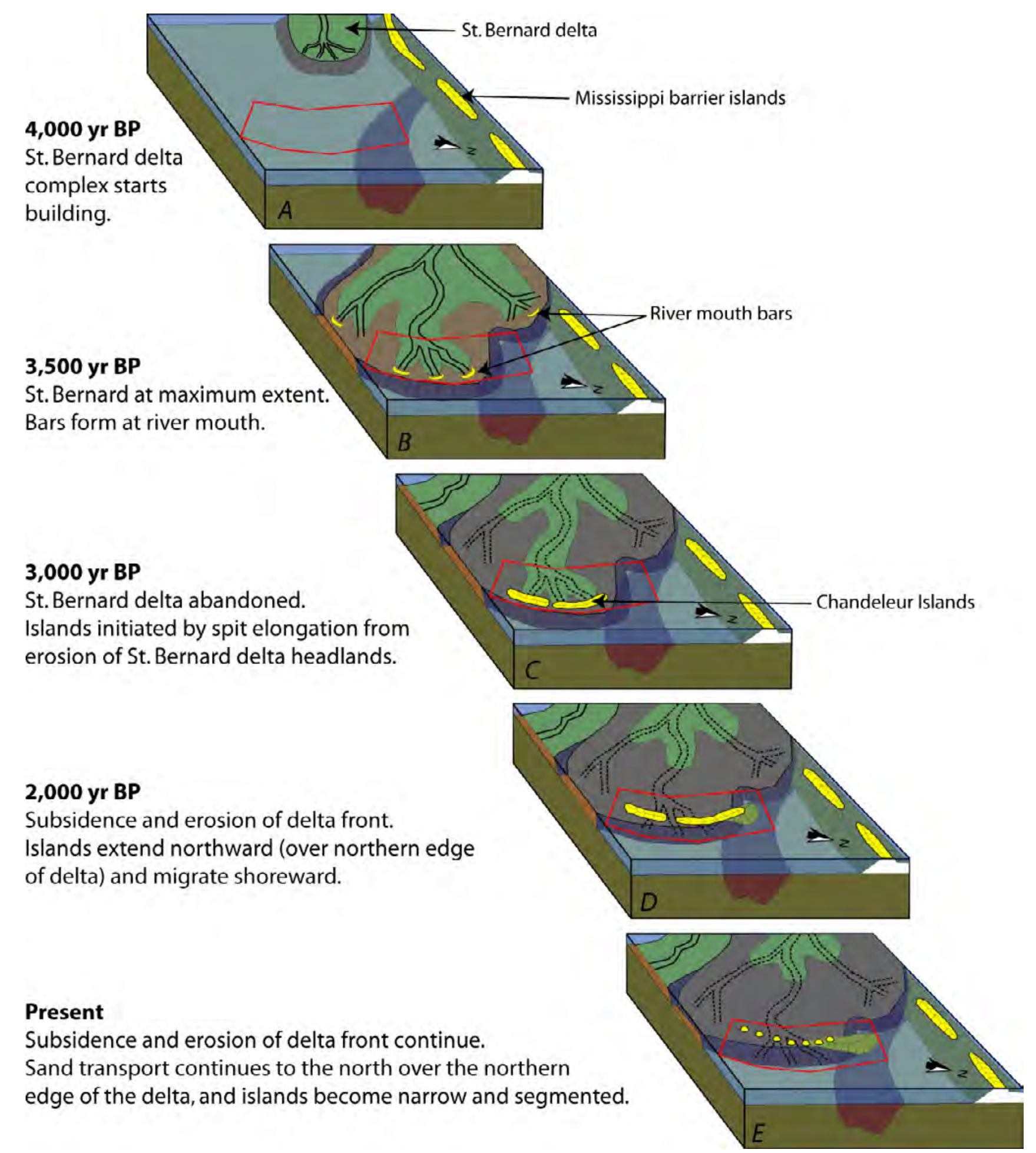

Figure 4. Schematic showing the evolution of the northern part of the Chandeleur Islands, La., region. $A, B$, The initial onset of the development of the St. Bernard Delta Complex. $C$, The abandonment of the delta complex and its reworking to form the initial Chandeleur Islands. $D$, Continued subsidence and isolation of the islands from their headland sources. $E$, The present, when the islands are greatly diminished in size and a large volume of sediment is transported northward out of the littoral system to Hewes Point. The red polygon indicates the approximate location of the northern half of the study area. BP, before present. 
others, 1992, 2006; Miller and others, 2004). After Hurricane Katrina, the islands became more fragmented and greatly diminished in subaerial extent (Sallenger and others, 2006; fig. $4 E$; chap. B).

The St. Bernard Delta Complex, which was the source of sand for these islands, has been studied extensively by Fisk and others (1954), Frazier (1967), Coleman and Prior (1980), and Coleman (1988), who recognized subaerial and submerged subunits. The original St. Bernard Delta Plain consisted of a network of distributary channels separated by interdistributary marsh deposits (fig. 5). Distributary channels incised the subaerial part of the delta. They were mostly filled with muddy sand and sandy mud, but sand-rich bars were common at their mouths (Coleman, 1988). Interdistributary marsh deposits occupied areas between the channels and primarily consisted of organic-rich sandy silt. Delta-front deposits accumulated offshore of the distributary channel and interdistributary marsh deposits. These deposits contained silt layers and thin sand laminae that dipped gently seaward and graded into adjacent prodelta deposits. The proximal edge of delta-front deposits was sandier than the distal edge, which merged with prodelta muds. Prodelta deposits accumulated farthest from the river mouth and were the finest grained. These deposits primarily consisted of clay with occasional silt beds that were deposited on the continental shelf well beyond the subaerial extent of the delta (Kindinger and others, 1982). As the delta complex expanded, distributary channel and interdistributary marsh deposits advanced seaward over the previously deposited delta-front deposits that, in turn, advanced over prodelta deposits. After the delta complex was isolated from its fluvial source, these sedimentary facies became the primary source of local sediment supply as they were eroded by inner shelf waves and currents.
The Chandeleur Islands are located near the transition between the original delta plain and delta front of the St. Bernard Delta Complex, a transition that is reflected in the modern bathymetry. The bathymetry shows that the Chandeleur Islands occupy the transition between shallow delta plain now submerged under Chandeleur Sound and moderate depths offshore of the islands where delta-front and prodelta deposits accumulated (fig. 6). The mean depth west of the islands, in Chandeleur Sound, is generally less than 5 $\mathrm{m}$. Depths increase to 10-16 $\mathrm{m}$ along the northern and eastern edges of the study area. The Chandeleur Islands rest on a narrow arcuate ridge that is about $4 \mathrm{~km}$ wide and rises about $4 \mathrm{~m}$ above the floor of Chandeleur Sound. The northernmost extent of the island chain is bounded by Hewes Point Shoal, a large sand deposit that extends northward from the islands into deeper water. Along the seaward side of the islands the sea floor has a slope of 3.6-5.0 $\mathrm{m} / \mathrm{km}$ in water depths less than 8 $\mathrm{m}$, except off Hewes Point, where the slope increases to 16.7 $\mathrm{m} / \mathrm{km}$ in deeper water.

\section{Methods}

\section{Seismic Data Acquisition}

Approximately $1,250 \mathrm{~km}^{2}$ of the inner continental shelf surrounding the Chandeleur Islands were surveyed by using CHIRP seismic-reflection systems during two cruises in July 2006 and two cruises in June 2007 (fig. 2). Two cruises along the eastern (seaward) side of the island chain were conducted aboard the Louisiana Universities Marine Consortium vessel

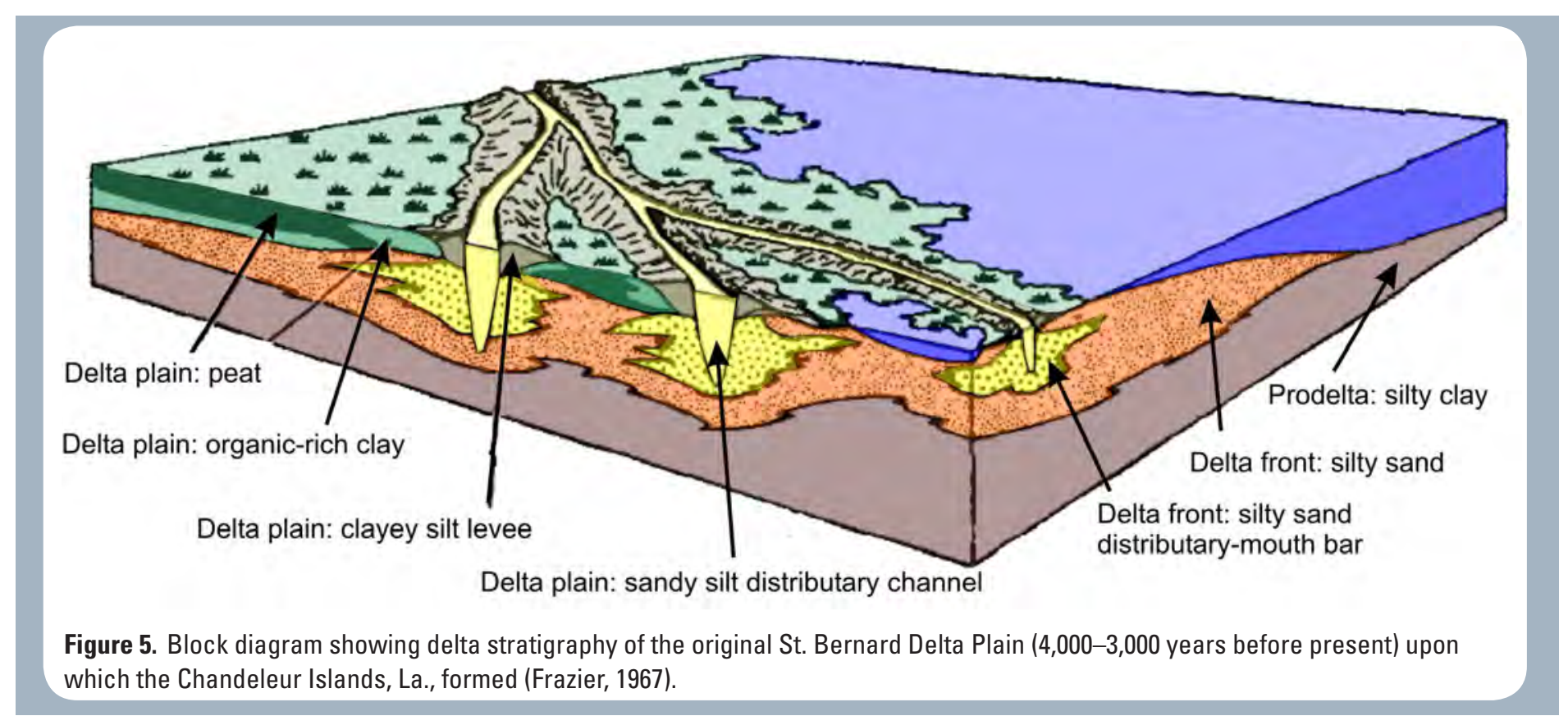




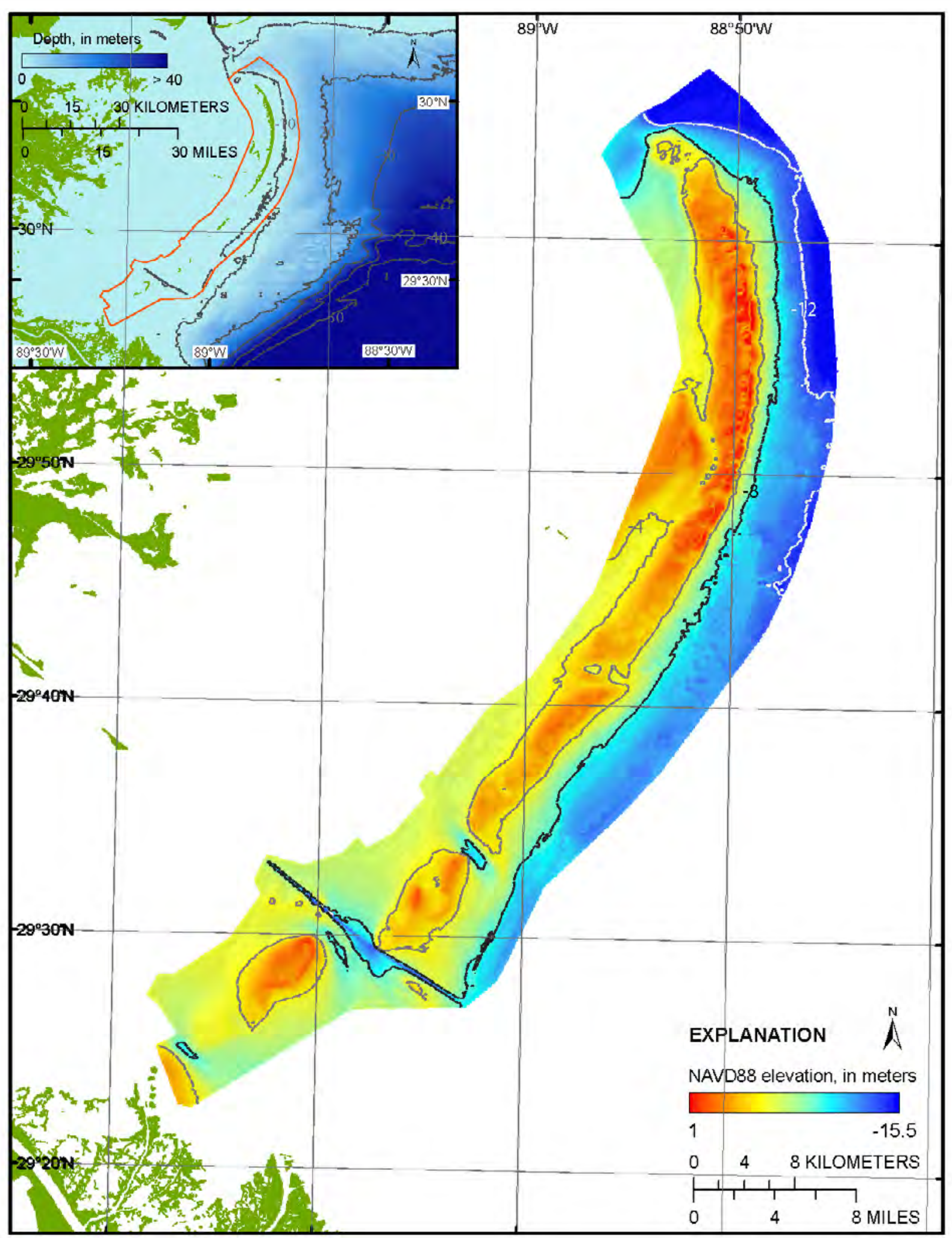

Figure 6. Interpolated bathymetry and lidar topography of the study area in the Chandeleur Islands, La., for the period from 2005 to 2007. Inset map shows the regional bathymetry along the eastern side of the Mississippi River Delta. The 2002 shoreline is shown on the inset map and in the background in solid green for reference. NAVD 88, North American Vertical Datum of 1988. 
$R / V$ Acadiana. Two cruises along the western (shoreward) side of the islands were conducted aboard the USGS vessel $R / V$ Gilbert. Aboard the $R / V$ Acadiana, data were collected in the area extending from $1-2 \mathrm{~km}$ seaward of the islands to $5-8 \mathrm{~km}$ offshore. Survey lines were spaced approximately $100-150$ $\mathrm{m}$ apart in the shore-parallel direction and about $1 \mathrm{~km}$ apart in the shore-perpendicular direction. Aboard the $R / V$ Gilbert, seismic data were collected along the back side of the islands extending from $1-3 \mathrm{~km}$ to $5-15 \mathrm{~km}$ shoreward of the islands. Survey lines were spaced approximately $1 \mathrm{~km}$ apart in the shore-parallel direction, and shore-perpendicular lines spaced about $750 \mathrm{~m}$ apart were concentrated at the northern end, the middle part, and the southern end of the island chain. Data were collected immediately seaward of the northern part of the islands from the $R / V$ Gilbert as well because its shallower draft allowed surveying closer to shore than was possible with the $R / V$ Acadiana. Positions of the ships and geophysical data were determined by using Differential Global Positioning System (DGPS) navigation. During acquisition, both vessels maintained speeds between 1.5 and $2.5 \mathrm{~m} / \mathrm{s}$.

In total, $3,550 \mathrm{~km}$ of high-resolution CHIRP seismicreflection profiles were collected from the $R / V$ Acadiana by using an EdgeTech (EdgeTech Marine, West Wareham, Mass.; product information at http://www.edgetech.com/ productlinemarine.html) Geo-Star FSSB system and an SB-512i tow vehicle (0.5-12 kHz) (fig. 7). During July 2006, 1,895 km of CHIRP seismic-reflection data were collected off the northern part of the island chain by using Triton SB-Logger acquisition software (Triton Imaging, Inc., Watsonville, Calif.; product information at http://www. tritonimaginginc.com/site/content/products/sblogger/) to control the Geo-Star topside unit and digitally log trace data in the SEG Y rev 1 standard format (Norris and Faichney, 2002). Data were acquired by using a $0.25 \mathrm{~s}$ shot rate, a $20 \mathrm{~ms}$ pulse length, and a $0.7-12 \mathrm{kHz}$ swept frequency. During June 2007, slightly less data $(1,655 \mathrm{~km})$ were collected off the southern part of the island chain because of system malfunctions caused by rough sea state. EdgeTech J-Star acquisition software was used to control the Geo-Star topside unit and digitally log trace data in the EdgeTech JSF file format. Data were acquired by using a $0.25 \mathrm{~s}$ shot rate, a $5 \mathrm{~ms}$ pulse length, and a $0.5-8 \mathrm{kHz}$ swept frequency.

Nearshore, the $R / V$ Gilbert was used to acquire subbottom data. In total, $900 \mathrm{~km}$ of high-resolution CHIRP seismic-reflection profiles were collected from the $R / V$ Gilbert in 2006 and 2007. An EdgeTech X-Star system was used with an SB-424 towfish (4-24 kHz) in July 2006 and an SB-512i towfish $(0.5-12 \mathrm{kHz})$ in June 2007 . Both systems used a shot rate of $4 \mathrm{~Hz}(250 \mathrm{~ms})$. During both cruises, Triton SB-Logger acquisition software was used to control the topside unit and digitally log trace data in the SEG Y rev 1 standard format (Norris and Faichney, 2002), and a CodaOctopus F190 motion sensor (Coda Octopus Products Limited, U.K., product information at http://www.codaoctopus.com/company/privacy. asp) was used to record the heave, pitch, and roll of the vessel.

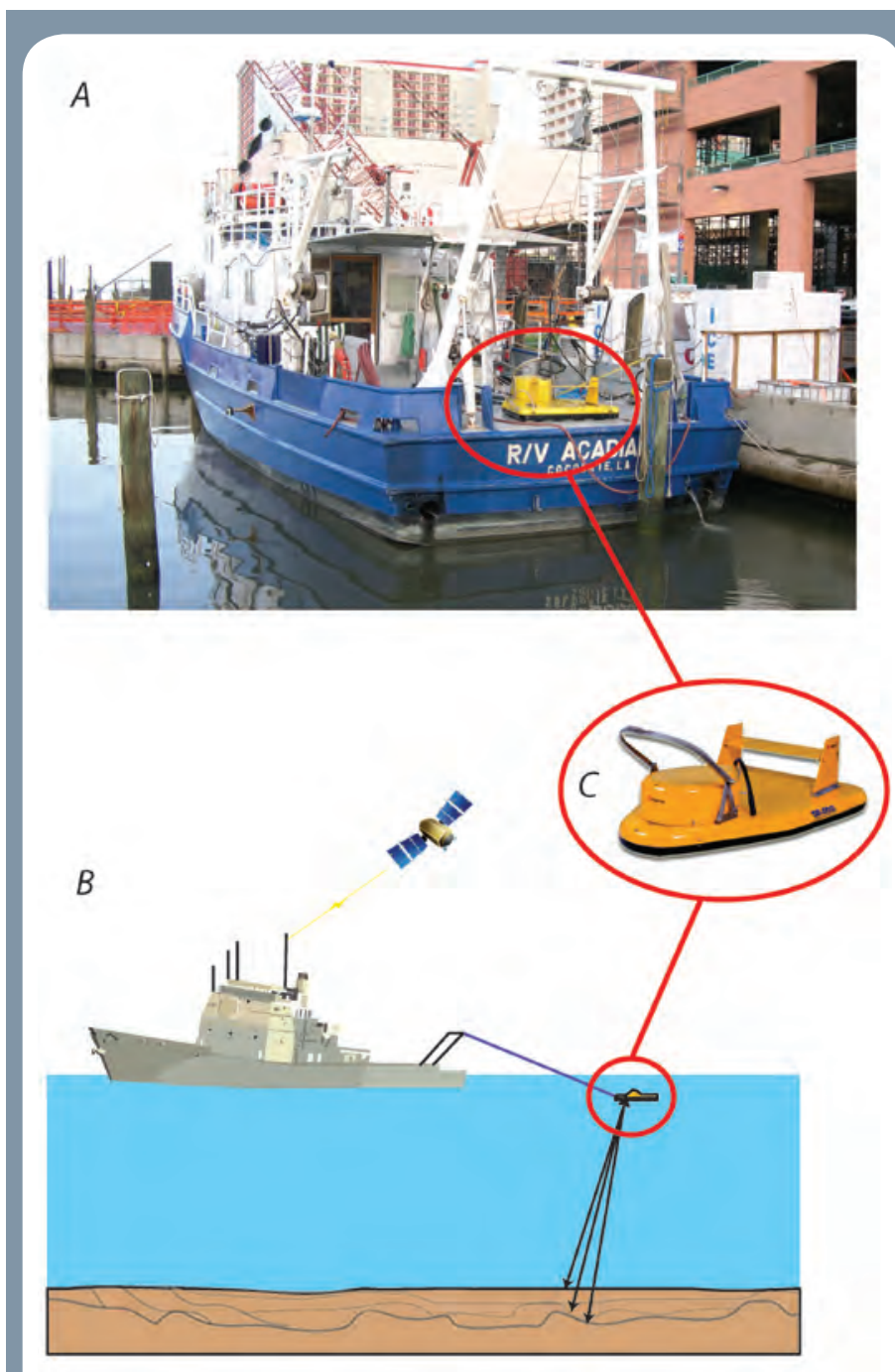

Figure 7. Equipment used to collect the high-resolution CHIRP seismic-reflection profiles for this study. $A$, CHIRP subbottom profiler on the after deck of the $R / V$ Acadiana. $B$, Schematic showing deployment of the tow vehichle astern of the vessel. C, An EdgeTech product detail photograph of the SB-512i tow vehicle.

\section{Seismic-Reflection Data Processing and Interpretation}

Postacquisition processing of the CHIRP seismicreflection data was conducted by using a suite of software including SIOSEIS (SIOSEIS, 2007), Seismic Unix (Stockwell and Cohen, 2007), and SeisWorks 2D v. R2003.12.0 (a twodimensional, digital seismic interpretation software package; Halliburton Energy Services, Inc., Houston, Tex.; product information at http://www.halliburton.com/ps/default.aspx?p ageid $=875 \&$ navid $=220 \&$ prodid $=P R N:: 11026259745705)$. A SIOSEIS script was used to vertically shift traces to account for towfish depth beneath the sea surface. A second SIOSEIS 
script was used to predict the vertical location of the sea floor by identifying peak amplitudes within a vertical window. Twoway travel times (in milliseconds) to the sea floor at each trace were recorded to an American Standard Code for Information Interchange (ASCII) text file. Next, all SEG Y trace data were imported into SeisWorks 2D, and sea floor values were imported as SeisWorks horizon data. Spurious sea floor values were edited for discrete traces through manual digitization of the SeisWorks horizon, and corrected values were exported to a new ASCII text file. SIOSEIS was also utilized to remove sea surface heave and mute water column portions of the traces by (1) loading the corrected sea floor times into the SEG Y trace headers; (2) smoothing the sea floor picks by using an along-track filter that approximates twice the period of sea surface heave to be removed; (3) creating a series of difference values between the raw and smoothed sea floor picks for each trace; (4) shifting traces up or down according to the difference values; and (5) muting each trace between time zero and the time of the smoothed sea floor pick, thus removing acoustic noise within the water column. Changes to the traces within each profile were saved to new "heave-corrected" SEG Y files and were used to interpret and map the different seismic facies. A full description of the processing steps and Joint Photographic Experts Group (JPEG) images of all of the seismic profiles collected from the $R / V$ Acadiana are given in Baldwin and others (2008) and are included in appendix 5.

The geologic interpretation and resource distribution mapping of the CHIRP seismic-reflection data were conducted in SeisWorks 2D, ArcGIS (Environmental Systems Research Institute, Inc., Redlands, Calif.; product information at http:// www.esri.com/), the Generic Mapping Tools (GMT; product information at http://gmt.soest.hawaii.edu/), and MatLab (The MathWorks, Inc., Natick, Mass.; product information at http://www.mathworks.com/). Horizons were digitized in SeisWorks 2D by tracing reflectors on heave-corrected seismic profiles for three primary facies: an acoustically transparent unit interpreted to be the barrier lithosome, an acoustically laminated unit interpreted to be delta-front and prodelta deposits, and a unit with steeply dipping reflections that was interpreted to be distributary channels. A surficial geologic map was created by digitizing the surficial exposure of the three facies on the seismic profiles (fig. 8). The digitized line segments for each of the three facies on all of the seismic profiles were converted to an ASCII text file (x,y recorded every 20 shots) and then exported from SeisWorks $2 \mathrm{D}$ for the generation of ArcGIS shapefiles. In ArcGIS, a polygon was drawn around the line segments to represent, in map view, the extent of each of the three facies (fig. 8A).
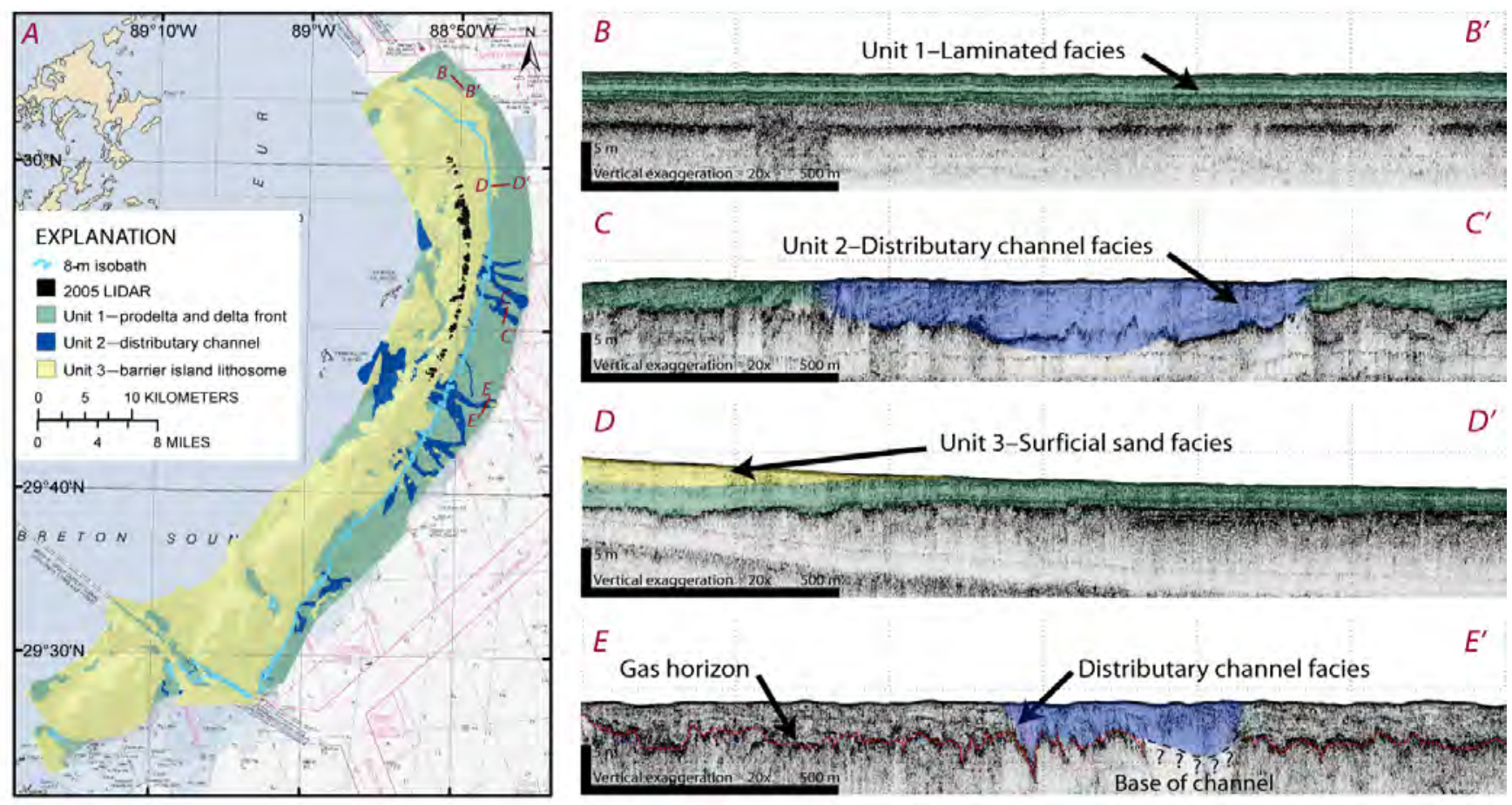

C

Unit 2-Distributary channel facies

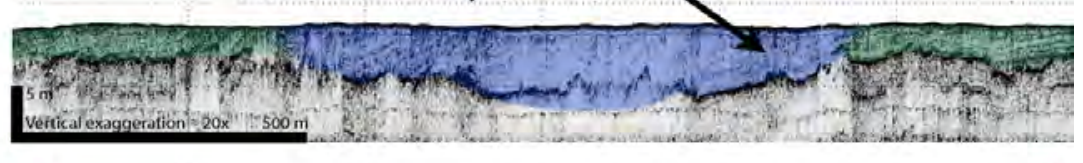

D

Unit 3-Surficial sand facies

$D^{\prime}$

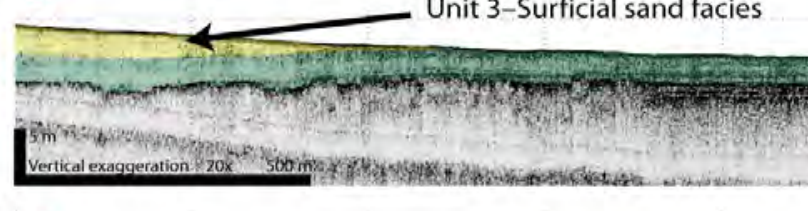

E

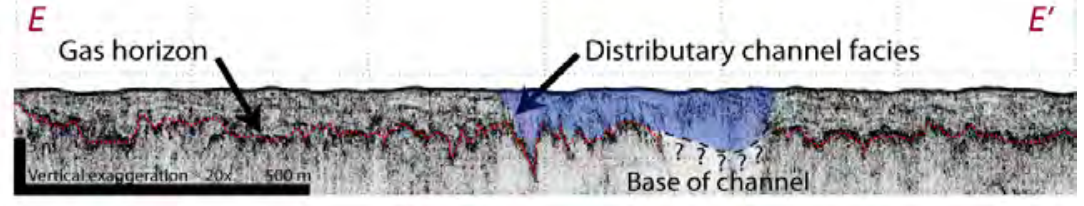

Figure 8. Surficial geologic map created by digitizing the surficial exposure of the three facies on the seismic profiles. $A$, The distribution of three different acoustic facies that are exposed on the sea floor surrounding the Chandeleur Islands, La. $B$, Example of the acoustically laminated prodelta and delta-front facies. $C$, Example of the acoustically transparent surficial sand facies. $D$, Example of the distributary channel facies with its steeply dipping reflections. E, Example of the irregular high-amplitude reflection that is interpreted to be gas in the sediment that blanks the acoustic signal. 
Horizons digitized in SeisWorks were exported as $\mathrm{x}, \mathrm{y}, \mathrm{z}$ files (where $\mathrm{z}$ is the depth in milliseconds to the base of a sediment unit). These $x, y, z$ files were then used to generate ArcGIS shapefiles or grids (100- to 200-m resolution). Twoway travel times (in milliseconds) measured from the seismic profiles were converted to depths (in meters) by assuming a constant sound velocity of $1,500 \mathrm{~m} / \mathrm{s}$ through seawater and sediment (Chen and Millero, 1977). Total sediment volumes were calculated from sediment thickness grids in MatLab.

One challenge encountered in the seismic interpretation was the presence of gas in the shallow subsurface. Gas horizons are known to saturate the seismic signal and obscure underlying strata (fig. 8E). A discontinuous gas layer, generally occurring at depths greater than $3 \mathrm{~m}$ below the sea floor, was present throughout much of the study area. Distributary channel deposits commonly appeared to extend below this gas horizon, but the bases of the deposits were commonly obscured. Core logs were also inconclusive in identifying the base of distributary deposits. To address this gas-induced uncertainty, we chose to map the volume of these deposits in two ways. First, a distributary channel volume was estimated by creating a surface of the "base of channel" horizon, which was digitized along the base of channel deposits, where they were readily identifiable, and along the top of the gas layer, where the channel base was obscured (fig. $8 E$ ). Second, a minimum volume of distributary channel sediment, which assumed a constant sediment thickness of $2 \mathrm{~m}$ within distributary channel extents, was also reported (table 1).

\section{Vibracore Collection and Analysis}

Once potential sand deposits were identified on the high-resolution seismic data, sediment cores were collected to confirm the nature of the deposits identified on the seismic data and provide samples for textural analysis (fig. 2). An effective means of quickly collecting sediment samples in shallow sandy environments is vibracoring, which utilizes a vibrating head to push a core barrel into the sediment. This technique preserves the sedimentary structures necessary for accurate interpretation of depositional environments and verification of sand resources. A complete description of the vibracoring systems used to collect sediment samples for this study is given in chapter F. Correlation between seismicreflection profile interpretations and sediment core results allows sand resources to be mapped between and beyond individual core sites.

A total of 124 cores were collected during June 2007: 91 from the $R / V$ Gilbert and 33 from the University of New Orleans (UNO) vessel $R / V$ Greenhead. An additional 20 cores from a regional coring study conducted in 1987 (Brooks and others, 1995) that overlapped with our study area were used in this analysis. The vibracoring systems used in 2007 were capable of handling aluminum barrels with a diameter of 7.6 $\mathrm{cm}$ and lengths of up to $6.1 \mathrm{~m}$. Upon recovery, the cores were cut into 2-m lengths. Core locations were logged by DGPS, and water depth was measured by echo sounder.

Personnel from the UNO Pontchartrain Institute for Environmental Sciences Coastal Research Laboratory analyzed the vibracores. The procedure began with splitting each vibracore in half lengthwise. One half was then visually described by using standard sediment logging methods, and the other half was sampled for textural analysis. Samples were taken from the different sedimentary units identified in each core and from the tops and bases of sand-rich intervals to allow for more effective textural classification. Between 4 and 11 texture samples were analyzed for sediment grain size from each core (average of 7 analyses per core). Each vibracore $\log$ includes a description of sediment texture, sedimentary structures, qualitative measure of sand percentage, physical characteristics, stratification type, sample location, and sample type. Analysis of the core data is presented in chapter F. Core description sheets were scanned and saved as Adobe Portable Document Format (PDF) files for digital access and are included in appendix 6. Original hardcopy description sheets are archived at the UNO Department of Earth and Environmental Sciences, and the split core sections were wrapped in plastic and stored at the UNO core storage warehouse.

\section{Fusion of Seismic-Reflection and Vibracore Data}

The dense network of seismic-reflection data was ideal for generation of sediment thickness maps (isopach maps) in the backbarrier and seaward side of the Chandeleur Islands; however, few profiles were collected in and around the islands in areas that were too narrow and shallow (water depths less than $2.5 \mathrm{~m}$ ) to safely navigate the survey vessels while towing geophysical equipment (fig. 2). To create continuous grids and maps covering the seaward to backbarrier extent of the study area, core log data were used to supplement the seismic data. In some locations cores provide only a minimum sediment thickness because the maximum retrievable vibracore $(6 \mathrm{~m}$ in length) was shorter than the thickness of the sedimentary unit being mapped. Elevations at the base of the barrier island lithosome and distributary channel deposits interpreted from the seismic-reflection and core data were merged into two $\mathrm{x}, \mathrm{y}, \mathrm{z}$ files. A GMT gridding routine was used to create two elevation surfaces that passed through all point data in each file. Quality control consisted of identifying and removing spurious points that produced "bull's-eye" anomalies in the surface grids. The workflow for generating isopach maps (see fig. 9) was as follows:

6. Digitize "base of facies" horizon in SeisWorks 2D. 


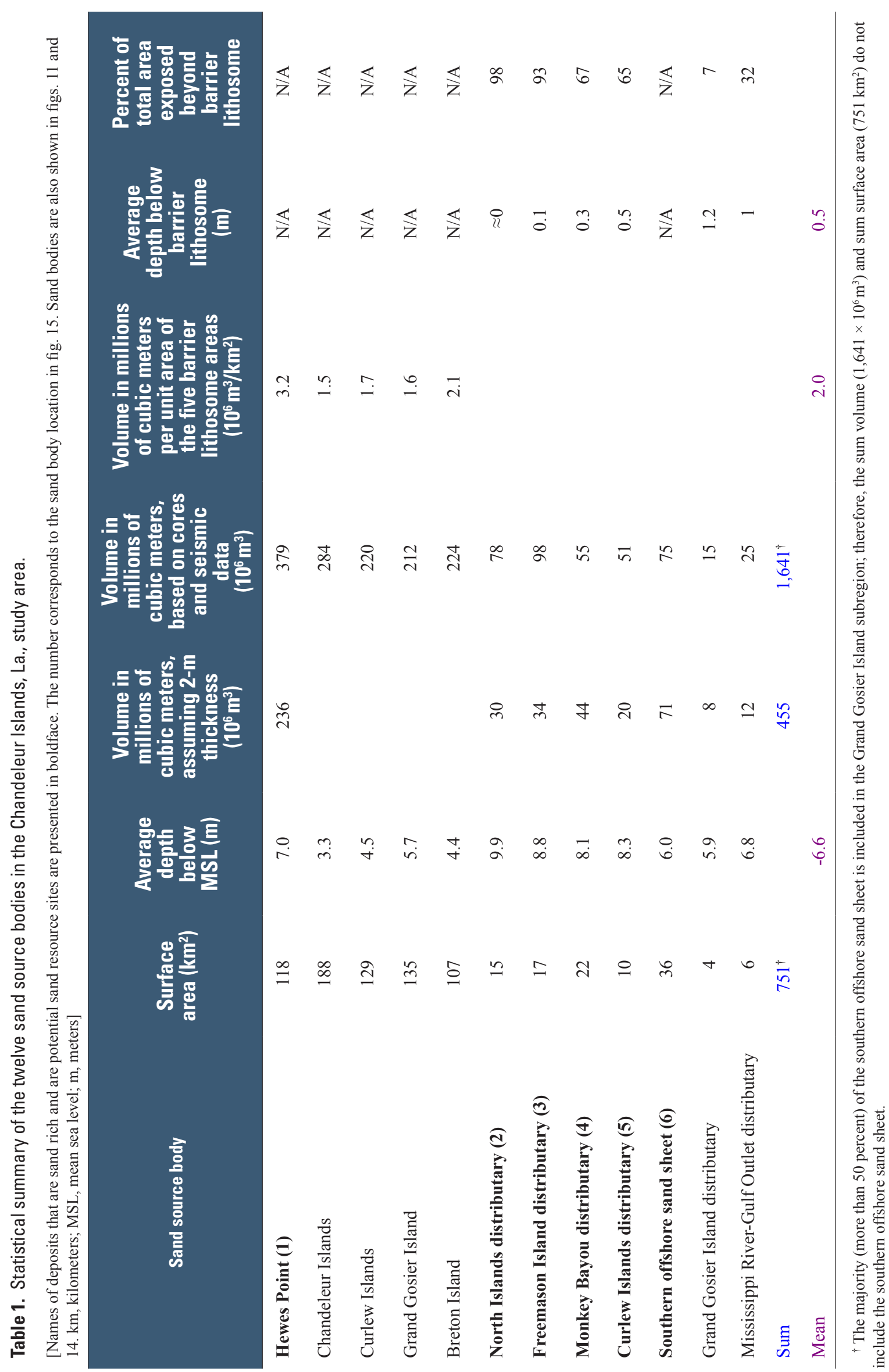




\section{Workflow for creating isopach maps}

1.Digitize "base of facies" horizon in SeisWorks 2D

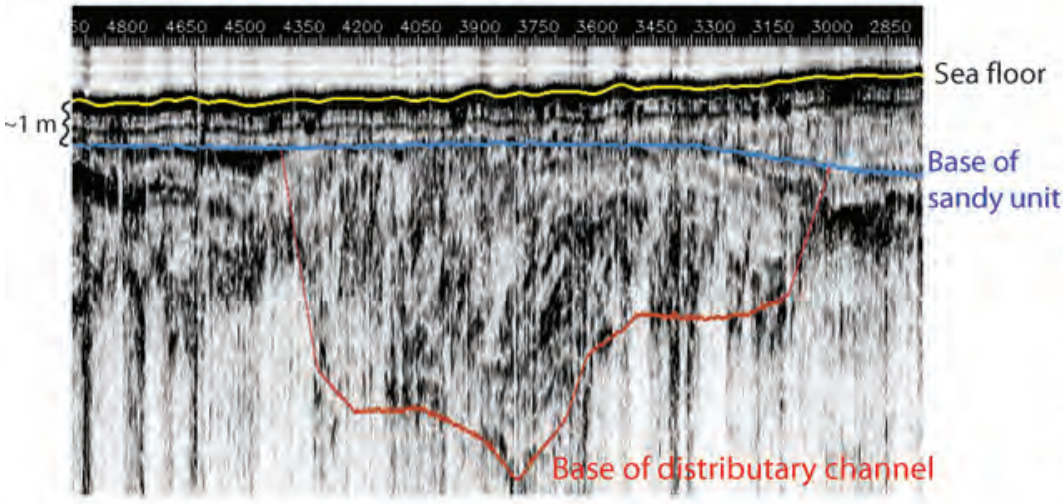

2. Identify "base of facies" on core logs

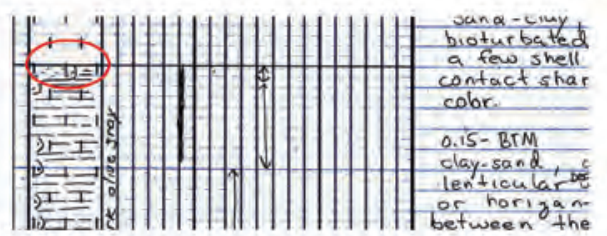

3. Export "base of facies"'to $x, y, z$ file $-88.834716666929 .9809670002-2.30999994278$ $-88.841266668929 .9793329978-2.49000000954$ $-88.881033330729 .7704329961-4.09000015259$ $-88.870749998729 .7789330021-4.46999979019$ $-88.854766668629 .8260829956-4.03000020981$ $-88.851949998729 .8266829968-3.43000006676$

\section{Merge core and} seismic"base of facies"

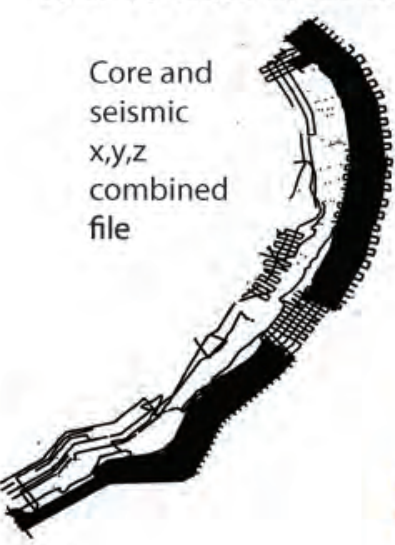

5. Create a continuous "base of facies" surface

\section{Subtract "base of facies" surface from modern bathymetry to create isopach map}

Modern bathymetric surface (used to derive isopach by subracting the base of barrier lithosome)

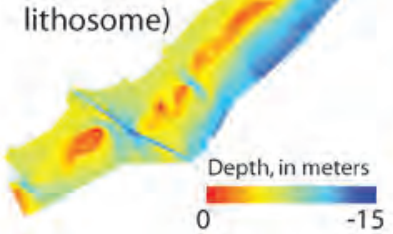

Barrier lithosome isopach (sediment thickness

map)

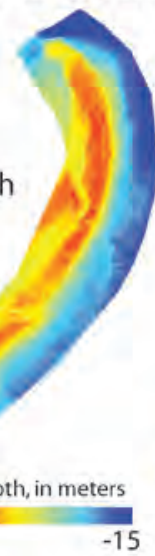

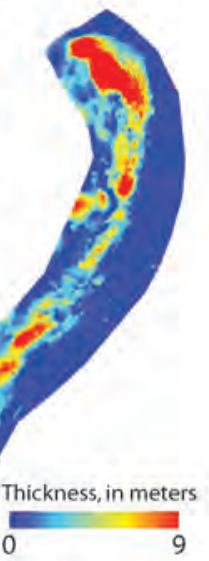

Figure 9. Data processing flow diagram showing the steps from interpreting a seismic profile to creating an isopach map. GMT, Generic Mapping Tools.

7. Identify "base of facies" on descriptive core logs.

8. Export horizon to $\mathrm{x}, \mathrm{y}, \mathrm{z}$ point file.

9. Merge core and seismic "base of facies" files.

10. Create a continuous "base of facies" surface by using GMT.

11. Subtract "base of facies" surface from modern bathymetry surface to create isopach (sediment thickness) map.

It is important to stress that these estimates, which are based on seismic profiles and core descriptions, are of the total sediment volume, not solely the volume of sand-sized sediment. Chapter F reports more precise estimates of sand- sized sediment availability that incorporate results from the sediment sample grain-size analyses.

\section{Results}

We focused primarily on the barrier island lithosome and the distributary channel deposits offshore of the islands as potential sand sources because these were the two sedimentary facies with the highest sand content. Sand resource sites shoreward of the islands were not assessed as this area is the platform that the islands would retreat over if they were to migrate shoreward. 


\section{Shallow Stratigraphy}

Seismic-reflection profiles and vibracore data show the stratigraphy of the uppermost part of the St. Bernard Delta Complex and the overlying barrier island lithosome. Three acoustic facies were identified on the seismic profiles: Unit 1 , nearly flat-lying moderate-to-high-amplitude continuous closely spaced reflections (fig. 8B); Unit 2, steeply dipping reflections commonly filling channel-shaped features (fig. $8 C$ ); and Unit 3, an acoustically transparent interval that, locally, contains short discontinuous reflections (fig. 8D). Unit 1 is exposed on the sea floor at the northern end and along the eastern side of the study area. The shoreward limit of the exposure of Unit 1 is in 4- to 5-m water depth in the central part of the study area and exceeds $12 \mathrm{~m}$ at the northern and southern limits of the study (fig. $8 A$ ). Unit 2 is incised into Unit 1 and is younger. Unit 3 is the youngest of the three units and overlies parts of the two older units.

Core data show that the three acoustic facies coincide with distinctive lithologic facies. Core sections that intersected Unit 1 recovered two facies: clay with scattered thin silt laminations and silty clay with thin sand laminations. The clay facies is consistent with prodelta deposits described by Fisk and others (1954) and Frazier (1967). Cores show that it crops out in deeper water at the northern end and along the eastern edge of the study area. The silty clay sections that contain thin sand beds are consistent with delta-front deposits (fig. 4) and are exposed on the sea floor offshore of the Chandeleur Islands in water depths of 5-12 m. These sedimentary facies could not be differentiated seismically and, for this reason, have been combined into one unit. Unit 2 displays channellike shapes in seismic profiles (fig. 8C) and a bifurcating nature in map view (fig. 8A). These morphological properties, and the higher sand content relative to delta-front and prodelta units (chap. F), indicate that Unit 2 represents distributary channel deposits. Unit 3 consists of sand and silty sand. This unit overlies the deltaic facies and is interpreted to be the barrier island lithosome (fig. 8D). Some of the discontinuous reflections seen in this unit are channel shaped. These shallow channels rarely can be traced from one seismic line to the next, and their discontinuous nature suggests that they are filled tidal inlet channels.

\section{Barrier Island Lithosome}

The thickness, distribution, and volume of the barrier island lithosome (Unit 3) have been mapped throughout the study area. This sediment body extends from the northern tip of Hewes Point to the southern end of the platform beneath Breton Island (fig. 10). The total volume of the barrier island lithosome is approximately $1,600 \times 10^{6} \mathrm{~m}^{3}$. It has been divided into five sections to provide a clearer understanding of sediment distribution within the study area. From north to south, these five sections were named "Hewes Point," "Chandeleur Islands," "Curlew Islands," "Grand Gosier Island," and "Breton Island" (fig. 11). The surface areas of each section and the volume of sediment that each contains are summarized in table 1 . The Hewes Point section contains the largest volume of sediment $\left(379 \times 10^{6} \mathrm{~m}^{3}\right)$, has the largest volume per unit area $\left(3.2 \times 10^{6} \mathrm{~m}^{3} / \mathrm{km}^{2}\right)$, and is the thickest part of the barrier island lithosome (maximum thickness of 8.9 $\mathrm{m})$. The profile in figure 12 shows the thickness of the Hewes Point deposit and illustrates how it has prograded northward over delta-front and prodelta deposits. The Chandeleur Islands section covers the largest area and contains the second largest volume of sediment $\left(284 \times 10^{6} \mathrm{~m}^{3}\right)$, but it has the smallest volume per unit area $\left(1.5 \times 10^{6} \mathrm{~m}^{3} / \mathrm{km}^{2}\right)$. It also is the narrowest section of the barrier island lithosome $(1.5-4.2 \mathrm{~km}$ wide) and, like the three sections to the south (Curlew Islands, Grand Gosier Island, and Breton Island sections), has a maximum thickness that does not exceed $5.5 \mathrm{~m}$. Large parts of this section are less than $3 \mathrm{~m}$ in thickness (fig. 11). The Curlew Islands section is slightly broader than the Chandeleur Islands section (3.7-5.2 km wide), has a similar maximum thickness $(5.2 \mathrm{~m})$, and has a larger volume per unit area $\left(1.7 \times 10^{6} \mathrm{~m}^{3} /\right.$ $\mathrm{km}^{2}$ ). The Curlew Islands and Grand Gosier Island sections are separated by an erosional channel that exceeds $9 \mathrm{~m}$ in depth. The Grand Gosier Island section is $7-12 \mathrm{~km}$ wide, covers the smallest area of the five sections, reaches $5.4 \mathrm{~m}$ in thickness, and has the smallest volume of the five sections. The Breton Island section is separated from the Grand Gosier Island section by a broad erosional depression that was dredged to accommodate the Mississippi River-Gulf Outlet (MRGO) channel. This section also reaches a maximum thickness of about $5.5 \mathrm{~m}$, but it is broader than the Chandeleur Islands and Curlew Islands sections (5.2-7.6 km wide) and has the second largest volume per unit area $\left(2.1 \times 10^{6} \mathrm{~m}^{3} / \mathrm{km}^{2}\right)$.

In summary, nearly 40 percent of the sediment in the barrier island lithosome is contained in the two end sections (Hewes Point and Breton Island), while the narrower middle sections (Chandeleur Islands and Curlew Islands) have similar volumes but cover much larger areas and consequently have the smallest volumes per unit area (fig. 11). The southern four sections are all fairly uniform in thickness (less than $5.5 \mathrm{~m}$ ), while the Hewes Point section is considerably thicker (table 1) because it, unlike the other sections, does not sit on the top of the St. Bernard Delta platform. Instead, the Hewes Point section has prograded northward over the edge of the delta platform accumulating on top of delta-front and prodelta deposits in deeper water (figs. $4 E, 12$, and 13). The deeper water provides accommodation space for this narrow northtrending spit. By contrast, the large volume of sediment at the southern end of the lithosome in the Breton Island and Grand Gosier Island sections is deposited in shallow water and thus is thin and has a sheetlike appearance (fig. 13). 


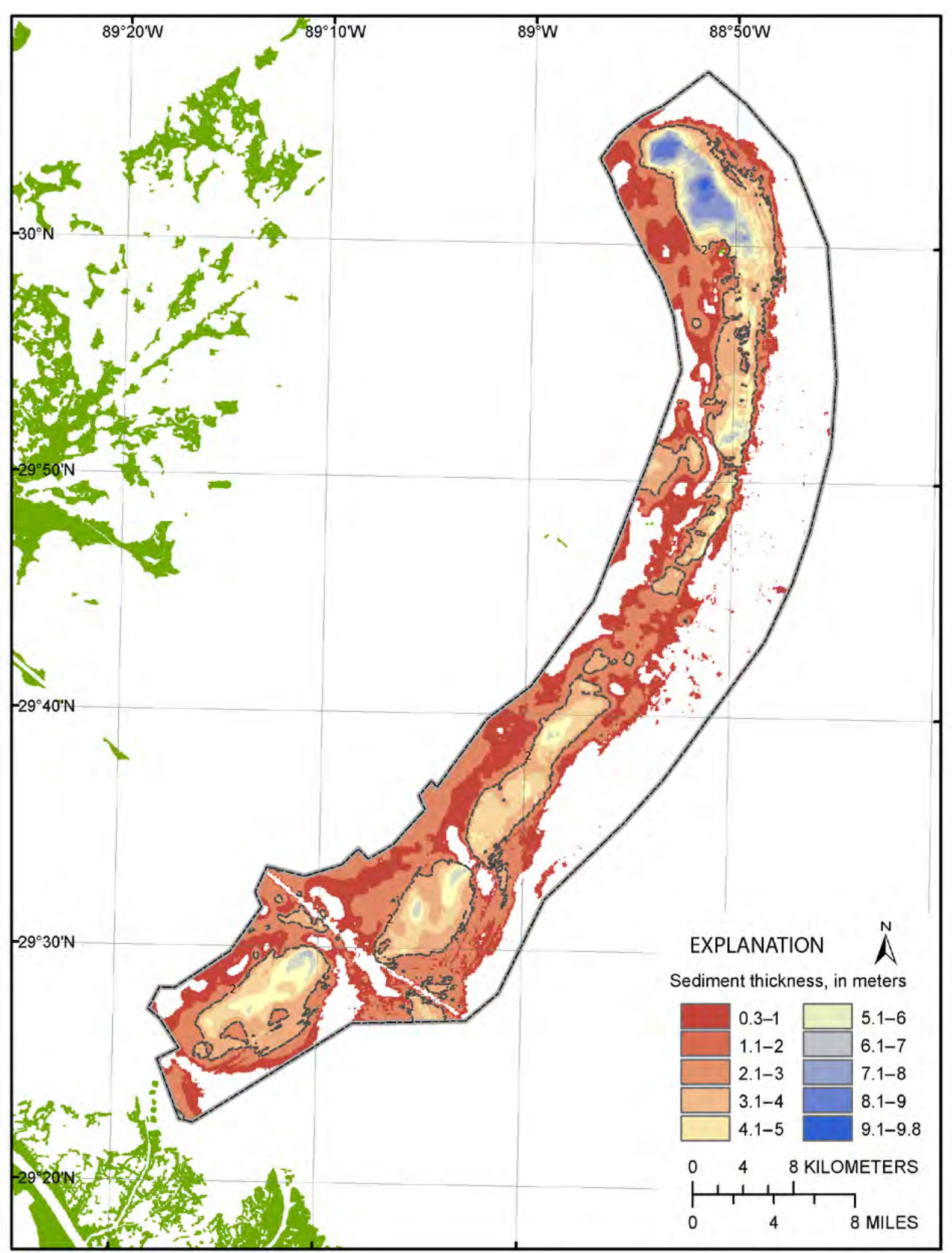

Figure 10. Barrier island lithosome isopach map of the Chandeleur Islands, La. The 2002 shoreline, exclusive of the Chandeleur Islands, is shown in the background for reference. The gray outline shows the extent of the study area. 


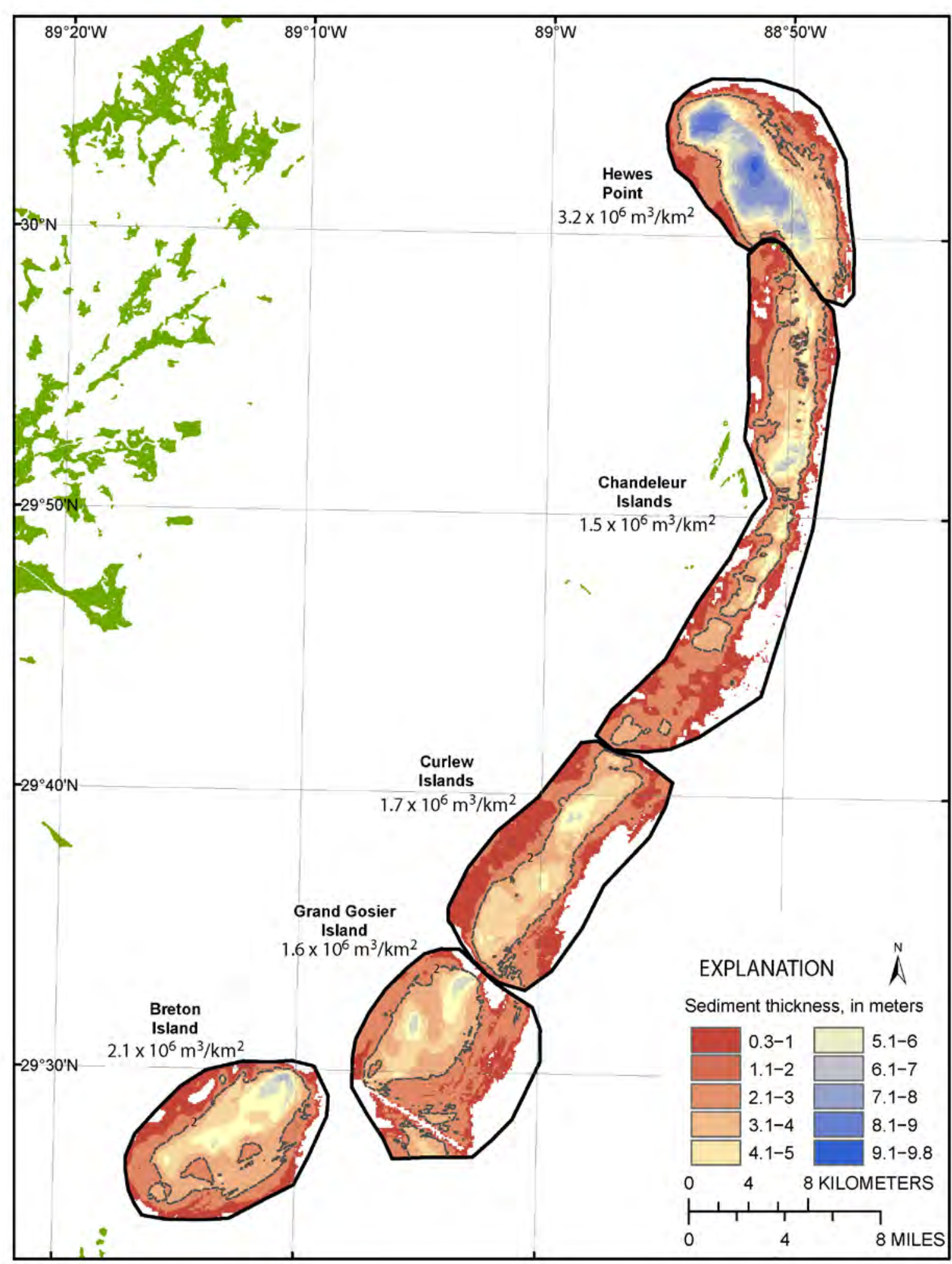

Figure 11. Barrier island lithosome isopach map of the Chandeleur Islands, La. (same as fig. 10), with the five subareas outlined. The 2002 shoreline, exclusive of the Chandeleur Islands, is shown in the background for reference. Volume of sediment in each of the barrier island regions is listed in table 1. Volume per unit area is shown adjacent to each subarea. The gray outline shows the extent of the study area. 


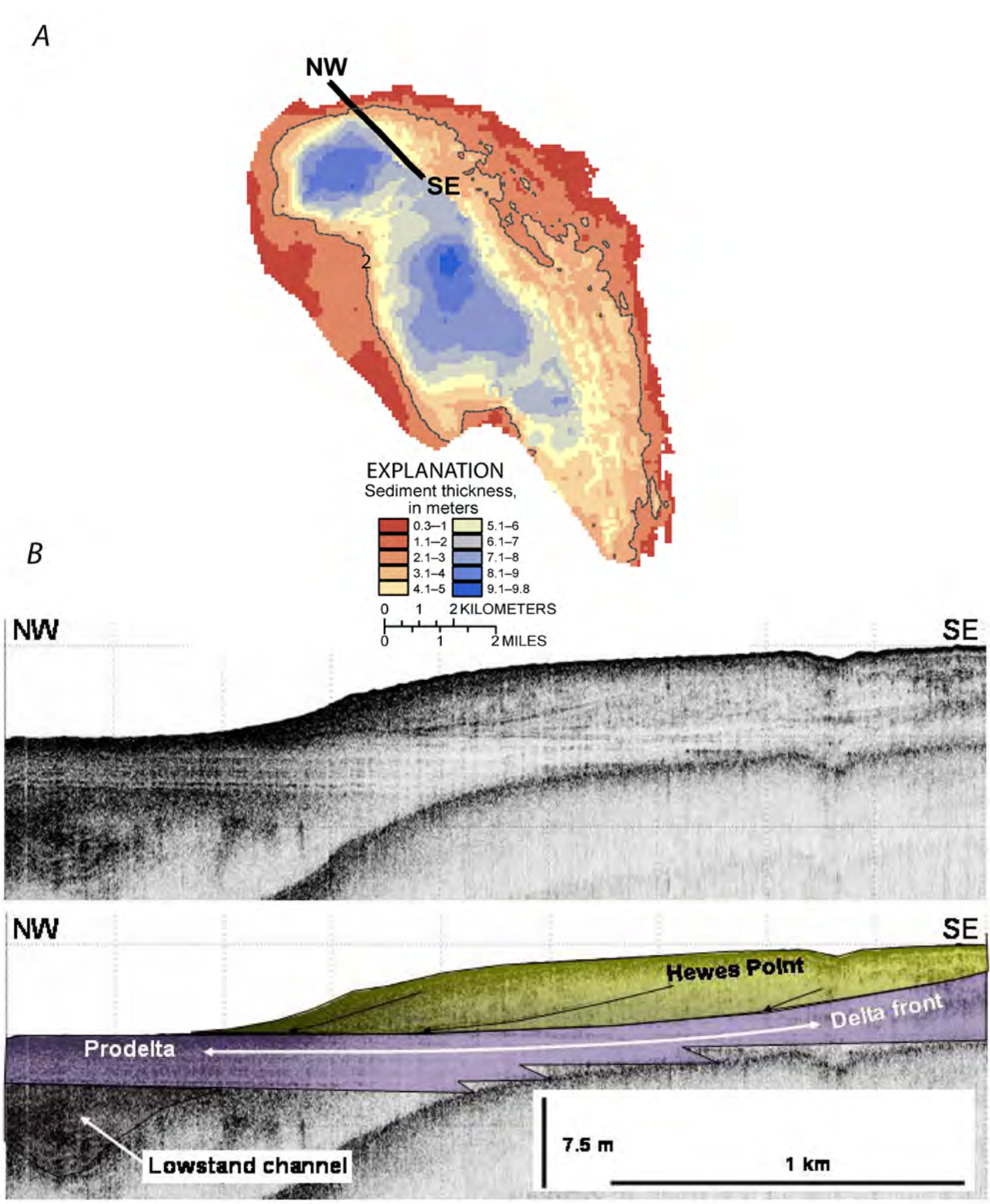

Figure 12. Seismic profiles across the Hewes Point section in the study area of the Chandeleur Islands, La. $A$, Isopach map showing the thickness of the Hewes Point deposit and the location of the seismic profile. B, Seismic-reflection profile showing progradation over delta-front and prodelta deposits. 


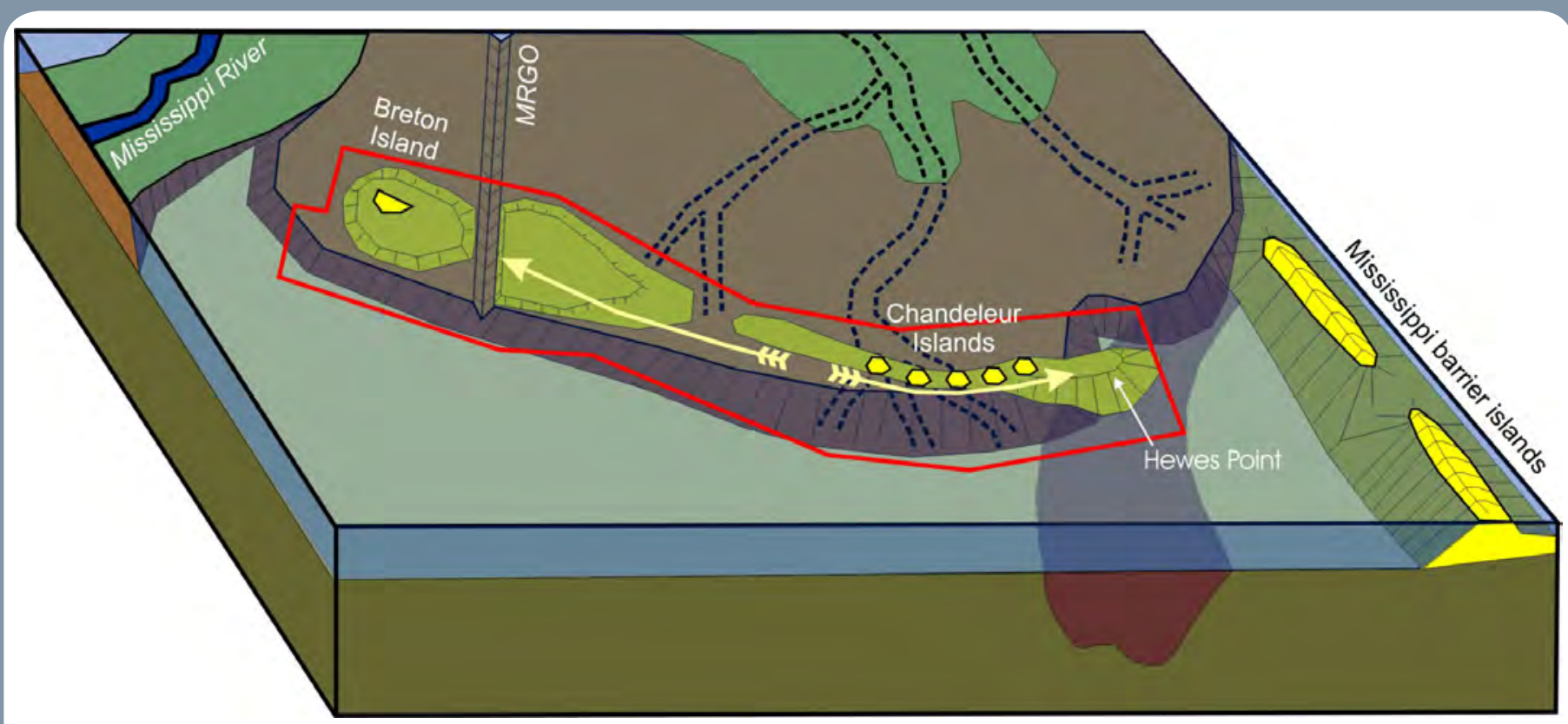

Figure 13. Illustrative diagram showing the distribution of sediment in the lithosome of the Chandeleur Islands, La., and the inferred long-term sediment transport pathways (yellow arrows) based on sediment distribution. The deposit at the northern end of the islands' transport path (Hewes Point) has accumulated beyond the edge of the original St. Bernard Delta, where water depths are deeper, and this increased accommodation space allows the deposit to be narrow but thick. The deposit at the southern end of the islands' transport path (around the Mississippi River-Gulf Outlet [MRG0]) is broad and thin because it has accumulated in shallow water on top of the St. Bernard Delta, where the lack of accommodation space resulted in a sheetlike geometry to the deposit.

\section{Potential Sand Resources off the Chandeleur Islands}

The two stratigraphic units identified in the seismicreflection profiles and cores that have the most potential to be sand resource sites are the northern and southern ends of the barrier island lithosome and the sections of the distributary channels that are exposed on the sea floor seaward of the islands (fig. 14). In total, six deposits have been identified that could contribute sediments suitable for shoreline renourishment. Two of these sites are modern deposits that developed contemporaneously or subsequent to the formation of the islands, and four are the offshore extensions of distributary channels that are associated with development of the St. Bernard Delta Complex.

\section{Modern Sand Deposits}

The two sediment bodies of the barrier island lithosome that could serve as sand resource sites are Hewes Point and the offshore part of the broad, thin sand sheet north of the MRGO in the Grand Gosier Island section of the lithosome (fig. 15). These sites lie at the northern and southern ends of the coastal transport pathways described by Ellis and Stone (2006) and appear to represent sediment that has been removed from the littoral zone and is in a setting that modern oceanographic processes can no longer rework. The total volume of sediment in Hewes Point is $379 \times 10^{6} \mathrm{~m}^{3}$, and approximately $190 \times$ $10^{6} \mathrm{~m}^{3}$ is available within $2 \mathrm{~m}$ of the sea floor. The southern offshore sand sheet near the MRGO is smaller in areal extent and thinner. Much of this deposit is only $2 \mathrm{~m}$ thick, and assuming that it has a uniform thickness of $2 \mathrm{~m}$, its total volume is $71 \times 10^{6} \mathrm{~m}^{3}$ (table 1$)$.

\section{Distributary Channel-Fill Deposits}

Distributary channels developed across the St. Bernard Delta Complex during its formation and were filled with sediment once they were abandoned. The material that fills these channels can be quite varied. Coleman (1988) reported that deeper channel fills commonly consist of poorly sorted sands and silts containing organic debris while shallower fills can contain finer grained sandy silts. Seismic-reflection profiles have been used to map the channel extents (fig. 14), but the results of core analyses reported in chapter $\mathrm{F}$ provide more detailed descriptions of the lithologies they contain.

We have estimated sediment volumes contained in six distributary channel systems of which four are exposed on the sea floor offshore of the islands and are viewed as potential 


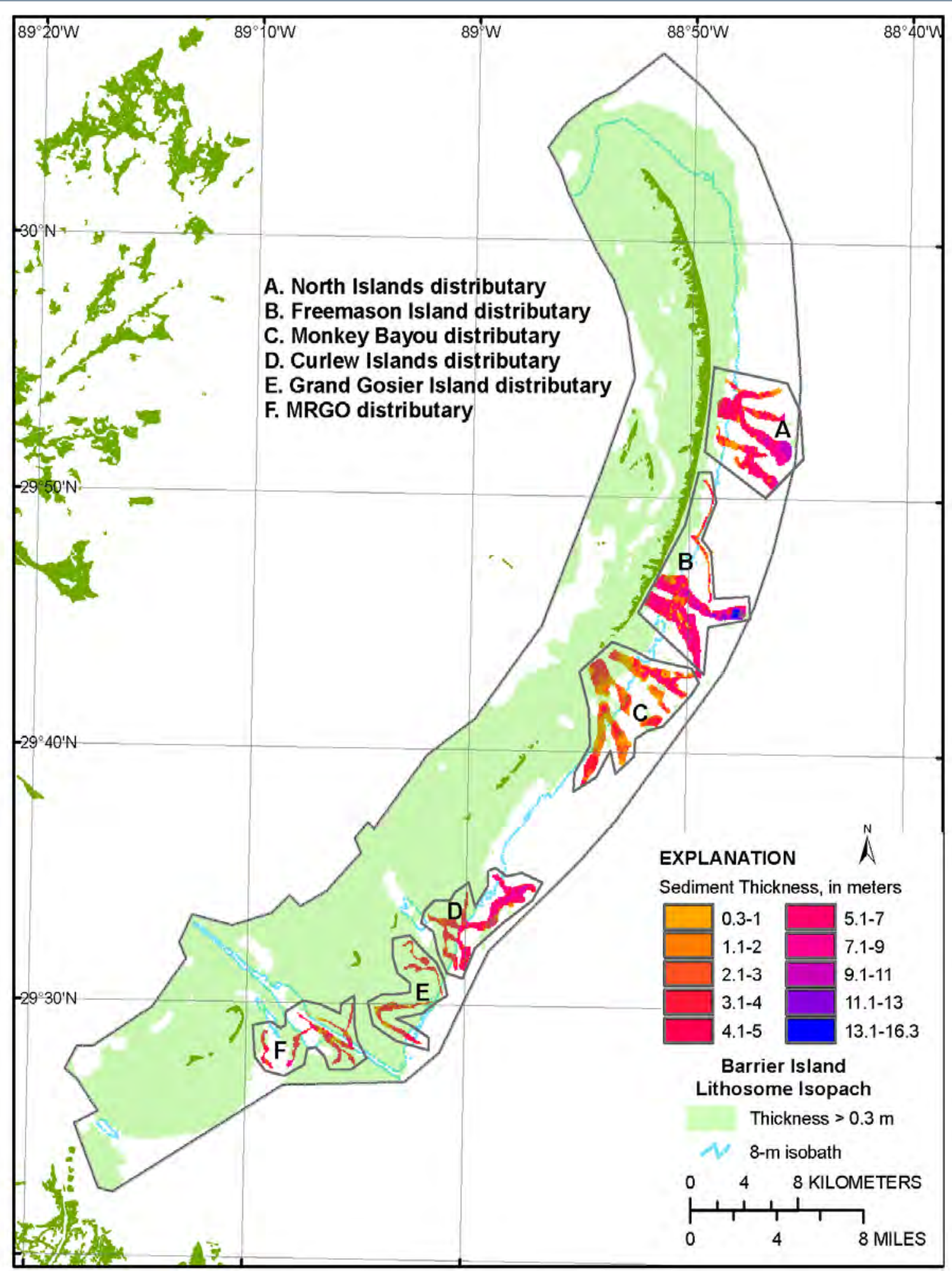

Figure 14. Isopach map of the distributary channel deposits within the Chandeleur Islands, La., study area (outlined in gray) and the subaerial extent of the barrier island lithosome (shaded in green). Note that parts of each of the distributary channel regions are buried by the barrier island lithosome. The percentage of the distributary channels exposed beyond the extent of the barrier lithosome is given in table 1 . The 2002 shoreline is shown in dark green for reference. MRG0, Mississippi River-Gulf Outlet. 


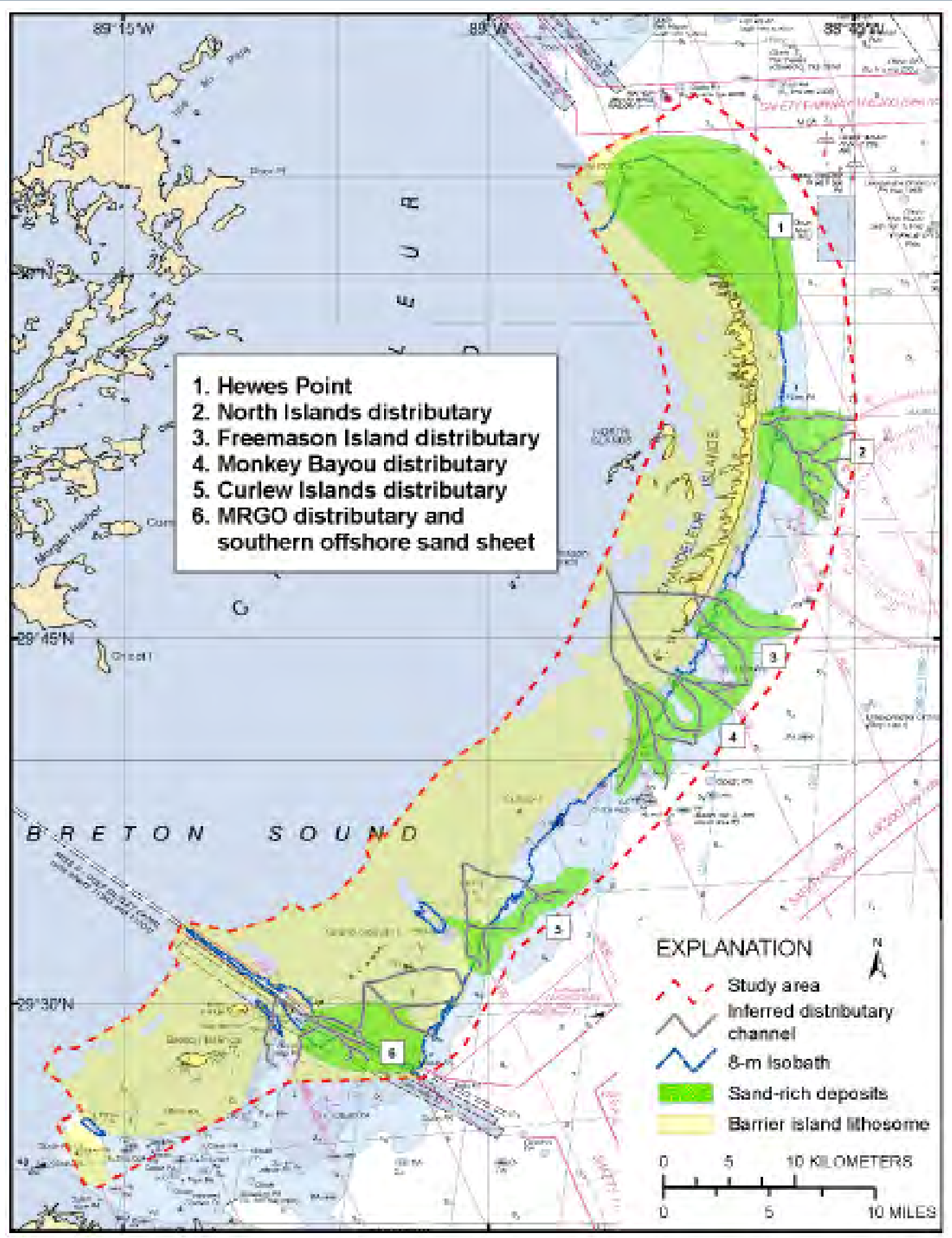

Figure 15. Potential sand-rich resource sites. Volumes of sediment in each of these six sites are given in table 1. MRG0, Mississippi River-Gulf Outlet. 
resource sites (table 1). The two other distributary channel systems (Grand Gosier Island and MRGO distributaries) are much smaller in volume (table 1) and underlie potential resource site 6 (fig. 15). These two distributary channel systems are buried by what is interpreted to be a sand deposit associated with the barrier island lithosome, and it is the overlying inferred sand sheet that is viewed as the potential resource. For much of the study area, only the uppermost 2-3 $\mathrm{m}$ of channel systems could be interpreted with confidence because their deeper fills were often masked by shallow gas (fig. 8E). Consequently, sediment volume estimates reported in table 1 are for only the upper $2 \mathrm{~m}$ of the channel fills. The volumes range from 15 to $98 \times 10^{6} \mathrm{~m}^{3}$. In contrast to the Hewes Point or the southern offshore sand sheet deposits, the extents of distributary channel sites are narrower and less continuous and consequently may be more difficult to mine (figs. 8 and 14).

\section{Discussion and Recommendations}

Analysis and interpretation of the dense network of high-resolution seismic-reflection data and integration with core log analyses have revealed six potential sand resource sites within the Chandeleur Islands study area (fig. 1). All six are surficial sites, but their sizes and geometries vary widely. Estimates of sediment volumes contained in the upper $2 \mathrm{~m}$ of each site range from as little as $20 \times 10^{6} \mathrm{~m}^{3}$ in the Curlew Islands distributary deposit to as much as $236 \times$ $10^{6} \mathrm{~m}^{3}$ in the Hewes Point deposit (table 1). In addition to variations in size, the geometry of each deposit is variable as well. The Hewes Point and southern offshore sand sheet sites are broad tabular deposits, while the four distributary sites consist of narrow bifurcating channels that are separated by adjacent fine-grained delta-front deposits (fig. 15). The Hewes Point and southern offshore sand sheet deposits account for approximately 70 percent of the total estimated sediment volume contained in the uppermost $2 \mathrm{~m}$ of the six sites (table 1). Sediment grain-size analyses show that much of the upper $2 \mathrm{~m}$ of the Hewes Point deposit contains more than 90 percent sand (chap. F). Unfortunately, no cores are available for the southern offshore sand sheet site, so its sand content remains unknown. Core logs of the distributary channel deposits show that they generally have a lower and more variable sand content. Sand content in the upper $2 \mathrm{~m}$ of seven cores collected from distributary channels averaged 53 percent with samples from each core showing a high degree of variability.

On the basis of its large size, estimated volume, and high sand content, the Hewes Point deposit represents the most promising sand resource site within the immediate vicinity of the Chandeleur Islands. Distributary channel deposits appear to be less desirable targets because they are smaller and more irregular in shape and their fills display variable grain-size distributions. The Hewes Point deposit, however, is part of the barrier island lithosome, and a full understanding of its relation to the regional sediment transport system and budget needs further study prior to committing to mining activities. Published sediment transport studies indicate a zone of divergence near Monkey Bayou at the southern end of the Chandeleur Islands, which is where the barrier island lithosome is narrowest and thinnest (Georgiou and others, 2005; Ellis and Stone, 2006). North of this divergence, net alongshore transport is directed to the north, whereas south of the divergence transport is southerly. Hewes Point extends northward beyond the northernmost extent of the Chandeleur Islands into deeper water. As such, it appears to be the depositional terminus of the alongshore transport system such that as sediment accumulates at Hewes Point in relatively deep water it may be removed from the littoral zone (fig. 13). Additional research is necessary to provide an understanding of the effects that tidal currents and storm waves from the north have on Hewes Point and whether these processes via an event-driven reversal in the dominant sediment transport direction reintroduce sediment to the littoral zone from Hewes Point. Alongshore transport to the south from the littoral divergence zone near Monkey Bayou may be responsible for the formation of the broad, thin southern offshore sand sheet immediately north of the MRGO (fig. 13). Before using this material for renourishment it will need to be sampled to determine its composition. In addition and similar to the investigation required at Hewes Point, circulation and wave modeling will be needed to determine how this shallow deposit would be redistributed by southeasterly storms.

Because of their proximity to the islands, the low sand content and the narrow and discontinuous nature of many of the distributary channel deposits, and our incomplete understanding of how the Hewes Point sand deposit may respond to dynamic oceanographic processes, it may be necessary to consider alternate sand resource sites. The St. Bernard Shoals area (fig. 1) is considerably farther away and in deeper water and thus is disconnected from the Chandeleur Islands littoral system. Consequently, removal of sediment from these offshore shoals would not affect the littoral system itself (chap. G).

\section{Acknowledgments}

We thank the captains and crews of the $R / V$ Acadiana and $R / V$ Gilbert along with USGS technicians Dana Weise, Charles Worley, Emile Bergeron, and William Danforth for their skilled assistance in the collection of this geophysical dataset. This chapter has benefited from discussions with $\mathrm{M}$. Kulp, M. Miner, S. Penland (all with UNO), J. Kindinger, D. Lavoie, A. Sallenger, and J. Williams (all with USGS). Funding was provided by the U.S. Fish and Wildlife Service, 
Louisiana Department of Natural Resources, and U.S. Geological Survey.

\section{References}

Baldwin, W.E., Pendleton, E.A., and Twichell, D.C., 2008, Geophysical data from offshore of the Chandeleur Islands, eastern Mississippi Delta: U.S. Geological Survey OpenFile Report 2008-1195, 1 DVD-ROM.

Brooks, G.R., Kindinger, J.L., Penland, S., Williams, S.J., and McBride, R.A., 1995, East Louisiana continental shelf sediments - a product of delta reworking: Journal of Coastal Research, v. 11, p. 1026-1036.

Chen, C.T., and Millero, F.J., 1977, Speed of sound in seawater at high pressures: Journal of the Acoustic Society America, v. 62, no. 5, p. 1129-1135.

Coleman, J.M., 1988, Dynamic changes and processes in the Mississippi River Delta: Geological Society of America Bulletin, v. 100, p. 999-1015.

Coleman, J.M., and Prior, D.B., 1980, Deltaic sand bodies: Tulsa, Okla., American Association of Petroleum Geologists, Continuing Education Course Note Series No. $15,171 \mathrm{p}$.

Divins, D.L., and Metzger, D., 2008, NGDC Coastal relief model, v. 4,: National Oceanic and Atmospheric Administration National Geophysical Data Center, accessed December 30, 2008, at http://www.ngdc.noaa.gov/mgg/ coastal/coastal.html.

EdgeTech, 2008, EdgeTech-sub-bottom profilers and topsides \& software: EdgeTech Web page, accessed December 30, 2008, at http://www.edgetech.com/ productlinemarine.html.

Ellis, J., and Stone, G.W., 2006, Numerical simulation of net longshore sediment transport and granulometry of surficial sediments along Chandeleur Island, Louisiana, USA: Marine Geology, v. 232, p. 115-129.

Fisk, H.N., McFarlan, E., Kolb, C.R., and Wilbert, L.J., 1954, Sedimentary framework of the modern Mississippi Delta: Journal of Sedimentary Petrology, v. 24, p. 79-99.

Frazier, D.E., 1967, Recent deltaic deposits of the Mississippi River - their development and chronology: Transactions of the Gulf Coast Association of Geological Societies, v. 27, p. 287-315.
Georgiou, I.Y., FitzGerald, D.M., and Stone, G.R., 2005, The impact of physical processes along the Louisiana coast: Journal of Coastal Research, v. 44, p. 72-89.

Halliburton, 2008, SeisWorks ${ }^{\circledR}$ 2D seismic interpretation software: Halliburton SeisWorks Web page, accessed July 16, 2008, at http:/www.halliburton.com/ps/default.aspx?pa geid=875\&navid=220\&prodid=PRN::11026259745705.

Kindinger, J.L., Miller, R.J., and Stelting, C.E., 1982, Depositional history of Louisiana-Mississippi outer continental shelf: U.S. Geological Survey Open-File Report 82-1077, 59 p.

McFarlan, E., 1961, Radiocarbon dating of late Quaternary deposits, south Louisiana: Geological Society of America Bulletin, v. 72, p. 129-157.

Miller, T.L., Morton, R.A., Sallenger, A.H., and Moore, L.J., 2004, The national assessment of shoreline change - a GIS compilation of vector shorelines and associated shoreline change data for the U.S. Gulf of Mexico: U.S. Geological Survey Open-File Report 2004-1089, accessed December 30, 2008, at http://pubs.usgs.gov/of/2004/1089/index.html.

Norris, M.W., and Faichney, A.K., eds., 2002, SEG Y rev 1 data exchange format: Tulsa, Okla., Society of Exploration Geophysicists, 45 p. (Also available at http://www.seg. org/SEGportalWEBproject/prod/SEG-Publications/PubTechnical-Standards/Documents/seg_y_rev1.pdf.)

Penland, S., Beall, A., and Kindinger, J., 2002, Environmental atlas of the Lake Pontchartrain basin: U.S. Geological Survey Open-File Report 02-206, accessed December 30, 2008, at http://pubs.usgs.gov/of/2002/of02-206/.

Penland, S., and Boyd, R., 1981, Shoreline changes on the Louisiana barrier coast: Oceans '81, p. 209-229.

Penland, S., Suter, J.R., and Boyd, R., 1985, Barrier island arcs along abandoned Mississippi River deltas: Marine Geology, v. 63, p. 197-233.

Penland, S., Suter, J.R., and Boyd, R., 1988, The transgressive depositional systems of the Mississippi River Delta Plain - a model for barrier shoreline and shelf sand development: Journal of Sedimentary Petrology, v. 58, no. 6, p. 932-949.

Sallenger, A., Howd, P., Stockdon, H., Wright, C.W., Fauver, L., and Guy, K., 2006, Barrier island failure during Hurricane Katrina: EOS Transactions AGU, v. 87, Fall Meeting Supplement, abstract H311-03. (Also available at http://www.agu.org/meetings/fm06.) 
SIOSEIS, 2007, SIOSEIS - the introduction: SIOSEIS Web page, accessed July 17, 2008, at http://sioseis.ucsd.edu/ sioseis.html.

Stockwell, J.W., Jr., and Cohen, J.K., 2007, The new SU user's manual (version 3.3): Golden, Colorado School of Mines, $153 \mathrm{p}$.

Suter, J.R., Penland, S., Williams, S.J., and Kindinger, J.L., 1988, Transgressive evolution of the Chandeleur Islands, Louisiana: Transactions - Gulf Coast Association of Geological Societies, v. 38, p. 315-322.

Triton Imaging, Inc., 2008, Triton SB-Logger: Triton Imaging, Inc., Web page, accessed July 17, 2008, at http://www. tritonimaginginc.com/site/content/products/sblogger/.

Williams, S.J., Penland, S., and Sallenger, A.H., 1992, Atlas of shoreline changes from 1853 to 1989-Louisiana barrier island erosion study: U.S. Geological Survey IMAP, 2150-A.

Williams, S.J., Reid, J.M., Cross, V.A., and Polloni, C.F., 2006, Coastal erosion and wetland change in Louisianaselected USGS products: U.S. Geological Survey Digital Data Series DDS-79. 
Appendix E-1. Geophysical Data from Offshore of the Chandeleur Islands, Eastern Mississippi Delta (See Index Page To Access Data) 
Publishing support provided by Lafayette Publishing Service Center 


\section{Sediment Sampling Analysis To Define Quality of Sand Resources}

By James Flocks, David Twichell, Jordan Sanford, Elizabeth Pendleton, and Wayne Baldwin

\section{Chapter F of}

Sand Resources, Regional Geology, and Coastal Processes of the Chandeleur Islands Coastal System: an Evaluation of the Breton National Wildlife Refuge

Edited by Dawn Lavoie

In cooperation with the U.S. Fish and Wildlife Service

Scientific Investigations Report 2009-5252 


\title{
U.S. Department of the Interior \\ KEN SALAZAR, Secretary \\ U.S. Geological Survey \\ Marcia K. McNutt, Director
}

\section{U.S. Geological Survey, Reston, Virginia: 2009}

\author{
This and other USGS information products are available at http://store.usgs.gov/ \\ U.S. Geological Survey \\ Box 25286, Denver Federal Center \\ Denver, C0 80225 \\ To learn about the USGS and its information products visit http://www.usgs.gov/ \\ 1-888-ASK-USGS
}

\begin{abstract}
Any use of trade, product, or firm names is for descriptive purposes only and does not imply endorsement by the U.S. Government.

Although this report is in the public domain, permission must be secured from the individual copyright owners to reproduce any copyrighted materials contained within this report.
\end{abstract}

Suggested citation:

Flocks, J., Twichell, D., Sanford, J., Pendleton, E., and Baldwin, W., 2009, Chapter F. Sediment sampling analysis to define quality of sand resources, in Lavoie, D., ed., Sand resources, regional geology, and coastal processes of the Chandeleur Islands coastal system—an evaluation of the Breton National Wildlife Refuge: U.S. Geological Survey Scientific Investigations Report 2009-5252, p. 99-124. 


\title{
Chapter F. Sediment Sampling Analysis To Define Quality of Sand Resources
}

\author{
By James Flocks, ${ }^{1}$ David Twichell, ${ }^{2}$ Jordan Sanford, ${ }^{1}$ Elizabeth Pendleton, ${ }^{2}$ and Wayne Baldwin ${ }^{2}$
}

\section{Abstract}

The Chandeleur Islands and surrounding waters provide habitat for a variety of threatened wildlife species, a platform for human infrastructure and recreation, and protection of interior environments and populations by reducing storm impact. A diminishing budget of sandy sediment needed to maintain the islands is continually scavenged by storms, reworked by prevailing wave climate, and inundated by a relative sea level rise, resulting in a net loss of island area. Researchers over the past two decades have documented an increasing inability of the island chain to recover from storm-induced breaching and dune erosion through the natural redistribution of sediment. In 2005, Hurricane Katrina overtopped the islands with up to $10 \mathrm{~m}$ of storm surge and caused catastrophic erosion of the shoreface and protective dune system. The event prompted a collaborative effort between State and Federal agencies to characterize the geologic framework of the Chandeleur Islands, which is composed of a sandy barrier island platform resting unconformably on the late Holocene St. Bernard Delta lobe of the Mississippi River. This geologic information provides insight into the storm response, evolutionary history, and fate of the barrier system. This chapter reports the results of sedimentologic investigations around the islands, which include the interpretation and analysis of a series of sediment vibracores collected in 2007 to ground-truth the geophysical surveys conducted the previous year (chap. E). The study characterizes several distinct depositional components that compose the barrier island platform and underlying deltaic stratigraphy. These deposits include sandy marinetransgressive deposits (barrier island, spits, overwash sheets, and inlet channel deltas) overlying mixed sand-mud facies of the older deltaic deposits (distributary and interdistributary, delta front and prodelta). The transition between adjacent units is typically subtle, and analysis of physical (for example, grain size) and textural (for example, bedding) characteristics is necessary to identify the environment of deposition. In the event that shoreline renourishment becomes a viable option for island management, the results of this study will provide the physical information necessary to identify the location and quality of suitable sand resources around the islands.

\section{Introduction}

The Chandeleur Islands, La., were formed through the erosion and reworking of the deltaic headland of the abandoned St. Bernard Delta Complex, a distributary of the Mississippi River (Suter and others, 1988; Brooks and others, 1995). During the past 4,000 years, distributaries of the Mississippi River discharged into the eastern Louisiana continental shelf, depositing sediments as a series of delta sublobes (fig. 1). The constructional phase of each lobe was rapid, about 1,000 years (Frazier, 1967; Roberts, 1997), and consisted of components found in prodelta, delta-front, and distributary environments (Coleman, 1982). (A plan diagram of these components is shown in fig. 5 of chap. E.) The textural composition of these deposits is a function of fluvial energy and proximity to the distributary mouth. The distributaries deposited sand-size sediments directly at the river mouth (mouth bar and delta front), whereas fine-grained materials were carried in suspension farther away from the distributaries, where they settled into extensive blankets of mud across the sea floor (prodelta).

Decrease in fluvial gradient and accommodation space of the receiving basin resulted in the distributary abandoning the delta complex for a more favorable gradient. The delta entered an abandonment phase, in which fluvial sediments were no longer supplied to the system. The delta deposits began to dewater, compact, and subside (Frazier, 1967; Coleman, 1982; Penland and others, 1988), leading to a regional relative sea level rise. Waves and currents reworked the delta deposits and winnowed out the fine-grained material. The coarser material was concentrated into shoals, which continued to develop through littoral processes into barrier island systems. During

${ }^{1}$ U.S. Geological Survey, St. Petersburg, Fla.

${ }^{2}$ U.S. Geological Survey, Woods Hole, Mass. 
this time estuarine environments in the area developed finegrained interdistributary and backbarrier deposits. As sea level continued to rise, less source sediment was available to the barrier system, which began to deteriorate as sand was continually removed from the system by littoral processes and storm impact.

Deltaic and marine-transgressive shelf deposits produce distinctive physical properties that can be identified through acoustic (seismic) profiling and direct sampling (table 1). Brooks and others (1995) identified fluvial-marine deposits across the eastern Louisiana shelf (fig. 2) and provided a

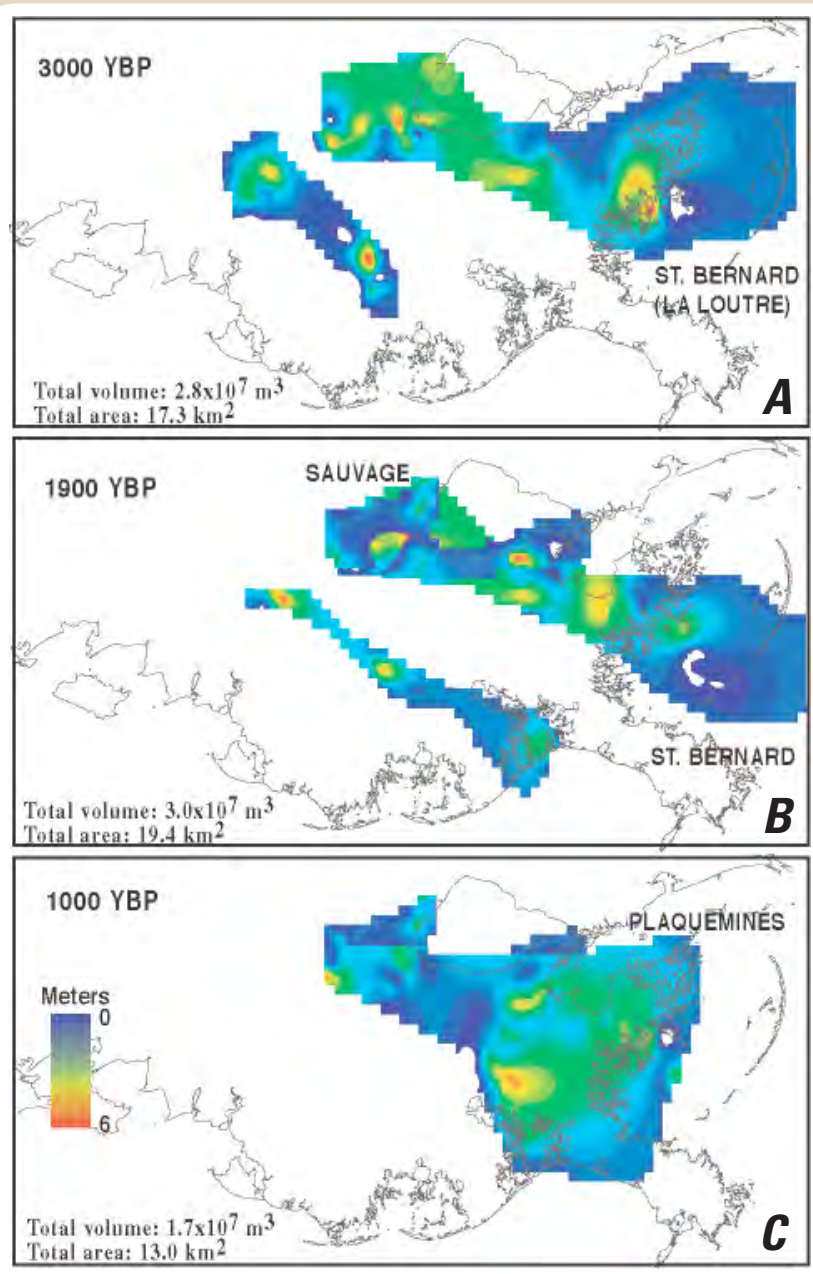

Figure 1. Isopachs of subdelta lobe progradations occurring along the eastern Louisiana coast during three time periods. $A$, Progradations 3,000 years before present (YBP). $B$, Progradations 1,900 YBP. C, Progradations 1,000 YBP. Thickness of deposit is shown by color scale. The modern shoreline is overlaid onto the subdelta lobes for reference. Two subdelta progradations of the St. Bernard complex set the stage for development of the Chandeleur Islands. Modified from Frazier (1967) and Flocks (2006). regional-scale description of the stratigraphy around the Chandeleur Islands. To supplement this information, in 2006 and 2007 the U.S. Geological Survey and collaborators at the University of New Orleans collected high-resolution seismic profiles and sea floor measurements around the islands. The seismic surveys (see chap. E) were followed by the collection of 124 vibracores to ground-truth the acoustic data (fig. 3). Interpretation of geophysical and sediment core data showed that the stratigraphy consists primarily of a thick sequence of prodelta and delta-front sandy silts, incised by sand, and siltfilled distributary channels. These deposits are overlain by the sandy modern barrier island platform. The relative positions, spatial extent, and elevations of these deposits determine the origin, history, and fate of the barrier island system. Chapter E provides a description of the seismic character of the deposits; this chapter provides a description of their physical characteristics.

\section{Methods}

\section{Vibracore Acquisition}

Following the seismic survey of the Chandeleur Islands, a sediment-coring strategy was developed to ground-truth the interpretations from the seismic profiles and to directly sample stratigraphic variation. Vibracores were obtained from onboard the 15 -m-long $R / V$ Gilbert by using a hydraulic crane to position and recover the vibracore rig. The rig is capable of handling aluminum barrels up to $6 \mathrm{~m}$ long with a diameter of $7.6 \mathrm{~cm}$ (fig. 4). The barrels were vibrated into the sediment by using a Rossfelder model P-3 electric motor in a waterproof housing driving offsetting concentric weights. Brass core catchers were riveted to the base of each barrel to inhibit loss of sediment during recovery, along with a check valve at the top to create a vacuum on the sediment. A linear transducer and wire line were attached to the top of the rig to measure penetration of the barrel into the sea floor. Upon recovery, the barrel was removed from the rig and cut to the length of core penetration. The ends of the core sample were capped, and the barrel was labeled with a unique identifier. Core length was measured and compared to the linear transducer reading to estimate compaction. Collected cores were transported to the core analysis laboratory at the University of New Orleans (UNO) for curation and description. Each core was visually described by using standard sediment logging methods, photographed in 1-m intervals, wrapped in plastic sleeves, and archived at the UNO Department of Earth and Environmental Sciences. To fit the page, the core photograph mosaics shown in this report are vertically compressed, which causes some features to appear distorted. Each core log includes a 
Table 1. Description of delta-related facies identified in this report for the Chandeleur Islands, La., study area.

[Layout of facies shows depth and age relation between deposits, with Units F and ETD being surficial and youngest]

\begin{tabular}{|c|c|c|c|}
\hline Facies & $\begin{array}{l}\text { Depositional } \\
\text { environment }\end{array}$ & Physical characteristics & Seismic characteristics \\
\hline Barrier platform & Marine & $\begin{array}{l}\text { Massive, medium to fine sand, } \\
\text { some shell lag }\end{array}$ & Distinct basal reflector, seaward-dipping reflections \\
\hline Ravinement & Marine & Erosional, shell lags and sands & Distinct seaward-dipping reflection throughout study area \\
\hline Interdistributary bay & $\begin{array}{l}\text { Estuarine/ } \\
\text { fluvial }\end{array}$ & $\begin{array}{l}\text { Laminated to bioturbated } \\
\text { silts with abundant organic } \\
\text { material }\end{array}$ & Low-angle, parallel reflections with acoustically transparent "fill" \\
\hline Distributary channel & Fluvial & $\begin{array}{l}\text { Fining-upward sequence of silty } \\
\text { sands, grading into laminated } \\
\text { sandy silts. Massive bedding, } \\
\text { also with wavy or x-bedded } \\
\text { laminations }\end{array}$ & High-angle reflections, distinct dogleg reflections and acoustic noise \\
\hline Delta front & Fluvial & $\begin{array}{l}\text { Laminated silts and lenticular } \\
\text { sands }\end{array}$ & Dipping parallel reflectors with occasional high-angle cross-cutting reflections \\
\hline Prodelta or marine & $\begin{array}{l}\text { Fluvial or } \\
\text { marine }\end{array}$ & $\begin{array}{l}\text { Laminated silts and clays, } \\
\text { grading upward to sandy } \\
\text { silts }\end{array}$ & Horizontal to low-angle reflections \\
\hline
\end{tabular}

description of sedimentary texture, which includes observed sand, silt, and clay percentages; sedimentary structures; physical characteristics; stratification type; sample interval; and location. The logs were scanned and saved as Adobe Portable Document Format (PDF) files for digital access (app. F-1). From each core, subsamples were taken at $80-\mathrm{cm}$ intervals for textural analysis. Additional samples were taken from the tops and bottoms of sand-rich intervals greater than approximately $0.6 \mathrm{~m}$ thick to allow for more effective textural classification of sandy sedimentary packages.

\section{Grain-Size Analysis}

Textural analyses of sediment samples taken from the vibracores were performed at the U.S. Geological Survey Center for Coastal and Watershed Studies in St. Petersburg, Fla., by using a Beckman Coulter LS 200 particle-size analyzer. This instrument utilizes laser diffraction to measure the size distribution of sedimentary particles between 0.375 and $2,000 \mu \mathrm{m}$. The utility of the LS 200 is the high reproducibility of measurements, rapid acquisition of results, ability to accurately and quickly provide quantitative measure of extremely small grain-size fractions, and customizable data output.

Sediment samples from selected intervals downcore were disaggregated in a sodium hexametaphosphate solution and resuspended through stirring and sonication for dispersement into the LS 200 module bath. The samples were dispersed by pipette until a desired 8-12 percent solution concentration was obtained. This procedure was repeated three times per sample, and the measurements were averaged to produce a single analysis per sample. If one measurement departed from the other two by one standard deviation, then the measurement was evaluated and removed if necessary. In a few cases samples were reanalyzed to ensure reliable results.

The LS 200 shines a laser on particles suspended in solution. The light is scattered in characteristic patterns based on particle size. These patterns are measured by photodetectors as intensity per unit area and broken down into 92 size-classification channels. The relative amplitude of light intensity for each channel is interpreted as the relative volume of spherical particles of that size. From the bin counts produced by the LS 200, cumulative weight percentages for 5th, 10th, 16th, 25th, 50th, 75th, 84th, 90th and 95th percentiles were calculated. From these measurements, mean grain size and sorting (Inman, 1962) were reported in millimeter and phi intervals. Percentages of sand, silt, and clay were reported for each core interval as tables in this chapter and in appendix F and are included in this report graphically as ternary plots. Statistical moments that correspond to sorting, skewness, and kurtosis were also calculated by following the procedure outlined in Folk (1968).

\section{Data Processing}

Vibracore description sheets were converted from paper copies to digital files by following the procedure outlined in 


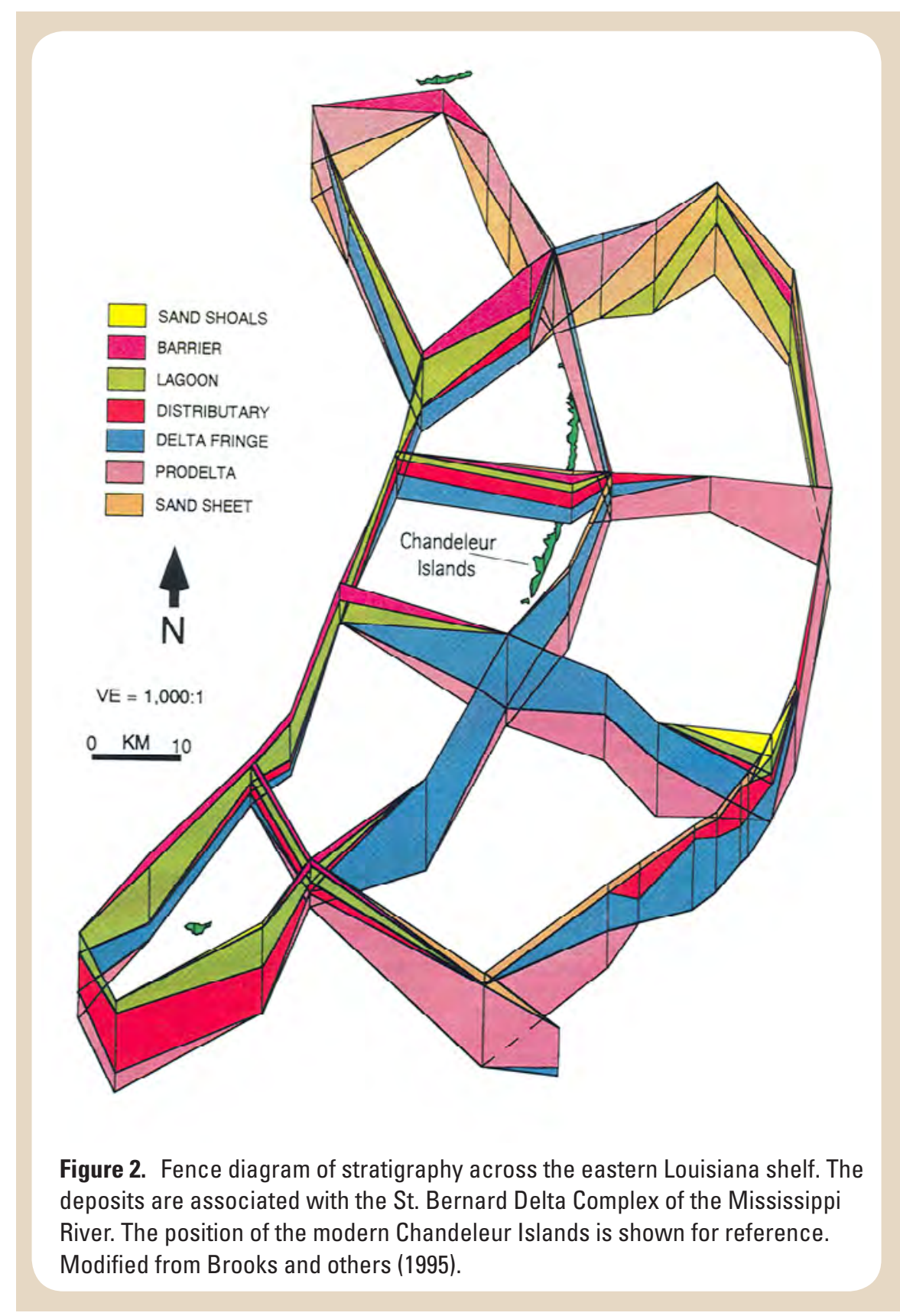

\section{Results}

Distinct sedimentary deposits were identified on the basis of integrated analysis and interpretation of the seismic and core data (fig. 5; table 2). The deposits were divided into two groups on the basis of their stratigraphic relation and process of formation. The first group comprises the deeper deposits associated with the development of the St. Bernard Delta (prodelta, delta front, distributary, interdistributary). The second group comprises the units that are overlain by deposits formed during the marine transgression that followed the abandonment of the St. Bernard Delta (tidal inlet, overwash, barrier sand deposits).

Descriptions of the deposits are provided in the following section.

\section{St. Bernard Deposits}

\section{Fine-Grained Prodelta, Delta- Front, and Interdistributary Deposits}

The stratigraphy below the barrier island chain is primarily composed of prodelta and delta-front muds of the St. Bernard Subdelta Complex (Brooks and others, 1995). Throughout the Mississippi River Delta Plain, prodelta muds exhibit high lateral continuity and low lithologic variation (Coleman, 1982). The distribution of this deposit is shown in figure $8 \mathrm{~A}$ of chapter $\mathrm{E}$, where it is described as laminated mud/clay (Unit 1). Core interpretations and grain-size analyses characterize the deposit as massive and poorly sorted clayey silts (fig. 6) that

Flocks (2004). Output of the qualitative descriptions allows for statistical analysis of textural similarities which determine stratigraphic units between cores. These results were used to generate abundance graphs of common textures and bedding. Ternary plots of sand/silt/clay ratios were generated from the LS 200 grain-size data. Contour plots of the grain-size data were generated by using CPS-3 gridding software. are gray in color. The base of this unit consists of massive fine silts to laminated clays. This texture represents prodelta deposits, suspension deposits that settle out of the water column some distance away from the distributary mouth. Since the concentration of muds in the water column can be seasonally episodic and of short duration (floods, eddies, storm resuspension, and others), laminations are common but very thin and are difficult to determine without $\mathrm{x}$-ray profiles. Cores collected from the northern portion of the study area penetrated deeper into the unit (table 2, prodelta muds) and contain fine silts and a massive texture. Around the islands, the 


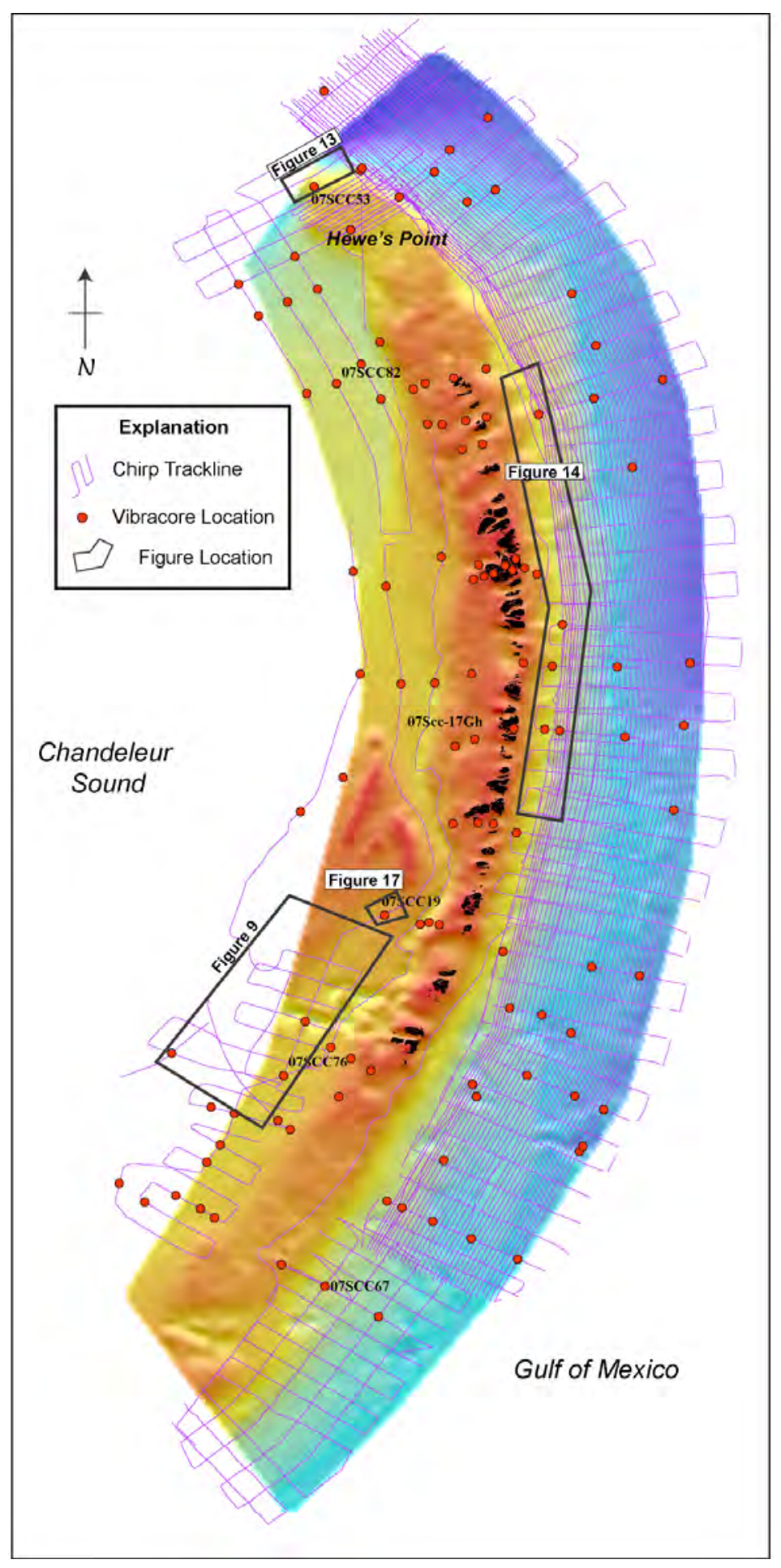

Figure 3. Location of seismic profiles and vibracores collected around the Chandeleur Islands, La., in 2006. Color-shaded relief represents bathymetry from the 2006 survey. Island shoreline positions (black polygons) were identified by using airborne laser altimetry data collected in 2006. 


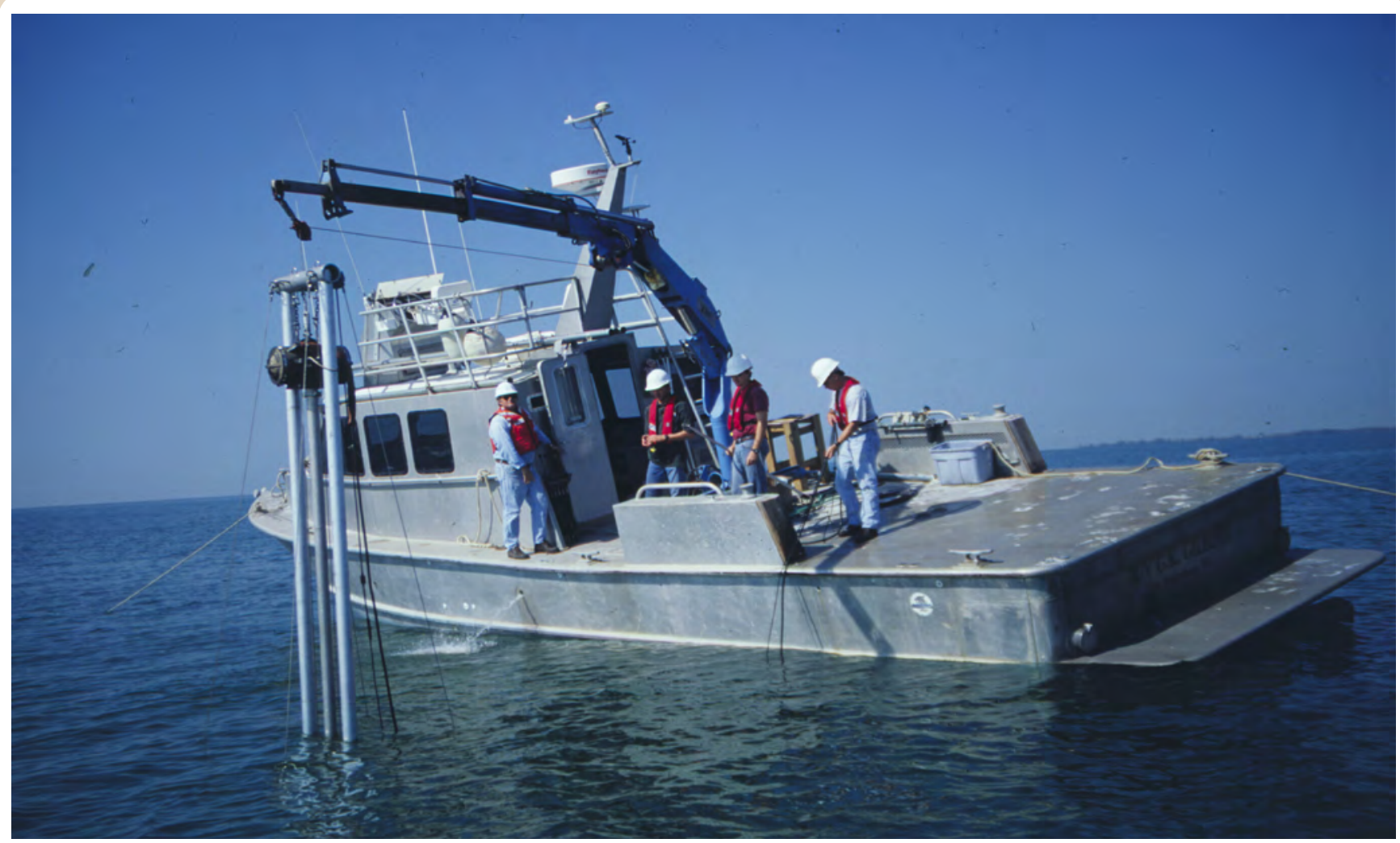

Figure 4. Vibracore rig being deployed from the R/V Gilbert. The vibracore consists of an electric motor spinning offset concentric weights, which vibrate an aluminum barrel into the unconsolidated sediment. A hydraulic crane is used to deploy and recover the rig.

prodelta grades vertically into delta-front sediments that were deposited more proximal to the distributary mouth. Deltafront sediments contain small lens-shaped (lenticular) sand laminations (fig. 7) and sometimes thin silt/clay laminations (fig. 8). Lenticular-sand deposits form in sand-starved, lowenergy environments. Episodic increases in current velocity, such as wind-driven waves in shallow water, concentrate the little sand that exists into thin laminae within the mud matrix (Coleman, 1982). The bimodal texture results in a high deviation from the mean grain size (poorly sorted), with a larger portion of the distribution in the silt fraction (fine skew) (fig. 6).

Sediment core interpretations of these fine-grained deposits noted very few shells, little organic material, and limited bioturbation. The lack of bioturbation indicates a very high particulate sedimentation rate, typical of prodelta and delta-front deposits (Coleman, 1982). Scattered layers of shells were observed as lag deposits that may indicate increased current velocity, possibly caused by storm events. Bioturbated zones may represent periods of decreased sedimentation.
Off the southern part of the Chandeleur Islands, the deposit is incised by distributary channels (fig. 5). In this area, root traces and organic material are present in the muds that flank the channels, suggesting a transition from delta-front to interdistributary (marsh/lagoon) environments. The transition from upper prodelta to delta-front to interdistributary deposits is virtually indistinguishable, indicating very subtle changes in depositional environments over time. High-resolution pollen analysis, age dating, or $\mathrm{x}$-ray profiles would be necessary to further constrain these environmental boundaries.

\section{Distributary}

Deltaic distributaries are the conduits for particulate and bedload transport to the receiving basin. Modern analogs within the Mississippi River Delta include channels that range in size from meters to a kilometer in width and up to $30 \mathrm{~m}$ deep (Coleman, 1982). Distributaries in the modern "birdsfoot delta" resemble a reverse dendritic pattern, with smaller channels radiating seaward from a main trunk. In the 


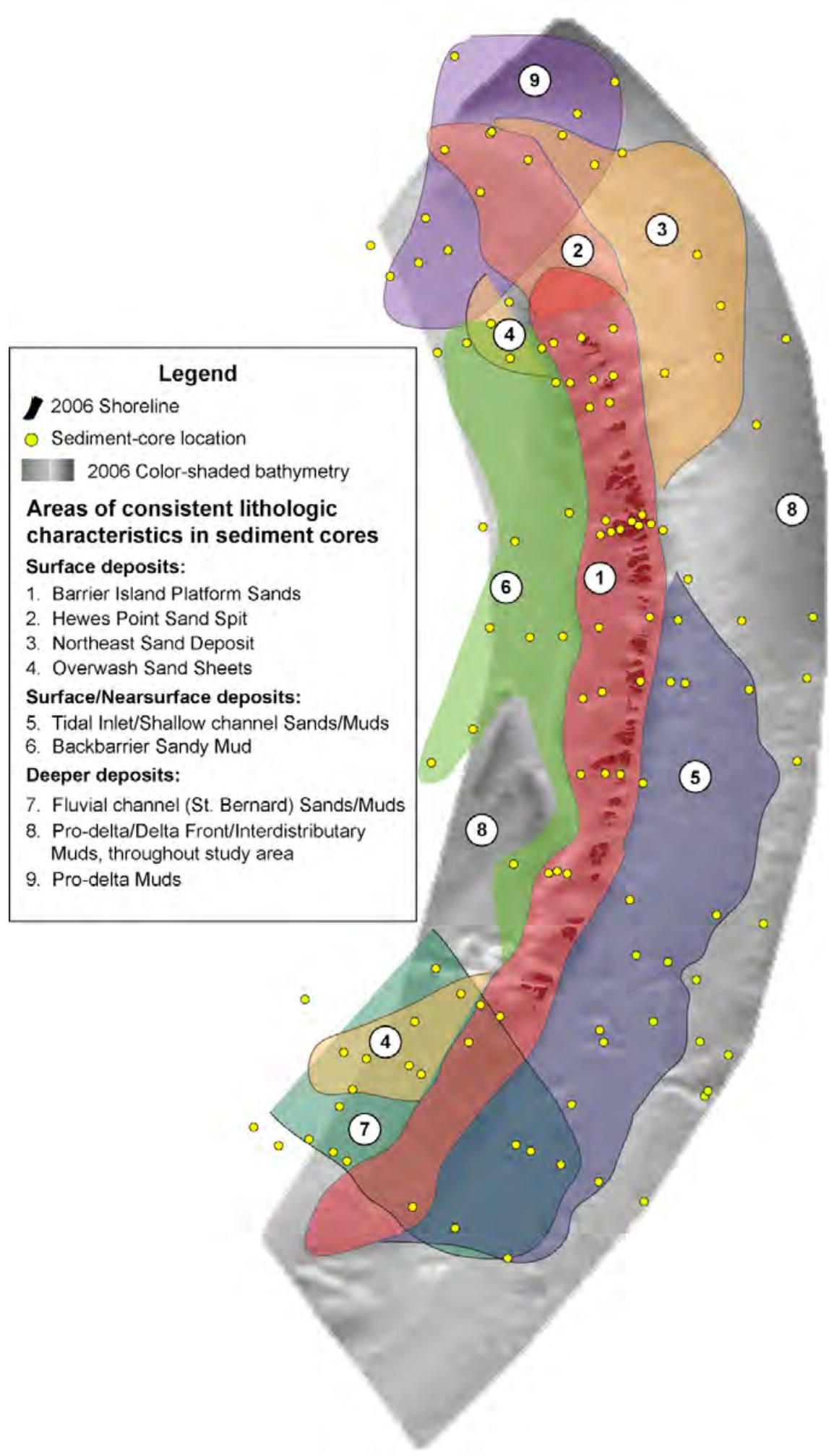

Figure 5. Location of deposits identified in this study in the area of the Chandeleur Islands, La. Spatial extents were interpreted by using seismic profiles (chap. E) and sediment core data. See table 2 for physical descriptions of deposits. 
Table 2. Physical descriptions of deposits identified in this study in the area of the Chandeleur Islands, La.

[m, meters; mbsl, meters below sea level; mbsf, meters below sea floor; mm, millimeters; \%, percent; Vf, very fine; med., medium; mod., moderately]

\begin{tabular}{|c|c|c|c|c|c|c|}
\hline Reference & Deposit & $\begin{array}{l}\text { No. of } \\
\text { samples in } \\
\text { average* }\end{array}$ & $\begin{array}{c}\text { Average } \\
\text { depth } \\
\text { (mbsl) }\end{array}$ & $\begin{array}{c}\text { Average } \\
\text { top } \\
\text { (mbsi) }\end{array}$ & $\begin{array}{c}\text { Average } \\
\text { base } \\
\text { (mbsi) }\end{array}$ & $\begin{array}{c}\text { Average } \\
\text { thickness } \\
(\mathrm{m})^{* *}\end{array}$ \\
\hline 1 & Barrier platform sand & 191 & -2.12 & 0.00 & 3.21 & 3.16 \\
\hline 2 & Hewes Point sand pit & 27 & -6.16 & 0.00 & 3.53 & 3.53 \\
\hline 2 & Hewes Point base & 6 & -8.53 & 2.51 & 3.68 & 1.17 \\
\hline 3 & Northeast sand deposit & 25 & -9.63 & 0.00 & 1.62 & 1.61 \\
\hline 4 & Overwash sand sheets & 17 & -3.66 & 0.00 & 0.25 & 0.25 \\
\hline 5 & Tidal inlet/nearsurface channel sands & 81 & -6.23 & 0.12 & 1.34 & 1.22 \\
\hline 6 & Backbarrier sandy mud & 24 & -4.43 & 0.16 & 1.52 & 1.36 \\
\hline 7 & St. Bernard distributary mixed & 53 & -9.22 & 2.87 & 4.10 & 1.23 \\
\hline 8 & Interdistributary (rooted zone) muds & 41 & -6.42 & 1.57 & 3.73 & 2.16 \\
\hline 8 & $\begin{array}{l}\text { Prodelta/delta front/ interdistributary } \\
\text { mixed }\end{array}$ & 245 & -10.89 & 1.16 & 4.11 & 2.94 \\
\hline \multirow[t]{3}{*}{9} & Prodelta muds & 51 & -12.20 & 0.02 & 4.36 & 4.35 \\
\hline & Sea floor composite $(0-1 \mathrm{~m})$ & 236 & -5.00 & 0.00 & 1.00 & 1.00 \\
\hline & Chandeleur Islands composite & 414 & -8.63 & 0.70 & 2.70 & 2.00 \\
\hline
\end{tabular}

\begin{tabular}{|c|c|c|c|c|c|c|}
\hline Reference & Deposit & $\begin{array}{l}\text { Mean } \\
\text { grain size } \\
\text { phi }(\mathrm{mm})\end{array}$ & $\begin{array}{l}\text { Wentworth } \\
\text { size class }\end{array}$ & $\begin{array}{c}\text { Amount } \\
\text { sand } \\
(\%)\end{array}$ & $\begin{array}{l}\text { Amount silt } \\
\qquad(\%)\end{array}$ & $\begin{array}{c}\text { Amount } \\
\text { clay } \\
(\%)\end{array}$ \\
\hline 1 & Barrier platform sand & $3.2(0.11)$ & Vf sand & 85.2 & 11.9 & 2.8 \\
\hline 2 & Hewes Point sand pit & $2.6(0.15)$ & Fine sand & 97.1 & 2.1 & 0.7 \\
\hline 2 & Hewes Point base & $3.1(0.11)$ & Vf sand & 92.6 & 5.6 & 1.8 \\
\hline 3 & Northeast sand deposit & $3.5(0.01)$ & Vf sand & 84.4 & 12.6 & 3.0 \\
\hline 4 & Overwash sand sheets & $3.6(0.08)$ & Vf sand & 79.1 & 16.4 & 4.5 \\
\hline 5 & Tidal inlet/nearsurface channel sands & $3.8(0.07)$ & Vf sand & 72.1 & 22.2 & 5.7 \\
\hline 6 & Backbarrier sandy mud & $4.4(0.05)$ & Coarse silt & 58.9 & 32.7 & 8.5 \\
\hline 7 & St. Bernard distributary mixed & $4.5(0.04)$ & Coarse silt & 52.8 & 38.3 & 8.8 \\
\hline 8 & Interdistributary (rooted zone) muds & $6.4(0.01)$ & Fine silt & 19.2 & 53.5 & 27.3 \\
\hline 8 & $\begin{array}{l}\text { Prodelta/delta front/ interdistributary } \\
\text { mixed }\end{array}$ & $6.6(0.01)$ & Med.-fine silt & 13.7 & 57.3 & 29.0 \\
\hline \multirow[t]{3}{*}{9} & Prodelta muds & $6.7(0.01)$ & Fine silt & 12.3 & 55.2 & 32.4 \\
\hline & Sea floor composite $(0-1 \mathrm{~m})$ & $3.8(0.07)$ & Vf sand & 72.6 & 20.6 & 6.8 \\
\hline & Chandeleur Islands composite & $5.7(0.02)$ & Coarse silt & 31.4 & 47.4 & 21.2 \\
\hline
\end{tabular}


Table 2. Physical descriptions of deposits identified in this study in the area of the Chandeleur Islands, La.—Continued

[m, meters; mbsl, meters below sea level; mbsf, meters below sea floor; mm, millimeters; \%, percent; Vf, very fine; med., medium; mod., moderately]

\begin{tabular}{|c|c|c|c|c|c|c|c|}
\hline Reference & Deposit & $\begin{array}{c}\text { Sorting } \\
\text { (folk) } \\
\text { phi }\end{array}$ & $\begin{array}{l}\text { Sorting } \\
\text { classification }\end{array}$ & $\begin{array}{l}\text { Skewness } \\
\text { (positive) }\end{array}$ & $\begin{array}{l}\text { Skew } \\
\text { direction (fine } \\
\text { to coarse) }\end{array}$ & Kurtosis & $\begin{array}{l}\text { Peakedness } \\
\text { description }\end{array}$ \\
\hline 1 & Barrier platform sand & 0.53 & mod. well sorted & 0.24 & fine-skew & 1.53 & very leptokurtic \\
\hline 2 & Hewes Point sand pit & 0.26 & very well sorted & 0.07 & symmetrical & 1.25 & leptokurtic \\
\hline 2 & Hewes Point base & 0.29 & very well sorted & 0.21 & fine-skew & 1.54 & very leptokurtic \\
\hline 3 & Northeast sand deposit & 0.46 & well sorted & 0.24 & fine-skew & 1.58 & very leptokurtic \\
\hline 4 & Overwash sand sheets & 0.71 & moderately sorted & 0.24 & fine-skew & 1.34 & leptokurtic \\
\hline 5 & Tidal inlet/nearsurface channel sands & 0.65 & mod. well sorted & 0.25 & fine-skew & 1.42 & leptokurtic \\
\hline 6 & Backbarrier sandy mud & 0.89 & moderately sorted & 0.44 & strong fine-skew & 1.59 & very leptokurtic \\
\hline 7 & St. Bernard distributary mixed & 0.76 & moderately sorted & 0.29 & fine-skew & 1.50 & leptokurtic \\
\hline 8 & Interdistributary (rooted zone) muds & 1.19 & poorly sorted & 0.03 & symmetrical & 1.10 & leptokurtic \\
\hline 8 & $\begin{array}{l}\text { Prodelta/delta front/ } \\
\text { interdistributary mixed }\end{array}$ & 1.16 & poorly sorted & 0.12 & fine-skew & 0.97 & leptokurtic \\
\hline \multirow[t]{3}{*}{9} & Prodelta muds & 1.28 & poorly sorted & 0.02 & symmetrical & 0.97 & leptokurtic \\
\hline & Sea floor composite $(0-1 \mathrm{~m})$ & 0.66 & mod. well sorted & 0.22 & fine-skew & 1.38 & leptokurtic \\
\hline & Chandeleur Islands composite & 1.05 & moderately sorted & 0.18 & fine-skew & 1.23 & leptokurtic \\
\hline
\end{tabular}

${ }^{*}$ Each sample is an average of six analysis runs.

${ }^{* *}$ Core sample may not have reached base of deposit.

*** Composite description; deposit may contain alternating intervals of different size (see sorting).

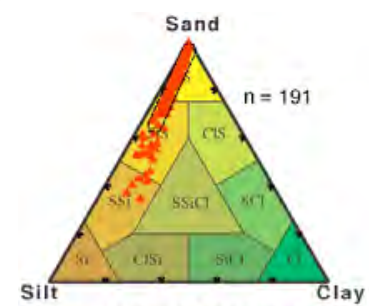

1. Barrier Platform

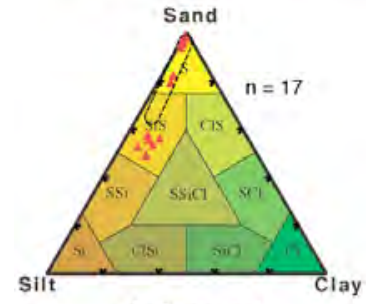

4. Overwash

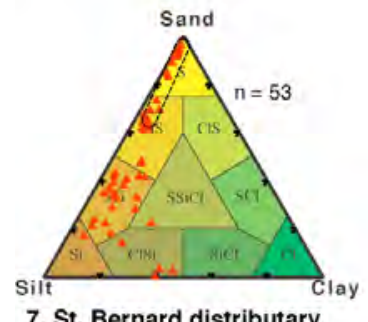

7. St. Bernard distributary

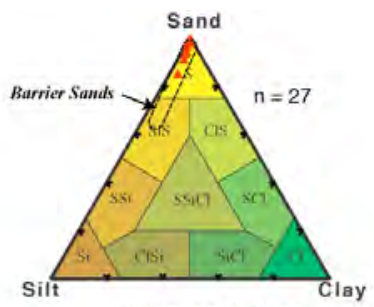

2. Hewes Point

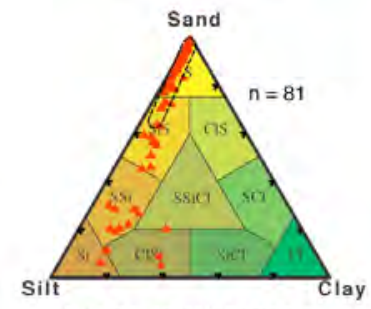

5. Tidal Inlet/channels

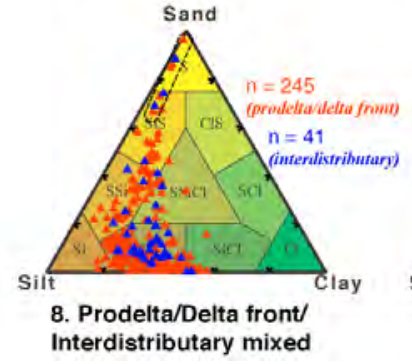

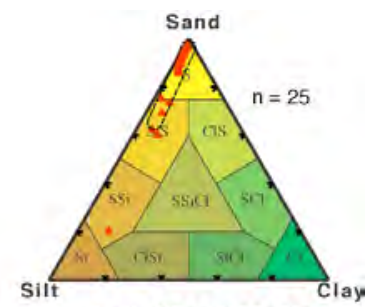

3. NE Sand Deposit

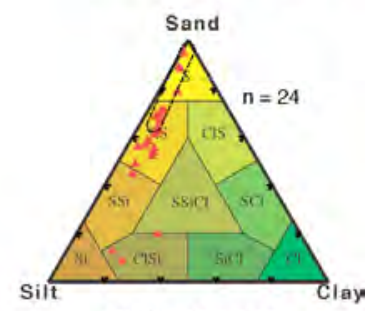

6. Backbarrier

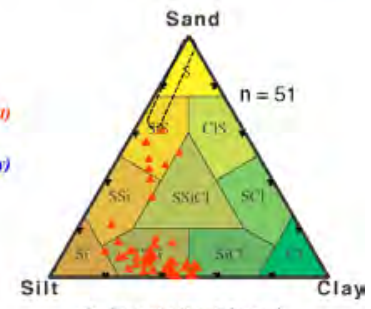

9. Prodelta (deep)
Figure 6. Ternary diagrams of sand (S)/silt (Si)/clay (CI) ratios in samples collected from deposits outlined in this study in the area of the Chandeleur Islands, La. Texture parameters were measured by laser diffraction analysis. Distributions of barrier platform sands are shown in each diagram for comparison (dashed polygon). 
stratigraphic record of the delta plain, however, this pattern is not often retained. Maps of drainage patterns on the near shelf in the northern Gulf of Mexico often show parallel and disconnected channels (Kindinger, 1989; Kindinger and others, 1994; Flocks and others, 2006), a result of the transitional nature of delta progradations and marine ravinement. Figure 15 in chapter E illustrates an interpreted distributary channel configuration mapped across the Chandeleur Islands by using a dense grid of seismic profiles collected during this study. The channels that are detectable in seismic profiles (fig. 9) are concentrated in the southern half of the main island chain. The locations of these channels play an important role in the evolution of the islands by providing sediment to the shoreface. During island development, sea level rise and littoral processes eroded sand from these channels and transported the sediment northward.

Sediment cores collected from the distributary deposits contain mixed lithologies and bedding types (fig. 10). These channels are sandier than adjacent interdistributary and delta-front deposits, but they also contain intervals of muddy material, leading to a wide distribution in texture. Distributary deposits contain over 50 percent sand, but their mean grain size ranges from very fine sand to coarse silt. Bedding within the deposits is also mixed (fig. 11). Sand layers occur in massive and laminated beds. The laminated bedding is often

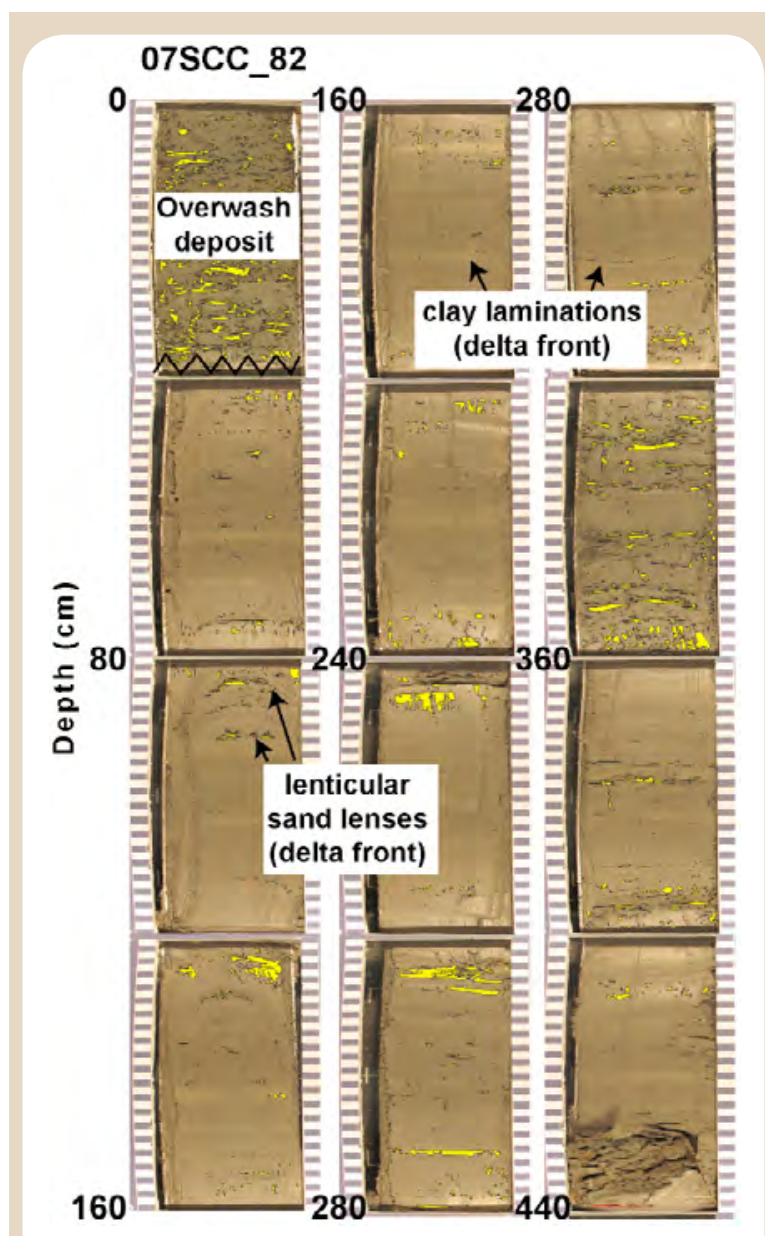

Figure 8. Sediment core (07SCC_82) that contains prodelta/delta-front deposits typical of the study area in the Chandeleur Islands, La. (see fig. 3 for core location). Sand lenses within laminated muds are highlighted.

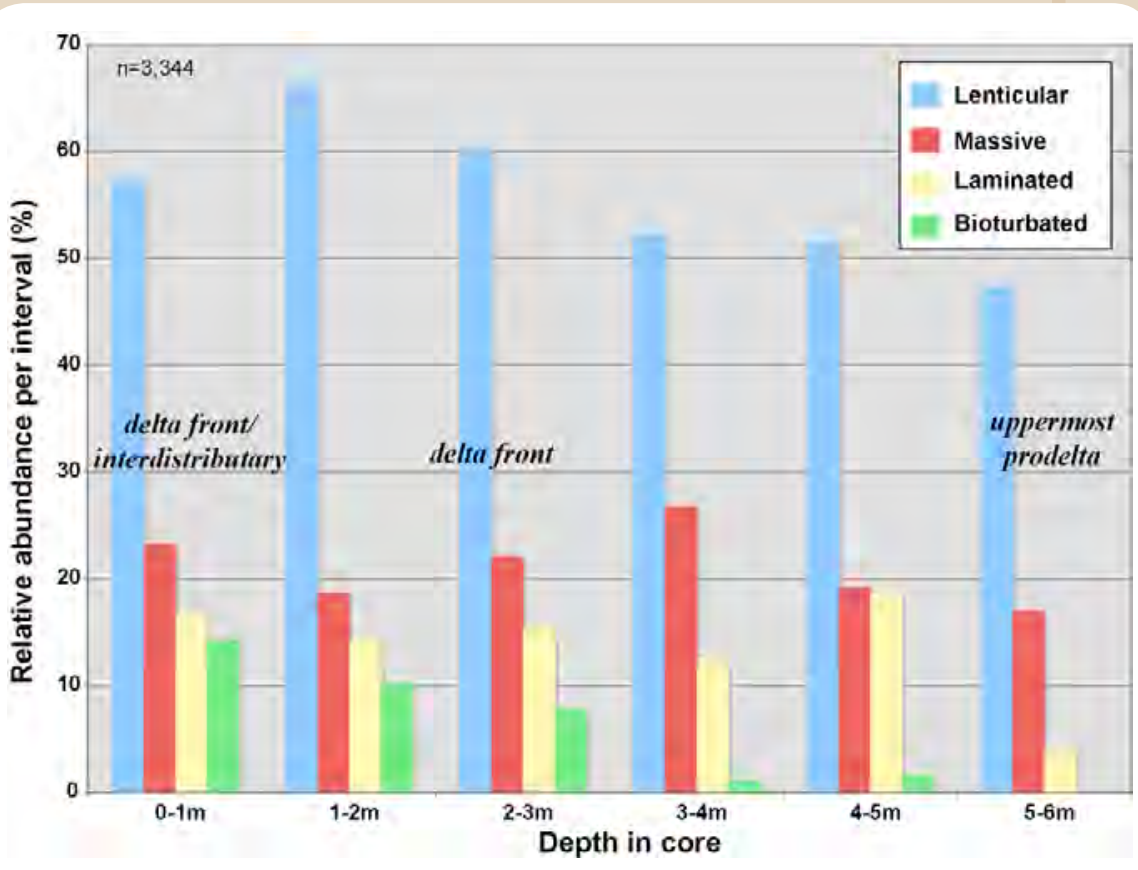

Figure 7. Distributions of predominant bedding type and bioturbation throughout the prodelta, delta-front, and interdistributary deposits in the Chandeleur Islands, La., study area. Based on sediment core interpretation. 

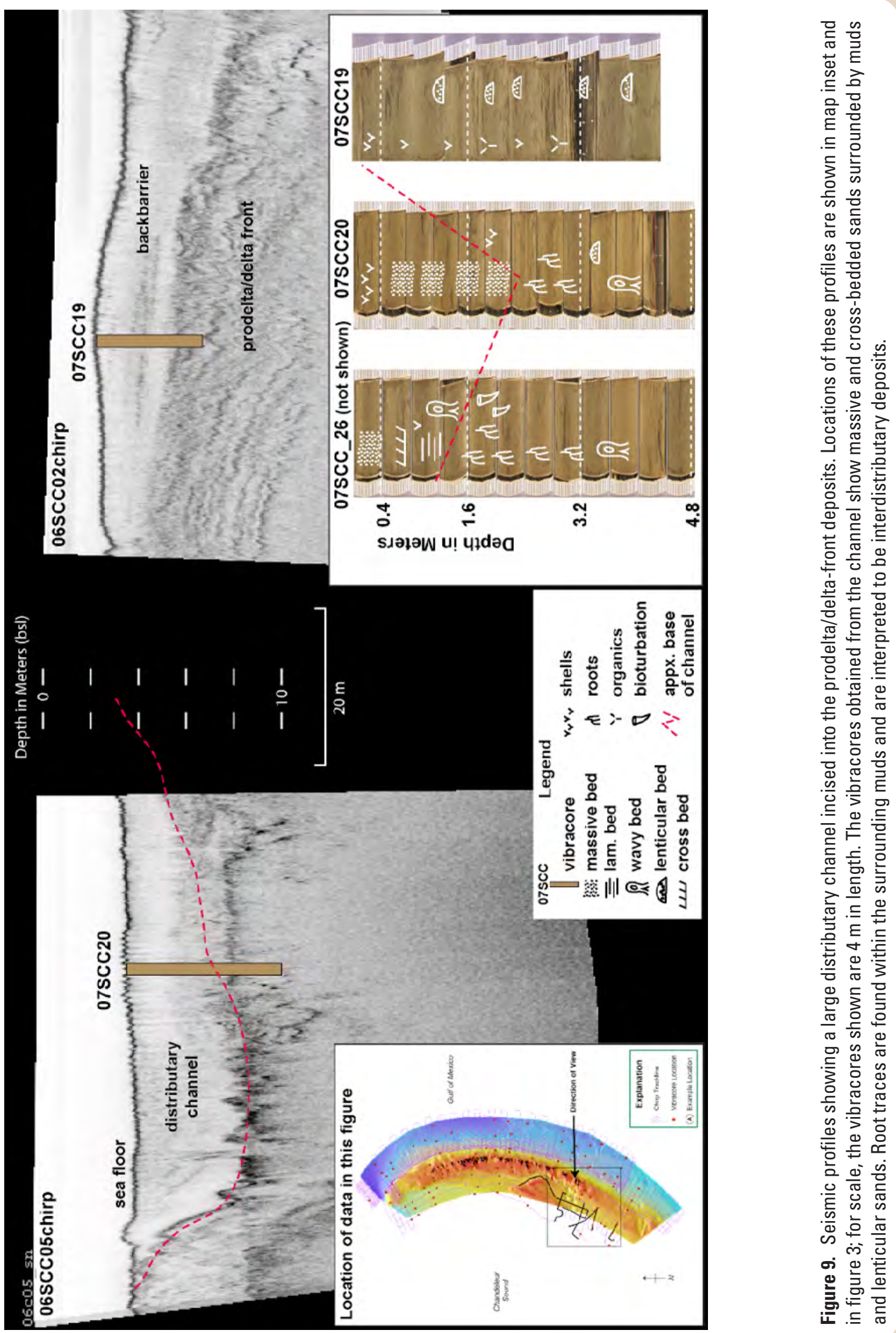

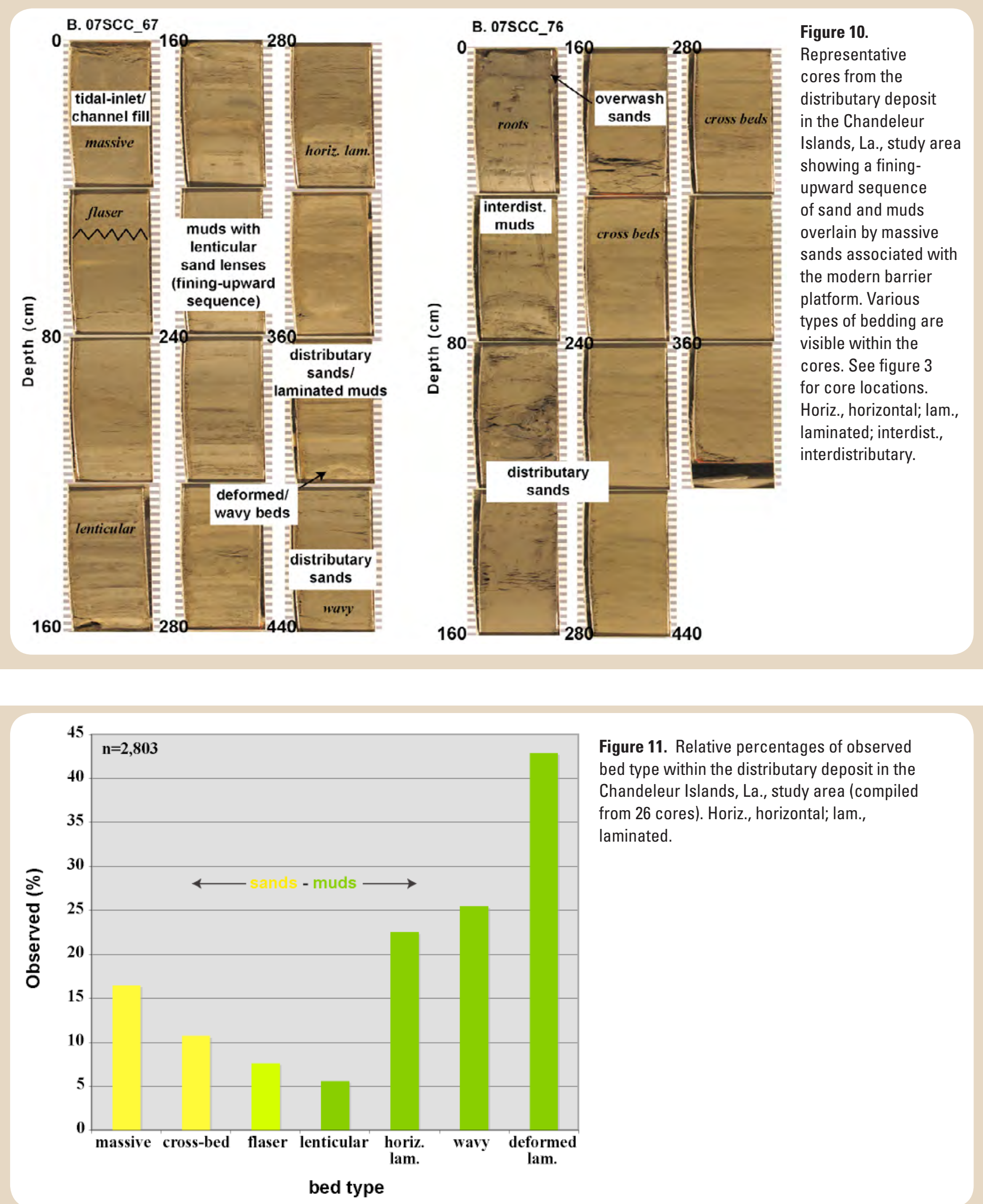

Figure 11. Relative percentages of observed bed type within the distributary deposit in the Chandeleur Islands, La., study area (compiled from 26 cores). Horiz., horizontal; lam., laminated. 
deformed, wavy or crossbedded. Mud intervals are typically laminated and may contain lenticular sands. Since these deposits are fluvial, shell material and bioturbation are rarely observed. The sand distribution is similar to that of the barrier island platform, and the deposit potentially represents a suitable source for renourishment.

\section{Transgressive Deposits}

Upon abandonment of the St. Bernard Delta lobe, active deposition across the lobe decreased. The delta environment entered the transgressive phase of development, when dewatering caused compaction in the fluvial deposits and subsidence at the surface, causing the marsh surface to drop below sea level. Throughout the study area, the prodelta/ delta front is overlain by shell lag, which in turn is capped by sands of the barrier island platform. The shell lag represents the ravinement surface associated with sea level rise and marine transgression across the marsh platform. During the transgressive phase, wave and current energy scoured the fluvial deposits and concentrated the sand into shoals. Rare sand ripples and scour features that are present within the upper intervals in some of the cores are indicative of erosion and transport during this time; however, the amount of sediment removed during marine inundation cannot be determined from the sediment cores. Vertical development and amalgamation of the shoals led to subaerial extension into barrier island deposits via littoral processes to shape the island arc. The modern barrier platform, tidal, and estuarine deposits are primarily composed of sands eroded from distributary deposits during the marine transgression.

\section{Barrier Deposits}

The core components of the barrier island chain are the sand deposits that compose the shoreface, subaerial dunes, and inlets. The islands contain the highest concentration of sand found in the Louisiana barrier islands system. These deposits are well sorted, have an average grain size of very fine sand, and exhibit very little deviation around the median grain size (fig. 6). Sediment texture distribution is skewed toward the fine sand-size fraction (table 2).

Although shell deposits can be found in abundance on the islands, most of the subaqueous barrier platform is distinctly clear of shells and organic material (fig. 12). When present, shells occur in lags, concentrated during high-energy events such as storms. Cores collected from the deposit exhibit very little bedding structure (more than 90 percent contain massive bedding). Sediment grain size in cores along the barrier islands' shoreface shows a consistent decrease in distribution around the median grain size from south to north. This trend suggests that sands are further concentrated because of winnowing caused by nearshore transport processes, which leads to an increase in the average grain size and sorting at the end of this transport system.

Much of the barrier platform rests on interdistributary and delta-front deposits. These deposits provide a vital foundation for sand deposition, which itself is protected from erosion by the sand deposits during normal wave activity. The sand is easily mobilized by storm events, which can redistribute sand and expose the marsh platform to wave attack.

\section{Hewes Point Barrier and Northeast Sand Deposits}

The prevailing wave climate across the Chandeleur Islands region is from the southeast, and littoral processes continually transport sands northward along the shoreface, as evidenced by active spit development off the north end of the island at Hewes Point (fig. 5). Hewes Point cores show an average increase in grain size of $0.05 \mathrm{~mm}$ and an increase in sand percent from 85 percent (barrier platform) to 97 percent when compared to the barrier platform cores. These sands are very well sorted and nearly homogenous in size (fig. 6). The spit deposit is more than $7 \mathrm{~m}$ thick in places (fig. 13). The volume calculated from seismic profile interpretations is estimated to be more than $350 \times 10^{6} \mathrm{~m}^{3}$ of sediment. For the purposes of sand resources, the Hewes Point sand deposit is suitable for direct placement on the shoreface and may provide a quasi-renewable source because it will be replenished by littoral processes.

The Hewes Point barrier spit is accompanied by a similar subaqueous sand deposit that extends to the northeast, seaward of the island axis (fig. 14). Littoral processes are also responsible for concentration of sand in this northern area. While the deposits are less well sorted and contain more silt-sized sediment than does the Hewes Point spit, the composition and texture of the subaqueous sand bodies make them a suitable source for borrow material (fig. 5). Although both deposits have low shell concentration, the spit contains a higher percentage of shell lag.

\section{Tidal/Shallow Fluvial Channel Fill}

The near surface (less than $2 \mathrm{~m}$ below sea floor [mbsf]) of the southern portion of the island chain is marked by small-scale, high-angle reflectors in seismic profiles (fig. 14). These patterns are consistent with channel-fill deposits in the Louisiana coastal zone (Flocks and others, 2006) and represent small-scale distributaries, tidal inlets, or spit-progradation deposits. It is likely that the deposits represent reworked distributaries that were subsequently occupied by tidal inlets 

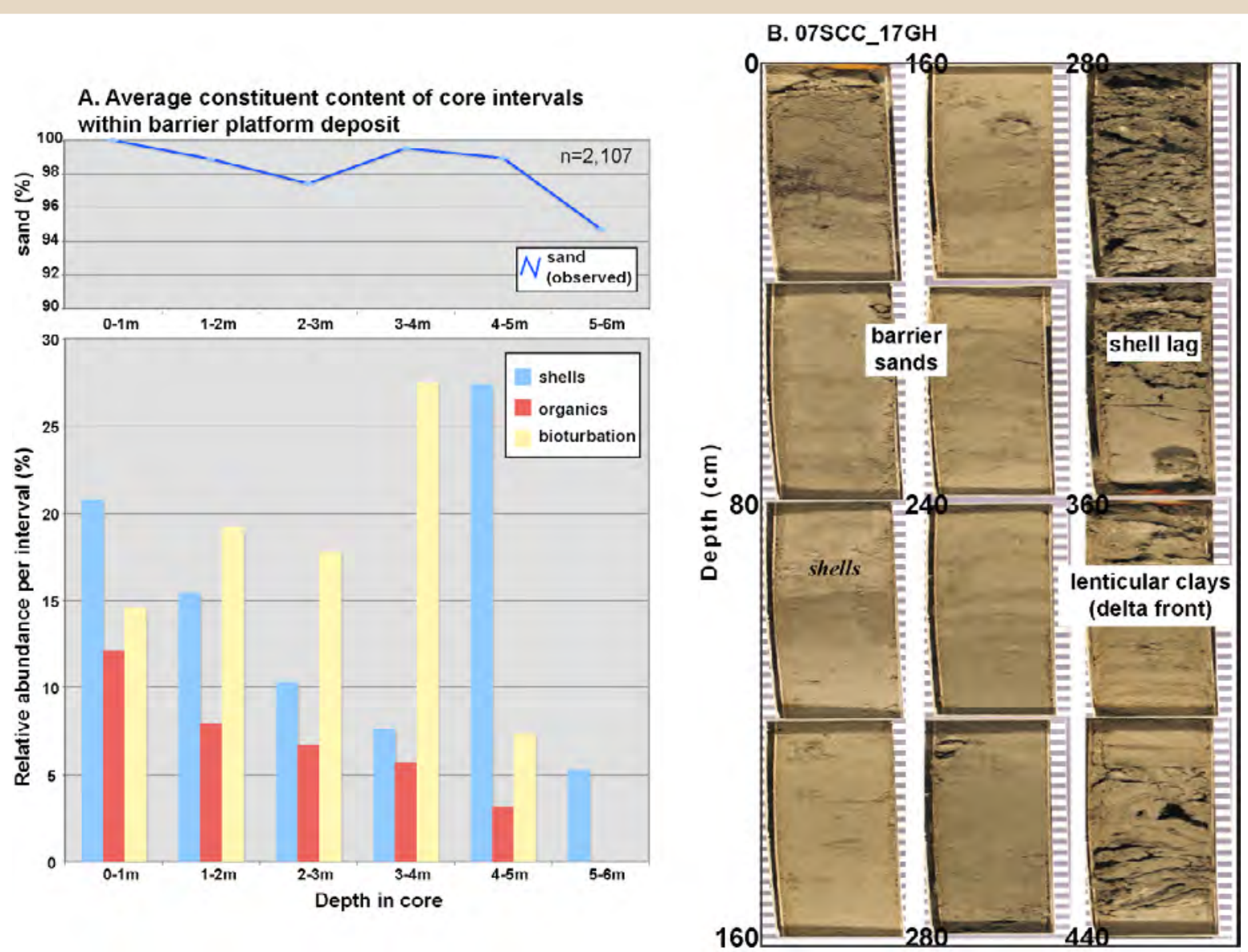

Figure 12. Relative percentages of sand and textural constituents within the barrier platform deposits in the Chandeleur Islands, La., study area (compiled from 33 cores) observed during core interpretations. $A$, Shells and organic material make up only a small portion of the unit, which is predominantly sand. $B$, Representative core (07SCC_17GH) from the deposit showing the well-sorted sand overlying delta-front muds. Cores show a prominent shell lag at base of barrier sands and increasing content of shell lags (although not abundant) upcore. See figure 3 for core location.

following marine ravinement. The features are laterally discontinuous and can contain similar material to both the underlying distributary channel and the island platform (fig. 10). On average, the deposits contain 73 percent very fine well-sorted sand (table 2). The bedding is commonly described as massive, although laminated and deformed bedding occur. The massive texture is more prevalent at the top of the section (fig. 15), which may be a product of reworking by wave action. Although the textural parameters of these deposits are similar to those of the barrier platform, the deposits may not be viable sources for sand renourishment because of their thin, discontinuous nature and their proximity to the barrier platform. The sands within these deposits represent an important natural source for replenishment, and their removal may impact the stability of the shoreface.

\section{Backbarrier Deposits and Overwash Sand Sheets}

Shallow deposits on the bay side of the barrier island chain represent the transition from earlier delta-front deposits to modern estuarine conditions. This zone is generally protected from normal nearshore wave and current energy, which allows fine-grained material to accumulate in layers within periodic high-energy deposits. This process leads to a mixed sediment of very fine sand to silt, strongly skewed toward the latter (table 2). The most distinct characteristic of these deposits is the wavy and deformed alternating beds of sand and silt that are observed in many of the cores (fig. 16). A seismic profile and core overlay show the gradual transition from the delta-front lenticular muds to the slightly coarser 

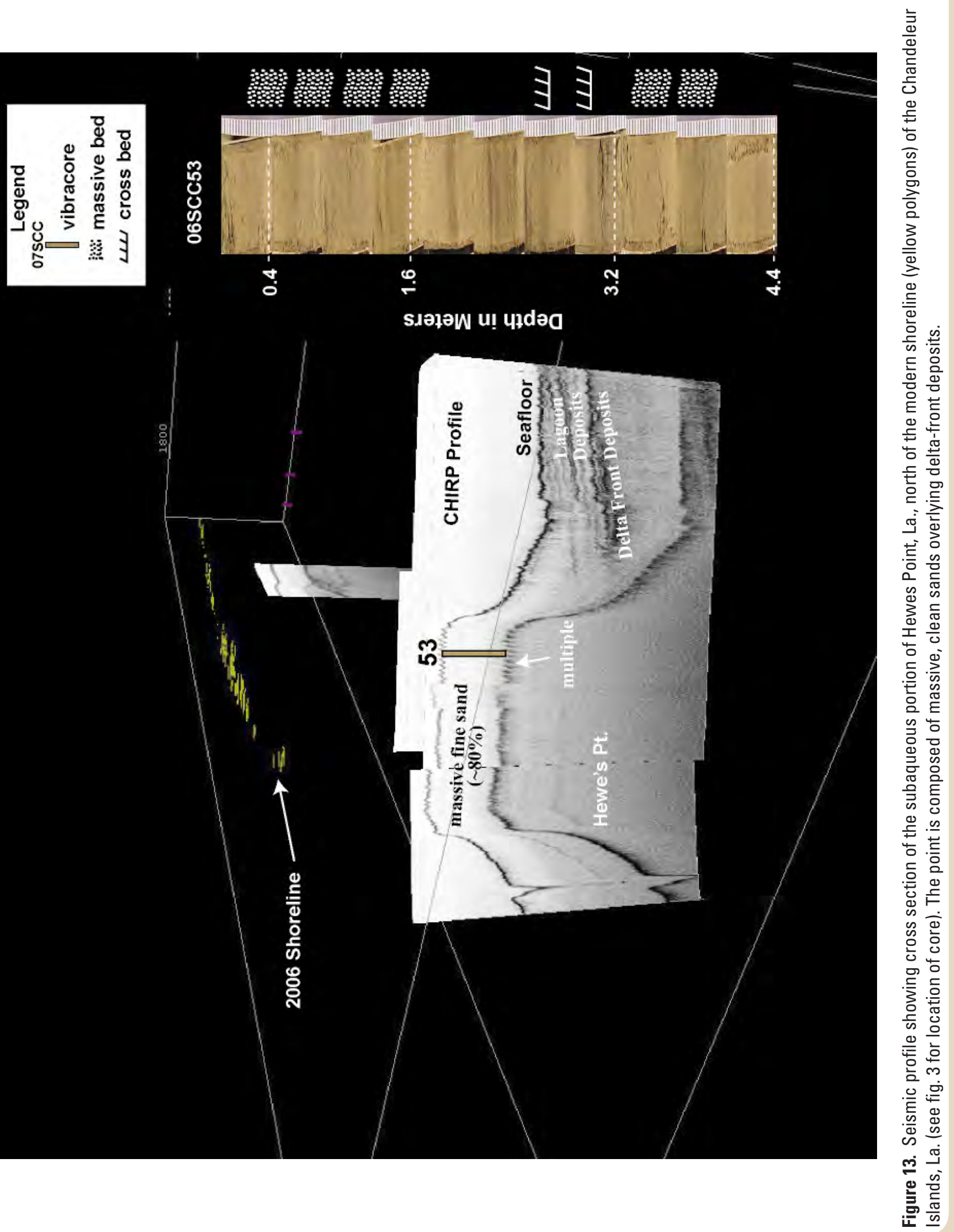

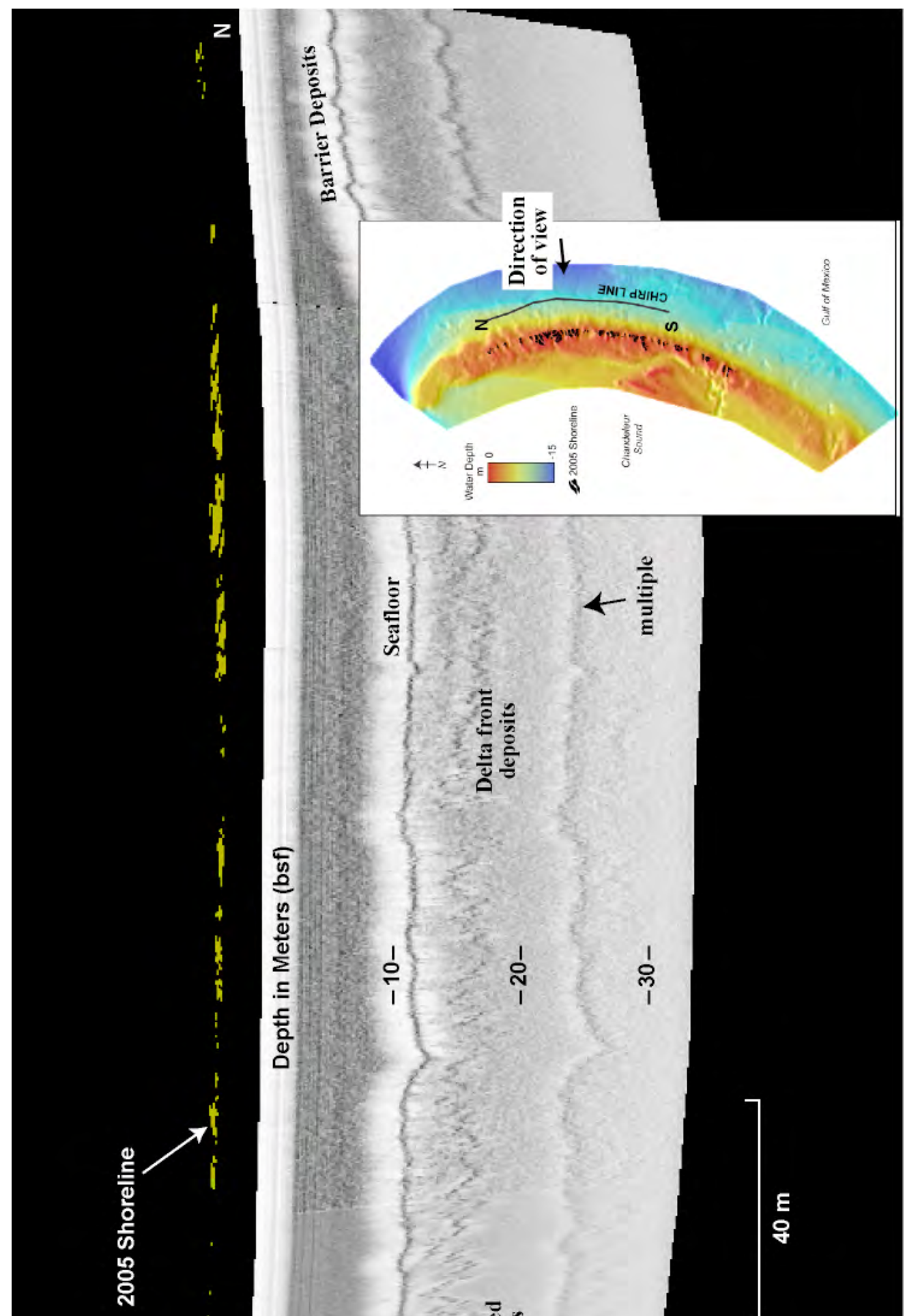

$$
4 \frac{\frac{0}{E}}{\frac{E}{3}}
$$

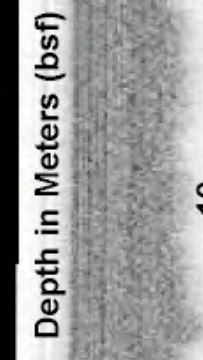

$\infty$

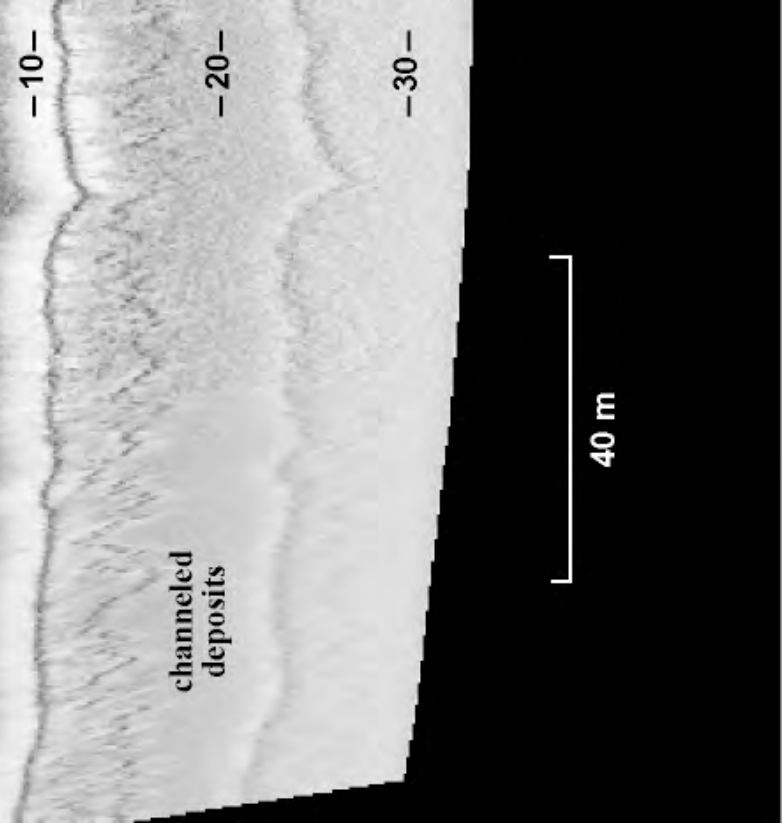

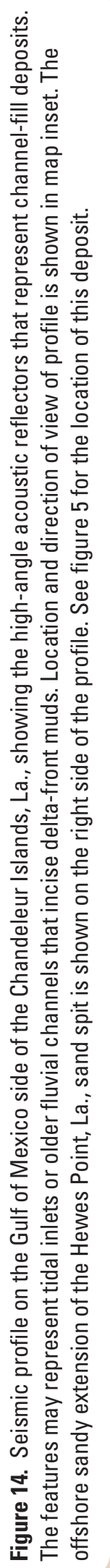




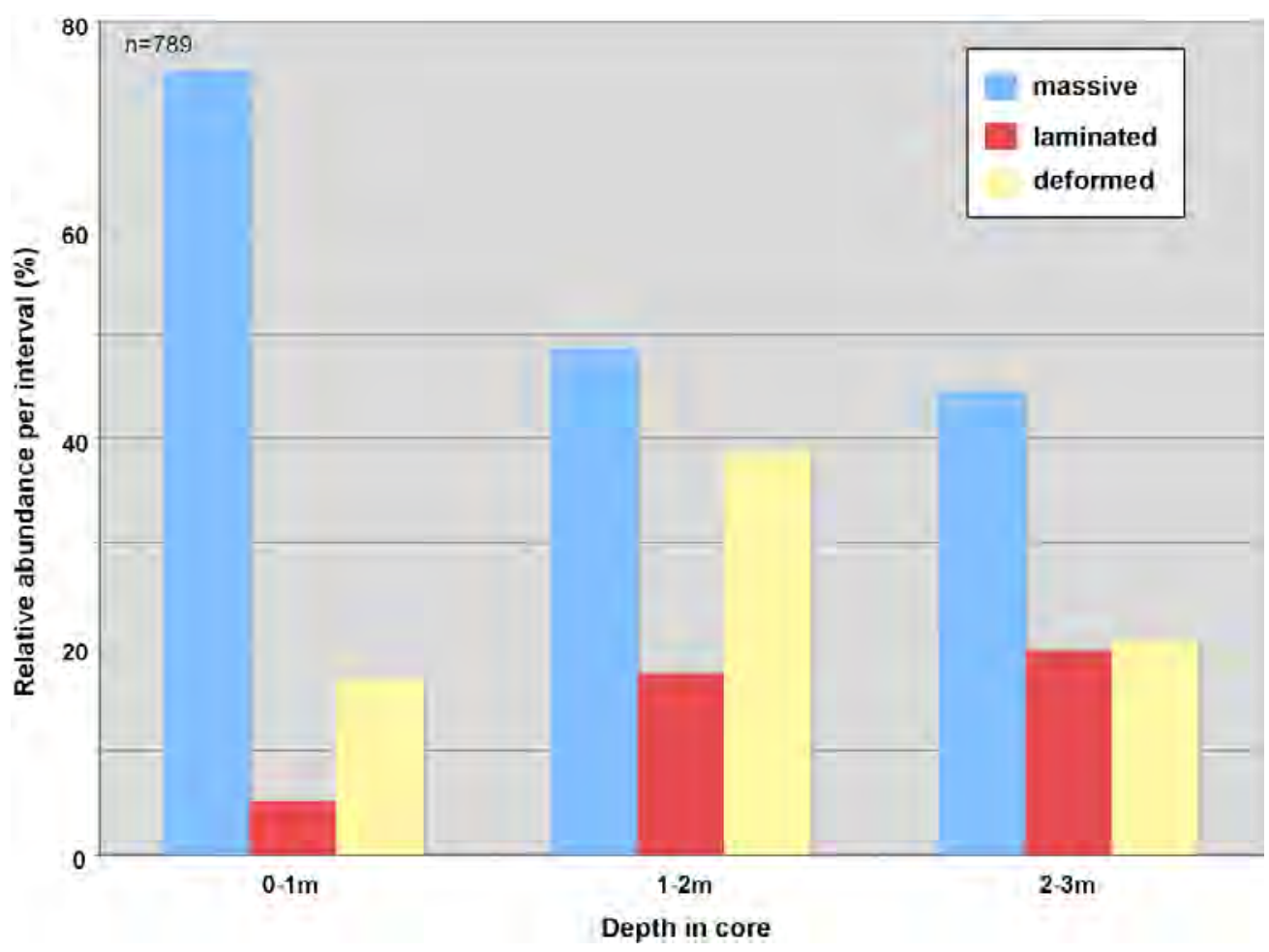

Figure 15. Relative percentages of observed downcore bed type within the tidal/distributary deposit (compiled from 32 cores) in the Chandeleur Islands, La., study area.
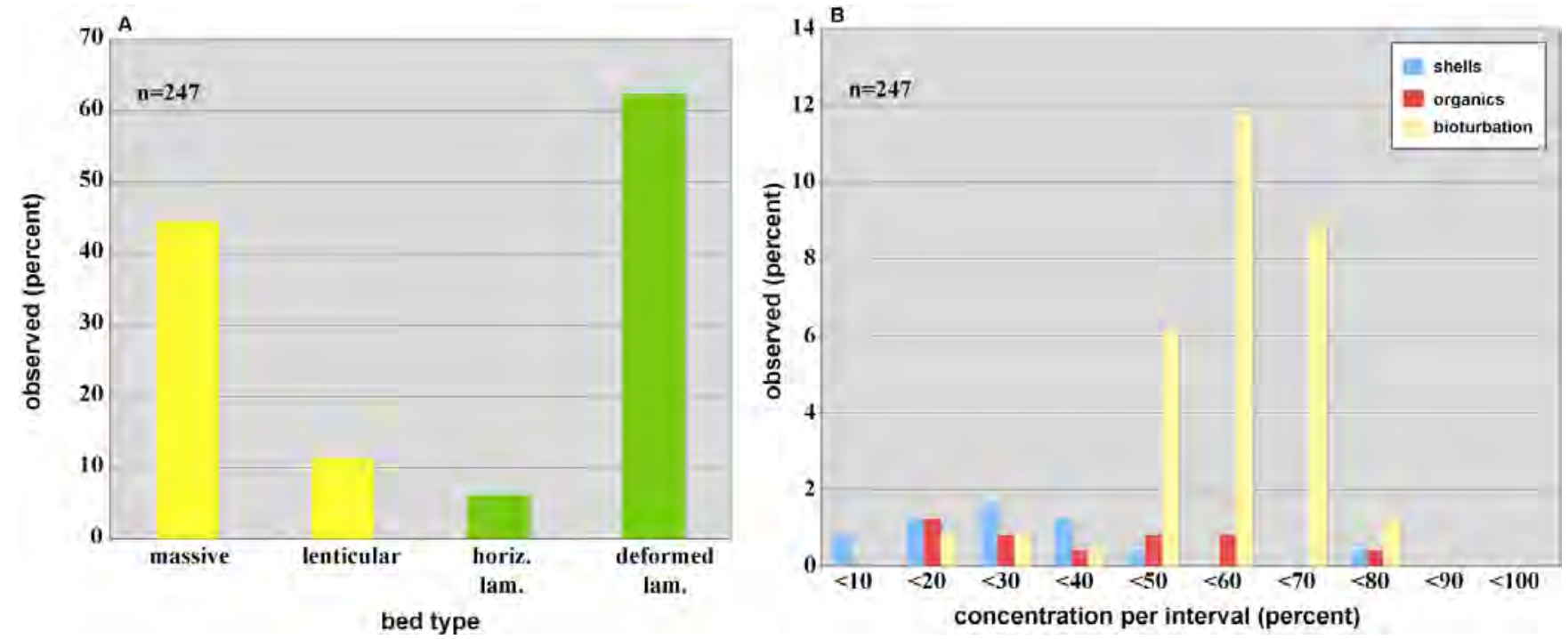

Figure 16. Relative percentages of observed bed type and texture content within the backbarrier deposits in the Chandeleur Islands, La., study area. $A$, Bed type. $B$, Texture content. Deposits contain massive or deformed bedding, and 73 percent of the deposit contains intense bioturbation (50-70 percent). Horiz., horizontal; lam., laminated. 
grained backbarrier deposits, with an increase in shell content upcore (fig. 17). Shell material is typically concentrated in distinct lags, and bioturbation is common (fig. 16B). Although average sand content exceeds 50 percent, the mixed nature of these deposits (table 2) makes it difficult to obtain a suitable texture similar to that of the barrier platform for renourishment purposes.

Mainland of the islands, thin discontinuous sheets of sand occur at the surface, adjacent to breaches in the barrier chain. These deposits are typically less than $0.5 \mathrm{~m}$ thick and rest unconformably on backbarrier, barrier platform, and distributary deposits. The positions of these features indicate that they are overwash deposits from storm events or are flood tide delta deposits (fig. 5). On average the sheets consist of 79 percent very fine sand and are moderately sorted (table 2). These thin and laterally discontinuous features are not favorable sand sources, and their removal may affect inlet dynamics and interfere with natural breach-closing processes.

\section{Sea Floor Sediments}

Wave and current-driven processes mobilize sediment in the nearshore. The texture and grain size of the available sediment influence the extent of littoral transport and shoreface erosion. Thus, to understand the present dynamics of a barrier island system, accurate characterization of the top $1 \mathrm{~m}$ of sediment is necessary. Most of the cores collected adjacent to the islands contain a layer of sand at the surface. In core 07SCC_02 (fig. 18), as much as $1 \mathrm{~m}$ of sand rests unconformably on delta-front muds with a shell lag between the two facies. In other areas this surface sand layer is less than $30 \mathrm{~cm}$ thick. A ternary plot of the sand/silt/clay ratios from all of the core tops (less than $1 \mathrm{~m}$ depth) shows the predominance of sand, with a slightly wider distribution of grain size in some of the intervals with increasing depth (fig. 19). The ternary distributions show an increase in sand content with decreasing water depth, decreasing sample depth, and distance north. Average sand content of the top $1 \mathrm{~m}$ of cores collected is almost 73 percent (table 2).

Average grain size and sand content in the upper $1 \mathrm{~m}$ of sediment are shown in figure 20. Fine sand is prevalent in the surface adjacent to the subaerial portions of the islands, with a transition to silt-size sediments within $1 \mathrm{~km}$ offshore. Sorting values also follow this pattern, with moderately to well-sorted sediments adjacent to the shoreline and moderately to poorly sorted sediments offshore. Surface sediments behind
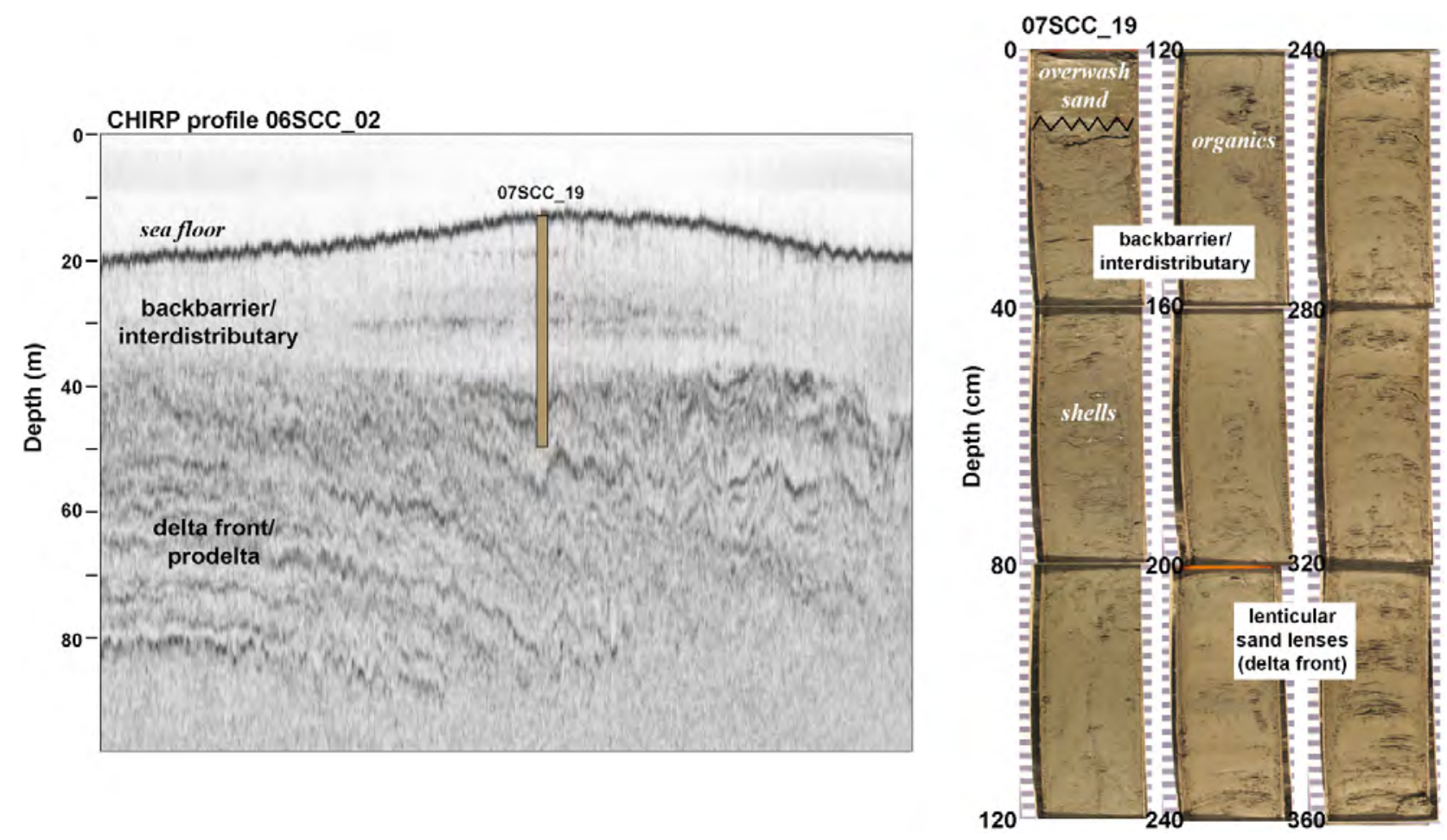

Figure 17. $A$, CHIRP profile showing vertical transition from prodelta to backbarrier deposits on the bay side of the Chandeleur Islands, La. (see fig. 3 for location of core). B, Although acoustically distinct, vibracore 07SCC_19 shows only subtle textural transition from lenticular in a clay matrix (delta front), overlain by laminated muds with organics and increasing shell content (interdistributary/ backbarrier). 


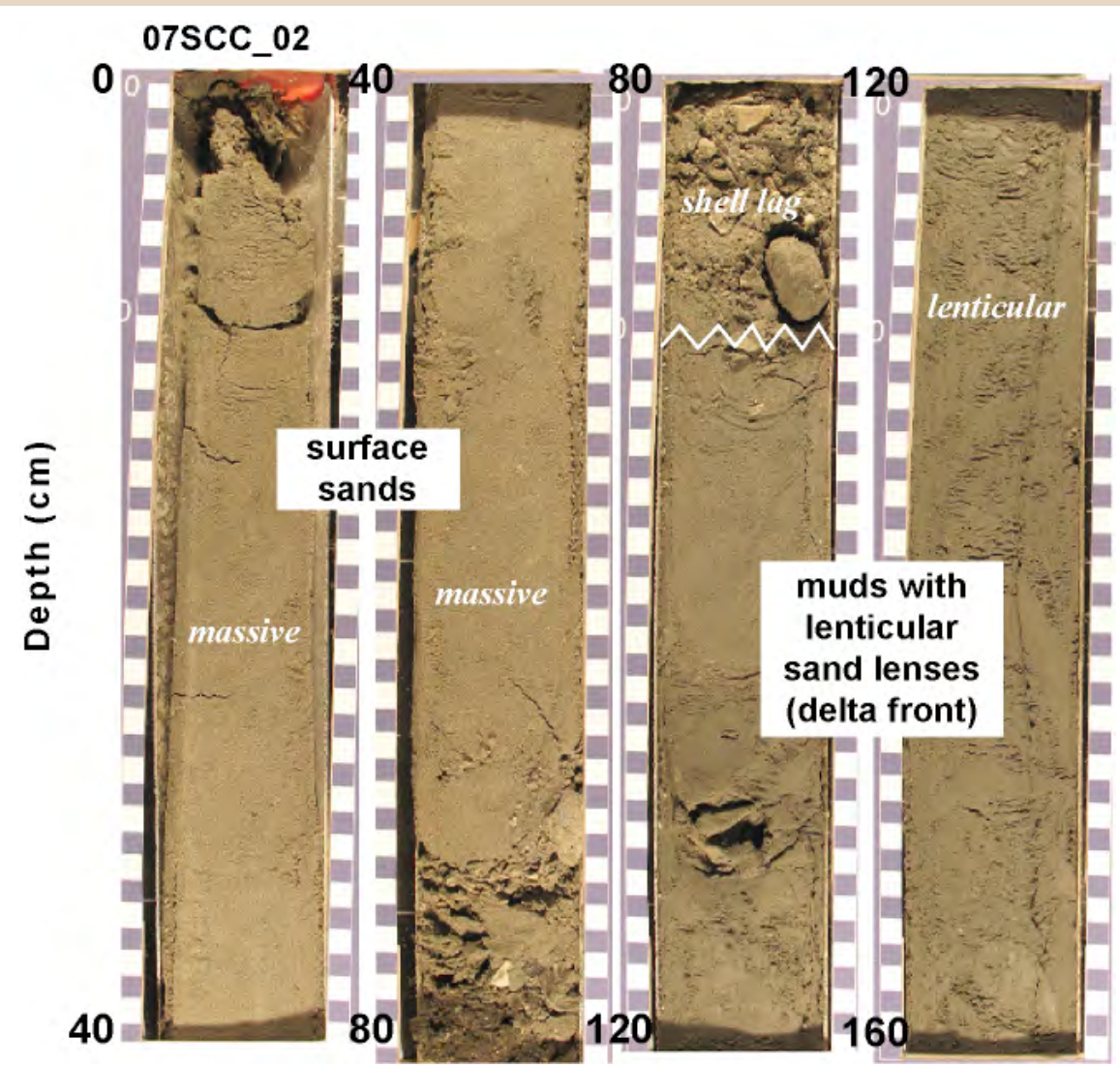

Figure 18. Top $1.6 \mathrm{~m}$ of vibracore $07 \mathrm{SCC} 02$ showing a shell lag overlain by $1 \mathrm{~m}$ of massive sand. Location of core is shown in figure 3 .
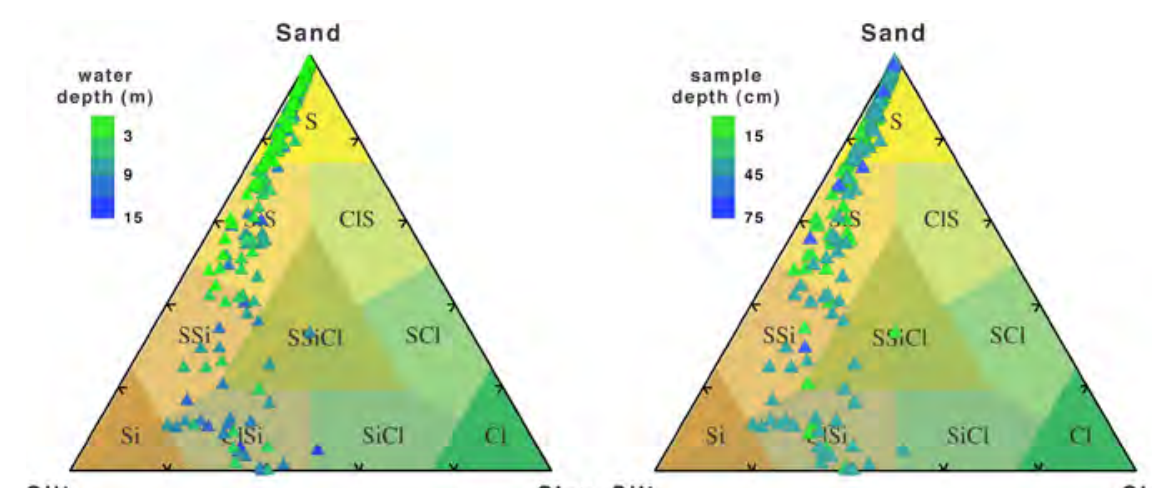

Clay Silt

Clay Silt

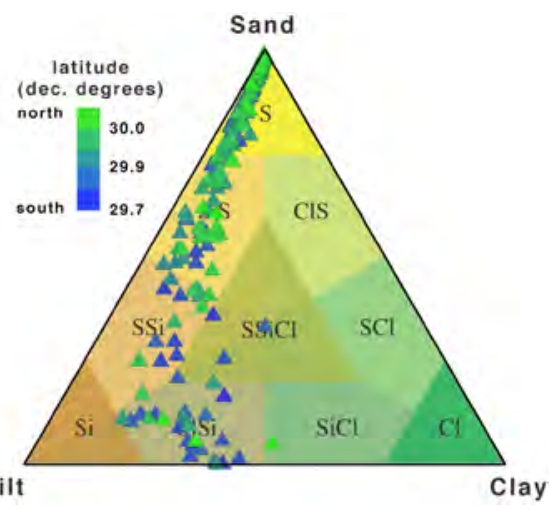

Figure 19. Ternary plots of sand (S)/silt (Si)/clay (CI) ratios from the surface intervals (less than $1 \mathrm{~m}$ ) of all cores collected during this study in the area of the Chandeleur Islands, La. The data points are the same for each ternary plot, but the color shading (blue to green) relates to water depth, sample depth in core, and latitude. Together the ternary plots show that the samples become sandier with decreasing water depth, decreasing sample depth, and increasing latitude (north). 
$\boldsymbol{A}$

B

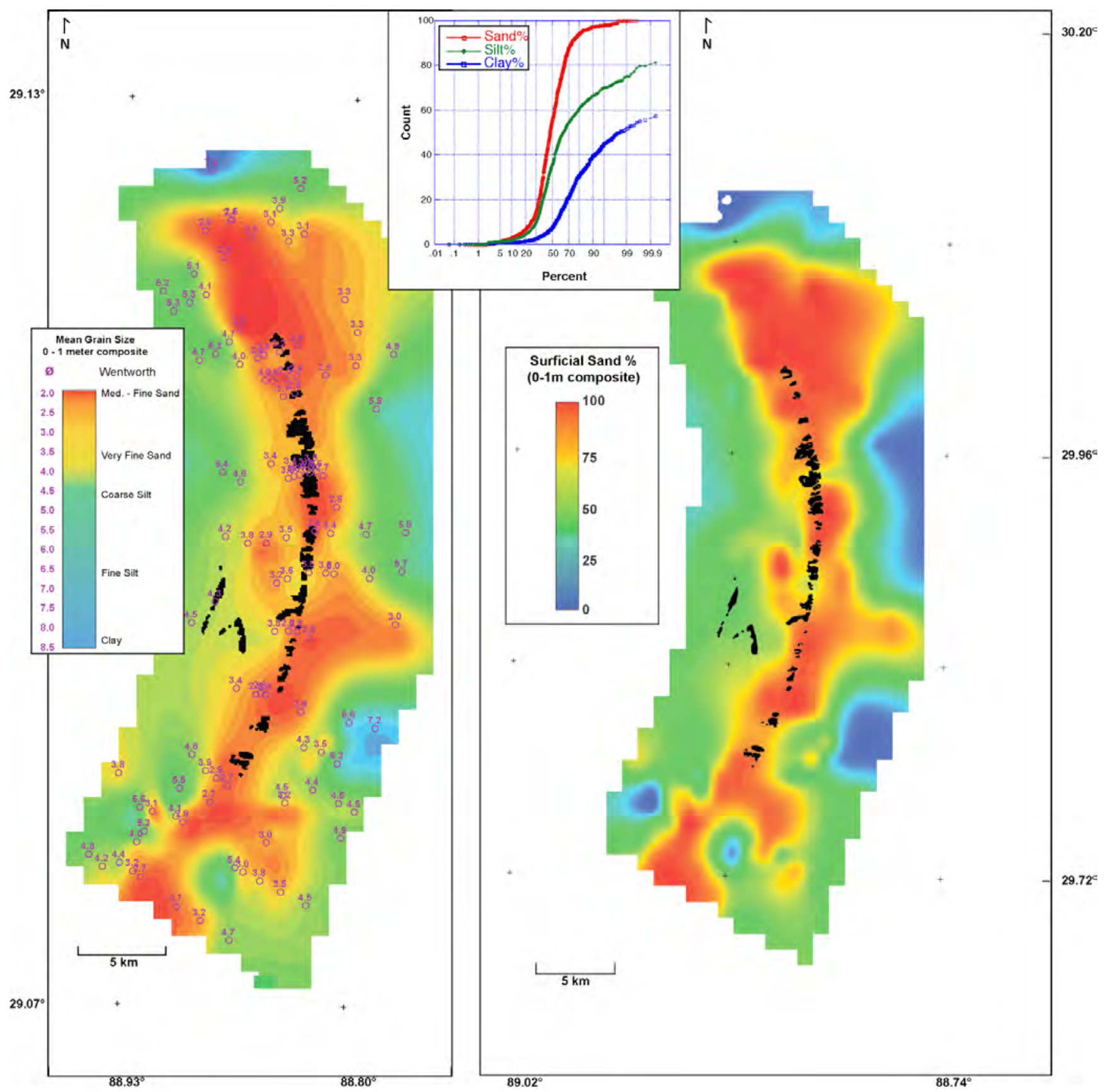

Figure 20. Color-shaded contour plots of the grain size and percent sand for a composite of the top $1 \mathrm{~m}$ of sediment in the Chandeleur Islands, La., study area (islands shown in black). $A$, Mean sediment grain size. $B$, Percent sand. Core locations are shown as circles, annotated with the mean grain size (phi). Grain size and associated Wentworth classification are shown in legend. Cumulative assemblages of sand, silt, and clay are shown in top inset. 
the islands tend to collect more fine-grained material, so their composite distributions are skewed toward the smaller grain size (fig. 21). From south to north, the distribution becomes narrower and more peaked around the sample's median grain size, at the expense of the fine-grained material contained in the tail of the distribution. This pattern results from the littoral process removing fine-grained material from the system as it reworks and transports the sediments from south to north.

\section{Potential Borrow Sites}

Through the interpretation and analysis of the seismic and sediment core data, six potential borrow sites have been identified offshore (see fig. 15 in chap. E); these sites contain sediment resources of suitable sand content and texture to replenish sand lost from the system through littoral transport and storm impact. These deposits include older, buried

A. Surface skewness

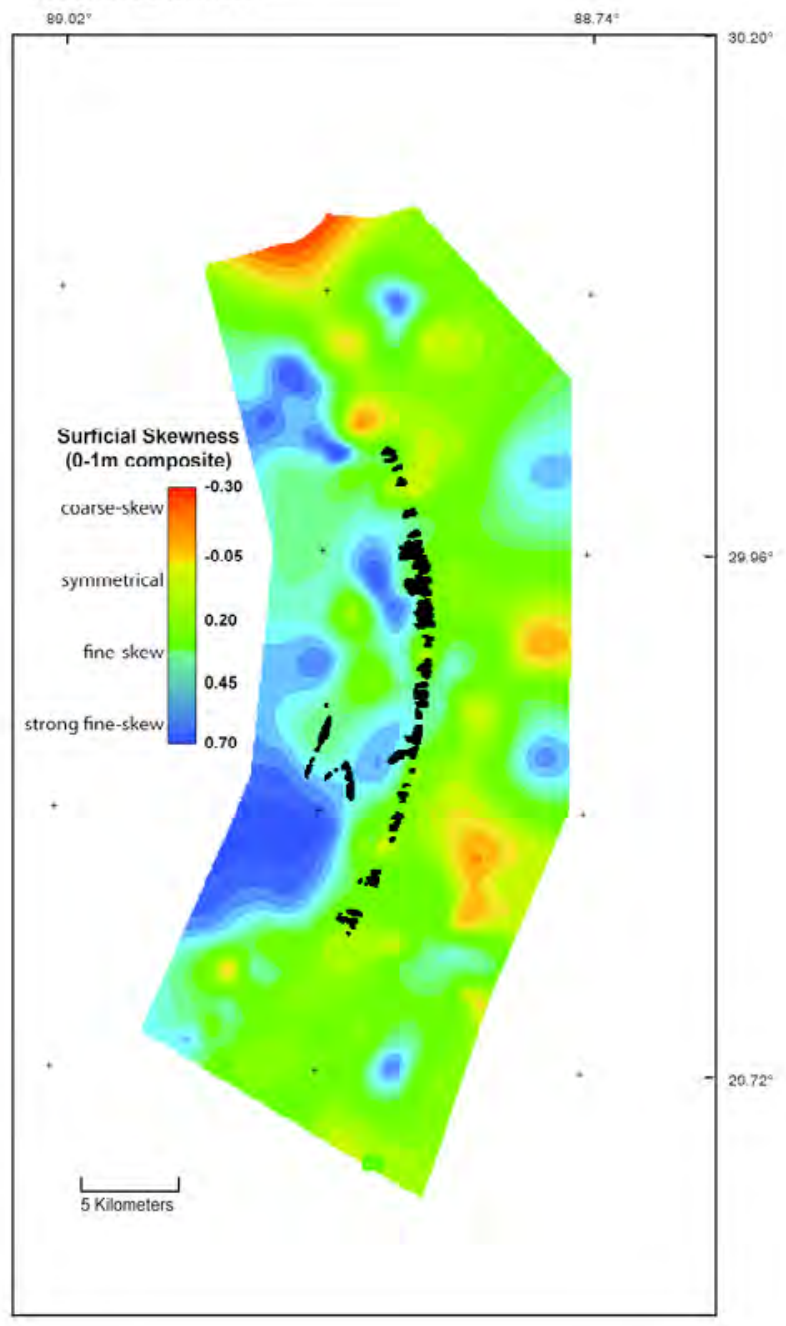

B. Surface kurtosis

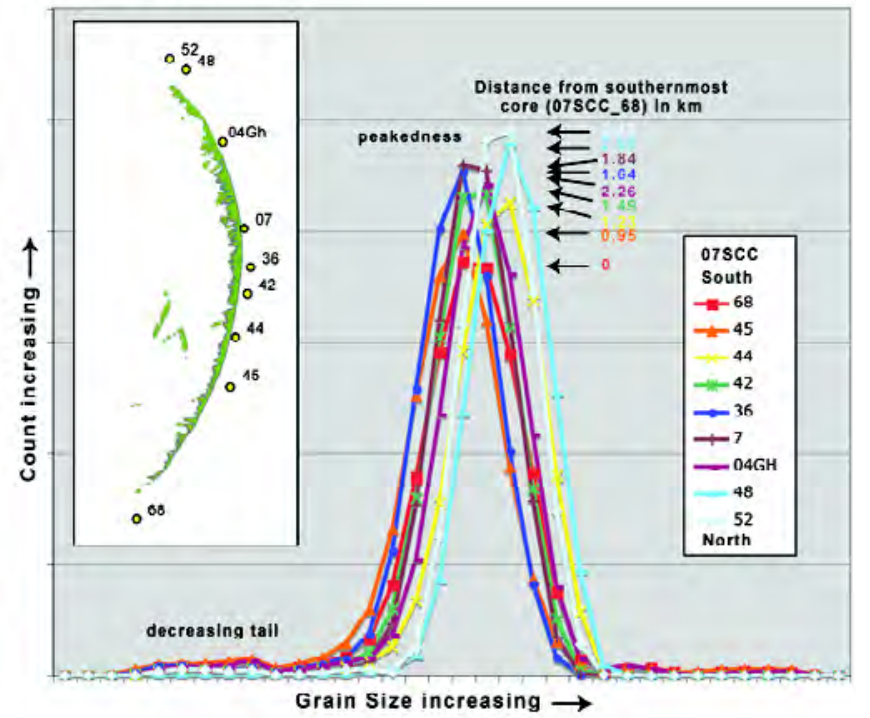

Figure 21. Sediment sorting of the barrier islands deposits. $A$, Color-shaded contour plot of skewness values for the composite top $1 \mathrm{~m}$ of sediment. Skewness is a measure of the grain-size distribution in a sample that reflects departure from the mean grain size. The plot shows that the surface sediments behind the island chain have increased fine-grained components. $B$, Plots of grain-size distribution in the upper $1 \mathrm{~m}$ of cores located along the front side of the barrier island chain (locations shown inset). Kurtosis reflects distribution of sediment grain size around the mean. The grain-size distributions in the samples decrease in variability around the mean grain size progressively northward in the transect (the curves become more peaked). The plot shows that the surface samples are increasingly sorted northward in the transect at the expense of the fine-grained material. 
distributary sands and modern transgressive sand sinks. The units are end-members of the littoral process that developed and maintains the barrier island system. The deposits described earlier in this chapter include distinct units between 1 and $4 \mathrm{~m}$ thick. The following descriptions include wholecore composites of samples collected from these sites since selective removal of sandy material for restoration purposes would be difficult.

\section{Hewes Point Sands}

The prograding spit and offshore sand deposit include the highest sand content in the study area, and arguably in the Mississippi River Delta Plain. These sands are well sorted and clean of organics and shell material. This deposit is the result of littoral processes transporting material across the barrier island platform and as such is similar material to what is found on the shoreface. Sediment cores collected from this deposit ranged from 3 to $5 \mathrm{~m}$ in length, although few penetrated the entire unit, and sand estimates exceed $240 \times 10^{6} \mathrm{~m}^{3}$.
Whole-core composites contain an average of 69 percent sand (table 3), which is much lower than the center of the deposit (table 2) because some of the cores on the flank penetrate underlying prodelta units.

\section{Distributary Sands}

The distributary units are identified as potential borrow sites because of their spatial extent, proximity to the surface, and high sand content. These deposits are the source of sand found along the shoreface of the islands and are suitable material for renourishment. Unlike the Hewes Point deposits, however, these sediments contain a mix of sands and muds associated with fluvial and marine infilling of the incised channels. The grain-size statistics of the deposits based on whole-core composites are classified as moderately sorted fine sand to clay (table 3). Massive-bedded sands occur more often mid-depth in the unit (fig. 22). Sand content within this interval (2-4 mbsf) exceeds 60 percent (fig. 22).

Table 3. Physical characteristics of deposits in the Chandeleur Islands, La., study area that have sand resource potential.

[Results are whole-core composites and contain samples from stratigraphy above and below the deposit. Physical characteristics of the isolated deposits are shown in table 2. dd, decimal degrees; $\mathrm{m}$, meters; mbsf, meters below sea floor; mm, millimeters]

\begin{tabular}{|c|c|c|c|c|c|c|c|c|}
\hline $\begin{array}{c}\text { Deposit } \\
\text { (no. of samples) }\end{array}$ & & $\begin{array}{l}\text { Longitude } \\
\text { dd }\end{array}$ & $\begin{array}{l}\text { Latitude } \\
\text { dd }\end{array}$ & $\begin{array}{l}\text { Water depth } \\
\text { (m) }\end{array}$ & $\begin{array}{l}\text { Core length } \\
\qquad(\mathrm{m})\end{array}$ & $\begin{array}{l}\text { Sample depth } \\
(\mathrm{m})\end{array}$ & \multicolumn{2}{|c|}{$\begin{array}{l}\text { Relative depth } \\
\text { (mbsf) }\end{array}$} \\
\hline Hewes Point & minimum & -88.88902 & 29.99058 & 4.1 & 3.0 & 0.0 & \multicolumn{2}{|c|}{7.1} \\
\hline (79) & maximum & -88.79880 & 30.07000 & 9.8 & 4.9 & 4.8 & \multicolumn{2}{|c|}{14.7} \\
\hline & average & -88.84472 & 30.04498 & 7.0 & 4.3 & 2.1 & \multicolumn{2}{|c|}{9.1} \\
\hline Distributaries & minimum & -88.89954 & 29.69943 & 4.0 & 3.3 & 0.0 & \multicolumn{2}{|c|}{7.3} \\
\hline (81) & maximum & -88.80237 & 29.79908 & 11.0 & 5.5 & 5.4 & \multicolumn{2}{|c|}{16.5} \\
\hline & average & $\mathbf{- 8 8 . 8 4 1 4 7}$ & 29.74560 & 8.8 & 4.5 & 2.1 & \multicolumn{2}{|c|}{10.9} \\
\hline $\begin{array}{c}\text { Deposit } \\
\text { (no. of samples) }\end{array}$ & & $\begin{array}{c}\text { Mean } \\
\text { grain size } \\
\text { phi (mm) }\end{array}$ & $\begin{array}{l}\text { Wentworth } \\
\text { classification }\end{array}$ & $\begin{array}{c}\text { Sorting } \\
\text { (folk) } \\
\text { phi }\end{array}$ & $\begin{array}{l}\text { Sorting } \\
\text { classification }\end{array}$ & $\begin{array}{l}\text { Sand } \\
(\%)\end{array}$ & $\begin{array}{l}\text { Silt } \\
(\%)\end{array}$ & $\begin{array}{l}\text { Clay } \\
(\%)\end{array}$ \\
\hline Hewes Point & minimum & $7.7(0.05)$ & Very fine silt & 2.21 & Very poorly sorted & 0.9 & 0.0 & 0.0 \\
\hline \multirow[t]{2}{*}{ (79) } & maximum & $2.3(0.20)$ & Fine sand & 0.21 & Very well sorted & 100.0 & 68.9 & 45.6 \\
\hline & average & $4.0(0.06)$ & Very fine sand & 0.58 & Moderately well sorted & 69.5 & 21.7 & 8.7 \\
\hline \multirow{3}{*}{$\begin{array}{l}\text { Distributaries } \\
\text { (81) }\end{array}$} & minimum & $8.2(<0.01)$ & Clay & 1.72 & Poorly sorted & 0.0 & 1.6 & 0.5 \\
\hline & maximum & $2.6(0.15)$ & Fine sand & 0.25 & Very well sorted & 97.9 & 79.9 & 55.0 \\
\hline & average & $5.7(0.02)$ & Medium silt & 0.94 & Moderately sorted & 31.3 & 46.3 & 22.4 \\
\hline
\end{tabular}




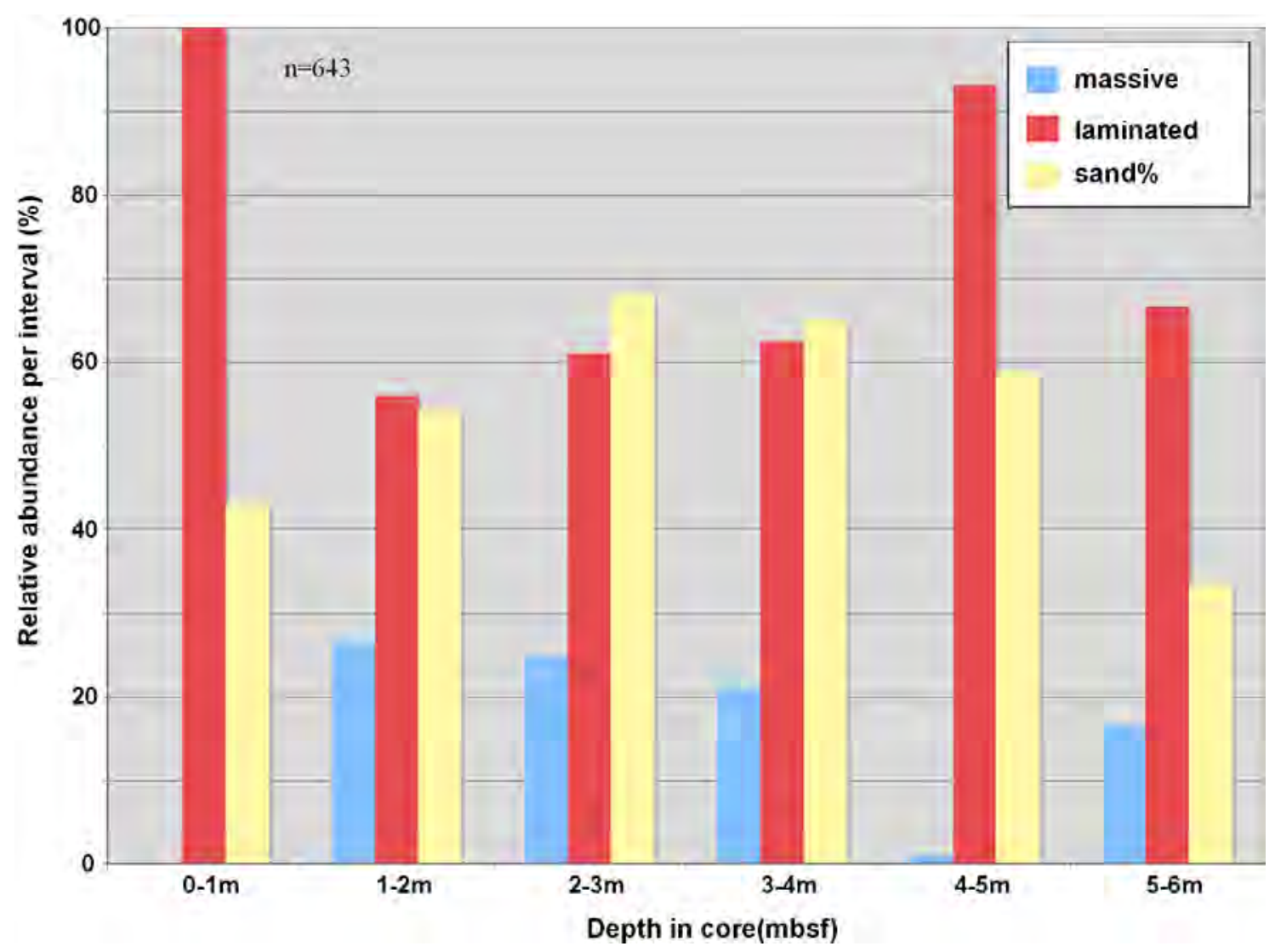

Figure 22. Distribution of bed type and sand content within the distributary deposit showing that sands are not uniformly distributed within the unit but are concentrated in massive and laminated beds $2-4 \mathrm{~m}$ below sea floor.

It should be noted that removal of material from the distributary deposits located adjacent to the islands could potentially alter the hydrodynamic regime by increasing tidal flow across the southern portion of the islands. Further study is necessary to determine how this would affect littoral transport along the barrier island chain.

\section{Acknowledgments}

The U.S. Fish and Wildlife Service, Louisiana Department of Natural Resources, and U.S. Geological Survey provided funding for this project. The authors would like to acknowledge the hard work of personnel from the University of New Orleans (Mike Brown, Phil McCarty, Dallon Weathers) and the U.S. Geological Survey (Nick Ferina, Chandra Dreher, Jordan Sanford, Keith Ludwig, Jackie Smith) who collected, processed, interpreted, and analyzed the sediment cores and samples.

\section{References}

Brooks, G., Kindinger, J., Penland, S., Williams, S.J., and McBride, R., 1995, East Louisiana continental shelf sediments - a product of delta reworking: Journal of Coastal Research, v. 11, no. 4, p. 1026-1036.

Coleman, J., 1982, Deltas — processes of deposition and models for exploration: International Human Resources Development Corporation, $112 \mathrm{p}$.

Flocks, J., 2004, Converting analog interpretative data to digital formats for use in database and GIS applications: USGS Open-File Report, 2004-1070.

Flocks, J., 2006, Revisiting Frazier's subdeltas —enhancing datasets with dimensionality to better understand geologic systems: Gulf Coast Association of Geological Societies Annual Meeting, September 2006, extended abstract. 
Flocks, J., Ferina, N., Dreher, C., Kindinger, J., FitzGerald, D., and Kulp, M., 2006, High-resolution stratigraphy of a recent delta lobe progradation-north-central Gulf of Mexico: Journal of Sedimentary Research, v. 76.

Folk, R., 1968, Petrology of sedimentary rocks: Hemphills Publishing, $170 \mathrm{p}$.

Frazier, D., 1967, Recent deltaic deposits of the Mississippi River - their development and chronology: Transactions of the Gulf Coast Association of Geological Societies, v. 17, p. 287-315.

Inman, D., 1962, Measures for describing the size distribution of sediments: Journal of Sedimentary Petrology, v. 22, p. $125-145$.

Kindinger, J., 1989, Upper Pleistocene to recent shelf and upper-slope deposits of offshore Mississippi-Alabama: GCSSEPM Seventh Annual Research Conference Proceedings, p. 163-174.
Kindinger, J., Balson, P., and Flocks, J., 1994, Stratigraphy of Mississippi-Alabama shelf and Mobile River incisedvalley system: Society for Sedimentary Geology, Special Publication No. 51, p. 83-96.

Penland, S., Boyd, R., and Suter, J., 1988, Transgressive depositional systems of the Mississippi Delta Plain-a model for barrier shoreline and shelf sand development: Journal of Sedimentary Petrology, v. 58, p. 932-949.

Roberts, H., 1997, Dynamic change of the Holocene Mississippi River Delta Plain - the delta cycle: Journal of Coastal Research, v. 13, no. 3, p. 605-627.

Suter, J., Penland, S., Williams, S.J., and Kindinger, J., 1988, Transgressive evolution of the Chandeleur Islands, Louisiana: Transactions of the Gulf Coast Association of Geological Societies, v. 38, p. 315-322. 
Appendix F-1. Core Descriptions (See Index Page To Access Data)

Appendix F-2. Geographic Data (See Index Page To Access Data)

Appendix F-3. Grain Sizes (See Index Page To Access Data) 
Publishing support provided by Lafayette Publishing Service Center 


\section{The St. Bernard Shoals: an Outer Continental Shelf Sedimentary Deposit Suitable for Sandy Barrier Island Renourishment}

By Bryan Rogers and Mark Kulp

Chapter $\mathrm{G}$ of

Sand Resources, Regional Geology, and Coastal Processes of the Chandeleur Islands Coastal System: an Evaluation of the Breton National Wildlife Refuge

Edited by Dawn Lavoie

In cooperation with the U.S. Fish and Wildlife Service

Scientific Investigations Report 2009-5252 


\title{
U.S. Department of the Interior \\ KEN SALAZAR, Secretary \\ U.S. Geological Survey \\ Marcia K. McNutt, Director
}

\section{U.S. Geological Survey, Reston, Virginia: 2009}

\author{
This and other USGS information products are available at http://store.usgs.gov/ \\ U.S. Geological Survey \\ Box 25286, Denver Federal Center \\ Denver, C0 80225 \\ To learn about the USGS and its information products visit http://www.usgs.gov/ \\ 1-888-ASK-USGS
}

\begin{abstract}
Any use of trade, product, or firm names is for descriptive purposes only and does not imply endorsement by the U.S. Government.

Although this report is in the public domain, permission must be secured from the individual copyright owners to reproduce any copyrighted materials contained within this report.
\end{abstract}

Suggested citation:

Rogers, B., and Kulp, M., 2009, Chapter G. The St. Bernard Shoals—an outer continental shelf sedimentary deposit suitable for sandy barrier island renourishment, in Lavoie, D., ed., Sand resources, regional geology, and coastal processes of the Chandeleur Islands coastal system —an evaluation of the Breton National Wildlife Refuge: U.S. Geological Survey Scientific Investigations Report 2009-5252, p. 125-142. 


\section{Chapter G. The St. Bernard Shoals: an Outer Continental Shelf Sedimentary Deposit Suitable for Sandy Barrier Island Renourishment}

By Bryan Rogers ${ }^{1}$ and Mark Kulp ${ }^{1}$

\section{Abstract}

The St. Bernard Shoals are a group of 61 individual subaqueous sand bodies $25 \mathrm{~km}$ southeast of the Chandeleur Islands, La. The shoals are estimated to contain $200 \times 10^{6}$ $\mathrm{m}^{3}$ of fine-grained, well-sorted, moderate yellowish brown sandy sediment. Individual shoals consist of as mush as 97 percent quartz sand. The shoals are the result of transgressive reworking of St. Bernard Delta distributary channels and have sedimentary characteristics similar to other beach sands and shoal deposits in the Mississippi River Delta. Two separate datasets were used to establish the sedimentary framework of the St. Bernard Shoals. The first of these datasets, which consists of subbottom seismic profiles and vibracores, was acquired in 1987 to characterize the stratigraphic architecture of the eastern Louisiana shelf. The other dataset was obtained in the summer of 2008 to update previous interpretations by using modern surveying technology and to establish whether the shoals had undergone any major modifications during the intervening 20-year lapse of investigations. The 2008 dataset consists of seismic profiles, side scan imagery, and sea floor grab samples. The 2008 seismic and side scan data show a sea floor morphology that is suggestive of large-scale erosional reworking but reveal a shoal system that has not substantially migrated since the 1980s. The St. Bernard Shoals have a sedimentary texture that is similar to that of the Chandeleur Islands, making them an ideal borrow site for renourishment of the Chandeleur Island system.

\section{Introduction and Background}

There are four widely spaced, shore-parallel shoals (subaqueous sand bodies) on the Louisiana continental shelf (Fisk, 1944; Kolb and Van Lopik, 1958; Ludwick, 1964; Frazier, 1967). These sandy sedimentary bodies are found beyond the edge of the modern subaerial Mississippi River

\footnotetext{
${ }^{1}$ University of New Orleans, Pontchartrain Institute for Environmental Sciences, New Orleans, La.
}

Delta marshes and barrier islands and form the modern sea floor where they are located (fig. 1). These shoals are as much as $6 \mathrm{~m}$ thick and locally consist of as much as 100 percent fine to very fine grained sand. One of these shoal systems, known as the St. Bernard Shoals, is located approximately $25 \mathrm{~km}$ southeast of the Chandeleur Islands, La. (fig. 2). As is the case for the other shoals on the Louisiana shelf, the St. Bernard Shoals have been suggested as a sedimentary body that could be mined and used to renourish a deteriorating sandy barrier island system such as the Chandeleur Islands. The purpose of this chapter is to outline the general framework and sedimentary composition of the St. Bernard Shoals and provide an understanding of the potential use of the shoals as renourishment sediment for the Chandeleur Islands.

Many regional studies of stratigraphic relations, deltaic evolution, and Louisiana continental shelf geology have contributed toward a generally acceptable evolutionary model for the Louisiana shelf shoals (for example, Fisk, 1944; Frazier, 1967, 1974; Penland and others, 1988). These models ascribe their formation to transgressive submergence of an abandoned deltaic headland that was formerly active and advancing seaward (Penland and others, 1988; Miner and others, this volume). Kindinger and others (1982), Pope and others (1993), and Brooks and others (1995) completed studies describing in detail the fundamental sedimentology and stratigraphic characteristics of the St. Bernard Shoals. The work by Pope and others (1993) provided a range of sedimentary data necessary to fully evaluate the use of the St. Bernard Shoals as a continental shelf borrow site. The following sections provide an overall summation of previous work regarding the shoals, describe their stratigraphic framework, and provide answers to questions regarding the extent and recent evolution of the shoals.

\section{Methods of Investigation}

Two separate datasets were used to establish the sedimentary framework of the St. Bernard Shoals. The first 


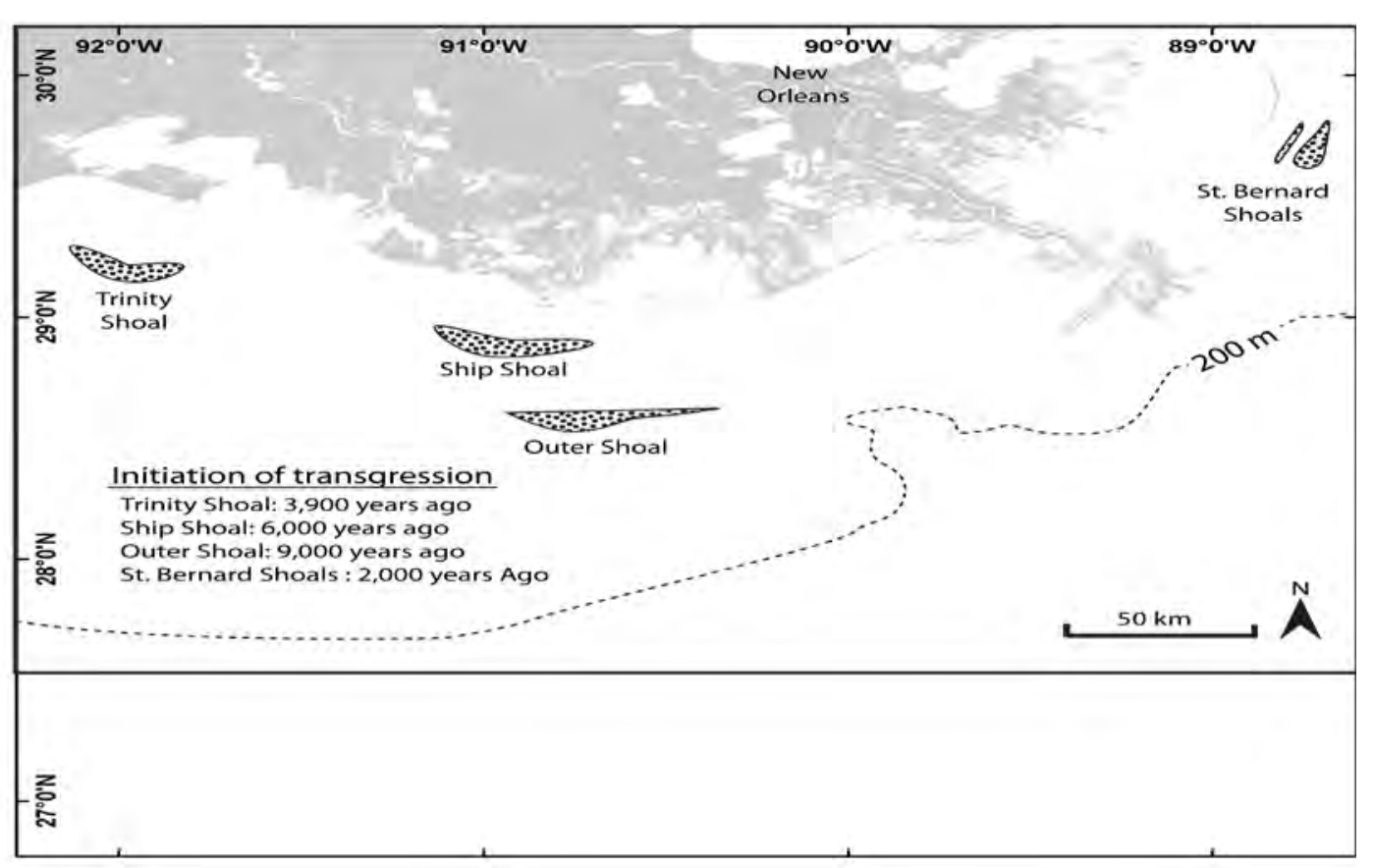

Figure 1. Location of the primary Holoceneage sand shoals on the Louisiana continental shelf. The St. Bernard Shoals represent the distal edge of a depositional platform that was built through progradation of distributaries from the more westward located modern deltaic plain.

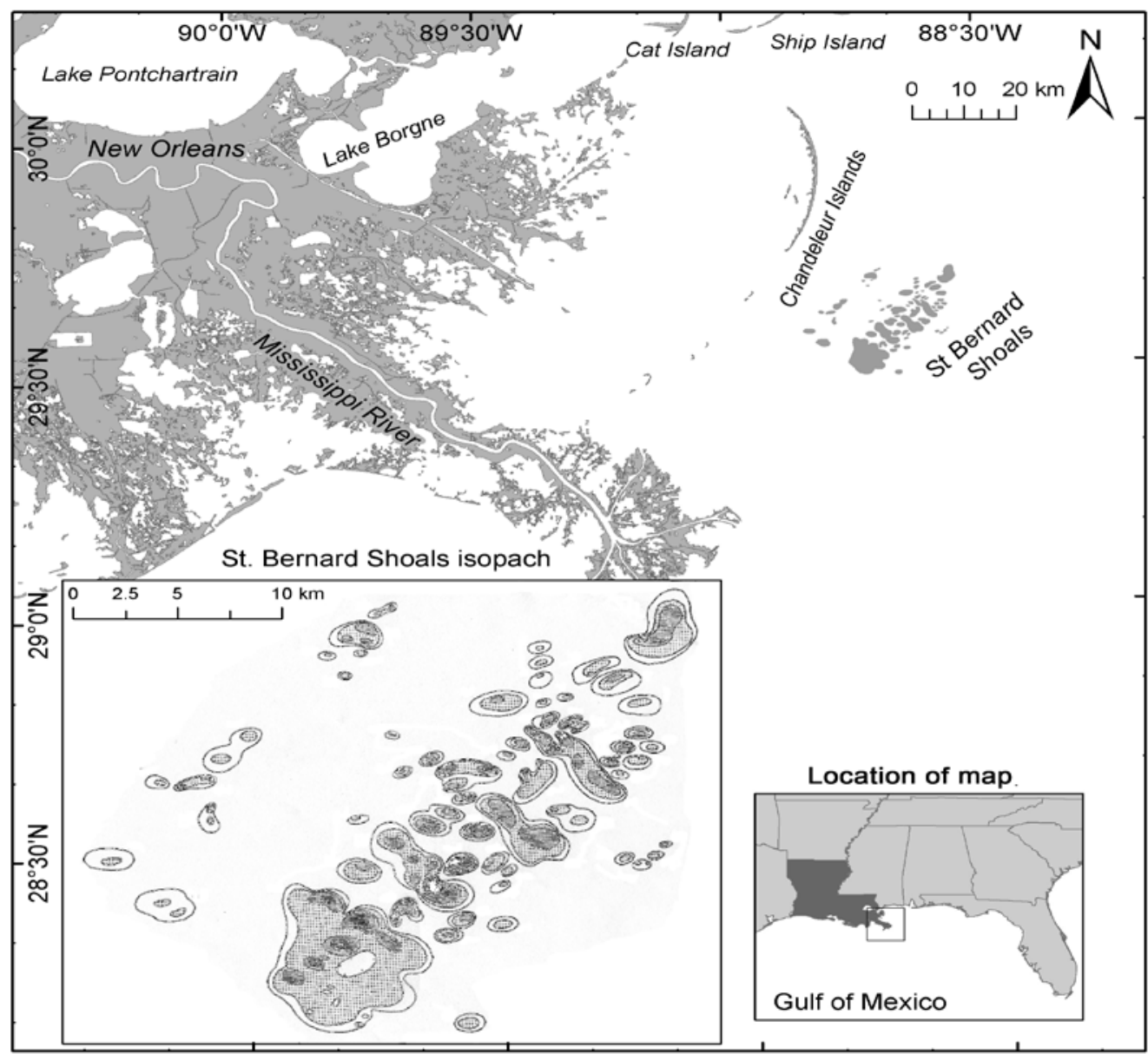

Figure 2. Map of the eastern Louisiana shelf showing the distribution of the St. Bernard Shoals relative to the Chandeleur Islands, La. Shoal contour map is from Pope and others (1993). 
dataset was acquired in the late 1980s. The second dataset was obtained in the summer of 2008 to update previous interpretations by using modern surveying technology and to establish whether the shoals had undergone any major modifications during the intervening 20 years.

\section{Datasets}

The first dataset (herein referred to as the CI-87 dataset) consisted of high-resolution seismic-reflection profiles and vibracores collected in 1987 by the U.S. Geological Survey, in cooperation with the Louisiana Geological Survey and the Louisiana Department of Natural Resources, to investigate shallow geologic framework of the Louisiana-Mississippi shelf (fig. 3). These 1987 seismic profiles were collected by Alpine Ocean Seismic Survey (Norwood, N.J.) from the Louisiana Universities Marine Consortium's $R / V$ Acadiana by using a 5-kHz transducer and a Ferranti Ocean Research Equipment (ORE) Geopulse boomer. Navigation at that time was accomplished by using a Northstar 600 LORAN-C receiver and a Morrow XYP-200 real-time LORAN-C plotter. The original digital seismic data from the survey are no longer available, but a complete analog dataset and the digital navigation data are archived by the University of New Orleans Coastal Research Laboratory. In this study, as in most studies of the Louisiana continental shelf stratigraphy, an acoustic velocity of $1,500 \mathrm{~m} / \mathrm{s}$ was used for determining the depth of stratigraphic units imaged in the seismic-reflection data.

After the completion of the seismic survey in 1987 , vibracores were collected across the eastern Louisiana shelf by Alpine Ocean Seismic Survey from aboard the $M / V$ Blue Streak (fig. 3). Fourteen of the vibracores from the CI-87 dataset were taken in the area of the St. Bernard Shoals and were used by Pope and others (1993) to map the shoals and

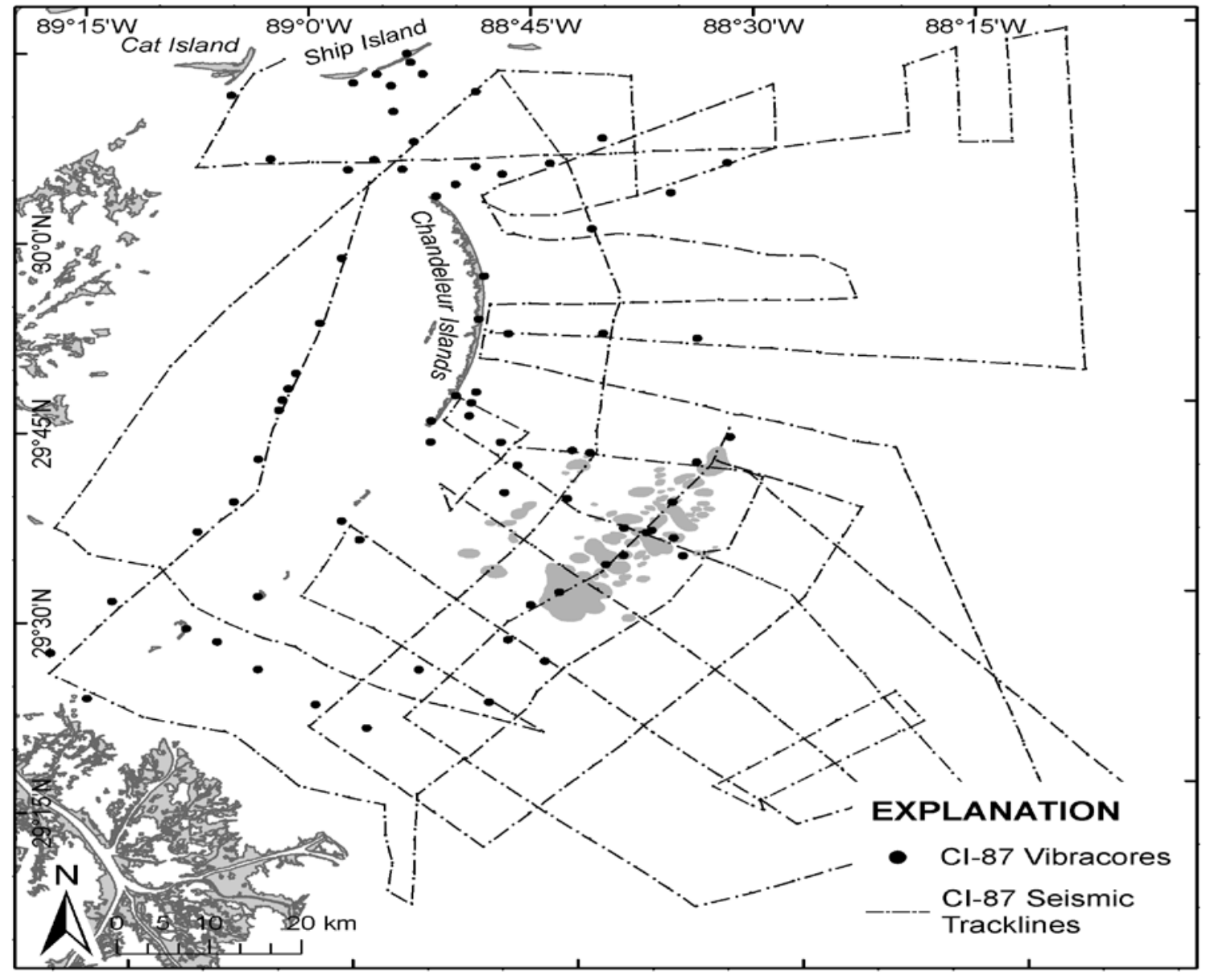

Figure 3. Map showing the distribution of the 1987 seismic tracklines and vibracores collected by the Louisiana Geological Survey on the eastern shelf of Louisiana. The subset of cores used in this study comes from this much larger and expansive 1987 dataset (which is also described in chap. $\mathrm{F}$ of this report). 
describe their sedimentary characteristics. The vibracore barrels used to collect the cores had an outside diameter of $10 \mathrm{~cm}$ and a length of $9 \mathrm{~m}$. Total lengths of the retrieved vibracores ranged between 6 and $12 \mathrm{~m}$. The longest cores were obtained by vibracoring in one 9 -m pipe to completion and then jetting down a second pipe to begin vibracoring where the previous pipe had stopped. A total of 19 sediment samples obtained from the cores were analyzed, and the results were published by Pope and others (1993). Details of the collection methods for all of the 1987 data can be found in Pope and others (1993) and Brooks and others (1995).

\section{Datasets}

A second, less extensive dataset consisting of subbottom seismic profiles, side scan imagery, and eight sea floor grab samples (referred to herein as the SBS-08 dataset [fig. 4]) was collected in the summer of 2008 by the University of New Orleans from aboard the $R / V$ Acadiana. This dataset was collected specifically for the purposes of confirming whether the shoals had changed substantially in form, location, or character since the work completed in the late 1980s, but the data were also used to more fully evaluate the origin and

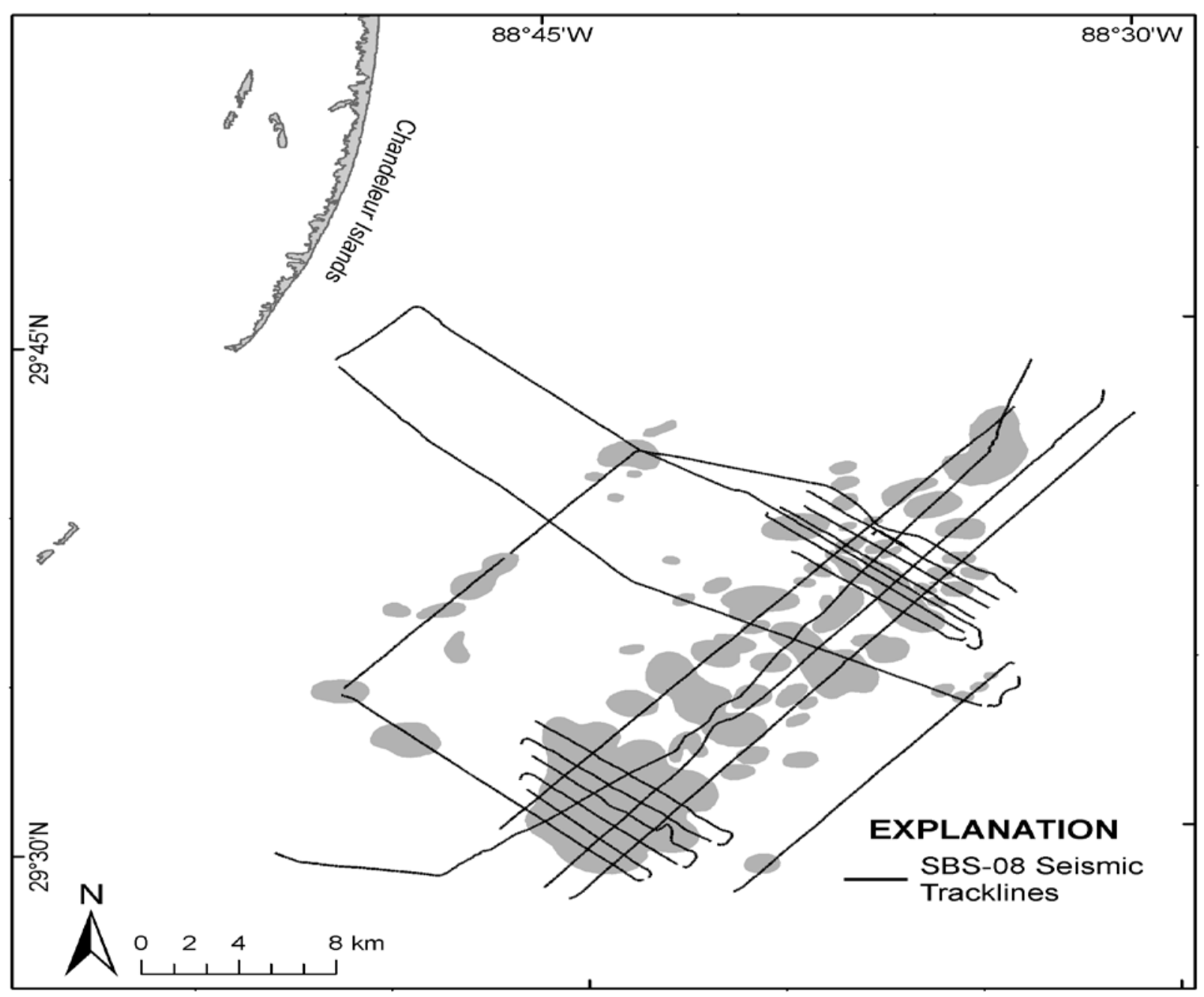

Figure 4. Distribution of the survey tracklines collected for this study by the University of New Orleans during summer 2008 aboard the $R / V$ Acadiana. The tightly clustered tracklines represent runs that were intended to provide greater detail on shoal morphology than that which was available from other datasets. The northward extension of the tracklines was completed to tie together the data of this effort with the 2008 data described in chapter $F$ of this report. 
evolution of the shoals and to link to the datasets of chapter $\mathrm{F}$ in this report. A total of 384 line-km of CHIRP seismic profiles and side scan images were collected by the University of New Orleans in 2008. CHIRP data were collected with an EdgeTech SB-216S towfish (EdgeTech Marine, West Wareham, Mass.) capable of 6-cm vertical resolution. Side scan imagery was collected by using an L-3 Klein Systems 3000 digital side scan sonar (L-3 Communications Klein Associates, Inc., Salem, N.H.) with a frequency range of 25-100 ms. A 200-m horizontal swath of sea floor was imaged. Additionally, eight sea floor samples were collected along an axis of a larger shoal by using a grab sampler. Sites for sediment sampling were selected by analyzing the side scan profiles. Samples were bagged and numbered and returned to UNO for sediment analysis. Grain size and sorting coefficients were determined by using a Beckman Coulter LS200 (Beckman Coulter Inc., Fullerton, Calif.) particle size analyzer. Differential Global Positioning System (DGPS) positioning was acquired by using a Thales dual frequency Z-Max GPS receiver with a $1.00 \mathrm{~s}$ update rate (Thales Navigation, San Dimas, Calif.). Hypack hydrographic survey software (Hypack, Inc., Middletown, Conn.) was used to record navigation and to serve the GPS signal to the CHIRP and side scan systems. CHIRP and side scan software systems recorded the positioning data, which were then imbedded into the data files.

\section{Morphology and Sedimentary Framework of the St. Bernard Shoals}

The St. Bernard Shoals were identified at least as early as 1778 in a British naval survey map of coastal Louisiana and Mississippi (fig. 5). Bathymetric measurements at that time indicated the presence of a crudely defined bathymetric high, relative to the adjacent shelf. Presumably some sea floor sediment sampling completed at that time was the basis for the indication of a sandy sea floor in the location of the bathymetric high (fig. 5). It was not until the middle of the 20th century, however, that the shoals became a topic of scientific inquiry and were recognized for their importance in reconstructing regional geologic evolution and their possible use as sediment for shoreline renourishment projects.

The St. Bernard Shoals are a system of individual shoals that have a common sedimentary framework and origin. The individual shoals rise as much as $4 \mathrm{~m}$ above the surrounding sea floor and sit on a well-defined northeaststriking bathymetric platform that extends from $15 \mathrm{~m}$ to about $20 \mathrm{~m}$ water depth (fig. 6). This bathymetric platform, referred to herein as the "St. Bernard Bathymetric High," covers an area of $530 \mathrm{~km}^{2}$ and is characterized by an irregular internal bathymetry that is a result of the location, morphology, and height of individual shoals on the larger platform. The internal morphology of the St. Bernard Bathymetric High is quite different from that of the other primary shoal platforms of the central and western Louisiana continental shelf. Whereas the other shoal systems are represented by large, shoreparallel elongated bodies of sand that can be continuous for kilometers, the St. Bernard Bathymetric High contains a group of 61 individual discontinuous shoals. Individual shoals within the system range in size from $0.05 \mathrm{~km}^{2}$ to $44 \mathrm{~km}^{2}$. On the basis of individual shoal size, the shoal platform can be differentiated into two well-defined shoal fields. The most expansive set of shoals is located between 16 and $20 \mathrm{~m}$ of water, whereas the smaller shoal field is $5 \mathrm{~km}$ northwest of the larger field in approximately $15 \mathrm{~m}$ of water (fig. 7).

\section{Stratigraphy of the Shoals}

Two stratigraphic cross sections were developed on the basis of sedimentary interpretations presented in the CI-87 vibracore descriptions (fig. 8). These cross sections provide a two-dimensional representation of the stratigraphy and serve to identify the lateral extent of some of the shoals, their thickness, and relations to the underlying stratigraphy. On the basis of the sedimentary characteristics presented in the 1987 vibracore descriptions, five progradational lithofacies were identified in the area: prodelta, delta front, distributary channel, interdistributary bay, and bay fill. Five transgressive lithofacies were also identified, including sand sheet, shoal, barrier shoreface, tidal channel, and tidal delta. The two stratigraphic sections show the distribution of these sedimentary units within the study area (fig. 9). One of the most noticeable features of the shoal stratigraphy is that the shoals are very closely correlated with the distribution of sedimentary facies that are interpreted to be the result of deposition by fluvial channels. As has been previously suggested by Pope and others (1993) and Brooks and others (1995), the close correlation of subsurface distributary channel deposits to the distribution of shoals suggests that the distributary and shoal environments are very closely genetically linked to the longer term evolution of this shelf environment. Frazier (1967) suggested that a lobe of the larger St. Bernard Delta Complex extended into the area of the current St. Bernard Shoals at some time between 2,480 and 1,800 years before present (BP). The character and distribution of sedimentary facies mapped in the area by using vibracores and seismic reflection, along with the chronology of past deltaic depositional events, suggest that the St. Bernard Shoals are the remnants of an abandoned deltaic headland. Since the time of abandonment this headland has been transgressively submerged and reworked by marine processes to create the shoals as they exist today on the continental shelf (see Penland and others, 1988). More details on the chronology of their evolution are presented in Rogers and others (2009). 


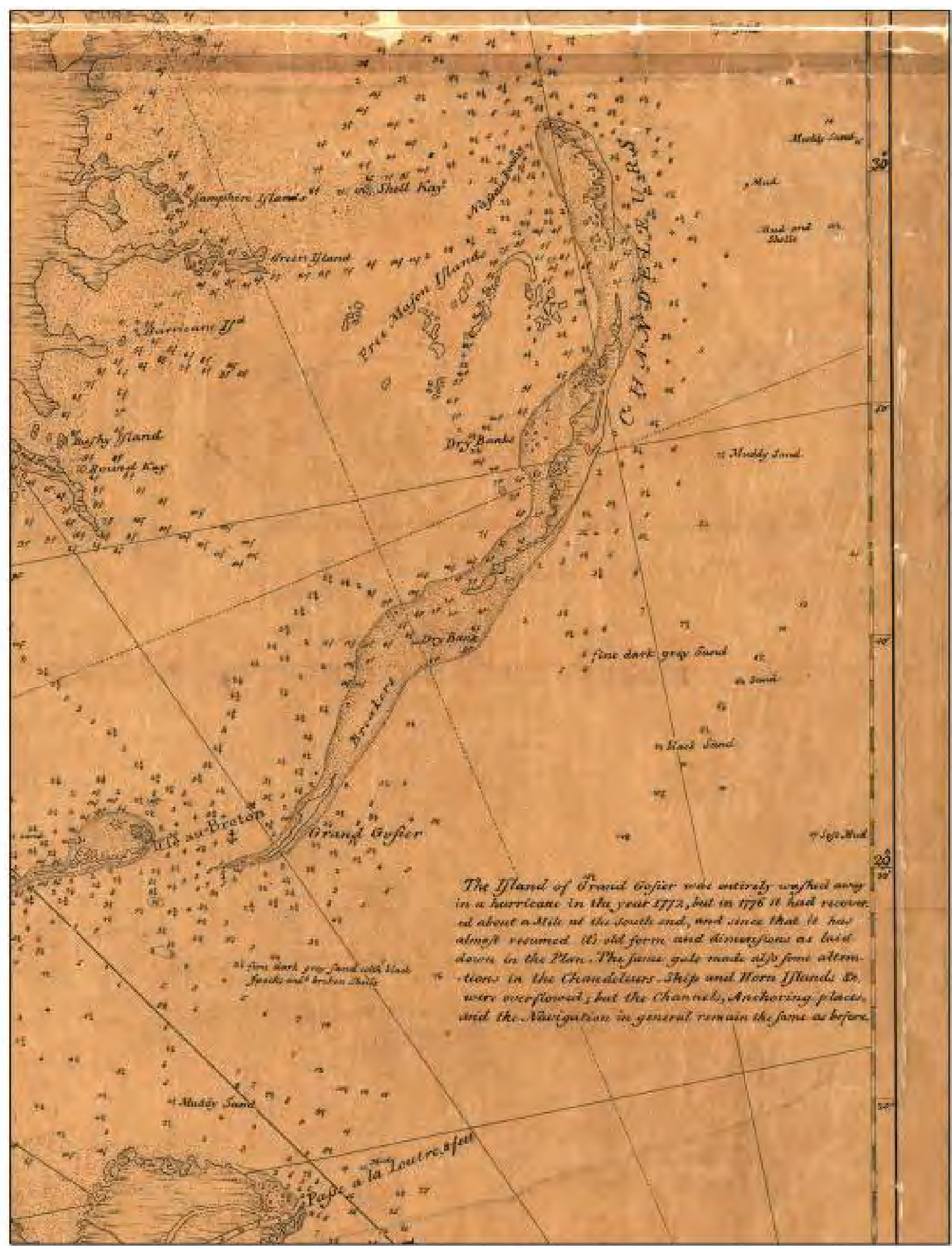

Figure 5. 1778 British naval survey map of the Louisiana coast with depth measurements in fathoms ( 1 fathom $=1.8 \mathrm{~m}$ ). This portion of the map shows the Chandeleur Island, Grand Gosier, Biloxi Marsh, and the St. Bernard Shoals. The shoals are acknowledged by the soundings with labels "Sand" and "Black Sand" southeast of the Chandeleur Islands. 


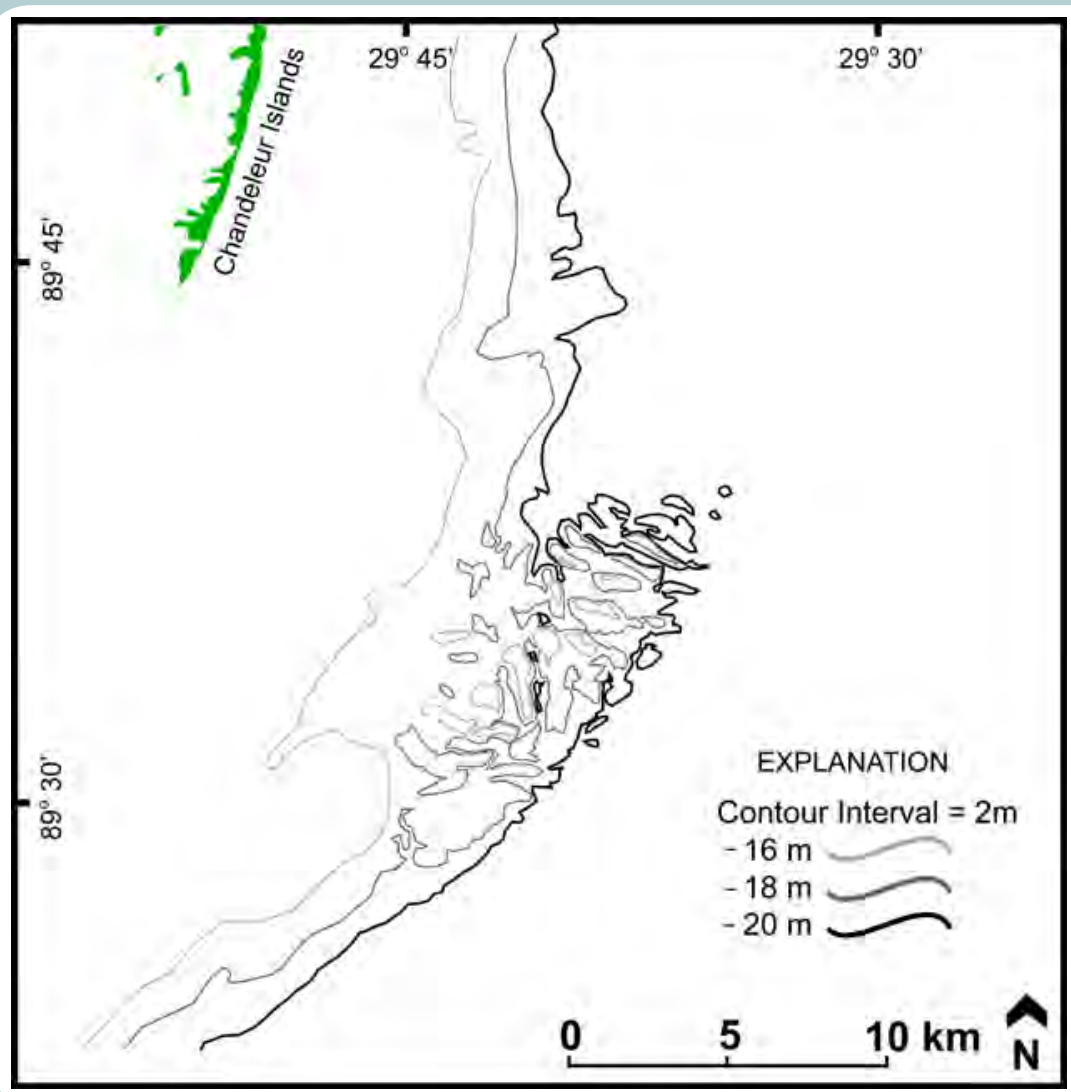

Figure 6. Bathymetry map of the St. Bernard Shoals, La., from 2004. The map shows the St. Bernard Bathymetric High as a platform that is broadly identified by the surrounding $15-$ to $20-\mathrm{m}$ isobaths. Note the irregular morphology of the contours within the bathymetric high.

$88^{\circ} 50^{\prime}$

$88^{\circ} 42^{\prime}$

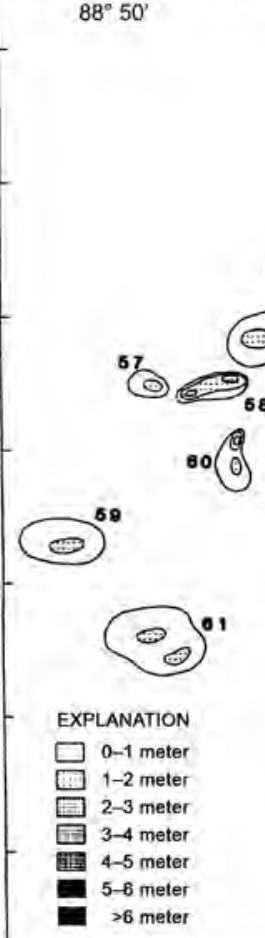

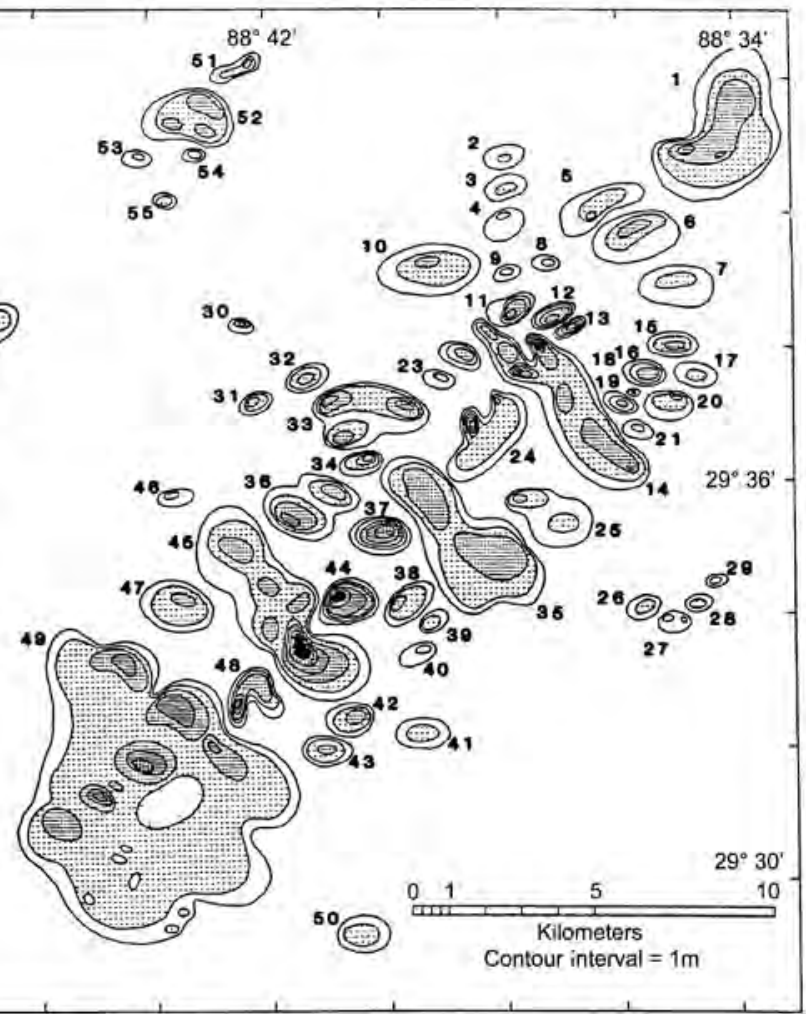

Figure 7. Isopach map of the St. Bernard Shoals, La., from Pope and others (1993). Note that the overall thickness of shoal deposits is greater in the outermost shoal field and that a general alignment of thickness trends exists. One large trend runs approximately northeast across the platform with smaller scale shoal axes trending northwest. 


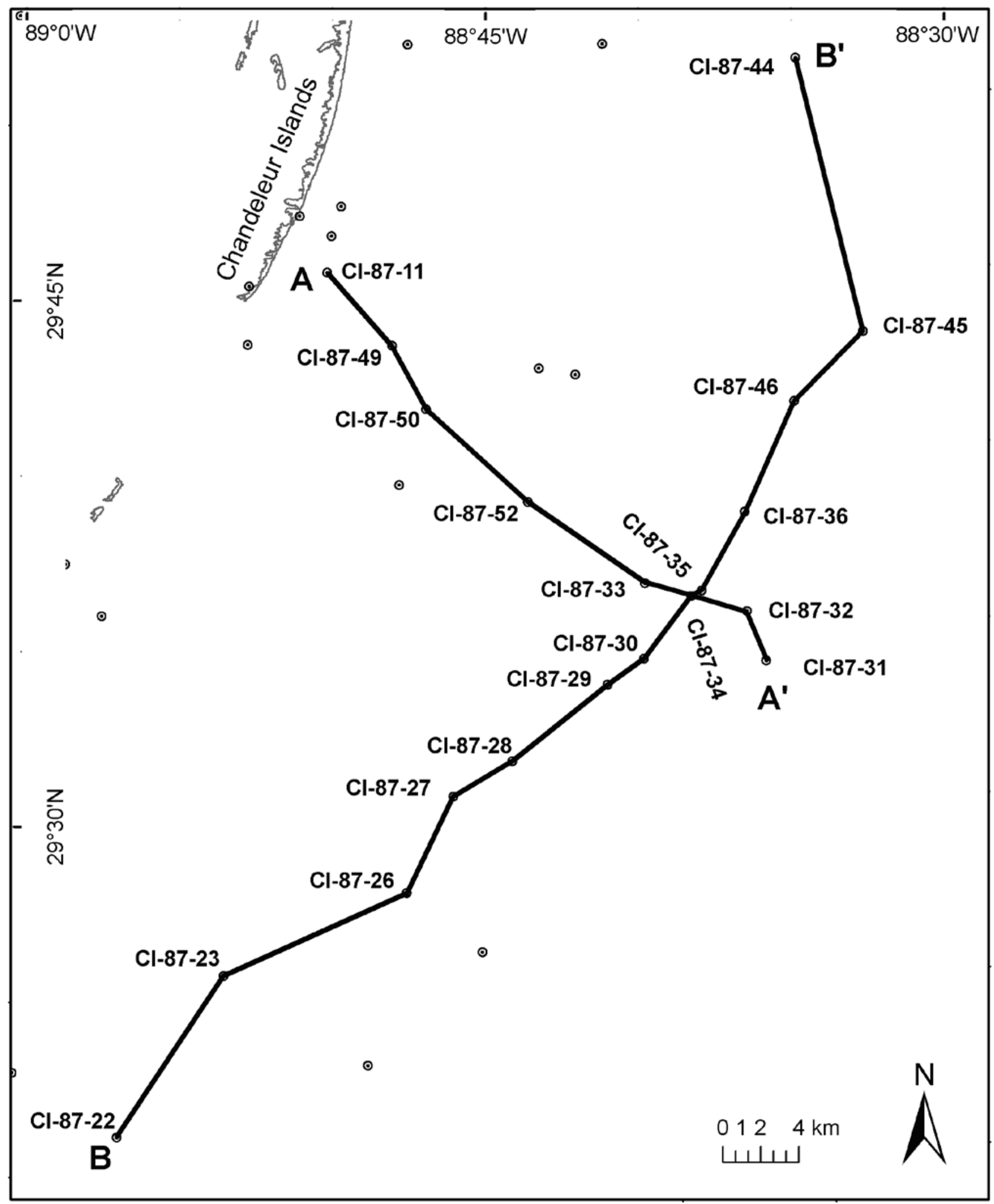

Figure 8. Base map showing the locations of stratigraphic cross sections throughout the St. Bernard Shoals, La. These cross sections were developed by using the 1987 core data and also aligned with 1987 seismic-reflection profiles. 


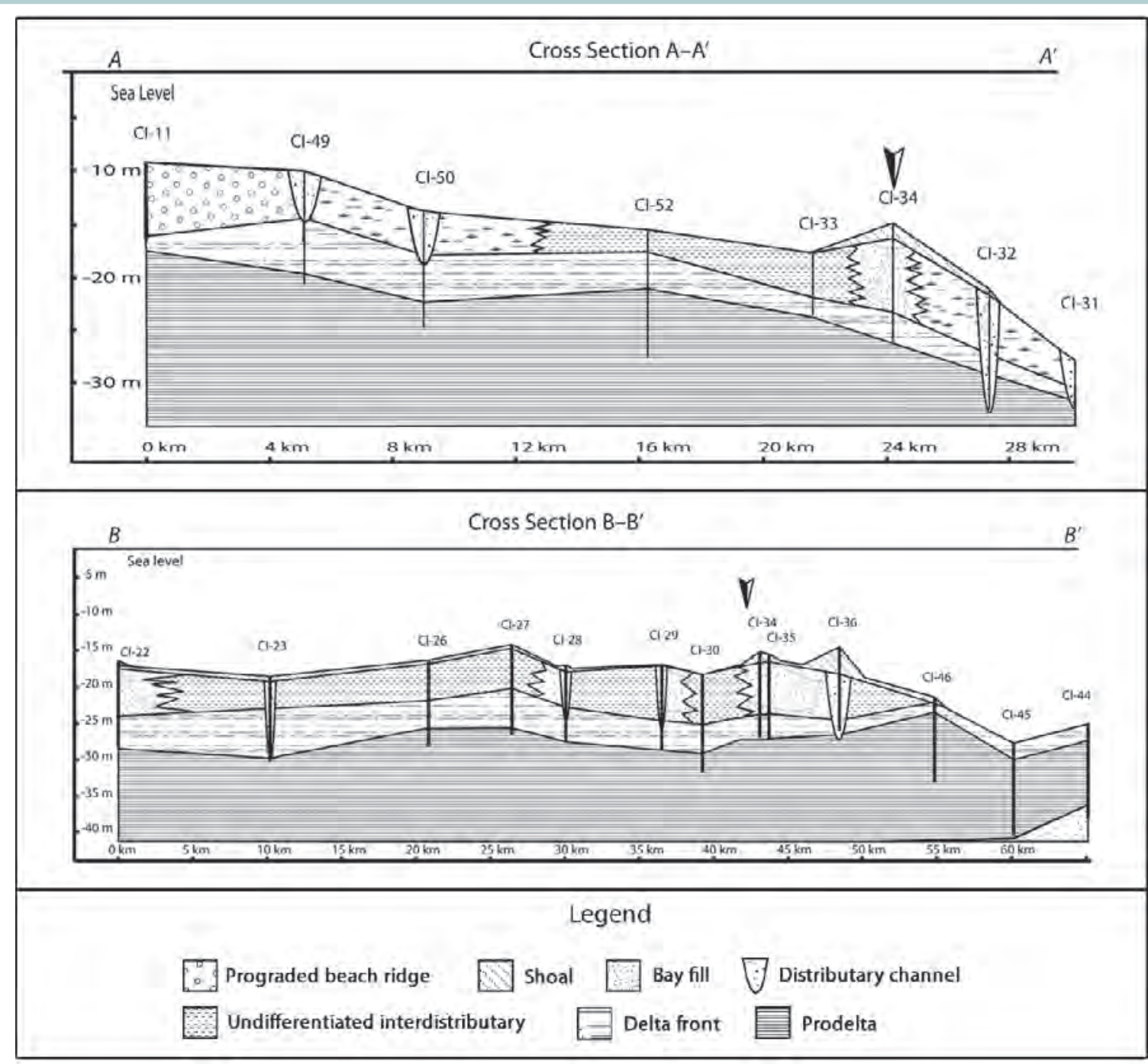

Figure 9. Stratigraphic cross sections of the St. Bernard Shoals, La., showing the shallow subsurface stratigraphy and overall cross-sectional framework and morphology of the shoals. Note the wide variability of interpreted depositional environments in the subsurface and the close relation between distributary facies and shoals. Locations of cross sections are shown in figure 8.

\section{Textural Character and Volume of the Shoals}

Grain-size analyses were initially conducted on sediments from the CI-87 vibracores in 1988 and 1989. A more complete analysis was performed by Pope and others (1993), which provided a comprehensive dataset describing grain size, sorting, and mineral composition of the shoal sediments.

The 2008 sea floor grab sample sediment analyses indicated that the shoal sand is fine to very fine in size (2-2.5 phi), moderate yellowish brown in color, and well sorted (fig. 10). As is typical of Mississippi River sediment, the sand of the St. Bernard Shoals is feldspathic or arkosic (25 percent), oligoclase dominant, and is garnet rich with very little staurolite or kyanite (Hsu, 1960; Pope and others, 1993). Earlier studies performed by Ludwick (1964), Frazier (1974), and Kindinger and others (1982) described similar characteristics for the sediment of the eastern Louisiana shelf and the St. Bernard Shoals. The sand present in the underlying distributary channel and bay fill deposits have color and grain size similar to that of the shoals, which suggests that transgression of the underlying, older distributary channels provided the sediment that ultimately formed the shoals. For more details of mineralogy, the reader is referred to Pope and others (1993). 


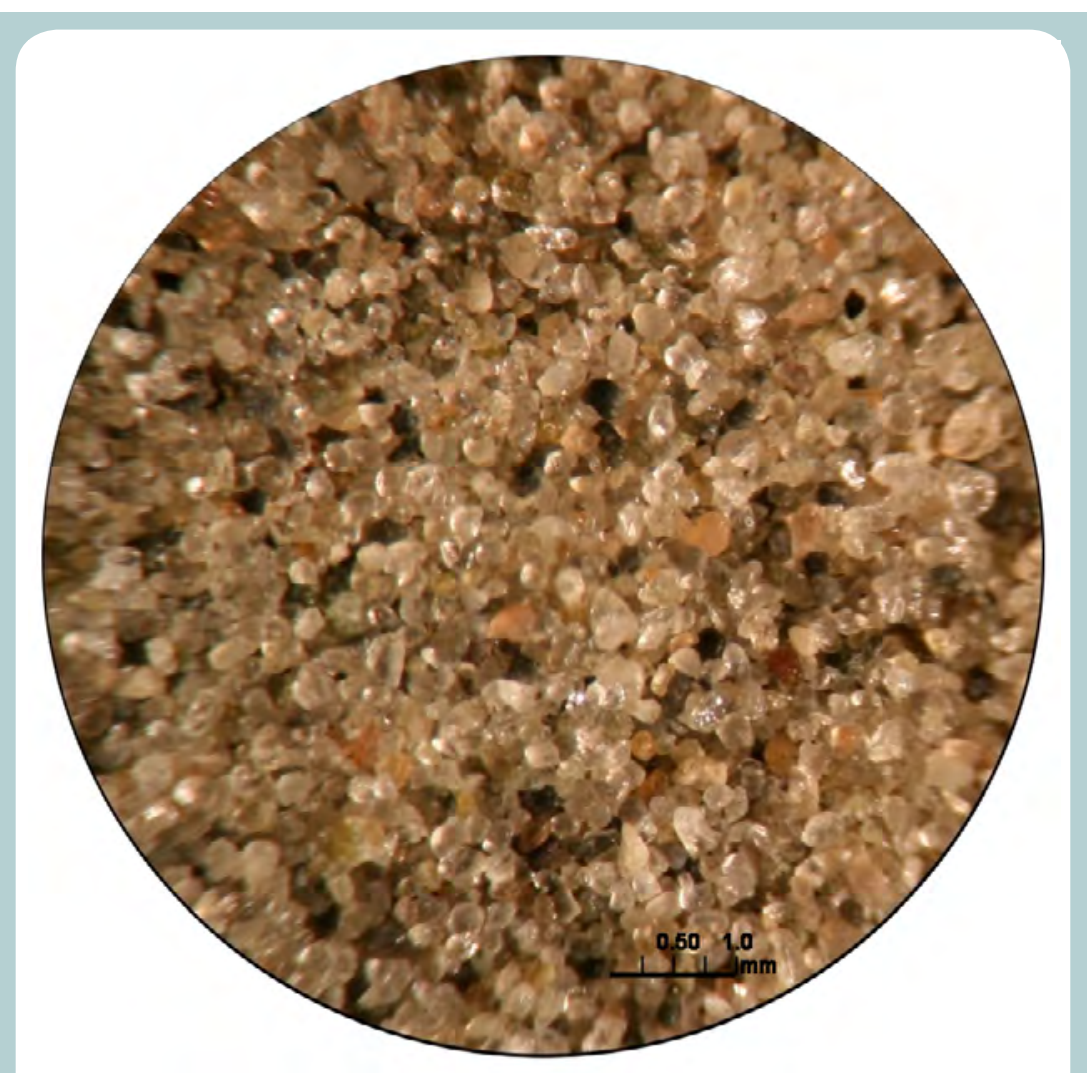

Figure 10. Magnified image of the sediment obtained from the 2008 sea floor grab sample from the top of shoal 14. The image shows that grain size ranges between 0.125 and $0.25 \mathrm{~mm}$ and that the grains are well rounded.

morphology, composition, and volumes. Numerous tropical cyclones have since then crossed over the shoals, which despite their depth (about 15-25 m) are subject to the marine processes generated by large tropical cyclones. Because no work had been done on the shoals since the 1980 s, a primary question of this assessment was whether after 20 years the shoals were still present or had been substantially modified.

The SBS-08 CHIRP and side scan datasets conclusively showed that the St. Bernard Shoals had not undergone any large-scale migrations (greater than $100 \mathrm{~m}$ ) since the CI-87 Louisiana Geological Survey data collection in 1987. The 2008 seismic and side scan data do, however, indicate a sea floor morphology that is highly suggestive of localized deposition and current reworking, as indicated by numerous erosional features.

\section{Shoal Tops}

In general the side scan images in conjunction with the seismic data revealed expansive flats that form large areas across the upper surface of each shoal. Grain-size analysis of the grab samples on these areas indicated the presence of sediment that approaches 100 percent sand. Mean grain size of grab samples from the top of shoal 14 was 2.8 phi with a mean phi sorting value of 0.4 (figs. 7 and 13),

\section{Volume of Shoals}

Pope and others (1993) also calculated the volume of the individual shoals and the entire shoal platform (fig. 11). Total volume of sediment was estimated by Pope and others (1993) to be approximately $200 \times 10^{6} \mathrm{~m}^{3}$ within the 61 discrete sand bodies. The southern shoal field, which is the larger of the two, contains $192 \times 10^{6} \mathrm{~m}^{3}$ of sand $(92$ percent of the total volume). The southern shoal field also contains the five largest individual shoals. Individual shoals range in volume from 75.6 $\times 10^{6} \mathrm{~m}^{3}$ to $0.14 \times 10^{6} \mathrm{~m}^{3}$. In order of decreasing volume the largest shoals are shoal 49 , shoal 45 , shoal 35 , shoal 1 , and shoal 14. These five shoals contain 65 percent of the entire volume of the St. Bernard Shoals, or $135 \times 10^{6} \mathrm{~m}^{3}$ of sandy sediment (figs. 7 and 12).

\section{Current Process Affecting Modern Day Shoal Evolution}

The research conducted in the late 1980s clearly established the presence of the shoals and their general representing well-sorted, fine-grained sand. Sediment color was moderate yellowish brown. Moreover, in many shoal top areas the side scan imagery revealed numerous largescale fields (greater than $100 \mathrm{~m}^{2}$ ) of sand waves. Although a thorough analysis of these sand waves has not yet been completed, the vast majority appear to have wavelengths of several meters and amplitudes of as much as $2 \mathrm{~m}$ locally. Because no previous side scan images exist for the shoals, it is not possible to gage from the 2008 data whether these features represent very recent features or have been a component of the shoal system since their origin.

\section{Shoal Margins}

In general the shoals are bounded by highly erosional features, and many of the shoal boundaries are represented by steep surfaces. These sharp boundaries along the shoals create a generally fragmented pattern for the shoals. Adjacent to the primary sand-rich shoals are numerous signs of scours, slumps, and slides. Evidence for the erosional features of the shoal system is most easily understood by looking at individual sea floor features that are herein referred to as 


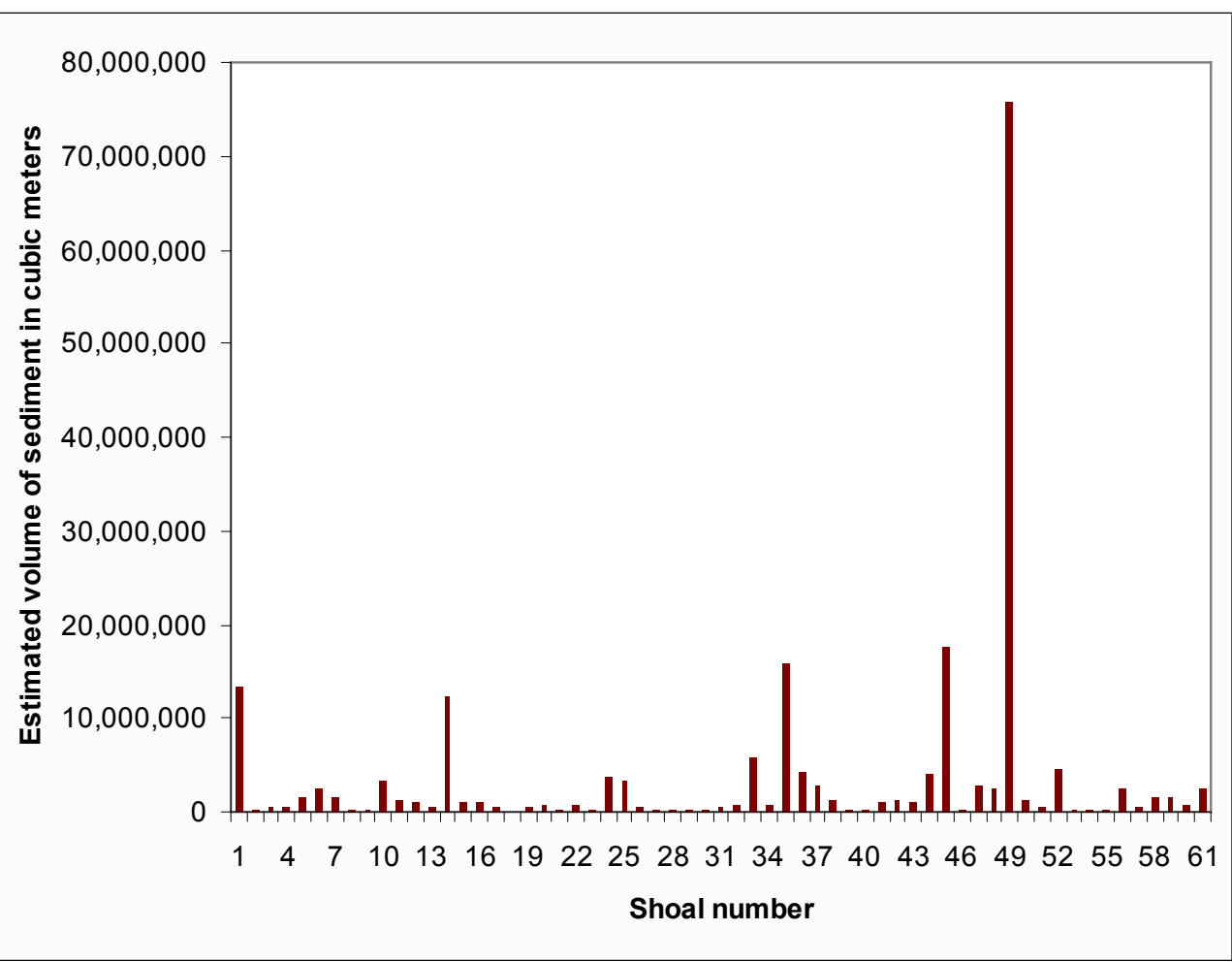

Figure 11. Graph depicting the estimated volume of individual shoals within the St. Bernard Shoals, La., based upon calculations from Pope and others (1993). The largest shoals are shoal 49 , shoal 45 , shoal 35, shoal 1, and shoal 14. Together they contain a total of $135 \times 10^{6} \mathrm{~m}^{3}$ of sandy sediment.

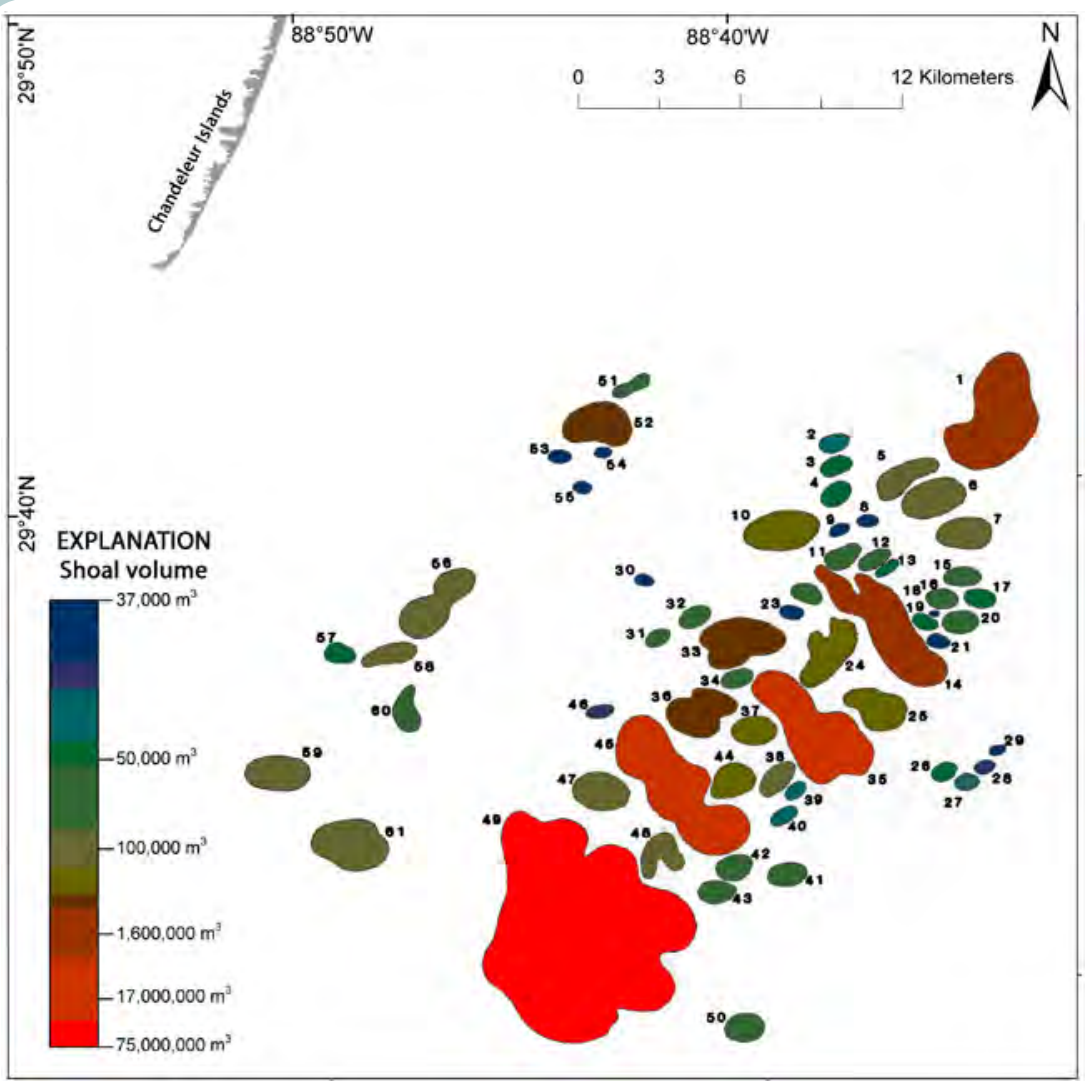

Figure 12. Map of the St. Bernard Shoals, La., depicting the volumes estimated to exist within the individual shoals. Note the spatial variance in the volumes of the shoals. 

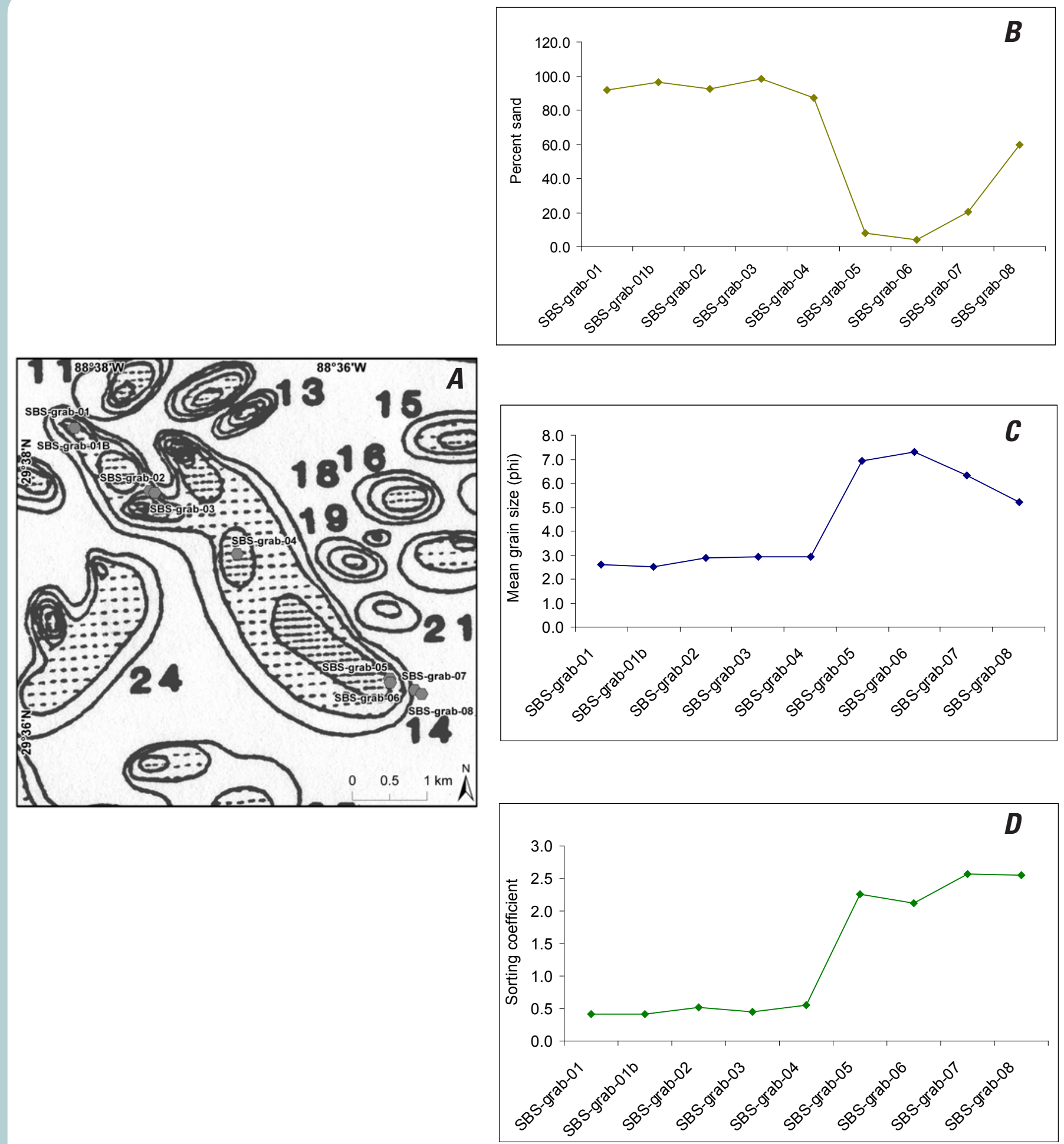

Figure 13. Distribution map and grain-size analysis results of grab samples acquired across shoal 14 in the St. Bernard Shoals, La. (location shown in fig. 7). A, Distribution map. B, Percent sand. C, Mean grain size. D, Sorting coefficient. The overall coarsest and most well sorted sediments are located along the northwestern end of the shoal and generally centered around the maximum areas of thickness for this individual body. 
"pedestals" (fig. 14). Pedestals are features that are elevated 1-3 $\mathrm{m}$ above the adjacent sea floor. In side scan images they appear as highly reflective features, and in the CHIRP seismic data they appear to have nearly vertical sides. These sea floor features are always separated from a nearby shoal by a low in the sea floor. On the basis of sea floor morphology it appears that the shoals are subjected to reworking and erosion by strong bottom currents. Overly steep margins along many of the shoals and the pedestals suggest that reworking may have taken place in the relatively recent past because the sea floor shows little indication of recovery toward less steep profiles. In chapter I, marine currents within the area of the shoals that may be driving current alteration of the shoals are discussed.

\section{Suitability as Borrow Material for the Chandeleur Islands}

Ideally, borrow material used for a beach/shoreline restoration and renourishment project is texturally equivalent to the native shoreline sediment. Hydrodynamic conditions along a shoreline influence the textural character, and placement of the appropriate material is fundamental to establishing a stable shoreline. Any borrowed material that is finer grained than the native sediment can generally be expected to be winnowed by marine processes. Thus, the volume of sediment added as fill to a shoreline and the longevity of a sediment-fill restoration project will ultimately be reduced if the borrow material does not closely match the native sediment. Fill ratios provide an estimate of the amount of borrow material required to produce a volume of sediment with the specific native grain-size characteristics.

Sediment analyses performed for this study and in several other studies (Hsu, 1960; Frazier and others, 1975; Mazullo and Bates, 1985; Penland and others, 1989; Pope and others, 1993) show that the St. Bernard Shoals consist of as much as 97 percent sand and that the sand has a rounded to wellrounded texture with a mean grain size ranging from 2.6 to 3.2 phi and sorting of $0.27-0.66$. The mean grain size of the St. Bernard Shoals sediment is similar to that of other beach sands and shoal deposits in the Mississippi River Delta. Sediments at Grand Isle, La., range in mean grain size from 2.7 to 2.8 phi (Hsu, 1960), and those at the Chandeleur Islands range between 2.1 and 3.0 phi with a sorting coefficient between 0.40 and 0.25 (Ellis and Stone, 2006). The sediment in Ship Shoal, La. (for location see fig. 1), can vary between 2.7 and 2.9 phi and has sorting coefficients that range between 0.35 and 0.46 (Penland and others, 1988).

The cut and fill ratios for the use of Ship Shoal and the St. Bernard Shoals on the Chandeleur Islands were compared by using the fill factor developed by Hobson (1977) (fig. 15). This method, developed to quantify the amount of borrow material for beach nourishment projects, is accomplished by comparing the sorting coefficient ratio of borrow material (b) to native

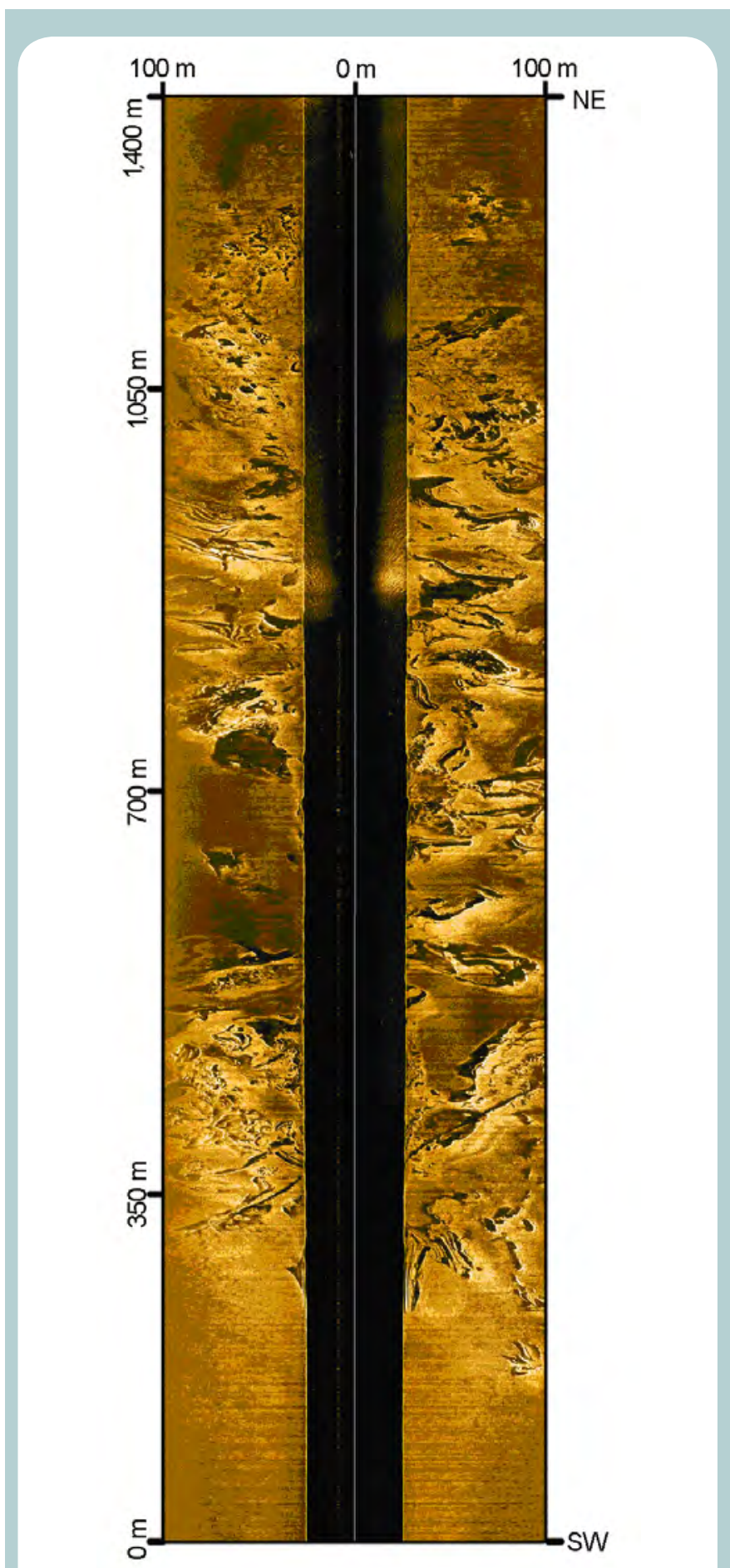

Figure 14. 2008 side scan image of the sea floor across shoal 27 and shoal 28 in the distal southeastern study area of the St. Bernard Shoals, La. The shoals are represented in the image at the ends of the transect where the sea floor appears relatively flat and featureless. Note the folded, tapestry-like appearance of the sea floor in the intervening low, which on the basis of CHIRP data appears to be the site of an intense scour. 


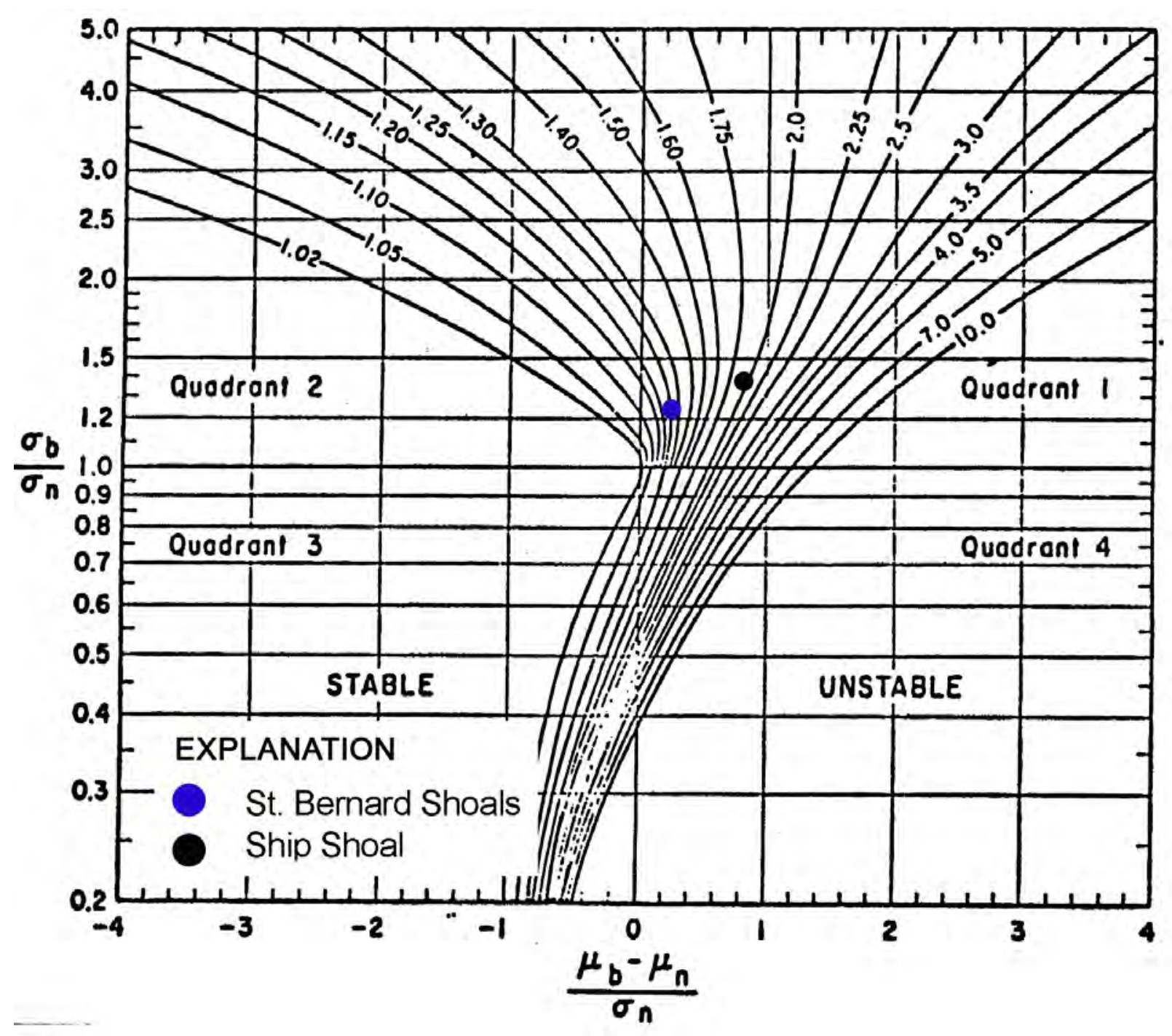

Figure 15. Graph showing the cut and fill ratios for sediment of the St. Bernard Shoals and Ship Shoal, La., if used to replace the native sediment of the modern Chandeleur Islands system. On the basis of this information it is suggested that the St. Bernard Shoals could provide a suitable and hydrodynamically stable sediment source for shoreline renourishment projects of the Chandeleur Islands because of the similarity of sediments (method and graph derived from Hobson, 1977).

material (n) versus the difference between borrow and native mean grain size scaled by the native sorting coefficient (Hobson, 1977). The sediment textures of the Chandeleur Islands reported by Ellis and Stone (2006) were used as the values for the native materials. The more alike two sediment sources are, the closer to the center of the graph they will be (fig. 15). On the basis of the available grain-size data, it seems that the sediment of the St. Bernard Shoals would be ideally suited for use as renourishment sediment of the Chandeleurs.

\section{Hydrodynamic Impacts}

The removal and relocation of sediment by dredging alter the sea floor topography and consequently the bathymetric profile of the dredged area. A consequence of sediment dredging is an increase in the water depth at the dredged area. The direction and magnitude of currents and sediment transport cells are in part controlled by sea floor topography; thus, currents, sediment transport cells, and wave climate 
offshore of the Chandeleur Islands could be altered by dredging of the recommended borrow sites. Quantitatively assessing these potential alterations is paramount because perturbations of these conditions could adversely impact the surrounding coastline and islands; however, the potential effects of dredging in the area have not yet been quantitatively studied, and it is unreasonable at this time to attempt to predict the exact effect that dredging of recommended sites would have on the eastern Louisiana continental shelf. It is common practice to use numerical models to assess the impact of dredging on currents, sediment budgets, and wave climates.

\section{Concluding Remarks}

High-resolution seismic-reflection profiles, side scan sonar, vibracores, and grain-size analysis have been used to clearly define the sedimentary framework and characteristics of the St. Bernard Shoals. These data indicate that the shoals are derived from sediment that was deposited by depositional systems similar to those that contributed to the formation of the Chandeleur Islands. Consequently the sediment that contributed to the generation of the shoals is similar to the sediment that contributed to the Chandeleur Islands. For this reason the shoals have a sedimentary texture that is quite similar to that of the Chandeleur Islands, making them an ideal borrow material for renourishment of the Chandeleur Island system.

Depending upon the location and extent of proposed dredging and the nature of the targeted borrow, additional sediment sampling may be required to fully define the character of the proposed dredged sites because of the lateral and vertical variability of the deposits addressed in this study. In addition, a magnetometer survey across the areas of proposed borrow material excavation would further refine the areas where dredging can be safely, efficiently, and economically completed by locating existing pipe and cable lines. Finally, quantitative modeling should be performed to assess the probable impact of dredging plans on offshore currents, sediment-transport cells, and wave climates in conjunction with environmental testing of the proposed dredge material. The results of these studies could be used to assess the potential for adverse effects on the surrounding wetlands and shorelines caused by dredging and to establish finalized plans for the renourishment of Chandeleur Islands.

\section{Acknowledgments}

We would like to thank Jeff Moti, Dane Fischer, and the crew of the $R / V$ Acadiana for all of their help in acquiring the SBS-08 dataset, the U.S. Fish and Wildlife Service for funding this project, and Dr. Dawn Lavoie and Dr. Mike Miner, who both provided much needed guidance.

\section{References}

Brooks, G.R., Kindinger, J.L., Penland, S., Williams, S.J., and McBride, R.A., 1995, East Louisiana continental shelf sediments - a product of delta reworking: Journal of Coastal Research, v. 11, p. 1026-1036.

Ellis, J., and Stone, G.W., 2006, Numerical simulation of net longshore sediment transport and granulometry of surficial sediments along Chandeleur Island, Louisiana, USA:

Marine Geology, v. 232, p. 115-129.

Fisk, H.N., 1944, Geological investigation of the alluvial valley of the lower Mississippi River: Vicksburg, Miss., U.S. Army Corps of Engineers, Mississippi River Commission, $78 \mathrm{p}$.

Frazier, D.E., 1967, Recent deltaic deposits of the Mississippi River - their development and chronology: TransactionGulf Coast Association of Geological Societies, v. 17, p. 287-315.

Frazier, D.E., 1974, Depositional episodes-their relationship to the Quaternary stratigraphic framework in the northwestern portion of the gulf basin: Austin, University of Texas at Austin, Bureau of Economic Geology, Geological Circular 74-1.

Frazier, D.E., Osanik, A., and Elsik, W.C., 1978, Environments of peat accumulation - coastal Louisiana, in Kaiser, W.R., ed., Proceedings Gulf Coast Lignite Conference-Geology, Utilization, and Environmental Aspects: Austin, University of Texas at Austin, Bureau of Economic Geology, p. 5-20.

Hobson, R.D., 1977, Review of design elements for beach fill evaluation: U.S. Army Corps of Engineers, Technical Report 77-6.

Hsu, K.J., 1960, Texture and mineralogy of the recent sands of the Gulf Coast: Journal of Sedimentary Petrology, v. 30, p. 380-403.

Kindinger, J.L., Miller, R.J., Stelting, C.E., and Bouma, A.H., 1982, Depositional history of the Louisiana-Mississippi outer continental shelf: U.S. Geological Survey Open-File Report 82-1077, 59 p.

Kolb, C.R., and Van Lopik, J.R., 1958, Geology of the Mississippi River deltaic plain southeastern Louisiana: U.S. Army Corps of Engineers, Technical Report 3-483, 120 p. 
Kulp, M.A., Howell, P., Adiau, S., Penland, S., Kindinger, J., and Williams, S.J., 2002, Latest Quaternary stratigraphic framework of the Mississippi Delta region: Gulf Coast Association of Geological Societies Transactions, v. 52, p. $573-582$

Ludwick, J.C., 1964, Sediments in the northeastern Gulf of Mexico, in Miller, R.L., ed., Papers in marine geology, Shepard commemorative volume: New York, Macmillan Co., p. 204-238.

Mazullo, J., and Bates, C., 1985, Sources of Pleistocene and Holocene sand for the northeast Gulf of Mexico shelf and Mississippi fan: Transactions - Gulf Coast Association of Geological Societies, v. 35, p. 457-466.

Penland, S., Boyd, R., and Suter, J.R., 1988, Transgressive depositional systems of the Mississippi Delta Plain-a model for barrier shoreline and shelf sand development: Journal of Sedimentary Petrology, v. 58, p. 932-949.
Penland, S., Suter, J.R., McBride, R.A., Williams, S.J., Kindinger, J.L., and Boyd, R., 1989, Holocene sand shoals offshore of the Mississippi River Delta Plain: Transactions - Gulf Coast Association of Geological Societies, v. 39, p. 471-480.

Pope, D., Conner, P., Jr., and Penland, S., 1993, Stratigraphical assessment of the mineral aggregate resources in the St. Bernard Shoal, offshore Louisiana: U.S. Minerals Management Service Professional Paper, 54 p.

Rogers, B., and Kulp, M.A., 2009, Late Holocene chronology, origin, and evolution of the St. Bernard Shoals, northern Gulf of Mexico, USA: Geo-Marine Letters, v. 29, no. 6, p. 379-394. 
Appendix G-1. SBS-08 Seism (See Index Page To Access Data) 
Publishing support provided by Lafayette Publishing Service Center 


\section{Numerical Simulation of Waves and Sediment Transport Along a Transgressive Barrier Island}

By loannis Y. Georgiou and Jennifer Schindler

Chapter $\mathrm{H}$ of

Sand Resources, Regional Geology, and Coastal Processes of the Chandeleur Islands Coastal System: an Evaluation of the Breton National Wildlife Refuge

Edited by Dawn Lavoie

In cooperation with the U.S. Fish and Wildlife Service

Scientific Investigations Report 2009-5252 


\title{
U.S. Department of the Interior \\ KEN SALAZAR, Secretary \\ U.S. Geological Survey \\ Marcia K. McNutt, Director
}

\section{U.S. Geological Survey, Reston, Virginia: 2009}

\author{
This and other USGS information products are available at http://store.usgs.gov/ \\ U.S. Geological Survey \\ Box 25286, Denver Federal Center \\ Denver, C0 80225 \\ To learn about the USGS and its information products visit http://www.usgs.gov/ \\ 1-888-ASK-USGS
}

\begin{abstract}
Any use of trade, product, or firm names is for descriptive purposes only and does not imply endorsement by the U.S. Government.

Although this report is in the public domain, permission must be secured from the individual copyright owners to reproduce any copyrighted materials contained within this report.
\end{abstract}

Suggested citation:

Georgiou, I.Y., and Schindler, J., 2009, Chapter H. Numerical simulation of waves and sediment transport along a transgressive barrier island, in Lavoie, D., ed., Sand resources, regional geology, and coastal processes of the Chandeleur Islands coastal system —an evaluation of the Breton National Wildlife Refuge: U.S. Geological Survey Scientific Investigations Report 2009-5252, p. 143-168. 


\title{
Chapter H. Numerical Simulation of Waves and Sediment Transport Along a Transgressive Barrier Island
}

\author{
By loannis Y. Georgiou' and Jennifer Schindler ${ }^{1}$
}

\section{Abstract}

Louisiana barrier islands, especially the chain surrounding the southeast region that encompasses Chandeleur and Breton Sounds, are undergoing rapid loss of land and extreme landward migration rates because of transgressive submergence and the landfall of several major hurricanes in the last decade. Migration rates and overall impacts to these barrier islands are poorly understood since they do not respond in a traditional way, such as barrier island rollover. To quantify the response to low-intensity, intermediate, and extreme events, as well as their recovery, a suite of computational tools were employed to help characterize the remote and local forcing on the barrier islands. The results from this study were compared against field observations (where available), observations and overall trends from sea floor change, and historical shoreline change trends. It was concluded that the barrier islands are undergoing high rates of transport in the northward direction during intermediate and high-intensity storms, that vast areas of the lower shoreface are activated and are undergoing erosion during these events, and that there is little or no fair weather mechanism to rework material into the littoral system. As a result, there is a net loss from the system.

\section{Introduction and Background}

The Chandeleur Islands (fig. 1), the largest barrier island arc in southeast Louisiana, formed from the abandonment of the St. Bernard Delta Complex approximately 2,000 years before present (BP) (Penland and others, 1988; Suter and others, 1988). While substantial research has historically been conducted along this barrier island chain, it was primarily focused on geomorphic response, evolution, historical shoreline change, and area change based on aerial and satellite imagery and framework geology. The literature regarding quantification of short-term physical processes, the historical physical processes, and the physics that drive the evolution of the barrier islands - such as waves, hydrodynamics, and resulting sediment transport-is rather limited (Georgiou and others, 2005; Ellis and Stone, 2006). These processes (which have not been well studied, measured, or understood) take place over multiple spatial and temporal scales and are extremely difficult to measure, quantify, and accurately describe. These complexities present challenges in attempts to numerically parameterize and use in forecasting relations, and in the absence of measurements, predictions can be rather unreliable when based upon assumptions or inferences that are not directly measured. Furthermore, measurements and attempts to capture all temporal and spatial scales are nearly impossible. The study of the Chandeleur Islands herein employed a reanalysis of the currently available historical wind and wave climate that drove the response and recovery of the barrier islands, the quantification of historical longshore sediment transport trends resulting from both fair weather and storms, and a first-order attempt to simulate event-driven response to storm waves and implications for sediment transport.

For this study, we employed simple wave forecasting by using a long-term dataset of offshore winds, applying simple transformation to breaking to get predictions of longshore sediment transport by using the Coastal Engineering Research Center (CERC; 1977) equation. These predictions were subsequently used to generate transport gradients to determine erosion and deposition areas along the Chandeleur Islands arc to help validate the landward migration of the barrier islands. Offshore deepwater wave buoys were also used to generate storm waves of different return periods $(1,10$, and 100 years) by using the peak over threshold (POT) method and were fitted to a Gumbel distribution. These storm waves were then propagated across the continental shelf, onto the barrier islands, inland into sounds and interior wetlands, to identify a mechanism for shoreface erosion. Propagation was achieved with the Simulation of WAves Nearshore (SWAN) numerical model (Holthuijsen and others, 1993). Finally, and since the shoreface is primarily composed of muddy substrate, tidal and storm-induced circulation in the vicinity of the Chandeleur Islands was conducted to identify potential pathways for shoreface material eroded during these events.

\footnotetext{
${ }^{1}$ University of New Orleans, Pontchartrain Institute for Environmental Sciences, New Orleans, La.
} 


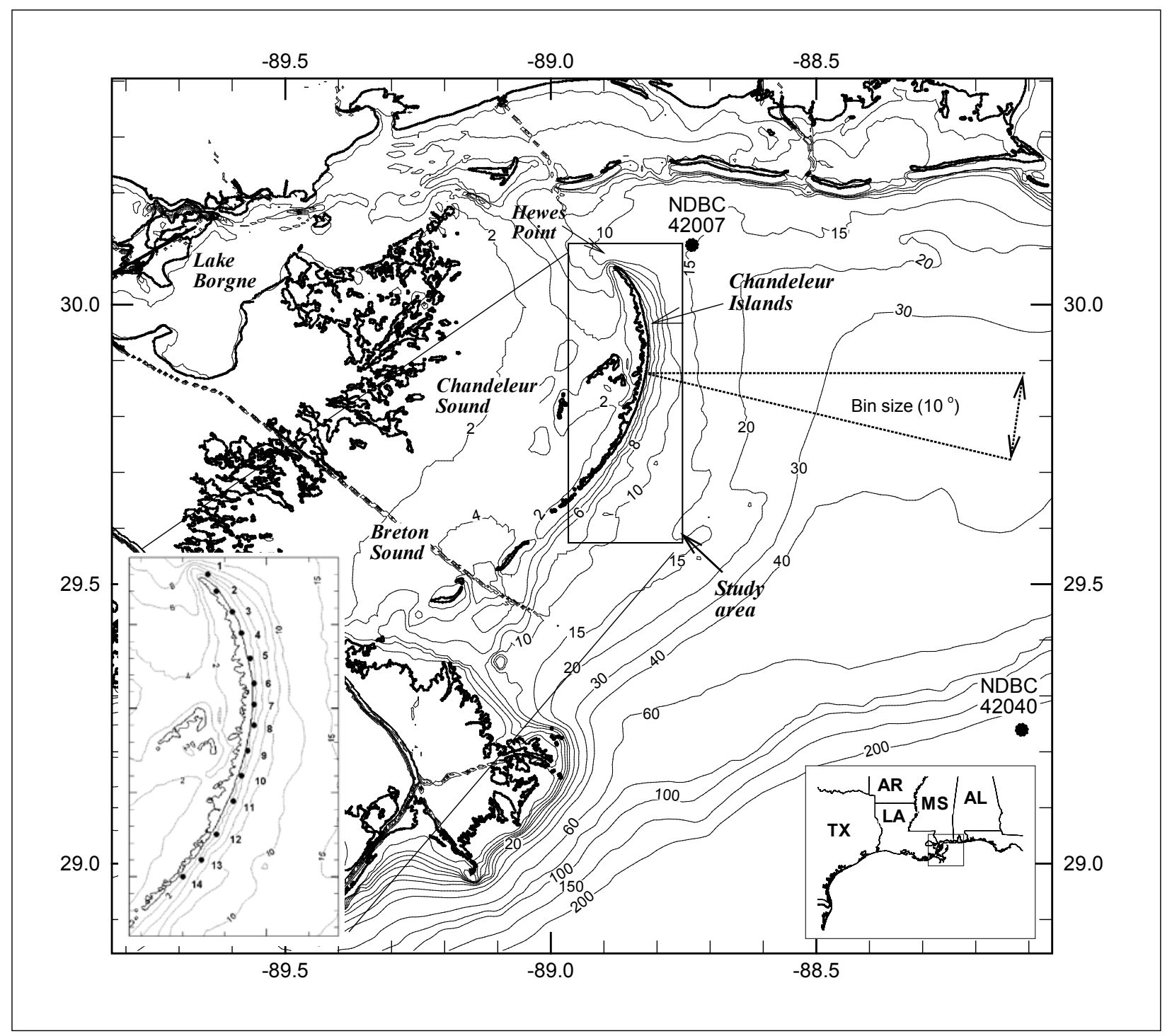

Figure 1. Regional map of the study area in the vicinity of the Chandeleur Islands, La., showing the locations of the 14 points used in the wave forecasting and alongshore sediment transport calculations (left inset map), the locations of two National Data Buoy Center (NDBC) buoys (solid circles), Hewes Point, and regional bathymetry.

\section{Methods and Materials}

\section{Wind and Wave Climate Analysis}

The present-day wave and wind climate in the vicinity of the Chandeleur Islands is unknown. To characterize the wave energy and regional wind along the barrier islands, the nearest wave buoy from the the National Oceanic and
Atmospheric Administration (NOAA) National Data Buoy Center (NDBC) was used. This wave buoy - a 3-m discus buoy reporting hourly observations with historical data since 1985-is NDBC station 42007, positioned 22 nautical miles (nmi) south-southwest of Biloxi, Miss., located at 30.09 degress North 88.77 degrees West (fig. 1). NDBC data streams were imported into wind rose analysis software (WRPLOT View, Lakes Environmental Software, Waterloo, Ontario, Canada) and were plotted and analyzed. We used a 10-degree directional bin for both wind and wave classification, while 
seven magnitude bins were used to capture the range within each record. Missing file indicators were defined to generate accurate wind rose plots and wind probabilities, excluding missing data records from frequency plots and counts.

Frequency distribution, frequency count, and wind rose plots for each year (1985-2006) were produced. Wind rose plots divide wind data into 36 directional bins and 7 windspeed classes. The records were subsequently split into three categories for further analysis and to develop seasonal trends. These three categories are annual, period 1 (which corresponds to the cold front season, from November 1 through March 30), and period 2 (which corresponds to the remaining part of the year, from April 1 through October 30). This classification enabled a comparison of the wind and wave climate between the hurricane season and the cold front season. For the annual analysis, 4 of the years during the period of 1985 through 2006 that had the minimum number of missing records were used, namely years 1989, 1994, 1999, and 2006. The missing records for these years were typically $5-15$ percent of the total annual record.

\section{One-Dimensional Wave Modeling and Longshore Sediment Transport}

A set of 14 points equally spaced across the barrier island chain were selected, with the first point located near Hewes Point, La., on the north end of the barrier island chain at 30.05 degrees North and the last point located south near 29.70 degrees North (fig. 1, inset). The same records used for the wind and offshore wave climate analysis were also used to create input files to drive a one-dimensional wave modeling and resulting longshore sediment transport model. Fetch and a depth profile were extracted along each radial line shown in figure 2 and were used for wave generation, propagation, and transformation. Wave generation along the radial lines (fig. 2) was computed with windspeed and direction observed at station 42007. Waves were assumed to be of zero height at the end of the radial lines (fig. 2), seas were assumed to be fully developed, and waves were assumed to be duration limited, except for waves approaching from

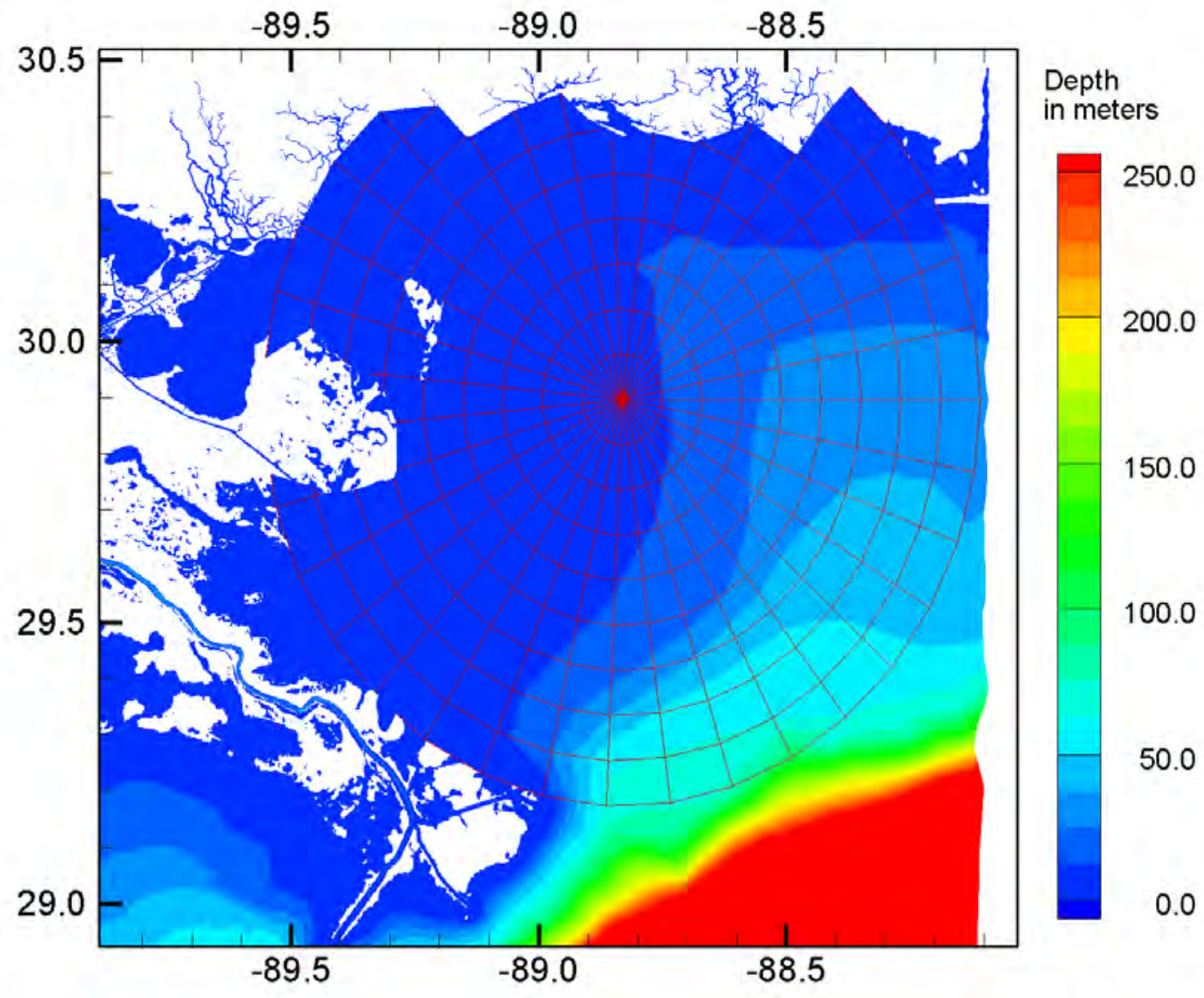

Figure 2. Circular pattern showing the directional bin size and typical extent for the one-dimensional wave generation, propagation, and longshore sediment transport calculations for the Chandeleur Islands, La. Each of the 14 equally spaced locations along the barrier island chain has a similar pattern. 
the northeast, where fetch-limited waves may be generated. Waves were transformed from deep to shallow water by incorporating effects due to refraction, shoaling, and breaking. Refraction coefficients $\left(K_{r}\right)$, shoaling coefficients $\left(K_{s}\right)$, and breaker indexes $\left(K_{b}\right)$ were computed for each wave that was generated (every hour) by using the power transmission equation, defined as

$$
\frac{H_{1}}{H_{0}}=K_{s} K_{r}
$$

where $H_{1}$ is the shallow water wave height and $H_{0}$ is the deep water wave height. The refraction coefficient $\left(K_{r}\right)$ was defined by

$$
K_{r}=\sqrt{\frac{\cos \left(\alpha_{0}\right)}{\cos \left(\alpha_{1}\right)}}
$$

where $\alpha_{0}$ is the deep water wave angle and $\alpha_{1}$ is the shallow water wave angle. The shoaling coefficient $\left(K_{s}\right)$ was defined by

$$
K_{s}=\sqrt{\frac{1}{2 n_{1} \tanh \left(\frac{2 \pi d}{L_{1}}\right)}}
$$

where $L_{1}$ is the shallow water wave length and $n_{1}$ is the fraction of wave energy being transmitted $=\frac{C_{g b}}{C}$. The group celerity at the breaker line, $C_{g b}$, is given by

$$
C_{g b}=\sqrt{g d_{b}}=\sqrt{g \frac{H_{b}}{K_{b}}}
$$

where $K_{b}=\left(\frac{H_{b}}{d_{b}}\right)$ represents the breaker index, taken as $K_{b}=0.78$ for a flat beach. Similarly, the shallow water

wave celerity $(C)$ is computed as $C=\sqrt{g d}$.

The wave angle was recorded at breaking and was used in reference to the coastline azimuth to produce the wave incident angle for the longshore sediment transport computation. The longshore sediment transport was then computed on the basis of the frequency of each wave occurring from a specific direction and magnitude bin for a record of 1 year as a percentage by using hourly data records. The CERC longshore transport equation (Coastal Engineering Research Center, 1977) was used to compute the potential transport of quartz sand with a sediment density of 2,650 kg/ $\mathrm{m}^{3}$. The cumulative southward and northward transport was calculated at each of the 14 locations, and the difference of the transport was recorded as the net transport for each location. For all wind records, windspeeds were corrected by using the 0.11 power law (Peterka and Shahid, 1998). Since the 42007 buoy anemometer is at $5 \mathrm{~m}$, a correction was applied as follows:

$$
\left(V_{\text {corrected }}\right)=\left(V_{\text {actual }}\right) *\left(10.0 / Z_{a}\right)^{0.11}
$$

where $Z_{a}$ is the station's anemometer height in meters, $V_{\text {corrected }}$ is the windspeed corrected for an anemometer height of $10 \mathrm{~m}$, and $V_{\text {actual }}$ is the original windspeed measured at a height of $Z_{a}$.

\section{Two-Dimensional Wave Modeling and Transport}

\section{SWAN Modeling}

The Simulation of WAves Nearshore (SWAN) (Holthuijsen and others, 1993) simulation program was used to propagate wave energy on the barrier island chain during storms. A computational domain with 600-m resolution covering the entire area of the Breton and Chandeleur Sounds, east to the outer continental shelf (fig. 3), was also used to propagate storm wave energy. This domain was nested twice, once covering the Chandeleur Islands with a 250-m resolution and once more near Hewes Point with a 50-m resolution. The eastern boundary for the large domain extended to the location of the NDBC buoy 42040. Observations from this buoy (which was operating during both Hurricane Ivan and Hurricane Katrina within hours of the storms passing from 


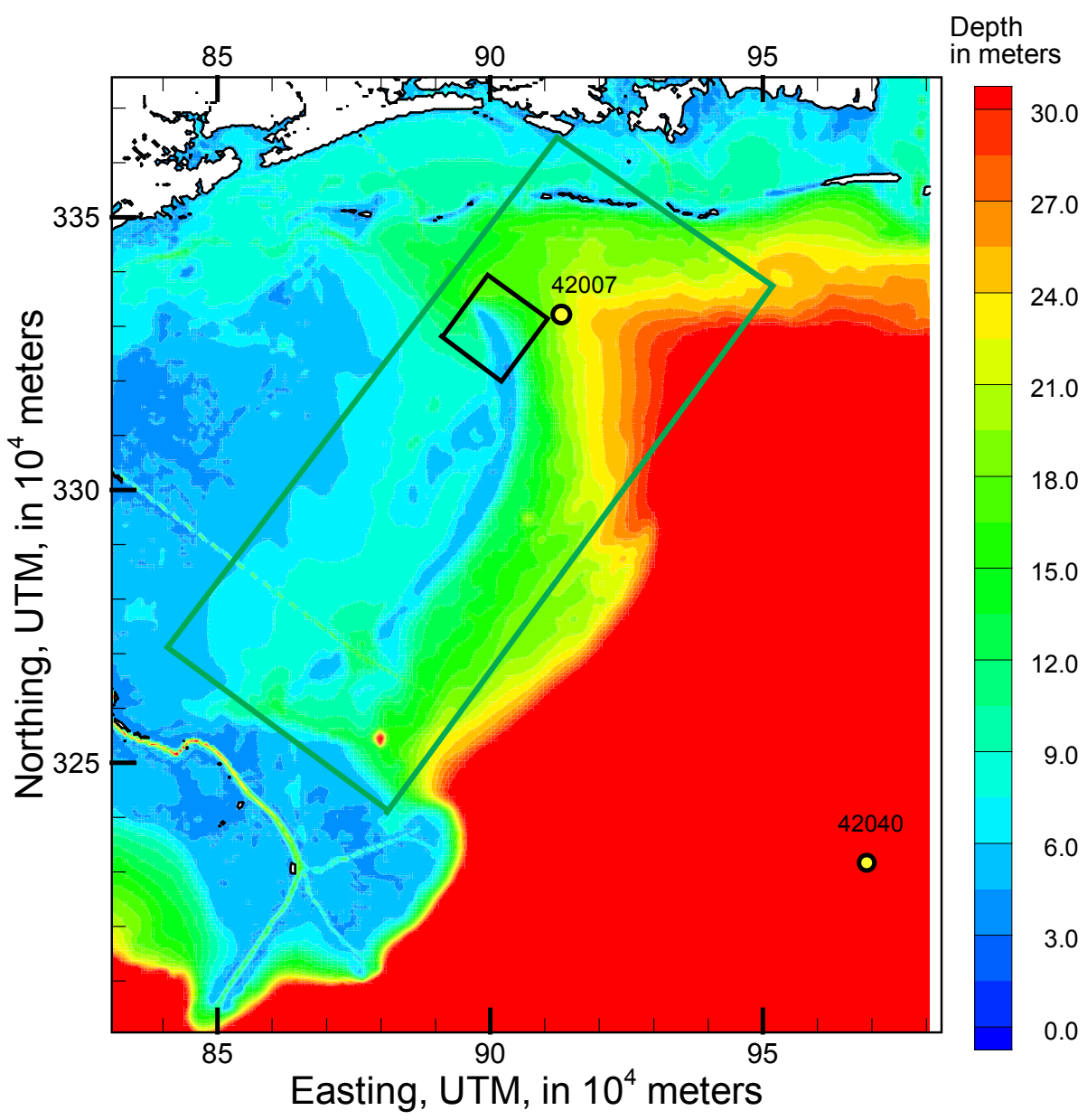

Figure 3. Overview of computational domains and boundaries of the numerical model Simulating WAves Nearshore (SWAN; Holthuijsen and others, 1993) for the Chandeleur Islands, La. Extent of the bathymetry file covers the large grid with 600-m resolution, the green grid covers the first nest grid with 250-m resolution, and the small black grid covers the second nest grid with 50-m resolution. The National Data Buoy Center (NDBC) buoy locations used for boundary condition and validation are also given in circles with their respective numbers/names. For clarity, contours greater than $30 \mathrm{~m}$ are not shown. UTM, Universal Transverse Mercator.

the area) were used to generate the storm wave characteristics at the boundary of the SWAN model. Since extreme statistics cannot be used because of the short record available at the station, the peak over threshold (POT) method was used. The data were fitted into a Gumbel distribution to extrapolate the extreme storm wave values for the 1-year, the 10-year, and the 100-year storm. (We emphasize that the data only covered a period of 10 years; hence, the extrapolation to a 100 -year storm is a combination of statistics using the Gumbel distribution, as well as methodology used in the Interagency Performance Evaluation Taskforce [U.S. Army Corps of Engineers, 2006] during Hurricane Katrina statistics on return period.) Model-derived storm surge levels resulting from tropical activity and extreme events (Resio and Westerink,
2008) indicate that water levels during Katrina reached $4 \mathrm{~m}$ at the peak of the storm in the vicinity of the study area. Tidal range in the vicinity of the barrier islands is small (about 0.8 $\mathrm{m})$. By using this information and expert judgment regarding storm track, forward speed, and other storm parameters, storm surge levels to accompany the storm waves for the 100-year, 10-year, and 1-year events were estimated at $4 \mathrm{~m}, 3 \mathrm{~m}$, and 1.5 $\mathrm{m}$ above mean sea level.

\section{Tidal and Storm-Induced Circulation}

Tidal circulation in the vicinity of the Chandeleur Islands is not well known. There exist very little data to describe tidal 
range and tidal velocities. To help meet this need, an existing validated numerical model (McCorquodale and others, 2008), based on the Finite Volume Coastal Ocean Model (FVCOM) originally developed by Chen and others (2003), was used to extract regional and local tidal currents, tidal range, and transport trends resulting from fair weather tidal motion. For circulation and velocity distribution and water level time histories during storms, the Advanced Circulation (ADCIRC) model was used (Resio and Westerink, 2008). Results and analysis for simulations from existing and previous U.S. Army Corps of Engineers efforts were requested, obtained, and analyzed accordingly (U.S. Army Corps of Engineers, 2006; Smith and others, 2007; Sleath and others, 2009).

\section{Results}

\section{Wind and Wave Climate Analysis}

Wind climate analysis generally indicated that while the annual wind and wave distribution at the NDBC buoy 42007 was relatively evenly distributed there were changes in the directional distribution and dominance with seasons. Period 1 (fig. $4 A$ ) had a dominant weighted direction from the southeast and northwest, confirming the typical response of cold fronts in which winds are generally from the southeast prior to the cold front and switch to the northwest once the front has passed through. Period 2 (fig. $4 B$ ) did not have a clear dominant weighted direction but generally showed higher magnitude winds from the northeast, southeast, and southwest. When combined, the annual resultant wind vector was from the east-southeast. Significant wave heights in the vicinity of the northern portion of the barrier islands appeared to be fairly similar for all years (fig. $4 C$, right), with a peak of $0.45 \mathrm{~m}$ (long-term hourly average for 25 years) and a skewed population. The tail of the population showed that significant wave heights in excess of $1 \mathrm{~m}$ occur approximately 4 percent of the year, while 2-m waves are rather rare, with return periods of less than 1 percent. Seasonal wind climate analysis showed similar results (figs. $4 A$ and $4 B$, left). The peak significant wave heights for the cold front season had a slightly lower frequency (about 11 percent) and lower peaks in the wave heights (approximately $0.4 \mathrm{~m}$; fig. $4 A$, right). During the hurricane season, however, wave heights of similar magnitude (about $0.5 \mathrm{~m}$ ) appeared to have a frequency of nearly 17 percent (fig. $4 B$, right).

\section{One-Dimensional Longshore Sediment Transport}

There is a net southern transport for locations south of the central segment of the barrier islands and a net northward transport on the northern portion of the barrier islands (fig. 5). Since the offshore NDBC buoys do not record wave direction, the wind distribution (shown in figs. $4 A-4 C$ ) is often used to define wave direction, which was the case for all simulations herein for the one-dimensional model. Furthermore, period 1 covers the entire cold front season, during which abrupt changes in speed and direction are expected fairly often (frequency of 7-10 days; see fig. 4A, which shows that a significant amount of the wind distribution is from the northwest). These winds will produce completely different waves nearshore of the barrier islands and subsequently produce different transport trends.

When all of the records representing 25 years of wind at this station are used to generate and propagate waves onshore, longshore sediment transport trends can be computed. For each of the 14 locations in figure 5 , waves were propagated to breaking, and depending on the breaking angle and local breaker height and assuming a sandy bottom, potential longshore sediment transport was computed by using the CERC equation (Coastal Engineering Research Center, 1977) and Komar (1998). The underlying assumption was that the waves generated would have similar direction to that of the observed wind in deep water. Comparisons of observed wave heights to those predicted by the Waves Information Studies (Hubertz, 1989) project showed that there are some discrepancies, but overall the assumption was assumed satisfactory. Each set of wave generation, propagation, and transformation was executed 8,760 times a year for 4 years and for 14 locations (total of 490,560 simulations). An additional 50,000 simulations were conducted to assess sensitivity on (1) atmospheric stability (gradient between air and sea surface temperature), (2) windspeed, (3) fetch, and (4) depth. The net transport was then computed as the net difference between north and south transport at each of the 14 locations. Figure 5 includes an uncertainty band for each location shown as "error bars"; this band was estimated on the basis of the cumulative effects of sensitivity analysis performed, which included variations in windspeed, atmospheric stability (the air-water temperature at the buoy was used here to set the stability parameter), fetch, and depth. The sensitivity analysis was performed to provide a quantitative measure of the resulting changes in transport because the methodology incorporates several parameterizations. The differencing of the net transport at each location was furthermore differenced along the barrier island chain to produce a transport gradient (sediment volume per unit time, per unit length of the barrier island chain) (table 1).

We found that the long-term transport trend is characterized by a bidirectional system (fig. 5), which is similar to observations by Georgiou and others (2005) and Ellis and Stone (2006). While differences exist in the determination of the nodal point between the literature and this study, the nodal point predictions are only 3-5 km apart. While wind and wave conditions are similar, local bathymetry contours, changes in barrier island configuration, and location 

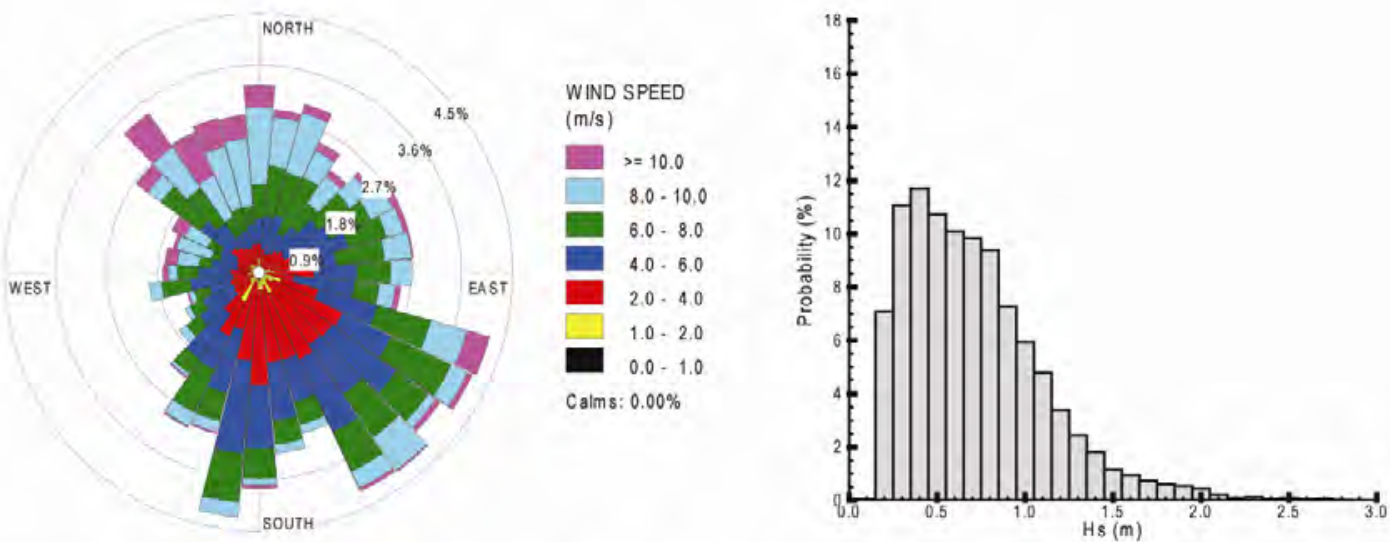

a. Coldfront season wind distribution for 1999
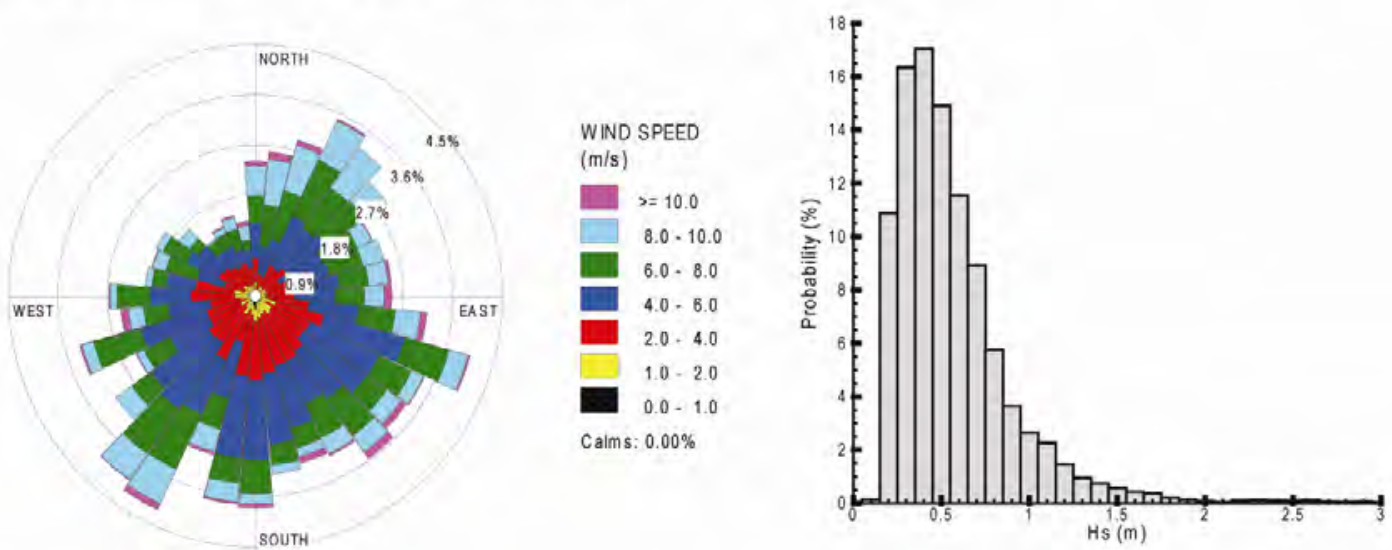

b. Hurricane season wind distribution for 1999
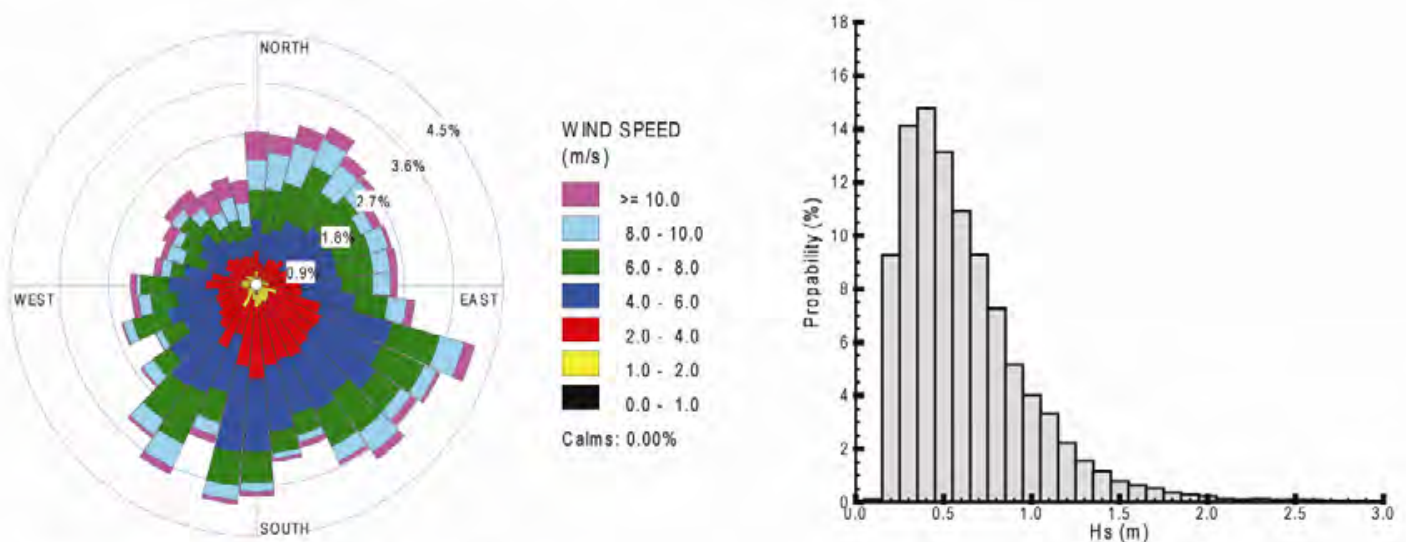

\section{c. Annual wind distribution for 1999}

Figure 4. Seasonal wind distribution and significant wave height probability at National Data Buoy Center (NDBC) buoy 42007 in the vicinity of the Chandeleur Islands, La. A, Annual wind distribution for 1999 and significant wave height probability. $B$, Cold front season (period 1) wind distribution for 1999 and significant wave height probability. C, Hurricane season (period 2) wind distribution for 1999 and significant wave height probability. 


\section{$\boldsymbol{A}$}

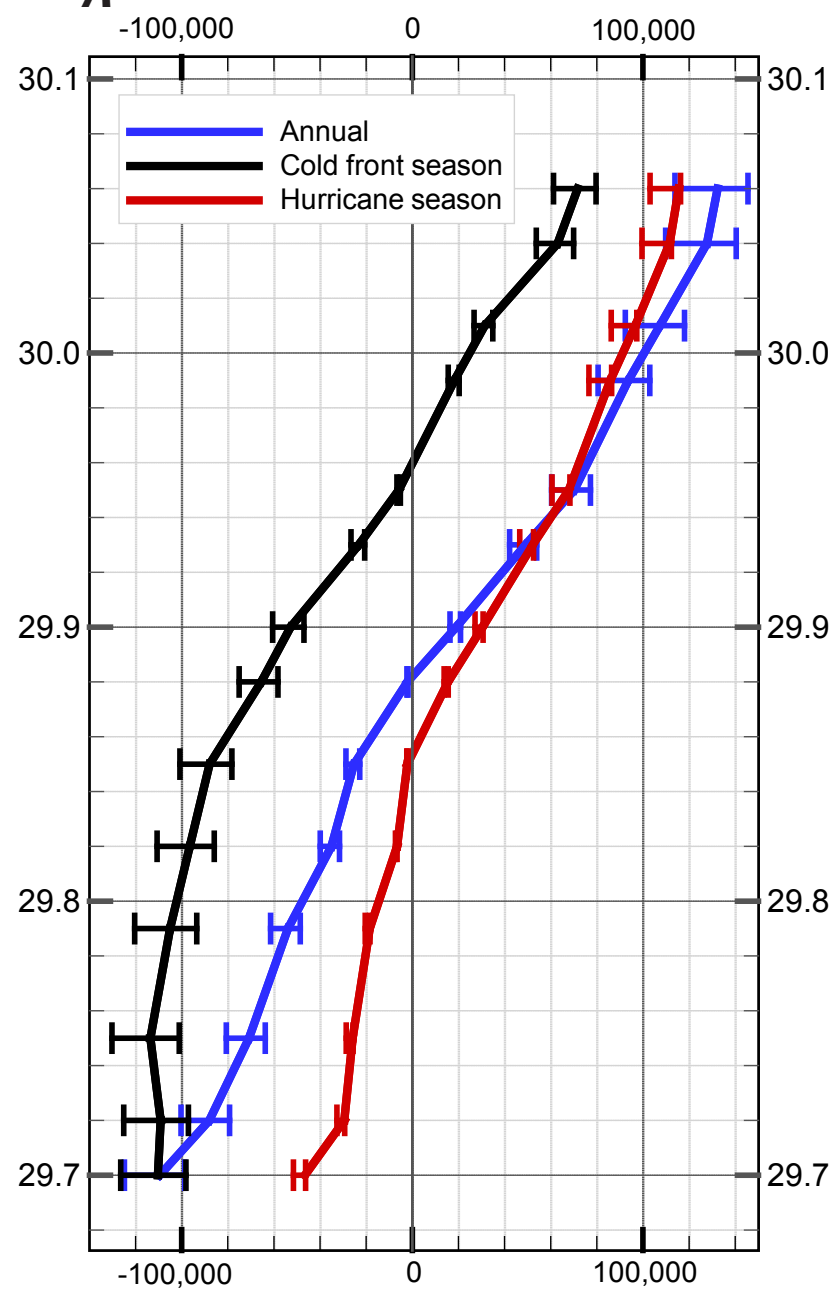

B

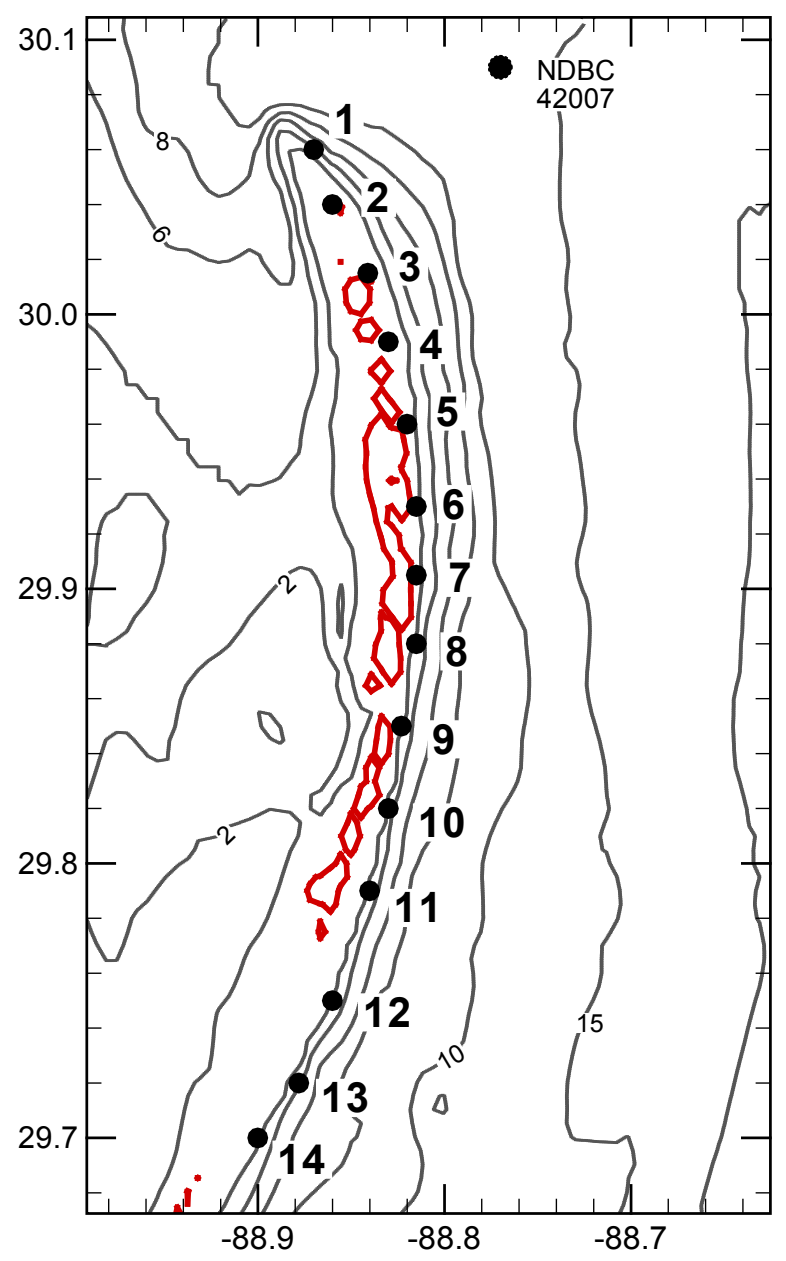

Net Transport $\mathrm{m}^{3} / \mathrm{yr}$

Figure 5. $A$, Seasonal changes in the potential net longshore transport rates across the northern Chandeleur Islands arc as a result of long-term annual forcing (blue line), hurricane season forcing (red line), and cold front season forcing (black line). $B$, The postHurricane Katrina subaerial island extent in relation to the location of the 14 points used in the wave predictions.

would cause predictions to be different. Transport magnitudes were also similar to the literature (Ellis and Stone, 2006) with transport rates in the northern portion of the barrier islands varying from 60,000 to $130,000 \mathrm{~m}^{3} / \mathrm{yr}$ and approximately 50,000 to $110,000 \mathrm{~m}^{3} / \mathrm{yr}$ for the southern part of the barrier islands. Transport gradients range from 0.3 to $6 \mathrm{~m}^{3} / \mathrm{m} / \mathrm{yr}$ in the southern part of the barrier islands, while the northern part can undergo gradients of $6 \mathrm{~m}^{3} / \mathrm{m} / \mathrm{yr}$. Sensitivity analysis and seasonal forcing indicated that the transport rates and gradients vary seasonally and can undergo variations from 0.5 to 2 times the long-term average during seasons. During the summer season, for example, transport to the south can decrease to $50,000 \mathrm{~m}^{3} / \mathrm{yr}$. These variations in transport rates are responsible for the oscillations to the nodal point.

\section{Two-Dimensional Wave Modeling}

\section{SWAN Wave Modeling Setup and Results- Storm Weather Simulations}

Statistics to characterize storm waves in the vicinity of the northern Gulf of Mexico were completed by using the 
Table 1. Summary of seasonal changes in the net longshore sediment transport rates and transport gradients.

[Note the resulting gradients produced by differencing the transport rates. Positive gradients indicate deposition, while negative gradient indicates erosion. $\mathrm{m}$, meters; yr, year]

\begin{tabular}{|c|c|c|c|c|c|c|c|c|}
\hline Point & Latitude & $\begin{array}{l}\text { Segment } \\
\text { distance } \\
\text { (m) }\end{array}$ & \multicolumn{2}{|c|}{ Annual (long-term) } & \multicolumn{2}{|c|}{ Cold front season } & \multicolumn{2}{|c|}{ Hurricane season } \\
\hline 1 & 30.06 & & 132,480 & & 71,831 & & 115,600 & \\
\hline 2 & 30.04 & 2422 & 127,814 & -1.9 & 63,086 & -3.6 & 111,665 & -1.6 \\
\hline 4 & 29.99 & 2940 & 93,765 & -4.7 & 18,359 & -4.5 & 85,930 & -3.7 \\
\hline 5 & 29.95 & 4445 & 70,336 & -5.3 & $-5,742$ & -5.4 & 67,955 & -4.0 \\
\hline 6 & 29.93 & 2222 & 49,147 & -9.5 & $-23,113$ & -7.8 & 52,316 & -7.0 \\
\hline 7 & 29.90 & 3470 & 19,104 & -8.7 & $-52,712$ & -8.5 & 30,561 & -6.3 \\
\hline 11 & 29.79 & 3334 & $-53,830$ & -5.7 & $-104,899$ & -2.6 & $-18,351$ & -3.5 \\
\hline 12 & 29.75 & 4445 & $-70,690$ & -3.8 & $-113,475$ & -1.9 & $-25,761$ & -1.7 \\
\hline 13 & 29.72 & 3470 & $-87,886$ & -5.0 & $-109,004$ & 1.3 & $-29,412$ & -1.1 \\
\hline \multirow[t]{3}{*}{14} & 29.70 & 3650 & $-109,423$ & -5.9 & $-110,180$ & -0.3 & $-46,471$ & -4.7 \\
\hline & & Average & 15,442 & -5.7 & $-41,706$ & -4.4 & 31,984 & -3.9 \\
\hline & & $\begin{array}{l}\text { Standard } \\
\text { deviation }\end{array}$ & 82,305 & 2.3 & 67,158 & 3.2 & 56,065 & 2.0 \\
\hline
\end{tabular}

\footnotetext{
* Positive transport is north; negative transport is south.

* Positive gradient indicates deposition; negative indicates erosion.

+ Transport gradients correspond to a location in the middle of points.
}

NDBC buoy 42040. By using the peak over threshold (POT) method and a fitted Gumbel distribution, the storm waves for the 100-year, 10-year, and 1-year storms were generated (table 1).

Initial and boundary conditions (table 2) were then applied to the boundary of the large computational domain. The frequency range was set to $0.025-0.8 \mathrm{~Hz}$ and $\Delta \mathrm{f}=0.1 \mathrm{f}$. The large grid was mainly intended to propagate wave energy to the nested grids. The SWAN model will ultimately use an $\mathrm{f}^{-5}$ diagnostic tail for wave input above the cutoff frequency if needed. The directional space was discretized with 36 bins of 10 degrees over the full directional circle. Default convergence criteria were imposed. For situations in which large gradients in currents and bottom profile are expected (which is not the case here), a stricter criterion can be used. None of the simulations reached an iteration count of 15 . The following physical settings were also applied (these are default in SWAN, except the whitecapping formulation of van der Westhuysen [van der Westhuysen and others, 2007]). Quadruplets were automatically accounted for when wind was applied. Default wave breaking was used. Friction was accounted for by a default Joint North Sea Wave Project (JONSWAP) criterion for general wind sea waves (for swell waves an alternative constant should be used).

A boundary condition was applied at the southern and eastern sides of the grid by using a JONSWAP spectrum, described by the $\mathrm{H}_{\mathrm{m} 0}, \mathrm{~T}_{\mathrm{p}}$, peak enhancement factor gamma (default 3.3). Direction spreading was assumed to be described with $\cos ^{2}(\theta)$. For wave and wind directions 90 degrees to 225 degrees, a constant boundary condition was applied on both boundaries. This condition was sufficient to describe the wave condition at the boundary, as the model quickly adapted to local driving conditions within a few hundred meters inside the model domain boundary. For waves with incident 
Table 2. Statistical estimate of return periods for wind, waves, and water level based on Gumbel distribution for different storm conditions applied as boundary conditions at the seaward open boundary in the numerical model Simulating WAves Nearshore (SWAN; Holthuijsen and others, 1993) for the Chandeleur Islands, La.

[m, meters; s, seconds; NAVD 88, North American Vertical Datum of 1988]

\begin{tabular}{lrrr} 
& $\begin{array}{r}100- \\
\text { year } \\
\text { storm }\end{array}$ & $\begin{array}{r}10- \\
\text { year } \\
\text { storm }\end{array}$ & $\begin{array}{r}1- \\
\text { year } \\
\text { storm }\end{array}$ \\
\hline $\mathrm{H}_{\mathrm{mo}}(\mathrm{m})$ & 20 & 14 & 6.5 \\
$\mathrm{~T}_{\mathrm{p}}(\mathrm{s})$ & 17 & 13.5 & 9 \\
Water level elevation $(\mathrm{m})$ in NAVD 88 & 4 & 3 & 1.5 \\
Wind speed $(\mathrm{m} / \mathrm{s})$ & 42 & 28 & 19 \\
\hline
\end{tabular}

angles of 45 degrees, it would be unrealistic to use the wave conditions shown in table 2 for the entire eastern boundary because of the proximity of land near the northern portion of the eastern boundary; hence, a simple Bretschneider's formula was used to account for finite wave growth occurring beyond the boundary. Additionally, an increasing wave spectrum was assumed starting at $\mathrm{H}_{\mathrm{m} 0}=1$ and $\mathrm{T}_{\mathrm{p}}=4$ to values of $\mathrm{H}_{\mathrm{m} 0}$ and $\mathrm{T}_{\mathrm{p}}$ (table 3) calculated by using Bretschneider's formula for the northernmost part of the eastern boundary and interpolated to deepwater conditions to the southeast corner of the boundary.

The model was validated by using a Hurricane Katrina hindcast stationary wave simulation using boundary conditions produced by Smith (2007). The simulation was compared to observations to check the assumptions and parameters within the model (table 4). The results were adequate and comparable, and the model was considered satisfactory and was used unchanged thereafter except for selection of different boundary conditions. Model sensitivity was also carried out to test the model's response to selection of initial and boundary conditions. All sensitivity reported change of less than 5 percent in general for wave heights and wave periods. For instance, a change in water level of $1 \mathrm{~m}$ as the initial condition resulted in a change of approximately 2.95 percent on the wave heights and approximately 2.8 percent on the wave periods. For each storm wave, incoming or approaching angles were selected at 45, 90, 135, 180, and 235 degrees. In addition, a cold front or winter storm was simulated with northwesterly winds, which are typical after the passage of a front.

\section{Wave Propagation}

The wave boundary condition is located in deep water (much greater than $200 \mathrm{~m}$ ). The propagation of wave energy
Table 3. Boundary conditions applied for the 45-degree calculation.

$[\mathrm{m}$, meters; s, seconds]

\begin{tabular}{ccccc} 
& & $\begin{array}{c}1- \\
\text { year } \\
\text { storm }\end{array}$ & $\begin{array}{c}10- \\
\text { year } \\
\text { storm }\end{array}$ & $\begin{array}{c}100- \\
\text { year } \\
\text { storm }\end{array}$ \\
\hline Boundary condition 1 & $\mathrm{H}_{\mathrm{mo}}(\mathrm{m})$ & 3.2 & 2.5 & 2 \\
& $\mathrm{~T}_{\mathrm{p}}(\mathrm{s})$ & 7 & 6 & 5 \\
& $\mathrm{H}_{\mathrm{mo}}(\mathrm{m})$ & 6.5 & 4.5 & 3 \\
\hline & $\mathrm{T}_{\mathrm{p}}(\mathrm{s})$ & 9.5 & 8 & 6.5 \\
\hline
\end{tabular}

Table 4. Comparisons between predictions made by using the Simulating WAves Nearshore (SWAN) numerical model and observations during a Hurricane Katrina hindcast.

[m, meters; s, seconds; NDBC, National Data Buoy Center]

\begin{tabular}{cccc} 
& $\begin{array}{c}\text { Predicted } \\
\text { with SWAN }\end{array}$ & $\begin{array}{c}\text { Observed at } \\
\text { NDBC buoy } \\
42007\end{array}$ & $\begin{array}{c}\text { Difference } \\
\text { (predicted - } \\
\text { observed) +/-\% }\end{array}$ \\
\hline $\mathrm{H}_{\mathrm{m} 0}(\mathrm{~m})$ & 5.38 & 5.64 & -5 \\
$\mathrm{~T}_{\mathrm{m} 01}(\mathrm{~s})$ & 8.44 & 8.1 & 4 \\
$\mathrm{~T}_{\mathrm{p}}(\mathrm{s})$ & 13.87 & 14.3 & -3 \\
\hline
\end{tabular}

directly off the boundary inwards is not affected by any finite water effects, as can be seen from the nearly constant wave period (fig. 6). The wave direction is identical to the wind direction, and hence the wave period remains more or less constant over the initial several kilometers. At the east side boundary, the effect of the decreasing depth can be seen in the upper part of the grid (fig. 6). The wave height decreases significantly when the waves propagate over the coastal shelf break, which can be observed in the region indicated by the solid ellipse in figure $6 A$ and also visible in $6 B$. Refraction of incoming wave rays can also clearly be seen in these results for the largest grid by the changing vector directions, which indicates that already at deeper waters (greater than $50 \mathrm{~m}$ ), waves can "feel" the presence of the bottom topography.

Wave heights and periods are higher at the northern part of the Chandeleur Islands, where a large tidal inlet stretches to the north of the barrier islands (fig. 6A). The northern part of the barrier islands is clearly more exposed to higher wave energy than is the southern part because the deeper isobaths penetrate closer to the barrier islands. As a result, larger wave energy propagates closer to the barrier islands 

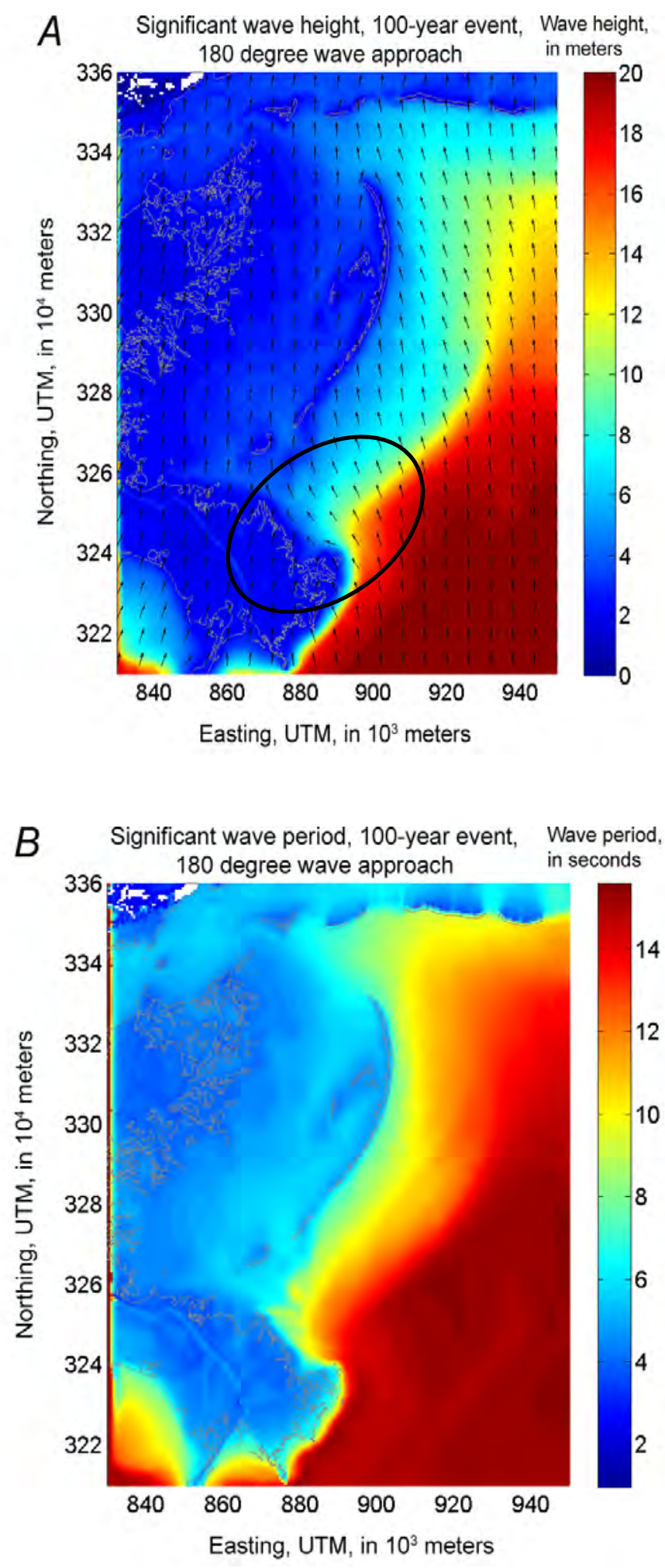

Figure 6. $A$, Wave height $\mathrm{H}_{\mathrm{m} 0}$ and $B$, wave period $\mathrm{T}_{\mathrm{m}-1,0}$ of results of grid "GridLarge" for a return period of 100-year and an incoming direction of 180 degrees predicted by using the numerical model Simulating WAves Nearshore (SWAN). 
before undergoing transformation and dissipation. It is also noted here that the local wave direction in the southern part is relatively more perpendicular to the depth contour lines or isobaths than in the northern part.

\section{Bottom Velocity}

From the boundary inwards (from the southeast corner), bottom velocities are zero, indicating that conditions are truly deep water (fig. 7). Propagating nearshore, an increase of the $\mathrm{U}_{\text {bot }}$ can be observed at the first break of the shelf, indicated with the dashed ellipse (fig. 7). As depth decreases, the presence of the bottom is felt by incoming waves, and the bottom velocity increases as a result. The bottom excursion velocities soon become significant, up to $1 \mathrm{~m} / \mathrm{s}$. The excursions in bottom velocity persist up to the second shelf break (see the solid ellipse in fig. 7). Here, orbital velocities become large, and surf breaking occurs. Wave energy is further dissipated over the shallow foreshore, shoreface, and near the Chandeleur Islands where orbital velocities in excess of $1 \mathrm{~m} / \mathrm{s}$ are still observed. Further to the north, at the large tidal inlet between Hewes Point and the Mississippi barrier islands, bottom velocities are larger than at the central part and southern end of the barrier island chain.

\section{Dissipation Terms}

In deeper water, the whitecapping term is dominant (fig. 8A), which can be explained by the fact that in the energy balance equation, wind input at deep water results in an increase of wave steepness. Part of the energy is then redistributed over frequencies, but most of it is dissipated by whitecapping. In shallower waters, the presence of the bathymetry results in wave shoaling with steeper waves as well. Breaking of these waves is accounted for by the surf dissipation term. There is clearly dissipation over the bars in front of the barrier islands (fig. $8 A$, left, and $8 B$, left), as well as the confined surf zone near the beach line of the barrier islands.

For the 1-year return period, the energy transfer from wind into the wave field is much lower, and hence all action balance terms are lower in absolute sense (fig. 8C). The presence of the shelf break is not observed anymore in the surf dissipation term. At deeper waters, whitecapping continues to be the predominant process, which indicates that for smaller return periods, the active surf zone is much more confined. Since depth-limited breaking occurs in the nearshore for both storm waves, the nearshore dissipation is similar, except for differences in breaking that are produced by the storm surge associated with each storm wave. Larger storms in this study were assumed to be accompanied by higher storm surge, therefore producing small differences in the size of the surf zone.

\section{Implications for Sediment Transport}

After analyzing all of the SWAN simulations (comparing the breaking wave angle relative to the shoreline), it was concluded that for incident wind and wave directions of 90 degrees (azimuth), the resulting longshore current indicates a nodal point in the central portion of the Chandeleurs. South of this point, the longshore current is directed southwards, and north of this point, longshore currents are directed northwards. This observation confirms results presented by the one-dimensional model and is consistent with the literature (Georgiou and others, 2005; Ellis and Stone, 2006). With increasing incoming wave and wind direction from the south, the longshore current along the barrier islands is directed northward along the entire barrier island chain. Therefore, for all simulations performed herein, and for incoming wave directions of greater than about 110 degrees and large incident wave heights and periods, longshore currents are mainly directed north. A northward transport direction is even more apparent during storms, especially those that pass westward of the barrier islands because they produce wind directions that range from 90 degrees to 180 degrees. Such observations further emphasize the importance of these storms not only on the evolution of the barrier island chain but also on the redistribution of the sand to the north.

\section{Bottom Velocity}

In addition to surf zone processes and longshore sediment transport resulting from storm waves and fair weather conditions, sea floor change analysis performed by Miner and others (this volume) indicate large erosion of the lower shoreface at depths that are beyond the fair weather wave base. Eroded and accreted sediment volume measured in this study cannot be accounted for by typical sediment transport in the littoral zone. These areas are active, however, during large or even intermediate storms (fig. 9) and may become part of the littoral transport system. We point out here that the shelf break plays a critical role in controlling large wave dissipation by reducing wave velocities by approximately $2 \mathrm{~m} / \mathrm{s}$. This dissipation is almost irrespective of incoming wave direction. For lower return periods, the extent of the area with large bottom velocities is far less but is substantial nonetheless. For instance, return periods of 10 years produce bottom velocities of $1.5 \mathrm{~m} / \mathrm{s}$ at depths of approximately $50 \mathrm{~m}$, and 1-year return period storms produce velocities of approximately $1 \mathrm{~m} / \mathrm{s}$ at similar depth. These results indicate that the entire lower shoreface is active at least once a year for transport and that at least once every 10 years substantial erosion can be expected. 


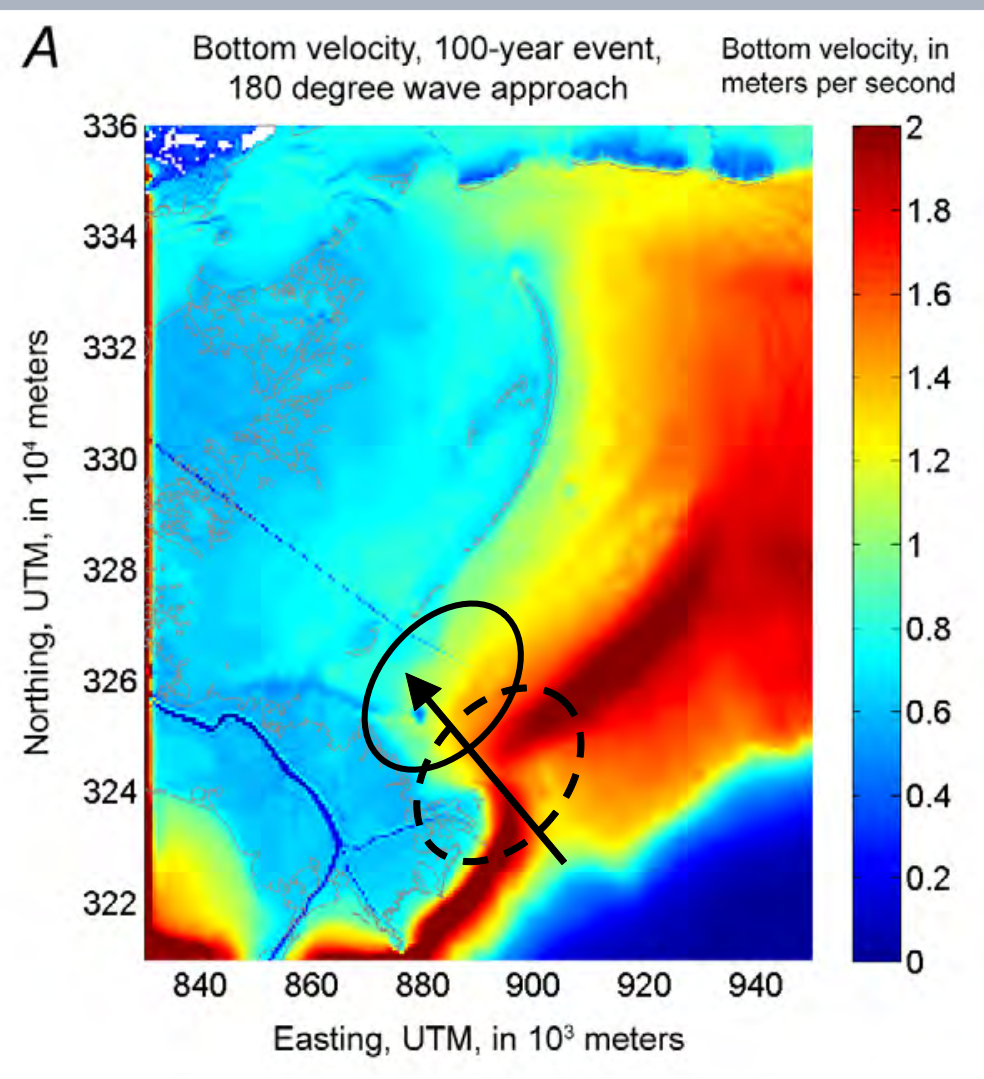

$B$ Bottom wave period, 100-year event, Bottom wave period,

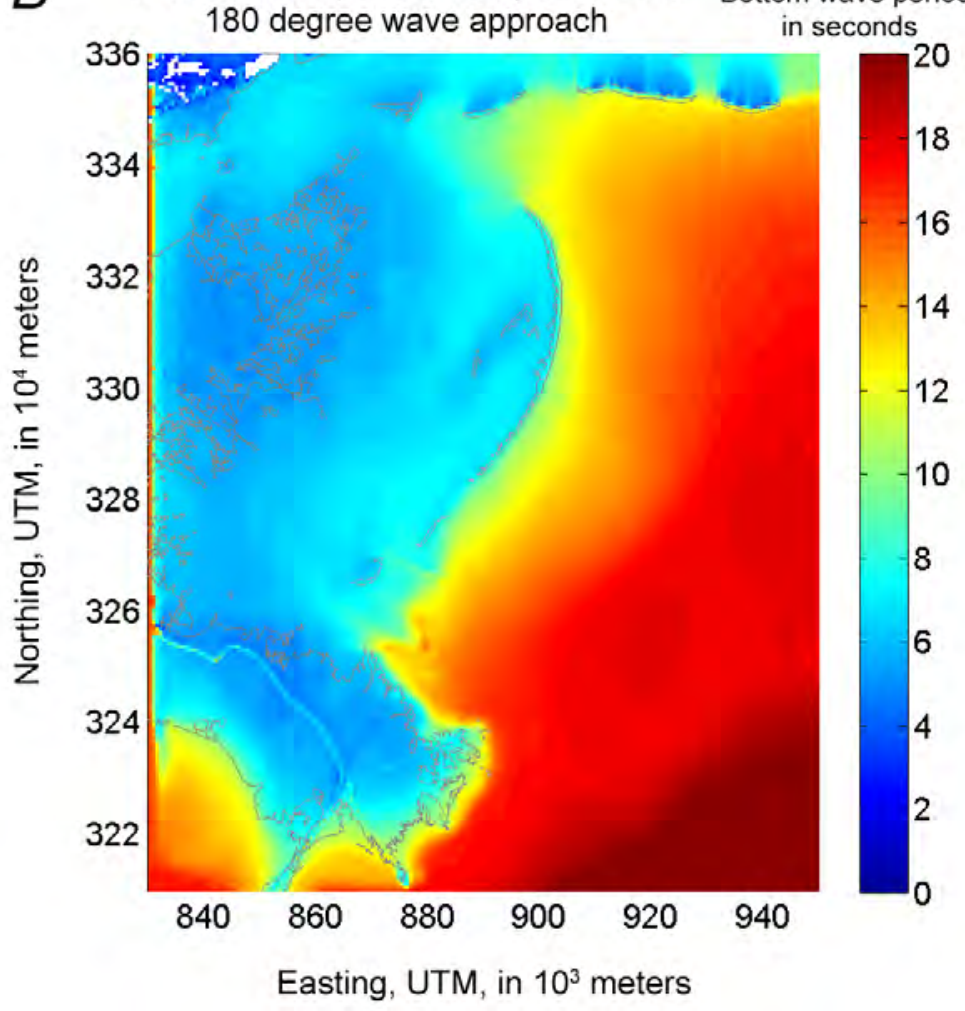

Figure 7. $A$, Bottom velocity $\mathrm{U}_{\text {bot }}$. $B$, Bottom wave period $\mathrm{T}_{\mathrm{mBot}}$. 

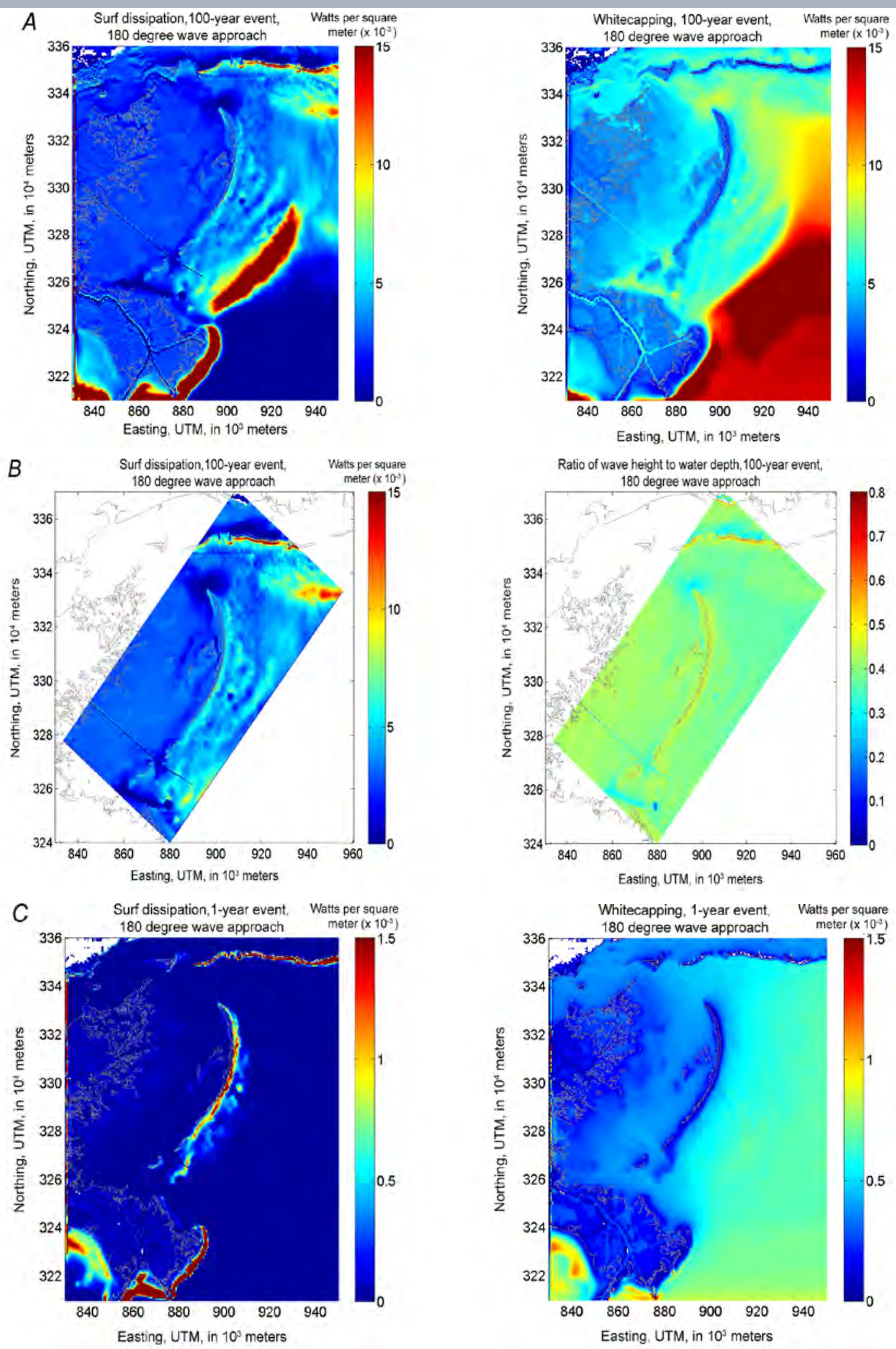

Figure 8. $A$, Surf breaking dissipation (left panel) and whitecapping (right panel) plotted at the same scale for 100-year event and 180 degrees. $B$, Surf dissipation and $\mathrm{H}_{\text {mo/d }}$ ratio of the nested grid for 100 -year event and 180 degrees. $C$, Surf breaking dissipation and whitecapping for 1-year event and 180 degrees. 

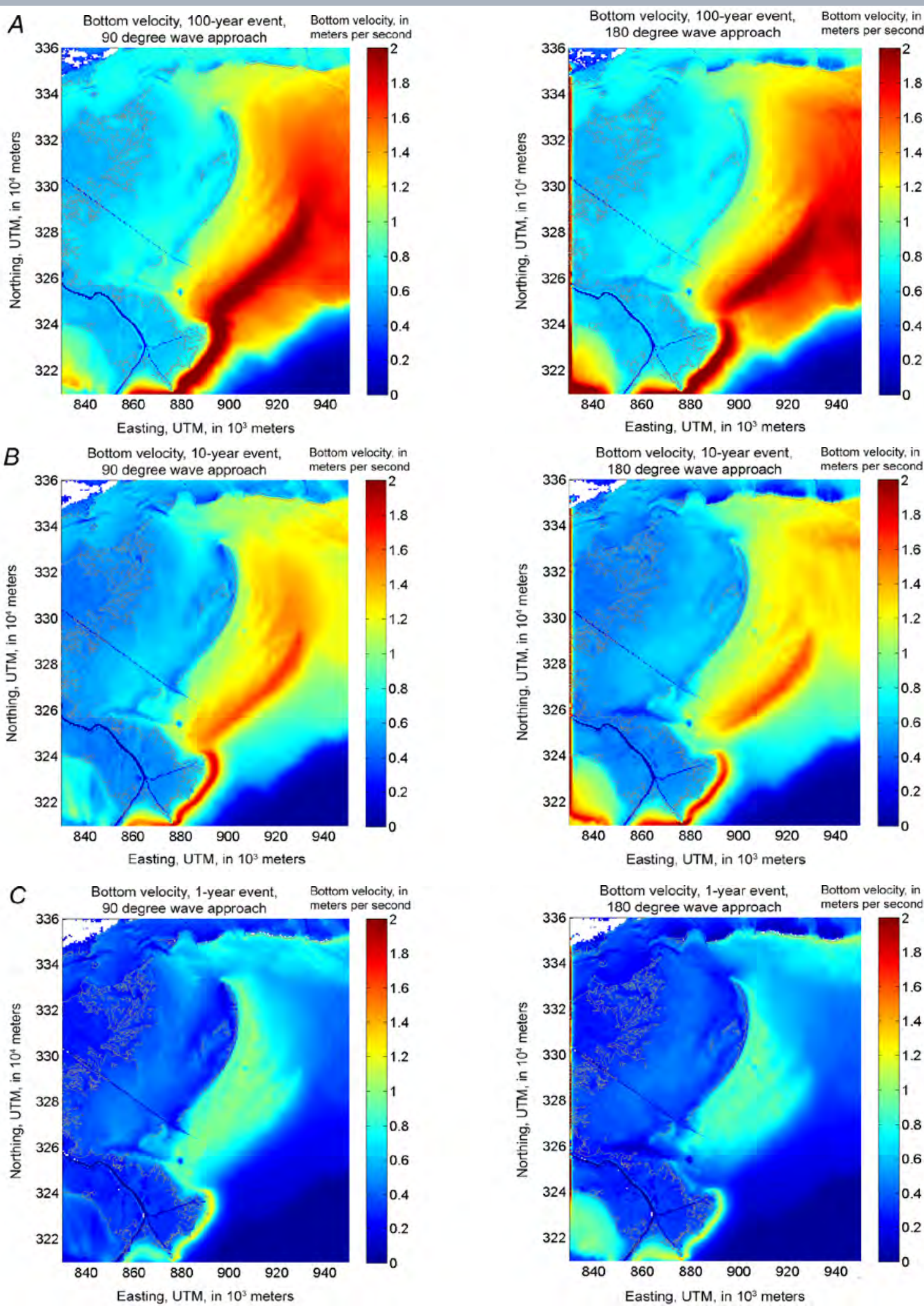

Figure 9. Bottom velocity for incoming waves of 90 and 180 degrees for the 100 -year, 10 -year, and 1-year return period storms. $A$, 100-yr event and 90 degrees (left panel) and 180 degrees (right panel). $B, 10$-yr event and 90 degrees (left panel) and 180 degrees (right panel). C, 1-yr event and 90 degrees (left panel) and 180 degrees (right panel). 


\section{Winter Storms and Cold Fronts}

Northwest of the Chandeleur Islands, finite water wave growth is observed around the Biloxi Marshes with a wave height up to $1 \mathrm{~m}$ and a wave period of 3 seconds. At the northern tip of the Chandeleurs, near Hewes Point, wave height increases further because of increasing depth (fig. $10 A$ ). The same observations appear for the wave period, which increases to values over 4 seconds (fig. 10B). At this point waves also refract in the southward direction because of increasing depth.

Orbital velocities near the sea floor do not exceed values of $0.4 \mathrm{~m} / \mathrm{s}$ (fig. 11A), which is much less than the values simulated during larger storms and hurricanes, where values were in excess of $2 \mathrm{~m} / \mathrm{s}$. This difference can mainly be attributed to the fact that a growth limit exists for waves growing over shallow waters, and hence both wave height and wave period are limited by depth. As a result of depth-limited waves, bottom velocities are rather small and cannot grow beyond these limitations. While the same limitations exist for larger storms, these storms are typically associated with higher storm surge, which allows for additional wave growth. Surf dissipation is only observed in areas with depth gradients, and the largest dissipation is observed at the northern tip of the Chandeleur Islands. In this area, incoming waves from the northwest refract and dissipate their energy around the Hewes Point spit, reshaping it in both directions. This energy is also important in reworking the sand that may exist landward of the backbarrier.

\section{Tide-Induced Currents}

Tide-induced currents in the vicinity of the Chandeleur Islands and the Chandeleur and Breton Sounds are perhaps not strong enough to mobilize sand because of the microtidal regime, but these currents can be very effective in transporting finer material once in suspension. To study the distribution and magnitude of tide-induced currents in the study area, a numerical model was used. The finite volume coastal ocean model (FVCOM; originally developed by Chen and others, 2003) has successfully been applied to southeast Louisiana by Georgiou and others (2007) and by McCorquodale and others (2008). In this study, the model spinup time was 2 days, and the remaining 28 days included two spring/neap cycles (fig. 12). In tidal inlets and small curved channels, the model predicted residual velocity patterns similar to those observed by Li and others (2008). In the vicinity of tidal inlets, depthaveraged velocities exceeded $1.0 \mathrm{~m} / \mathrm{s}$ during the spring tides, while residual currents averaged through the entire simulation appeared to be $0.25 \mathrm{~m} / \mathrm{s}$, and they were generally higher in the north end of the barrier island chain compared to the central portion.

While residual currents provide insight into the available energy in the water column to transport fine material, they also provide potential preferential pathways for flow through the barrier island chain, and perhaps information on available pathways for storm-induced flow. Tidal inlets undergo approximately $1 \mathrm{~m} / \mathrm{s}$ higher velocities than do other shorelines (fig. 13) and can be used to infer potential transport of sediment through these inlets given material in suspension from an event (that is, a cold front). Once in suspension, these currents can also be used to infer the potential of this material to be imported into the bays and sounds or to be exported offshore.

\section{Storm-Induced Circulation and Transport}

During storms, waves activate deeper areas offshore and subject the bed to applied shear stresses suitable for erosion. This erosion was observed in the sea floor change analysis by Miner and others (this volume) and was reported by List and others (1997) and Jaffe and others (1997) for studies west of the modern delta of the central Louisiana coast. Once this material is eroded, and while in suspension, it can leave the system by means of circulation during the event. Circulation patterns during a storm can maintain particles in suspension and given enough turbulence in the water column can transport them outside the system-offshore or onshore. Conditions may be such that (1) this material never returns to the vicinity of the barrier islands or (2) the return takes place over a longer timescale or with a different process or mechanism. To investigate and quantify this process are extremely difficult without observations of the specific event. There are several unknown parameters that not only are not available in literature but also have time-dependent properties that make it impossible to capture both spatially and temporally. For instance, we know very little about the strength, cohesion, erosion rates, and in situ properties of prodelta material, which is the material that underlies the St. Bernard Delta Complex. In addition, bottom boundary layer development during a storm and accurate measurements of currents near the bed are also largely unknown except in much deeper water from acoustic current profilers. For this purpose, numerical tools can help provide a first-order estimate and give enough information to direct further studies and measurements. To achieve this, the Advanced Circulation Model (ADCIRC) was used with post-Katrina bathymetry (Resio and Westerink, 2008). This coupled wave-storm surge model was used to perform a suite of simulations for lower intensity storms (Sleath and others, 2009) rather than extremely large events because the lower intensity events have smaller return periods. A suite of hypothetical storms were used, which were developed by the U.S. Army Corps of Engineers (2006) during post-Hurricane Katrina design and probability analysis. Several storms were simulated with tracks passing both east and west of the barrier islands within approximately $40 \mathrm{~km}$. A direct hit on the Chandeleur Islands was not investigated. For simplicity, shore-perpendicular 

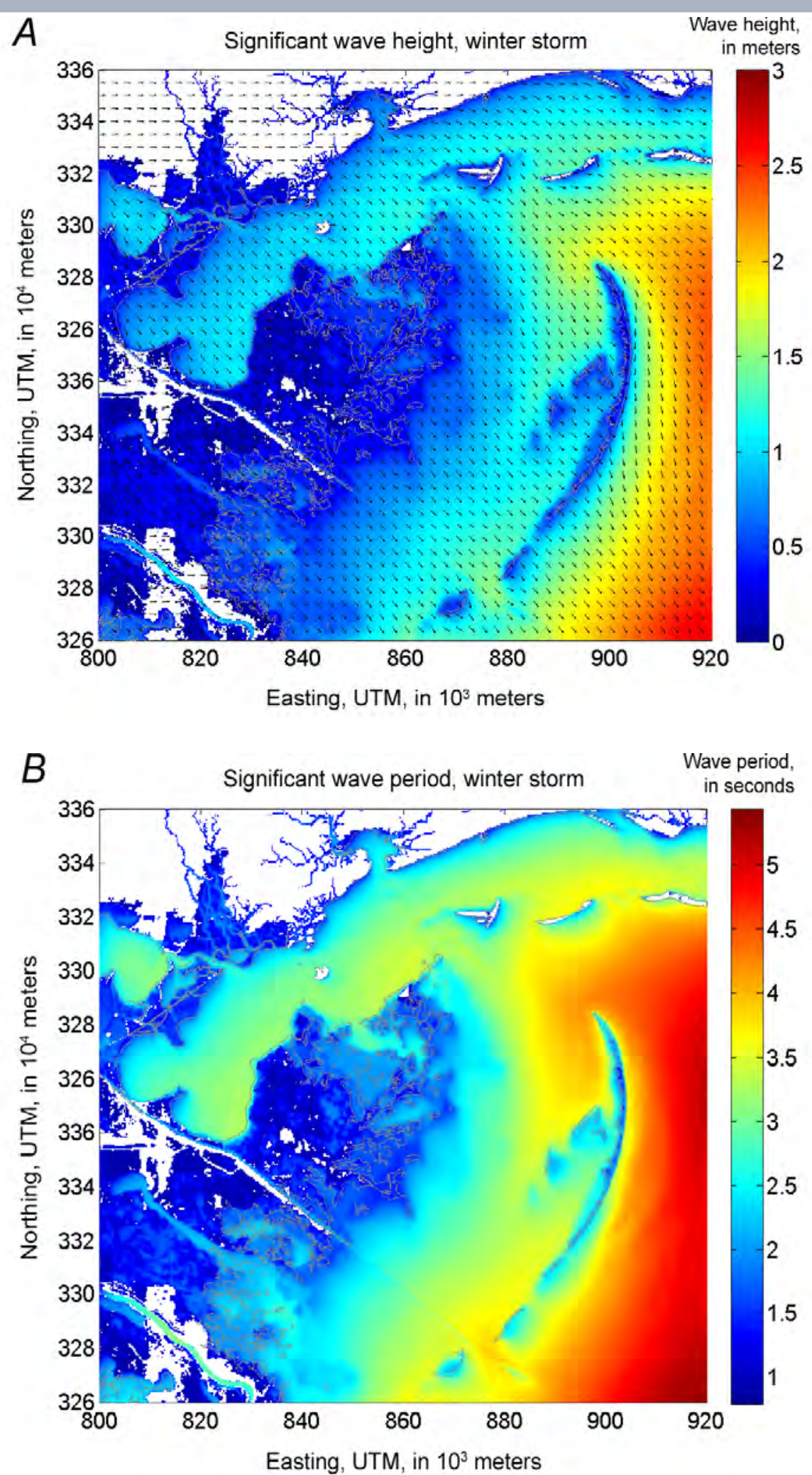

Figure 10. $A$, Wave height $\mathrm{H}_{\mathrm{m} 0}$ of the winter storm. $B$, Wave period $\mathrm{T}_{\mathrm{m}-1,0}$ of the winter storm. 


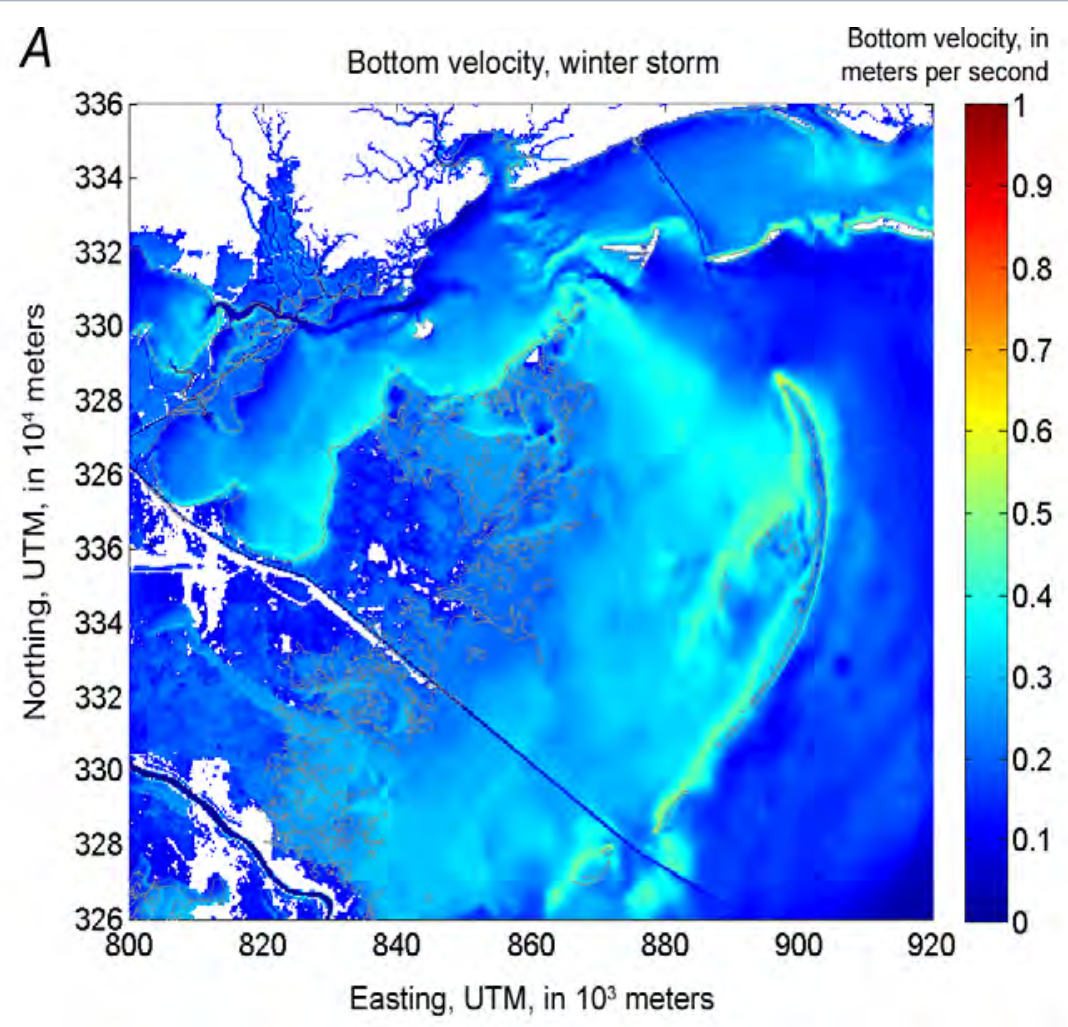

$B$

Surf dissipation, winter storm

Watts per square

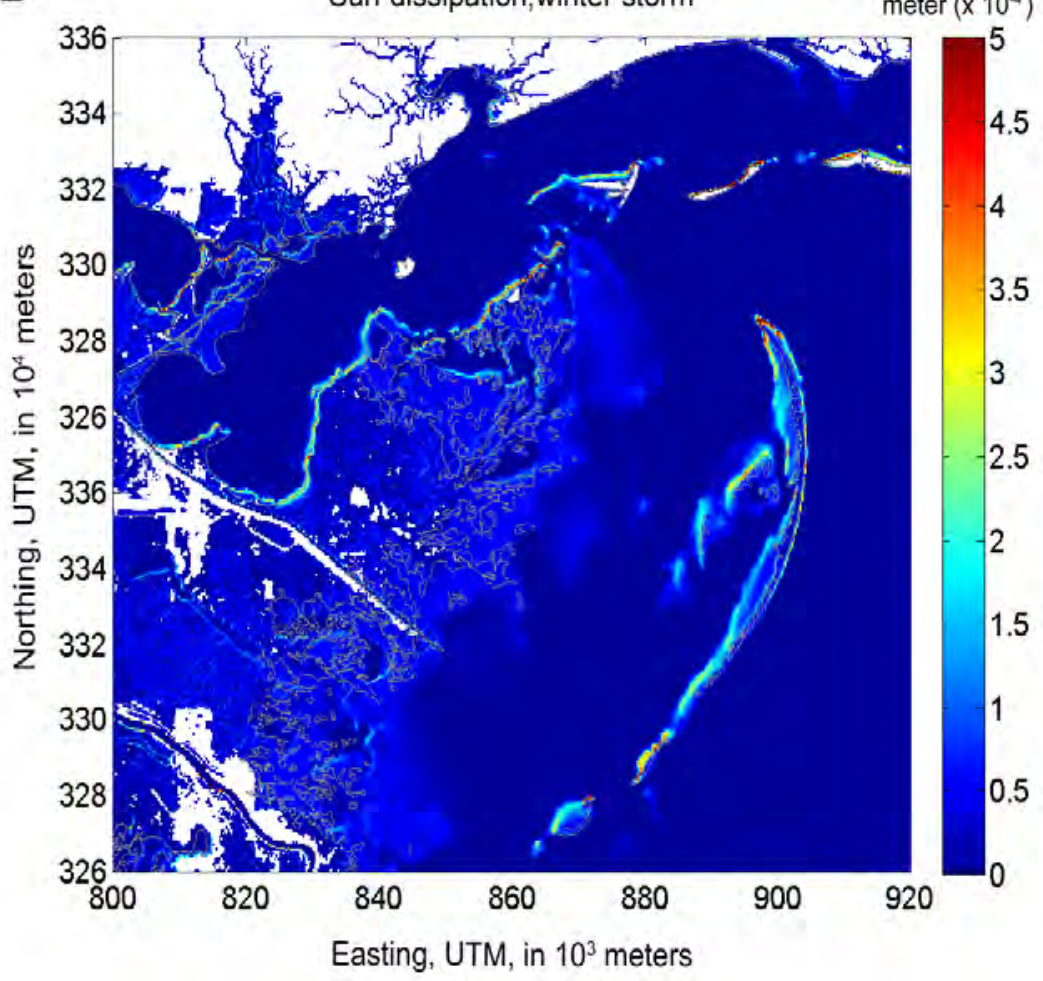

Figure 11. $A$, Bottom velocity $\mathrm{U}_{\text {bot }}$ during a winter storm simulation. $B$, Surf dissipation in a winter storm simulation. 


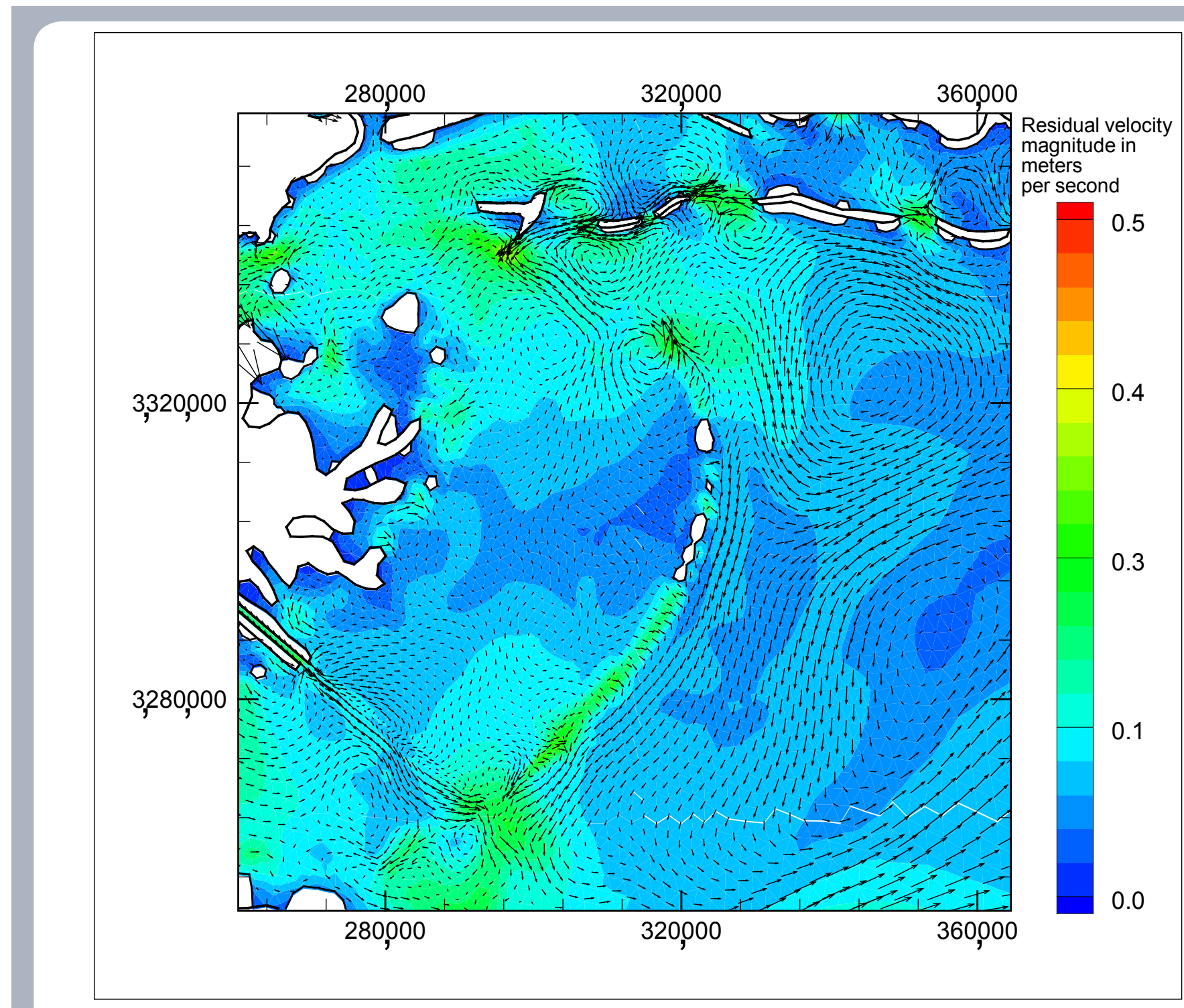

Figure 12. Residual tidal currents (depth-averaged) after a 30-day tidal simulation without wind forcing. Velocity vectors indicate direction, while the color contours indicate magnitude.

profiles were selected to extract velocity and water surface elevation (surge) information. The model output timedependent information every 30 minutes along this profile, which extended beyond the lower shoreface into water depths beyond $30 \mathrm{~m}$. Information and discussion that follow are based on one of these profiles (fig. 14). The history, during the development of the storm, is shown along this profile (fig. 14) to characterize general circulation in the vicinity of the barrier islands during such events and infer resulting transport.

Of particular importance in the storm surge simulations was the overtopping of the barrier islands with a rather small intensity storm (fig. 15), which was primarily due to the fact that the elevation post-Katrina generally showed low subareal exposure and very little dune fields. Ground observations also reported the highest dunes 2 years after Hurricane Katrina in the north-central portion of the Chandeleur Islands to be approximately $1.2-1.4 \mathrm{~m}$ in height. We note that this elevation will most likely be exceeded during an intermediate event or a low-intensity storm. The values shown in figure 15 (an averaged storm surge of approximately $0.5 \mathrm{~m}$ in the vicinity of the barrier islands as the storm nears and a maximum surge of $1.2 \mathrm{~m}$ ) do not include the wave setup, which would only increase the maximum surge observed near the islands. At time 96 hours, the barrier islands are overtopped, and overland 

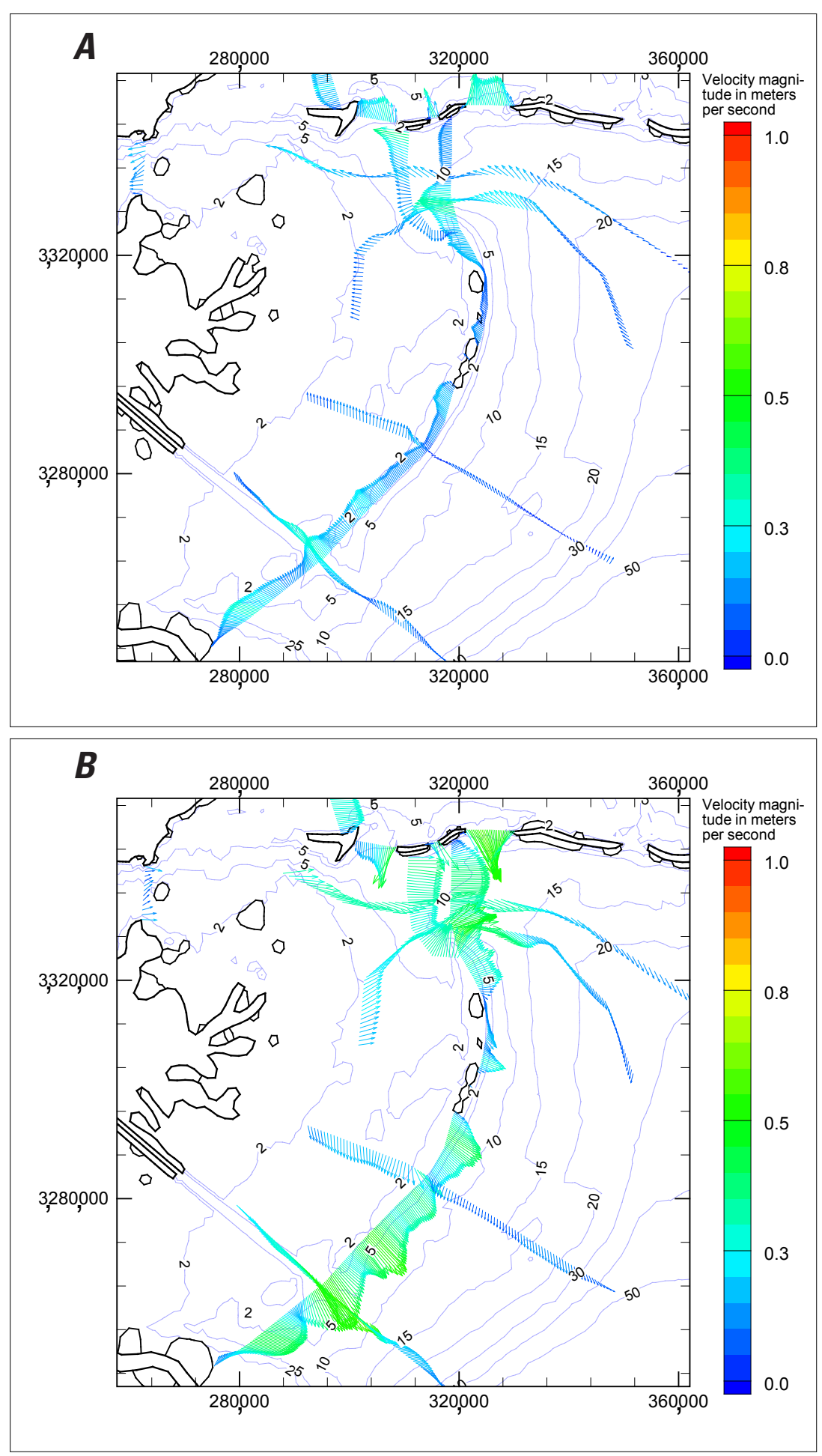

Figure 13. A, Maximum tidal current magnitude (colored) and direction (vector) for spring tides during flood. $B$, Maximum tidal current magnitude (colored) and direction (vector) for spring tides during ebb. Note the broad sheet of high-velocity areas in the ephemeral sand bodies (previously known as Curlew and Grand Gosier Islands) and through other inlets across the barrier islands including the one north of Hewes Point between the Chandeleurs and the Mississippi barrier islands. 


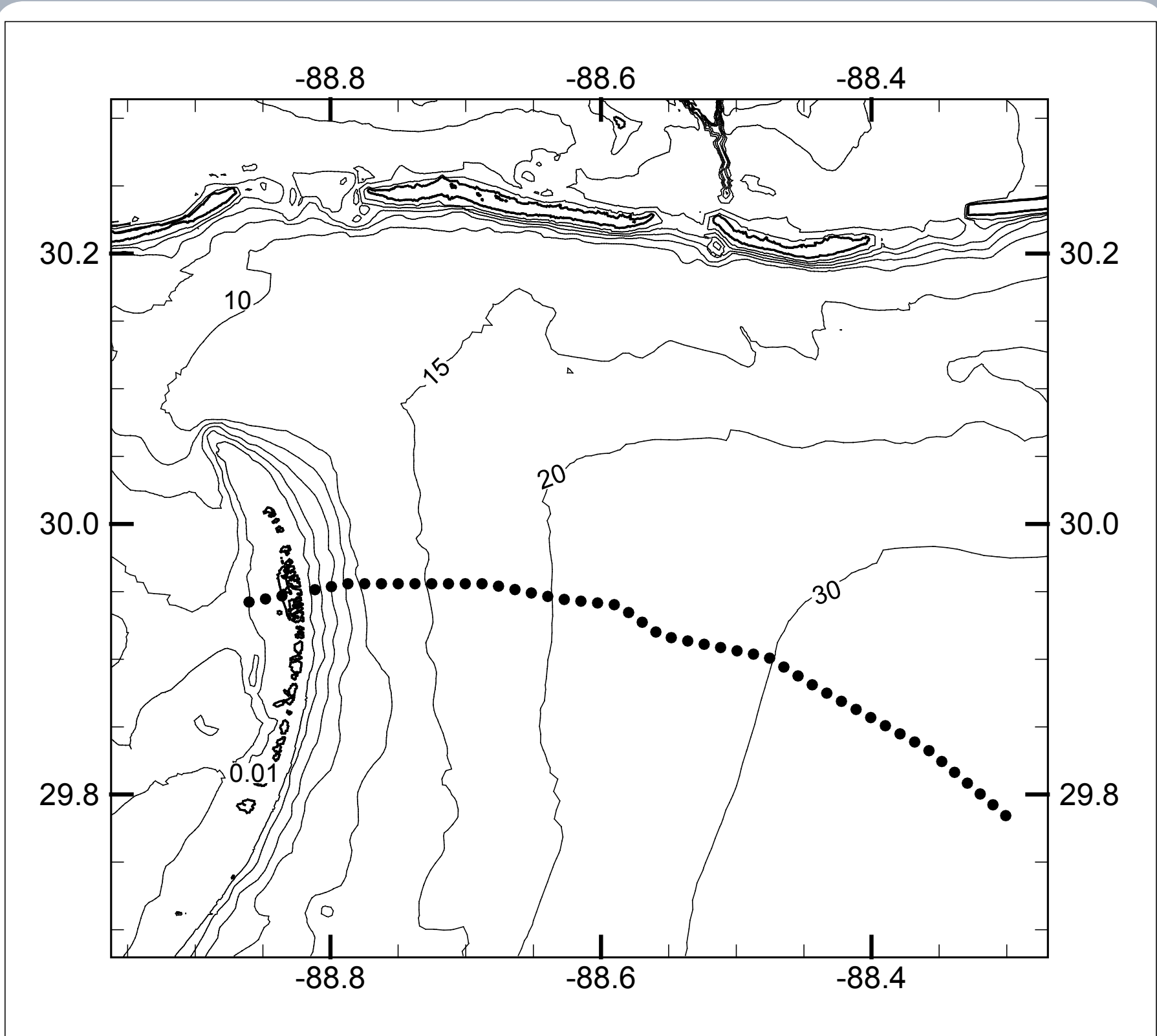

Figure 14. Shore-perpendicular profile showing the data extraction during the Advanced Circulation (ADCIRC) storm simulations (Sleath and Georgiou, 2009).

flow occurs for the majority of the barrier islands (fig. 15). Velocities of $1 \mathrm{~m} / \mathrm{s}$ are observed, directed westward, as flow is directed over the barrier islands. At this instant, velocities of up to $0.5 \mathrm{~m} / \mathrm{s}$ are also observed at offshore depths of $12-15 \mathrm{~m}$ (indicated in the upper panel of fig. 15 by the gray box). As the storm moves farther north and wind fields change, water and surge start to recede and are directed eastward. Setup in the backbarrier forces water over the barrier islands again (shown in fig. 15 to be directed eastward) with magnitudes of $0.5-0.6$ $\mathrm{m} / \mathrm{s}$. Shortly after, northwesterly winds and the relaxation scale of the event drive water to move toward the southeast with velocities of $0.5 \mathrm{~m} / \mathrm{s}$. This velocity is similar to offshore depths of approximately $20 \mathrm{~m}$. When the surge recedes more, the barrier islands are no longer overtopped, and conditions slowly relax and return back to normal tidal conditions. It should be noted that the velocity and elevation shown in figure 15, in particular when the barrier island is inundated, may show higher than expected pressure gradients across 

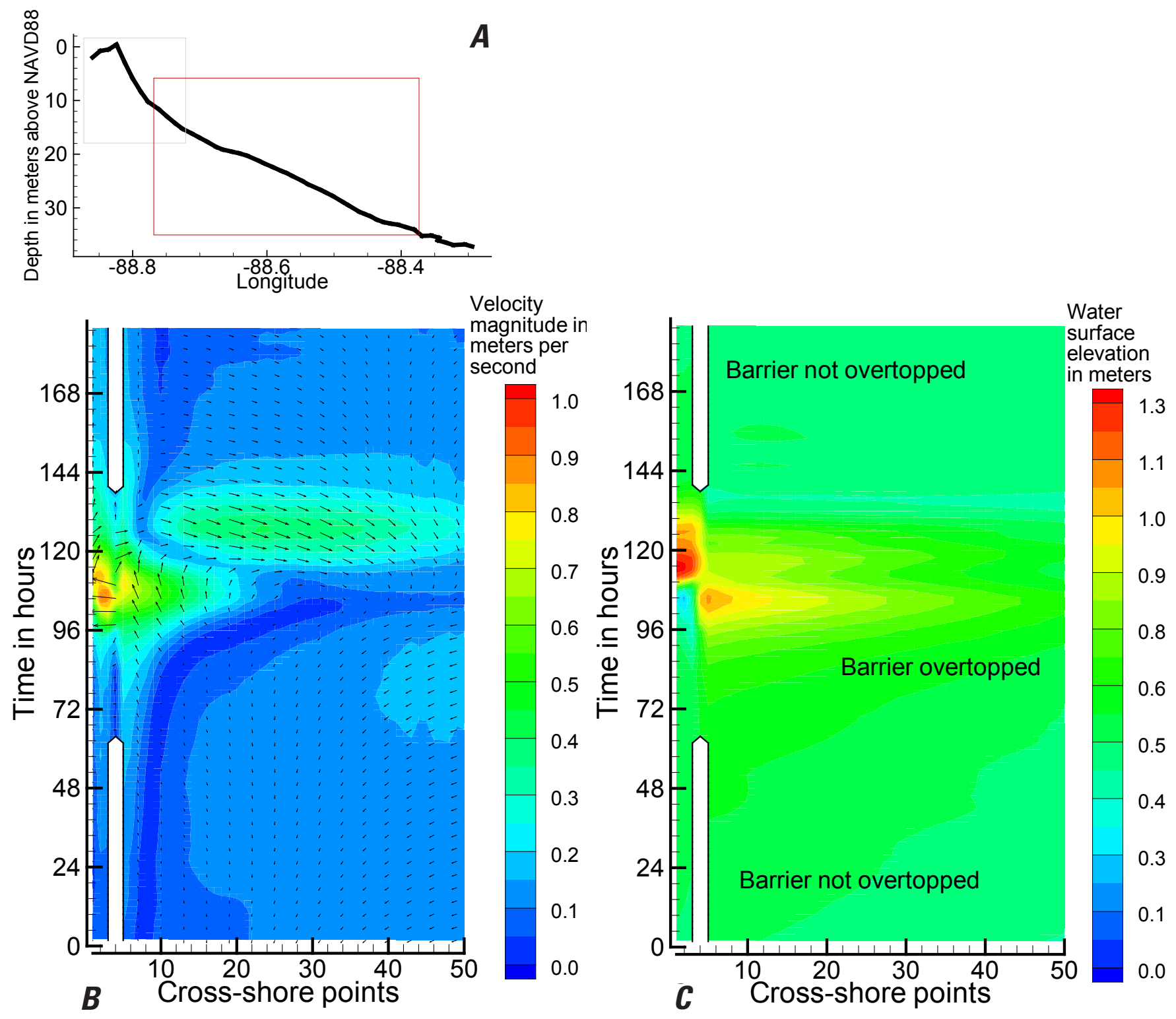

Figure 15. Evolution of the depth-averaged velocity magnitude (color), direction (vector), and storm surge during a storm along the profile shown in figure 14. Information starts at about 1 day before the storm is felt in the area. Therefore, time zero corresponds to approximately 1 day prior to the storm being in the vicinity of the modern delta. The specific storm in this figure has a track that is west of the Chandeleur Islands going northward over the east edge of the Biloxi Marshes and a central pressure of 975 millibars, $11 \mathrm{kn}$ forward speed, and $11 \mathrm{nmi}$ radius to maximum winds. $A$, Cross-shore depth. Gray box shows the active barrier bed during the advancement of the storm, and red box shows the active bed during the return flow. The $y$-axis indicates the depth at which derived data are displayed. $B$, Time-dependent velocity (cross-shore points refer to the individual points shown in fig. 14). C, Storm surge (cross-shore points refer to the individual points shown in fig. 14). NAVD 88, North American Vertical Datum of 1988. 
the barrier islands, and as a result a higher velocity could be observed. These high pressure gradients are not necessarily true, even with extreme setdown in the backbarrier, and may be an artifact of the extracted information from the model nodes. The general circulation pattern and the time-dependent evolution of the profile (as well as the relative physical processes) are, however, captured accurately and provide insight into the evolution of water surface elevation and velocities along the barrier islands.

\section{Discussion and Conclusions}

The Chandeleur Islands are undergoing rapid transgression or transgressive submergence (Miner and others, this volume). The barrier islands have been impacted severely by storms in the last decade, and there has been a very slow process of recovery. A similar recovery of this system after Hurricanes Camille (1969) and Betsy (1965) was possible because of the subsequent quiescent period of 25 years, during which no named storms were recorded until Hurricane Andrew in 1992. During this quiescent period, the Chandeleur Islands built a substantial subaerial footprint, large enough to absorb substantial energy from Hurricane Georges in 1998. Some recovery after Hurricane Georges gave the barrier islands sufficient footprint to withstand the immense forces of Hurricane Ivan (2004); however, a year later and with little defense, the barrier islands were completely obliterated by Hurricane Katrina. The entire sand volume in the system disappeared and was only seen in the form of offshore bars that slowly started to migrate onshore after several months. With sand not seen in the immediate footprint of the barrier islands for months post-Katrina, the Chandeleur Islands' recovery period slowly started (as recorded in this volume). Not long after, Hurricanes Gustav and Ike (2008) caused additional impacts on the Chandeleur Islands that were of different nature and scale. Field observations of subsurface methods (Twichell and others, this volume), coring and grain-size analysis (Flocks and others, this volume), and shoreline change analysis (Fearnley and others, this volume) suggest that the north portion of the barrier island is not migrating or eroding as fast as is the southern portion, that there exists sufficient sand in the system, and that some progradation has been observed. The central and southern portions of this barrier island chain are undergoing extreme change with rapid erosion rates that are perhaps due to coastal straightening response to modern delta progradation. The longshore sediment transport rates produced herein and those that exist in the literature cannot explain the volumes of sand identified by other studies in this report. These processes, however, have been operating in a similar way since the last abandonment of the St. Bernard Delta Complex. We note that during storms with return periods of 1,10 , and 100 years, wave modeling has shown that northward transport is dominant. This dominance in fact occurs when incident wave angles are greater than 110 degrees. A storm with a typical path to the west of the barrier islands will produce winds and wave conditions that will have incident angles in excess of 90 degrees for more than 75 percent of the time. In addition, during these events, rates of transport can more than double because transport rates predicted by the CERC equation (Coastal Engineering Research Center, 1977) are proportional to the wave height raised to the $5 / 2$ power or $\mathrm{H}^{5 / 2}$. Since fair weather wind and wave energy is not available to rework this material and redistribute it back in the littoral system, large accumulation rates take place on the northern portion of the barrier island and especially close to Hewes Point. In addition, the large accommodation space that exists north of the Hewes Point spit acts as a sink of sediment that is permanently lost from the littoral system. Winter storm simulations performed herein have demonstrated some ability to rework some of this sediment back into the littoral system; however, these waves are not large enough because of an imposed depthlimited condition, and large volumes of sand are beyond the wave base. It is therefore difficult for this sediment volume to return to the littoral system and subsequently rework toward the central and southern portion of the barrier islands. Storm wave simulations have also indicated that large areas of the lower shoreface are activated during storms and undergo erosional conditions for several hours during one storm event. Circulation patterns from storms have also indicated that there is sufficient turbulence in the water column to erode and transport material outside the littoral system in areas where it cannot be returned with normal fair weather processes. In summary,

- The Chandeleur Islands are undergoing high rates of transport in the northward direction during highintensity and intermediate storms.

- Large areas of the lower shoreface are activated and are undergoing erosion during intermediate and large storms.

- There is little or no fair weather mechanism to rework material into the littoral system.

- There is a net sediment loss from the system.

\section{References}

Chen, C., Liu, H., and Beardsley, R., 2003, An unstructured grid, finite-volume, three-dimensional, primitive equations ocean model - application to coastal ocean and estuaries: Journal of Atmospheric and Oceanic Technology, America Meteorological Society, v. 20, p. 159-186. 
Coastal Engineering Research Center, 1977, Shore protection manual: Washington, D.C., U.S. Army Corps of Engineers, Coastal Engineering Research Center.

Ellis, J., and Stone, W.G., 2006, Numerical simulation of net longshore transport and granulometry of surficial sediments along the Chandeleur Island, Louisiana, USA: Marine Geology, v. 232, p. 115-129.

Georgiou, I.Y., Fitzgerald, D.M., and Stone, G.W., 2005, The impact of physical processes along the Louisiana coast: Journal of Coastal Research, Special Issue 44, p. 72-89.

Georgiou, I.Y., McCorquodale, J.A., Retana, A.G., FitzGerald, D.M., and Hughes, Z., 2007, Hydrodynamic and salinity modeling in the Pontchartrain basin-assessment of freshwater diversion at Violet with MRGO modifications: University of New Orleans, Final Report to the National Oceanic and Atmospheric Administration, 35 p.

Holthuijsen, L.H., Booij, N., and Ris, R.C., 1994, A spectral wave model for the coastal zone, in Wiegel, R.L., Magoon, O.T., and Hemsley, J.M., Ocean Wave Measurement and Analysis - Proceedings of the Second International Symposium, Honoring Professor Robert L. Wiegel, New Orleans, Louisiana, July 25-28, 1993: New York, American Society of Civil Engineers, p. 630-641.

Hubertz, J.H., Abel, C.E., Jensen, R.E., Vincent, C.L., 1989, Gulf of Mexico hindcast wave information. Waterways Experiment Station Report, vol. 18: Vicksburg, Miss., U.S. Army Corps of Engineers.

Jaffe, B.E., List, J.H., and Sallenger, A.H., Jr., 1997, Massive sediment bypassing on the lower shoreface of a wide tidal inlet-Cat Island Pass, Louisiana: Marine Geology, v. 136, p. 131-149.

Komar, P.D., 1998, Beach processes and sedimentation (2d ed.): New York, Prentice Hall, 544 p.

Li, C., Chen, C., Guadagnoli, D., Georgiou, I.Y., 2008, Geometry-induced residual eddies in estuaries with curved channels - observations and modeling studies: Journal of Geophysical Research, v. 113, C01005, doi:10.1029/2006JC004031.

List, J.H., Jaffe, B.E., Sallenger, A.H., Jr., and Hansen, M.E., 1997, Bathymetric comparisons adjacent to the Louisiana barrier islands - processes of large-scale change: Journal of Coastal Research, v. 13, no. 3, p. 670-678.
McCorquodale, J.A., Georgiou, I., Retana, A.G., and Roblin, R.J., 2008, Assessment of integrated hydrodynamic and transport for long-term predictions-FVCOM \& water quality modeling of the Pontchartrain Estuary including subprovinces 1 and 5, chap. 11a, in Twilley, R.R., ed., Coastal Louisiana Ecosystem Assessment \& Restoration (CLEAR) Program - a tool to support coastal restoration. v. IV: Baton Rouge, La., Final Report to Department of Natural Resources, Coastal Restoration Division, 491 p. (Available at http://www.clear.lsu.edu/pdfs/clear_ report_20081023154426.pdf.)

Penland, S., Boyd, R., and Suter, J.R., 1988, Transgressive depositional systems of the Mississippi Delta Plain - model for barrier shoreline and shelf sand development: Journal of Sedimentary Petrology, v. 58, p. 932 -949.

Peterka, J.A., and Shahid, S., 1998, Design gust wind speeds in the United States: Journal of Structural Engineering, v. 124, no. 2, p. 207-214.

Resio, D.T., and Westerink, J.J., 2008, Hurricanes and the physics of surges: Physics Today, v. 61, no. 9, p. 33-38.

Sleath, A.G., and Georgiou, I.Y., 2009, The impact of barrier islands on low intensity storms in southeast Louisiana: Accepted, American Water Resources Association, Annual Meeting, Abstract, Portland, Oregon, November.

Smith, J.M., 2007, Modeling nearshore waves for Hurricane Katrina. ERDC TNSWWRP-07-6: Vicksburg, Miss., U.S. Army Engineer Research and Development Center. (Available at https://swwrp.usace.army.mil/portal/alias swwrp/lang_en-US/tabID_3637/DesktopDefault.aspx.)

Smith, J.M., Sherlock, A.R., and Resio, D.T., 2001, STWAVE — steady-state spectral wave model user's manual for STWAVE, version 3.0. ERDC/CHL SR-01-1: Vicksburg, Miss., U.S. Army Engineer Research and Development Center.

Suter, J.R., Penland S.P., Williams, S.J., Kindinger, J.L., 1988, Transgressive evolution of the Chandeleur Islands, Louisiana: Transactions, Gulf Coast Association of Geological Societies, v. 38, p. 315-322.

U.S. Army Corps of Engineers, 2007, Performance evaluation of the New Orleans and southeast Louisiana hurricane protection system: Interagency Performance Evaluation Task Force, Final Report. (Available at https://ipet.wes. army.mil/.)

van der Westhuysen, A.J., Zijlema, M., and Battjes, J.A., 2007, Nonlinear saturation-based whitecapping dissipation in SWAN for deep and shallow water: Coastal Engineering, v. 54, p. 151-170. 
Appendix H-1. Wind and Wave Climate Analysis, Wave Recasting, and Simulation of Longshore Sediment Transport (See Index Page To Access Data) 
Publishing support provided by Lafayette Publishing Service Center 


\section{Summary and Discussion}

By Dawn Lavoie, Michael D. Miner, loannis Y. Georgiou, Sarah Fearnley, Asbury H. Sallenger, Jr., S. Jeffress Williams, David Twichell, James Flocks, and Mark Kulp

Chapter I of

Sand Resources, Regional Geology, and Coastal Processes of the Chandeleur Islands Coastal System: an Evaluation of the Breton National Wildlife Refuge

Edited by Dawn Lavoie

In cooperation with the U.S. Fish and Wildlife Service

Scientific Investigations Report 2009-5252 


\title{
U.S. Department of the Interior \\ KEN SALAZAR, Secretary \\ U.S. Geological Survey \\ Marcia K. McNutt, Director
}

\section{U.S. Geological Survey, Reston, Virginia: 2009}

\author{
This and other USGS information products are available at http://store.usgs.gov/ \\ U.S. Geological Survey \\ Box 25286, Denver Federal Center \\ Denver, C0 80225 \\ To learn about the USGS and its information products visit http://www.usgs.gov/ \\ 1-888-ASK-USGS
}

\begin{abstract}
Any use of trade, product, or firm names is for descriptive purposes only and does not imply endorsement by the U.S. Government.

Although this report is in the public domain, permission must be secured from the individual copyright owners to reproduce any copyrighted materials contained within this report.
\end{abstract}

Suggested citation:

Lavoie, D., Miner, M., Georgiou, I.Y., Fearnley, S., Sallenger, A.H., Jr., Williams, S.J., Twichell, D., Flocks, J., and Kulp, M., 2009, Chapter I. Summary and discussion, in Lavoie, D., ed., Sand resources, regional geology, and coastal processes of the Chandeleur Islands coastal system—an evaluation of the Breton National Wildlife Refuge: U.S. Geological Survey Scientific Investigations Report 2009-5252, p. 169-180. 


\title{
Chapter I. Summary and Discussion
}

\author{
By Dawn Lavoie, ${ }^{1}$ Michael D. Miner, ${ }^{2}$ loannis Y. Georgiou, ${ }^{2}$ Sarah Fearnley, ${ }^{2}$ Asbury H. Sallenger, Jr., ${ }^{3}$ \\ S. Jeffress Williams, ${ }^{4}$ David Twichell, ${ }^{4}$ James Flocks, ${ }^{3}$ and Mark Kulp ${ }^{2}$
}

\section{Abstract}

Breton National Wildlife Refuge, the Chandeleur Islands chain in Louisiana, provides habitat and nesting areas for wildlife and is an initial barrier protecting New Orleans from storms. The U.S. Geological Survey (USGS) in partnership with the University of New Orleans Pontchartrain Institute for Environmental Sciences undertook an intensive study that included (1) an analysis of island change based on historical maps and remotely sensed shoreline and topographic data; (2) a series of lidar surveys at 3- to 4-month intervals after Hurricane Katrina to determine barrier island recovery potential; (3) a discussion of sea level rise and effects on the islands; (4) an analysis of sea floor evolution and sediment dynamics in the refuge over the past 150 years; (5) an assessment of the local sediment transport and sediment resource availability based on the bathymetric and subbottom data; (6) a carefully selected core collection effort to ground-truth the geophysical data and more fully characterize the sediments composing the islands and surrounds; (7) an additional survey of the St. Bernard Shoals to assess their potential as a sand resource; and (8) a modeling study to numerically simulate the potential response of the islands to the low-intensity, intermediate, and extreme events likely to affect the refuge over the next 50 years.

Results indicate that the islands have become fragmented and greatly diminished in subaerial extent over time: the southern islands retreating landward as they reorganize into subaerial features, the northern islands remaining in place. Breton Island, because maintenance of the Mississippi RiverGulf Outlet (MRGO) outer bar channel requires dredging, is deprived of sand sufficient to sustain itself. Regional sediment transport trends indicate that large storms are extremely effective in transporting sand and controlling the shoreline development and barrier island geometry. Sand is transported north and south from a divergent zone near Monkey Bayou at the southern end of the Chandeleur Islands. Numerical simulation of waves and sediment transport support the geophysical results and indicate that vast areas of the lower shoreface are affected and are undergoing erosion during storm events, that there is little or no fair weather mechanism to rework material into the littoral system, and that as a result, there is a net loss of sediment from the system. Lidar surveys revealed that the island chain immediately after Hurricane Katrina lost about 84 percent of its area and about 92 percent of its prestorm volume. Marsh platforms that supported the islands' sand prior to the storm were reduced in width by more than one-half. Repeated lidar surveys document that in places the shoreline has retreated about $100 \mathrm{~m}$ under the relatively low-energy waves since Hurricanes Katrina and Rita; however, this retreat is nonuniform. Recent high-resolution geophysical surveys of the sea floor and subsurface within 5-6 km of the Chandeleur Islands during 2006 and 2007 show that, in addition to the sand that is rebuilding portions of the island chain, a large volume of sand is contained in Hewes Point, in an extensive subtidal spit platform that has formed at the northern end of the Chandeleur Islands. Hewes Point appears to be the depositional terminus of the alongshore transport system. In the southern Chandeleurs, sand is being deposited in a broad tabular deposit near Breton Island called the southern offshore sand sheet. These two depocenters account for approximately 70 percent of the estimated sediment volume located in potential borrow sites. An additional large potential source of sand for restoration lies in the St. Bernard Shoals, which are estimated to contain approximately $200 \times 10^{6} \mathrm{~m}^{3}$ of sand.

Successful restoration planning for the Breton National Wildlife Refuge should mimic the natural processes of early stages of barrier island evolution including lateral transport to the flanks of the island chain from a centralized sand source that will ultimately enhance the ability of the islands to naturally build backbarrier marsh, dunes, and a continuous sandy shoreline. Barrier island sediment nourishment should be executed with the understanding that gulf shoreline erosion is inevitable but that island area can be maintained and enhanced during retreat (thus significantly prolonging the life of the island chain) with strategic sand placement.

\footnotetext{
${ }^{1}$ U.S. Geological Survey, Stennis Space Center, Miss.

${ }^{2}$ University of New Orleans, Pontchartrain Institute for Environmental Sciences, New Orleans, La.

${ }^{3}$ U.S. Geological Survey, St. Petersburg, Fla.

${ }^{4}$ U.S. Geological Survey, Woods Hole, Mass.
} 


\section{Rationale}

Breton National Wildlife Refuge is composed of a discontinuous barrier island chain along the eastern side of the Mississippi River Delta in Louisiana that trends northsouth for approximately $85 \mathrm{~km}$ from the northern Chandeleur Islands to Breton Island in the south. In addition to providing habitat and nesting areas for endangered species (for example, brown pelican [Pelecanus occidentalis], least tern [Sterna antillarum], piping plover [Charadrius melodus]), and other wildlife species (nesting and wading birds, waterfowl, rabbits, raccoons, and loggerhead sea turtles [Caretta caretta]), the refuge provides an initial barrier to storms for the southeastern Louisiana wetlands and is a fundamental component of the geomorphologic features that protect the metropolitan New Orleans area. The refuge has been impacted by hurricanes throughout history but never as severely as by Hurricane Katrina in 2005, during which the island chain lost 84 percent of its aerial extent. In the 3 years following the hurricane, the islands have shown only limited and slow recovery. The severity of damage brings into question what the future configuration of the island chain will be, what protective function the islands will provide for the mainland wetlands and New Orleans, and whether the refuge can continue to provide the same level of functional habitat for endangered species and other wildlife as it did prior to the 2005 hurricane season.

The U.S. Geological Survey (USGS) in partnership with the University of New Orleans Pontchartrain Institute for Environmental Sciences undertook an intensive year-long study to provide the U.S. Fish and Wildlife Service (FWS) with information needed to answer these and similar questions and make management decisions relating to the future of the Breton National Wildlife Refuge. The effort built on the Barrier Island Comprehensive Monitoring (BICM) program's bathymetric data collection effort funded by the Louisiana Coastal Area Science and Technology Program (jointly funded by the Louisiana Department of Natural Resources and the U.S. Army Corps of Engineers) that surveyed all of the sandy shorelines of Louisiana. The FWS effort included (1) an analysis of island change based on historical maps and remotely sensed shoreline and topographic data; (2) a series of lidar surveys at 3- to 4-month intervals after Hurricane Katrina to determine barrier island recovery potential; (3) a discussion of sea level rise and effects on the islands; (4) an analysis of sea floor evolution and sediment dynamics in the refuge over the past 150 years; (5) an assessment of the local sediment transport and sediment resource availability based on the bathymetric and subbottom data; (6) a carefully selected core collection effort to ground-truth the geophysical data and more fully characterize the sediments composing the islands and surrounds; (7) an additional survey of the St. Bernard Shoals to assess their potential as a sand resource; and (8) a modeling study to numerically simulate the potential response of the islands to the low-intensity, intermediate, and extreme events likely to affect the refuge over the next 50 years. A summary of information resulting from these investigations is synthesized in this chapter.

\section{Summary}

The location of the Chandeleur Islands is controlled by the late Holocene development of the Mississippi River Delta, which started forming on the shelf about 7,000 years before present (BP) (refer to chaps. D, E, and F for a complete discussion and references). Sites of active deltaic deposition shifted over time as the receiving basin filled and the Mississippi River sought a more favorable gradient. One of the intermediate deltas, the St. Bernard Delta Complex, forms the foundation beneath the Chandeleur Islands.

Once the St. Bernard Delta Complex was abandoned, the Chandeleur Islands started to form about 2,000 years BP in response to erosion of deltaic headlands and spit elongation driven by longshore transport. With continued subsidence of the underlying deltaic deposits, the islands became separated from the subaerial part of the delta and, consequently, from their original sand source. Historically, the islands have decreased in subaerial extent largely by narrowing, but they have not moved landward appreciably. After Hurricane Katrina, the islands became more fragmented and greatly diminished in subaerial extent (chaps. A and B).

An analysis of hurricane impacts and resultant shoreline change since the early 1700 s shows very clearly the dynamic nature of the Chandeleur Islands. Maps from the age of discovery show the Chandeleur Islands and the Biloxi Marshes behind the present islands although the location and extent of the marshes differ on all four maps, possibly because navigation was more primitive; however, these maps are our record of the region before the extensive influence of humans. Since the advent of the U.S. Coast and Geodetic Survey topographic smooth sheets in 1970s, shoreline position and change can be measured accurately.

The long-term evolution of the northern Chandeleur Islands has been characterized by Gulf of Mexico shoreline erosion and island arc rotation because of variations in rates of erosion and accretion along the shoreline. The gulf shoreline erosion has not accompanied by increased land area in the backbarrier or a landward migration of the backbarrier shoreline; therefore, the islands have been rapidly decreasing in area. The islands maintained a steady rate of erosion of about $35 \mathrm{ft} / \mathrm{yr}$ between 1922 and 2004 with brief periods (between 1965 to 1969) of accretion prior to Hurricane Camille and between 2002 to 2004 prior to Hurricane Ivan. A simple extrapolation of the rate of diminishing land area suggests that the islands will either become shoals or disappear altogether by 2064 if no significant storms the magnitude of Hurricane Katrina occur. If in this changing 
global climate with storms expected to bring more intense wind fields and rain the northern Chandeleurs are hit again, the islands' lifespan might end as soon as 2013 (see chap. A, especially fig. 10, for details).

The southern Chandeleur Islands - which include Breton Island, Grand Gosier Islands, Curlew Islands, and Errol Islands (historical) — have shown a different and more dramatic storm impact response and mode of recovery over time than have the northern Chandeleur Islands. Like the northern barrier arc, the southern Chandeleur Islands are characterized by shoreface retreat; however, major storm impacts have resulted in complete island destruction and conversion to inner shelf shoals. During extended periods of calm weather following storm impacts, new islands have emerged along this sector. Because the islands have been completely destroyed during storms, it has been difficult to relate storm impacts to shoreline position. Moreover, island area change through time has not been linear because relatively long periods of calm weather produced more robust islands. Over the long term, however, the rate of shoreline retreat was approximately $50 \mathrm{ft} / \mathrm{yr}$ for the time period from 1869 to 1996 . Island area for the time period from 1869 to 2005 decreased from 1,939.8 acres to 43.6 acres (see chap. A for details).

Hurricane impacts to the Chandeleur Island chain are dependent upon storm intensity, path, and duration, and so the geomorphic response to each storm and subsequent recovery are highly variable. The recorded period (1855-2005) of evolution has been characterized by a continual decrease in island area driven by storm impacts from 11,004 acres to 1,164 acres. Almost instantaneously, strong storms greatly increased the rate of shoreline retreat and reduction in island area. Any increase in storm frequency and intensity rapidly accelerates the land loss, and with each storm impact the islands have become less efficient at poststorm recovery because of decreased sediment supply (chap. A).

The data indicate that the Chandeleur Islands have undergone a higher frequency of storm events during the past two decades than during the entire previous 150 years. A simple extrapolation of existing data suggests that the Chandeleur Islands may disappear as early as 2013 if storm frequency remains the same as documented during the past two decades; however, the islands may persist in their present condition until 2037 if storm frequency decreases to the level documented between 1855 and 1988. In the absence of another major storm impact and with limited sediment availability, the northern Chandeleur Islands will likely disappear between 2013 and 2064 (fig. 9 in chap. A).

Storm track has emerged as a key factor in estimating shoreline erosion rates from an approaching storm. Hurricanes Camille and Katrina caused the most severe rates of shoreline erosion on the northern Chandeleur Islands largely because the storm tracks passed directly over the southern portions of the islands. The tracks resulted in the eastern eye wall, with the highest winds and surge levels, passing over the northern islands and causing extensive shoreline erosion. Other Category 3 storms of similar size to Hurricane Katrina that passed more than 75 miles to the west of the islands (for example, Hurricane Betsy) or more than 75 miles to the east (Hurricane Ivan) did not result in the same amount of shoreline erosion; in fact, the passage of Hurricane Ivan actually resulted in accretion of the shoreline during the time period 2002-4 (fig. 11 in chap. A).

The next stage of evolution of the northern Chandeleur Islands may be represented by the present-day configuration of the southern Chandeleur Islands. The southern Chandeleur Islands are ephemeral barrier islands undergoing early stages of transgressive submergence and conversion to an inner shelf shoal. Storm intensity and frequency, as the major controls on island/shoal evolution, destroyed and converted the southern Chandeleur Islands to submerged shoals during periods of high storm frequency and allowed them to emerge and rebuild as relatively robust barrier shorelines during extended periods of calm weather. During the two periods of relative quiescence, Curlew and Grand Gosier Islands were able to recover from complete destruction and increase in area from 39 acres to 596 acres. Also during this quiescent period, backbarrier marsh and mangrove swamp accreted in the shelter of the sandy shoreline, and extensive submerged grass bed meadows blanketed the sea floor landward of the islands. Unfortunately, this period of relative quiescence was followed by the stormiest period on record for the Gulf of Mexico, during which four major hurricanes resulted in the destruction and submergence once again of these southern islands.

The submergence of the southern islands after storms and subsequent reemergence at locations landward of their prestorm positions result in the landward translation of the entire barrier island. This landward barrier retreat in response to relative sea level rise is driven by poststorm hydrodynamics that reorganize the islands into a subaerial feature, which is in contrast to the northern islands, where minimal landward translation of the subaerial barrier occurs. The disparity between the northern and southern islands' responses to storms, storm recovery periods, and sea level rise is attributable to the absence of a well-established backbarrier marsh along the southern chain (with the exception of small portions of Breton Island). As the northern islands erode and are stripped of sand during storms, this backbarrier marsh becomes exposed. Because it is composed of a thick organic root mat within a cohesive fine-grained sediment matrix, the marsh resists rapid erosion and prohibits island submergence.

It is important to note that Breton Island does not follow the same trends in island area change exhibited by Curlew and Grand Gosier Islands to the north. This difference is attributed to the construction and maintenance of the Mississippi River-Gulf Outlet (MRGO) outer bar channel for navigation purposes. Sand that would naturally be transported alongshore and delivered to Breton Island is either deposited updrift of the MRGO channel by the strong tidal currents that flush the channel of sand or is mechanically removed from the 
navigation channel during maintenance dredging efforts and transported to an offshore disposal site, thereby removing it from the littoral system (chap. A, especially fig. 8). This process prohibits Breton Island from recovering from storms in a similar manner to the islands to the north and has resulted in long-term reduction in Breton Island area.

\section{Sediment Transport}

A sea floor digital elevation change model was constructed from a comparison of bathymetric and shoreline data collected in 2006 and 2007 and similar historical data from the U.S. Coast and Geodetic Survey from the 1970s and 1920s (see chap. D for details). Regional sediment transport trends were inferred from this comparison based on zones of erosion and accretion, and calculations of the volume of sediment eroded or accreted for each zone were then used to derive a long-term sediment budget for the system. The results demonstrate that processes that occur offshore along the lower shoreface govern sediment supply to the shoreline and, ultimately, the long-term evolution of the island chain. Results based on hydrodynamic data and modeling (chap. H) illustrate that these lower shoreface sediment transport processes are active during large storms; thus, the shoreface retreat and large volumes of sediment eroded and accreted measured in this study cannot be accounted for by typical sediment transport in the littoral zone.

Shoreline development and barrier island geometry are controlled by the orientation of the abandoned Mississippi River deltaic headland relative to the dominant wave approach. Wave-induced lateral transport, the most significant factor in the development of the Chandeleur Islands chain, produces sand-rich flanking barrier islands. Because the transgressive shoreline is now isolated from its original source, the sediment load of the Mississippi River, only a finite supply of sediment is available for natural island maintenance.

In earlier stages of the island chain development, significant amounts of sand were derived from erosion of the shoreface deposits. Once that deltaic sediment source was reworked, or subsided below effective wave base (about $7 \mathrm{~m}$ for the Chandeleur Islands), in order for the barrier system to maintain exposure during relative sea level rise, barrier and lagoonal deposits must be continually recycled at the shoreface during retreat.

Prior to this study, it was suggested that the net loss of sediment from the Chandeleur Islands system was driven by an imbalance between onshore sediment transport volumes during fair weather conditions and offshore sediment transport volumes during storm conditions. This net export of sediment in an offshore direction produces a thin transgressive sand sheet offshore of the islands that is too deep for onshore transport by constructive fair weather waves. Based on model results, transgressive submergence eventually occurs because development of this sand sheet constantly removes sediment from the barrier system until a threshold is reached, beyond which the islands cannot maintain exposure. In contrast, this study demonstrates that sand is indeed being lost from the nearshore system to deepwater sinks, but the process is more complicated than the previously suggested cross-shore sediment budget model and (similar to the early stages of barrier island development) is driven by lateral sediment transport to the flanks of the island arc.

As demonstrated by the sea floor change digital elevation model, the dominant sediment transport trends are shoreface erosion and deposition in deepwater sinks at the northern and southern flanks of the island arc. Backbarrier deposition is minimal relative to the volumes eroded from the shoreface, indicating that for the most part sand is not being transferred in a landward direction for future recycling. Instead, lateral spit accretion to the north and south of a nodal point, sourced by island and shoreface erosion, has led to sand being sequestered in downdrift, deepwater sinks, removed from the littoral system.

One of the most apparent trends demonstrated in the profile data is the relation among shoreface retreat rates, shoreline erosion rates, and decreasing shoreface slope through time. The southern Chandeleurs have a relatively gentle shoreface slope and are characterized by barrier landward retreat, barrier shoals, and ephemeral barrier islands with no well-established backbarrier marsh. The northern Chandeleurs have a relatively steep shoreface and are characterized by barriers that are undergoing shoreline erosion not accompanied by barrier island landward migration. These northern islands are backed by a well-established backbarrier marsh (thought to be more than 150 years old on the basis of historical maps). Within the period of study some sections of coast (for example, the central Chandeleurs just south of Monkey Bayou [see fig. 4, chap. D, for location]) converted from the steeply sloping/shoreline erosion category to the gently sloping/ephemeral barrier type. Along sections of coast where a thick backbarrier marsh is present, the shoreline is somewhat anchored by the cohesive sediment and root mat that makes up the marsh deposits. The presence of these marsh deposits serves as a nucleation site upon which sand accumulates during storm recovery periods. This erosionresistant substrate prevents total destruction of islands during storms and slows the rate of shoreline erosion. It forms a barrier, beyond which sand transported by waves cannot pass, and therefore sand accumulates as bars weld to the shoreline. In contrast, where no backbarrier marsh is present or is destroyed during storms, sand in the nearshore zone can be transported in a landward direction by waves, but there is no nucleation site for sand to accumulate.

The Chandeleur Islands are undergoing transgressive submergence by means of a multistage process that involves the following: 
- Decreased barrier sand supply restricts new backbarrier marsh development.

- Continued Gulf of Mexico and backbarrier shoreline erosion results in barrier thinning and segmentation. Landward migration is limited because islands are stabilized by backbarrier marsh deposits that inhibit landward transfer of sediment by waves.

- Overwash and eolian processes are not effective at facilitating landward migration because of the paucity of sand in the subaerial barrier.

- Fragmented marsh islets that are the remnants of landward protrusions from the backbarrier shoreline (for example, Redfish Point, Schooner Harbor, Monkey Bayou) anchor the longshore sediment transport system.

- Spits laterally accrete to form a continuous shoreline between these islets.

The gulf shoreline ultimately reaches the backbarrier shoreline, and islands are no longer stabilized by backbarrier marsh, resulting in a sandy ephemeral barrier and the onset of transgressive submergence. The ephemeral barriers are destroyed during storms when the sand is dispersed both offshore and into the backbarrier. During calm weather, sand is moved in volumes that are sufficient to maintain island exposure in response to relative sea level rise. This transport forces a shift in the sediment transport regime from the previously dominant longshore direction to one dominated by cross-shore processes where the system becomes more efficient at recycling sediment. Increased storm frequency accelerates landward retreat rates and in turn inhibits the ability for sand to be reorganized into linear shoals.

Effects from climate change are not uniform but vary considerably from region to region and over a range of time periods because of regional and local differences in atmospheric, terrestrial, and oceanographic processes. The processes driving climate change are complex, and so-called feedback interactions between the processes can both enhance and diminish sea level rise impacts, making prediction of long-term effects difficult. Accelerated global sea level rise, a major outcome of climate change, will have increasingly farreaching impacts on coastal regions of the United States and around the world. Sea level rise impacts are already evident for many coastal regions and will increase significantly during this century and beyond, causing changes to coastal landforms (for example, barrier islands, beaches, dunes, marshes), as well as ecosystems, estuaries, waterways, and human populations and development. Low-lying coastal plain regions, particularly those that are densely populated including the north-central Gulf of Mexico, are especially vulnerable to sea level rise and its associated impacts (see chap. C for details).

\section{Sand Resources}

Sediment transport studies indicate a zone of divergence near Monkey Bayou at the southern end of the Chandeleur Islands, which is where the barrier island lithosome is narrowest and thinnest. North of this divergence, net alongshore transport is directed to the north, whereas south of the divergence transport is southerly. Hewes Point extends northward beyond the northernmost extent of the Chandeleur Islands into deeper water. As such, it appears to be the depositional terminus of the alongshore transport system. As sediment accumulates at Hewes Point in relatively deep water it may be removed from the littoral zone.

The original St. Bernard Delta Plain consisted of a network of distributary channels separated by interdistributary marsh deposits that incised the subaerial part of the delta. They were mostly filled with muddy sand and sandy mud, but sand-rich bars were common at their mouths (see chap. E for details). Interdistributary marsh deposits occupied areas between the channels and primarily consisted of organic-rich sandy silt. Delta-front deposits accumulated offshore of the distributary channel and interdistributary marsh deposits. These deposits contained silt layers and thin sand laminae that dipped gently seaward and graded into adjacent prodelta deposits. The proximal edge of delta-front deposits was sandier than the distal edge, which merged with prodelta muds. Prodelta deposits accumulated farthest from the river mouth and were the finest grained. These deposits primarily consisted of clay with occasional silt beds that were deposited on the continental shelf well beyond the subaerial extent of the delta. As the delta complex expanded, distributary channel and interdistributary marsh deposits advanced seaward over the previously deposited delta-front deposits which, in turn, advanced over prodelta deposits. After the delta complex was isolated from its fluvial source, these sedimentary facies became the primary source of local sediment supply as they were eroded by inner shelf waves and currents.

The thickness, distribution, and volume of the barrier island lithosome extend from the northern tip of Hewes Point to the southern end of the platform beneath Breton Island. The total volume of the barrier island lithosome is approximately $1,600 \times 10^{6} \mathrm{~m}^{3}$. It has been divided into five sections from north to south: (1) Hewes Point, (2) the Chandeleur Islands, (3) Curlew Island, (4) Grand Gosier Island, and (5) Breton Island (fig. 11 in chap. E). The Hewes Point section contains the largest volume of sediment $\left(379 \times 10^{6} \mathrm{~m}^{3}\right)$, has the largest volume per unit area $\left(3.2 \times 10^{6} \mathrm{~m}^{3} / \mathrm{km}^{2}\right)$, and is the thickest part of the barrier island lithosome (maximum thickness of 8.9 $\mathrm{m})$. The Chandeleur Islands section covers the largest area and contains the second largest volume of sediment $\left(284 \times 10^{6} \mathrm{~m}^{3}\right)$ but has the smallest volume per unit area $\left(1.5 \times 10^{6} \mathrm{~m}^{3} / \mathrm{km}^{2}\right)$. It also is the narrowest section of the barrier island lithosome $(1.5-4.2 \mathrm{~km})$ and like the three sections to the south (Curlew, 
Grand Gosier, and Breton Islands) has a maximum thickness that does not exceed $5.5 \mathrm{~m}$. Large parts of this section are less than $3 \mathrm{~m}$ in thickness. The Curlew Island section is slightly broader than the Chandeleur Islands section $(3.7-5.2 \mathrm{~km})$, has a similar maximum thickness $(5.2 \mathrm{~m})$, and has a larger volume per unit area $\left(1.7 \times 10^{6} \mathrm{~m}^{3} / \mathrm{km}^{2}\right)$. The Curlew and Grand Gosier Islands sections are separated by an erosional channel that exceeds $9 \mathrm{~m}$ in depth. The Grand Gosier Island section is $7-12 \mathrm{~km}$ wide, covers the smallest area of the five sections, reaches $5.4 \mathrm{~m}$ in thickness, and has the smallest volume of the five sections. The Breton Island section is separated from the Grand Gosier section by a broad erosional depression that was dredged to accommodate the Mississippi River-Gulf Outlet channel. This section also reaches a maximum thickness of about $5.5 \mathrm{~m}$, but it is broader than the Chandeleur and Curlew sections (5.2-7.6 km wide) and has the second largest volume per unit area $\left(2.1 \times 10^{6} \mathrm{~m}^{3} / \mathrm{km}^{2}\right)$.

The two stratigraphic units identified in the seismicreflection profiles and cores that have the most potential to be sand resource sites are (1) the northern and southern ends of the barrier island lithosome and (2) sections of the distributary channels that are exposed on the sea floor seaward of the islands. In total, six deposits have been identified that could contribute sediments suitable for shoreline renourishment. Two of these sites are modern deposits that developed contemporaneously or subsequent to the formation of the islands, and four are the offshore extensions of distributary channels that are associated with development of the St. Bernard Delta Complex.

The two sediment bodies of the barrier island lithosome that could serve as sand resource sites are (1) the Hewes Point deposit and (2) the offshore part of the broad, thin sand sheet north of the Mississippi River-Gulf Outlet in the Grand Gosier section of the lithosome (herein referred to as the "southern offshore sand sheet"). These sites lie at the northern and southern ends of the coastal transport pathways and appear to represent sediment that has been removed from the littoral zone and is in a setting that modern oceanographic processes can no longer rework. The total volume of sediment in the Hewes Point deposit is $379 \times 10^{6} \mathrm{~m}^{3}$, and approximately 190 $\times 10^{6} \mathrm{~m}^{3}$ is available within $2 \mathrm{~m}$ of the sea floor. The southern offshore sand sheet near the Mississippi River-Gulf Outlet is smaller in aerial extent and thinner. Much of this deposit is only $2 \mathrm{~m}$ thick, and assuming it has a uniform thickness of 2 $\mathrm{m}$, its total volume is $71 \times 10^{6} \mathrm{~m}^{3}$.

The four distributary channel deposits appear to be less desirable targets because they are smaller and more irregular in shape than the Hewes Point and southern offshore sand sheet, and their fills display variable grain-size distributions. In addition, their shallower depths suggest that the hydrography might be altered with significant sand removal.

The St. Bernard Shoals are a series of shoals located in about $20 \mathrm{~m}$ of water just beyond the edge of the modern subaerial Mississippi River Delta marshes and barrier islands approximately $25 \mathrm{~km}$ southeast of the Chandeleur Islands.
They are up to $6 \mathrm{~m}$ thick and locally consist of as much as 100 percent fine- to medium-grained sand. The shoals are derived from sediment that was deposited by a depositional system similar to that which formed the Chandeleur Islands. Consequently the sediment that constitutes the shoals is similar to the sediment that constitutes the Chandeleur Islands, which may make them an ideal borrow site for renourishment of the Chandeleur Islands system (chap. G).

The removal and relocation of sediment from borrow sites will alter the sea floor topography and consequently the bathymetric profile of the dredged area, resulting in an increase in the water depth at the dredged area. Since the direction and magnitude of currents and sediment transport cells are in part controlled by sea floor topography, currents in the shallow borrow sites noted above may be significantly altered by dredging. In the deeper borrow sites (for example, Hewes Point, the southern offshore sand sheet, and the St. Bernard Shoals), winter storm simulations have demonstrated the storms' limited ability to rework some of this material back into the littoral system (chap. H); however, large volumes of sand are far enough beyond wave base that the sediment cannot return to the system. Thus, the negative impacts to the island chain caused by altered hydrology from dredging the St. Bernard Shoals or Hewes Point may be slim to nonexistent. In contrast, storm wave simulations have indicated that large areas of the lower shallow shoreface are activated during storms (chap. H); thus, dredging these four potential borrow sites may not be beneficial for maintaining island area.

\section{Conclusions and IImplications for Island Management}

Understanding the phases of island evolution and sediment dynamics is fundamental to formulating sustainable island management strategies. The Chandeleur Islands evolution model based on framework geological data and previous investigations demonstrates that the islands built laterally to the north and south from sediment sourced from an erosional headland located along the central portion of the modern shoreline. Sea floor change analysis (fig. 1), subbottom profile data, and model-derived longshore transport predictions confirm that this phenomenon of lateral spit accretion at the flanks of the island arc has continued into recent times. During the early stages of island development, this lateral accretion process allowed for the development of robust backbarrier marsh upon relict spit platforms, landward of the shoreline. This process resulted in the broad backbarrier marshes fronted by a retreating sandy shoreline. This sandy shoreline continues to migrate landward, truncating the backbarrier marshes. During the past century new backbarrier marsh formation has been insignificant and limited to localized areas. 


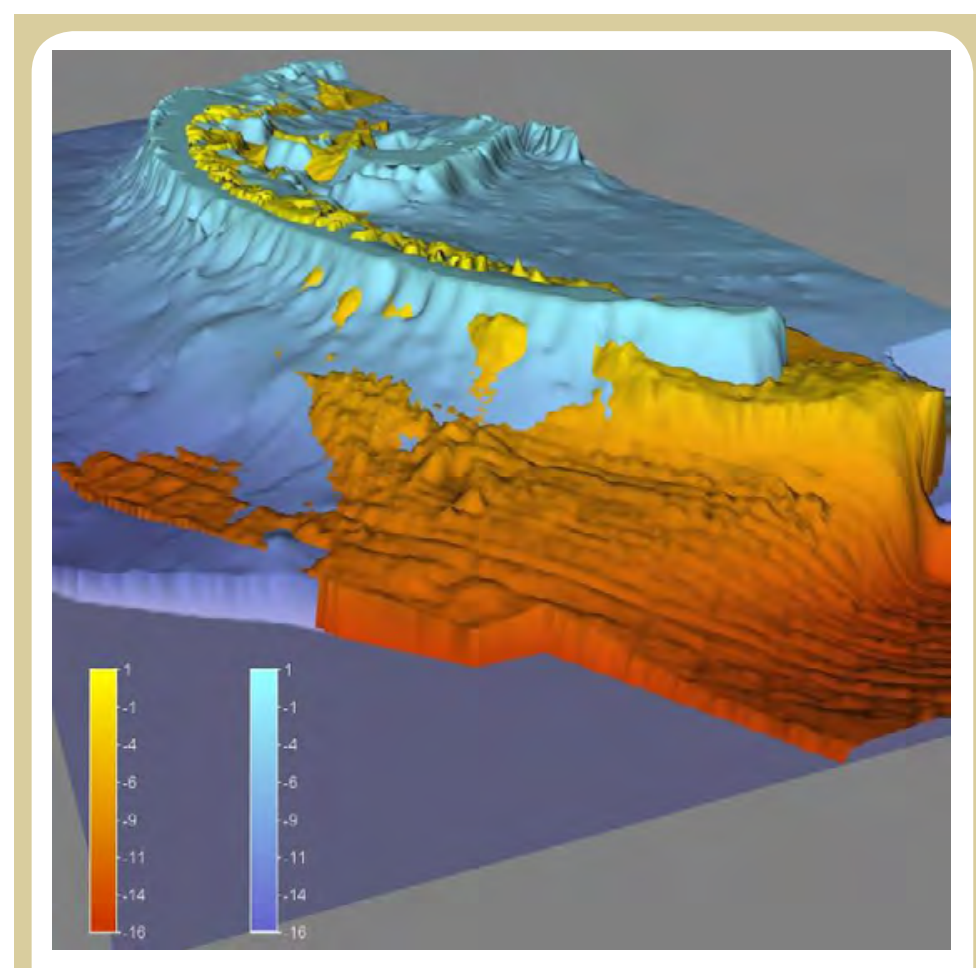

Figure 1. View to the south of the sea floor surfaces of the Chandeleur Islands, La., of the 1870s (blue) versus those of 2006 (orange). Note the large accretionary zone north of Hewes Point, La. (orange in foreground). transfer of sand by overwash processes and subsequent colonization of overwash deposits by backbarrier marsh vegetation. It has been observed that during the poststorm recovery period, landward transfer of sand is facilitated by (1) landward migration of offshore bars that weld to marsh islets,

(2) recurved spit formation at hurricane-cut inlets,

(3) eolian processes (dunes, wind tidal flats, and deposition on the marsh surface), and (4) shoal aggradation and landward migration (figs. 3 and 4). The islands are sediment starved, and these recovery processes appear to have exhausted most of the available sand supply, thereby limiting further recovery.

The long-term diminished sediment supply, location of sediment sinks, and storm recovery processes documented in this study provide an understanding of the mechanism that drives barrier island arc transgressive submergence and the natural sediment dispersal processes at work that prolong submergence. On the basis of this newly developed understanding of where the sand is going, how long it takes to get there, and how the islands naturally respond to a rapid introduction of new sediment, efficient barrier management strategies can be developed.

The dominance of lateral transport over crossshore transport is important. Sand is not being removed and deposited offshore in thin sand sheets as proposed by previous works; instead, sand is being concentrated as thick sediment bodies at the flanks of the island arc (fig. 1). These downdrift sand reservoirs lie outside of the littoral system and provide a unique, quasi-renewable resource for nourishing the updrift barrier system (that is, the central arc).

Restoration goals might mimic the natural processes of early stages of barrier island evolution (fig. 5) including lateral transport to the flanks from a centralized sand source that will ultimately enhance the islands' ability to naturally build backbarrier marsh, dunes, and a continuous sandy shoreline (fig. 6). Barrier island sediment nourishment should be executed with the understanding that gulfside shoreline erosion is inevitable; however, island area can be maintained and enhanced during retreat with strategic sand placement if the following are accomplished:

- Nourishment sand recovered from deepwater sinks at the flanks of the island arc is reintroduced to the barrier sand budget at a centralized location chosen on the basis of longshore sediment transport predictions.

- Distribution of naturally occurring hurricane-cut passes is maintained as storm surge/overwash pathways. These natural high-energy environments should be avoided as sand placement areas. accelerated by Hurricane Katrina; fig. 2), the islands are not capable of maintaining exposure by means of landward 

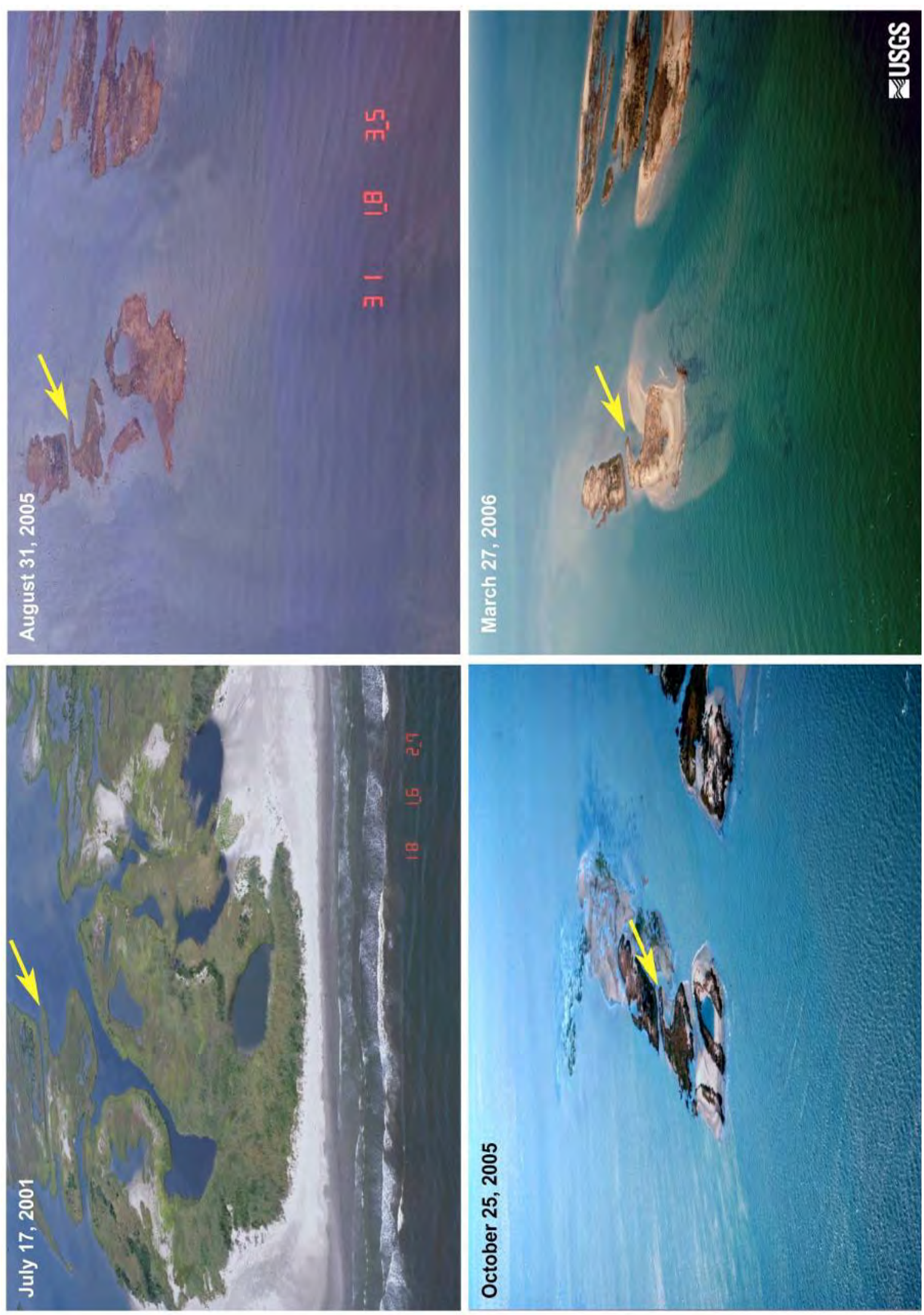

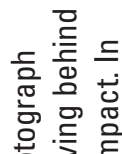

은 정 트

등 क् क्

ब त

$\subseteq \underline{\underline{D}} \cong$

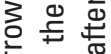

충 등

实

क 든 인

品

क 亦

うㄴㅇㅇ

क के

잉

흔 豆

잉응

吉춴

웡 巳

증 을

응 잉

흐 흔

舟需

눙유은

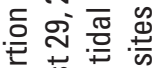

응 苛 중 익 을

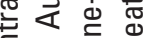

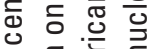

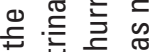
을 $\bar{E}$ 음 व) 히월 고 을 드

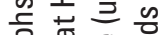
준 क्ष 을 ลे क 등 Ф 즌 은 ब तु 으 잉

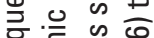
흥 응 㐘 प 등 is 4 क्ष 为 $\overline{\bar{\pi}} \bar{\pi}$ (ֻ)

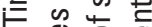
i t艹 is 인 든 임

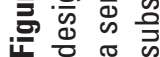



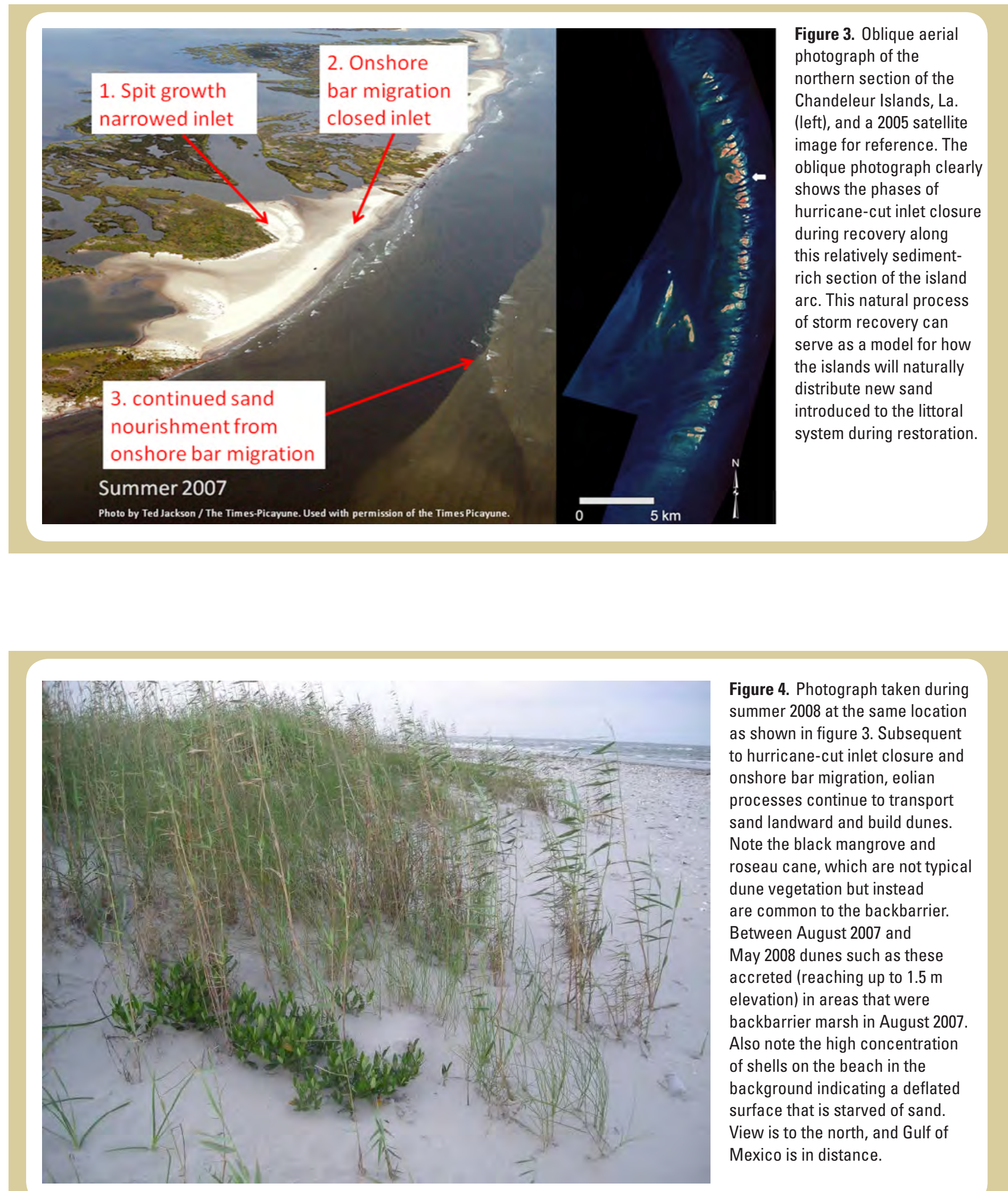

Figure 4. Photograph taken during summer 2008 at the same location as shown in figure 3 . Subsequent to hurricane-cut inlet closure and onshore bar migration, eolian processes continue to transport sand landward and build dunes. Note the black mangrove and roseau cane, which are not typical dune vegetation but instead are common to the backbarrier. Between August 2007 and May 2008 dunes such as these accreted (reaching up to $1.5 \mathrm{~m}$ elevation) in areas that were backbarrier marsh in August 2007. Also note the high concentration of shells on the beach in the background indicating a deflated surface that is starved of sand. View is to the north, and Gulf of Mexico is in distance. 


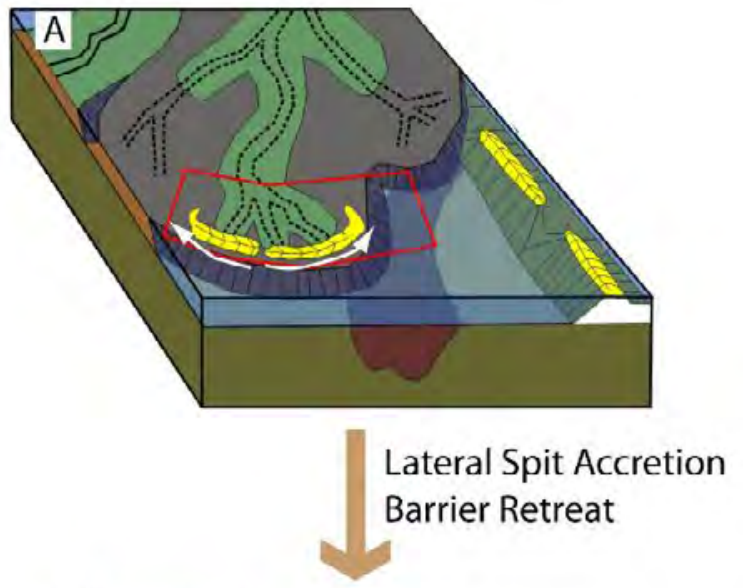

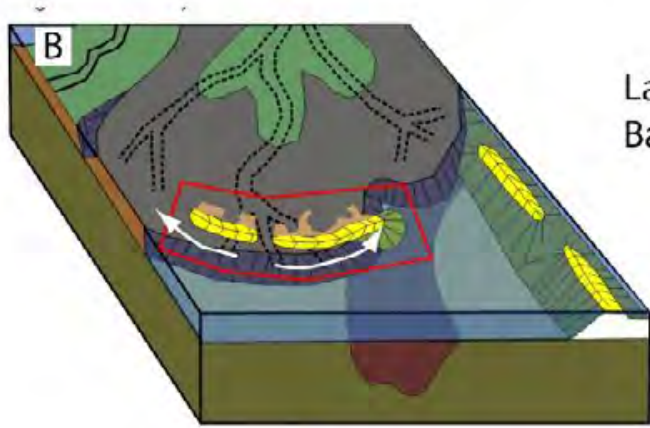

Transgressive Submergence

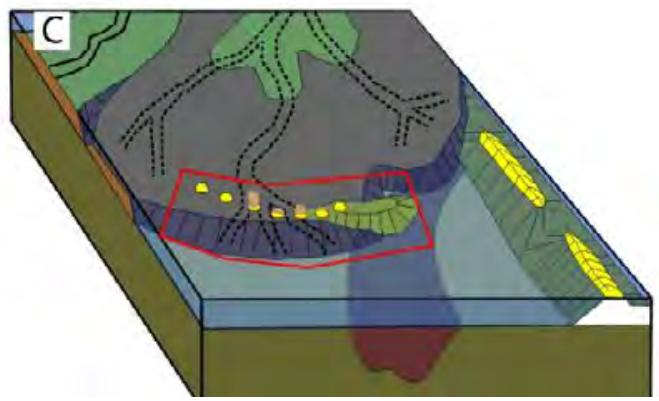

Lateral Spit Accretion Barrier Retreat
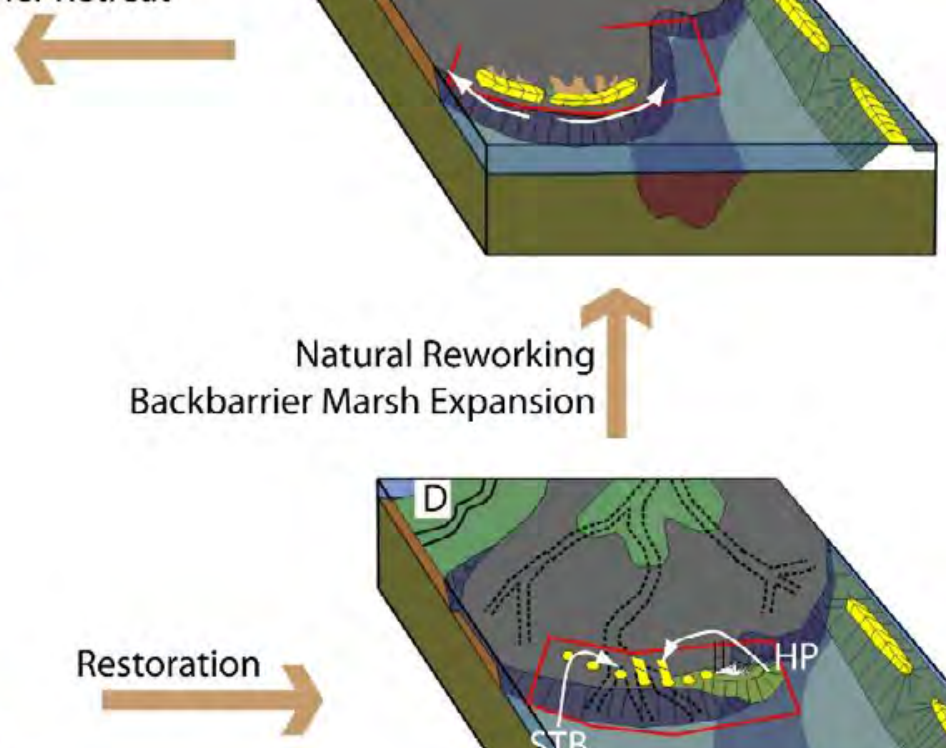

Figure 5. Conceptual model demonstrating barrier island management approach that would employ natural physical processes to extend the lifespan of the Chandeleur Islands, La. The model is based on a conceptual model of Chandeleur Islands evolution (stages $A-C$; Twichell and others, chap. E) interpreted from framework geological data. $A$, Natural island formation is the result of mainland detachment from an abandoned deltaic headland. $B$, Continued wave reworking of the headland and island arc results in barrier landward retreat, and sediment that is sourced from a centralized location is transported alongshore to the flanks of the island arc. $C$, Continued transport to the flanks removes sediment from the littoral system and results in exhaustion of centrally located sand sources forcing island degradation and eventually transgressive submergence. $D$, The process of transgressive submergence can be reversed by mechanical removal of sediment from the Hewes Point, La., sink in the north (HP) or St. Bernard Shoals, La., offshore to the east (STB) and strategic sand placement at a central location along the island arc. E, Sand will be naturally distributed from this central location by longshore currents to close inlets, broaden beaches, and increase dune elevations. This will make sand available for overwash and spit building upon which backbarrier marsh vegetation will colonize. Updrift reintroduction of sand that was lost from the system effectively sets back the clock to stages $A-B$. 


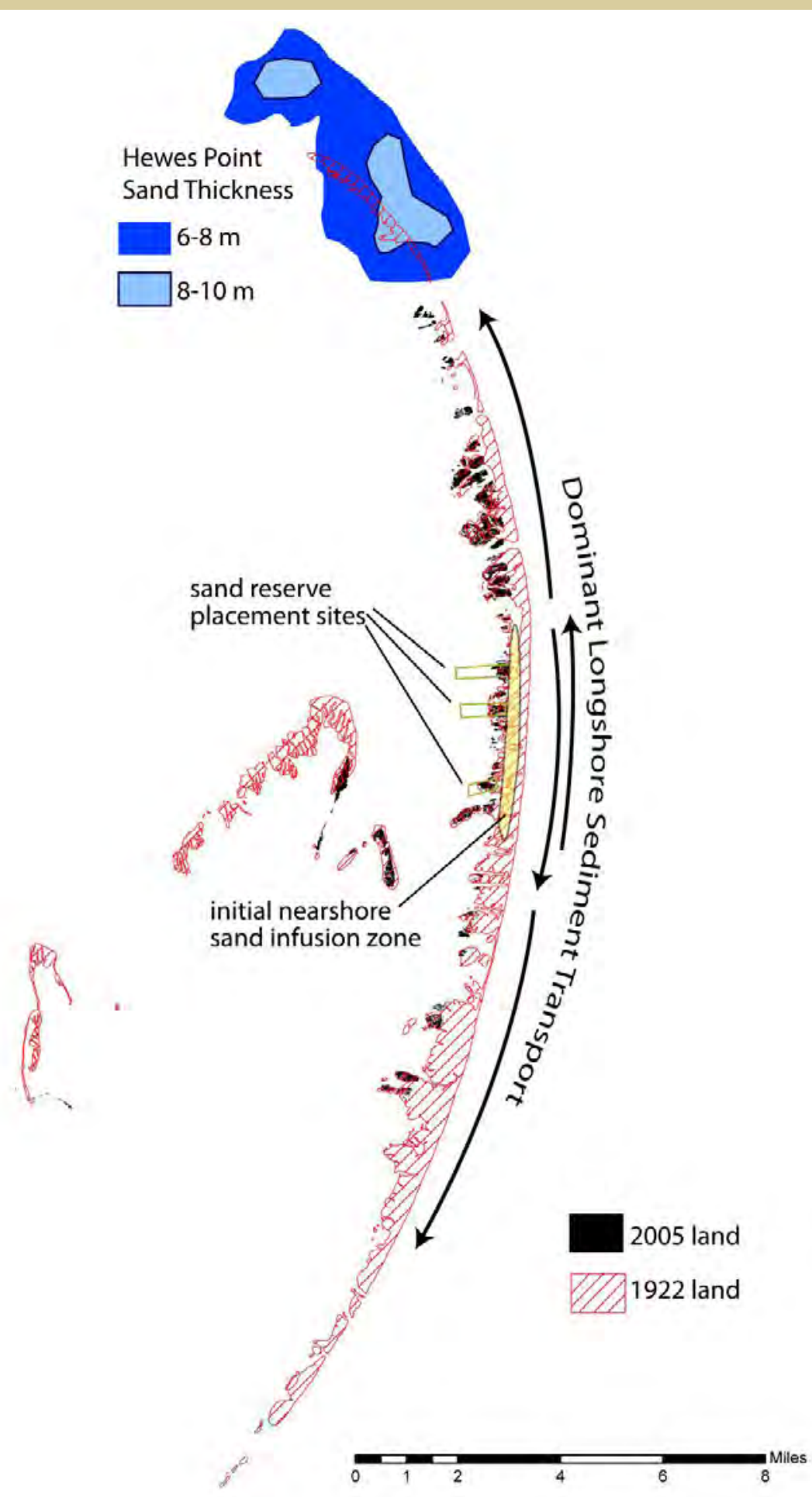

Figure 6. Plan view of the arc of the northern Chandeleur Islands, La., showing the location of the Hewes Point sand resource and possible placement sites that are centrally located within the zone of longshore sediment transport divergence. This divergent zone varies seasonally and was determined from wave modeling based on a 20-year wind record (Georgiou and Schindler, chap. H). The sand reserve placement sites constructed as shore-perpendicular ridges in the backbarrier would serve to continually nourish the island as the shoreline migrates landward, and the initial infusion zone would provide a rapid influx of sand to the littoral system for natural lateral distribution by wave-induced longshore currents. 
- Sand is placed at a centralized location along the island arc from which it will naturally disperse to the flanks. Hurricane-cut inlets will heal by spit accretion and bar welding processes. These processes will increase sand in the littoral system and will nourish the beach, providing material for eolian dune building, which will result in increased island elevation and storm protection.

- Sand reserves are strategically placed in the backbarrier as shore-perpendicular platforms over which the island can migrate. These will also serve to reintroduce sand into the littoral system as the island migrates.

- An initial sand infusion to the littoral system along the central barrier arc fronting the backbarrier sand reserves, in the form of nearshore bars and beach, and area-specific restoration can simultaneously be placed.

- An additional or alternative sand source to the Hewes Point sand target is used. The St. Bernard Shoals lie about $25 \mathrm{~km}$ offshore of the southern Chandeleur Islands in water depths of less than $20 \mathrm{~m}$. The textural properties of the St. Bernard Shoals sand match those of the Chandeleur Islands sand.

Island lifespan is a function of the magnitude of sand reintroduced and the placement locations. This relation is nonlinear. As sand volumes increase in the littoral system, they will lengthen the islands' lifespan, help reduce erosion rates, and increase island sustainability. When sufficient sand is introduced into the system, it will result in the natural development of robust backbarrier marshes. A naturally well-established (decadal to century scale) backbarrier vegetation is crucial to long-term sustainability because it acts as a nucleation site for material removed during overwash processes, is naturally more resilient to storms, and provides a stable migration or rollover platform. Periodic reintroduction will additionally ensure that the natural rebuilding process is successful.

Breton Island, because of its unique position and importance to habitat, might be treated somewhat differently. Breton Island has been sediment starved because of maintenance dredging of the Mississippi River-Gulf Outlet updrift of Breton Island, which has resulted in rapid island degradation. The island is in need of immediate sand nourishment. A significant volume of sediment (the largest accumulation in the study area during the past 130 years) has accumulated downdrift (southwest) of Breton Island. This accumulation is similar to the sediment sink found at the barrier island arc, north of Hewes Point. The proximity of this source and the location relative to modern processes (downdrift of the outermost littoral zone) make it ideal for restoration of Breton Island. The sandy portion of Breton Island could be nourished to produce a robust beach, beach slope, berm, and dune system. The existing marsh islands at the edges of the islands could also be fronted with a robust beach and dune compartment to maintain and protect the remaining marsh platform for nesting birds. Additional sand can be placed landward of the existing backbarrier to produce migration platforms, encourage colonization of vegetative species, and increase nesting grounds. 
음

흠

묭

응

$$
\text { 흘 }
$$

8

कै

$\frac{4}{5}$ 